WORK AROUND THE GLOBE: HISTORICAL COMPARISONS AND CONNECTIONS

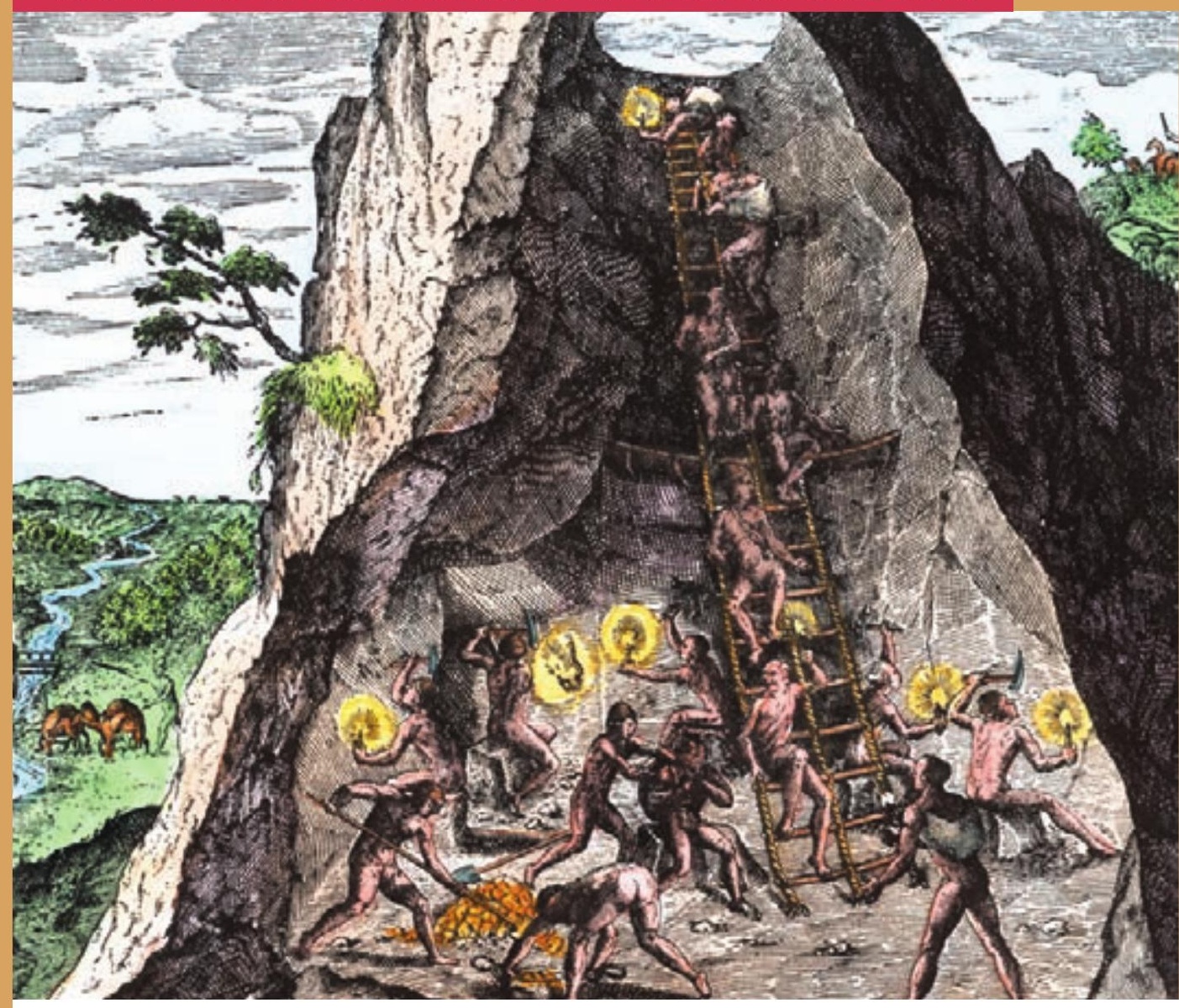

Edited by Karin Hofmeester and Pim de Zwart

\title{
Colonialism, Institutional Change, and Shifts in Global Labour Relations
}


Colonialism, Institutional Change, and Shifts in Global Labour Relations 


\section{Work Around the Globe: Historical Comparisons and Connections}

\section{Open Access Book Series of the International Institute of Social History (IISH)}

Most human beings work, and growing numbers are exposed to labour markets. These markets are increasingly globally competitive and cause both capital and labour to move around the world. In search of the cheapest labour, industries and service-based enterprises move from West to East and South, but also, for example, westwards from China's east coast. People move from areas with few employment opportunities to urban and industrial hubs, both between and within continents. However, labour relations have been shifting already for centuries, labour migrations go back far in time, and changing labour relations cannot be comprehended without history. Therefore, understanding these developments and their consequences in the world of work and labour relations requires sound historical research, based on the experiences of different groups of workers in different parts of the world at different moments in time, throughout human history.

The research and publications department of the International Institute of Social History (IISH) has taken on a leading role in research and publishing on the global history of labour relations. In the context of Global Labour History, three central research questions have been defined: (1) What labour relations have emerged in parallel with the rise and advance of market economies? (2) How can their incidence (and consequently the transition from one labour relation to another) be explained, and are these worldwide transitions interlinked? (3) What are the social, economic, political, and cultural consequences of their changing incidence, and how do they relate to forms of individual and collective agency among workers? These three questions are interconnected in time, but also in space. Recent comparative Global Labour History research demonstrates that shifts in one part of the globe have always been linked to shifts in other parts.

Series Editor: Leo Lucassen, International Institute of Social History, Amsterdam Editorial Board: Ulbe Bosma, Karin Hofmeester, Marcel van der Linden, International Institute of Social History, Amsterdam Executive Editor: Aad Blok, International Institute of Social History, Amsterdam 


\title{
Colonialism, Institutional Change, and Shifts in Global Labour Relations
}

\author{
Edited by \\ Karin Hofmeester and Pim de Zwart
}


Cover illustration: Workers in the silver mine in Potosí, an engraving from Theodor de Bry in Historia Americae sive Novi Orbis, 1596

(C) Nancy Carter, North Wind Picture Archives

Cover design: Coördesign, Leiden

Lay-out: Crius Group, Hulshout

Amsterdam University Press English-language titles are distributed in the US and Canada by the University of Chicago Press.

$\begin{array}{ll}\text { ISBN } & 9789462984363 \\ \text { e-ISBN } & 9789048535026 \text { (pdf) } \\ \text { DOI } & 10.5117 / 9789462984363 \\ \text { NUR } & 696\end{array}$

\section{(C)}

Creative Commons License CC BY NC ND (http://creativecommons.org/licenses/by-nc-nd/3.o)

@ The authors / Amsterdam University Press B.V., Amsterdam 2018

Some rights reserved. Without limiting the rights under copyright reserved above, no part of this book may be reproduced, stored in or introduced into a retrieval system, or transmitted, in any form or by any means (electronic, mechanical, photocopying, recording or otherwise) without the written permission of both the copyright owner and the author of the book.

Every effort has been made to obtain permission to use all copyrighted illustrations reproduced in this book. Nonetheless, whosoever believes to have rights to this material is advised to contact the publisher. 


\section{Table of Contents}

Acknowledgements

1 Introduction

Colonialism, Institutional Change, and Shifts in Global Labour

Relations

Karin Hofmeester and Pim de Zwart

\section{Part I Labour in the Production of Global Commodities}

2 The Industrialization of the Developing World and Its Impact on Labour Relations, 1840 s to 1940 s

William G. Clarence-Smith

3 Economic Institutions and Shifting Labour Relations in the Indian, Brazilian, and South African Diamond Mines Karin Hofmeester

4 The Global Detour of Cane Sugar 109

From Plantation Island to Sugarlandia

Ulbe Bosma

5 Threads of Imperialism

Colonial Institutions and Gendered Labour Relations in the Textile Industry in the Dutch Empire

Elise van Nederveen Meerkerk

6 The Triumph of the Peasant Option and the Parasitic Cotton Sector in Malawi, 1891 to 1995

Elias C. Mandala 


\section{Part II Changing Labour and Land Market Institutions}

7 Extractive Economy and Institutions?

Technology, Labour, and Land in Potosí, the Sixteenth to the

Eighteenth Century

Rossana Barragán

8 Changing Tides

Maritime Labour Relations in Europe and Asia

Matthias van Rossum

9 Wage Labour and Slavery on the Cape Frontier

The Impact of the Abolition of Slave Imports on Labour Relations in the Graaff-Reinet District

Johan Fourie and Erik Green

\section{Part III Monetization and the Payment of Work}

10 Paying in Cents, Paying in Rupees

Colonial Currencies, Labour Relations, and the Payment of Wages in Early Colonial Kenya

Karin Pallaver

11 Labour and Deep Monetization in Eurasia, 1000 to 1900 Jan Lucassen

Notes on Contributors

Index 


\section{List of Figures and Tables}

\section{Figures}

1.1 Taxonomy of Labour Relations $\quad 12$

$\begin{array}{lll}3.1 & \text { Diamond fields in India } & 70\end{array}$

3.2 Value of diamond imports from India 73

$\begin{array}{lll}3.3 & \text { Diamond fields in Brazil } & 79\end{array}$

3.4 Slaves washing diamond-bearing soil 80

3.5 Diamond production Minas Gerais in carats, 1740-1824 86

3.6 Southern Africa and the diamond fields, c. 1870-1871 91

3.7 The Bultfontein, Dutoitspan, De Beers, and Kimberley mines 92

3.8 Diamonds found in the Kimberley, De Beers, Bultfontein, and Dutoitspan mines, in carats, 1867 to 1913

5.1 Total imports of cotton goods (cloth and yarns) in Java, as well as exports, 1822 to 1873

5.2 Estimated per capita imports, Java 1822 to 1870 (in kg) 145

5.3 Yarn imports, in value (1000 Dfl., left-hand y-axis) and weight (1000 kgs, right-hand y-axis), 1828-1878 148

5.4 Imported cotton cloth (left-hand y-axis) and cotton yarns (right-hand y-axis) in Java, 1874 to 1913 (in 1,000 1913-Dfl.) 154

5.5 Imports of cotton yarns and volume of home-produced cotton, Dutch East Indies 1904 to 1913 (in tonnes) $\quad 15^{6}$

$\begin{array}{lll}5.6 & \text { Two Javanese women batiking, c. } 1910 & 157\end{array}$

5.7 A Javanese man tjapping (block printing) cotton cloth, c. $1910 \quad 158$

5.8 Percentages of men and women working in different sectors, Java and Madura $1905 \quad 160$

5.9 Men and women working in industry, the Netherlands $1899 \quad 162$

7.1 Painting of Cerro Virgen 208

$\begin{array}{lll}7.2 & \text { An ingenio in } 1585 & 215\end{array}$

7.3 Instruments used in the oven to distil mercury according to Alonso Barba, $1640 \quad 216$

7.4 Evolution of the number of mitayos arriving in Potosi 223

8.1 Absence of VOC workers at departure from the republic, per origin, percentages per year $\quad 250$

9.1 Coefficients of male Khoesan and male slaves, 1800-1825 280

9.2a Coefficients of male slaves for stock farming, 1800-1825 280

9.2b Coefficients of male slaves for grain farming, 1800-1825 281

9.2c Coefficients of male slaves for viticulture, 1800-1825 281

9.3 Kernel density estimates of male slaves by year 286 
11.1 The relationships between types of commodified labour relations (vertical from free to unfree) and of remuneration (horizontal from none to monetized)

11.2 Deep Monetization in Europe and Asia, 1000 to 1885

\section{Tables}

5.1 Registered labour-force participation of the adult population, Java and Madura, 1905

5.2 Indexed real wages in some Western European countries, 1850 to $1913(1860=100)$

6.1 Price per kilogram of first grade cotton in British, Malawi, and US currencies

6.2 ADMARC Crop Trading Accounts, 1966 to 1977 (in MWK1,0oo) 195

7.1 Regiments and shifts of work 220

7.2 Workers' changing between different categories in a month 221

8.1 Share of absent VOC employees with a transportbrief, but without a maandbrief (percentages) 252

9.1 Totals of tax census variables, Graaff-Reinet, 1790-1828 274

9.2 Average per household across six tax censuses, 1800-1825 276

9.3 Regression of labour inputs on the value of production 279

9.4 Urban and rural slave ownership 284

9.5 Test for complementarity between male Khoesan and male slaves $\quad 285$

9.6 Concentration of slave ownership over time 287

10.1 Value in rupee of the coins in circulation in Kenya and Uganda, 15 February 1921

11.1 Deep monetization levels for several countries c. 1885

11.2 Primary labour relations (\%) in three collectorates in the Deccan in the 1820 s 


\section{Acknowledgements}

This book is one of the outcomes of the project the "Global Collaboratory on the History of Labour Relations, 1500-2000" set up by the International Institute of Social History (IISH) in Amsterdam. We would like to express our gratitude to the Gerda Henkel Stiftung in Düsseldorf for its generous support for this project, which would not have been realized without its help.

As part of the project we organized a workshop on Economic Institutional Change and Global Labour Relations at the IISH in 2014. The framework of this book is based on a selection of the papers presented at that conference and on the lively discussions we had during the meeting. We would like to thank all the participants of this workshop for their contribution, whether reworked into articles and included in this volume or expressed during presentations (the work of Shahana Bhattacharya, Nirmal Dewasiri, Rosemarijn Hoefte, and Alessandro Stanziani) and in comments (Lex Heerma van Voss and Marcel van der Linden).

We would like to thank the members of the Editorial Board of the Work around the Globe: Historical Comparisons series at Amsterdam University Press for including us in the series and we are grateful for their helpful comments as well as of those of the anonymous reviewers of the manuscript. We thank our colleagues at the publications department of the IISH Aad Blok and Angelie Sens as well as the team at Amsterdam University Press: Saskia Gieling,Jaap Wagenaar, and their gatekeeper, Victoria Blud, for their guidance during the realization of the project. Many thanks go to Anne Lee and Richard Bowles for their excellent proofreading work and to Charlotte Stam for her work on the bibliography. Any remaining errors or omissions are ours.

Karin Hofmeester and Pim de Zwart, Amsterdam and Utrecht, September 2017 



\title{
$1 \quad$ Introduction
}

\author{
Colonialism, Institutional Change, and Shifts in Global \\ Labour Relations*
}

Karin Hofmeester and Pim de Zwart

\begin{abstract}
Hofmeester, Karin \& Pim de Zwart (eds.), Colonialism, Institutional Change, and Shifts in Global Labour Relations. Amsterdam: Amsterdam University Press, 2018
\end{abstract}

DOI: $10.5117 / 9789462984363 / \mathrm{CHo1}$

\begin{abstract}
The introduction explains the purpose of this volume: to explain the development of labour relations by looking at the institutions pertaining to various economic resources in society: commodities, land, labour, and capital. Rather than looking at the effect of colonial institutions on economic growth and viewing labour in a static and generic manner, we want to establish a more precise relationship between colonial institutions and changing labour relations. Therefore the pre-colonial, colonial, and post-colonial periods are taken into account and we carefully look at changes over time in the institutions and the various forms of labour relations that prevailed, both free and unfree. The agency of the workers and their possible options to opt out of the labour system that was established by the colonizers are explicitly included.
\end{abstract}

Keywords: colonial institutions, labour relations, dynamism, agency, workers

This volume is one of the outcomes of the "Global Collaboratory on the History of Labour Relations, 1500-2000", a project of the International Institute of Social History (IISH). The project aims to draw up a worldwide inventory

\footnotetext{
* This project has been made possible by generous grants from the Gerda Henkel Stiftung in Düsseldorf and the Netherlands Organisation for Scientific Research (NWO). For more information on the project and its background, see Hofmeester et al., "The Global Collaboratory on the History of Labour Relations".
} 
Figure 1.1 Taxonomy of Labour Relations

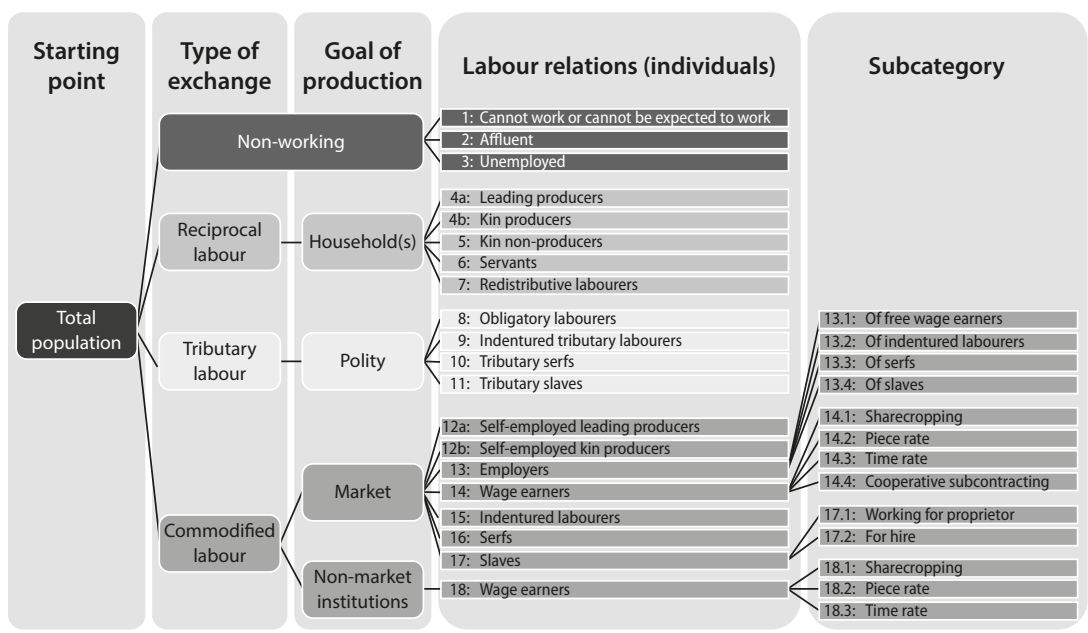

(c) 2015-17 Global Collaboratory on the History of Labiour Relations, 1500-200 http://www.historyoflabourrelations.org

of all types of labour relations, in all their facets and combinations, in different parts of the world, and at five points in time: 1500, 1650, 1800, 1900 (also 1950 for Africa), and 2000. The first phase of this project (2007-2012) consisted of data mining. ${ }^{1}$ The second phase of the project sets out in search of explanations for shifts in labour relations, as well as for the possible patterns observed therein. Causes and consequences of changes in labour relations are explored in a series of dedicated workshops, by looking in depth at possible explanatory factors, such as the role of the state, demography, family patterns, and - the topic of this volume - economic institutions. ${ }^{2}$

In order to compare and analyse all types of work and labour relations, the collaboratory starts off from a very comprehensive definition of work, provided by the sociologists Charles and Chris Tilly: "work includes any human effort adding use value to goods and services". ${ }^{3}$ In our view, labour relations define for or with whom one works and under what rules. Taking these definitions of work and labour relations as a starting point, members of the collaboratory developed a taxonomy of labour relations that allows for long-term global comparisons.

1 For the data, please refer to https://collab.iisg.nl/web/labourrelations/results.

2 Papers from the first workshop on the role of the state have been published in Hofmeester, Kessler, and Moll-Murata, Conquerors, Employers and Arbiters; a number of papers from the workshop on demography and family patterns have been published in a special section of History of the Family (vol. 22, no. 1).

3 Tilly and Tilly, Work under Capitalism, p. 22. 
First, the taxonomy distinguishes between those who are able to work and those unable to do so. Next, in Column 2 it distinguishes between the three types of exchange in organizing the interchange of goods and services, including work. These types of exchange link up with the three levels of analysis listed in Column 3, which reflect the target of production: the household (or a community consisting of a group of households), the polity, or the market. There are three principles on which this exchange takes place. The first is reciprocity: work done for other members of the same household or a group of households that form a community. The second principle is tribute giving: work based on obligations vis-à-vis the polity. The third principle is market exchange, in which labour is commodified: in this case the worker - or in the case of unfree labour, the owner of the worker sells their means of production or the products of their work. In Column 4, the labour relations of individuals are listed. They are based on the position of individuals within the entities that organize labour (households, polities, and markets), the degree of freedom, and the methods of remuneration.

The preliminary outcomes of this project suggest that in the long run, the proportion of the population engaged in commodified labour increased at the expense of reciprocal labour and tributary labour. Commodified labour began earlier than expected, but at the same time reciprocal labour lasted longer than previously assumed. This can be explained by another important finding, that, from early on, many individuals and households pooled various types of labour relations (for example, combining commodified labour with reciprocal labour). Shifts in labour relations are frequently manifested as shifts in combinations of labour relations. Within the category of commodified labour, we see a change from self-employment to wage labour. This was not a linear development. The most recent examples are the many regions in the world that exhibited decreases in wage labour in the twenty-first century. What drove these developments?

In New Institutional Economics, institutions and institutional change are identified as crucial variables in shaping all economic relations, thus including labour relations. Douglass North defines institutions as "humanly devised constraints that structure political, economic and social interactions". ${ }^{4}$ These constraints may be both formal (for example, constitutions, laws, and property rights) and informal (for example, customs and traditions). It is the purpose in this volume to analyse and explain the development of labour relations by looking at the institutions pertaining to various economic resources in society: commodities, land, labour, and capital. Institutions 
can affect the distribution of these resources across the population, which can in turn determine labour relations.

Daron Acemoglu, Simon Johnson, and James Robinson are strongly influenced by North and the institutional approach. ${ }^{5}$ They suggest that those countries colonized by European powers that were relatively rich 500 years ago, are now relatively poor - and vice versa - and argue that this reversal reflects an "institutional reversal" caused by the colonial powers. In those areas that were relatively prosperous and densely settled in 1500 , or that were characterized by high rates of (European) settler mortality due to tropical diseases, the Europeans introduced (or maintained already existing) extractive institutions to profit from this wealth, whereas in poorer and sparsely populated areas, Europeans themselves settled in large numbers, and created "inclusive" institutions that safeguarded private property, thereby encouraging commerce and industry. ${ }^{6}$ More recently, they have synthesized this research in Why Nations Fail. ${ }^{7}$ Their work has been highly influential and has prompted economists to take more seriously the role of the history of institutions, especially of colonial institutions in the Global South. ${ }^{8}$ As a result, various economists have started testing whether the implementation of a specific institution in the past (for example, the slave trade, the mita, or colonial land revenue systems) had long-term consequences for economic development in Africa, Latin America, and Asia. ${ }^{9}$

Nevertheless, such works have not remained without critics, and some have questioned the quality of the underlying data used in the analyses, especially the data on settler mortality and population density in the 1500 benchmark. ${ }^{10}$ Historians have pointed out the rather a-historical approach taken up by these "historical" economists. Regression analyses linking a point in the past (1500) with outcomes expressed in terms of GDP per capita

5 See Acemoglu, Johnson, and Robinson, “Colonial Origins”; Acemoglu, Johnson, and Robinson, "Reversal of Fortune".

6 Acemoglu, Johnson, and Robinson, "Reversal of Fortune”, p. 1279.

7 Acemoglu and Robinson, Why Nations Fail.

8 See the discussion in Nunn, "The Importance of History for Economic Development". Also see Woolcock, Szreter, and Rao, "How and Why Does History Matter for Development Policy?". 9 Widely cited examples include Nunn, "The Long-Term Effects of Africa's Slave Trades"; Dell, “The Persistent Effects of Peru's Mining Mita”; Banerjee and Iyer, "History, Institutions and Economic Performance".

10 See, e.g., Albouy, "The Colonial Origins of Comparative Development"; Austin, "The 'Reversal of Fortune' Thesis". See also Easterly and Levine, "The European Origins of Economic Development". The authors show that the small number of European settlers indeed correlates with a stagnating economic growth. They do not find evidence, however, that this was caused by institutions. 
today, suffer from what Gareth Austin terms the "compression of history". Institutions were clearly not the same over this long period of time (half a millennium), and nor were the consequences of these institutions. In this volume, we follow up on such critiques and investigate the relationship between institutions and labour relations over time, focusing on changes that took place both in institutions (for example, in response to indigenous reactions) and in their effects as time progressed. ${ }^{12}$

In congruence with some of the other literature that has appeared over recent years, we believe that colonial regimes had more manifestations than the binary classification put forward by Acemoglu and colleagues. Anthony Hopkins, for example, notes that among historians it is currently more common to differentiate between at least three types of colonies: settlements (such as South Africa), concessions (such as the Belgian Congo), and trade colonies (such as Nigeria). ${ }^{13}$ The regimes that were introduced were not only determined by geography, endowments, population density, or orders from the metropolis, but also by pre-colonial power relations, including economic institutions such as rules on land distribution, property rights, and tribute and tax systems. In addition, the response of the indigenous and other population groups to the institutions that the colonizers established, ${ }^{14}$ or tried to establish, have to be taken into account to obtain a complete picture.

Furthermore, the works that try to show the persistent effects of colonial institutions primarily focus on economic growth and how to explain it. While labour and labour relations do play a role in these works, it is always described from this perspective, and often in a static and generic manner. To give just one important example: the availability and allocation of labour is generally not discussed as a variable, although a recent publication edited by Gareth Austin and Kaoru Sugihara is a very welcome exception to that rule. ${ }^{15}$ Furthermore, it is not always clear what "extractive" institutions

11 Austin, "The 'Reversal of Fortune' Thesis".

12 Jerven, "African Growth Recurring", focuses on periods of economic growth, explaining them by looking at institutions that changed over time as a consequence of African agency in the form of economic specialization. Labour and labour relations do not play a role in his argument, however.

13 Hopkins, "New Economic History", p. 168. Ewout Frankema distinguishes four types of colonial states and relates them to the character of their tax levels and spending patterns. See his "Colonial Taxation and Government Spending in British Africa".

14 See, for example, Bayly, "Indigenous and Colonial Origins", on institutional changes spurred by indigenous elites in Colonial India in the nineteenth century. On the local elites in the Spanish empire, see Grafe and Irigoin, "A Stakeholder Empire".

15 Austin and Sugihara, and the authors of the articles in their edited volume Labour-Intensive Industrialization in Global History, do analyse labour as a variable, discussing not only its 
are and how these have changed due to colonial rule. A distinguishing feature of extractive institutions, according to Acemoglu and colleagues, is "a high concentration of political power in the hands of a few who extracted resources from the rest of the population". ${ }^{16}$ As an example, they mention the silver-mining networks set up by the Spanish and Portuguese colonizers that were based on forced labour and oppression of the native population with the help of monopolized military power to extract silver. ${ }^{17}$ The contribution by Rossana Barragán in this volume shows, however, that the situation in the Potosí silver mines was far more complex - characterized by a wide range of labour relations and an important role for indigenous and "informal" institutions - and that it is was more dynamic than the description by Acemoglu and colleagues suggests. In this respect, the non-Eurocentric, more global approach to institutions (both formal and informal) as suggested by Jean-Laurent Rosenthal and Roy Bin Wong, seems more fruitful than the division between "good" inclusive institutions, more or less based on what was the norm in Western Europe, and "bad" extractive institutions that were established in other parts of the world..$^{18}$

The concept of "inclusive institutions", that is, institutions that "secure private property, an unbiased system of law, and a provision of public services that provides a level playing field in which people can exchange and contract" ${ }^{\prime 19}$ may also benefit from further refinement. In South Africa, British colonial power created inclusive institutions in the sense that there were constraints on executive power and secure private property rights. Nonetheless, despite colour-blind laws and a functioning democratic system, the specific institutions created to supply the diamond mines with labour were openly racist and excluded many black workers from private property and an opportunity to "contract", as Karin Hofmeester shows in her chapter. Further, the European institutions mentioned in Matthias van Rossum's chapter on maritime labour relations in Europe and Asia, enforced upon Asian (maritime) labour markets, can be considered "inclusive" economic institutions, organizing market exchange and safeguarding contractual agreements. These contracts, however, generally did increase inequalities

availability and allocation (including the allocation and division of labour within the household), but also the quality of labour and the role of colonial and also indigenous or local and often very informal (among others, schooling and training) institutions that played a role in it. See especially p. 296 for this.

16 Acemoglu, Johnson, and Robinson, "Reversal of Fortune", p. 1234.

17 Ibid., p. 1264.

18 Rosenthal and Wong, Before and Beyond Divergence.

19 Acemoglu and Robinson, Why Nations Fail, pp. 74-75. 
in power relations, as they often favoured the claims of employers over the protection of the rights of labourers.

Power relations are a crucial element in both the development and the effects of institutions. ${ }^{20}$ In this volume, Elias C. Mandala examines power relations between the colonial governments and capitalist enterprises. $\mathrm{He}$ discusses how the high freight costs charged by private railroad owners in Malawi hindered the development of the cotton industry that the British colonizers so eagerly wanted to stimulate. Another example is the British colonial officials in South Africa, who tried to gain mineral rights, but lost the battle with the internationally financed diamond-mining companies. In addition, the power relations between the colonial rulers in the metropolis and the colonial administrators "on the ground" in the colonies should be taken into account if we want to know the exact effects of colonial institutions. In both Java and Cuba, the powerful sugar plantation conglomerates were well able to further their interests vis-à-vis those of the (semi-) colonial state, as Ulbe Bosma's contribution demonstrates.

To establish a more precise relationship between colonial institutions and changing labour relations, we want to take the pre-colonial, colonial, and post-colonial periods into account and carefully look at changes over time in the institutions and the various forms of labour relations that prevailed, both unfree and free. We want to examine the agency of the workers and their possible options to combine labour relations to at least partially opt out of the labour system the colonizers established. Various contributions in this volume therefore also deal with the role of migratory labour and household labour strategies, including the work carried out by women and children.

It is our intuition that colonial rule, which originated from the European quest for exotic commodities, first and foremost manifested itself in the systems of production and trade of global commodities. Therefore the first, and largest, section of this volume is devoted to institutions related to commodity production and trade. Scholars such as Immanuel Wallerstein and Andre Gunder Frank have argued that between 1500 and 1900, global trade resulted in a specific pattern of intercontinental specialization: whereas the periphery concentrated on the production of primary goods, the European core could shift part of its production into more productive sectors of the

20 See also Acemoglu and Robinson, Economic Origins of Dictatorship and Democracy; North, Summerhill, and Weingast, "Order, Disorder and Economic Change”; North, Wallis, and Weingast, Violence and Social Orders. For a specific focus on labour, see Cooper, Decolonization and African Society. 
economy, such as manufacturing. ${ }^{21}$ More recently, Jeffrey Williamson argued that the favourable terms of trade for cash crops led to deindustrialization in the "poor periphery". ${ }^{22}$ As these economies focused on the export of only a few cash crops, they also became more vulnerable to price volatility.

In his contribution, William Clarence-Smith takes issue with these narratives. He emphasizes that industries in the "Global South" in the nineteenth century were much more developed than one might think when starting off from deindustrialization and dependency theories. He stresses that in addition to the role of import-substitution of consumer goods, export substitution, artisanal production (including producing under putting-out, sharecropping, and other more complex forms of labour relations), and the processing of "primary goods" were important in the development of industries in the developing world. The latter development could lead to more wage labour, though other forms of (unfree) labour were also applied. His chapter convincingly shows that (colonial) economic institutions during the free trade period (the 1850s to 1914) stimulated the development of industries in the developing world, whereas the institutions developed during the period of protection (1914 to the 1950s) had severely hindering effects, especially on export substitution.

In his contribution concerning cotton agriculture in Malawi, Mandala shows that although the British wanted to introduce commercial agriculture based on European capital and African wage labour, the high producer costs, low cotton prices, and resistance of rural Africans to wage labour, led to the failure of capitalist agriculture. Instead, cotton production came to be based on unpaid family labour on peasant smallholdings. Malawian peasants responded to economic realities and British demands for cotton by integrating cotton cultivation within their existing systems of food production as well as other economic activities, often combining several types of labour relations. Mandala furthermore shows that despite the general failure of cotton agriculture, which had negative effects for the wider economy, there were few substantive differences between the British colonial policies and institutions and those of the post-colonial governments (which continued to pay low prices to producers and extracted the surpluses, as they sold the cotton for a higher price on the world market).

The production of specific global commodities has been associated with specific modes of production. In a famous contribution, Stanley Engerman and Kenneth Sokoloff associate the production of sugar, tobacco, and 
cotton with large-scale production on plantations using slave labour. ${ }^{23}$ As ever-increasing quantities of sugar, coffee, cotton, and other products, in various stages of production, were being transported across the globe, labour relations changed. However, the organization of production (and thus the associated labour relations) might not only differ between commodities (some raw materials have to be processed into manufactured goods before they can be transported, others not). The organization of production of one particular product - as Ulbe Bosma shows in his contribution about sugar and Karin Hofmeester indicates in her chapter about diamonds - could also differ between areas, depending on the scale of production and the method of financing the operations. What the contribution by Clarence-Smith shows, is that some of the export processing industries in the Global South disappeared because of protective institutions (such as tariffs and import restrictions) developed by the colonial powers to protect labour in the metropolis. This same protection of labour in the metropolis could lead to worsening labour conditions and labour relations for maritime labour in Asia, as Matthias van Rossum discusses. Thus, changes in colonial economic institutions could lead to shifts in labour relations, both in the colonies and at home. As Elise van Nederveen Meerkerk illustrates, the introduction of the Cultivation System (in Dutch: cultuurstelsel) in the Netherlands Indies altered institutions such as property rights, which not only affected labour relations in the colonies, but also led to changing labour relations in the Netherlands.

In addition, various studies have emphasized indigenous reactions to the implementation of colonial institutions. ${ }^{24}$ Following up on this, the current volume also takes into account the agency of different population groups as they responded to changing colonial institutions. In some cases, local institutions could not be replaced or controlled by colonial institutions, such as land property rights, the bazaar, and the role of the middlemen in India, as discussed in the contribution by Bosma. The resistance of African farmers to engage in wage labour hindered the rise of a capitalist cottonfarming sector in Malawi, as mentioned above. The same resistance against (often unfree) forms of wage labour can be found in various other African

23 Engerman and Sokoloff, "History Lessons".

24 See, for example, Bayly, "Indigenous and Colonial Origins"; Hopkins, "New Economic History", p. 170, and Cooper, Decolonization and African Society. The latter focuses on labour and responses to colonial and post-colonial institutions. More recently, Ewout Frankema, Erik Green, and Ellen Hillbom have shown that the actions indigenous people undertook determined to a large extent the institutions established by colonial governments. See their "Endogenous Processes of Colonial Settlement". 
countries, such as the Belgian Congo. The alternative of subsistence or independent commercial farming played an important role in the reluctance of Africans to take up wage labour in the Belgian mines and plantations. With the introduction of forced cultivation and the destruction of local markets, this alternative disappeared. As the information on the Netherlands Indies in the contribution by Elise van Nederveen Meerkerk shows, this was less the case under the Cultivation System. ${ }^{25}$ Apart from resisting wage work, there are also examples of workers running off and starting out for themselves, such as the slaves in the Brazilian diamond mines as discussed by Hofmeester. Various contributions discuss the importance of (seasonal) migration. Yet another indigenous response that can be identified is the rearranging of household strategies. If we take the agency of the indigenous population seriously, we should include the whole population and thus also look at gendered responses to colonial institutions. The chapter by Van Nederveen Meerkerk shows that the "extractive institution" embodied by the Cultivation System initially caused a shift among a large group of Javanese women from working for the market to subsistence labour. However, the later reawakening of the textile industry was based on their return to producing textiles for the market. Van Nederveen Meerkerk's contribution makes a case against the deindustrialization thesis. In addition, both her contribution and that of Clarence-Smith stress the importance of local consumption for commodity production (and thus labour relations) in the overseas areas.

Access to land and labour is of course vital to commodity production, and as such it is dealt with in the first part of this volume, which is therefore the largest. In a provocative recent publication, Bas van Bavel suggests first of all that markets for land, labour, and capital have existed since antiquity, and are thus not a modern phenomenon as often thought. However, he admits that in some parts of the world, markets for land and labour remained weak up to the nineteenth century. ${ }^{26}$ In many of these areas, colonial powers thus played an important role in introducing such markets and altering the previous systems for allocating labour and land. One of his main points is that the rise of markets for land and labour is, in the long run, associated with greater discrepancies in wealth and power. ${ }^{27}$ Colonial elites often

25 See Houben and Seibert, “(Un)freedom”. For the consequences of later institutional changes in the Netherlands Indies and Belgian Congo and their effects among others on (forced) labour, see Booth, "Varieties of Exploitation".

26 Van Bavel, The Invisible Hand?, p. 14.

27 Ibid., p. 21. 
brought in, or maintained, coercive elements in markets, which further spurred trends towards more inequality, especially between different ethnic groups. Various contributions to this volume also hint at such dynamics (for example, Van Rossum and Hofmeester).

The second part of the volume is specifically dedicated to the land and labour market institutions established by the colonizers in order to produce the commodities they needed, including cash and food crops. To start with the labour market institutions: the mita is an example of an institution to allocate unfree labour (see Barragán's contribution), in the same way as labour recruitment institutions that consciously established segmented labour markets, which is the subject of the contribution by Van Rossum and is also dealt with in the chapter by Hofmeester where she discusses diamond mines in South Africa. At the same time, a labour market for free wage labour existed in Potosí and aboard the ships in the Asian maritime trade, and various chapters seem to point in the direction of combined labour relations (for example, Barragán, Mandala, and Karin Pallaver). If pre-colonial land property rights of the small-scale peasantry were secured during colonial times, subsistence farming was frequently a way out for workers to escape from forced labour: by migrating back to their small plots of land, workers could escape the system of unfree labour in the mines. Another important element that Barragán puts forward is that the mita changed over time, which contains a clear warning against a static view of the functioning of economic institutions.

The abolition of the slave trade provides a very clear example of changing colonial labour market institutions. What happened to labour relations after this most coercive form - often not established by, but massively expanded by colonial powers and their institutions - had to give way? This is the subject of the contribution by Johan Fourie and Erik Green. They compare the input of slave and local Khoesan labour (often in apprenticeship form but also in working gangs) on pastoral farms in the interior of the Cape Colony after a ban was introduced on the import of slaves. At first, a shift of slave labour from the west to the east of the Cape Colony took place and an increase of slave labour went hand in hand with a decrease of Khoesan labour in the farms in the interior. After the ban on the import of slaves of 1807 , and the 1809 colonial labour code that restricted Khoesan labour mobility and enabled farmers to tie the children of Khoesan labourers to their farm for unpaid labour, a form of semi-bonded labour, the authors note a decrease of slave productivity and an increase of Khoesan (bonded) labour.

The final part of the volume contains two examinations of the effects of monetization and taxation on labour relations. To date, few scholars have 
connected the study of numismatics with the study of labour relations. In this volume, we bring together two prominent experts in this field and we hope that these stimulating contributions will spur further study at this intersection. Colonial powers often introduced currencies and tried to "extract" money via taxation. It was also hoped that imposing taxes, which required the local population to have cash, would increase the availability of wage labour (also discussed in the contribution by Mandala). All of this led to increased commercialization, the commodification of labour, and the monetization of the colonial economies. As a side effect, the local population sometimes entered into wage labour relations to be able to buy products that became available because of the colonial presence. Pallaver, however, suggests that taxation was not always a very effective way to raise the number of permanent wage labourers in the East African Protectorate in the late nineteenth and early twentieth century, as one month of wage work or the sale of a small amount of livestock sufficed to pay the annual hut tax. Finding enough wage labourers remained problematic in the colony until the latter half of the 1920s, when economic crises, growing population pressure in the reserves, and a growing African taste for consumer imports, ensured an adequate flow of labourers without further coercion by the colonial state. There were two types of coins that were used to pay for wage labour, the large denominations of silver rupees ("the coercive currency of taxes") and the smaller copper cents. Rupees were paid to those permanent labourers who needed colonial money to pay the tax or to buy cattle to provide a bridewealth. These were workers who were unable to increase their agricultural production or sell cattle in order to obtain the money needed for tax payments. However, for everyday needs, it was sufficient to work for only a few days and to obtain cents. These were then used in the local markets. Women, who worked for wages only for very short periods, were instrumental in favouring the circulation of cent coins, as were casual labourers. The circulation in cents says something about women's wage labour. Pallaver's contribution clearly shows the direct relationship between labour relations and the circulation of coins of specific denominations.

Jan Lucassen works on the same theme in his contribution and finds that the degree of monetization in societies is a good proxy for the prevalence of wage labour. On the basis of estimates of the amount of small denomination currencies in circulation per capita, he derives levels of monetization for Europe and Asia in the second millennium and finds that India and Europe generally had similar levels of monetization between 1000 and 1900, but that China had generally (much) higher levels. Furthermore, he shows that Europe and India show roughly similar trends in the degree of monetization over 
this period, whereas trends in China exhibit different movements. Although these developments in monetization in part depend on the availability of institutions supplying (small) credit to workers, Lucassen argues that there is a strong relationship with shifts in labour relations: rises in monetization coincide with shifts from unfree to free labour, and from reciprocal to commodified labour. Lastly, he provides examples where workers demanded payment in specific types of coins, again demonstrating the agency and responses of local workers to institutions and institutional changes.

In sum, inspired by the path-breaking works of North and Acemoglu and colleagues, this collection of writings tries to explain shifts in labour relations by focusing on the effects of colonial institutions. In all the contributions, it becomes clear that colonial institutions played a major role in the persistence or change of certain labour relations. However, the precise manner in which these institutions were implemented and the channels through which they affected labour relations were dependent on local contexts and more complex than one would expect on the basis of a binary model of inclusive versus extractive institutions. Colonial powers were often not in a position to simply introduce institutions as they saw fit: they were not able to easily change pre-colonial institutions, but instead took over those institutions and made adaptations. The implementation of institutions by colonial governments was often contested by local populations, but also by the power of international capitalists. In terms of changes in labour relations, the implementation or adaption of institutions did not always lead to the shifts anticipated or wished for by colonial governments. Nor did colonial governments in the overseas territories simply execute policies or implement institutions as they were set out by governments in the metropolis. Local colonial officials also did not always carry out orders from the metropolis, suggesting that power relations played an important role in the actual functioning of institutions at various administrative levels. It is important that the local population often reacted to the colonial policies and institutions by combining labour relations. Furthermore, the aforementioned nuances and complications also blur the distinction between extractive and inclusive institutions. If one zooms in closer on the effects for different types of workers, the effects of what in principle may be seen as inclusive institutions were in practice quite extractive and vice versa. In emphasizing these complicated interactions between institutions and labour relations, this volume hopes to contribute to the wider literature on the effects of colonial institutions on development and the role of labour and labour relations in this, as well as to our understanding of the factors influencing changes in labour relations from the fifteenth century onward. 


\section{Bibliography}

Acemoglu, Daron, and J. Robinson, Economic Origins of Dictatorship and Democracy (Cambridge, 2006).

Acemoglu, Daron, and J. Robinson, Why Nations Fail: The Origins of Power, Prosperity and Poverty (New York, 2012).

Acemoglu, Daron, Simon Johnson and James A. Robinson, "The Colonial Origins of Comparative Development: An Empirical Investigation”, American Economic Review, 91 (2001), pp.1369-1401.

Acemoglu, Daron, Simon Johnson and James A. Robinson, "Reversal of Fortune: Geography and Institutions in the Making of the Modern World Income Distribution", Quarterly Journal of Economics, 117 (2002), pp. 1231-1294.

Albouy, David Y., “The Colonial Origins of Comparative Development: An Empirical Investigation: Comment", American Economic Review, 102 (2012), pp. 3059-3076.

Austin, Gareth, "The 'Reversal of Fortune' Thesis and the Compression of History: Perspectives from African and Comparative Economic History", Journal of International Development, 20 (2008), pp. 996-1027.

Austin, Gareth, and Kaoru Sugihara (eds), Labour-Intensive Industrialization in Global History (London, 2013).

Banerjee, Abjith, and Lakshmi Iyer, "History, Institutions and Economic Performance: The Legacy of the Colonial Land Tenure Systems in India", American Economic Review, 95 (2005), pp. 1190-1213.

Bayly, C.A., "Indigenous and Colonial Origins of Comparative Economic Development: The Case of Colonial India and Africa”, World Bank Policy Research Working Paper 4474 (2008).

Booth, Anne, "Varieties of Exploitation in Colonial Settings. Dutch and Belgian Policies in Indonesia and Congo and Their Legacies", in Ewout Frankema and Frans Buelens (eds), Colonial Exploitation and Economic Development: The Belgian Congo and the Netherlands Indies Compared (London, 2013), pp. 60-87.

Cooper, Frederick, Decolonization and African Society: The Labor Question in French and British Africa (Cambridge, 1996).

Dell, Melissa, “The Persistent Effects of Peru's Mining Mita”, Econometrica, 78 (2010), pp. 1863-1903.

Easterly, William, and Ross Levine, "The European Origins of Economic Development", NBER Working Paper 18161 (2012).

Engerman, Stanley, and Kenneth Sokoloff, "History Lessons: Institutions, Factor Endowments and Paths of Development in the New World", Journal of Economic Perspectives, 14 (2000), pp. 217-233.

Frankema, Ewout, "Colonial Taxation and Government Spending in British Africa, 1880-1940", Explorations in Economic History, 48 (2011), pp. 136-149. 
Frankema, Ewout, Erik Green, and Ellen Hillbom, "Endogenous Processes of Colonial Settlement: The Success and Failure of European Settler Farming in Sub-Saharan Africa", Revista de Historia Economica, 34 (2016), pp. 237-265.

Grafe, Regina, and Alejandra Irigoin, "A Stakeholder Empire: The Political Economy of Spanish Imperial Rule in America", Economic History Review, 65 (2012), pp. 6o9-651.

Gunder Frank, Andre, World Accumulation (New York, 1978).

Hofmeester, Karin, Gijs Kessler, and Christine Moll-Murata (eds), Conquerors, Employers and Arbiters: States and Shifts in Labour Relations, 1500-2000, special issue of International Review of Social History, 61:S24 (2016).

Hofmeester, Karin, Jan Lucassen, Leo Lucassen, Rombert Stapel, and Richard Zijdeman, "The Global Collaboratory on the History of Labour Relations, 1500-2000: Background, Set-Up, Taxonomy, and Applications" (2015). Available at: http:// hdl.handle.net/10622/4OGRAD.

Hopkins, Anthony, "The New Economic History of Africa", Journal of African History, $5^{0}$ (2009), pp. 155-177.

Houben, Vincent, and Julia Seibert, "(Un)freedom. Colonial Labor Relations in Belgian Congo and the Netherlands Indies Compared", in Ewout Frankema and Frans Buelens (eds), Colonial Exploitation and Economic Development: The Belgian Congo and the Netherlands Indies Compared (London, 2013), pp. 178-192 Jerven, Morten, "African Growth Recurring: An Economic History Perspective on African Growth Episodes, 1690-2010", Economic History of Developing Regions, 25 (2010), pp. 127-154.

North, Douglass C., "Institutions", Journal of Economic Perspectives, 5 (1991), pp. 97-112.

North, Douglass C., John Joseph Wallis, and Barry R. Weingast, Violence and Social Orders: A Conceptual Framework for Interpreting Recorded Human History (Cambridge, 2009).

North, Douglass C., William Summerhill, and Barry R. Weingast, "Order, Disorder and Economic Change", in B. Buen de Mesquita and H.L. Roots (eds), Governing for Prosperity (New Haven, 2000), pp. 17-58.

Nunn, Nathan, "The Importance of History for Economic Development", Annual Review of Economics, 1 (2009), pp. 65-92.

Nunn, Nathan, “The Long-Term Effects of Africa's Slave Trades”, Quarterly Journal of Economics, 123 (2008), pp. 139-176.

Rosenthal, Jean-Laurent, and Roy Bin Wong, Before and Beyond Divergence: The Politics of Economic Change in China and Europe (Cambridge, 2011).

Tilly, Charles, and Chris Tilly, Work under Capitalism (Boulder, 1998).

Van Bavel, Bas, The Invisible Hand? How Market Economies Have Emerged and Declined since AD 500 (Oxford, 2016). 
Wallerstein, Immanuel, The Modern World System, 3 vols (New York, 1974-1989).

Williamson, Jeffrey, Trade and Poverty: When the Third World Fell Behind (Cambridge, MA, 2011).

Woolcock, Michael, Simon Szreter, and Vijayendra Rao, "How and Why Does

History Matter for Development Policy?", Journal of Development Studies, 47 (2011), pp. 70-96.

\section{About the Authors}

Karin Hofmeester is Senior Researcher and Deputy Director of Research at the International Institute of Social History in Amsterdam (The Netherlands) and Professor of Jewish Culture at the University of Antwerp (Belgium). Her publications include The Joy and Pain of Work: Global Attitudes and Valuations, 1500-1650 (Cambridge, 2012) (co-edited with Christine Moll-Murata), Luxury in Global Perspective: Objects and Practices, 1600-2000 (Cambridge, 2016) (co-edited with Bernd-Stefan Grewe), Conquerors, Employers, and Arbiters: States and Shifts in Labour Relations, 1500-200o (Cambridge, 2016) (co-edited with Gijs Kessler and Christine Moll-Murata).

E-mail: kho@iisg.nl

Pim de Zwart is Assistant Professor at the department of Rural and Environmental History, Wageningen University (The Netherlands). He received his $\mathrm{PhD}$ (cum laude) from Utrecht University in 2015 and his work has mainly dealt with the Dutch East India Company (VOC) and the integration of global commodity markets and the development of living standards in the VOC's empire in the East Indies in the period between 1600 and 1800. Articles on these subjects have appeared in, among others, the Journal of Economic History and the European Review of Economic History and he has recently published a book entitled Globalization and the Colonial Origins of the Great Divergence (Leiden, 2016).

E-mail:pim.dezwart@wur.nl 


\section{Part I}

Labour in the Production of Global Commodities 



\title{
2 The Industrialization of the Developing World and Its Impact on Labour Relations, 1840 s to 1940 s
}

\author{
William G. Clarence-Smith
}

Hofmeester, Karin \& Pim de Zwart (eds.), Colonialism, Institutional Change, and Shifts in Global Labour Relations. Amsterdam: Amsterdam University Press, 2018

DOI: $10.5117 / 9789462984363 / \mathrm{CHo} 2$

\begin{abstract}
The deindustrialization of the developing world is a myth. Modern manufacturing extended beyond the import substitution of consumer products to modernizing handicrafts, export processing, intermediate and light capital goods, and certain services. Developing economies were held back, partly by internal factors resulting in low productivity, and partly by aspects of imperialism. While some Westerners sought modernization, others followed "romantic anti-capitalism", and Western labour leaders obtained protection to save jobs for their followers. Manufacturing did well in the era of free trade, and faltered after 1914. The impact on labour relations was ambivalent. Modern industry is usually linked to free wage labour, but slaves, bonded workers, family members, and part-time peasants all worked in manufacturing in the developing world.
\end{abstract}

Keywords: handicrafts, import substitution, export processing, imperialism, protection, labour

\section{Introduction}

It is argued in this chapter that the deindustrialization of the developing world in modern times is a myth. However, no attempt is made to quantify the scale and speed of industrial growth in these lands. Only a radical re-thinking of the issue will enable cliometricians to begin the arduous task of revising the statistics, from the bottom up. 
Historiographical blindness to industrialization in the developing world partly reflects the influence of Dependency Theory. For "dependentistas", the purpose of free trade was not to increase the wealth of all while securing world peace. Instead, free traders set out to destroy existing industries on the "periphery", prevent the creation of new ones there, and keep manufacturing as a monopoly of "core" countries. The public institutions of late-developing countries therefore had to intervene in a wide variety of fields to achieve industrialization. ${ }^{1}$

Jeffrey Williamson has recently restated the deindustrialization thesis, while pointing to causes that were economic rather than political. In the nineteenth century, terms of trade favoured raw materials, causing the Third World to turn to the production of primary goods. Producing raw materials harmed long-term economic growth, however, because techniques failed to raise the productivity of labour. As terms of trade gradually became less favourable for primary goods, Third World industrialization began on a modest scale. Williamson further proposes that prices for raw materials were particularly volatile, damaging the economies of primary producers. ${ }^{2}$

Although coming at the issue from different perspectives, these two schools of thought work in terms of a priori definitions. As Kathy Ferguson writes, with regard to feminism, "The questions we can ask about the world are enabled, and other questions disabled, by the frame that orders the questioning. When we are busy arguing about the questions that appear within a certain frame, the frame itself becomes invisible; we become enframed within it."3

As a result of distorting ideological frames, research on the industrialization of the developing world, and the impact this had on labour relations, remains in its infancy. Two decades ago, Ian Brown rightly noted, referring to Southeast Asia, that "distressingly little has been written on the growth of modern industry", even though the sector was "surprisingly substantial" by $1938 .{ }^{4}$ Since he wrote that, advances in research have been limited, not just with regard to Southeast Asia, but also across all developing economies.

For labour relations, the extent and nature of industrialization in the Global South had significant implications, though these are not what they might appear to be at first glance. A larger manufacturing sector than heretofore envisaged might seem to imply a more precocious proletarianization

$1 \quad$ Wallerstein, The Modern World-System; Jean Batou, Cent ans de résistance au sousdéveloppement; Kemp, Industrialisation in the Non-Western World.

2 Williamson, Trade and Poverty.

3 Ferguson, The Man Question, p. 7 .

4 Brown, Economic Change in Southeast Asia, pp. 204, 214. 
of labour than that portrayed in previous literature. In reality, however, the types of industry that developed were extremely diverse, ranging from enormous state-of-the-art factories to partially modernized workshops. Moreover, the social and cultural contexts in which industrialization expanded also differed greatly. Unsurprisingly, all the forms of labour analysed in this volume were represented, whether reciprocal, tributary, or commodified.

\section{Industrialization in developing economies: An overview}

Modern manufacturing is defined as the application of inanimate energy, machinery, and scientific knowledge to produce both goods and services. Supplies of inanimate energy progressed from coal-fired steam engines, through oil-fired engines, to electric motors. From this perspective, it makes no sense to limit industrialization to the import substitution of consumer goods for the internal market, as Gregg Huff does for Malaya. Indeed, he soon finds himself obliged to consider other forms of manufacturing. ${ }^{5}$ It is even more perilous to take the production of finished textiles for the internal market as a proxy for industrialization, as Williamson does, following in the footsteps of many before him. ${ }^{6}$ Communist commentators demonstrated yet another ideological obsession, by stressing heavy capital goods, for example, at the Sixth Comintern Congress of 1928.7

A more satisfactory enframing of industrialization must extend to types of manufacturing other than the factory-based import substitution of consumer goods. Export-substituting plant, processing raw materials for foreign markets, was of great significance. The frame of reference should also be enlarged to consider the production of intermediate and light capital goods for internal consumption, industrialized services, and handicrafts, all of which almost imperceptibly became industrial. Although there remains a crucial question as to why most developing economies did not industrialize more deeply and more rapidly, it is wise to begin with what was actually achieved.

The balance between the impact of internal and external factors on industrialization is hard to establish. As Sidney Pollard observes, internal factors largely explain why Scandinavia overcame the challenges faced by the "third wave" of industrialization, whereas many parts of southern and 
eastern Europe did not. ${ }^{8}$ Internal factors could be institutional in a narrow sense, for example, in terms of governance, but could also embrace wider social and cultural factors, which would fall into Douglass North's broad definition of institutions. ${ }^{9}$ In this vein, historians of East Asia have debated skill sets, and views of society and the world. ${ }^{10}$

Imperialism is the external factor most commonly blamed for hampering industrialization, but its impact was equivocal. Westerners sometimes attempted to impose a package of relentless modernization on "the rest", including factories. ${ }^{11}$ Vietnam was set to become a "new Japan" in the 1930s, even though the plans met with strong domestic opposition in France, and were only partially enacted before the outbreak of war. ${ }^{12}$ At the opposite end of the spectrum, an ethos of romantic anti-capitalism sought to protect subjects from "dark Satanic mills". ${ }^{13}$ One example was Catholic missionary theocracies in Angola, harking back to the famous Jesuit Reductions of Paraguay. ${ }^{14}$

To the extent that imperialist protectionism harmed industrial growth in developing economies, it often originated in institutions of organized labour. Leaders flexed their growing muscles - industrial and political to hinder the establishment of factories on the periphery, believing that they were saving jobs at home for their members. Trade unionists allied with marginal and declining industrialists, whereas many dynamic and successful entrepreneurs favoured peripheral industrialization. Jacques Marseille was a pioneer of analysing this process in France and its empire, and it could also be observed in the Portuguese case. ${ }^{15}$

In terms of periodization, Williamson wrongly asserts that the nadir of Third World industry correlated with the zenith of free trade in the long nineteenth century. The era of free trade actually involved a rapid development of factories for export processing and intermediate goods, the industrialization of some services, and a hesitant emergence of importsubstituting industries, whether craft based or not. Conditions were favourable in many respects. The "colonial peace" was generally achieved quickly and cheaply, due to the technological gap between the West and the

9 North, Institutions.

10 Chan, Business Expansion; Tanimoto, The Role of Tradition.

11 Warren, Imperialism.

12 Bernard, Nouveaux aspects, pp. 79-84.

13 Löwy and Sayre, Romanticism; Kaarsholm, Imperialism.

14 Clarence-Smith, Slaves, pp. 89-93.

15 Marseille, Empire colonial; Marseille, "The Phases of French Colonial imperialism”; ClarenceSmith, The Third Portuguese Empire. 
rest. ${ }^{16}$ Existing infrastructure remained largely unscathed by fighting, and security favoured investment in expensive, risky, and lumpy fixed capital assets. ${ }^{17}$ International migration lowered labour costs and raised skills, and the "coolie system" was not a modern form of slavery. ${ }^{18}$ Non-Western diasporic entrepreneurs brought capital, commercial skills, and an intimate knowledge of markets. They were usually more active and effective in fomenting early manufacturing than firms from colonial metropoles. ${ }^{19}$

By contrast, growing protectionism, particularly from 1914, did much less than Williamson asserts to boost industrialization in developing economies. Protection negatively affected export substitution, while timid attempts at import substitution were incoherent, ineffective, and at times counterproductive. Deepak Lal elegantly argues this for the Indian case, with a wealth of statistical data. ${ }^{20}$

Overall, the industrialization of developing economies consisted of loosely connected strands. Some craft workshops evolved into industrial units, while new factories emerged from the $1850 \mathrm{os}$. Both sectors were oriented to the internal market, but also exported their wares. Modern factories supplied intermediate goods, including light capital equipment, to local and regional markets, simultaneously sustaining newly industrialized transport and energy services. The processing of "primary goods", chiefly for export, was probably the most significant industrial development, yet scholars have accorded little importance to this phenomenon. ${ }^{21}$

\section{The nine lives of artisans}

Logically, dependentistas are wrong to point to the alleged destruction of handicrafts as deindustrialization, because households and workshops were not modern factories. Artisans worked with simple tools, employed mainly human or animal energy, and relied on useful and reliable knowledge, as in the case of Persia. ${ }^{22}$ However, crafts are important to this story,

17 Ferguson, Empire.

18 Northrup, Indentured Labor.

19 Cohen, Global Diasporas; Baghdiantz McCabe, Harlaftis, and Pepelasis Minoglou, Diaspora Entrepreneurial Networks; Dobbin, Asian Entrepreneurial Minorities; Clarence-Smith, "Indian and Arab Entrepreneurs".

20 Lal, The Hindu Equilibrium, pp. 189-198.

21 Pomeranz, The Pacific. 
not only because they survived more effectively than dependentistas allege, but also because some of them gradually approximated to modern industries.

The cause célèbre of the imperialist "destruction" of crafts is the fate of Indian weaving, dominant in the global cotton textile markets of the eighteenth century. ${ }^{23} \mathrm{~A}$ tweet that went viral in 2015 put the argument in dramatic terms: "The British cut off the thumbs of Bengali weavers, smashed their looms, and placed high duties on textile imports into Britain from India." ${ }^{24}$ The last accusation is partly true, even if the tariff of 1813 was introduced in a large part to finance the Napoleonic Wars, and imports from India failed to recover when British tariffs soon fell again in times of peace. ${ }^{25} \mathrm{As}$ for allegations of cutting off thumbs and breaking looms, they are unsupported by evidence, and contrary to logic. The East India Company, which governed India until 1858, benefited from exporting locally woven textiles to Britain, and feared nothing more than an uprising in India. References to cutting off weavers' thumbs are indeed heard in Bengal into our own times, but in a metaphorical sense. ${ }^{26}$

Karl Marx's argument, in Das Kapital, was instead that Indian handicrafts succumbed to imports of cheap industrial goods. He thus stresses the power of machines to create unemployment. In support of his position, Marx cites Governor-General William Bentinck in 1834, to the effect that "the bones of the cotton weavers are bleaching the plains of India". ${ }^{27}$ However, Marx never went to India, and his apocalyptic portrayal has been undermined by decades of painstaking research. Historians now argue that free trade neither destroyed nor devitalized Indian artisans across the board. Instead, the fortunes of different crafts varied tremendously. Hand spinning of yarn retrogressed, whereas handloom weaving boomed, stimulated by the availability of cheap, strong, consistent, machine-made yarn. Dyeing and printing similarly benefited from imports of industrial dyes. The fate of all branches often depended on niche markets. ${ }^{28}$

The situation in China was similar. As late as 1933, some two-thirds of China's sizeable manufacturing output was estimated to come from the artisanal sector. Albert Feuerwerker acknowledges that imports,

24 Small Town Capitalism, pp. 5-18; Tyabji, Colonialism, pp. 25-26. 
increasingly from Japan rather than the West, disrupted handicrafts, but he also demonstrates how some branches effectively reorganized and expanded. Thus, though spinning generally declined, some weavers blended hand-spun weft with machine-made warp, to produce a more durable cloth. Oil pressing and rice milling were among other sectors that stood up well to competition from imports. ${ }^{29}$

Historians of the Middle East have proposed a revisionist account along the same lines. ${ }^{30}$ Although hand spinning declined, neither wheel nor spindle vanished. Indeed, in 1900, hand-spun yarn still accounted for about a quarter of Ottoman needs. As in China, artisans mixed machine-made warp and hand-made weft to produce a popular fabric..$^{1}$ Overall, Suraiya Faroqhi opines, there was probably no absolute decline in Ottoman handicrafts, in terms of either output or employment. ${ }^{2}$

Charles Issawi initially accepted the notion of the destruction of crafts, but by 1982 he had come to recognize that retrogression in some sectors, such as spinning, was counterbalanced by expansion in others. Examples of growth include weaving with imported machine-made yarn, and dyeing and printing with imported aniline dyes. In the same way, metals, leather, wood, pottery, and glass experienced varying fates. ${ }^{33}$

Guilds have bedevilled the issue in the Middle East, because historians have taken the decline of these institutions as a proxy for the retrogression of handicrafts. However, local elites, obsessed with political opposition from guilds, and dreaming romantically of factories, scarcely noticed the large and growing number of non-guild crafts, which were especially prevalent in rural areas. ${ }^{34}$

As for other parts of the world, Donald Quataert exaggerates when he suggests that there were lightly populated economies that "entirely deindustrialized and switched over to the agricultural or emerging service sectors of the new, Third, world". ${ }^{35}$ Kenneth Pomeranz sees the allure of this view, but rightly notes a need for careful qualification..$^{3}$ Southeast Asia is especially relevant in this regard, as geography opened the region to

29 Feuerwerker, The Chinese Economy, pp. 30-43; Feuerwerker, "Handicraft"; Myers, The Chinese Economy, pp. 133-134.

30 Quataert, Ottoman Manufacturing; Owen, The Middle East.

31 Quataert, Ottoman Manufacturing, pp. 23-24, 36-40, 148-149.

32 Faroqhi, Artisans of Empire, pp. 186-188, 192-193, 195-196.

33 Issawi, An Economic History, pp. 151-153. See also Owen, The Middle East, pp. 93-95.

34 Quataert, Ottoman Manufacturing, pp. 6-14.

35 Ibid., pp. 15-16.

36 Pomeranz, The Pacific, pp. xiv-xvii, xxxvi. 
sea-borne imports more than anywhere else on the globe. And yet, weaving grew, stimulated by the availability of machine-made yarn. Dyeing, notably the reputed batiks of Java, benefited from supplies of machine-made cambric cloth and industrial dyes. ${ }^{37}$ Even spinning persisted, for example, in the eastern archipelago, where both drop-spindles and wheels continued into modern times. ${ }^{38}$

Some of Sub-Saharan Africa's artisans also survived and adapted, such as producers of cotton textiles in West Africa. ${ }^{39}$ Indeed, the British famously failed to turn Northern Nigeria into a supplier of raw cotton for Lancashire mills after 1900, in part because dynamic Hausa spinners eagerly bought up the local crop. Moreover, to supplement local supplies, machine-made yarn and plain cloth came on the back of camels across the Sahara, boosting weaving and dyeing. ${ }^{40}$ Even in eastern and southern Africa, where some scholars pronounced the unequivocal death of hand-made textiles, some survived..$^{41}$ The artisans of southern Somalia, who spun cotton with wheels and wove it into cloth, prospered in the nineteenth century. ${ }^{42}$

Latin America's handicrafts were also more resilient than has often been stated. ${ }^{43}$ Natural protection, local tastes, and low incomes played a role in ensuring that artisans continued to ply their trade. ${ }^{44}$ Survival, and expansion in places, also reflected indigenous Amerindian workmanship and patterns of consumption, stretching back to before the European conquest. The Mayan cultural zone of Mesoamerica was a good example of this phenomenon. ${ }^{45}$

\section{Export markets and the stimulation of handicrafts}

Far from merely serving stagnant rural zones and nostalgic cultural norms, artisans exploited rapidly expanding urban markets and new

37 Matsuo, Javanese Cotton Industry, pp. 12-17; Kerlogue, Batik; Brown, Economic Change. See Elise van Nederveen Meerkerk's chapter in this volume.

38 Hamilton, Gift of the Cotton Maiden, pp. 61, 233.

39 Kriger, Cloth in West African History.

40 Candotti, "Cotton Growing".

41 Davison and Harries, "Cotton Weaving"; Clarence-Smith, "Textile Industry".

42 Alpers, "Futa Benaadir".

43 Halperín Donghi, "Economy and Society", pp. 326-327.

44 Bulmer-Thomas, The Economic History, pp. 130-132.

45 Martin, "Weaving the World". 
export opportunities in the West. Forms of export processing long remained artisanal, as in the case of Western Africa's hand-pressed palm oil..$^{46}$ Purchases of hand-made exotic objects benefited from the Arts and Crafts movement, inspired by William Morris, together with burgeoning Orientalist ideals. ${ }^{47}$

Hand-made rugs and carpets fared particularly well, in part because production was technically difficult to mechanize. Western demand sparked significant growth in artisanal production in the Middle East and India, from as early as the 1820 s. Between 1889 and 1913, the value of Ottoman carpet exports doubled, and Iran also benefited..$^{48}$ In India, where carpets had largely been procured from Inner Asia, export opportunities positively transformed artisanal activity. ${ }^{49}$ Embroidery and lace are other examples, with nineteenth-century Ottoman exports of both increasing rapidly..$^{50}$ Although Swiss machines that could produce a reasonable type of lace emerged from around the 1880 s, the quality of machine-made embroidery remained unsatisfactory. Exports of hand embroidery thus thrived, coming initially from Europe, but increasingly from China and the Philippines, especially after the First World War had disrupted commercial circuits. ${ }^{51}$

Swelling numbers of tourists and pilgrims stimulated first the sales, and then the exports, of hand-crafted mementos and souvenirs, notably early in Egypt..$^{2}$ Sindhi Lohana merchants from Hyderabad, today in Pakistan, were quick to seize the opportunity. Settling in many ports around the globe, they sold hand-crafted "curios" to travellers, and later distributed Japanese silks around the world. ${ }^{53}$ Palestine's bustling workshops began by making religious items for pilgrims out of olive wood and mother-of-pearl. Bethlehemite Christian Arabs then gradually dispersed, peddling these items in devoutly Christian lands around the planet. ${ }^{54}$

Hartley, The Oil Palm, ch. 14; Martin, Palm Oil and Protest.

47 Cumming and Kaplan, The Arts and Crafts Movement; Quataert, Ottoman Manufacturing, p. 134; Roy, Traditional Industry, pp. 133, 201-202, 204.

48 Issawi, An Economic History, p. 153; Quataert, Ottoman Manufacturing, ch. 5; Owen, The Middle East, p. 212.

49 Roy, Traditional Industry, ch. 7.

50 Quataert, Ottoman Manufacturing, pp. 16, 132.

51 Amoroso Leslie, Needlework through History.

52 Faroqhi, Artisans of Empire, p. 187.

53 Markovits, The Global World.

54 Norris, "Exporting The Holy Land". 


\section{From crafts to modern industry: Institutional and technical factors}

Scholars are ambivalent about the role of technical versus institutional change in the handicraft sector, for example in British India. In addition to an increasingly elaborate division of labour, workshops grew in size and moved into cities. Their owners slowly became more autonomous of merchants, more dominant over peasant entrepreneurs, and in some senses more capitalist. Caste, kinship, and ethnicity continued to flourish, however, creating complex networks of social patronage..$^{55}$

Technical change further boosted productivity in India. There were indirect contributions from modern transport and from manufactured inputs, such as machine-made yarn, aniline dyes, and sheet metal. More directly, weavers adopted flying shuttles, beam warping, and metal Hattersley domestic looms with foot treadles. The gradual introduction of electric-powered looms further blurred the boundaries between workshops and factories. As for makers of brassware in Moradabad, near Delhi, they took to metal rolling, power forges, power tools for polishing, and eventually, electroplating in nickel and silver..$^{56}$

The picture in East Asia was similarly mixed, despite Western portrayals of artisanal techniques as both "primitive" and unchanging. ${ }^{57}$ Improved wooden foot treadles initially stimulated weaving in China, as well as cotton ginning. Iron-gear looms, imported from Japan, marked a further step..$^{58}$ Korean weavers also upgraded technologically..$^{59}$ As late as 2004, Japanese artisans in Kyoto were weaving expensive silk obi belts for kimonos by hand, while computers generated the patterns for the weavers. ${ }^{60}$

West Java's cotton-weaving industry is an instructive example of how a craft could be technically transformed, while clinging to apparently "traditional" forms of organization for institutional reasons. From the 1880 , wider looms, worked with treadles, produced mainly sarong, cotton clothing in the local style. After 1918, workshops - centred in Majalaya - thrived with imports of cheap and strong Japanese machine-made yarn, on which import duties were halved in 1927. The Textiel Inrichting Bandoeng (TIB), a research institute, developed a new handloom in 1922, and further refined it in 1926. A TIB loom was about five times more expensive than the existing

Roy, Traditional Industry, pp. 20-23, 44-45, 131, 233; Haynes, Small Town Capitalism, pp. 5-18.

56 Roy, Traditional Industry, pp. 44-45, 61-62, 146-148; Morris, "Indian Industry and Business",

pp. 221-222; Haynes, Small Town Capitalism, pp. 3-18.

57 Hommel, China at Work.

$5^{8}$ Feuerwerker, The Chinese Economy, pp. 38, 43.

59 Larsen, "Competition in Absentia".

6 o Personal observation. 
ones, but it could produce about five times the output, and about a third of that of a power loom. Majalaya sarongs dominated Java's internal market, especially from 1933, when Japanese imports were curtailed and yarn was relieved of all duty. Electrification began in 1935, power looms were introduced four years later, and some 500 had been installed in West Java by the beginning of 1942. However, workshops, often owned by entrepreneurs of Chinese and Hadhrami Arab extraction, rarely contained more than four looms, in order to avoid Dutch licensing and taxing of larger units. This artificially made the sector appear less modern than it really was. ${ }^{61}$

Technical advances were not necessarily modern in nature. The thriving batik workshops of Java, which exported some of their output, adopted copper stamps (tjap/cap) from South Asia in the mid-nineteenth century. This greatly increased output and lowered production costs for cheaper batiks, while simultaneously expanding the arena of men's work. ${ }^{62}$ The invention of the canting, a type of pen for the application of melted wax onto cloth, improved more expensive types of batik. This local invention, already in use around 1800 , gradually spread. ${ }^{63}$

In some places, workshops converged with factories over time. ${ }^{64} \mathrm{Joel}$ Mokyr refers to this in a Western context as "growing up". ${ }^{65}$ This process also fitted in with a more general "labour-intensive path to industrialization", which characterized much of Asia as well as parts of Europe ${ }^{66}$ Thomas Smith's pioneering work from the 1950 s stresses convergence as a key to Japan's industrial success, and Erich Pauer elegantly expands on the theme. ${ }^{67}$ Indeed, Masayuki Tanimoto's edited collection shows how some modern Japanese industries gave way to smaller units over time, as in the pearl-button factories of Kansai. ${ }^{68}$ In parts of China as well, such as Gaoyang County in the north, there were intimate connections between handicrafts and modern industries. ${ }^{69}$

61 Matsuo, Javanese Cotton Industry, pp. 18, 26-39, 47, 80; Segers, Manufacturing Industry, pp. 153-156; Dobbin, Asian Entrepreneurial Minorities, pp. 182-184; Sutter "Indonesianisasi", pp. 42-44; Palmer, Textiles in Indonesia, pp. 19-23, 44; Oki, "A Note on the History”, p. 150; Antlöv and Svensson, "From Rural Home Weavers", pp. 113-116; Lindblad, Bridges to New Business, p. 32. 62 Matsuo, Javanese Cotton Industry, pp. 78-79, 86; Kerlogue, Batik, p. 21. See Elise van Nederveen Meerkerk's chapter in this volume.

63 Raffles, History ofJava, vol. 1, pp. 168-169; Ponder, Javanese Panorama, pp. 139-140.

64 Amsden, Asia's Next Giant, pp. 161-164; Owen, The Middle East, pp. 211, 240.

65 Cited in Pomeranz, The Pacific, p. xiv.

66 Austin, and Sugihara, Labour-Intensive Industrialization.

67 Smith, Native Sources ofJapanese Industrialization, pp. 44-45; Pauer, "Traditional Technology". See also Macpherson, The Economic Development, pp. 12-15, 19-22.

68 Tanimoto, The Role of Tradition.

69 Pomeranz, The Pacific, p. xiv; Grove, A Chinese Economic Revolution. 
Certainly, British colonial planners in interwar India did not begin to grasp the need for a symbiotic association between artisanal and modern industry until late in the 1930 s. $^{70}$ Nevertheless, Tirthankar Roy argues cogently that "'traditional' industry represented one root of 'modern' industry in India". For example, the workshops of the brass industry of Moradabad gave rise to modern metal industries. ${ }^{71}$

Sub-Saharan Africa and Latin America displayed much less continuity between artisanal and industrial production. Madagascar, in many ways culturally Asian, provides a rare African example of textile artisans morphing into minor industrialists..$^{72}$ Victor Bulmer-Thomas summarily dismisses any such evolution in Latin America, portraying factories merely as rivals to workshops, which suffered from shortages of capital, lack of sociopolitical influence, and the constraints of family labour. ${ }^{73}$ However, such problems were overcome elsewhere, and scarce labour may have been the main reason for the poor performance of handicrafts. ${ }^{74}$

\section{Labour relations in the handicrafts sector}

Craft production undoubtedly acted as a brake on proletarianization, especially when work took place in rural households. Workers were rarely separated from the means of production, and were thus not obliged to survive by selling their labour power, although they depended to varying degrees on craftwork to supplement their incomes. Reciprocity remained a major principle of labour allocation, mediated by a complex web of social relations of kinship, ethnicity, caste, and so forth. Tributary labour, notably slavery, also made an appearance in some cases. That said, wage labour slowly spread, notably in urban zones.

Putting-out, whereby traders supplied inputs to households, usually rural, and purchased finished products, was common in European protoindustry. Roy argues that this institution was rare in British India, although Haynes depicts the relationship between some weavers and Marwari traders in western India in this light. ${ }^{75}$ In addition, putting-out is said to have existed

72 Fee, "Madagascar's Textiles". 
in the Middle East, Southeast Asia, and China.$^{76}$ In Java, the 1920 involved an upsurge in putting-out for batik production, in order to avoid a Dutch tax levied according to the number of employees. ${ }^{77}$

Craft workers in households were generally assumed to be free family members, but in southern Somalia's cotton textile sector - located in cities rather than in the countryside - the situation was more complicated. Most Somali weavers were free, but of low caste. They spun and wove full time, and bought their food on the market. Family members assisted them, but so did slaves and free clients. The combination of diverse labour relations was especially apparent in this sector. ${ }^{78}$

Even in the slightly more institutional setting of workshops, a bewildering variety of contracts and informal arrangements existed. In China, wage labour probably grew slowly overall, but economic shocks at times reversed this process. Large workshops employed many non-kin workers in textiles, cotton ginning, milling, and the production of salt, metals, and pottery. People classed as "peasant weavers" might have owned many looms, situated in different workshops. ${ }^{79}$

British India's workshops were increasingly urban, and wage work gradually became more common, but share work and piece work frequently prevailed. Credit and apprenticeship tied workers to some extent, albeit never completely. The salience of caste varied greatly, being more significant in weaving than in metals. ${ }^{80}$ Indian weavers were being drawn into trade union activity and strikes by the 1930 s. $^{81}$

A major and unresolved debate over artisanal labour in the modern era concerns the extent to which standards of living fell, stagnated, or rose. In the Indian case, Tirthankar Roy hesitates, accepting that "self-exploitation" was a condition for survival in some cases. ${ }^{82}$ Douglas Haynes is more pessimistic, seeing immiseration as the norm. ${ }^{8}$ It is likely that outcomes were actually extremely diverse, and that improvements in productivity were a key to better conditions of life.

76 Quataert, Ottoman Manufacturing, pp. 85-86; Feuerwerker The Chinese Economy, pp. 33, 38; Matsuo, Javanese Cotton Industry, p. 81; Boomgaard, Children of the Colonial State, pp. 126-129.

77 Vuldy, Pekalongan, pp. 124-125.

78 Alpers, "Futa Benaadir", pp. 77-98.

79 Feuerwerker, The Chinese Economy, p. 31.

80 Roy, Traditional Industry, pp. 149-152, 222-228; Haynes, Small Town Capitalism, p. 14.

81 Haynes, Small Town Capitalism, p. 15.

82 Roy, Traditional Industry.

83 Haynes, Small Town Capitalism, p. 9. 


\section{Import substitution of consumer goods under free trade, $1850 \mathrm{~s}$ to 1914}

Factories producing consumer goods for the internal market sprang up de novo in developing economies. As the cumbersome institutions of mercantilism were dismantled, exports of machinery were no longer subject to high duties, or even outright prohibition. Cheap second-hand machinery, which was tried and tested, thus became abundantly available. ${ }^{84}$ The absence of state protection for industrialization also meant that only competitive factories flourished.

The most successful case of large-scale import substitution, leading over time to export substitution, was the Indian cotton-spinning industry, which Williamson inexplicably ignores. Despite a complete lack of tariff protection, modern industrial production of cotton goods began in British India in 1854 , and grew rapidly from the 1870 s to 1914 . These cotton mills were almost entirely owned and financed by local entrepreneurs. Indian mills produced much more yarn than cloth, making India self-sufficient in yarn by the 1880 s, and acting as a stimulus to handlooms. Indian yarn exports then largely replaced the British variety in the Indian Ocean and China Sea markets by 1906, and penetrated into the Ottoman Empire. By contrast, it was only in around 1910 that the woven output of Indian mills began to surpass that of local handlooms. Moreover, some imports of piece goods continued ${ }^{85}$ Ceylon (now Sri Lanka) was unusual in having become self-sufficient in cotton textiles by $1913 .{ }^{86}$

Latin American import-substituting industrialization was not sustained, possibly because of excessive protection by newly independent governments. In Mexico, the creation of a modern textile industry benefited from a large internal market, numerous skilled artisans in old craft centres such as Puebla, vigorous local trade on mule back, and the natural protection afforded by Mexico's tortured geography. ${ }^{87}$ However, manufacturing of this type was undermined by the advent of railways, which reduced the costs of imports. ${ }^{88}$

84 Kenwood and Lougheed, Technological Diffusion; Macpherson, The Economic Development, p. 13 .

85 Morris, "Indian Industry and Business", p. 204; Dobbin, Urban Leadership, pp. 154-156; Charlesworth, British Rule, pp. 34, 37-39. On Chinese imports, see Shiroyama, China during the Great Depression, pp. 42-50; on Ottoman imports, see Quataert, Ottoman Manufacturing, p. $3^{2}$.

86 Huff, "Boom-or-Bust Commodities", p. 1085.

87 Halperín Donghi, "Economy and Society", pp. 327-328.

88 Haber, Industry and Underdevelopment. 
Egypt is routinely presented as an example of manufacturing that was strangled at birth by imperialism. It is true that Muhammad 'Ali's ambitious projects, especially in the field of cotton textiles, went into steep decline after Britain imposed free trade by treaty in 1838 . However, Muhammad 'Ali's industrial structure was fatally weakened by clumsy state interference, notably high rates of protection, monopolies, and forced labour. Moreover, the British occupation of Egypt, in 1882, was followed by a burst of free trade manufacturing growth, including cotton textiles, as well as soap, sugar, tobacco, and fertilizers, which most historians have ignored. ${ }^{89}$

Import substitution also progressed in states such as the Ottoman and Qing empires, which were not formally colonized, but were subject to "informal imperialism". Despite being placed under the yoke of the Public Debt Administration from 1881, the Ottoman Empire witnessed steady growth in modern manufacturing. Textiles were at the fore, with a focus on spinning cotton and wool, and reeling silk, partly for export. ${ }^{90}$ As for China, foreign-owned cotton mills in Shanghai provoked the emergence of successful Chinese-owned mills up-country. ${ }^{91}$

Although free trade did not prevent import-substituting industries from emerging, structural factors limited expansion. Colonial parsimony arguably hampered education, although Gregg Huff notes that male literacy in parts of Malaya had reached nearly $5^{0}$ per cent by $1931 .{ }^{92}$ Shortages of social overhead capital more generally, and low demand from the agrarian sector, also played a part. ${ }^{93}$ However, Clive Dewey argues that it simply made more economic sense to focus on export processing. ${ }^{94}$

\section{Import substitution of consumer goods under protection, 1914 to $1950 \mathrm{~s}$}

Protectionist impulses were felt in the global economy from the 1880s, but effective tariff rates remain subdued, and it took the First World War to seriously hobble free trade. The depressions of the early 1920 and early

89 Issawi, An Economic History, pp. 236-239.

90 Quataert, Ottoman Manufacturing, pp. 32-40, 125-127, 148-150; Owen, The Middle East, pp. 211-212.

91 Liu, "Paradoxical Development", ch. 4; Shiroyama, China during the Great Depression, pp. 45-48.

92 Huff, "Boom-or-Bust Commodities", pp. 1086-1087.

93 Dewey, "The Government of India", pp. 215-257; Lal, The Hindu Equilibrium, pp. 189-190; Tomlinson, "Technical Education".

94 Dewey, "The Government of India", pp. 215-257. 
1930s compounded problems, and the Second World War completed the closing of economies. ${ }^{95}$

In this context, metropolitan opinion was divided over the development of colonial import-substituting industry. Persistent structural unemployment, emerging in the West after the First World War, made workers keen to safeguard their jobs. French manufacturers could not agree about the colonial option. $\cdot{ }^{96}$ Only the authoritarian regime of António de Oliveira Salazar in Portugal actually banned colonial industries, in 1936. This was political theatre, however, as the prohibition was full of loopholes, and was reversed as soon as war threatened communications with the empire. ${ }^{97}$

Nationalist movements in Africa and Asia increasingly clamoured for import-substituting manufacturing under state protection. ${ }^{9}$ For socialists, industry would reinforce a class structure favourable to their goals. ${ }^{99}$ After the Accra riots in the Gold Coast (Ghana) in early 1948, the Watson Commission of Enquiry reported that "at every turn, we are pressed with the cry of industrialization". ${ }^{100}$ For many nationalists, however, manufacturing was a nebulous badge of progress, rather than a well-considered economic strategy. ${ }^{101}$ Heavy industry loomed large in such dreams, symbolically equated with Soviet and Nazi power. ${ }^{102}$ However, there were countercurrents. Most famously, Mahatma Gandhi set his face against disruptive manufacturing in British India, while sponsoring a renewal of handicrafts. ${ }^{103}$

White settlers were particularly successful in gaining the ear of officials to implement import substitution under tariff protection. Wherever there was a danger of "poor whites" subverting racial stratification in colonial society, demands reached a crescendo. However, this kind of industry was often inefficient, especially when employment was subject to a racial "colour bar". ${ }^{104}$

Most colonial officials hesitated to support industrialization, fearing the social and political consequences of proletarianization and urbanization

95 O'Brien, "Intercontinental Trade"; Capie, Tariffs and Growth.

96 Marseille, Empire Colonial; Marseille, "The Phases of French".

97 Clarence-Smith, The Third Portuguese Empire, ch. 6.

98 Tyabji, Colonialism, pp. 96, 139 .

99 Botwe-Asamoah, Kwame Nkrumah's Politico-Cultural Thought.

100 Phillips, The Enigma of Colonialism, p. 152.

101 Dewey, “The Government of India”, p. 234; Tomlinson, "Technical Education", p. 328.

102 Ansden, Asia's Next Giant, pp. 19-20; Ray, Industrialisation in India.

103 Chatterjee, Nationalist Thought, pp. 88-9o.

104 Mosley, The Settler Economies; Clarence-Smith, "Textile Industry". 
after the Bolshevik triumph in $1917 .^{105}$ They also disliked diasporic industrialist communities, such as the Indians in East Africa, or the Chinese and the Hadhrami Arabs in Indonesia. Colonial authorities thus tended to promote manufacturing only in reaction to crises. Strikes and riots reflected unemployment, inflation, and shortages of wage goods, due to shipping bottlenecks or falling export revenues. Colonial authorities then undertook short-term and uncoordinated initiatives, of dubious economic value. ${ }^{106}$

The example of British India illustrates the problems with particular clarity. Officials leant towards fashionable strategic autarky, and were trapped in a dualistic vision of modern heavy industry and romantic cottage crafts. However, heavy industry required a great deal of capital, foreign exchange, expensive machinery, scarce skilled labour, entrepreneurial know-how, and geographical concentration, while doing little to boost incomes. Indeed, when overly protected, the sector pushed up the cost of living, and consequently wages in the wider economy. ${ }^{107} \mathrm{~A}$ "beggar my neighbour" attitude protected Indian sugar from Javanese imports in the 1930s, hindering the modernization of Indian production, while driving modern Javanese factories to the verge of bankruptcy. Emerging industrial sectors, dependent on the crutches of state aid, were badly located, employed too much capital and skilled labour, and could not compete in regional markets, let alone international ones. ${ }^{108}$ Colonial institutions charged with stimulating manufacturing were poorly supported and resourced. ${ }^{109}$ This was not just a colonial problem, for the authoritarian regime in Republican Turkey provides egregious examples of badly executed, state-directed autarkic industrialization. ${ }^{110}$

At the same time, a raft of policies indirectly hindered the expansion of import-substituting manufacturing, reflecting colonial institutional structures. Officials in British India stuck to rigidly balanced budgets, limiting the supply of services and depressing demand. They overvalued the exchange rate to avoid inflation and to secure the worth of remittances

105 Butler, Industrialisation.

106 Havinden and Meredith, Colonialism and Development, pp. 159, 168-174; Drummond, Imperial Economic Policy, pp. 439-443; Phillips, The Enigma of Colonialism, ch. 7; Dick, Surabaya, pp. 274-279; Brown, Economic Change in Southeast Asia, pp. 211-214; Tyabji, Colonialism.

107 Dewey, "The Government of India", pp. 239-241.

108 Tomlinson, The Economy of Modern India, ch. 3. For Java sugar, see the chapter by Ulbe Bosma in this volume.

109 Tyabji, Colonialism.

110 Hershlag, Turkey. 
to the metropolis. A strong rupee may have been the main reason for India losing markets for cotton yarn exports to Japanese rivals. Measures to keep peasants on the land, by protecting them from expropriation through debt, choked off the flow of labour to towns, and caused rural stagnation, which in turn restricted overall spending power. ${ }^{111}$ Gregg Huff sees currency overvaluation as Malaya's chief industrial constraint. ${ }^{112}$ The scarcity of electricity supplies in rural areas was another structural barrier. ${ }^{113}$

China's experience was more positive in this period, paradoxically because Chinese nationalists were barely in control of their vast state after the revolution of 1911, and were thus unable to grant much effective protection to their industries. China's currency also remained competitively valued. ${ }^{114}$ In this environment, Chinese industrialization powered ahead, in sectors as diverse as tobacco and rubber goods. Even all-out war with Japan from 1937 did not entirely halt the process. ${ }^{115}$

Japan itself provides an object lesson in sensible protection, at least up to the imposition of militarist autarky in the 1930s, when living standards first began to decline. Up to the 1920s, the country's economy rested largely on a textile industry that had deep rural and pre-modern roots. ${ }^{116}$ As late as 1928, six out of ten ofJapan's leading industries in terms of employment, including the top three, were in this sector. ${ }^{117}$ After regaining tariff autonomy in 1911, governments remained highly selective about import duties. Tariffs were steep on "luxuries", and gave some support to "infant industries", but were low on imports of vital inputs for manufacturing. ${ }^{.18}$

\section{Export processing concealed}

Export-processing industrialization was probably much more important than the import-substituting variety, but statistical quirks obscure this. Tables appear to reveal a deepening concentration on exports of "raw

\footnotetext{
111 Tomlinson, The Economy of Modern India; Charlesworth, British Rule, pp. 38-39, 64-65.

112 Huff, "Boom-or-Bust Commodities", pp. 1080, 1087, 1100.

113 Tyabji, Colonialism, pp. 19, 30-31, 210.

114 Chan, Business Expansion, ch. 2; Myers, The Chinese Economy, Part 3; Shiroyama, China during the Great Depression.

115 Cochran, Big Business in China; Coble, The Shanghai Capitalists.

116 Smith, Native Sources.

117 Blanchard, The Textile Industries, p. 5 .

118 Macpherson, The Economic Development, pp. 32-34.
} 
materials". For example, steam-driven filatures for silk developed from 1861 in China, but export statistics did not reflect this till 1894. Even then, all exports in this branch continued to be misleadingly labelled as "raw silk". ${ }^{19}$

Much modern export-processing industry was simply not recorded. In British India up to 1911, official reports excluded enterprises employing fewer than fifty workers, as well as plant working for less than four months a year. Many industrial establishments in India are therefore known only from descriptive and photographic records, whether they were shelling groundnuts, ginning and pressing cotton, or milling rice..$^{120} \mathrm{~A}$ similar problem besets reporting in the Ottoman Empire and Egypt, where cotton gins and presses, steam-powered flour mills, and modern oil mills were ignored. ${ }^{121}$

Although "low tech" industries, especially those tucked away in remote rural locations, could be hard to detect, the most casual observer could not fail to miss a range of export-processing facilities, which were both precocious and physically impressive. The technical requirements of grinding mills and boiling houses for Caribbean sugar may even have influenced the development of the Industrial Revolution in Britain. ${ }^{122}$ "Factories in the fields" certainly pioneered industrial advances in the processing of sugar cane, ${ }^{123}$ and mechanized sugar production then spread around the tropical world. ${ }^{124}$ Another instance of early and large-scale export processing was the dressing and smelting of mineral ores. ${ }^{125}$ David Igler argues persuasively that the industrialization of California before 1941 has been hidden from view by historians' refusal to consider this sector as an industrial one. ${ }^{126}$

Enframing is a major problem in this respect, as historians fail to notice that empirical material contradicts standard interpretative frameworks. Thus, Yoshiko Nagano intones the familiar mantra that the Philippines after 1898 became "dependent" on the USA as an exporter of raw materials. However, she then proceeds to demonstrate, in fascinating empirical detail, how capital was poured into the mechanical preparation of sugar, coconut oil, and Manila hemp for export to America. ${ }^{127}$

119 Eng, Economic Imperialism in China, pp. 37-38.

120 Tyabji, Colonialism, p. 19.

121 Owen, The Middle East, pp. 151-152.

122 Meide, "The Sugar Factory".

123 Curry-Machado, "Rich Flames and Hired Tears".

124 Bosma, The Sugar Plantation (and the chapter in this volume); Knight, Commodities and Colonialism; Brown, Economic Change, pp. 205-206.

125 Dennis A Hundred Years of Metallurgy. Also see Rossana Barragán's chapter in this volume. 126 Igler, "The Industrial Far West".

127 Nagano, State and Finance, pp. 42-46. 


\section{Export processing under free trade, 1850 s to 1914}

Free trade was especially conducive to adding value to exports, an industrial sector that often employed more labour than any other. ${ }^{128}$ Williamson fails to realise that profits arising from favourable terms of trade stimulated capital intensity in export processing, partly to overcome bottlenecks in production. ${ }^{129}$ Thus, sugar factories in Java reinvested retained profits to achieve ever more mechanization, as costs of imported machinery and chemical fertilizers fell in tandem with the maritime costs of exporting sugar overseas. ${ }^{130}$

Williamson emphasizes the negative impact of price volatility with regard to primary goods, and yet he ignores hedging against price movements through the issuing of futures contracts on specialized exchanges. ${ }^{131}$ Such exchanges multiplied in the course of the nineteenth century, allowing economic actors to know the price that they would receive in advance, while leaving speculators to carry the risks of price fluctuations. This certainty of capital returns favoured long-term investment in processing. ${ }^{132}$

Clive Dewey argues persuasively that adding value to raw materials for export was British India's most promising avenue to industrialization, in terms of the allocation of scarce resources of capital and skilled labour, but he misses further advantages. ${ }^{133}$ First, for poor territories with small internal markets, access to the world allowed for production on a scale appropriate to new technologies. Second, export processing could lead organically to the import substitution of consumer goods. For example, soap works for the local market were a logical extension of processing coconut oil for export in southern India. ${ }^{134}$ Third, consumer goods produced in this way for the internal market might eventually be exported. In this way, Tan Kah-Kee progressed from milling rubber in the Malay Peninsula to producing rubber footwear for local requirements, and then to exporting this footwear. ${ }^{135}$ "Resource-based industrialization" is therefore attracting increasing attention. ${ }^{136}$

128 Brown, Economic change, p. 204.

129 Williamson, Trade and Poverty, ch. 3.

130 Knight, Commodities and Colonialism.

131 Williamson, Trade and Poverty, ch. 10.

132 Williams, "The Origins of Futures Markets”; Engel, "Buying Time”.

133 Dewey, "The Government of India".

134 Tyabji, Colonialism, pp. 138, 198-20o.

135 Tan, The Memoirs of Tan Kah-kee; Goldthorpe, Rubber Manufacturing, p. 65 .

136 Goldthorpe, Rubber Manufacturing. 
Export-substituting industries could simultaneously provide goods for local markets at lower prices. As Southeast Asia became the world's rice granary from the mid-nineteenth century, steam mills proliferated, both small up-country units and large factories in port towns. While most of the milled rice was exported, its price on the internal market fell. ${ }^{137}$

The examples of Australia and New Zealand, underdeveloped and poor countries at the beginning of the nineteenth century, shows that exporting processed raw materials could be an effective avenue to development. Similar to other thinly populated temperate zones, these antipodean lands achieved high productivity and a comfortable standard of living by exporting mainly animal and mineral products. Indeed, protecting consumer manufacturing for the internal market in the interwar years may well have retarded Australia's long-term economic development. ${ }^{138}$

Countries with a similar resource endowment in Latin America enjoyed less success, but essentially because of institutional weaknesses. ${ }^{139}$ Victor Bulmer-Thomas mentions precocious Latin American industrial processing of animal products, sugar, and mineral ores, and yet he does so briefly, and in a disparaging tone. ${ }^{140}$ Celso Furtado, a dependentista, recognizes that processing agricultural and animal goods constituted "the original nucleus of modern Argentine industry", but he sees this merely as a step on the path to "real" industrialization. ${ }^{141}$

Japan's modern economic trajectory is a striking example of the value of an export-processing strategy. Japan "caught up" with the West after the Meiji Restoration of 1868 by ever more effectively exporting processed tea and silk, taking over a substantial part of China's international market share. Indeed, silk still accounted for 46 per cent of Japan's total merchandise exports in the early 1920s. By contrast, governments quickly abandoned clumsy and loss-making state-directed efforts to create heavy industry in the 1880 os, ${ }^{142}$ yet William Macpherson refers dismissively to "raw silk, often categorized as a primary rather than a secondary product". ${ }^{43}$

Other countries failed to replicate Japan's success, even if their achievements have been underestimated. China established steam filatures for

137 Brown, Economic Change, pp. 204-205.

138 Cochrane, Industrialization and Dependence; Denoon, Settler Capitalism.

139 Platt and Di Tella, Argentina, Australia and Canada.

140 Bulmer-Thomas, The Economic History, pp. 131, 134.

141 Furtado, Economic Development, p. 105.

142 Macpherson, The Economic Development; Nakamura, Economic Growth.

143 Macpherson, The Economic Development, p. 10. 
silk from the 1860 , and they expanded from the 1880 s. ${ }^{144}$ From the $1860 \mathrm{os}$ also, an "industrial revolution overtook the tea-garden factories, as steampowered equipment for withering, rolling, firing, and sorting black tea steadily replaced workers skilled in these tasks". ${ }^{145}$ Debin Ma attributes China's inability to build on these developments to political and institutional weaknesses. ${ }^{146}$ Silk reeling also developed into a significant modern industry in Lebanon and Northwestern Anatolia, albeit without working any long-term developmental magic on the Middle East. ${ }^{147}$

\section{The uneven distribution of export processing}

A striking aspect of export processing was its unevenness. For example, sugar was generally transformed at source more than coffee, and palm oil more than rubber. ${ }^{148}$ Similarly, base metal ores were processed more than gemstones. An identical commodity might even receive different degrees of treatment according to location and firms. Thus, British Malaya led the way in intensifying the milling of rubber. ${ }^{149}$

Some commodities were speedily processed because they would otherwise have deteriorated, for example, the sucrose content of sugar cane quickly falling after harvesting. ${ }^{15^{0}}$ With vegetable oils, rapid acidification posed a similar problem. ${ }^{15^{1}}$ Animal and fish products rotted, if they were not dried, salted, chilled, frozen, tinned, or otherwise preserved. Precocious export-oriented factories therefore prepared salted meat for export from southern South America from the middle of the nineteenth century. ${ }^{152} \mathrm{~A}$ more modest example concerns the fish and whale factories of coastal southern Angola. ${ }^{153}$

In some cases, the extent of processing at source depended on the desired end products. Simple milling turned rubber into smoked and dried sheets, which could be stored for a long time in situ, to be exported at leisure to

144 Eng, Economic Imperialism; Feuerwerker, The Chinese Economy, pp. 41-42; Shiroyama, China during the Great Depression, pp. 53-59.

145 Gardella, Harvesting Mountains.

$146 \mathrm{Ma}$, "Between Cottage and Factory".

147 Owen, The Middle East, pp. 154-159, 211-212, 249-253.

148 Slijper, Technologie en warenkennis.

149 Goldthorpe, Rubber Manufacturing, pp. 62-64.

150 Meide, "The Sugar Factory".

151 Hartley, The Oil Palm, p. 692.

152 Hanson, Argentine Meat; Halperín Donghi, "Economy and Society", pp. 314-315.

153 Clarence-Smith, Slaves, pp. 21-23. 
make tyres and other products. By contrast, more sophisticated industrial treatment was required, immediately after tapping, to make liquid latex for the manufacture, by moulding, of surgical gloves and similar goods. ${ }^{154}$

In other cases, substantial transport savings were secured by processing prior to shipment. ${ }^{155}$ Thus, mineral ores were treated close to mines, especially when their mineral content was low. ${ }^{156}$ Diamonds, by comparison, took up little room, and relied on highly skilled and specialized communities elsewhere for cutting and polishing. ${ }^{157}$ Sawing logs into planks saved much precious space on ships, compared to shipping circular tree trunks. ${ }^{158}$

There were differences between colonial empires, in part because of higher rates of protection adopted by poorer metropoles with small and uncompetitive industrial sectors. ${ }^{159}$ Thus, in 1894, groundnuts were imported in their shells from Senegal for oil mills in Marseilles, rather than being locally decorticated in West Africa. ${ }^{160}$ Groundnuts were exported shelled from South India, but high duties on imported vegetable oils in many Western countries frustrated plans for oil milling in Madras, whether based on groundnuts, copra (coconut flesh), or other oilseeds. ${ }^{161}$

Britain was more relaxed than most about importing vegetable oils, so that obstacles to colonial industrialization tended to be economic in nature. Export processors were cautious about investing in expensive buildings and machinery, as interest rates were high in peripheral areas. Moreover, investment was at the mercy of vagaries in the world economy. United Plantations bravely inaugurated a state-of-the-art palm oil factory in Malaya in 1933 , in the midst of the ravages of the Great Depression. ${ }^{162}$

Hardest of all to explain is why more value was added to the same commodity in different places, notably in Asia compared to in Africa. For example, tin was exported for a long time as roughly washed mineral ore from Nigeria and the Belgian Congo, with a metal content of around 25 per cent, whereas it was smelted in Malaya to 90 per cent or higher purity. ${ }^{163}$ By 1911, the Straits Trading Company of British Malaya smelted about a

154 Polhamus, Rubber, pp. 203-207.

155 Brown, Economic Change, p. 207.

156 Thoburn, Tin in the World Economy, pp. 7-8. Also see Rossana Barragán's chapter in this volume.

157 Hofmeester, "Shifting Trajectories".

158 Bullock, Timber, p. 126.

159 Clarence-Smith, The Third Portuguese.

160 Smith, Peanuts, p. 67.

161 Tyabji, Colonialism, pp. 1-2, 36, 41, 65-73, 81 .

162 Martin, The UP Saga, pp. 62-63.

163 Yip, The Development; Freund, Capital and Labour. 
third of the world's output of tin ore, drawing on local supplies, but also on shipments from Siam, Yunnan (Southwestern China), Indochina, and Indonesia. ${ }^{164}$ Possible reasons for Africa's lesser degree of processing were its closer proximity to Western markets, a smaller scale of mining, insufficient energy and capital, and inadequate labour skills.

\section{Export processing under threat, 1914 to $1940 \mathrm{~s}$}

After 1914, many earlier advantages for export processing were curtailed. Imperial autarky meant that industries had to produce for an empire rather than for the world. For the Portuguese Empire, which was quite small, this implied radically shrinking horizons. Certainly, colonial manufactures, such as tinned fish from southern Angola, were re-exported from Lisbon, but at substantial cost. ${ }^{165}$ Major industries were sacrificed on the altar of inefficient import substitution in other lands, for example, Java losing its sugar market in British India. ${ }^{166}$

Pressures to save, or create, jobs in the West increased, as structural unemployment took hold after the First World War. For instance, in 1928, the Billiton Company opened a tin-smelting works in Arnhem, in the Netherlands. From 1933, an increasing proportion of Indonesia's tin ore was redirected to Arnhem, whereas it had earlier gone to smelters in the Malay Peninsula ${ }^{167}$ By this stage, Malayan smelters were exporting almost pure tin metal. ${ }^{168}$ That said, the need to cut shipping costs in the Great Depression led to a modest increase in the processing of tin ore in the Belgian Congo. ${ }^{169}$

Another example of increased metropolitan protectionism was the "sugar trusts", which kept the final steps of sugar refining in Britain and the USA, rather than allowing them to occur in producer territories. ${ }^{170}$ However, companies argued that locating sugar refineries close to their main markets meant that they could obtain unrefined sugar from various sources, and could therefore operate all year round. ${ }^{171}$

164 Brown, Economic Change, pp. 206-207

165 Clarence-Smith, The Third Portuguese, ch. 6.

166 Dewey, "The Government of India”, pp. 239-241. Also see the chapter by Ulbe Bosma in this volume.

${ }_{167}$ Thoburn, Tin in the World Economy, p. 76; Allen and Donnithorne, Western Enterprise, p. 161. 168 Yip, The Development.

169 Clarence-Smith, "The Effects of the Great Depression", p. 182.

170 Ward, Poverty and Progress, pp. 51-52.

171 Barnes, The Sugar Cane, pp. 355-356. 
It is currently impossible to draw up a balance sheet for export processing after 1914, as historians have neglected the sector, but growth probably slowed rather than stopped. Descriptive evidence is often all that exists. Thus, in the 1930s, one observer commented on Saigon's large mechanized rice mills, housed in "ugly buildings, several stories high", and employing machinery made in Germany or America. ${ }^{172}$

\section{The industrialization of the service sector}

The application of modern industrial methods to the provision of services has been even more neglected, due to a definition of industry restricted to the production of goods. In reality, transport and energy sectors were susceptible to high levels of industrialization, in contrast to finance or education. The vast body of literature on modern transport rarely considers it as a process of industrialization, and the same can be said about electricity, which had to be generated within a limited distance from consumers. ${ }^{173}$ Thus, the industrial impact on California of a behemoth like the Southern Pacific Railroad has generally been ignored. ${ }^{174}$ This is strange, because transport may well have been the single most striking application of industrial methods in developing economies. From steamships to railways, and from automotive vehicles to aircraft, the situation was radically transformed. ${ }^{175}$ These technologies have been amply discussed as "tools of empire", but not as contributions to industrialization. ${ }^{176}$

The industrialization of transport and energy was intimately linked to other forms of manufacturing. Rural electrification was seen as the key to developing all forms of industry in India in the interwar years. ${ }^{177}$ Transport was a necessity for many forms of export processing in remote locations. Indeed, the industrialization of agricultural and mining firms often took the form of building light railways, with locomotives slowly replacing animals to pull wagons. ${ }^{17}$

172 Brown, Economic Change, p. 204.

173 Headrick, Power over Peoples; Hausman, Hertner, and Wilkins, Global Electrification.

174 Igler, "The Industrial Far West”, pp. 174-175.

175 Clarke, Encyclopedia of Transport.

176 Headrick, Power over Peoples.

177 Morris, "Indian Industry and Business", pp. 221-222; Tyabji, Colonialism, pp. 19, 30-31, 210.

178 Graham and Floering, The Modern Plantation, pp. 159-160. 


\section{Intermediate and capital goods for local markets}

Historians have equally neglected the manufacture of intermediate and light capital goods. Demand for such products arose from the needs of a particularly broad range of economic actors, such as other factories, plantations, mines, construction, transport, energy, government, and the armed forces. Repair and maintenance workshops sprung up quickly, and many of them morphed into small factories producing spare parts. They initially met the needs of locomotives and steamers, and then increasingly those of motor vehicles. ${ }^{179}$ India's railway workshops, employing some of the most modern industrial technology in the colony, were long unjustly neglected by researchers. ${ }^{180}$

Engineering firms became increasingly significant over time. In the Javanese industrial hub of Surabaya, transport and sugar enterprises were their main markets. ${ }^{181}$ Similar companies, clustered in Kuala Lumpur and Ipoh, supplied rubber-milling machinery to Malaya, as well as pumps and dredges to extract tin from marshland ${ }^{182}$ Singapore was another centre, sending railway brake fittings across much of Asia by $1941 .{ }^{183}$ The Socfin plantation group set up a subsidiary in Northern Sumatra in the 1930s, the Medansche Machine Fabriek, which produced storage tanks for palm oil prior to shipment. ${ }^{184}$ Mysore and Madras firms made soap machinery, paddy separators, centrifugal pumps, and acetone for rubber coagulation, the latter as a by-product of Mysore's iron works. ${ }^{185}$ In the 1860 s, Shanghai's first silkreeling factories used engines, boilers, and reeling equipment manufactured in Hong Kong. ${ }^{186}$ From 1917, the electrification of China resulted in a flourishing local production of electrical equipment. ${ }^{187}$ Coffee planters invested in turning out boilers, pumps, and boxcars in the Brazilian state of São Paulo, the largest regional industrial agglomeration in Latin America by the $1940{ }^{188}$

Production of intermediate goods for local markets benefited from natural protection afforded by transport costs. Bulky and heavy products, especially if they were easily made from local raw materials and with local labour,

179 Dick, Surabaya, ch. 5 .

180 Morris, "Indian Industry and Business", p. 213.

181 Dick, Surabaya, ch. 5 .

182 Goldthorpe, Rubber Manufacturing, p. 63.

183 Huff, Economic Growth of Singapore, p. 218.

184 Clarence-Smith, "The Rivaud-Hallet Plantation".

185 Tyabji, Colonialism, pp. 31, 144.

186 Shiroyama, China during the Great Depression, p. 53.

187 Myers, The Chinese Economy, pp. 140-141.

188 Dean, The Industrialization of São Paulo, pp. 20-33, 37-38. 
needed little or no tariff protection. Construction materials are typical for this sector, especially cement, but also bricks, tiles, pipes, tanks, plaster, lime, gravel, stone, and sawn timber, with the size and capital intensity of plant varying greatly. Agricultural exports required sacking, made from jute, sisal, hemp, or similar fibres, some of which also served to produce ropes and twine. Barrels, chests, and other containers were used to package exports. Tin cans were made in Indonesia from 1913 to hold kerosene, produced locally, together with petrol, aviation fuel, diesel oil, paraffin wax, asphalt, and so forth. Chemicals, such as sulphuric acid or vegetable oils for flotation, entered into the treatment of mineral ores. Railways consumed huge quantities of wooden sleepers and gravel, and India produced iron rails. Glass bottles and flasks served for locally produced beverages, such as beer and mineral water. In small territories, manufacturers developed regional export markets. ${ }^{189}$

Historians of India and China, influenced by communist notions, have been at the fore in arguing that all this was insufficient, as it did not amount to the "holy grail" of producing heavy capital goods ${ }^{190}$ However, a reluctance to produce such goods may have been wise, given that economically draining "white elephants" in these sectors became the bane of many independent countries after 1945 .

\section{Labour relations in modern industries in the developing world}

Modern industry, in all its sectors, was more likely to employ wage labour than handicrafts, but this was not a "default setting". There is nothing about the definition of modern industry used in this chapter that indicates that industrial workers must be divorced from the means of subsistence, and thus obliged to sell their labour power.

Modern industry could even employ slave labour. ${ }^{191}$ Meat packing and tallow plants, the largest and most advanced industrial units of southern South America in the nineteenth century, contained a mixture of free and slave workers. Slaves were soon confined to Brazil, however, where slavery lasted till 1888 , whereas the institution was abolished soon after independence in the Hispanic republics. ${ }^{192}$ Similarly, the fish-processing

189 Brown, Economic Change, ch. 14; Clarence-Smith, "The Effects of the Great Depression", pp. 188-19o; Chan, Business Expansion and Structural Change, ch. 5 .

190 Ray, Industrialisation in India; Kirby, "Engineering China".

191 Karasch, Slave Life; Starobin, Industrial Slavery.

192 Halperín Donghi, "Economy and Society", p. 315. 
plants of southern Angola relied on slave labour in reality, tolerated by the authorities until the Republican Revolution of 1910. ${ }^{193}$ Slavery was an institution of civil society, buttressed by religion and politics, and it took major crises to shift the institutional landscape.

The suppression of slavery did not entail a simple transition to wage labour. G. Roger Knight demonstrates how population pressure and land shortage combined to produce some early proletarianization in Java, with gangs of landless men travelling across the island for casual wage employment in sugar factories. However, there were many other types of workers in sugar factories who had some access to rural resources. ${ }^{194}$ Indeed, this provides a classic example of the combination of different labour relations in a single plant. Among the most proletarianized workers in Java, and forming the spearhead of worker militancy, were those employed by the increasingly industrialized transport system. ${ }^{195}$

In the case of British India, local jobbers controlled an unstable, free labour force, characterized by high turnover. The salience of caste is hotly debated, although industrial workers were clearly drawn from a variety of castes. Moreover, by 1931, about four-fifths of the workers in Indian cotton textile mills were men, contrasting with predominantly women in Japan and the Middle East. The significance of jobbers in organizing the workforce in India meant that labour was not subsumed to capital according to classic models. ${ }^{196}$

The processes of proletarianization may have stalled, or even gone into reverse, from 1914, as Southern Africa became a model for a particular form of social engineering. The region had a well-established export-processing sector - notably for minerals - and an expanding consumer goods industry, stimulated by extensive protectionism. Worried by the social and political threats posed by proletarianization and urbanization, political leaders tried to artificially shore up rural subsistence production and to enforce repatriation to rural labour reserves. Representing white voters, politicians were keen to ward off the "black peril". At the same time, employers saw this as a way of lowering wages, by not having to pay for the subsistence needs of a worker's family. ${ }^{197}$

193 Clarence-Smith, Slaves, pp. 33, 36-37.

194 Knight, “Coolie or Worker?”; Knight, Commodities and Colonialism, pp. 69-87, 195-202. See Ulbe Bosma's chapter in this volume.

195 Ingleson, In Search of Justice.

196 Charlesworth, British Rule, pp. 42-43; Chandavarkar, The Origins of Industrial Capitalism. 197 Marks and Rathbone, Industrialisation. 


\section{Conclusion}

It is not possible to maintain that developing economies deindustrialized from the 1840 s to 1914 . Instead, there was an initial sensible emphasis on export-processing manufacturing, benefiting from a broadly free trading environment. This went together with the industrialization of key services, the factory production of intermediate and light capital goods, and a little import substitution, which benefited from not being distorted by protective tariffs. At the same time, a large number of handicrafts survived and flourished, and some evolved in a more industrial direction, serving not only the internal market, but also foreign customers.

Conversely, the argument that industrial growth in the Global South speeded up from 1914 is open to considerable doubt. As protectionism gripped the world, problematic and limited forms of import substitution of consumer goods emerged in colonial and semi-colonial lands. These were typically the fruit of uncoordinated official reactions to short-term crises. Such schemes suffered from excessive protection through tariffs and other measures, poor linkages with other industries and economic sectors, and great locational inefficiencies.

At the same time, greater barriers to export-processing manufacturing emerged from 1914, and the role played in this by organized labour in the West needs to be better understood. There has been such a strong emphasis on protectionism emanating from capitalists manipulating governments that the roots of such measures in labour movements, which were institutions of civil society, have been largely ignored. This is perhaps the topic that the enframing of research agendas has obscured the most.

In general terms, Williamson correctly pinpoints the low productivity of labour as a major explanation for relatively low levels of industrialization in developing economies, but he wrongly attributes this productivity gap to specialization in the production of raw materials for export. In reality, there were deep historical roots governing how labour skills evolved. Productivity was further influenced by policies on education, health, and the provision of other public goods, all of which need to be comprehended from an institutional perspective.

The implications of modern experiences of industrialization in the Global South for the general schema of labour relations proposed by the collaboratory are important, even though they do not necessarily suggest that more commodified labour existed than historians have thought to date. Indeed, taking manufacturing in all its astonishing diversity, this chapter reinforces the notion that labour relations did not march forward through 
time in clearly delineated stages. Instead, manufacturing was characterized by complex combinations of labour relations, similar to those in other economic sectors. Wage labour might at times have progressed, but it could also regress. There is a need to study empirical experiences with great care, avoiding becoming enframed within ideological presuppositions.

\section{Bibliography}

Allen, G.C., and A.G. Donnithorne, Western Enterprise in Indonesia and Malaya: A Study in Economic Development (London, 1954).

Alpers, Edward A., "Futa Benaadir: Continuity and Change in the Traditional Cotton Textile Industry of Southern Somalia, c. 1840-1980", in Entreprises et Entrepreneurs en Afrique, XIXe et XXe siècles (Paris, 1983), pp. 77-98.

Amoroso Leslie, Catherine, Needlework through History: An Encyclopedia (Westport, 2007).

Amsden, Alice, Asia's Next Giant: South Korea and Late Industrialization (New York, 1989).

Antlöv, Hans, and Thommy Svensson, "From Rural Home Weavers to Factory Labour: The Industrialization of Textile Manufacturing in Majalaya", in Paul Alexander, Peter Boomgaard, and Ben White (eds), In the Shadow of Agriculture: Non-farm Activities in the Javanese Economy, Past and Present (Amsterdam, 1991), pp.113-126.

Austin, Gareth, and Kaoru Sugihara (eds), Labour-Intensive Industrialization in Global History (London, 2013).

Baghdiantz McCabe, Ina, Gelina Harlaftis, and Ioanna Pepelasis Minoglou (eds), Diaspora Entrepreneurial Networks: Four Centuries of History (Oxford, 2005).

Barnes, A.C., The Sugar Cane:Botany, Cultivation, and Utilization (New York, 1964). Batou, Jean, Cent ans de résistance au sous-développement: l'industrialisation de l'Amérique Latine et du Moyen-Orient face au défi européen (Geneva, 1990).

Bernard, Paul, Nouveaux aspects du problème économique indochinois (Paris, 1937), pp. 79-84.

Blanchard, Fessenden S., The Textile Industries of China and Japan: Post-War Opportunities and Problems for America (New York, 1944).

Boomgaard, Peter, Children of the Colonial State: Population Growth and Economic Development in Java, 1795-1880 (Amsterdam, 1989).

Bosma, Ulbe, The Sugar Plantation in India and Indonesia: Industrial Production, 1770-2010 (Cambridge, 2013).

Botwe-Asamoah, Kwame, Kwame Nkrumah's Politico-Cultural Thought and Policies: An African-Centred Paradigm for the Second Phase of the African Revolution (Abingdon, 2005). 
Brown, Ian, Economic Change in Southeast Asia (Kuala Lumpur, 1997).

Bullock, William, Timber: From the Forest to Its Use in Commerce (London, c. 1914).

Bulmer-Thomas, Victor, The Economic History of Latin America since Independence (Cambridge, 1994).

Butler, Lawrence J., Industrialisation and the British Colonial State: West Africa 1939-1951 (London, 1997).

Callwell, C.E., Small Wars: A Tactical Textbook for Imperial Soldiers (London, 1990).

Candotti, Marisa, "Cotton Growing and Textile Production in Northern Nigeria: From Caliphate to Protectorate, c. 1804 to 1914" (PhD diss., University of London, 2015). Capie, Forrest H., Tariffs and Growth: Some Insights from the World Economy, 18501914 (Manchester, 1994).

Chan, Kai Yiu, Business Expansion and Structural Change in Pre-War China: Liu Hongsheng and His Enterprises, 1920-1937 (Hong Kong, 2006).

Chandavarkar, Rajnarayan, The Origins of Industrial Capitalism in India: Business Strategies and the Working Classes in Bombay, 1900-1940 (Cambridge, 1994).

Charlesworth, N., British Rule and the Indian Economy, 1800-1914 (London, 1982).

Chatterjee, Partha, Nationalist Thought and the Colonial World: A Derivative Discourse (Minneapolis, 1993).

Clarence-Smith, William G., "The Effects of the Great Depression of the 1930 s on Industrialisation in Equatorial and Central Africa”, in Ian Brown (ed.), The Economies of Africa and Asia in the Inter-War Depression (London, 1989), pp. 170-202.

Clarence-Smith, William G., "Indian and Arab Entrepreneurs in Eastern Africa, 1800-1914", in Hubert Bonin and Michel Cahen (eds), Négoce blanc en Afrique noire: l'évolution du commerce à longue distance en Afrique Noire, du 18 e au $20 e$ siècles (Paris, 2001), pp. 335-349.

Clarence-Smith, William G., "The Rivaud-Hallet Plantation Group in the Economic Crises of the Inter-War Years", in Pierre Lanthier and Hubert Watelet (eds), Private Enterprises during Economic Crises: Tactics and Strategies (Ottawa, 1997), pp. 117-132.

Clarence-Smith, William G., Slaves, Peasants and Capitalists in Southern Angola, 1840-1926 (Cambridge, 1979).

Clarence-Smith, William G., "The Textile Industry of Eastern Africa in the Longue Durée", in Emmanuel Akyeampong, Robert Bates, Nathan Nunn, and James A. Robinson (eds), Africa's Development in Historical Perspective (Cambridge, 2014), pp. 264-294.

Clarence-Smith, William G., The Third Portuguese Empire, 1825-1975: An Economic Imperialism (Manchester, 1985).

Clarke, Donald (ed.), The Encyclopedia of Transport: The Technology and History of Transportation by Land, Sea, and Air (London, 1976). 
Coble, Parks M., The Shanghai Capitalists and the Nationalist Government, 1927-1937 (Cambridge, 1986).

Cochran, Sherman, Big Business in China: Sino-Foreign Rivalry in the Cigarette Industry, 1890-1930 (Cambridge, 1980).

Cochrane, Peter, Industrialization and Dependence: Australia's Road to Economic Development, 1870-1939 (Saint Lucia, 1980).

Cohen, Robin, Global Diasporas: An Introduction (London, 2008).

Cumming, Elizabeth, and Wendy Kaplan, The Arts and Crafts Movement (London, 1991).

Curry-Machado, Jonathan, “'Rich Flames and Hired Tears': Sugar, Sub-Imperial Agents, and the Cuban Phoenix of Empire”, Journal of Global History, 4 (2009), pp. $33-56$.

Davison, Patricia, and Patrick Harries, "Cotton Weaving in South-East Africa: Its History and Technology”, Textile History, 11 (1980), pp. 175-192.

Dean, Warren, The Industrialization of São Paulo, 1880-1945 (Austin, 1969).

Dennis, W.H., A Hundred Years of Metallurgy (London, 1963).

Denoon, Donald, Settler Capitalism: The Dynamics of Dependent Development in the Southern Hemisphere (Oxford, 1983).

Dewey, Clive, “The Government of India's 'New Industrial Policy', 1900-1925: Formation and Failure", in K.N. Chaudhuri and Clive Dewey (eds), Economy and Society: Essays in Indian Economic and Social History (Delhi, 1979), pp. 215-257.

Dhamija, Jasleen, "Regional Weavers of India", in Jasleen Dhamija and Jyotindra Jain (eds), Handwoven Fabrics of India (Ahmedabad, 1989), pp. 115-155.

Dick, H.W., Surabaya, City of Work: A Socioeconomic History, 19oo-20oo (Athens, 2002). Dobbin, Christine, Asian Entrepreneurial Minorities: Conjoint Communities in the Making of the World-Economy, 1570-1940 (Richmond, 1996).

Drummond, Ian, Imperial Economic Policy, 1917-1939: Studies in Expansion and Protection (London, 1974).

Elster, John (ed.), Karl Marx: A Reader (Cambridge, 1986).

Eng, Robert Y., Economic Imperialism in China: SilkProduction and Exports, 1861-1932 (Berkeley, 1986).

Engel, Alexander, "Buying Time: Futures Trading and Telegraphy in Nineteenth-Century Global Commodity Markets",Journal ofGlobal History, 10 (2015), pp. 284-306. Faroqhi, Suraiya, Artisans of Empire: Crafts and Craftspeople under the Ottomans (London, 2009).

Fee, Sarah, "Madagascar's Textiles through History", in Christine M. Kreamer and Sarah Fee (eds), Objects as Envoys: Cloth, Imagery and Diplomacy in Madagascar (Washington, DC, 2002), pp. 74-86.

Ferguson, Kathy E., The Man Question: Visions of Subjectivity in Feminist Theory (Berkeley, 1993). 
Ferguson, Niall, Empire: How Britain Made the Modern World (London, 2004).

Feuerwerker, Albert, The Chinese Economy, 1870 to 1949 (Ann Arbor, 1995).

Feuerwerker, Albert, "Handicraft and Manufactured Cotton Textiles in China, 1871-1910", Journal of Economic History, 30 (1970), pp. 338-378.

Freund, Bill, Capital and Labour in the Nigerian Tin Mines (London, 1981).

Furtado, Celso, Economic Development of Latin America: Historical Background and Contemporary Problems (Cambridge, 1976).

Gardella, Robert, Harvesting Mountains: Fujian and the China Tea Trade, 1757-1937 (Berkeley, 1994).

Goldthorpe, C.C., RubberManufacturing in Malaysia:Resource-Based Industrialization in Practice (Singapore, 2015).

Graham, Edgar, and Ingrid Floering, The Modern Plantation in the Third World (London, 1984).

Grove, Linda, A Chinese Economic Revolution: RuralEntrepreneurship in the Twentieth Century (Lanham, 2006).

Haber, Stephen H., Industry and Underdevelopment: The Industrialization of Mexico, 1890-1940 (Stanford, 1989).

Halperín Donghi, Tulio, "Economy and Society in Post-Independence Spanish America", in Leslie Bethell (ed.), Cambridge History of Latin America, Volume 3: From Independence to c. 1870 (Cambridge, 1985), pp. 297-346.

Hamilton, Roy (ed.), Gift of the Cotton Maiden: Textiles of Flores and the Solor Islands (Los Angeles, 1994).

Hanson, Simon G., Argentine Meat and the British Market: Chapters in the History of the Argentine Meat Industry (Stanford, 1938).

Hartley, C.W.S., The Oil Palm (London, 1977).

Hausman, William J., Peter Hertner, and Myra Wilkins, Global Electrification: Multinational Enterprise and International Finance in the History of Light and Power, 1878-2007 (Cambridge, 2008).

Havinden, Michael, and David Meredith, Colonialism and Development: Britain and Its Tropical Colonies, 1850-1960 (London, 1993).

Haynes, Douglas E., Small Town Capitalism in Western India:Artisans, Merchants, and the Making of the Informal Economy, 1870-1960 (Cambridge, 2012).

Headrick, Daniel R., Power over Peoples: Technology, Environments and Western Imperialism, 1400 to the Present (Princeton, 2009).

Hershlag, Z.Y., Turkey: The Challenge of Growth (Leiden, 1968).

Hofmeester, Karin, "Shifting Trajectories of Diamond Processing: From India to Europe and Back, from the Fifteenth Century to the Twentieth",Journal of Global History, 8 (2013), pp. 25-49.

Hommel, Rudolf P., China at Work: An Illustrated Record of the Primitive Industries of China's Masses (Cambridge, 1969). 
Huff, W.G., "Boom-or-Bust Commodities and Industrialization in Pre-World War II Malaya", Journal of Economic History, 62 (2002), pp. 1074-1115.

Huff, W.G., The Economic Growth of Singapore: Trade and Development in the Twentieth Century (Cambridge, 1994).

Igler, David, "The Industrial Far West: Region and Nation in the Late Nineteenth Century", Pacific Historical Review, 69 (2002), pp. 159-192.

Ingleson, John, In Search of Justice: Workers and Unions in Colonial Java, 19o8-1926 (Oxford, 1986).

Issawi, Charles, An Economic History of the Middle East and North Africa (New York, 1982).

Kaarsholm, Preben, Imperialism and Romantic Anti-Capitalism: Four Papers on Culture and Ideology c. 1900 (Roskilde, 1983).

Karasch, Mary C., Slave Life in Rio de Janeiro, 1808-1850 (Princeton, 1987).

Kemp, Tom, Industrialisation in the Non-Western World (London, 1989).

Kenwood, A.G., and A.L. Lougheed, Technological Diffusion and Industrialisation before 1914 (London, 1982).

Kerlogue, Fiona, Batik: Design, Style and History (London, 2004).

Knight, G. Roger, Commodities and Colonialism: The Story of Big Sugar in Indonesia, 1880-1942 (Leiden, 2013).

Knight, G. Roger, "Coolie or Worker? Crossing the Lines in Colonial Java, 1780-1942", Itinerario, 23 (1999), pp. 62-77.

Kriger, Colleen E., Cloth in West African History (Lanham, 2006).

Lal, Deepak, The Hindu Equilibrium, Volume 1: Cultural Stability and Economic Stagnation: India c. 1500 BC-AD 1980 (Oxford, 1988).

Larsen, Kirk, "Competition in Absentia: China, Japan, and British Cotton Textiles in Korea, 1876-1910”, in Kenneth L. Pomeranz (ed.), The Pacific in the Age of Early Industrialization (Farnham, 2009), pp. 153-173.

Lindblad, J. Thomas, Bridges to New Business: The Economic Decolonization of Indonesia (Leiden, 2008).

Liu, Xiazhu, "Paradoxical Development: China's Early Industrialization in the Late Nineteenth Century" (PhD diss., University of Arizona, 1995).

Löwy, Michael, and Robert Sayre, Romanticism against the Tide of Modernity (Durham, 2001).

Ma, Debin, "Between Cottage and Factory: The Evolution of Chinese and Japanese Silk-Reeling Industries in the Latter Half of the Nineteenth Century", Journal of the Asia Pacific Economy, 10 (2005), pp. 195-213.

Macpherson, W.J., The Economic Development ofJapan, 1868-1941 (Cambridge, 1995). Markovits, Claude, The Global World of Indian Merchants, 1750-1947: Traders of Sind, from Bukhara to Panama (Cambridge, 2000). 
Marks, Shula, and Richard Rathbone (eds), Industrialisation and Social Change in South Africa, 1870-1930 (Harlow, 1982).

Marseille, Jacques, Empire Colonial et capitalisme français: histoire d'un divorce (Paris, 1984).

Marseille, Jacques, "The Phases of French Colonial Imperialism: Towards a New Periodization", Journal of Imperial and Commonwealth History, 13 (1985), pp. 127-141.

Martin, Leonide, "Weaving the World of Ancient Mayan Women", available at: http://www.ancient-origins.net/ancient-places-americas/weaving-worldancient-mayan-women-001976.

Martin, Susan M., Palm Oil and Protest: An Economic History of the Ngwa Region, South-Eastern Nigeria, 1800-1980 (Cambridge, 2006).

Martin, Susan M., The UP Saga (Honolulu, 2003).

Matsuo, Hiroshi, The Development ofJavanese Cotton Industry (Tokyo, 1970).

Meide, Chuck, "The Sugar Factory in the Colonial West Indies: An Archaeological and Historical Comparative Analysis", available at: https://www.academia. edu/3258102/The_Sugar_Factory_in_the_Colonial_West_Indies_an_Archaeological_and_Historical_Comparitive_Analysis, 2003.

Mohebbi, Parviz, Techniques et ressources en Iran, du 7e au rge siècle (Teheran, 1996).

Morris, Morris, D., "Indian Industry and Business in the Age of Laissez-Faire", in Rajat K. Ray (ed.), Entrepreneurship and Industry in India, 1800-1947 (Delhi, 1993, pp. 187-227.

Mosley, Paul, The Settler Economies: Studies in the Economic History of Kenya and Southern Rhodesia, 1900-1963 (Cambridge, 1983).

Myers, Ramon, The Chinese Economy, Past and Present (Belmont, 1980).

Nagano, Yoshiko, State and Finance in the Philippines, 1898-1941: The Mismanagement of an American Colony (Singapore, 2015).

Nakamura, Takafusa, Economic Growth in Prewar Japan (New Haven, 1983).

Norris, Jacob, "Exporting the Holy Land: Artisans and Merchant Migrants in Ottoman-era Bethlehem", Mashriq and Mahjar, 2 (2013), pp. 14-40.

North, Douglass C., Institutions, Institutional Change and Economic Performance (Cambridge, 1990).

Northrup, David, Indentured Labor in the Age of Imperialism, 1834-1922 (Cambridge, 1995).

O'Brien, Patrick, "Intercontinental Trade and the Development of the Third World since the Industrial Revolution", Journal of World History, 8 (1997), pp. 75-133.

Oki, Akira, "A Note on the History of the Textile Industry in West Sumatra", in Francine van Anrooij (ed.), Between People and Statistics: Essays on Modern Indonesian History (The Hague, 1979), pp. 147-156. 
Owen, Roger, The Middle East in the World Economy, 1800-1914 (London, 1981).

Palmer, Ingrid, Textiles in Indonesia: Problems of Import Substitution (New York, 1972).

Parthasarathi, Prasannan, Why Europe Grew Rich and Asia Did Not: Global Economic Divergence, 1600-1850 (Cambridge, 2011).

Pauer, Erich, “Traditional Technology and Its Impact on Japan's Industry during the Early Period of the Industrial Revolution", Economic Studies Quarterly, 38 (1987), pp. 354-371.

Phillips, Anne, The Enigma of Colonialism:British Policy in West Africa (London, 1989). Platt, D.C.M., and Guido di Tella (eds), Argentina, Australia and Canada: Studies in Comparative Development, 1870-1965 (London, 1985).

Polhamus, Loren G., Rubber: Botany, Cultivation and Utilization (London, 1962).

Pollard, Sidney, Peaceful Conquest: The Industrialization of Europe, 1760-1970 (Oxford, 1982).

Pomeranz, Kenneth L. (ed.), The Pacific in the Age of Early Industrialization (Farnham, 2009).

Ponder, H.H., Javanese Panorama: More Impressions of the 193os (Singapore, 1990).

Quataert, Donald, Ottoman Manufacturing in the Age of the Industrial Revolution (Cambridge, 1993).

Raffles, Thomas S., The History ofJava, 2 vols (London, 1817).

Ray, Rajat K., Industrialisation in India: Growth and Conflict in the Private Corporate Sector, 1914-47 (Delhi, 1982).

Roy, Tirthankar, Traditional Industry in the Economy of Colonial India (Cambridge, 1999).

Segers, W.A.I.M., Manufacturing Industry, 1870-1942: Changing Economy in Indonesia, vol. 8 (Amsterdam, 1987).

Shiroyama, Tomoko, China during the Great Depression: Market, State, and the World Economy, 1929-1937 (Cambridge, 2008).

Slijper, H.J., Technologie en warenkennis, tweede deel, organische producten en eenige ook voor Ned.-Indië belangrijke cultures (Purmerend, 1927).

Smith, Andrew F., Peanuts: The Illustrious History of the Goober Pea (Urbana, 2002).

Smith, Thomas C., Native Sources ofJapanese Industrialization, 1750-1920 (Berkeley, 1988).

Starobin, Robert S., Industrial Slavery in the Old South (London, 1970).

Sutter, John O., "Indonesianisasi: A Historical Survey of the Role of Politics in the Institutions of a Changing Economy, from the Second Word War to the Eve of the General Elections, 1940-1955" (PhD diss., Cornell University, 1959).

Tan, Kah-kee, The Memoirs of Tan Kah-kee (Singapore, 1994).

Tanimoto, Masayuki, The Role of Tradition in Japan's Industrialization: Another Path to Industrialization (Oxford, 2006). 
Tharoor, Shashi, "Viewpoint: Britain Must Pay Reparations to India”, BBC, 22 July 2015, available at: http://www.bbc.com/news/world-asia-india-33618621.

Thoburn, John T., Tin in the World Economy (Edinburgh, 1994).

Tomlinson, B.R., The Economy of Modern India, 1860-1970 (Cambridge, 1993).

Tomlinson, B.R., "Technical Education in Colonial India, 1880-1914: Searching for a 'Suitable Boy', in Sabyasachi Bhattacharya (ed.), The Contested Terrain: Perspectives on Education in India (Hyderabad, 1998), pp. 322-341.

Tyabji, Nasir, Colonialism, Chemical Technology and Industry in Southern India (Delhi, 1995).

Vuldy, Chantal, Pekalongan: batiket islam dans une ville du nord de Java (Paris, 1987). Wallerstein, Immanuel, The Modern World-System, 3 vols (New York, 1974-1989).

Ward, J.R., Poverty and Progress in the Caribbean, 1800-196o (London, 1985).

Warren, Bill, Imperialism: Pioneer of Capitalism (London, 1980).

Williams, Jeffrey C., "The Origins of Futures Markets", Agricultural History, $5^{6}$ (1982), pp. 306-316.

Williamson, Jeffrey G., Trade and Poverty: When the Third World Fell Behind (Cambridge, 2013).

Yip, Yat-Hoong, The Development of the Tin Mining Industry of Malaya (Kuala Lumpur, 1969).

\section{About the Author}

William Gervase Clarence-Smith is Professor of the Economic History of Asia and Africa, at SOAS, University of London (United Kingdom). He is editor of the Journal of Global History. He has researched the history of cotton textiles and various export-processing industries in the Global South. More widely, he has written on the history of commodities, animals, labour, diasporas, and Islam. His latest book is Islam and the Abolition of Slavery (London, 2006).

E-mail:wc2@soas.ac.uk 



\title{
$3 \quad$ Economic Institutions and Shifting Labour Relations in the Indian, Brazilian, and South African Diamond Mines
}

Karin Hofmeester

Hofmeester, Karin \& Pim de Zwart (eds.), Colonialism, Institutional Change, and Shifts in Global Labour Relations. Amsterdam: Amsterdam University Press, 2018

DOI: $10.5117 / 9789462984363 / \mathrm{CHo} 3$

\begin{abstract}
This chapter investigates if and how colonial economic institutions influenced shifts in labour relations in the diamond mines in India, Brazil, and South Africa. Diamond mining is very labour intensive, and institutions developed to recruit, employ, and control labour were pivotal for the success of diamond mining. They also had a major impact on labour relations in the mines as the widespread use of slave labour in the Brazilian mines and the shift from reciprocal labour to wage labour in South Africa show us. However, the effectiveness of these institutions cannot be analysed without taking power relations into account, both between pre-colonial and colonial institutions, as well as within colonial administration, as the differences between Brazil and South Africa reveal.
\end{abstract}

Keywords: diamonds, extractive institutions, power relations, labour

\section{Introduction}

Diamonds have a long history as a global commodity. They were first mined, polished, sold, and consumed in India, found their way to the Indian Ocean seaboard, and reached Europe in the early Renaissance. For a long 
time, India had a near monopoly on diamond production, ${ }^{1}$ until diamonds were found in Brazil in the 1720 s. In the 1870 s, the discovery of primary deposits in South Africa meant another major change in the global diamond commodity chain. ${ }^{2}$ Although geological fate determines where diamonds can be found, political systems and economic institutions - such as land, subsoil, and other property rights - determine who can exploit the mines. In addition to mining rights, capital and technology is needed, especially in the case of deep mining, but even more important is labour. Diamond mining is very labour-intensive, and institutions that were developed to recruit, employ, and control labour were pivotal for the success of diamond mining and had a major impact on labour conditions and labour relations in the mines, such as the widespread use of slave labour in the Brazilian mines and the shift from reciprocal labour to wage labour in South Africa as a consequence of the development in the diamond mines.

This chapter investigates if and how economic institutions influenced shifts in labour relations in the diamond mines in India, Brazil, and South Africa. To analyse this influence, we need to know who the workers were, where they came from, how mining fitted into existing systems of household, seasonal and migratory labour, what the conditions of labour were (including payment), and most of all, what type of labour relations prevailed in and around the mines and how they changed over time. The development of economic institutions cannot be analysed without taking political changes into account. In the late eighteenth and early nineteenth century, the British gained power over parts of India where diamond mines were located, taking over the right to exploit the mines from the royal rulers they defeated. In the last quarter of the nineteenth century, the British took control over parts of South Africa where mines were located, and in Brazil, the Portuguese Crown considered the diamond mines part of its possessions from the moment their discovery was reported. As we will see, regime changes often led to economic institutional changes, though existing institutions sometimes remained in place and in other cases colonial institutions lingered on long after independence. Diamonds are special. They have to be rare and expensive to be attractive, which makes control of the supply and price a very important part of the governance of

1 Diamonds were also found in Borneo, though in much smaller quantities and local rulers were reluctant to sell them.

2 Primary deposits are pipes that bring the diamonds to the surface in volcanic magma, often called Kimberlite after Kimberley in South Africa where their existence was first discovered in the 1870 s. Secondary deposits comprise diamonds from primary deposits that are washed to a lower area by rainwater. These deposits are also termed alluvial deposits. 
the segments in the diamond commodity chain. In the three case studies discussed in this chapter, we see how institutions were used to establish global monopolies; in mining, but often also in trading, in price setting, and sometimes even in transport. At the same time, we see how illicit mining and trading always managed to evade the institutions meant to control the processes, which could deeply influence labour relations.

\section{India}

India's Golconda mines had worldwide fame in the early modern world. The mines were actually not located in Golconda itself - the diamonds were only sold there - but situated further east on the Deccan plateau, near rivers in and around Kollur, Kurnool, and Cuddapah. A second group of mines existed around Sambalpur, in present-day Orissa. The third group was located in Panna, in Central India.

From a number of sixteenth- and seventeenth-century descriptions, we can obtain a picture of the activities in and around the mines. ${ }^{3}$ Usually the emperor, king, or sultan who had the mines in his territory also owned them. He could choose whether or not he wanted to farm out the mine, and if so, to whom. ${ }^{4}$ The ruler leased the mine to the highest bidder. ${ }^{5}$ These governors - revenue farmers - acted as intermediaries between the ruler on the one hand, and the merchants who actually commissioned miners to dig for diamonds on the other. ${ }^{6}$ These merchants were often Banians from Gujarat, who maintained a tight grip on the diamond trade and had a wide trade network. The capital needed to rent the mine and to hire miners was provided from within their family networks. ${ }^{7}$

3 Verberckmoes and Stols, Aziatische omzwervingen, pp. 172-177; Tavernier, Travels in India, vol. 1, pp. 240-243; Howard, "A Description of the Diamond-Mines"; Methwold, "Relation", 3033; Temple, Diaries of Streynsham Master, pp. 113-114, 172-175; Van Dam, Beschrijvinge van de Oostindische Compagnie, vol. 2, pp. 176-181.

4 According to Henry Howard, several rajas and sultans in South India had (some of) their mines dug out only privately, "A Description of the Diamond-Mines", pp. 907-909.

5 For the highest bidder, Mentz, The English Gentleman Merchant at Work, p. 111; for the goldsmith, see Methwold, "Relation”, p. 31, and Chetty, Manual of the Kurnool District, p. 94; for the Portuguese, see Verberckmoes and Stols, Aziatische omzwervingen, p. 177, and Wolf, "Jews in Elizabethan England", 24-25.

6 Mukund, "Mining in South India", 17.

7 Tavernier, Travels in India, vol. 2, p. 47; Report by Pieter de Lange as included in Van Dam, Beschrijvinge van de Oostindische Compagnie, vol. 2, p. 179; Howard, "A Description of the Diamond-Mines", p. 915 . 
Figure 3.1 Diamond fields in India

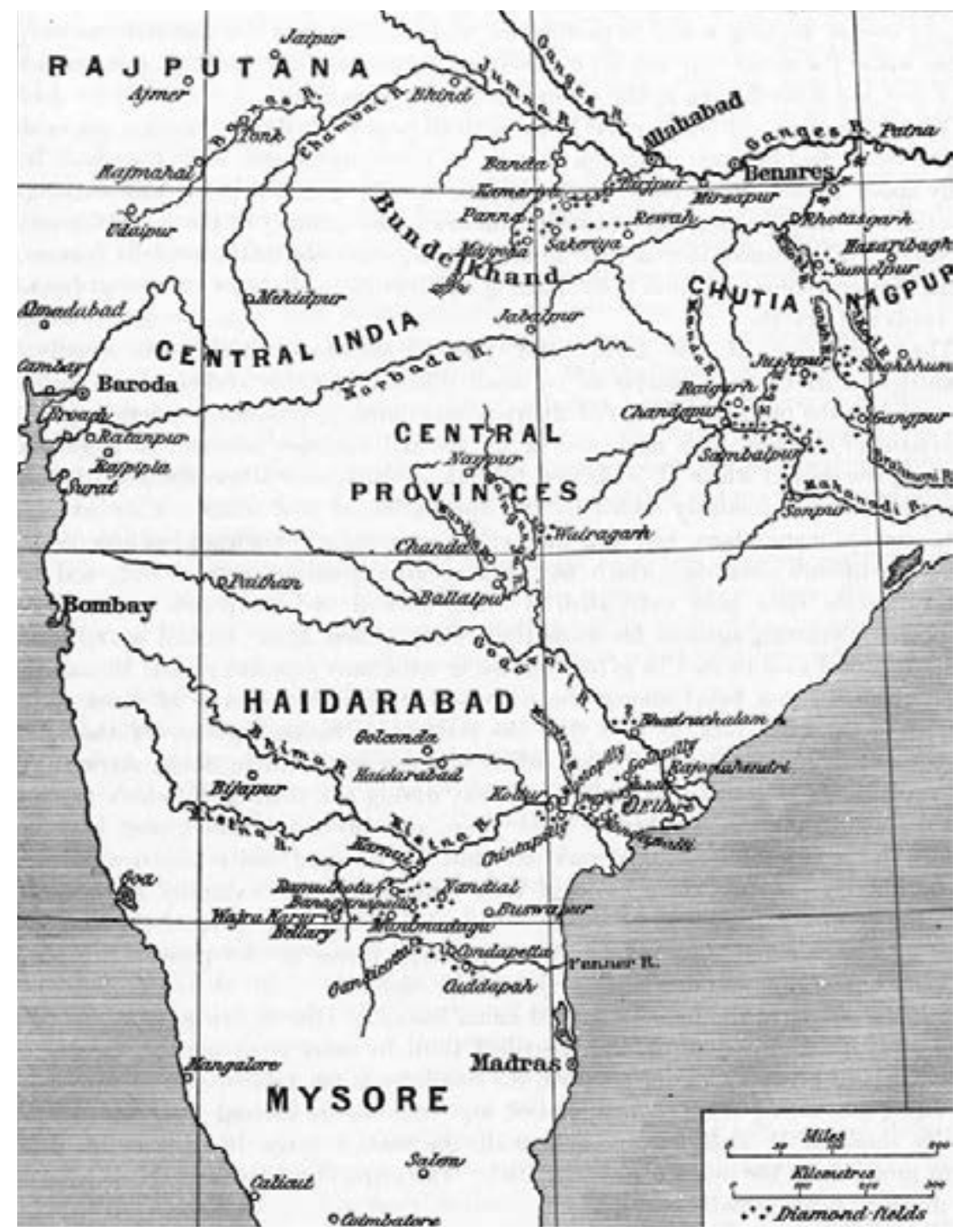

Source: Bauer, Precious Stones, vol. 1, p. 144

In some mines, merchants only had to pay a fee per miner to the governor. In the Kollur mine, the governor provided the merchants with workers, suggesting he may have acted as a labour recruiter. He also equipped miners with tools and he divided the merchant's fee between the king and 
the miners. ${ }^{8}$ In addition to rent, the king also received 2 per cent of all diamond purchases and sales, and any diamonds of more than ten carats. ${ }^{9}$ Notwithstanding the presence of overseers - hired by the merchants - large diamonds were often excavated without being reported to the governor, and sometimes sold to foreigners for half the price the merchant would ask. Usually, stones were bought and sold in public and assessed by special weighers, employed by the king. ${ }^{10}$ Generally speaking, the Indian rulers, whether they were Deccan sultans, Mughal emperors, or rajas of smaller successor states, arranged the ownership and revenue rights reasonably well, though they could not prevent some large stones from not reaching their treasury, or that price setting through royal weighers also sometimes failed. Good care was taken of production control. The Bijapur sultan appears to have shut down a number of mines in 1622 , just when the Dutch East India Company (VOC) had started trading the stones very profitably, in order "to keepe the commoditie in request".

Mining methods differed somewhat from mine to mine, depending on the type of diamantiferous stratum. In all cases, very few technological devices were used and all the methods were very labour-intensive. Men dug the pits and removed the earth (and superfluous water), which was carried away in baskets by women and children. Indian miners could not dig below the water table, pits therefore varied from four to fourteen feet deep. ${ }^{12}$ These pits were not supported with timber and could easily collapse after heavy rainfalls, taking the lives of the miners. ${ }^{13}$ The miners used no "pullies and such like devices", but sat on top of each other, and passed on the baskets. ${ }^{14}$ The women and children carried the soil to a place where they would wash and dry it. Lastly, they would sieve and search the earth to find the diamonds. ${ }^{15}$ Although the miners worked in small groups, the total number of miners in a field could be enormous. In the early seventeenth

8 Tavernier, Travels in India, vol. 2, p. 46; Report by Pieter de Lange as included in Van Dam, Beschrijvinge van de Oostindische Compagnie, vol. 2, p. 180.

9 Tavernier, Travels in India, vol. 2, p. 46. Different authors mention different numbers; see Verberckmoes and Stols, Aziatische omzwervingen, p. 173; Methwold, "Relation", p. 33; Tavernier, Travels in India, vol. 2, p. 47; Report by Pieter de Lange as included in Van Dam, Beschrijvinge van de Oostindische Compagnie, vol. 2, p. 181.

10 Tavernier, Travels in India, vol. 2, pp. 47-48, 54.

11 Raychaudhuri, Jan Company, p. 171; Methwold, "Relation", p. 33.

12 Howard, "A Description of the Diamond-Mines", p. 910; Temple, Diaries of Streynsham Master,

p. 174; Tavernier, Travels in India, vol. 2, p. 60.

13 Verberckmoes and Stols, Aziatische omzwervingen, p. 174.

14 Methwold, "Relation", p. 32

15 Tavernier, Travels in India, vol. 2, pp. 6o-61. 
century, the Flemish merchant De Coutre counted 50,000 men, women, and children in one mine field, while a little later, the East India Company (EIC) administrator Methwold counted some 30,000 "souls" working in the diamond fields near the Kollur mine. In the 166os, the famous precious stone merchant Tavernier signalled no less than 6o,ooo men, women, and children at work in the Kollur mine. ${ }^{16}$ These large numbers can only be explained by the very labour-intensive production process.

According to De Coutre, the miners were the poorest of the poor. Tavernier thought they were peasants, who went back to tilling the soil when the mines were exhausted. ${ }^{17}$ This would suggest that work in the mines was not part of a system of seasonal migration. During the monsoon season, the mines would fill up with water and digging was not possible, but washing and sieving continued. Ishrat Aslam categorizes the miners as "possibly [...] pauperised peasants and landless workers from the villages". ${ }^{18}$ The fact that women and children joined the male miners supports Aslam's idea of landless workers, otherwise the women and children would have taken care of the land. We may therefore suppose that at least a large number of miners were labour migrants who moved with their families from agricultural areas to the mines and vice versa, working as wage earners in both sectors. Miners were contract labourers who worked for wages in cash, and who were sometimes also partly compensated in food. ${ }^{19}$ Observers noted monthly wages from 0.5 to 1.5 pagodas (a pagoda was roughly equal to eight British shillings). ${ }^{20}$ Compared with the other production costs (merchants usually had to pay two pagodas a day per fifty miners as a fee), wages were very low. These low labour costs were also indicated by De Coutre, who stated that they would be much higher in Spain, leading to a higher price per carat. ${ }^{21}$ From De Coutre's descriptions, we learn that the miners were sometimes paid per stone by merchants, who in return supplied them with food. As the miners might sometimes not find a stone for two or three months, they could easily end up in a position of

16 Verberckmoes and Stols, Aziatische omzwervingen, p. 172; Methwold, "Relation", p. 31; Tavernier, Travels in India, vol. 2, p. 59.

17 Verberckmoes and Stols, Aziatische omzwervingen, p. 172; Tavernier, Travels in India, vol. 1, p. 230 .

18 Alam, “Diamond Mining”, p. 300.

19 Ibid., p. 300; Report by Pieter de Lange as included in Van Dam, Beschrijvinge van de Oostindische Compagnie, vol. 2, p. 180.

20 Mukund, "Mining in South India", p. 18. According to Ravi Ahuja, a male general worker in Madras would have earned a monthly money wage of one pagoda around 1760: Ahuja, Die Erzeugung kolonialer Staatlichkeit, Appendix 8.1.

21 Verberckmoes and Stols, Aziatische omzwervingen, p. 174. 
Figure 3.2 Value of diamond imports from India

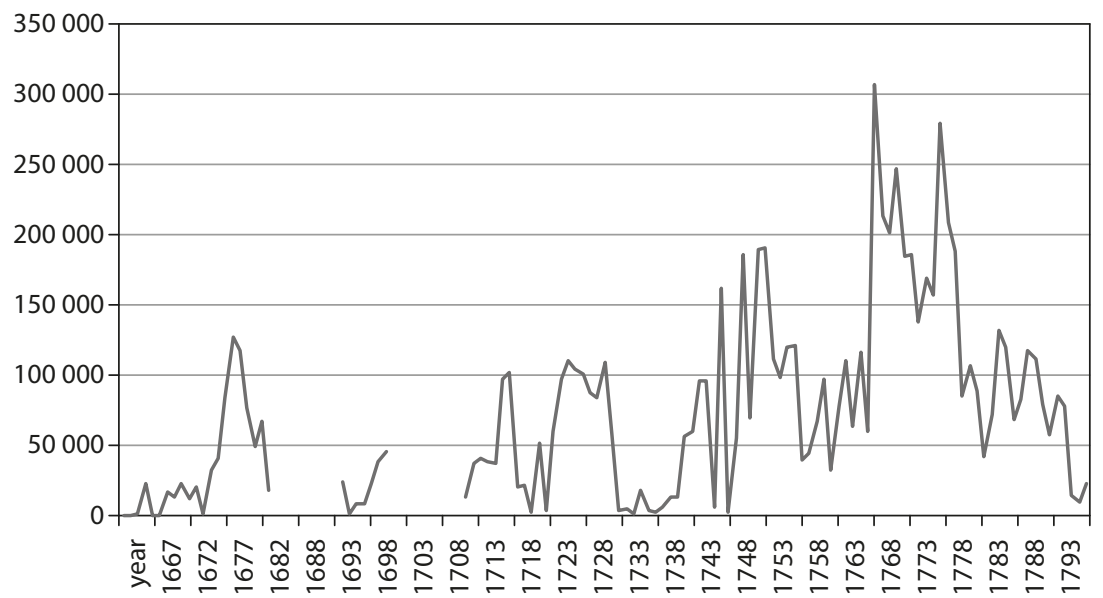

Sources: For 1663-1681: Samuel, "The Diamond Trade", p. 69; for 1682-1683: Mentz, The English Gentleman Merchant at Work, pp. 111-112; for 1694-1700: Samuel, “The Diamond Trade”, p. 77; for 1711-1796: Yogev, Diamonds and Coral, pp. 337-338

debt bondage. ${ }^{22}$ Although the miners were often exploited by the merchants, they were worse off if they were not hired by them, because they then had to carry out mine work for the king, in exchange for only board. The VOC administrator De Lange described these miners as "slave-like objects". ${ }^{23}$ This would suggest these people had no other source of income apart from the mines, owned no land, and were not hired by farmers as day labourers, which made them effectively tributary labourers for the king, as long as no commercial exploiters worked the mine. This tributary aspect is also mentioned by the British duke, Howard, who visited the Mallavilly mine in the $1670{ }^{24}$

By the end of the eighteenth century, production from the Indian mines seems to have slowed down, though it is very difficult to estimate the output of the Indian mines, as royal bookkeeping is silent on these matters and foreign trade was measured in monetary value, not carats. Nevertheless, the development of the value of the Indian diamonds imported via the EIC does tell us something about diminishing returns from the mines by the end of the eighteenth century (see Figure 3.2). Right at that moment, the British gained control over a number of mines.

22 Ibid., pp. 172-174.

23 Report by Pieter de Lange, as included in Van Dam, Beschrijvinge van de Oostindische Compagnie, vol. 2, pp. 179-181.

24 Howard, "A Description of the Diamond-Mines", p. 909. 


\section{British rule, mine exploitation, and labour relations}

In 1796, the Deccan Nizam Asaf Jah II opted to obtain British military protection against attacks from the Marathas and the Tipu Sultan. In return, the Nizam ceded a large portion of his territory to the British, who called it Ceded Districts. There are quite a number of reports from British officials who explored the possible revenues from diamond mines in these districts. Starting in 1796, Benjamin Heyne - a surgeon, naturalist, and botanist working for the EIC - wrote several reports on the mines. The exploitation of the mines near Cuddapah he described was more or less the same as in the sixteenth and seventeenth century: the mines were governed by a headman who paid a yearly rent of 130 pagodas - this time to the EIC and who worked some mines himself, farming out the rest. For diamonds weighing more than twelve carats, he had to pay one-third of their value to the company. Miners were hired by the headman and received one pagoda per month. Heyne noted that men, women, and children were working in the mines. As in previous centuries, the actual owner of the mine (in this case the EIC) farmed it out, received rent as a percentage of the larger stones, but as before, did not carry the financial risks; these were borne by the renters. The renter made 5,000 pagodas profit per year, against 2,000 pagodas in expenses. ${ }^{25}$ Labour costs still seemed to have been only a small part of the production expenses. The mining procedures were much the same as in the earlier descriptions, though the number of miners was much lower than in the earlier days, which could point to the exhaustion of the mines, or at least the layers that could be worked with the simple methods the miners had at their disposal.

In 1814, a collector from the Board of Revenue in Fort St George for Kurpah (near Cuddapah), wrote a report on the mines stating that most miners owned shares in the produce, and only some were "mere labourers for hire". Given the prevailing output of the mines, he did not expect cultivators to go working in the mines, although this might change if mining would become more profitable. He was convinced that in reverse, miners would never engage in cultivation as their job was hereditary (suggesting a specific caste background, which is not confirmed by other sources). If they could find no work in one mine they went to another. One might conclude from this that labour migration continued, although not from agricultural areas to mining areas, but from one mining area to another.

25 Heyne, Tracts, pp. 101-102; British Library, London [hereafter, BL], India Office Records [hereafter, IOR] F/4/275/6149 and $\mathrm{P} / 243 / 35$. 
In addition, the number of wage labourers seems to have diminished in favour of the number of self-employed miners, probably as a consequence of the reduced yields that attracted a lower number of entrepreneurs. To make the exploitation of the mines more profitable, smaller plots of the mine were rented out and advertised in the District Gazette. Only some Indian entrepreneurs responded. ${ }^{26}$ In 1821 , the Board of Revenue found that the rent had yielded no more than 200 pagodas a year, and therefore they stopped the exploitation. ${ }^{27}$

In the meantime, another EIC servant suggested that convicts in the Cuddapah district could be put to work in the mines nearby. They cost the company a fortune each year, and although they worked to build water tanks, roads, and bridges, in the mines their unpaid work would be much more profitable since nobody wanted to rent the plots of mines, because "coolie hire" was expensive and the rent was too high in relation to the profits. He added an extra encouragement: "The government of Brazil employs all its convicts and many slaves in digging and searching for diamonds. ${ }^{{ }^{2} 8}$ The Board of Governors of the EIC rejected the plan. The convicts did useful work already, and it was not wise to put people who had been convicted for theft to work in a diamond mine, where they had to be guarded and peons had to be paid. Most of all, the capital for exploitation should be provided by private individuals and not by the government. ${ }^{29}$

Throughout the nineteenth century, mining in the Ceded Districts seems to have continued under unchanged conditions. In 1834, a British researcher noted that the mines near Cuddapah were rented by a "native contractor" and that a labourer could be hired on the spot for four pice (0.06 rupees) a day plus a rice meal..$^{\circ} \mathrm{A}$ report written in 1872 , by an employee of the Geological Survey of India (GSI) ${ }^{31}$ on the mines near Kurnool and Cuddapah, reconfirms the existing exploitation methods and labour relations. ${ }^{32}$ Though solid production figures are lacking, the general impression is that the mines in the Ceded Districts in South India at that time were not very profitable. ${ }^{33}$

26 BL, IOR F/4/540/13001, letter by C. Ross, 24 December 1814.

BL, IOR F/4/676/18769, extract of revenue letter from Fort St George, 6 July 1821.

BL, IOR F/4/676/18769, letter of Mr Christy, 9 January 1817.

29

BL, IOR F/4/676/18769, letter from England, 22 May 1819.

30 Newbold, "Mineral Resources of Southern India", pp. 228, 231-232.

31 The Geological Survey of India was established in 1851 , as a follow-up to the EIC Commission on Coal, which aimed to study and explore the availability of coal in the eastern parts of India. Eventually it became a government organization, controlled by the Union Ministry of Mines for conducting geological surveys and studies.

32 King, "On the Kadapah and Karnul Formations", pp. 100-101. 
The mines in and around Panna in Central India seemed more profitable: in an 1831 publication, annual production with a value of 120,000 rupees is mentioned. ${ }^{34}$ Around that time, the monthly exploitation of a mine cost 122 rupees. Some forty rupees were needed to hire twenty miners who each earned two rupees a month, thirty rupees were needed to hire twenty "water women" (whose wages were not mentioned in the source), six rupees were needed to hire two guards, and some forty rupees were needed for implements for digging. ${ }^{35}$ Other than the ones in the Ceded Districts, these mines were still in the hands of the local ruler: the Raja of Panna. In 1820, an EIC captain suggested a considerable investment of capital, knowledge, and technique by the EIC and by private investors in the Panna mines, but the company turned this plan down as these mines were still "in the possession of a foreign power". ${ }^{6}$

The mine works in and around Panna consisted of two different types: alluvial mining and the mining of the deeper deposits that were part of a more rock-like matrix. For the latter, pits from thirty to forty feet deep had to be dug, and water and diamantiferous soil had to be removed from the mine with the help of a Persian wheel, driven by bullocks. ${ }^{37}$ For this type of mining, slightly more capital investment was needed than for riverbed mining. An estimated 6,00o miners worked in the whole district, and on average some 240 carats per year were found in the period from 1889 to $1903 .^{38}$ According to a report written for the British, basically anybody could start mining as long as royalties were paid per stone, while stones of more than six carats had to be handed in to the maharaja, who gave the finder a percentage. ${ }^{39}$ This would mean that the merchants no longer functioned as commissioners for mining work. The price of the stones was determined by appraisers of the maharaja, and the stones were sold once a month by auction. This situation would last until the end of the nineteenth

34 Franklin, “Diamond Mines of Panna”, p. 161.

35 Ball, Diamonds, Coal and Gold, p. 51.

36 BL, IOR F/4/661/18326, Extract Bengal Public Consultation, 15 September 1820.

37 For a vivid description and a drawing of this deep mining, see Rousselet, L'Inde des Rajahs, pp. 440-443.

38 National Archives of India, Delhi [hereafter, NAI], Bundelkhand agency 19, 189o, for carats and miners. Some 925 miners worked in the two smaller mines. Based on the ratio between carats and miners, the largest mine is calculated to have been worked by some 4,200 miners. Another document gives a total of 4,415, i.e., 4,017 carats for the years 1892 to 1901 . NAI Bundelkhand Agency files Progs. no. 147 .

39 NAI Bundelkhand Agency file no. 19 of 1890, undated statement on Panna mines. Raja Nirpat Singh assisted the British in 1857, for which the British rewarded him and his successors with the title maharaja. 
century, when the maharaja wanted to investigate if a more modern way of exploiting the mine could be profitable, especially since more and more entrepreneurs, both from India and abroad, started asking for concessions and even a monopoly on the Panna mines..$^{40} \mathrm{~A}$ GSI researcher had already advised the maharaja in 1892 to import technical management and not to allow a monopoly, but instead to let his state manage the mines, leasing portions of the property if needed..$^{41}$ In 1904, the maharaja again asked the GSI for help, and its researcher again concluded that the mines could still be worked profitably, as long as modern science and techniques were used. Of course, Indian labourers would still have to do the real mining work, and this should be family work: men, women, and children working together, as "the Indians clearly preferred this way of working". Strict supervision of the workers was needed, but since there were women and children involved "such severe measures as are practiced in the South African mines" were of course impossible. ${ }^{42}$

The Indian case shows that migratory wage labour, often family labour, was the major form of labour relations that prevailed in the Indian mines from the seventeenth till the early twentieth century, although in the seventeenth century, tributary labour seemed to have existed in the mines in Kollur and nearby Mallavilly. The property and exploitation rights of the Indian rulers were firmly installed; a governor exploited the mine, and in general, merchants provided the capital and labour to work the mines. When the British gained control over the districts where some of the mines were located, they took over these rights and left the exploitation system intact. Although the British did investigate the options of new (possibly labour saving and production enhancing) mining techniques, they decided not to invest in the mines and the actual situation remained unchanged. The existing wage labour relations of migrants - often families - working for merchants remained in place. Convict labour was not considered appropriate, as it would involve investment by the British government, whereas private individuals were supposed to invest. In addition, family labour seemed to have such a strong tradition in the Indian mines that even in the twentieth century, a British researcher suggested retaining this specific type of labour. The only real change in labour relations in the

40 NAI Bundelkhand Agency file no. 19 of 1890; NAI Bundelkhand Agency/English files/Progs. no. 239,1903 .

41 NAI Bundelkhand Agency file no. 19 of 189o, report no. 670, 21 May 1892.

$42 \mathrm{BL}, \mathrm{IOR} / \mathrm{R} / 2 / 449 / 4$ E. Vredenburg, Geology of the State of Panna, principally with reference to the diamond-bearing deposits (1904), p. 37. 
mines was caused by a severe drop in output. Merchants were no longer interested in investing and the miners became self-employed, rather than wage earners. This shift had very little to do with colonial institutions. The colonial impact on labour relations was much greater in Brazil - the next case we will study - where diamonds were discovered in the 1720 s.

\section{Brazil}

In the 1690 , gold was discovered in riverbeds in the Brazilian Minas Gerais district, north of Rio de Janeiro. In the late 1720s, these riverbeds also proved to contain large deposits of alluvial diamonds. Within the Minas Gerais Captaincy it was especially in the Serro do Frio district that diamonds were found, mostly in the village of Tijuco, later called Diamantina. In the 1740s, diamonds were also found in the Mato Grosso district on the Bolivian frontier and lastly in the 1840 s, new fields were discovered in Bahia, though they produced primarily black diamonds used in industry.

Diamonds were found in riverbeds, which had to be dammed or redirected to smaller channels to be able to dig out the diamantiferous sands and gravel. In addition, valleys and plateaus could contain diamond-bearing ground, which had to be separated from more solid matter. Collecting work could only be done during the dry season. The gravel was subsequently sieved and washed, a job that could also be performed during the rainy season. The procedure was more or less the same as in India, though here, bed-like sieves were used with holes in the bottom where water ran through, as well as sieving pans for the finer soil. ${ }^{43} \mathrm{~A}$ big difference from India was the composition of the workforce: in Brazil it consisted of male slaves supervised by overseers.

The discovery of diamonds in Brazil, and the way the mines were exploited, meant a major change in the global diamond commodity chain. No longer was India the sole supplier of rough diamonds, and no longer did local rulers control the mines. The diamond fields in Brazil were exploited by colonial powers in Lisbon, where the Crown had declared the diamond deposits (and other subsoil rights) to be royal property. ${ }^{44}$ The Crown was not in the first place interested in diamonds for its own adornment, as in India, but in making as much profit out of extraction and trade as possible. Initially, the exploiter welcomed all merchants and miners to work the

43 For a detailed description, see Mawe, Travels in the Interior of Brazil, pp. 222-224; Von Eschwege, Pluto Brasiliensis, pp. 416-417.

44 Triner, Mining and the State, p. 20. 
Figure 3.3 Diamond fields in Brazil

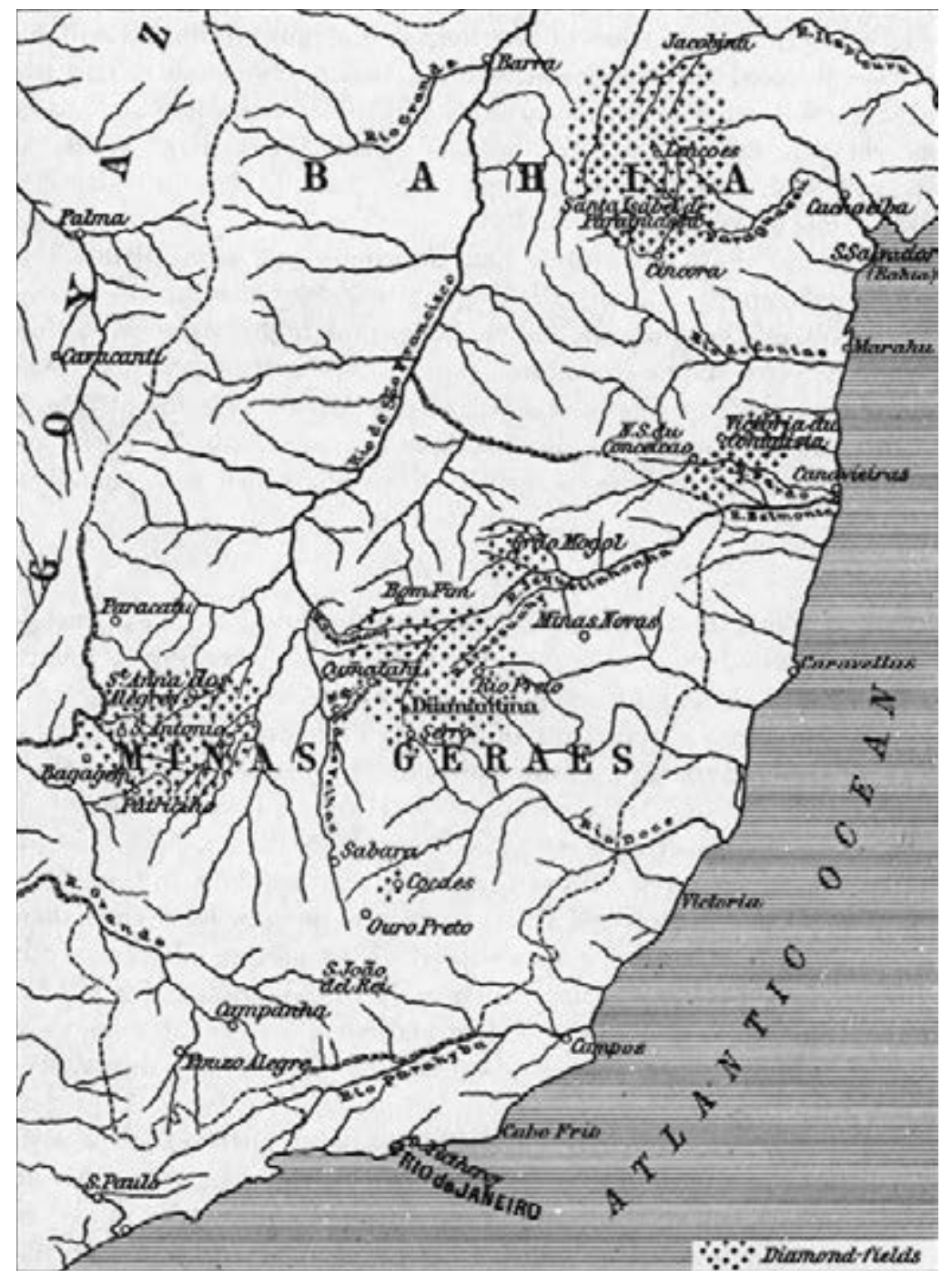

Source: Bauer, Precious Stones, vol. 1, p. 156 
Figure 3.4 Slaves washing diamond-bearing soil

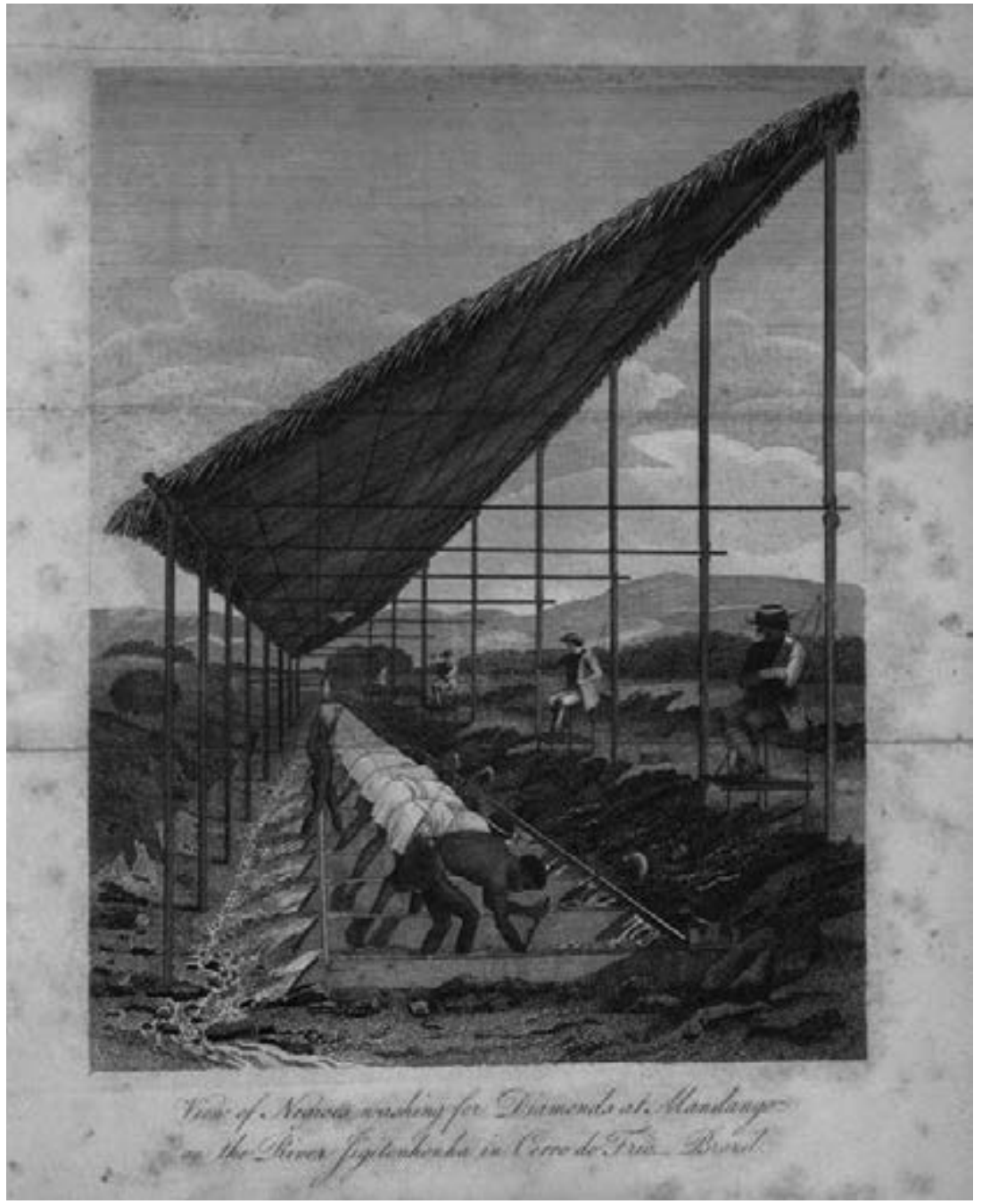

Source: Mawe, Travels in the Interior of Brazil

mines, as long as they paid a tax per miner to the Portuguese treasury. Most mineworkers were slaves; some of them had already migrated with their masters from the coastal areas to the interior when gold was discovered, others were brought in later from Rio. ${ }^{45}$ Before the 1690 , the interior region 
of Minas Gerais had only been populated by "unconquered" Indians who lived off their own produce. They either ran off, were caught and killed, or were enslaved by the gold seekers. ${ }^{46}$ By 1735 , there were about 96,500 slaves in Minas Gerais, some 10.5 per cent of whom lived in Serro do Frio, ${ }^{47}$ in addition to some $1,75^{0}$ white people and 1,750 pardos (people of mixed descent). ${ }^{48}$

The slaves worked under harsh conditions; removing the gravel was heavy work, controlled by force though not intensely guarded. The washing and sieving work was also very exhausting, since the workers stood bent over from little before sunrise until sunset, with a half-hour break for breakfast and a two-hour break at noon. ${ }^{49}$ This part was much more controlled, as diamonds could easily be hidden in the eyes, ears, nose, or and other body parts, or thrown away to be picked up after dark. Although the overseers in this part of the process carried a whip, they also applied positive incentives. To encourage the slaves to report the diamonds they found, they were compensated. Depending on the size of the stone slaves could "earn" a hat, clothing, a knife, or a day off. Reporting a stone of seventeen and a half carat or more would lead to manumission. ${ }^{50}$ Slaves could also be paid in money for good finds, and thus they could save for their manumission. There are no remaining lists of manumissions, so we have no clue how many slaves "earned" their freedom via diamond finds, though there are testimonies of male slaves receiving their freedom via diamonds. ${ }^{51}$ In addition, slave owners sometimes allowed their slaves to work independently as itinerant miners (faiscadores) as long as the slave paid a daily fixed sum to his owner..$^{2}$

\section{The global diamond market and the establishment of the Diamond District}

The uncontrolled diamond explorations caused an enormous flow of rough diamonds into the world market, more than five times the value that usually came from India. This led prices to drop to half, and in some cases even

46 Hell, "Die Sklaverei”, pp., 110, 113, 118.

47 Bergad, Slavery, p. 84.

48 Ferreira Furtado, O Livro da Capa Verde, p. 41.

49 Mawe, Travels in the Interior of Brazil, p. 225.

50 Ibid., p. 224; Ferreira Furtado, O Livro da Capa Verde, p. 54.

51 For the non-existence of such lists, see Bergad, "Demographic Change", 898; for the testimonies, see Ferreira Furtado, O Livro da Capa Verde, p. 114.

52 Klein and Luna, Slavery in Brazil, pp. 120-121; Kiddy, Blacks of the Rosary, p. 74. 
to a third, of what they had been..$^{53}$ The Indo-European trade came to a complete standstill. Startled by the lowered prices and the responses of the European traders - who feared that in Brazil "diamonds were as plenty as transparent pebbles" - the Portuguese Crown shut down the mines in the Minas Gerais district in $1734 .{ }^{54}$ Like many other rules that would come from Lisbon, in reality the area was difficult to control and illicit mining and trading continued, though on a smaller scale.

To control production, the Portuguese Crown established a demarcated Diamond District of some ninety square kilometres, where nobody except administrators, miners, and their slaves were supposed to live. ${ }^{55}$ Not only was entrance to the district controlled, but also exit from it. Several companies of dragoons, supplemented by slave catchers, had to prevent slaves from escaping. Anyone who was accused of smuggling could be expelled from the district..$^{6}$ In the district, an intendant was appointed, with far-reaching judicial, fiscal, and administrative powers. On top of that, when the mines officially reopened in 1739, the Portuguese Crown established a mining monopoly, with the actual mining entrusted to one single contractor or consortium (a group of investors, partners, and stockholders associated with them). The contractor had to bid for this closed contract and had to pay rent per slave. He was not allowed to employ more than 600 slaves, in order to avoid overproduction. ${ }^{57}$ João Fernandes de Oliveira (a merchant from Lisbon) held this contract for the first and subsequent four years. After a gap of four years, Oliveira regained the contract and he and his son held it in different partnerships until 1771.

Because of the restricted number of slaves, the Crown demanded exact information for every slave owned, so lists had to be kept for each contract, with individual data on the slaves. One of these lists has been preserved. It covers the years 1753 to $175^{8}$, and gives information about 394 slaves. The largest proportion of these were owned by João Fernandes de Oliveira himself, almost one-third were owned by individuals whose holdings ranged from one to thirty-one slaves. ${ }^{8}$ From the list, we learn that over 43 per cent of all the slaves came from the Banto West coast of Africa, almost 30 per cent from the Gold Coast, some 5 per cent from Sudan, and the rest from Brazil", p. 48.

$5^{8}$ Ramos, "Slavery in Brazil", p. $5^{8 .}$ 
diverse groups. Brazilian-born black slaves only formed 1 per cent of the total. The slaves on the list were all men, with an average age of twenty-eight. The slave force on this list quickly diminished: at the end of the contract almost 20 per cent had died and 32 per cent had escaped. The mean age of the slaves who died was thirty-one, the largest percentage of slaves died in the first four years of the contract, which is telling with regard to their working and living conditions. Most escapes took place in the first two years of the contract. ${ }^{59}$

The slaves usually ran away in groups based on ethnic origin. They developed communities of runaway slaves, termed the quilombos. Around Tejuco, approximately twelve such groups were known to exist, each with between fifteen and sixty inhabitants. They often lived off illegal mining, and as such resembled the garimpeiros (workers who became illegal miners after they had lost their official jobs because of the Portuguese measures). The groups helped each other, and sometimes even received help. In 1782, a lieutenant and sergeant of the army were accused in two separate cases of delivering food to runaway slaves and garimpeiros. Many of their settlements were close to centres of habitation, and a "horizontal solidarity" existed between clandestine miners, quilombolas, army members, slaves, and inhabitants. ${ }^{60}$ Though the list mentioned above contains data on fewer than 400 slaves, during his second contract in the 1740s, João Fernandes de Oliveira employed at least 1,200 slaves, twice the number that was admitted. ${ }^{61}$ The intendant reported this abuse to the governor of the Minas Gerais Captaincy, but the latter preferred to feign ignorance, probably because of his personal interest in the diamond trade..$^{62}$ This was neither the first nor the last time the policy of the Crown in Lisbon did not correspond with social reality in the Diamond District, where not all the servants of the Crown obeyed its laws.

In order to control the world diamond market, the Portuguese Crown decided not only to control production but also the trade in rough diamonds, so the latter was linked up with the mining monopoly. This meant that representatives of the contractor could only sell their products in Lisbon, where trading procedures were state controlled and officials of the king

59 Ibid., pp. 50-56.

60 Vanneste, "Commercial Culture and Merchant Networks", pp. 297-298.

61 In reality, the total number of slaves was even higher: more than 2,00o in the early 1740 s according to Tijl Vanneste, who made an estimate of the total number of slaves in the Diamond District from 1734 to 1785 based on a calculation of average productivity of carats per mined slave. See Vanneste, "Women in the Colonial Economy", p. 261.

62 Von Eschwege, Pluto Brasiliensis, p. 357. 
had first choice. The main goal of this rule was to direct the best stones to the royal treasury and to settle the lucrative resale of rough diamonds in Lisbon. Only after this procedure could representatives of the contractor sell the remaining diamonds to other European merchants. ${ }^{63}$ In 1753 , the Crown - in an attempt to stop the ongoing illegal mining and smuggling - decided to split up the two parts of the diamond commodity chain, establishing a separate trading monopoly. The Dutch consul in Lisbon, Daniël Gildemeester, obtained this extremely valuable trading monopoly in 1761 and held it for several decades ${ }^{64}$ This meant that in reality he held the monopoly on selling rough diamonds in Lisbon, though only after the Crown had selected the best diamonds first. As a consequence of the 1753 rule, the Crown, via its contractors, now had an overall monopoly on the mining, buying, selling, transporting, and dealing of diamonds.

Despite, or in many cases because of, the severe measures, illicit mining and trading continued, starting in and around the mines themselves. Mines were scattered, so controlling them was difficult, even though soldiers searched the Diamond District. Intendants, the diamond council, and the contract holders did not always obey the law. They employed more slaves than allowed and they bought diamonds from garimpeiros. Runaway slaves worked as independent miners, and many of the diamonds they discovered found their way to the contractors and to Rio and Bahia via ambulant merchants who supplied the ever-growing community in Minas Gerais with all kinds of commodities. In the second half of the eighteenth century, intensely used trading routes developed between the mines, Rio de Janeiro, and Bahia. ${ }^{65} \mathrm{~A}$ number of sources claim that the number of illicitly mined and traded diamonds was at least as great as the number of diamonds officially administered in Diamantina and Lisbon. ${ }^{66}$

\section{The Royal Extraction and its consequences for labour relations}

In 1772 , the Crown - or rather, the Marquis de Pombal - ended the mining concessions and started to exploit the mines directly under the name Real Extração do Diamante. This decision should be seen in the light of Pombal's radical economic reforms, which included the expansion of colonial

63 Vanneste, "Commercial Culture and Merchant Networks", pp. 231, 281.

64 Ibid., pp. 231-235; Yogev, Diamonds and Coral, p. 122.

65 Mawe, Travels in the Interior of Brazil, p. 259.

66 Ibid., p. 258; Von Eschwege, Pluto Brasiliensis, p. 401. 
exploitation ${ }^{67}$ Pombal himself was to be the director of this "Royal Extraction", and he introduced a "Regimento" or very strict standing orders for the administration of the Diamond District. ${ }^{68}$ Its main goal was to regulate supply and eliminate smuggling. In accordance with these rules, royal cashiers were appointed to receive, weigh, and transport the diamonds in Diamantina. Once a year, a ship - guarded by soldiers - carried the diamonds from Brazil to Lisbon. The demarcated Diamond District was well guarded; everyone entering or leaving was checked and only people with a license could enter. All the slaves in the district had to be registered, and unregistered slaves were heavily punished. Whites, mulattos, and free blacks without legal occupations had to leave the district at short notice. Ambulant traders could only stay there for twenty-four hours, female slaves living in the district were no longer allowed to work as peddlers, and anyone breaking these and other rules could be punished by ten years of exile in Angola. ${ }^{69}$ People who bought illicitly mined diamonds were also heavily punished. Soldiers could carry out person and house searches, and the intendant would function as judge for the whole Diamond District. Lastly, from then on, the intendant of the Diamond District would exploit the mines himself, directly employing slaves to mine the diamonds.

This latter rule in particular had an important impact on labour relations within the Diamond District. The Crown now put slaves to work, hiring them from their masters. This "slaves for hire" system stimulated the ongoing importation of slaves from Africa. This effect becomes clear if we compare the situation in Minas Gerais as a whole with the situation in the Diamond District. In Minas Gerais the import of slaves decreased and the reproduction of slaves increased in the second half of the century. When the gold boom had ended around 1750, and by approximately $177^{\circ}$ the biggest diamond boom seemed to have passed, a local economy developed in Minas Gerais, characterized by heavy trade with Rio and Bahia, and based on agriculture and raising cattle, first for self-sufficiency and the local market, later for export (with goods also including coffee, cotton, and tobacco). This led to a more diversified economy in Minas Gerais, which stimulated reproduction amongst slaves. ${ }^{70}$ In the Diamond District, the situation was different. Here, African-born slaves remained the majority

67 Triner, Mining and the State, p. 36.

68 Quoted in Von Eschwege, Pluto Brasilienis, pp. 359ff. For the impact of his policy on social reality in the Diamond District, see Ferreira Furtado, O Livro da Capa Verde.

69 On female peddlers, see Vanneste, "Women in the Colonial Economy".

70 Bergad, Slavery, pp. 16-23, 126-127. 
Figure 3.5 Diamond production Minas Gerais in carats, 1740-1824

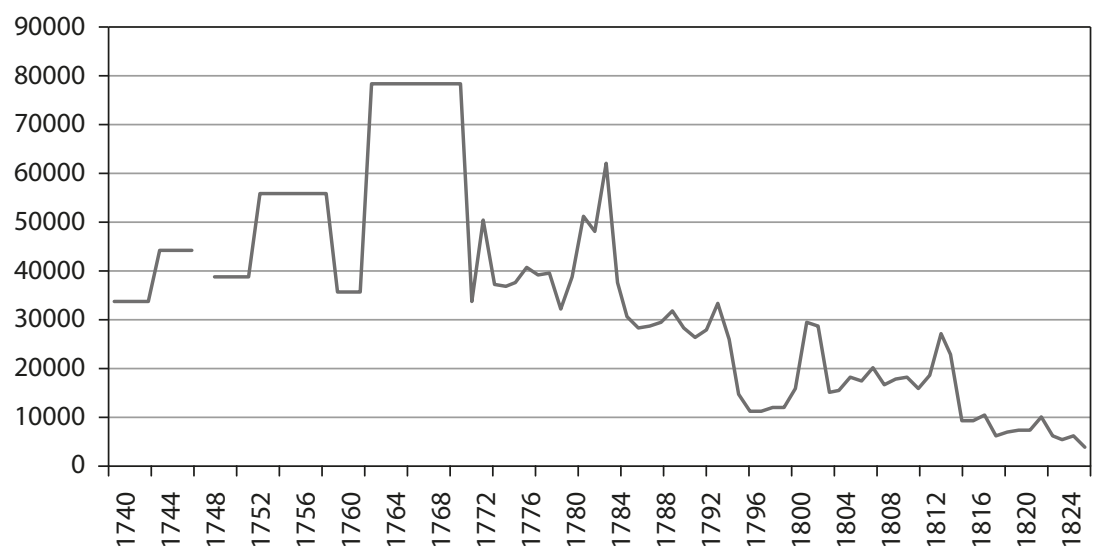

Sources: For 1740-1771 (data per contract, average per year calculated): Von Eschwege, Pluto Brasiliensis, pp. 391-392; for 1772-1824: Calogeras, As Minas do Brasil, vol. 1, pp. 323-324

until the early nineteenth century. ${ }^{71}$ This was not only a consequence of the high death and escape rates in the diamond mines, but also of the Royal Extraction. During peak years, such as 1773 and from 1780 to 1785 (see Figure 3.5), over 4,0oo slaves were rented for the Royal Extraction and slave prices increased in Diamantina. ${ }^{2}$ Slave owners rose to the occasion and let out their slaves on a large scale, buying new slaves specifically for this purpose. Even people who had not owned slaves before, now saved some money to be able to buy slaves so they could rent them to the Crown. Slave owners received a secure 16 per cent profit from renting out their slaves. ${ }^{73}$ Because escape, sickness, and death usually occurred in the first two to four years of enslavement, this newly imported slave population probably declined more rapidly than the group of slaves born in Brazil, which also led to new imports.

The development of the slave for hire system had various consequences for labour relations. Masters received a monthly payment for their slaves, whereas slaves seem to have received a small daily wage..$^{74}$ "The pay of the

71 Ibid., pp.128-130, based on censuses and data on slaves in probate inventories; Ferreira Furtado, "Quem nasce, quem chega", p. 228, based on baptismal records that present the same results.

72 Bergad, Slavery, pp. 129, 191.

73 Ferreira Furtado, O Livro da Capa Verde, p. 47; Saint-Hillaire, Voyage dans le district des diamans, vol. 1, p. $5^{8}$.

74 Mawe, Travels in the Interior of Brazil, p. 254 ; Saint-Hillaire, Voyage dans le district des diamans, vol. 1, p. 10. 
slaves is trifling compared with the risk, their labour being heavy, their maintenance poor and their treatment harsh", according to Mawe, who also stated that the masters "lived idly" on their slaves' wages. ${ }^{75}$ The masters had to clothe the slaves and take care of them when they were sick, and the administration of the Royal Extraction had to feed them..$^{76}$ Employees of the Crown could also own and rent slaves, and some of them possessed up to fifty. ${ }^{77}$ The administration of the Royal Extraction even had a preference for hiring slaves from people who worked in the service of the Crown.$^{7}$ In general, masters seemed to prefer renting out their slaves to the Crown rather than having them in the house, and even the slaves seemed to have preferred to work in the diamond mines, rather than in their master's house. For both, the biggest advantage was the possibility of illicitly mining and selling stones to increase their income, or in the case of slaves, buy their freedom.

The establishment of the Royal Extraction clearly did not diminish illicit mining and trading. The contractors who were left aside by the Royal Extraction often switched to illicit mining and trading. Moreover, many employees working at all levels in the Royal Extraction were engaged in smuggling. ${ }^{79}$ There were conflicts of power - as had also existed during the monopoly period - between the governors of the Captaincy of Minas Gerais and the intendant of the Diamond District, and the latter clearly did not have a tight grip on the local elite and their illicit practices. Intendants, contractors, overseers, slave owners, and slaves all had their reasons for smuggling diamonds and they frequently joined forces.

The Portuguese Crown, spending too much money on slave hire, salaries of administrators, and material costs, lost on the mining operations, which yielded no more than 20,000 carats a year in the period from 1801 to $1806 .^{80}$ Therefore, when the Crown settled in Rio in 1808 after the French had occupied Portugal, foreign powers were allowed to trade with Brazil, and British capital entered the mining operations, though in Minas focusing on gold only. ${ }^{81}$

Even though Brazil became independent in 1822 , very little changed in the actual situation in the Diamond District. In the political turmoil of 1830.

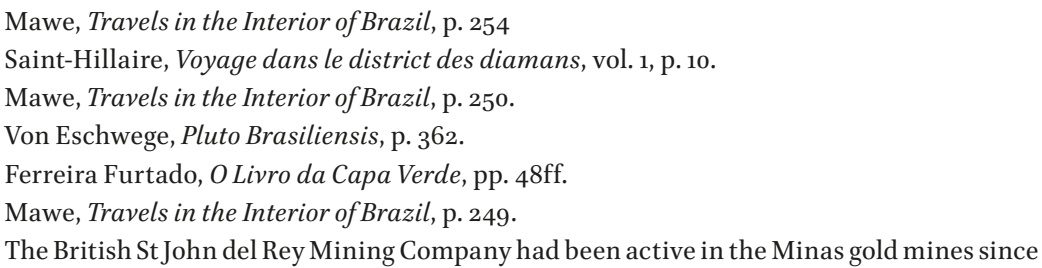


the first years of the rule of the Portuguese-Brazilian King, Dom Pedro I, a struggle broke out over the ownership of the mines between the Cortes in Lisbon and the ruler of now independent Brazil. In this vacuum, the situation remained unchanged and existing claimholders kept their rights for a number of years. ${ }^{82}$ Legally, Tijuco was still governed as a form of camp; it was only in 1831 that it officially became a township with its own local government, and in 1838 it became a town called Diamantina. The governance of the mining area was changed as late as 1845, when the Royal Extraction was officially abolished and a new "Regimento Diamantino" was established, governed by an inspector-general, a fiscal prosecutor, a secretary, and an engineer. They had to arrange public auctions of diamond claims that would last for four years. Because of legal quarrels over existing claims, the Royal Extraction was effectively ended only in 1853 , after an amendment to the law that settled these cases. ${ }^{83}$ From that moment on, mines were leased to private entrepreneurs, who employed slaves but invested little in more modern mining techniques. ${ }^{84}$

The settlement of Portuguese colonists in the gold- and later diamondmining areas of Minas Gerais led to massive migrations of Portuguese settlers, their slaves, and people of mixed descent from the coastal areas to the interior. For the indigenous population of Minas Gerais - if they did not run away or fall victim to murder - this settlement meant a shift from self-subsistence to slavery. The majority of the workforce in the diamond mines consisted of male slaves from Africa. This situation remained unchanged in the Diamond District until the beginning of the nineteenth century, despite the fact that in the surrounding areas in Minas Gerais slaves started to reproduce as a consequence of a more diversified economy. The continuation of slave imports was partially caused by the establishment of the Royal Extraction, which led to the slaves-for-hire system and an increase in the number of slave owners and imports.

Despite the development of a series of colonial institutions (including the Diamond District with its seemingly powerful intendant, a Crown monopoly on mining and trading, and eventually the Royal Extraction) set up to control diamond production and trade, illicit mining and trading seemed unstoppable, leading to a situation where slaves could more or less work as self-employed diggers, albeit in an unfree and unstable position.

82 Bernstein, The Brazilian Diamond, p. 93; Ferreira Furtado, O Livro da Capa Verde, p. 6.

83 Ferreira Furtado, "O Distrito Diamantino", p. 7.

84 Russell, "Diamond Mines of Brazil”, p. 7313. 
The Brazilian case shows that economic institutions alone could fail to control labour and labour relations if the state that tried to enforce them was represented at various levels of administration, often in conflict with each other and plagued by corruption. The next case, South Africa, seems to be the success story, where local representatives of the colonial government paved the way for institutions that had a huge impact on labour conditions and labour relations in the diamond mines and their hinterlands.

\section{South Africa}

In 1867 , diamonds were discovered near the confluence of the Vaal and Orange rivers, north of Cape Colony and west of the Orange Free State. The Griqua (descendants from relationships between the Khoikhoi and European colonists in the Cape) were the main inhabitants of this area, and in 1834 the British recognized the area as Griqualand-West and promised the Griqua protection and self-government. ${ }^{85}$

Mining started on a relatively low scale: by the end of 1870 , some 5,000 people were working at the river diggings ${ }^{86}$ where the mining, sieving, and washing techniques needed to retrieve the alluvial diamonds resembled the Indian and Brazilian procedures. Digging and washing was carried out by men, often Boers from the Orange Free State and the South African Republic, or by their black employees. Women and children usually took on the sorting.

Late in 1869, larger deposits were found on the farms of Dorstfontein and Bultfontein, not only in surface soil but also deeper. The discovery - of what would turn out to be primary diamond deposits - led to a rush. After several conflicts, the farmer proprietors, who were considered to be the owners of the minerals in "their soil", opened up their farms to diggers who paid them a monthly fee and in return received a claim on part of the mine. By 1871, some 50,00o diggers were working on what were termed "dry diggings", and encamped on the farms; some 20,000 of them white, the rest black. ${ }^{87}$ At this time, working methods were more or less the same as in the river diggings: diggers and their workers used picks, shovels, and buckets to remove the soil, and a series of sieves to separate the diamond-bearing matter from the rest. Even with these simple tools, 
some 269,000 carats were found in that year (see Figure 3.8 ). ${ }^{88}$ The diggers sold the diamonds locally to representatives of European merchants. In contrast to the situation in the 1720 s when the Brazilian diamond fields led to a crisis on the global diamond market, this time the diamonds were very welcome, as Brazilian yields were low and consumer demand was growing, leading to high prices. ${ }^{89}$ At this point in time, no institution had been established to limit or even guard against overproduction, so exploitation expanded.

In 1871, a group of London diamond merchants bought the farms of Dorstfontein (the diamond deposit called Dutoitspan) and Bultfontein from their owners. Now that the area turned out to be rich in diamonds and people from different parts of the world rushed towards Griqualand-West, conflicts over access to the land and mineral rights broke out between the Griqua chief, representatives of the Afrikaner Orange Free State, and the South African Republic, who all claimed ownership over parts of the territories. The same year, the British intervened by annexing not only the diamond fields, but also a considerable additional part of Griqualand-West. Two years later, they made the area a Crown Colony and called the mining region Kimberley. From then on, British officials administered the area and collected and redistributed the rent, while diamond merchants had to pay a licence fee..$^{\circ}$ The British officials were answerable for their actions to the governor of the Cape and ultimately to the British Colonial Office in London. Although British administrators had taken over the administration of the mining region, in name replacing the diggers' republican self-government, this did not mean they had taken over the property rights for the diamantiferous soil. Accordingly, a group of merchants bought two diamond deposits on the Vooruitzicht farm, called Kimberley Mine and De Beers Mine. Kimberley was the richest deposit, and since it was located in a relatively small area, the prices of claims rose sky high. To control the situation, the diggers decided that none of them could hold more than two claims, although there was no limit on the number of workers each could employ. ${ }^{91}$

The workers in the diamond mines were male migrants, basically from almost all black societies south of the Zambezi River though the Pedi, the Tsonga, and the South Sotho formed the largest groups until at least $1885 \cdot{ }^{92}$

88 Turrell, Capital and Labour, p. 10.

89 Lenzen, History of Diamond Production, pp. 134-135.

90 Worger, South Africa's City of Diamonds, pp. 27-28.

91 Ibid., p. 17.

92 Ibid., p. 74; Turrell, Capital and Labour, pp. 20-21, 92-93. 
Figure 3.6 Southern Africa and the diamond fields, c. 1870-1871

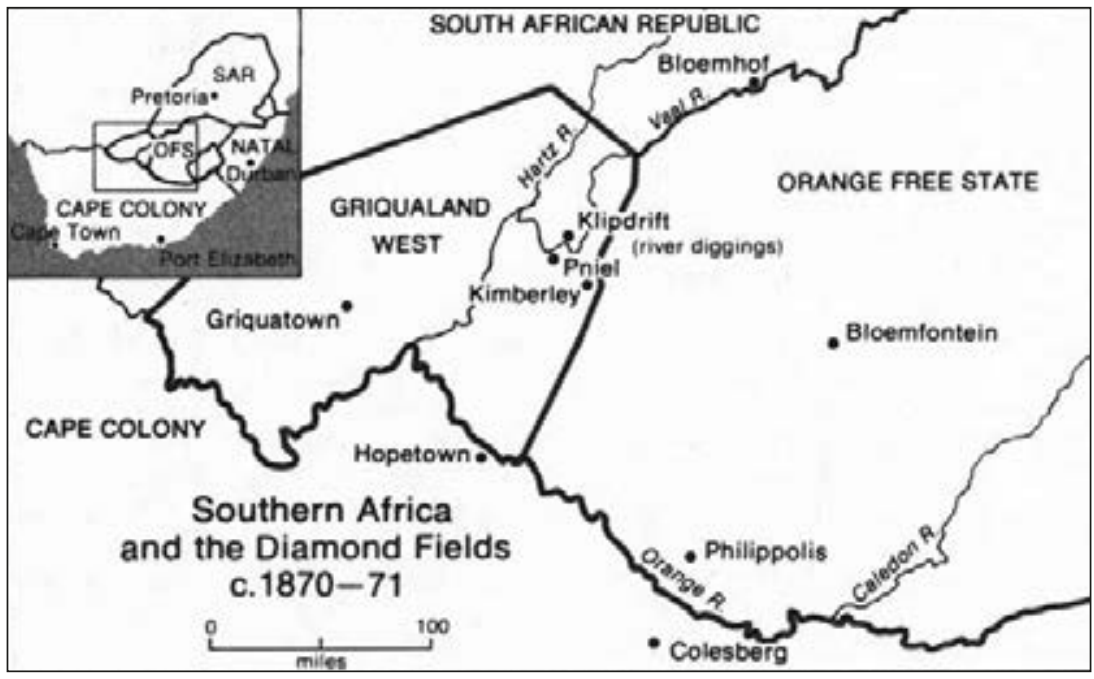

Source: Worger, South Africa's City of Diamonds, p. 13

They had once lived off hunting-gathering and subsistence farming, but ecological pressures and regional conflicts had already driven many of them to look for other economic possibilities long before the development of diamond mining. ${ }^{93}$ For many others, work in the diamond mines was a seasonal job they took on for three to six months before returning home, thereby combining wage labour with self-subsistence farming. The money they earned in the mines was often spent on the purchase of tools to improve their agricultural output, but also on guns and bridewealth. Initially, a number of chiefs directed the migrant labourers to the mines and they could also call mine workers back home in the case of conflict or war. ${ }^{94}$ The black communities that lived near the mines produced foodstuff and fuel for the mining town.

Because of the labour intensity of mining, there was a shortage of labour for at least a decade after the first discovery. Migrant mine workers could gain high wages by moving from one mine to another, or by going temporarily to the Cape for other wage work. Between 1871 and 1875 , weekly wages quintupled from five shillings per week to twenty-five shillings per week plus

93 Worger, South Africa's City of Diamonds, p. 65; Turell, Capital and Labour, ch. 2; Harries, Work, Culture and Identity, ch. 3 .

94 Turrell, Capital and Labour, p. 24. 
Figure 3.7 The Bultfontein, Dutoitspan, De Beers, and Kimberley mines

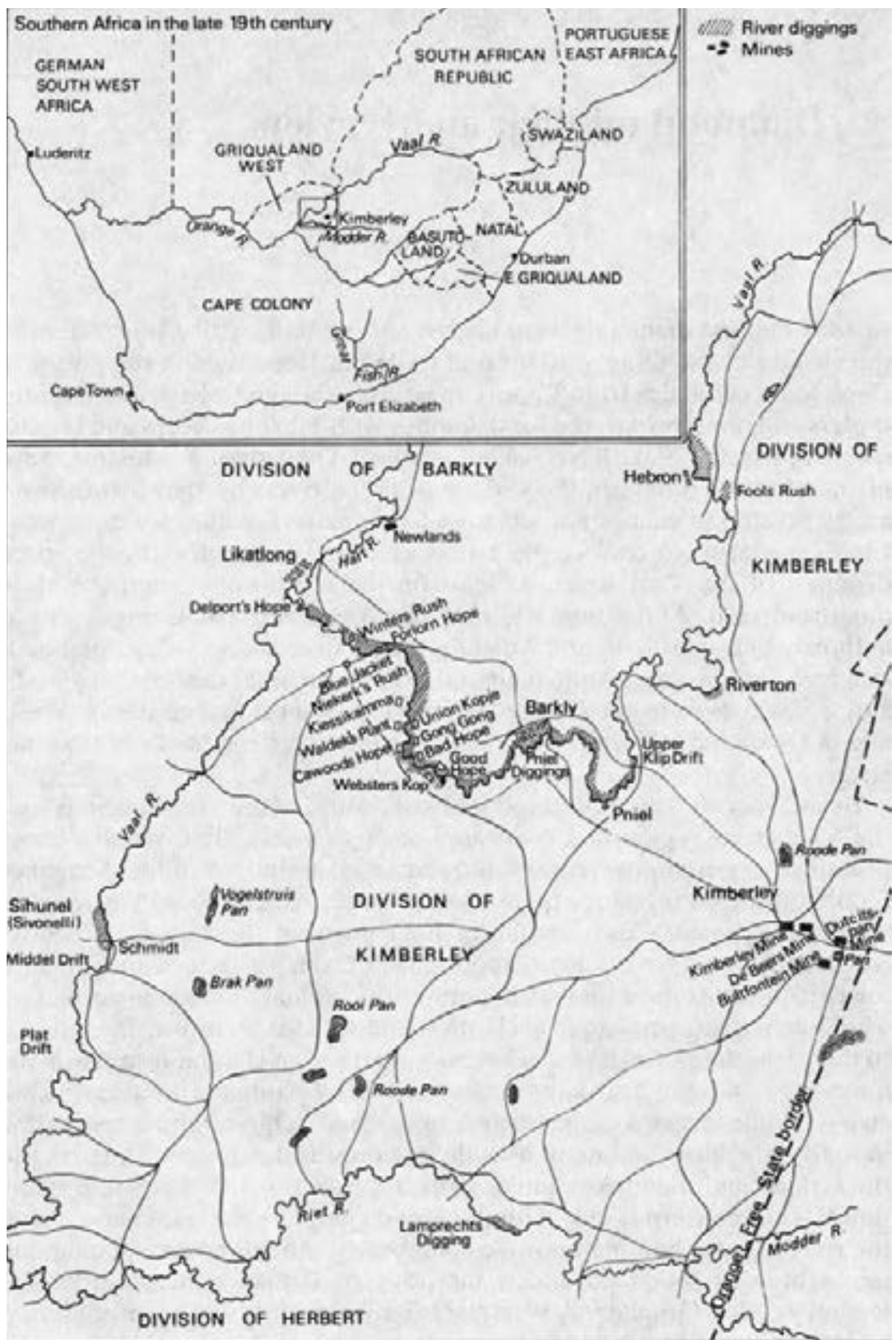

Source: Turrell, Capital and Labour, p. 2 
food. ${ }^{95}$ In 1872 , in an attempt to regulate labour supply, the Cape Governor proclaimed that labour contracts had to be registered as contracts of service. Connected to this, each employee was given a pass: a piece of paper stating their name, the name of their master, the duration of the contract, and their wage. The proclamation in itself was colour blind; only the terms masters and servants were used. In practice, only black Africans were contracted, whereas all the other workers refused to comply with a system they regarded as being for natives only. ${ }^{96}$ When a worker wanted to leave the diamond fields, he had to present a discharge certificate, or a pass attesting his conduct, before the registrar handed him a travel pass. Men who broke the pass law were liable to three months imprisonment, or a fine up to twenty-five pounds or twenty-five lashes. ${ }^{97}$ In the beginning, the passes did little to prevent black workers from leaving the mines. Since diggers had to pay the British administrator for the registration of a contract, many choose not to do so; only later did the system become more elaborate and the control more strict.

In addition to the government, white diggers also started to draw up regulations - not supported by the Cape Governor - that prohibited blacks from holding claims, thus basically keeping then from self-employment or working as an employer. The motivation was theft. Claim ownership entitled blacks to sell diamonds and thus could facilitate theft. Theft had already been used as a motive against what the employers called desertion: if a black worker left the diamond fields before the end of a contract he had probably stolen a diamond. ${ }^{98}$ Black claim owners nonetheless continued their work, though mainly in the poorer Bultfontein and Dutoitspan mines. ${ }^{99}$

\section{Technological change, consolidation, institutional change, and labour relations}

Digging in the relatively small but rich Kimberley and De Beers mines went deeper, and as a consequence, the rims of the mines started to collapse, while heavy rainfalls often flooded the deep, open-cast mines, making them largely inaccessible. In the second half of the 1870 , several technological

95 Worger, South Africa's City of Diamonds, p. 87.

96 Turrell, Capital and Labour, p. 24; Worger, South Africa's City of Diamonds, p. 28.

97 Harries, Work, Culture and Identity, p. 54.

98 Turell, Capital and Labour, pp. 25, 29. Exact data on the prevalence of diamond theft is non-existent. We do know how illicitly mined stones were sold and we know white workers were reported as thieves as often as black workers, see ibid., pp. 56, 174-181.

99 Worger, South Africa's City of Diamonds, p. 17; Turrell, Capital and Labour, pp. 29-30. 
innovations (the use of dynamite, haulage systems based on aerial tramways, and the use of horse power and small steam engines) were introduced. This made mining more capital intensive, and many small claim holders went bankrupt and left. As a consequence of the rising claim prices, a system of share working developed: one claim could be subcontracted to a number of share workers. The claim holder paid the licence and the mining taxes, the share-workers paid him a percentage of the net profit of the enterprise, varying from 40 to 90 per cent. ${ }^{100}$ Share-workers (Africans and others) did the digging, hired labourers, bought tools, and sold the diamonds. They considered themselves to be in a partnership, and saw the percentage as payment not as a wage. In 1875 there were some $75^{\circ}$ owners, holding a total of some 1,240 claims in the four mines. At least 120 of these owners were Africans, Indians, or "persons of colour". ${ }^{101}$ By that time, there were some 15,000 to 20,000 mine workers, 85 per cent of whom were black. ${ }^{102}$

In an attempt to organize the now more complex mining structure, Richard Southey, the British lieutenant-governor who had governed Griqualand-West since it became a Crown Colony, put in place "mining boards", one for each mine, and composed of representatives of the claim holders. ${ }^{103}$ At the same time, he tried to protect the minor claim holders (since the British collected a fee per claim holder), to limit the amount of money landowners could charge for a claim and to increase taxation. On top of that, he wanted to establish British Crown ownership of all minerals. ${ }^{104}$ In 1875 , after fierce and violent protests against the measures by claim holders, share-workers, and people who lived of the mining activities - such as storekeepers and canteen keepers - the British intervened with military power. After this "Black Flag Revolt", Colonel Owen Lanyon was appointed as the new administrator of Griqualand-West, while a commission wrote instructions for the new government of the mines: "The mines should be looked upon partly as municipality and partly as a trading corporation, and Government should interfere with them as little as possible."105

Regulations that limited the number of the claims per digger were now abolished, and foreign capital was invited to buy claims and farms with diamantiferous soil. One important outcome of this conflict was that other

100 Turrell, Capital and Labour, pp. 49-50.

101 Ibid., pp. 50-52.

102 Based on Turrell, Capital and Labour, pp. 26, 228.

103 Worger, South Africa's City of Diamonds, p. 28.

104 Ibid., pp. 28-29.

105 Ibid., p. 30. 
than in Brazil and parts of India, the British Crown did not succeed in making the mineral rights a Crown property.

The new policy led to a process of consolidation. As claims became bigger and more valuable, and more capital was needed to employ large steam engines to pump the water from the mine and to wash the diamantiferous soil with rotary washing machines, smallholders and share-workers disappeared. The remaining claim holders clustered their existing claims. From 1880 onwards, to obtain the capital needed for the technological innovations, claim holders transformed their firms into joint-stock companies, selling part of the shares to the public. The capital supply problem was now more or less solved, although labour supply was still an issue.

In the second half of the 1870 s, the colonial state tried to solve the problem of scarcity of labour in various ways. The police force in Kimberley was more than doubled, and was told to enforce the pass law more strictly than before. However, this and other regulations were not subsequently enforced. When in 1876 a crisis in the diamond trade occurred because of overproduction and a price fall, employers cancelled the contracts they had registered and reduced wages by half. As a consequence, more than half the work force left Kimberley, so labour supply was far from being stabilized. ${ }^{106}$

In the same year, Colonel Lanyon proposed the establishment of rural locations where blacks in Griqualand-West were forced to live after the land they owned was annexed. In 1878, black land owners resisted this legal expropriation, but their resistance was broken and localization continued, segregating whites from blacks, and leaving blacks with plots of land too small to be self-sufficient, meaning that they had to hire themselves as wage labourers either to white farmers or in the mines. ${ }^{107}$ This policy was extended one year later by the introduction of a hut tax in the area. For people who were already unable to live off their land, the hut tax was actually an incentive to enter wage labour. Nevertheless, the Griqua and other populations together only formed only 4 per cent of the labour force in the mines in $1880 .{ }^{108}$ So as harsh as the measures were, they did not solve the problem of labour scarcity. The destruction of the Pedi polities and the annexation of the Transvaal in 1880 seem to have been more productive. After a strict round of hut tax collection that year, almost 12,000 Africans went to Kimberley. However, this solution was only temporary, as Transvaal

106 Worger, South Africa's City of Diamonds, p. 35 (on crisis) and p. 127 (on contracts).

107 Ibid., p. 94; Turrell, Capital and Labour, p. 99.

108 Worger, South Africa's City of Diamonds, pp. 94, 96. 
regained its independence in 1881 and the Boers now profited from black labour and the collection of the hut tax..$^{109}$

In 1880 , a crucial event took place that deeply influenced the way institutions governing both mining and trading would develop, and that in the end would also affect labour control, labour supply, and labour relations. The Cape Colony annexed the Crown Colony of Griqualand-West, abolished the local British administrator in Kimberley, and made the Cape parliament directly responsible for enacting legislation for the territory. The parliament in Cape Town was now the place where decisions about the mines were made. ${ }^{110}$ In 1881 , J.B. Robinson, one of the major shareholders of the Kimberly mines, and Cecil Rhodes of the De Beers Mining Company, were both elected for Kimberley in the Cape Parliament and had a heavy influence on decision making in this political institution. According to Colin Newbury, the annexation and its political and economic consequences led to the control of diggers and mine owners by local government, which made it easy for the latter to control the minerals, manpower, town, and its market "with a minimum of legal or fiscal interference" and this "early weakness in state rights to dispose of precious stones and in administrative supervision explains the coercive and protective legislation framed by diggers and mine owners". ${ }^{111}$

One of the first things the Cape Parliament enacted in 1882 was the "Diamond Trade Act", suggested by Rhodes and Robinson. People accused of illicit diamond buying were presumed guilty until they could prove their innocence. A special court without a jury decided on these cases. Punishments for whites could be imprisonment for up to fifteen years, fines, and the possibility of banishment from Griqualand-West. Blacks would be subject to the same punishments, together with flogging. ${ }^{112}$ The pass law was enforced with the help of extra police, and as a consequence of both measures, the number of arrests rose from some 8,500 in 1876 to 14,000 in $1897{ }^{113}$ The police force controlled the urban locations and the act also allowed the mining companies to set up searching houses, where white and black employees were checked in separate rooms when entering or leaving the diamond mines. Blacks had to strip naked and had to undergo intimate body searches, whites could keep on their clothes and were only visually inspected. Although very few diamonds were found in these searching houses, the process did function

109 Turrell, Capital and Labour, p. 92; Worger, South Africa's City of Diamonds, pp. 99, 105.

110 Turrell, Capital and Labour, p. 133.

111 Newbury, The Diamond Ring, p. 361.

112 Ibid., p. 134

113 Worger, South Africa's City of Diamonds, p. 136. 
Figure 3.8 Diamonds found in the Kimberley, De Beers, Bultfontein, and Dutoitspan mines, in carats, 1867 to 1913

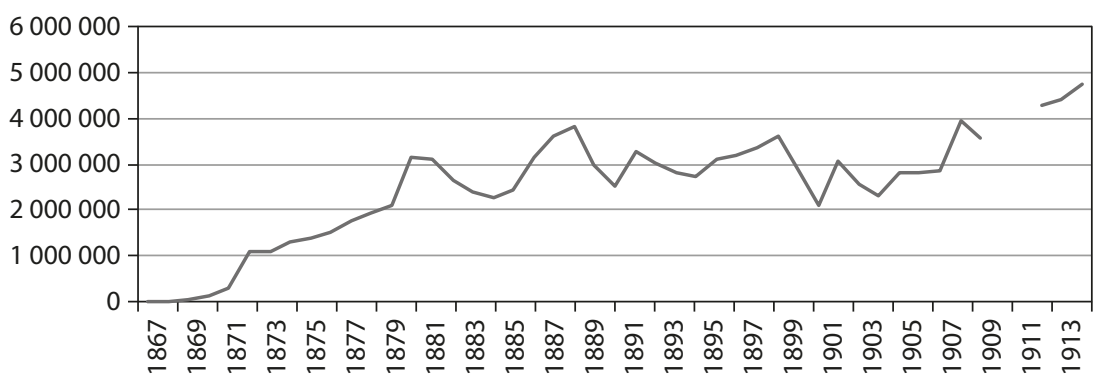

Sources: For 1867-1893: Bauer, Precious Stones, vol. 1, p. 204; for 1894-1913: Lenzen, History of Diamond Production, pp. 159-160

as form of labour control. ${ }^{114}$ In 1883 , the De Beers Mining Company successfully negotiated with the Cape government to establish a privately controlled convict station on its mining compound. It started with a convict labour force of 200 men; in 1894 there were $800 .{ }^{115}$ The men carried out compulsory work in the mines, were housed in the convict station, and fed by De Beers, which paid a small fee to the Cape government in return for this favour. ${ }^{116}$

In the first half of the 188 os, a stricter control on labour and labour supply was established via land grabbing, the introduction of the hut tax, imprisonments and forced labour in convict stations, the control of urban locations and streets, and searching houses in the mines. However, all these regulations and institutions would have failed to control labour supply, had things in the diamond industry and in the labour supplying areas not dramatically changed in exactly the same period.

The establishment of joint-stock mining companies had led to a "company mania", with shares becoming expensive objects of speculation. ${ }^{117} \mathrm{By}$ the end of 1881, the collapse of these speculative shares led to a depression in Kimberley that coincided with the collapse of the European diamond market as a consequence of overproduction. ${ }^{118}$ The depression that would last until 1885 , led to bankruptcies and takeovers, and would in the end be an incentive for further concentration. As a consequence of the depression,

114 Ibid., p. 140.

115 Turrell, Capital and Labour, p. 155.

116 Worger, South Africa's City of Diamonds, p. 145.

117 Turrell, Capital and Labour, p. 89.

118 Worger, South Africa's City of Diamonds, p. 54. 
more than half of the mining companies disappeared and the demand for labour dropped. In 1882 there were 17,00o black mine workers, in 1885 their numbers had dropped to 11,300 , and in 1890 there would be only $6,000 .{ }^{119}$ Wages dropped by 50 per cent. ${ }^{120}$ Not only did the demand for labour fall, but also supply increased as a consequence of the annexation in 1882 of Basutoland (north of Griqualand-West) and in 1885 of Bechuanaland (southeast of the Orange Free State), and the consequences this had for ecology and the reallocation of land. Many former black farmers were no longer forced to go to the mines and other places for wage labour. ${ }^{121}$ By that time, work in the mines had changed drastically.

\section{Deep mining, amalgamation, closed compounds, and labour relations}

As the production costs of open-pit mining kept rising, the mining companies decided to shift to deep mining. For deep mine shafts (reaching over 400 feet below surface level), tunnels and galleries had to be made. To avoid overproduction, open-cast mining was restricted. ${ }^{122}$ The capital investments were large, so to get as much out of their capital as possible, mine owners introduced a system of continuous twelve-hour back-to-back shifts. The disciplining, supervising, and controlling of the underground work was carried out by white subcontractors. As control on production below the surface was difficult, piece rates were introduced. Subcontractors were remunerated according to the amount of diamantiferous soil brought to the surface by their teams, the men were remunerated per inch drilled or the number of trucks filled. Deep mining also meant dangerous working conditions. Apart from accidents, pneumonia was the most important cause of death because of the temperature differences between underground and above ground.

Deep mining also stimulated the process of amalgamation: the three largest companies were now Kimberley Central, the Compagnie Française, and Rhodes' De Beers Mining Company. ${ }^{123}$ This reduced the bargaining powers of the workers, especially since the few remaining mining companies

119 Ibid., p. 103; Harries, Work, Culture and Identity, p. 66.

120 Worger, South Africa's City of Diamonds, p. 102.

121 Ibid., pp. 105-106; Turrell, Capital and Labour, p. 133.

122 Harries, Work, Culture and Identity, p. 69.

123 Turrell, Capital and Labour, ch. 10, pp. 206-227; Worger, South Africa's City of Diamonds, pp. 192-198. 
decided to cooperate rather than to compete over labour. Now that deep mining needed a stable, skilled workforce and the position of the workers had weakened, the mining companies decided to fence off the compounds many black workers stayed in.

Between 1885 and 1886, the three big mining companies closed their compounds, taking the De Beers Convict Station as a model. The workers at De Beers and Kimberley Central refused to accept the situation, but were soon replaced by others, and their strikes were broken. ${ }^{124}$ Living conditions in the compounds were bad; they were often overcrowded, sanitary conditions were insufficient, sleeping barracks were cold, there was no proper medical care, contagious diseases spread fast, and a death rate of around 80 per 1,00o workers prevailed. ${ }^{125}$ Workers (apart from the convict labourers, of course) entered the compounds on a voluntary basis. This was often on a two-to-four month contract that could be voluntarily re-registered, though in practice pressure was often used. However, a large proportion of the workers in the compound were uncontracted. ${ }^{126}$ Although this was in contravention of the law, mine owners let the miners who had ended their contract and were not directly needed, stay in the compound ${ }^{127}$ These uncontracted people were the reserve pool of trained labour: "to work 900 men we want 1,400 or 1,500", according to a representative of the De Beers Mining Company. ${ }^{128}$ Several economic reasons could make miners stay in the closed compounds. If piece work rates were low, miners had to stay longer to earn enough to be able to go home, in addition there were all kinds of fines that could oblige the miners to stay longer. ${ }^{129} \mathrm{By} 1889$, practically all the black mine workers were housed in closed compounds and supplied by company stores. ${ }^{130}$

In 1890, a crisis in the diamond trade led to lowered wages, while at the same time prices for basic goods in the company stores remained at the same level. ${ }^{131}$ Discontent rose, and in 1891 , black mine workers started resisting against their white subcontractors, leading to severe racial antagonisms in the mines. ${ }^{132}$ Protests against the by now truly explosive and exploitative

124 Worger, South Africa's City of Diamonds, p. 144.

125 Turrell, Capital and Labour, pp. 161-162, Worger, South Africa's City of Diamonds, p. 100.

126 Turrell, Capital and Labour, p. 170.

127 Worger, South Africa's City of Diamonds, p. 266.

128 Turrell, Capital and Labour, p. 171.

129 Ibid., pp. 171-172.

130 Newbury, Diamond Ring, p. 228.

131 Harries, Work, Culture and Identity, p. 70; Worger, South Africa's City of Diamonds, pp. 257ff., on prices see p. 266.

132 Harries, Work, Culture and Identity, p. 71; Worger, South Africa's City of Diamonds, p. 279. 
situation in the compounds led to some improvements, such as a change to eight-hour shifts and better medical and sanitary services. ${ }^{133}$ By that time, the De Beers Mining Company had bought all remaining shares in the South African diamond mines and reached a complete mining monopoly in 1888 as the De Beers Consolidated Mines. This mining monopoly was expanded in 1893, when De Beers established a London-based diamond syndicate, together with the major diamond merchants. The syndicate bought the compete yield of all the De Beers mines and controlled the resale, including the prices, securing the De Beers a mining and trading monopoly for quite a long time.

Apart from the introduction of convict labour and the semi-free wage labour of mine workers in between contracts, what other effects did the introduction of closed compounds have on the labour relations of miners? Did closed compounds mean the end of circular migration between the mines and the fields, and thus of double labour relations? We do not know exactly. What we do know is that in the period up until 1886, more and more miners who stayed for a contract period had already worked in the mine. Therefore, it is probable that a stabilized circular migration existed of men who consciously combined wage work and subsistence farming. ${ }^{134}$ When the closed compounds were established, the number of miners that remained in the urban locations between two contracts increased. ${ }^{135}$ According to the historian Patrick Harries, the fact that in 1891 the black miners revolted in the closed compounds and the mines, rather than returning home, is also a sign of the permanency of wage work of these men. ${ }^{136}$ At the same time, the composition of the mining labour force changed: the Pedi and the Tsonga started carrying out wage work in the Rand gold mines, and the South Sotho were now the largest group of diamond miners. In the region of Basutoland where they had their farmlands, the ploughing season was in November and December, and in the 1890 s these became months of labour scarcity in the mines, pointing in the direction of a continuation of the system of circular or seasonal migration, although for a different group. Nevertheless, by 1903 the number of women living in urban locations and dependent on men working in the mines, seems to have increased, pointing to a general increase of wage workers without land. ${ }^{137}$

133 Ibid., p. 290; Harries, Work, Culture and Identity, p. 77.

134 Turrell, Capital and Labour, pp. 165-167.

135 Ibid., p. 168.

136 Harries, Work, Culture and Identity, p. 71.

137 Turrell, Capital and Labour, p. 169. 
In the first decades of diamond mining in South Africa there was a shortage of labour, due to the migratory workers who combined wage work in the mines with self-subsistence on their farms in the homelands. This combination of labour relations and the structural shortage of wage labour gave them a strong bargaining power. To control labour and labour supply, the private mine owners used their influence in the Cape Parliament, which ruled the mining area after its annexation in 188o, to instal a series of institutions: pass laws and the Diamond Trade Act, a legal apparatus to punish alleged illegal diamond buying. These measures worked against the black mine workers, in particular, and turned a proportion of them into convict labourers. The establishment of rural locations, the introduction of the hut tax, and land annexations, were all institutions that forced black workers to leave their land and spend more - or all - of their time on wage work. The establishment of the closed compound system ended the combination of self-subsistence and wage work for many mineworkers, turning them into full-time wage labourers.

\section{Conclusion}

The three case studies show how diverse authorities made use of their (appropriated) land and mineral rights, as well as of taxes and laws, to govern as many segments of the diamond commodity chain as possible. In India, the Deccan sultans, Mughal emperors, and rajas of native states, as well as the EIC; in Brazil the Portuguese Crown in the metropolis; and in South Africa a concentration of mining and merchant capital well represented and highly influential in local politics. For the Indian rulers, the situation was relatively easy. Until the 1720s, India was the only diamond-producing part of the world, global demand for diamonds was high, and overproduction was not an issue. Labour was abundant, because profitable alternatives were lacking for the migratory wage labourers and their families who went to work in the mines, often combining this with agricultural work, thus combining wage labour with reciprocal labour. Even though conditions were harsh and wages low, in general wage work was free and there was very little incentive on the part of the rulers to change the situation. When the EIC gained control over some of the mines, it more or less continued the pre-colonial governing rules. With no inclination whatsoever to invest in mining, and with relatively low yields, the EIC did not consider unfree labour as a serious option. The only shifts in labour relations we see in the Indian mines had little to do with (colonial) institutions, but were 
the consequence of the exhaustion of the mines, or at least a diminishing number of merchants willing to invest in mining. Sometimes this situation was temporary, such as in the seventeenth century, when some Indian rulers used the labour force of the landless migrant labourers for tributary purposes for a brief period. In the nineteenth century, we see an increase of self-employed mineworkers as a consequence of the structurally diminished interest of entrepreneurs.

In Brazil, the situation was completely the reverse. The Brazilian mines yielded more diamonds than the Indian mines, and when they were appropriated by the Portuguese Crown, overproduction led to a crisis on the global diamond market. The problem of labour shortage was solved by major imports of slaves from Africa. Slave labour was almost endemic in the Brazilian economy under Portuguese rule, and when diamonds were discovered in Minas Gerais, slaves moved with their masters from the coastal areas to the inland. Here, the problem was to control the workforce, its owners, and their administrators, in order to keep them from illicit mining and trading and to stop overproduction.

On paper, all the institutions shaped by the colonial powers in Lisbon to control production, including labour, seem harsh and effective, and those who fell into the hands of the authorities were worse off. However, few illicit miners and traders did fall into the hands of the authorities, whose institutions to control mining and trading failed. The Diamond District was in many ways a model for the later South African closed compounds, except for the fact that in the district, the rules were colour blind and applied to white, mulatto, and free and unfree black inhabitants alike. Nevertheless, despite the demarcated area and the guards controlling its borders, there were many possibilities both inside and outside the district to combine slave labour with self-employment or even to shift from slave labour to selfemployment, albeit with very insecure foundations. The most important reason for these institutional failures was conflicts, including conflicts of interests, between the Crown in Lisbon, the governor of the Captaincy of Minas Gerais, and the intendant of the Diamond District. On top of that, corruption was rampant at various levels of governance. Lastly, the area was geographically widespread and not easy to control. The Royal Extraction did have one important consequence for labour relations though: when the Portuguese Crown started to employ slaves for hire in 1772, the number of slaves imported from Africa increased in the Serro do Frio district, whereas in Minas Gerais as a whole, imports diminished.

In South Africa, the diamond deposits were primary, and therefore yields were enormous and - with the exception of a number of periods 
of overproduction and crisis - in demand on the global diamond market with its growing number of consumers. Here, the British government was quick to annex the diamond-bearing grounds, and these were bought by mining entrepreneurs, although they never acquired the mineral rights. After several stages of consolidation and amalgamation, a few joint-stock mining companies were left, which could easily dispose of capital and make investments. For a long time, labour supply was unstable and insufficient, as many black miners combined wage work in the mines with subsistence farming in their homeland, and left if they considered the wages too low. To control labour supply, mining entrepreneurs suggested all sorts of mechanisms that failed until the second half of the 1880 s.

What made the later institutions a success is the influence of mining entrepreneurs on the local Cape government, which had controlled Griqualand-West since 1880. Without much resistance, these entrepreneurs were able to develop a set of institutions that helped them to control labour. Discriminatory pass laws, imprisonments, and searching houses were steps in the direction of a tightly controlled and segmented labour market. After the introduction of deep mining, convict labour, and closed compounds, mining entrepreneurs truly governed the mining area and all aspects of the production that took place there. The colonial power's activities, such as the establishment of agricultural black localizations, the introduction of the hut tax, the destruction of local polities, and the annexation of Basuto and Bechuanaland "helped" the mining entrepreneurs solve their labour problems and economically forced many black farmers into permanent wage labour.

If we compare the three case studies, we see that colonial institutions only had an impact on the development of the diamond mines and on labour relations if the colonizer was willing to invest in them. The British Empire did not invest in the Indian mines, but did invest in the South African ones. Here, power relations were extremely important. In principle "inclusive institutions" were established: a parliament, respect for property rights, rule of law, and contracts, which all stimulated the development of the diamond-mining industry, but in the words of Charles Feinstein "of course, like almost everything else in South Africa, these institutions were warped by racism" ${ }^{138}$ This makes these institutions only "inclusive" for part of the white population. The influence of diamond producers on local political power relations and on colonial institutions was great. This had a huge impact on the labour relations of the black workers; it did, however, lead to smaller revenues for the Empire than one would have expected. 
In Minas Gerais, the Portuguese Empire seems to have established a series of classical extractive institutions. However, power relations also played a major role here: disrupted power relations within the colonial administration made the institutions in the local context far less effective than those in South Africa, even when the empire itself - during the Royal Extraction - invested heavily in slave labour. Large quantities of diamonds were certainly extracted from the Brazilian mines with the help of enslaved labour and then sent to the Lisbon treasury, but half of the revenues ended up in the pockets of private individuals, and even slaves - at least some of them - had some room for manoeuvre in this failing system.

\section{Bibliography}

Ahuja, Ravi, Die Erzeugung kolonialer Staatlichkeit und das Problem der Arbeit: eine Studie zur Sozialgeschichte der Stadt Madras und ihres Hinterlandes zwischen 1750 und 1800 (Stuttgart, 1999).

Alam, Ishrat, "Diamond Mining and Trade in South India in the Seventeenth Century", Medieval History Journal, 3 (2001), pp. 291-310.

Ball, V., The Diamonds, Coal and Gold of India: Their Modes of Occurrence and Distribution (London, 1881).

Ball, V., The Geology of India, Part 3: Economic Geology, 4 vols (Calcutta, 1881).

Bauer, Max, Precious Stones, 2 vols (New York, 1986).

Bergad, Laird W., "Demographic Change in a Post-Export Boom Society: The Population of Minas Gerais, Brazil, 1776-1821",Journal of Social History, 29 (1996), pp. 895-932.

Bergad, Laird W., Slavery and the Demographic and Economic History of Minas Gerais, Brazil, 1720-1888 (Cambridge, 1999).

Bernstein, Harry, The Brazilian Diamond in Contracts, Contraband and Capital (Lanham, 1986).

Calogeras, João Padiá, As Minas do Brasil e sua Legislaçao (Rio de Janeiro, 1904).

Chetty, Narahari Gopalakristnamah, Manual of the Kurnool District in the Presidency of Madras (Madras, 1886).

Feinstein, Charles H., An Economic History of South Africa: Conquest, Discrimination and Development (Cambridge, 2005).

Ferreira Furtado, Júnia, “O Distrito Diamantino”, available at: www.fafich.ufmg. br/pae/apoio/distritodiamantino.pdf.

Ferreira Furtado, Júnia, O Livro da Capa Verde. O Regimento Diamantino de 1771 e a Vida no Distrito Diamantino no Período da Real Extração (São Paulo, 2008). 
Ferreira Furtado, Júnia, "Quem nasce, quem chega: o mundo dos escravos no Distrito Diamantino e no Arrial do Tejuco", in Douglas Cole Libby and Júnia Ferreira Furtado (eds), Trabalho livre, trabalho escravo: Brasile Europa, séculos XVIII e XIX (São Paulo, 2006), pp. 223-250.

Franklin, James, "On the Diamond Mines of Panna in Bundelkhand", Edinburgh Journal of Science, 5 (1831), pp. 150-166.

Harries, Patrick, Work, Culture and Identity: Migrant Laborers in Mozambique and South Africa, c. 1860-1910 (Portsmouth, 1994).

Hell, Jürgen, “Die Sklaverei im brasilianischen Minen-Komplex (1700 bis 1908)", Jahrbuch für Wirtschaftsgeschichte, 1 (1981), pp. 107-123.

Heyne, Benjamin, Tracts, Historical and Statistical on India, with Several Tours through Various Parts of the Peninsula: Also an Account of Sumatra, in a Series of Letters (London, 1814).

Howard, Henry, "A Description of the Diamond-Mines, as It Was Presented by the Right Honourable, the Earl Marshal of England", Philosophical Transactions of the Royal Society, 12 (1677), pp. 887-917.

Jeffries, David, A Treatise on Diamonds and Pearls (London, 1751).

Kiddy, Elizabeth W., Blacks of the Rosary: Memory and History in Minas Gerais, Brazil (University Park, 2005).

King, William, "On the Kadapah and Karnul Formations in the Madras Presidency", Memoirs of the Geological Survey of India, 8 (1877), pp. 1-320.

Klein, Herbert S., and Francisco Vidal Luna, Slavery in Brazil (Cambridge, 2010). Legassick, Martin Chatfield, The Politics of a South African Frontier: The Griqua, the Sotho-Tswana and the Missionaries, 1789-1814 (Basel, 2010).

Lenzen, Godehard, The History of Diamond Production and the Diamond Trade (London, 1970).

Mawe, John, Travels in the Interior of Brazil, Particularly in the Gold and Diamond Districts of That Country (London, 1812).

Mentz, Søren, The English Gentleman Merchant at Work: Madras and the City of London, 1660-1740 (Copenhagen, 2005).

Methwold, William, "Relation", in W.H. Moreland (ed.), Relations of Golconda in the Early Seventeenth Century (London, 1931), pp.1-50.

Mukund, Kanakalatha, "Mining in South India in the $17^{\text {th }}$ and $18^{\text {th }}$ Centuries", Indica, 52-53 (1991), pp. 13-52.

Newbold, Thomas John, "Mineral Resources of Southern India. No 8. Diamond Tracts", Journal of the Royal Asiatic Society of Great Britain and Ireland, 7 (1843), pp. 226-240.

Newbury, Colin, The Diamond Ring: Business, Politics and Precious Stones in South Africa, 1867-1947 (Oxford, 1989). 
Ramos, Donald, "Slavery in Brazil: A Case Study of Diamantina, Minas Gerais", Americas: A Quarterly Review of Inter-American Cultural History, 45 (1988), pp. 47-59.

Raychaudhuri, Tapan, Jan Company in Coromandel, 1605-169o: A Study in the Interrelations of European Commerce and Traditional Economies (The Hague, 1962).

Rousselet, Louis, L'Inde des Rajahs. Voyage dans l'Inde centrale (Paris, 1877).

Russell, Daniel, “Diamond Mines of Brazil”, Scientific American Supplement, 18 (1884), pp. 7313-7314

Saint-Hilaire, Auguste de, Voyage dans le District des diamans et sur le littoral du Brésil, 2 vols (Paris, 1833).

Samuel, Edgar Roy, "The Diamond Trade in the late Seventeenth Century with Special Reference to London", MPhil thesis, London School of Economics, 1978.

Tavernier, J-B., Travels in India, trans. V. Ball, 2 vols (New Delhi, 1989).

Temple, R.C. (ed.), The Diaries of Streynsham Master, 1675-1680, and other Contemporary Papers Relating Hitherto, Vol. 2: The First and Second "Memorialls", 1679-168o (London, 1911).

Triner, Gail D., Mining and the State in Brazilian Development (London, 2011).

Turrell, Robert Vicat, Capital and Labour on the Kimberley Diamond Fields, 1871-189o (Cambridge, 1987).

Van Dam, Pieter, Beschrijvinge van de Oostindische Compagnie, 4 vols (The Hague, 1932).

Vanneste, Tijl, “Commercial Culture and Merchant Networks: Eighteenth-Century Diamond Traders in Global History” (PhD diss., European University Institute, 2009).

Vanneste, Tijl, "Women in the Colonial Economy: The Agency of Female Food Sellers in Brazil's Diamond District”, Tijdschriftvoor Genderstudies, 18 (2015), pp. 255-272.

Verberckmoes, Johan, and Eddy Stols (eds), Aziatische omzwervingen. Het levensverhaalvan Jaques de Coutre, een Brugs diamanthandelaar1591-1627 (Berchem, 1988).

Von Eschwege, Wilhelm Ludwig, Pluto Brasiliensis. Eine Reihe von Abhandlungen über Brasiliens Gold-, Diamanten- und anderen Mineralischen Reichthum, über die Geschichte seiner Entdeckung, über das Vorkommen seiner Lagerstatten, des Betriebs, der Ausbeute und die daraufbezugliche Gesetzgebung u.s.w. (Berlin, 1833).

Wolf, Lucien, "Jews in Elizabethan England", Transactions of the Jewish Historical Society of England, 11 (1928), pp. 1-91.

Worger, William H., South Africa's City of Diamonds: Mine Workers and Monopoly Capitalism in Kimberley, 1867-1895 (New Haven, 1987).

Yogev, Gedalia, Diamonds and Coral: Anglo-Dutch Jews and Eighteenth-Century Trade (Leicester, 1978). 


\section{About the Author}

Karin Hofmeester is Senior Researcher and Deputy Director of Research at the International Institute of Social History in Amsterdam (The Netherlands) and Professor of Jewish Culture at the University of Antwerp (Belgium). Her publications include The Joy and Pain of Work: Global Attitudes and Valuations, 1500-1650 (Cambridge, 2012) (co-edited with Christine Moll-Murata), Luxury in Global Perspective: Objects and Practices, 1600-2000 (Cambridge, 2016) (co-edited with Bernd-Stefan Grewe), Conquerors, Employers, and Arbiters: States and Shifts in Labour Relations, 1500-2000 (Cambridge, 2016) (co-edited with Gijs Kessler and Christine Moll-Murata).

E-mail:kho@iisg.nl 



\title{
4 The Global Detour of Cane Sugar
}

\author{
From Plantation Island to Sugarlandia*
}

Ulbe Bosma

Hofmeester, Karin \& Pim de Zwart (eds.), Colonialism, Institutional Change, and Shifts in Global Labour Relations. Amsterdam: Amsterdam University Press, 2018

DOI: $10.5117 / 9789462984363 / \mathrm{CHo} 4$

\begin{abstract}
Cane sugar is known as the typical "plantation crop", which encompasses monocrop cultivation and total control over the entire production process, from land, technology, and botany, to labour. This obviously requires full political control over the site of production by the plantation owners. The plantation model has proved to be remarkably resilient over the past 800 years and capable of adapting to varied types of labour relations. Contrary to what some might have expected, slavery was not inexorably linked to the plantation. Apart from slaves, sugar was produced using Chinese labour gangs, Indian indentured labour, debt contracts in Latin America, tenants and sharecroppers in the Philippines, coerced cultivation in Java, and smallholder cane production combined with sugar cooperatives in Java and India.
\end{abstract}

Keywords: plantations, sugar, labour, extractive institutions

As Acemoglu, Johnson and Robinson point out, a distinguishing feature of "extractive institutions" is "a high concentration of political power in the hands of a few who extracted resources from the rest of the population". Both the classical plantation islands in the Caribbean and the massive sugar-producing conglomerates of twentieth-century Cuba, Java, and the

* Much of this chapter is derived from earlier publications, most notably, Bosma, The Sugar Plantation in India; Bosma and Curry-Machado, "Two Islands, One Commodity"; Bosma and Knight, "Global Factory and Local Field"; and Bosma, "Cane Sugar and Unlimited Supplies".

1 Acemoglu, Johnson, and Robinson, “Reversal of Fortune”, p. 1234. 
Philippines are examples of extractive institutions par excellence. In every historiographical survey on commodity production, sugar appears as the typical "plantation crop", which encompasses monocrop cultivation and total control over the entire production process; from land, technology, and botany, to labour. This obviously requires full political control over the site of production by the plantation owners.

The plantation model has proved to be remarkably resilient over the past 800 years, and capable of adapting to varied types of labour relations. Contrary to what some might have expected, slavery was not inexorably linked to the plantation. Apart from slaves, sugar was produced using Chinese labour gangs, Indian indentured labour, debt contracts in Latin America, tenants and sharecroppers in the Philippines, coerced cultivation in Java, and smallholder cane production combined with sugar cooperatives in Java and India. In the terms of the Global Collaboratory on the History of Labour Relations, not only all forms of commodified labour, but also tributary labour and dependent household labour were involved on a fairly large scale. Further, a number of sites of sugar production combined different labour relations. However, despite all these different sets of labour relations, the basic principles of the plantation as an extractive institution stayed the same.

Over time, sugar plantations evolved from being slaveholding appanages of absentee metropolitan commercial and political elites, to immense sugar conglomerates that had inserted themselves in local peasantries. This was a consequence of changes in location, scale, and technology. First of all, the centre of gravity of plantation-style sugar shifted from the Western to the Eastern Hemisphere. Simultaneously, a transformation of sugar from a luxury item to a bulk commodity took place, and with that a thorough industrialization of the milling of sugar. Labour-intensive mills and boiling pans were replaced by fully mechanized, highly capitalintensive factories, haulage was mechanized, and for cutting, the plantations either employed combines, or, if it was cheaper, relied on massive numbers of impoverished and often indebted seasonal labour migrants to clear the fields of cane.

Through these changes in time and place, the political environment of the plantations also changed radically. The plantation owners could no longer rely on their political influence in metropolitan courts and parliaments, but had to deal with the colonial or semi-colonial states in Asia, which were much larger entities than the administrations of Caribbean islands. Moreover, whereas slaves were considered to be the plantations' capital, labourers in the Asian colonies were colonial subjects, and hence the 
responsibility of the colonial state. Whereas in the pre-eighteenth century plantation islands the planters had no other interests to take into account than their own, in nineteenth-century Asia they had to deal with local peasantries and the colonial state. This led to new organizations, such as, for example, the Sugar Syndicates in Java that at the turn of the twentieth century united all the 140 sugar factories in one powerful lobbying machine, and to refer to the vocabulary of Acemoglu, Johnson and Robinson, became "one juggernaut of extraction". Alternatively, to use a word coined by Larkin to describe the situation in the Philippines, a "Sugarlandia", where "monopoly of credit, control of information and higher education, an intricate web of strategic marriages, and a strong network of ritual kin helped the rich retain power and wealth and deny these to others". ${ }^{2}$ This definition neatly overlaps with the one of Acemoglu and colleagues of an "extractive institution". While the "plantation" spread over Asia, its victory was far from complete. In India, for example, peasants produced their own "cottage sugar" on the spot throughout the nineteenth century. Protected by their property rights and enmeshed in local systems of credit and advances, they not only managed to stay out of the thralls of sugar plantations, but also improved the efficiency of cane processing substantially. Even today, the large cane-processing factories only have a partial share in India's sugar production. In other words, the situation with respect to "weak property rights", "extractive institutions", and "deindustrialization" is much more nuanced than Acemoglu and colleagues claim. The plantation was an extremely powerful business model and extractive institution, but not omnipotent.

In this contribution, I first briefly sketch the development of the sugar plantation as a business model and argue that its existence was not restricted to a Caribbean environment, and not inexorably linked to slavery. I also elaborate on the fact that although plantations initially only existed on islands or in colonial enclaves, from 1800 onwards, the plantation overcame its spatial bounds. In the next section, I dwell on the fact that the plantation as a business model was indeed pliable enough to coexist with Asian peasant societies, but only if it could control these societies by allying itself with native elites. In the final sections, I argue that regardless of the labour relations and factor endowments in place, fully developed plantation conglomerates belonged to the most powerful institutions in the Global South, invoking the examples of Java, Cuba, the Philippine sugar island of Negros, and post-colonial sugar cooperatives of India and Indonesia. 


\section{The sugar plantation as a business model}

Sugar cane needs to be milled within forty-eight hours of being cut, otherwise it will lose most of its sucrose content. The fact that cultivation and processing need to take place in the immediate vicinity of one another allows for only two business models. The first one is that peasants have their own small plot of land, a collectively owned mill, and a set of boiling pans, enabling them to produce raw sugar on the spot. In theory, they can then decide to whom they sell their product: either to refineries in nearby towns - which was and still is to certain extent the case in India - or for their own consumption or as a currency in the reciprocal village economy. The second model is the plantation, which unites the agricultural and manufacturing parts of the process under a single leadership. Control, though not necessarily legal ownership, over land and labour is a prerequisite for large-scale processing of cane.

From the fact that there are only these two working business models available, and that the plantation is closely associated with colonialism, it would be misguided to think that "plantation sugar" was the global item and "peasant sugar" was just for local markets. As Mazumdar outlines in her book Sugar and Society in China, peasant-produced sugar played a prominent role in the global trade. ${ }^{3}$ This was equally true for Bengal as well as for China. Well into the nineteenth century, most of the global sugar production was peasant sugar located in India and China, a fact that has been more or less overlooked in much of the literature on the subject. Moreover, it was only in the final decades of the nineteenth century that industrial sugar-producing technology had become sufficiently developed to marginalize Chinese and Indian sugar exports and to conquer markets in Asia.

Indeed, the Western Hemisphere comprises just one leg of the global history of sugar production, which commenced in India, and via beet sugar, involved every single continent until mass sugar production with mechanical harvesting reached New Guinea (Irian Jaya) in the twenty-first century. The different locations and narratives of sugar production were linked to one another by a number of transfers of technology, dissemination and crossing of cane varieties, and migrations of planters. To follow the western leg of sugar production, after sugar making had reached Egypt at the time of the Arab Agricultural Revolution in the seventh and eighth centuries, its journey continued into the Mediterranean region at the time 
of the crusades. Here, the business model of the plantation run by coerced labour and slaves appeared for the first time, and sugar-producing islands such as Cyprus and Crete were ruled as colonial dependencies of Venice, which further traded the sugar into Europe. From the Mediterranean, the plantation model crossed the ocean, first to the Cape Verdean Islands, where in the course of the fifteenth century, sugar cultivation was introduced by the Portuguese colonizers who also imported African slaves to the island. Fifty years later, the Portuguese established their first sugar plantations in Brazil, again with slave labour.

In terms of the division of labour and technology used, the Caribbean plantation counts as not yet industrial, but definitely developing early within the context of emerging global capitalism. A sixteenth-century priest who visited a sugar plantation in Brazil saw hundreds of people drudging in a dehumanizing environment, with military discipline, to get the cane harvested and milled, and the juice boiled. He exclaimed that it was a "tropical Babylon", the inverse of the holy city of Jerusalem, and therefore "indeed the image of hell". ${ }^{4}$ In the seventeenth and eighteenth centuries, this model was further developed and technologically enhanced in the Caribbean region, by the Dutch and British planters. Marcel van der Linden suggests that the labour management of the sugar plantations had set a model for the labour management of the factories equipped with steam and steel that would emerge in nineteenth-century Europe. ${ }^{5}$

In sum, since the days of the Venetian hegemony over the Mediterranean world, and the creation of the Atlantic world by different European colonial powers, the plantation has been a pivot of imperial production and trade, or as Dale Tomich puts it in a recent article: "World market and division of labour and social relations of production are integrated with one another through the institutional matrix of the plantation. ${ }^{\prime 6}$ This observation is visibly true for early modern plantations, importing all their labour and implements and being satellites of European business, but it is in a different way true a few hundred years later in the age of high imperialism, when factories operated in a single global market and were tied to their environment by massive flows of seasonal migrant labour to carry out the cane cutting. The plantation did not disappear once colonial sugar production entered the era of mass production and transcended its insular character; plantations simply enlarged their span of political and social control. Sugar plantations 
developed into more or less contiguous plantation belts, which were united in so-called "sugar syndicates" for lobbying and marketing purposes.

Moreover, the existence of plantations was not restricted to the Western Hemisphere or to European enterprise. Chinese history shows us the contrary is true. After the Chinese Empire had lifted its ban on coastal shipping in the late seventeenth century, Southeast Asia became the site of a burgeoning Chinese sugar sector catering for the European and Asian markets. ${ }^{7}$ Increased demand furthered the dissemination of technological innovations, such as more powerful mills that were capable of pressing more juice from the cane, which in all likelihood were copied from the Portuguese or the Spanish. ${ }^{8}$ The enhanced mills paved the path for the emergence of Chinese plantations on islands just offshore of the Chinese coast, where sugar manufacturing was carried out by labour gangs, termed kongsis, in which the migrant workers chose their leaders from their midst and shared in the profits made. This method of cane processing was further spread throughout East and Southeast Asia. Up to the nineteenth century, Cochin China (modern-day Vietnam), Siam, the Philippines, and Java were sites of Chinese sugar production, and even the British attracted Chinese labour gangs and sugar millers to their settlements of Bengkulen and Penang in the late eighteenth century. ${ }^{9}$

When the Dutch arrived in Java by about 160o, Chinese sugar millers were already present. Although the VOC encouraged the latter's business, it also tried to create its own Caribbean-style sugar islands in Asia. After the Dutch lost their Brazilian possessions to the Portuguese in the 1650 , the VOC hoped to transform Mauritius into a sugar colony. However, it encountered major problems importing sufficient numbers of labourers who were capable of growing and processing cane, and was furthermore seriously constrained by adverse weather conditions. It was only under French and British rule that Mauritius became an important sugar producer, employing respectively slave and indentured labour. ${ }^{10}$

In any case, the attempt by the VOC to establish a sugar island in the Indian Ocean region fits the pattern that practically all pre-180o sugar plantations were located on small islands or colonial enclaves, where control over land and labour, as well as political institutions and links with

7 Marks, Tigers, Rice, Silk \& Silt, pp. 163-194.

8 Mazumdar, Sugar and Society, pp. 152-153, 157. See also Sabban, "L'industrie sucrière".

9 "Witness Examined - Henry Botham", p. 134. The British must have been aware of the skills of the Chinese sugar millers because, after they had taken possession of Penang in 1786, they invited them to set up plantations on their new acquisition. For sugar manufacturing in Penang, see Low, Dissertation, pp. 49-58.

10 Coombes, A History of Sugar Production, pp. 3-7. 
markets, were secure. Competition with other crops and markets would jeopardize the regular input of cane, and was therefore almost prohibitive of plantation-style sugar production. The value of the insular plantation as a business model in Asia is also demonstrated by the fact that the Chinese had their "offshore" plantations throughout Southeast Asia. And again, it is not coincidental that in the 1630s, the VOC started sugar production in Formosa (Taiwan) in collaboration with a Chinese entrepreneur who was based in Batavia, which is a good example of how both Europeans and Chinese had a preference for insular environments in which to start sugar plantations. ${ }^{11}$

Eventually, the VOC concentrated its sugar production neither on Mauritius nor on Formosa, which it lost in 1662, but in the colonial enclave south of Batavia (the Ommelanden), where the land was privately owned by Europeans who usually rented it out to Chinese millers. In addition to Chinese labour gangs, work in the fields around Batavia was carried out by bujangs (labour gangs of bachelors), who were wage workers arriving on their own initiative. Other labourers were engaged by paying village heads a recruitment fee, or by hiring bondsmen or peons from the Javanese nobility. ${ }^{12}$ In the seventeenth and eighteenth centuries, sugar produced by the Chinese entrepreneurs around Batavia - and increasingly further eastward along Java's north coast - was traded by the VOC and found its way to West Asian markets. ${ }^{13}$

With the expansion of its sugar production along the coast of North Java, the VOC began to move away from the traditional plantation model. In terms of the absence of local peasant production and consumption of sugar, we can still speak about plantation-style production in Java, but control over land was only established around Batavia, and control over labour - and over the Chinese labour gangs, in particular - was precarious. Moreover, Chinese millers and the colonial state were not identical or overlapping agencies, as was the case in the sugar islands of the Caribbean, but had different interests. This became tragically apparent when the influx of Chinese migrant labour took on alarming proportions in the eyes of the Batavia authorities, prompting them to resort to deportation measures, and sparking off a revolt by the immigrants that ended in a general massacre of the Chinese in and around the city in 1740.

What the Batavia massacre shows, in as early as the eighteenth century, is that although the plantation model is not inexorably linked to slavery and not necessarily confined to secluded locations, the absence of these 
conditions created conflicts about labour and land that would only be solved in favour of the European powers with the emergence of the modern colonial states a century later.

From the days of the abolition of slavery onwards, which coincided with sugar becoming a mass commodity, plantations would exhibit a wide spectrum of unit sizes as well as a range of labour relations. Moreover, and contrary to what was accepted as fact until relatively recently, new technology did not necessarily bring about new labour relations. In Cuban factories, slaves could be found working machines alongside British engineers. ${ }^{14}$ In fact, the Cuban sugar plantation complex, the remaining giant in the Caribbean, would continue the trajectory of the classical plantation as it had emerged in the Mediterranean region. Cuba's success was the logical terminus of a moving sugar frontier zone that had been travelling throughout the Western Hemisphere since the twelfth century. After having spread among the entire Mediterranean, cane cultivation practically disappeared from this area after 1600 as a result of soil exhaustion and deforestation. Sugar islands such as Cyprus, Crete, and Sicily were completely cleared of firewood for boiling the syrup. ${ }^{15}$

Meanwhile, a seemingly inexhaustible frontier was opened up in Brazil. This happened thanks to the fact that improved refining technology made it possible to preserve semi-refined sugar for some months; long enough to carry it across the Atlantic. The economies of scale in the New World - fed by slave transports from Africa - referred to as the "New Babylon", outcompeted the mills of the Western Mediterranean by about $1600 .{ }^{16}$ The story repeated itself in the course of the eighteenth century, when small Caribbean sugar plantations became as equally ecologically exhausted as their Mediterranean forerunners. However, technological progress in the shape of a series of boiling pans - termed the "Jamaica train" - enabled plantations to economize substantially on fuel. British investors turned Jamaica into the technologically most advanced sugar producer of the day, standing at the apex of pre-industrial sugar production. ${ }^{17}$ What remained, however, was the problem of soil exhaustion, which gave the larger and fertile island of Cuba, and Java for that matter, a decisive advantage in the nineteenth

14 Curry-Machado, Cuban Sugar Industry.

15 For the ecological problems that were concomitant with sugar production on the Atlantic islands, see Halikowski-Smith, "The Mid-Atlantic Islands", pp. 63-67.

16 Galloway, "The Mediterranean Sugar Industry", p. 193.

17 For an overview of the innovations that were driven by high benefits and the constant threat of the depletion of resources in the Caribbean sugar industry, see Galloway, "Tradition and Innovation". 
century. One may add that Cuba kept slavery, but that as such it did not entail a cost advantage.

Neither did the managerial unity of field and factory disappear in the nineteenth century. It is true that the technological advance of sugar factories reduced the number of mills, which led to the reduction of most plantations to cane farms. This concentration of milling in what were termed centrals severed the managerial unity between factory and field, which was the key element of the plantation. However, this was not a general phenomenon. On the contrary, in the eastern part of Cuba, American companies opened up a new sugar frontier in the early twentieth century, establishing formidable self-sufficient complexes. In the words of Hoernel, these "took care to avoid dependence on anyone or anything they could not control". ${ }^{18}$

In fact, Hoernel is just one author in a long succession since Mintz and Wolf "liberated" the concept of sugar plantation from being inherently linked to slavery. ${ }^{19}$ In addition to the twentieth-century American complexes in Cuba, those of twentieth-century Java and contemporary West India can be properly described as plantations..$^{20}$ Together with the broadening of an understanding of what qualifies as a plantation, we have acknowledged that slavery and insularity are not intrinsic to the plantation. Nevertheless, once these two features were lost, plantations became subject to increasing interaction with their environment.

In the field of labour, this interaction is ideally captured by the phrase "peasants with one foot in the plantation and the other in the peasant holding", an expression often used after Wolf and Geertz made similar observations for locations as widely distanced as the Caribbean region and Java. Sharecroppers and smallholders engaged in food production were also hired as wage workers at plantations.

In short, the plantation as a business model escaped from its initial confines of slavery and insularity, and by about 1800 proved to be adaptable to a diversity of labour relations and able to survive in societies that were not entirely plantation economies, as long as it could exert political control over these societies. Bosma, Giusti-Cordero, and Knight put it this way: "Like other agrarian formations, and surely more so than most, in plantation production labour form, crops, scale, and productive space are informed

\footnotetext{
18 Hoernel, "Sugar and Social Change", p. 240.

19 See Mintz and Wolf, "Haciendas and Plantations"; Bosma, Giusti-Cordero, and Knight, "Sugarlandia Revisited", p. 11.

20 Breman, Wage Hunters \& Gatherers, p. 214. Breman defines the constellation in West India as one that "closely approximates the plantation model". Boomgaard classifies the Java sugar industry as a plantation system: Boomgaard, "Treacherous Cane", p. 159.
} 
by and inform a larger space of social production relations." ${ }^{21}$ Again, in the political domain, the interaction became somewhat asymmetrical. In their drive to gain absolute control over land and labour, the large sugar complexes that were owned by bourgeoisies rooted in Java, Cuba Negros, or West India, deeply impinged on the political culture of their societies.

\section{The sugar plantation and the Asian peasantry}

The abolition of slavery and the simultaneous ascendency of sugar as the largest bulk commodity in the nineteenth century in terms of value, went along with immense spatial relocations. Whereas in the early nineteenth century, Latin America's share had been 85 per cent, it was only 47 per cent by the end of the century, most of which came from Cuba. Meanwhile, Asia's share rose from 6 to 39 per cent. ${ }^{22}$ Underneath this massive shift, there was a process of trial and error, in which the plantation could no longer rely on slavery and insularity and had to be reshaped to fit local conditions, as I discuss further on with regard to India and Indonesia.

While continental Europe developed its beet sugar industry, the colonial powers, such as Britain and the Netherlands, experimented with different ways of obtaining sugar from Asia. They either bought sugar from local manufacturers - as they did in Bengal - or from Chinese millers - as they did in Java or the Philippines - or tried to obtain cane from local peasantries, which they milled and boiled with the equipment that had been developed in West India. From the late eighteenth century onwards, Caribbean sugar planters brought their methods to the British and Dutch possessions in Asia. Although there were many locations in monsoon Asia where soil and climate offered perfect conditions for such transfers, most of them proved to be unsuitable for a variety of reasons, such as labour shortages and the fragmentation of landholding. Colonial powers, and the British and Dutch in particular, tried to change these parameters, sometimes with success but more often in vain.

Whatever policies colonial governments chose with regard to property rights, they could do little to change the fact that these continued to be solidly enmeshed in economic inequalities within the peasants' communities. As Charlesworth puts it for the Bombay Presidency: "Even if the peasant agriculturalist remained the owner of his traditional holding, 
traders and moneylenders, through the operation of the credit and marketing systems, were, perhaps, able to secure growing proportions of the output." ${ }^{23}$

Another element concerns the market organization, which is termed the "bazaar" by Rajat Kanta Ray. The point he makes is that the colonial sector could not reshape local rural conditions into plantations, simply because it did not control the economy of the middlemen. It had to leave a substantial part of the economy to the bazaar: "Only the bazaar could 'deliver' the goods from the bottom to the top by virtue of complex financial arrangements that interlocked its own numerous successive layers." ${ }^{24}$ This situation is also described by Christof Dejung in his important study on the cotton trade of the Swiss house of Volkart. For this firm, as well as for any other global player in this business, it turned out to be impossible to control the cotton supplies and to suppress adulterations, even after the construction of railroads brought Europe to the doorstep of Indian rural life. ${ }^{25}$ One aspect of Dejung's analysis is particularly relevant for sugar, as it alludes to the complex of a dense system of advances provided to cane cultivators. The East India Company (EIC) knew very well how this system functioned, and when it decided to increase its sugar exports to Britain in the 179os, it did so by joining - rather than by trying to beat - the bazaar, and started to purchase refined sugar from Indian urban workshops, the khandsaris. The EIC gave a handful of West Indies' planters some support to produce sugar the Jamaican way, but it did not expect much from these experiments.

The Dutch faced other problems in Java, which had great potential as sugar producer, but which was so distant from European markets that freight costs were almost prohibitive. Moreover, by the late eighteenth century, its Chinese mills in Batavia's Ommelanden had reached the same ecological limits as the Mediterranean, and later on the smaller Caribbean islands, had encountered. Soil exhaustion, the disappearance of the forests needed to provide the wood for fuel, and the shortage of buffalos to grind and transport the cane, plagued the sugar millers around Batavia. ${ }^{26}$ Firstly, the colonial authorities of Java sought to revive the sugar sector by introducing fuel-saving equipment from Jamaica. In addition, British and French planters came to Java shortly after 1800 to introduce the West Indies 
equipment, and a steam-driven mill was brought to Java by a British-Danish house accompanied by eight British technicians. ${ }^{27}$

In the 1820 , the expensive steam-powered milling equipment and improved boiling pans suffered from labour shortages, whereas the Chinese mills rapidly lost ground. The dwindling output of West Java could easily have been compensated for by East Java, where at that time, more or less spontaneously, a new sugar frontier emerged, dominated by Chinese merchants and Javanese nobility. Another available alternative was the Dutch sugar colony of Suriname. History would unfold differently through the agency ofJohannes van den Bosch, the architect of early-nineteenth-century Dutch colonialism. His aim was to subsume the sugar frontier of East Java in a Dutch-led colonial economy, which he foresaw as having to compete with the Americas, where slave-run plantations could survive the abolition of the slave trade by improving the living conditions of the slaves, thus allowing the slave populations to reproduce. Moreover, the Americas had the considerable advantage of their shorter distance from Europe. Ensuring the longer term profitability of East Java's sugar sector by creating a stable environment for the sugar factories was one, if not the most important, reason for Van den Bosch to introduce his Cultivation System (1830-1870) ${ }^{28}$

Under the Cultivation System, the colonial government took control of the supplies of cane to the manufacturers, who were obliged to invest in state-of-the-art equipment and to sell their sugar to the semi-governmental Netherlands Trading Society (NHM). ${ }^{29}$ The system was reinforced by the presence and key involvement of migrants from elsewhere in Europe and North America, backed up by British and North American investors and local Chinese capital. Furthermore, the Cultivation System relied on the collaboration of the local aristocracy, and most notably the village heads, who were assigned the tasks of supplying blocks of land and of implementing the system of labour conscription to feed the factories with cane. After forced cane cultivation was phased out in the 1860s, sugar factories became even more reliant on the cooperation of the village elites for regular cane supplies.

In fact, we can view the Cultivation System as a radical intervention, which limited the property rights of the peasantry, strengthened the power of the sugar factories, and connected the Javanese rural economy with the global markets. A key role in forging this connection was played by banking institutions - first the Netherlands Trading Society, and later on 
the "cultivation banks" - which supplied the funds to pay for the advances to Javanese peasants to plant their land with cane. This system of advances subsumed rather than eliminated local systems of moneylending, often by wealthy farmers to poor ones.

A lasting legacy of the Cultivation System in Java, which enabled sugar factories without direct government intervention, was the "areaal" that encircled each factory and compensated for the fact that the factory did not own the land. Within a circle of a few miles, the factory was freed from competition by other factories or colonial cash crop producers, while leasing land from local farmers for cane cultivation. The circles or zones around factories, controlled by the alliances between factory and village elites, were an Asian approximation of the control over the field that had been exerted in the traditional Caribbean plantation model.

As long as the industry did not own the land on which cane was grown, its success was reliant on the symbiosis between rich farmers and factories. The wealthy farmers, or "big peasants", commanded the necessary land and labour for the factories through the indebtedness of marginal peasants. The entire system was further beefed up by advances to peasants provided by the sugar factories, and supplied by the so-called "cultivation banks". During the Cultivation System, the colonial government incurred massive costs for administration and fees for both indigenous and European civil servants, and in the case of sugar, its production only became profitable after more than a decade. Nonetheless, it was the massive changes in the institutional make up, in terms of labour and land allocation and financial infrastructure, that ensured the long-term competiveness of Java sugar on the European, and later, the Asian market. The downside of this success was that via the systems of advances and indebtedness, hundreds of thousands of Javanese farmers were more or less coerced to relinquish their land, and often also their labour, to sugar factories against prices that were sub-economic. The profits went to the sugar factories and to the "big peasants" who had lent them the money. ${ }^{30}$

\section{Different factor endowments but similar extractive institutions: Java and Cuba compared ${ }^{31}$}

In terms of labour relations, Java and Cuba shared a relatively ruthless approach to labour mobilization and control. While the Cuban plantation

30 Bosma, The Sugar Plantation in India, pp. 176-177.

31 See Bosma and Knight, "Global Factory and Local Field", and Bosma and Curry-Machado, "Two Islands, One Commodity". 
holders imported 780,000 slaves between 1790 and 1868, the Cultivation System had 700,00o to 800,00o households under its sway (about 35 to 40 per cent of the households in Java under direct government rule)..$^{2}$ In an age of spreading liberalism, both islands demonstrated that advanced modes of production could flourish with forced labour, which was against the grain of the purported nexus between capitalist development and proletarianization. Nonetheless, the sugar estates in both Java and Cuba increasingly employed wage labour, rather than respectively conscript and slave labour, and this particularly involved migrant labour during the harvesting season.

The difference between the islands of Java and Cuba, which are almost equal in size, is that Java's population was about ten times larger than that of Cuba throughout the nineteenth and twentieth centuries. Java experienced massive demographic growth, leading to the quintupling of its population during the nineteenth century. Whereas in Cuba a surplus of land enabled expanding cultivation, but a shortage of labour limited the capability to exploit this; in Java, land was the constraining factor. In Java, the challenge was to obtain the maximum yield per acre. This was achieved by planting cane in sawahs and alternating it with paddy cultivation, thereby helping to prevent the exhaustion of the soil. While ratooning - taking harvests from the cane plants for a couple of consecutive years - was the rule in Cuba, for each harvest in Java, the cane had to be planted again. A massive (semi-)proletarian rural workforce that was dependent on by-employment to make ends meet provided the necessary labour force. ${ }^{33}$ By contrast, in Cuba the slave population was limited and in decline before slavery was eventually abolished in 1886 . From the late nineteenth century onwards, hundreds of thousands of immigrant workers - mostly from Haiti, Jamaica, and other Caribbean islands, as well as from rural Spain - flocked into the Cuban cane fields. Though nominally free and not indentured, their actual working conditions were not much better than those of the slaves had been. The Cuban government had a clear preference for Spanish migrant workers, but was forced by American plantation interests to allow Jamaican and Haitian workers in. ${ }^{34}$

Technological advances set the labour regimes of the sugar sectors even further apart from one another. In Cuba, the technological developments

32 The proportion of households involved in the Cultivation System declined over time, but 35-40 per cent is a reasonable estimate for the 1840 s. See Bosma and Curry-Machado, "Two Islands, One Commodity", p. 252; Fasseur, The Politics of Colonial Exploitation, p. 17.

33 Elson, "Sugar Factory Workers"; Knight, "Peasant Labour"; Bosma, "Discourse on Free Labour".

34 Fuente, “Two Dangers, One Solution”, p. 34. 
and investments in infrastructure in the early nineteenth century facilitated the opening up of new fertile frontier zones for sugar production, raising the output per unit labour. ${ }^{35}$ In Java, the opposite happened when the colonial government successfully created a semi-proletarianized workforce, a process, as stated, that was further engendered by rapid demographic growth. Even though this labour was not indentured, it consisted of labour gangs led by mandurs (foremen), who acted as intermediaries and subcontractors for the cane cutters, and who were often tied to the team through debt bondage. In late colonial society, many of these seasonal labourers came to the sugar belt in East Java from the relatively infertile and overpopulated island of Madura. ${ }^{36}$ Some of the immigrants were settled around the factory, to provide a basic stabilized workforce beyond the cane-milling season. Attempts by the colonial government of the Netherlands Indies shortly after the First World War to improve the conditions of the workers in the Java sugar industry were immediately rebuffed by the organization of sugar factories in Java, the Java Sugar Syndicate. ${ }^{37}$ Whatever the factor endowments were, and regardless of the nationality and ethnicity of the ownership of the sugar factories - in both Cuba and in Java this involved a mixture of local and metropolitan ownership - the sugar plantation conglomerates were capable of imposing their will on the colonial state, or as was the case in Cuba, the semi-colonial state.

\section{The Negros sugar frontier}

Both Cuba and Java provide examples of post-slavery plantations that no longer operated as insular units, but had much wider ramifications. They were, for example, linked to neighbouring islands through seasonal migration circuits, and were no longer satellites of European ownership, but acted as independent agencies - usually united in associations or syndicates - within a colonial context. The Philippine sugar island of Negros offers another example of the post-slavery sugar plantation belt, where sugar planters managed to turn pioneering smallholder cane cultivators into their indebted clients and transform the system into wage labour under

35 Bergad, "The Economic Viability of Sugar Production", p. 97.

36 Spaan, Labour Circulation and Socio-Economic Transformation; Spaan and Hartveld, "Socioeconomic Change and Rural Entrepreneurs".

37 Bosma, The Sugar Plantation, pp. 181-182. 
notoriously coercive conditions. In the process, they would establish their Sugarlandia.

The story of this modern sugar island has been thoroughly documented. After the Spanish authorities opened up the port city of Iloilo to foreign trade in 1855 , the British established a vice-consulate, directed by Nicholas Loney. Described by McCoy as just an agent of the Liverpudlian textile workers, Loney embarked on an aggressive policy aimed at developing sugar production in Negros and retailing cotton in the Visayas, ruining the textile sector of Iloilo. Its textile entrepreneurs shifted their business to the west coast of the island of Negros, which was just twenty miles across the sea from Iloilo city, to become major landholders (hacenderos). ${ }^{38}$ Much of the land was cleared by immigrants from Iloilo. The hacenderos provided crop loans to these immigrant settlers against an interest rate of 25 per cent, which made many lose their land just one year after they had entered into their contract loans. ${ }^{39}$ If financial extortion did not work fast enough, the landlords would resort to using armed gangs. This way, the hacenderos grabbed massive amounts of land between the 1860 os and 1880 s, reducing smallholders first to tenants and then to sharecroppers. ${ }^{40}$ Whereas the cultivation of cane was preferably carried out by sharecroppers, for harvesting and haulage the planters relied on seasonal labourers, or sacadas, arriving in gangs of twenty or so men led by a kapatas (patron). ${ }^{41}$ As a matter of fact, this bifurcation of sedentary cane growers and itinerant cane cutters was also visible in East Java, where a proportion of the immigrant labourers settled around the factories and were sometimes provided with land to tie them to the factory.

In spite of the fact that the population of Negros almost quintupled from about 100,000 to 463,000 residents in the second half of the nineteenth century, ${ }^{42}$ labour shortages were endemic and the planters used a pass system, corporal punishments, and locking up the labourers at night to maintain discipline and prevent workers from running away to other plantations. ${ }^{43}$ Coercion and duress was the planters' response to workers walking away with their advance without performing labour. However, planters and sympathetic officials did not succeed in convincing the American

38 McCoy, "A Queen Dies Slowly", p. 317,

39 Lopez-Gonzaga, "The Roots of Agrarian Unrest”, p. 165; Larkin, "Philippine History Reconsidered", p. 617 .

40 Aguilar, Clash of Spirits, pp. 111-113; McCoy, "Sugar Barons", p. 114.

41 Bankoff, "Wants, Wages, and Workers", p. 68; Aguilar, Clash of Spirits, p. 128.

42 Aguilar, Clash of Spirits, pp. 126-127.

43 McCoy, "A Queen Dies Slowly", pp. 323, 325. 
administrators in Manila that plantation bosses should be allowed to hold on to passports and maintain their own rural police.

The American administrators of the Philippines felt that the central government should not intervene directly on behalf of a private party in a matter in which the state had no part whatsoever. ${ }^{44}$ The illegal coercive practices employed by the planters on their labour force continued nonetheless, regularly meeting violent resistance from the oppressed workers. Moreover, it was not just that the central administration in Manila was too weak to reign in the sugar planters, the latter would even emerge as a dominant national political factor. It was exactly during American rule that the Philippine sugar industry was revamped into a small number of highly capitalized sugar-processing factories (termed Centrals), which came under the control of a tight network of Filipino sugar entrepreneurs who would rule the country for most of the twentieth century. They constituted, as Larkin has aptly called it, a Sugarlandia.

\section{Indian and Indonesian sugar cooperatives: An alternative institution?}

When India embarked on a trajectory of large-scale industrialization in the 1930s, it was after an earlier serious attempt a century before had ended in failure. At the time of emancipation of the slaves in the British West Indies, investment in steam-powered sugar production in India had looked quite promising. Within a decade, about eighty such factories emerged, but by the end of the $1850 \mathrm{os}$, practically all sugar in India was again being produced as it had been for two thousand years; peasants grew cane on minute plots, which was ground by a collectively owned sugar mill. The juice was boiled on the spot into a brown mass, termed gur. White sugar was produced in urban workshops, khandsaris, which bought the gur from the peasants to refine it. Even after the 1930s, when the industrialization of sugar took off, the traditional way of making sugar and of sugar consumption continued to exist. The reason India was able to resist the global trend towards industrial sugar is that cultivators were used to working on small plots, and that in most of the country their property rights were solid enough to prevent both European and Indian capitalists from bringing together large plots of land to feed steam-powered sugar manufacturing equipment. This is of course an important caveat to the notion advanced by the institutional approach;

Aguilar, Clash of Spirits, pp. 137-138; McLennan, "Land and Tenancy", p. 675. 
that weak property rights are to blame for the reversal of fortune of once relatively wealthy countries in the Global South.

It was only in the 1930s that the industrialization of the Indian sugar sector experienced a breakthrough. The government of India was the decisive factor, as it closed the Indian markets for sugar imports from Java and Europe in 1930. It did so to protect Indian cane cultivators, for whom this crop was an important source of additional income. Within a few years, over a hundred state-of-the-art sugar factories emerged in India, most of which were financed by Indian business circles. The format of the field-factory relationship of this emerging sugar industry was derived from Java during a trip by the Indian Sugar Committee to the island in 1920, where among other things it studied the areaal, the designated circle ensuring factories of their stable cane supplies. Some members of the committee became staunch supporters of introducing this system in India. However, because of the increasing political participation of the Indian National Congress in the country's government, the idea became politically unfeasible, as it would simply throw the peasants under the thrall of the factories. Nonetheless, zoning was a prerequisite, as well as coordination between field and factory, for the viable industrialization of the sugar sector. In the course of the 1930s, the answer was found by combining zoning with "farmer's cooperatives", which were instrumental in coordinating supplies of cane at such a scale that industrial sugar production became profitable.

Nonetheless, the cooperative was not egalitarian, as the cases of India and in Indonesia unambiguously show. Whereas in the post-colonial development model the cooperative was presented as the breakaway from the plantation, in fact it was the terminus of long trajectory to unite field and factory through a coalition of the "big peasants" and the factories. The reason is that industrialization of cane processing required the subordination of the agricultural part of the process to the manufacturing part. Moreover, factories would only survive if they were able to prevent the cultivators from growing other - often more profitable - crops, or diverting their cane to other purposes such as peasant sugar, which was the case in India. Conversely, once the sugar factory controlled labour and land, it assumed many of the features of a plantation.

In Java, smallholder sugar production was advocated by Indonesian nationalists in late-colonial society and attempted under the presidency of Sukarno. However, the attempts by his successive governments to eliminate the role of the village elites and foster true smallholder cane cultivation, in which each individual smallholder had to contract with the factory, turned into a complete failure. In the Suharto era (1965 to 1997), the smallholder 
model was reshaped into a cooperative structure to restore the synchrony between field and factory. The gist of this programme, called TRI (Tebu Rakyat Intensifikasi), or "intensified smallholder cane", was, however, that in order to maintain a viable sugar industry, the cultivators simply had to be coerced to supply sufficient quantities of cane.

Hence, under the Suharto regime the central role of the village head in designating land for cane cultivation was re-established - as it was under the Cultivation System - and the village elites resumed their role of controlling land and labour on behalf of the sugar factories. Undoing the earlier attempts during the Sukarno years to escape from the colonial setting by encouraging smallholders to replace the colonial plantation, the institutional framework of sugar production under Suharto came cynically close to the Cultivation System.

For both India and Indonesia, sugar cooperatives were a way to transfer the plantation model into the new era of independence. However, the cooperatives could not even mitigate the inequalities that existed at the village level in Java and West India. In the Bombay Deccan, Asian societies were not egalitarian prior to the arrival of industrial sugar production in their villages. In contrast to what a long line of authors on rural society, from Van den Bosch to Geertz, have written about communalism and shared poverty, the realities were not egalitarian, and divisions were only sharpened under pressures from the sugar industries. The post-colonial cane sugar industries were either dominated by huge commercial firms working with wage labour, or by sugar cooperatives. However, in either model, immense armies of cane cutters had to be hired, while debt contracting was ubiquitous in the world's cane fields; in the Philippines, in Latin America, in Java, in West India, etc. Almost invariably, the arduous work of cane cutting was carried out by migrant workers from poorer regions on a seasonal basis.

Massive cane combines were first introduced in Cuba and the United States in the 1970s, and the system of engaging indebted seasonal labourers holds, as long as the cane cutters cost the factories less than mechanized harvesting. ${ }^{45}$ In West India, mechanization is a much more recent phenomenon, as it only commenced in the twenty-first century after cane cutters put up increasingly effective collective action against their exploitation. ${ }^{46} \mathrm{In}$ Indonesia, the mechanization of the cane cultivation is part of the transfer of peasant-embedded cane production to the outer islands of the Indonesian archipelago, which entailed a full restoration of the insular plantation 
model. In Irian Jaya, large fields are exploited by a company that first burns the cane fields, to get rid of the unusable cane leaves, before sending in gargantuan cane mowers. The immense advantage for the Indonesian state is that this mode of production entails minimal social risks and no difficulties in finding an equilibrium between factory and field, as has been the challenge in the post-colonial Javanese countryside.

Large-scale cane processing requires a synchrony between field and factory, which could either be accomplished by the factory owning the field, as was the case in parts of Negros and Cuba, or by an alliance between "big peasants" and the factory against the smallholders. In India and postcolonial Indonesia, the cooperative was a vehicle to accomplish the latter. In both cases, sugar production was based upon sharp social inequalities, in which smallholders were reduced to being sharecroppers. The fate of the seasonal migrant labourers who carried out, and still do today, the arduous work of cane harvesting and haulage, was even more miserable. Again, since the 1970s, their room for negotiation has been seriously limited by the alternative of mechanization.

\section{Conclusion}

The traditional sugar plantation island, working with commodified slave labour, was the most efficient unit of production for sugar in the Atlantic region for consumption in Europe. Meanwhile, in Asia, peasant sugar - a mixture of household and commodified labour - was the dominant mode. In the Western Hemisphere, slave labour was considered to be part of the plantation's capital and the absentee planters were capable of controlling the governance of their sugar islands thanks to their entrenchment in metropolitan government. This completely changed with the abolition of the slave trade in 1807 , and the simultaneous ascendency of sugar as a bulk commodity. While continental Europe developed its beet sugar industry, the colonial powers such as Britain and the Netherlands experimented with different ways of obtaining sugar from Asia. Indian peasant sugar, Chinese, or Mestizo Chinese plantation production in Java and the Philippines, as well as processing cane from peasants conscripted into cane cultivation; these practices all belonged to the early-nineteenth-century repertoire of sugar production in the British, Dutch, and Spanish possessions in Asia.

From the late nineteenth century onwards, the sugar factory would become the dominant type of production for the global market, with the important caveat that peasant sugar still made up half of India's sugar 
output by the end of the twentieth century. Moreover, the factories no longer operated in the sequestered environment of the island or plantation, but had to deal with the colonial or semi-colonial state and the peasantry. Their strategy was invariably to use their formidable economic power to further their interests in the political realm, and where necessary to seek alliances with peasant elites to secure land and labour. Both India and Indonesia tried to escape from the predicament of the plantation as an extractive institution, but failed to protect the largest and most vulnerable segment of the labour force; the cane cutters who usually worked on piece rate. These states were not able to change the configuration so aptly termed "Sugarlandia" by Larkin; indeed the quintessential extractive institution. The history of the plantation shows its pliability as a business model and its "extractive" power, but also - as Acemoglu, Johnson and Robinson as well as many other authors before them have pointed out - the dependency of these institutions on already existing local social formations. This made the plantation as an extractive institution immensely powerful, but also set it within clear bounds. The plantation could only exist in Asia with the cooperation of the peasant elites. In this respect, secure property rights could either be a deterrent for the plantation as an extractive institution, or be its facilitator; it all hinged on the attitudes and interests of the local peasant elites.

\section{Bibliography}

Acemoglu, Daron, Simon Johnson, and James A. Robinson, "Reversal of Fortune: Geography and Institutions in the Making of the Modern World Income Distribution", Quarterly Journal of Economics, 117 (2002), pp. 1231-1294.

Aguilar, Filomono V., Clash of Spirits: The History of Power and Sugar Planter Hegemony on a Visayan Island (Honolulu, 1998).

Bairoch, Paul, and Bouda Etemad, Structure par produits des exportations du Tiers Monde 1830-1937 (Geneva, 1985).

Bankoff, Greg, “Wants, Wages, and Workers”, Pacific Historical Review, 71 (2005), pp. 59-86.

Bergad, Laird W., "The Economic Viability of Sugar Production Based on Slave Labor in Cuba, 1859-1878", Latin American Research Review, 24 (1989), pp. 95-113. Boomgaard, Peter, "Treacherous Cane: The Java Sugar Industry between 1914 and 1940", in: Bill Albert and Adrian Graves (eds.), The World Sugar Economy in War and Depression (London: Routledge, 1988), pp. 157-169. 
Bosma, Ulbe, "Cane Sugar and Unlimited Supplies of Labor in the 1930s: New Thinking and the Origin of Development Economics", in Marcel van der Linden and Leo Lucassen (eds), Working on Labor: Essays in Honor of Jan Lucassen (Leiden, 2012), pp. 371-394.

Bosma, Ulbe, "The Discourse on Free Labour and Forced Cultivation System: The Contradictory Consequences of the Abolition of the Slave Trade for Colonial Java 1811-1863", in Marcel van der Linden (ed.) Humanitarian Intervention and Changing Labor Relations: The Long-Term Consequences of the Abolition of the Slave Trade (Leiden: Brill, 2011), pp. 387-418.

Bosma, Ulbe, "The Cultivation System (1830-1870) and Its Private Entrepreneurs on Colonial Java", Journal of Southeast Asian Studies, 38 (2007), pp. 275-291.

Bosma, Ulbe, "Het cultuurstelsel en zijn buitenlandse ondernemers. Java tussen oud en nieuw kolonialisme", Tijdschrift voor Sociale en Economische Geschiedenis, 2 (2005), pp. 3-28.

Bosma, Ulbe, The Sugar Plantation in India and Indonesia: Industrial Production, 1770-2010 (Cambridge, 2013).

Bosma, Ulbe, and G. Roger Knight, "Global Factory and Local Field: Convergence and Divergence in the International Cane Sugar Industry, 1850-190o", International Review of Social History, 49 (2004), pp. 1-26.

Bosma, Ulbe, and Jonathan Curry-Machado, "Two Islands, One Commodity: Cuba, Java, and the Global Sugar Trade (1790-1930)", New West Indian Guide, 86 (2012), pp. 237-262.

Bosma, Ulbe, Juan Giusti-Cordero, and G. Roger Knight, "Sugarlandia Revisited: Sugar and Colonialism in Asia and the Americas, 1800-1940", in Ulbe Bosma, JuanGiusti Cordero and G. Roger Knight (eds), Sugarlandia Revisited: Sugar and Colonialism in Asia and the Americas, 1800-1940 (New York, 2007), pp. 5-30.

Breman, Jan, Wage Hunters \& Gatherers: Search for Work in the Urban and Rural Economy of South Gujarat (Delhi, 1994).

Bunsha, Dionne, "Machines That Mow Down Migrants", blog post, 31 March 2007, available at: https://dionnebunsha.wordpress.com/2007/03/31/ machines-that-mow-down-migrants.

Charlesworth, Neil, Peasants and Imperial Rule: Agriculture and Agrarian Society in Bombay (Cambridge, 1985).

Coombes, Alfred North, A History of Sugar Production in Mauritius (Port Louis, Mauritius, 1993).

Curry-Machado, Jonathan, Cuban Sugar Industry: Transnational Networks and Engineering Migrants in Mid-Nineteenth Century Cuba (New York, 2011).

Dejung, Christof, Die Faden des Globalen Marktes: Eine Sozial Und Kulturgeschichte des Welthandels am Beispiel der Handelsfirma Gebruder Volkart 1851-1999 (Koln, 2013). 
Elson, R.E., “Sugar Factory Workers and the Emergence of 'Free Labour' in Nineteenth-Century Java", Modern Asian Studies, 20 (1986), pp. 139-174.

Fasseur, Cornelis, The Politics of Colonial Exploitation: Java, the Dutch and the Cultivation System (Ithaca, 1992).

Fuente, Alejandro, "Two Dangers, One Solution: Immigration, Race, and Labor in Cuba, 1900-1930", International Labor and Working-Class History, $5^{1}$ (1997), pp. 30-49.

Galloway, J.H., “The Mediterranean Sugar Industry”, GeographicalReview, 67 (1977), pp. 177-194.

Galloway, J.H., "Tradition and Innovation in the American Sugar Industry, c. 1500 1800: An Explanation", Annals of the Association of American Geographers, 75 (1985), pp. 334-351.

Halikowski-Smith, Stefan, "The Mid-Atlantic Islands: A Theatre of Early Modern Ecocide?", International Review of Social History, 55 (2010), pp. 51-78.

Hoernel, Robert B., "Sugar and Social Change in Oriente, Cuba, 1898-1946",Journal of Latin American Studies, 8 (1976), pp. 215-249.

Knaap, G.J., "Slavery and the Dutch in Southeast Asia”, in Gert Oostindie (ed.), Fifty Years Later: Antislavery, Capitalism and Modernity in the Dutch Orbit (Pittsburgh, 1995), pp. 193-206.

Knight, G. Roger, "From Plantation to Padi Field: The Origins of the Nineteenth Century Transformation of Java's Sugar Industry”, Modern Asian Studies, 14 (1980), pp. 177-204.

Larkin, John A., "Philippine History Reconsidered: A Socioeconomic Perspective", American Historical Review, 87 (1982), pp. 595-628.

Levert, Philip, Inheemsche arbeid in de Java suikerindustrie (Wageningen, 1934).

Lopez-Gonzaga, Violeta, "The Roots of Agrarian Unrest in Negros, 1850-189o", Philippine Studies, 32 (1988), pp. 151-165.

Low, James A., Dissertation on the Soil \& Agriculture of the British Settlement of Penang or Prince or Prince of Wales Island, in the Straits of Malacca: Including Province Wellesley on the Malayan Peninsula: With BriefReferences to the Settlements of Singapore and Malacca, and Accompanied by Incidental Observations on Various Subjects of Local Interest in These Straits (Singapore, 1836).

Marks, Robert B., Tigers, Rice, Silk \& Silt:Environment and Economy in Late Imperial South China (Cambridge, 1998).

Mazumdar, Sucheta, Sugar and Society in China: Peasants, Technology and the World Market (Cambridge, 1998).

McCoy, Alfred W., "A Queen Dies Slowly: The Rise and Decline of Iloilo City", in Alfred W. McCoy and Edilberto C. de Jesus (eds), Philippine Social History: Global Trade and Local Transformations (Honolulu, 1982), pp. 296-358. 
McCoy, Alfred W., "Sugar Barons: Formation of a Native Planter Class in the Colonial Philippines", Journal of Peasant Studies, 19 (1992), pp. 106-141.

McLennan, Marshall S., "Land and Tenancy in the Central Luzon Plain", Philippine Studies, 17 (1969), pp. 651-682.

Mintz, Sidney W., and Eric Wolf, "Haciendas and Plantations in Middle America and the Antilles", Social and Economic Studies, 6 (1957), pp. 380-412.

Ray, Rajat Kanta. "Asian Capital in the Age of European Domination: The Rise of the Bazaar, 1800 1914", Modern Asian Studies, 29 (1995), pp. 449-554.

Ray, Rajat Kanta. "The Bazaar: Changing Structural Characteristics in the Indigenous Section of the Indian Economy Before and After the Great Depression", Indian Economic Social History Review, 25 (1988), pp. 263-318.

Reesse,J.J., De suikerhandel van Amsterdam. Een bijdrage tot de handelsgeschiedenis desvaderlands, hoofdzakelijkuit de archieven verzameld en samengesteld, 2 vols (Haarlem, 1908).

Sabban, Françoise, "L'industrie sucrière, le Moulin à sucre et les relations Sino Portugaises aux XVIe-XVIIIe siècles", Annales, Economies, Sociétés, Civilisation, 49 (1994), pp. 817-861.

Sánchez, Juan Tomás, "Sugarcane Mechanical Harvesting: Future Applications in the Sugar Business in Cuba", Cuba in Transition, ASCE, 21 (2011), pp. 451-455.

Schwartz, Stuart B., "Introduction", in Stuart B. Schwartz (ed.), Tropical Babylons: Sugar and the Making of the Atlantic World, 1450-1680 (Chapel Hill, 2004), pp. 1-26.

Spaan, Ernst, Labour Circulation and Socio-economic Transformation: The Case of East Java, Indonesia (The Hague, 1999).

Spaan, Ernst, and Aard Hartveld, "Socio-economic Change and Rural Entrepreneurs in Pre-Crisis East Java, Indonesia: Case Study of a Madurese Upland Community", Sojourn, 17 (2002), pp. 274-300.

Teisseire, Andries, Verhandelinge over den tegenwoordigen staat der Zuikermolens omstreeks de Stadt Batavia, Benevens de middelen tot derzelver herstel, en eenige verdere daar toe betrekkelijke aanmerkingen (Batavia, 1785).

Tomich, Dale, "Rethinking the Plantation: Concepts and Histories", Review, 34 (2011), pp. 15-39.

Van der Linden, Marcel, "Re-constructing the Origins of Modern Labor Management”, Labor History, $5^{1}$ (2011), pp. 509-522.

"Witness Examined - Henry Botham", in Abridgement of the Minutes of Evidence Taken Before a Committee of the Whole House to Whom It Was Referred to Consider the Slave-Trade (London, 1789), p. 134. 


\section{About the Author}

Ulbe Bosma is Senior Researcher at the International Institute of Social History in Amsterdam and Professor of International Comparative Social History at the Vrije Universiteit Amsterdam (The Netherlands). His publications include The Sugar Plantation in India and Indonesia:Industrial Production, 1770-2010. (Cambridge, 2013), Commodities, Ports and Asian Maritime Trade, 1750-1850 (Bastingstoke, 2015) (co-edited with Anthony Webster), and Being "Dutch" in the Indies: A History of Creolisation and Empire, 1500-1920 (Singapore, 2008) (with Remco Raben).

E-mail: ubo@iisg.nl 



\title{
$5 \quad$ Threads of Imperialism
}

Colonial Institutions and Gendered Labour Relations in the Textile Industry in the Dutch Empire*

Elise van Nederveen Meerkerk

Hofmeester, Karin \& Pim de Zwart (eds.), Colonialism, Institutional Change, and Shifts in Global Labour Relations. Amsterdam: Amsterdam University Press, 2018

DOI: $10.5117 / 9789462984363 / \mathrm{CHo} 5$

\begin{abstract}
This chapter explores the effect of colonial institutions on gendered labour relations in the Javanese and Dutch textile industries through the perspective of mutual colonial influences. Indigenous Javanese textile production was less dramatically affected by Dutch state-subsidized textile imports than most historians suggest. Javanese workers, particularly women, found niche markets and profited from the imported factory-made yarns and white cloth, which stimulated hand-weaving and -printing until the 1920s. Simultaneously, colonial policies and connections affected metropolitan textile production. Firstly, Dutch exports to Java stimulated industrialization in the Netherlands, entailing new gendered divisions of labour. Secondly, colonial profits contributed to rising male wages in the late nineteenth century, presumably causing married Dutch women to comparatively quickly and extensively withdraw from formal paid work.
\end{abstract}

Keywords: textile production, colonialism, women's work, Java, The Netherlands

* I would like to thank Corinne Boter, Arunima Datta, Ewout Frankema, Katharine Frederick, Michiel de Haas, Karin Hofmeester, Stef Severt, and Pim de Zwart for their useful comments on an earlier draft of this contribution. 


\section{Introduction}

The process of industrialization has been vital to many historical explanations for sustained economic development. In the late eighteenth and early nineteenth century, many countries in the "Global North" succeeded in enhancing their labour productivity through the mechanization and rationalization of production, leading to unprecedented levels of economic growth. ${ }^{1}$ Although there is an ongoing debate among historians about the timing of the "Great Divergence" between "the West" and "the rest", it is clear that the beginning of the nineteenth century marked a significant widening of this gap, and that this was related both to the process of industrialization and to the increasing impact of colonial institutions, particularly in this period.

As Jeffrey Williamson has recently argued, in the nineteenth century, the economic gap between the First World and the Third World grew enormously. In the context of industrialization and the global trade boom, the "poor periphery", as Williamson terms it, specialized in the export of primary products and raw materials, whereas the industrializing "core" exported manufactures globally. This worldwide specialization led to unequal terms of trade that favoured deindustrialization of the periphery and furthered the Great Divergence, because industrialization in the same period led to unprecedented economic growth in the core. ${ }^{3}$ However, with his emphasis on global market mechanisms, Williamson largely overlooks the role of institutions, and, to a lesser degree, the role of relative factor prices. He barely engages with the debates on the effects of colonial policy, ${ }^{4}$ nor does he pay much attention to different paths towards industrialization, such as labour-intensive industrialization, in which labour - rather than capital or land - provided the competitive advantage in the world economy. ${ }^{5}$

The labour-intensive textile industry offers an excellent case study for investigating the relations between industrialization, labour intensity, and colonial institutions. In many countries, textile production was (one of) the first to be mechanized and rationalized. Cotton textiles - which until well into the eighteenth century had (literally) been in Asian hands were especially prone to mechanization. Before industrialization, India in

1 See, e.g., Mokyr, The British Industrial Revolution.

2 E.g., Parthasarathi, "Rethinking Wages"; Pomeranz, The Great Divergence; Broadberry and Gupta, "The Early Modern Great Divergence”; Allen et al., "Wages, Prices".

3 Williamson, Trade and Poverty.

4 For an excellent review of Williamson's book, see Crafts, "Review: Trade and Poverty".

5 Austin and Sugihara, Labour-Intensive Industrialization. 
particular had been the major exporter of cotton cloth, due to its competitive advantage in terms of low wage costs. ${ }^{6}$ Supposedly, "this global competition became the impetus for transforming the textile manufacturing process in Europe", ${ }^{7}$ meaning that the overwhelming demand for Indian cotton textiles stimulated Europeans to find ways to raise productivity in this industry at home. Indeed, colonial policies after the British "Calico Acts" of the early 1700 s, aimed at a severe restriction of Indian imports, influencing domestic textile production in Asia.

Colonial institutions intensified during the nineteenth century, when European empires increased their political influence on the Asian continent. This chapter explores to what extent (colonial) institutions entailed the process of deindustrialization of the Dutch East Indies, present-day Indonesia, in relation to parallel industrialization in the Netherlands, and how this affected labour relations in both the colony and the metropole. The case of the Dutch Empire is particularly interesting, as colonial extraction in the Dutch East Indies was stringent compared with many other empires in the nineteenth and early twentieth century. ${ }^{8}$ The forced cultivation of export commodities via the colonial "Cultivation System" (c. 1830 to 1870) in Java led to favourable terms of trade for agricultural export commodities. While the exports of tropical goods from Java accordingly took off, Dutch policy simultaneously favoured the imports of textiles from the Netherlands, thus artificially creating a new market for its emerging textile industry.

Many historians contend that these complementary trade flows ruined indigenous textile production in Java, contributing to declining living standards and deindustrialization. ${ }^{9}$ This chapter takes a rather different approach, by investigating to what extent Javanese textile producers responded to the consequences brought about by colonial economic institutions. There are several reasons to believe that native indigenous consumers were for quite some time reluctant to buy European textiles, as has likewise been noted for India and Africa. ${ }^{10}$ It may be very worthwhile to explore local production with a more nuanced perspective on native Javanese people's agency

6 Broadberry and Gupta, "Lancashire".

7 Parthasarathi, "Rethinking Wages", p. 107.

8 See, e.g., Maddison, “The Colonial Burden”, pp. 361, 367 ; Van Zanden and Van Riel, Strictures of Inheritance.

9 E.g., Boomgaard, "Female Labour"; Lindblad, "De handel in katoentjes"; Van Zanden and Marks, An Economic History, pp. 92-93. A notable exception is Van der Eng, "Why Didn't Colonial Indonesia". Van der Eng acknowledges that cotton textile production increased during most of the colonial period, but contends that it was internationally non-competitive.

10 Haynes, Small Town Capitalism, p. 13; Austin, "Resources", p. 602. 
and flexibility under the constraints of colonial institutions. As textile production was traditionally women's work, the effects of the imported cotton goods from Europe on gendered labour relations in Java must have been enormous, but this has barely been studied. ${ }^{11}$ In addition, this chapter aims to explore what effects textile imports in Java had on labour relations in the metropole. The work of girls and women was presumably particularly affected by the increasing quantities of cloth exported from the Netherlands to the Dutch East Indies. Parts of the Netherlands, especially the formerly agrarian eastern province of Overijssel, experienced rapid industrialization, drawing - at least for a few decades - many young women to the emerging textile factories. ${ }^{12}$ This shift in Dutch labour relations and women's labour force participation has, to my knowledge, not yet been explicitly linked to the colonial enterprise. ${ }^{13}$

This chapter aims to contribute to the debates both on the effect of colonial institutions on economic development and on changes in gendered labour relations, by studying developments in the textile industry in Java and the Netherlands through the perspective of mutual colonial influences. While the framework of "extractive institutions" has attracted ample scholarly attention to explain persistent economic underdevelopment, ${ }^{14}$ it entails the danger of overlooking alternative forms of (temporal) development, as well as outings of colonial agency, resulting in a teleological view on the world, or a "compression of history". ${ }^{15}$ Closer scrutiny of the workings of colonial institutions and changes over relatively shorter periods of time, and the responses of indigenous people - men and women - allows us to gain a less linear picture of economic development in colonies, and the ways in which colonial agency featured. In turn, it is highly relevant to study the effects of colonial institutions on economic development and labour relations in the "industrial core", to avoid the impression of straightforward endogenous growth. ${ }^{16}$ Moreover, analysing such imperial connections may provide important insights into women's position in metropolitan society

11 An exception is Boomgaard, "Female Labour", but his article focuses more on the demographic than the socioeconomic aspects, let alone the labour relations involved.

12 For a recent analysis of women's rising labour force participation in the Enschede textile industry, see Boter, "Before She Said 'I Do'”.

13 Several economic historians have noted the interconnections between Dutch industrialization and textile exports to Indonesia, e.g., Fischer, "De ontwikkeling"; Lindblad, "De handel in katoentjes”; Van Zanden and Van Riel, Strictures of Inheritance, p. 178. The link between women's work in the Netherlands and colonial institutions, however, has not often been made.

14 E.g., Acemoglu, Johnson, and Robinson, "Colonial Origins".

15 Austin, “The 'Reversal of Fortune' Thesis".

16 Cooper, Colonialism in Question, p. 4; Van Zanden and Van Riel, Strictures of Inheritance. 
on the one hand, and colonial society on the other, in connection to their labour relations in the textile industry.

The chapter is structured chronologically, exploring labour relations in the textile industry in the Dutch empire in three different periods: before the nineteenth century, between 1824 and 1873 , in which colonial institutions were most important, and the period from 1874 up to the First World War, constituting a period of trade liberalism.

\section{Prelude: Textile production, gender, and colonial connections before the nineteenth century}

In pre-colonial times, cloth in the Indonesian archipelago had a religious and ceremonial value, and increasingly served as a marker of socioeconomic status. Moreover, textiles were commonly used as currency and also frequently in gift giving. As a rule, both bark cloth - still very common in Southeast Asia at that time - and cotton textiles were produced by women ${ }^{17}$ Cloth making was primarily associated with women and the "life-giving properties of females", who metaphorically spun the "thread of life". ${ }^{18}$ This differed, for instance, from India, where cotton weaving was mainly executed and controlled by men. Batik, the traditional labourintensive Indonesian craft of wax printing cotton cloth with all sorts of artistic patterns, was practiced by elite women, for instance at courts. ${ }^{19}$ However, the elites increasingly started to be interested in cotton and silk fabrics from India and China.

From the seventeenth century onwards, the Dutch East India Company (VOC) tightened its grip on trade in the Dutch East Indies, most notably Java and the "spice islands" of the Moluccas. Textiles formed an intrinsic part of this chain, being shipped from the coasts of China and India to the East Indies, to be traded for spices and other goods by the VOC. ${ }^{20}$ Certainly, the VOC built on earlier trade routes forged by Asian merchants, and historians have debated the actual impact of the Europeans on trade and production in Asia in the eighteenth century, ${ }^{21}$ but there is no doubt that textiles were very important under merchant colonialism. Indian textiles

17 Hall, "Textile Industry", p. 101.

18 Watson Andaya, "Cloth Trade”, pp. 30-31.

19 Jasper and Pirngadie, De inlandsche kunstnijverheid in Nederlandsch Indië. Vol. III, p. 3.

20 Matsuo, Javanese Cotton Industry, p. 2; Prakash, The Dutch East India Company.

21 See, e.g., Chaudury's critique on Prakash: Chaudury, "European Companies"; See also Hall, "Textile Industry", p. 108. 
were shipped to the archipelago for consumption by indigenous elites, a trade that the VOC tried to monopolize, but both tariffs and prohibition of local cotton production and weaving failed. While until the first half of the seventeenth century, domestic cotton spinning and weaving had suffered fierce competition from Indian imports, increasing prices led to a revival of cotton weaving on the islands of Java, Bali, and Sumatra from the seventeenth to the early nineteenth century. ${ }^{22}$ In the wake of this growing production and the waning trade in Indian textiles, the VOC shifted to collecting cotton yarns produced by the local population to satisfy the increasing demand for cotton in Europe. Where the VOC closely cooperated with local elites, they imposed a tax on the local population to be paid not in cash, but in yarn. ${ }^{23}$

In Europe, cotton textiles had been virtually unknown until the sixteenth century. Spinners and weavers processed wool, flax, and hemp, which were generally coarse fabrics that required intensive labour. By the late Middle Ages, a pronounced division of work had already come into being, in which women dominated the more labour-intensive preparatory stages of textile production, and men were occupied in the processes with higher added value, such as weaving, cloth shearing, and dyeing. In the Netherlands, these finishing stages had become mostly urban artisanal work, and craft guilds tried to monopolize and regulate production and set rules against the acceptance of married women as independent artisans. In addition, they tried to restrict the rural production of cloth. ${ }^{24}$ When global trade expanded from the end of the fifteenth century onwards, the lighter and more colourful cotton fabrics from India became increasingly popular among European elites. Because the techniques for producing cotton thread and cloth were not available in Europe, artisans realized they had to find alternative ways to compete. ${ }^{25}$ From the end of the sixteenth century, lighter types of woollen cloth (such as serge) emerged, first in the Southern and Northern Netherlands, and later in England. For much of the seventeenth century, the Dutch town of Leiden became the leader in the production of woollen cloth for the world market. This greatly affected gendered labour relations in the Netherlands. In the first place, wage labour and forms of subcontracting in textiles increased; for both men and for women. As there was a growing demand for yarn, the labour-force

Watson Andaya, "Cloth Trade", pp. 38-40; Clarence-Smith, "Production of Cotton Textiles".

Rouffaer, "Aanhangsel”, pp. 12-13.

Van Nederveen Meerkerk, "Segmentation".

Lemire and Riello, "East and West", pp. 893-894. 
participation of women increased significantly, both in the textile towns and in the countryside. ${ }^{26}$

Despite these innovations, the demand for cotton in Europe continuously grew. Feeling the threat of cotton imports from the British and the Dutch East India Companies, many governments, including the British and the French, imposed restrictions on calico imports to protect their home textile industries. However, the Dutch opposed such mercantilist measures and continued to import and re-export cotton cloth via the VOC. In the continued absence of the knowledge to process cotton, large volumes of cotton yarn were imported from the East Indies, which Dutch weavers used in their mixed linen-cotton fabrics. ${ }^{27}$ Moreover, European entrepreneurs started to develop workshops for printing imported calicoes in the last quarter of the seventeenth century. Around 1740, the Netherlands counted about a hundred printing shops, and similar initiatives were taken in British and French towns. ${ }^{28}$ Accordingly, the larger calico workshops experimented with hiring women and children, thus providing an alternative to the waning of spinning labour in the same period. ${ }^{29}$ Thus, in many ways, mercantile colonial connections, as well as (more or less successful) mercantilist institutions, had already changed labour relations as well as gendered work patterns both in East and West before the advent of nineteenth-century industrial colonialism. While introducing new techniques, the textile industries in both parts of the world largely kept following the labour-intensive pathway. This was about to change in the century to come.

\section{Deindustrialization or adaptation? Colonial institutions and Javanese textile production, 1824 to 1873}

After the VOC's abolition in 1799, the Dutch aimed to centralize, bureaucratize, and monetize Javanese society, thus strengthening direct rule over the colony. In 1809, for example, the yarn tax was transformed into a monetary household tax. ${ }^{30}$ The British interregnum of Sir Thomas Raffles (from 1811 to 1816) accelerated these processes. The British were keen on importing cotton 
calicoes produced in English factories into the Indonesian archipelago..$^{31}$ Around 1815, Raffles noted about these imports:

A very extensive and valuable assortment of these cottons, imitated after the Javan and Malayan patterns, was recently imported into Java by the East India Company, and on the first sale produced very good prices; but before a second trial could be made, the natives had discovered that the colours would not stand, and the remainder were no longer in demand..$^{32}$

The Dutch, who regained control over Java in 1816, attempted to replicate the British system. However, despite the immediate introduction of import tariffs on goods transported on foreign ships in $1817,,^{33}$ as well as tariff increases and implicit government subsidies later in the nineteenth century, their policies only partly succeeded. In part, as I argue below, this was due to obstacles similar to those indicated by Raffles regarding the native consumptive demand for textiles, even if European textiles were certainly cheaper than the labour-intensive, home-made cottons. Dutch imports most likely led to a variety of strategies by local Javanese textile producers, who seem to have been able to adapt quite flexibly to the given circumstances.

In 1824, the Dutch King Willem I established the Dutch Trading Company (Nederlandsche Handel-Maatschappij, or NHM), which concentrated on trade with the Netherlands' overseas possessions, most notably the East Indies. While formally a private company, the NHM was intended to promote Dutch economic interests, in the broadest sense, particularly by stimulating metropolitan industry and international trade. The king himself, envisaging a successor to the VOC in the new company, took 4,000 shares with a total value of four million Dutch guilders (Dfl.).34 Although the NHM did not gain a full monopoly, it was given trading preferences for Dutch goods and ships sailing under the Dutch flag, as well as the exclusive rights to handle all government shipping to and from the colonies. ${ }^{35} \mathrm{After}$ 1830, when the Cultivation System was implemented in Java by the colonial government, the NHM was thus crucial in the shipping of increasing exports of agricultural products from Java. Under the Cultivation System (c. 1830

33 Van der Eng, "Why Didn't Colonial Indonesia”, p. 1025.

34 This was almost 15 per cent of the eventual starting capital of the company. De Graaf, Voor handel en maatschappij, pp. 39-41.

35 Van Zanden and Van Riel, Strictures of Inheritance, p. 112. 
to 1870 ), Javanese peasants were forced to cultivate a certain percentage ${ }^{36}$ of their land for cash crops such as coffee, sugar, and tea, for which they received - a very small - monetary recompense, called plantloon (cultivation wage). This forced system of cultivation led to an intensification of labour and increasing monetization of the Javanese economy in the first half of the nineteenth century. ${ }^{37}$

Before the Cultivation System, Javanese men and women mostly worked in subsistence agriculture, with a specific division of labour. Rice growing on dry (tegal) lands and garden agriculture were more the prerogative of women, whereas both men and women were required for wetland (sawah) rice cultivation. ${ }^{3}$ Women, sometimes assisted by children, were responsible for the labour-intensive transplanting of young rice seedlings onto the sawahs, whereas men in the following three months were in charge of the maturing of the crop, carrying out tasks such as weeding, tilling, and water control. Harvesting was a community task, done by men, women, and children. ${ }^{39}$ Moreover, regional market exchange traditionally existed in large parts of Java, and a proportion of the agricultural produce, as well as processed food, was traded for money or goods. Women dominated local markets and often ran warungs (small shops), implying their longstanding significance in commodified labour relations. ${ }^{40}$ Other important economic activities for women were spinning and weaving, both for their own household use and for regional markets. In some areas, such as Surabaya, Gresik, and Besuki, about 50 per cent of all households owned a spinning wheel and/or a loom at the beginning of the nineteenth century. It is unclear how much of this activity was market production, but its contribution must have been substantial, ranging from small pocket money to more than the amount the household earned from agriculture. ${ }^{41}$

Some historians have suggested that Javanese women had less time to produce their own textiles after the introduction of the Cultivation System, because they had to devote more time to (subsistence) agricultural activities, while their husbands now had allocated time to the forced cultivation of cash crops. In addition, they would have found more profitable side activities

36 The percentage varied over space and time - some historians report an overall average of 20 per cent, others note that it varied from 6 per cent in 1830 up to 75 per cent in some regions in the 1840 . Elson, Village Java; Boomgaard, "Female Labour", p. 8.

37 For more on the Cultivation System, see Fasseur, Kultuurstelsel; Elson, Village Java.

38 Stoler, "Class Structure", p. 77.

39 Elson, Village Java, p. 6.

40 Watson Andaya, The Flaming Womb, pp. 121-124; Elson, Village Java, p. 255.

41 Boomgaard, Children of the Colonial State, pp. 127, 131. 
Figure 5.1 Total imports of cotton goods (cloth and yarns) in Java, as well as exports, 1822 to 1873

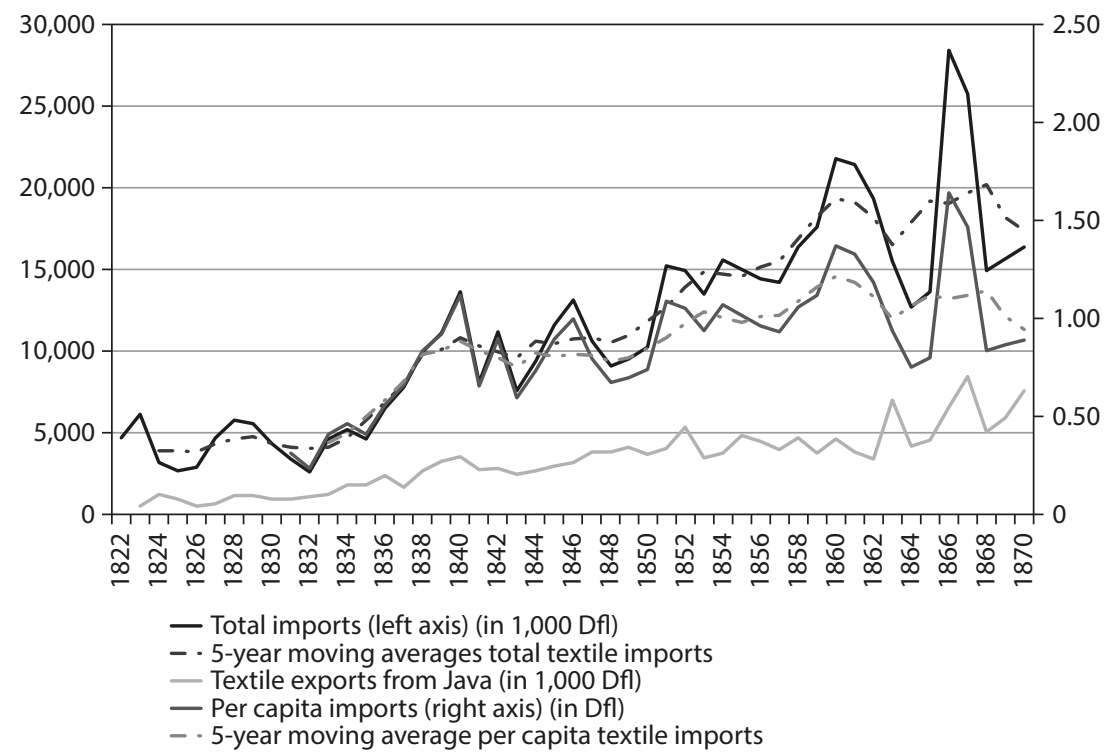

Sources: Korthals Altes, General trade statistics 1822-1940, pp. 107-112; Boomgaard and Gooszen, Population trends 1795-1942, pp. 105-110, 116-117, 119-121

than spinning and weaving, such as preparing and selling food to male workers. ${ }^{42}$ Moreover, the monetization that the Cultivation System entailed provided native households with more cash and the opportunity to buy their cotton cloth in the market. These two factors would have ruined local textile production in the Dutch East Indies. ${ }^{43}$ Although European imports (see Figure 5.1) definitely affected markets for locally produced textiles, in my opinion the story is far more complicated than one of outright decline.

First, while large-scale cotton spinning had seriously declined by 1900, local hand weaving remained important until the $1920{ }^{44}$ This was similar to India, where local hand weaving in the colonial period has likewise been overlooked due to a focus on Western-style industrialization. ${ }^{45}$ Second, as I

42 Elson, Village Java, p. 276.

43 Matsuo, Javanese Cotton Industry, p. 8; Boomgaard, "Female Labour", pp. 17-18; Lindblad,

"De handel in katoentjes", pp. 91-92; Elson, Village Java, pp. 272-277.

44 Seegers, Manufacturing Industry, p. 153.

45 Roy, Artisans and Industrialization; Haynes, Small Town Capitalism. 
Figure 5.2 Estimated per capita imports, Java 1822 to 1870 (in $\mathbf{k g}$ )

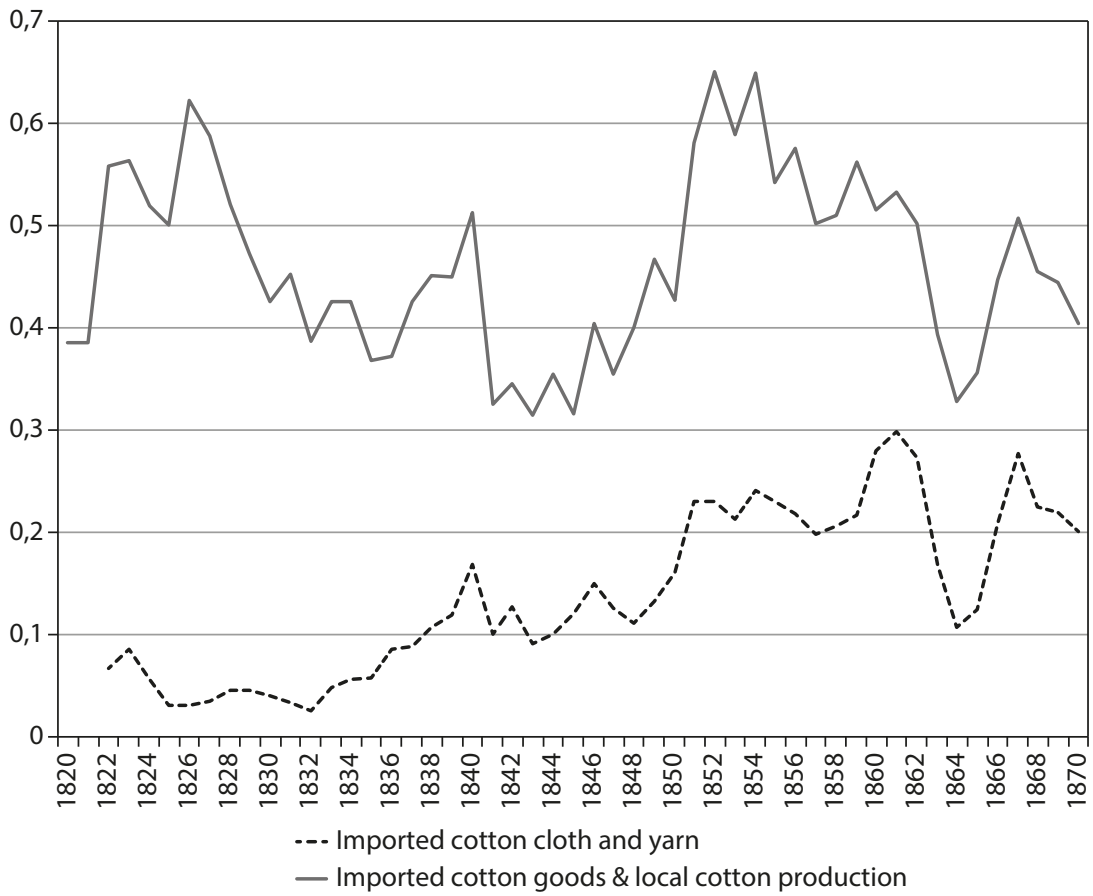

Source: Van der Eng, "Why Didn't Colonial Indonesia", p. 1023

now turn to show, Javanese producers were able to make qualitative shifts in textile production, specializing in particular niches, due to which they were still well able to compete against imported cottons. Both of these developments, I argue, are closely related to the reallocation of women's time, as well as to shifts in the division of labour between men and women. A third factor may have been that the development of regional markets - in which women played a large role - after some time indeed led to the loss of local textile production in particular regions, whereas it simultaneously intensified in others.

Figure 5.1 indicates that, in terms of trade volume in Dutch guilders, textile imports into Java rose tremendously from the early 1820 s onwards. However, if we look at the five-year moving averages of per capita imports (the grey dotted line), we see that whereas imports per person rose quickly before around 1840, they remained relatively stable thereafter until the early 1870 s (around Dfl. 1.25). Textile exports from Java (the light grey line) also followed a steady upward trend in this period, suggesting that - in 
addition to production for home use and regional markets - indigenous weaving for export markets remained substantial. Moreover, the overall rise in the total value of textile imports (the black line) should be related to market prices and population growth. Therefore, it is worthwhile to look at per capita imports in volume, instead of total value, as price shocks may distort the actual imported amount of cloth. This exercise was carried out by Van der Eng (see Figure 5.2).

By calculating the per capita volume of imported cotton goods (cotton cloth and yarns together), Van der Eng made estimates of local textile production by gauging local demand, which he estimated to be between 0.4 and 0.6 kilograms per capita, depending on economic circumstances, and roughly equalling only one sarong per year. According to his estimates, local production seems to have been quite inelastic, in the sense that the cumulative trends (imports plus local production) followed the more general patterns of effective demand for imported textiles. However, there are reasons to believe local textile producers responded in much more flexible ways to particular events. As Haynes describes for India, handloom weavers in this period adjusted their production swiftly in response to favourable or unfavourable prices, as well as occasions of famine or drought. ${ }^{46}$ Thus, colonial institutions did not unilinearly lead to deindustrialization.

Taking the issue to a less aggregated level may inform us more precisely about what happened in this period. First, we need to disaggregate the import statistics and distinguish between imported cloth (and the different types of cloth) and imported yarns. Second, we must disaggregate at the geographical level, and examine local reports and what they state about textile imports and production. Third, it is vital to take gendered labour relations into account when making assumptions about textile production, something not many historians have yet considered. ${ }^{47}$ Changes in the allocation of labour time, as well as some shifts in the gendered division of labour, allowed the Javanese to compete with textile imports both at the higher- and the lower-quality ends of the market for textiles.

Both the increased labour burden on the Javanese peasants and the success of textile imports from the Netherlands under the Cultivation System are said to have disrupted traditional Javanese spinning and weaving. However, whereas colonial institutions may have hampered local production at first, Javanese textile producers seem to have found a new balance

46 Haynes, Small Town Capitalism, p. 174.

47 With the exception of Boomgaard, "Female Labour", Elson, Village Java, and, more recently, Legêne, Spiegelreflex, ch. 3, pp. 119-155. 
in the 1840 s. For some decades they even profited to some extent from the imports of European cottons, both factory-made yarns and uncoloured woven cloth. Indeed, hand spinning in these years slowly but surely disappeared and made way for imported cotton yarns. The question is to what extent this was actually a problem for the local population, and whether historians should consider it as such. Hand spinning is extremely time consuming, and especially for finer yarns, spinning machines deliver a more even product. Even if opportunity costs traditionally may have been low for hand spinning, thus enabling competition with factory-made yarns, ${ }^{48}$ the Cultivation System probably made women's labour time in subsistence as well as market agriculture more valuable than before. ${ }^{49}$ This implies that households instead bought imported factory yarns that women could weave into cloth, either for home use or for the (local) market.

Although the general colonial trade statistics for the period 1825 to 1874 do not distinguish between imported yarns and other cotton goods, I found evidence in other sources that, especially after the 186os, yarn imports increased considerably, both in terms of value and of weight. As Figure $5 \cdot 3$ below shows, imports of cotton yarns increased dramatically, particularly in two periods, first in the 1840 - an increase of over 200 per cent within the decade - and then again in the 1870 s, actually increasing as much as fivefold. As Figure 5.2 shows, total per capita cotton imports (the dotted line) declined in exactly the same periods, which suggests that local weaving with the use of imported yarns may have increased, instead of more or less following the general trends of cotton imports, as suggested by Van der Eng.

Both records in the local archives and more qualitative indications in literature indeed suggest that Javanese women started to weave on a larger scale in the decades after 1840; not only for household use, but also for the market. As we have seen, exports from Java - mainly to the outer islands of the Indonesian archipelago - continued to grow in this period (Figure 5.1). In some regions in particular, such as Priangan (West Java), thousands of women were active in weaving - sometimes with their own spun yarns, but increasingly with European yarn - and their cloth was traded both locally and regionally in the 1840 s and $18505.5^{\circ}$ In 1862 , it was stated that cotton cultivation could not revive in this residency, because the Javanese

48 As was also argued for pre-colonial Africa: Austin, "Resources", p. 603.

49 Elson, VillageJava, p. 277. A similar process occurred in the mid- to late nineteenth century in India, but Haynes reports that there were fewer labour market alternatives for women, as Indian weavers were generally male. Haynes, Small Town Capitalism, pp. 44-47.

$5^{0}$ Arsip Nasional di Republik Indonesia, Jakarta (henceforth ANRI), Residential Archives Priangan, 3/12, Algemeen Verslag (henceforth AV) 1849 and 3o/4, Statistiek 1852. 
Figure 5.3 Yarn imports, in value (1000 Dfl., left-hand y-axis) and weight (1000 kgs, right-hand y-axis), 1828-1878

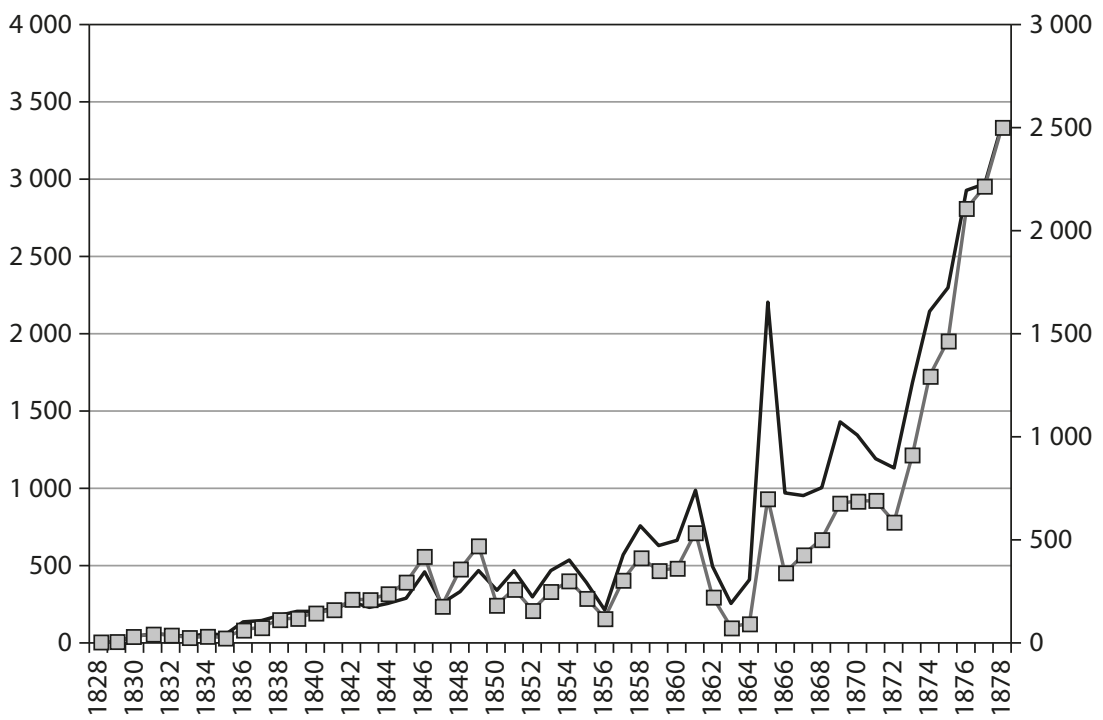

— Yarn imports (in 1,000 Dfl) $\quad-$ - Yarn imports (in 1,000 kg)

Sources: Muller Szoon, De Nederlandsche katoennijverheid; Bijdragen van het Statistisch Instituut, p. 415; Jansen, De industriële ontwikkeling in Nederland, p. 329; Van der Eng, "Why Didn't Colonial Indonesia", p. 1034

population "rather bought [...] European yarns to weave their rugs"..$^{11}$ And in 1864 , the Resident of Batavia noted that as a result of high textile prices due to the American Civil War, demand for imported cotton cloth was low, with the sole exception of cotton yarns for which there was still a demand (see also Figure $5 \cdot 3)^{5^{2}}$

In the 1860 s, the colonial authorities became increasingly concerned about the stagnating consumption of Dutch fabrics in Java. Complaints were heard about the increasing volume of unused textiles rotting away in the Batavian warehouses. Several reports were made, but these could not give conclusive answers to the reasons for the decline: could it be the high textile prices, combined with the declining welfare of the Javanese population? Or was it perhaps the increased competition by local producers, as some reports seemed to suggest? Estimates were given that in the period from 
1864 to 1868 , cotton imports could only have catered for somewhat over a third of all Javanese textile consumption, implying that Javanese production amounted to about 65 per cent of the total value of textile consumption of the (adult) Javanese population! ${ }^{53}$ This contemporary figure seems to suggest that Van der Eng's estimates of local consumption were somewhat modest, and that perhaps consumption was - at least in this period - less influenced by imports than he proposed ${ }^{54}$ It is telling that contemporary observers could not understand why Javanese peasants complained about their increased labour efforts due to the forced deliveries of cash crops, but were still able to increase their textile production. ${ }^{55}$ Clearly, they too overlooked the labour input of Javanese women in weaving.

Native consumer tastes played a large role in such shifts. As had earlier been noted by Raffles, the Javanese consumer preferred the higher-quality dyed domestic textiles over the cheaper, but lower-quality European ones. Apparently, now, Javanese producers also started to compete with lowerquality textiles, as a report notes:

The time is gone, that the native exclusively focused on the making of batiks as a form of art, which were of exquisite beauty, but had to be recompensed likewise. Nowadays, he delivers products in this genre that, in quality related to the price, are in no sense inferior to those fabricated in Europe. To sustain competition with him, the European batik producer will need to be able to deliver his manufactures for a much fairer price. $5^{6}$

One observer around 1900 even called tjapping (block printing) "the answer of the Javanese batik industry to European factory competition". ${ }^{57}$ In addition to the flexibility and agency Javanese textile producers clearly displayed, there is an interesting gender dimension to this new competitiveness, as the more traditional, labour-intensive batik production continued to be performed by women, and the newer, more mechanical,

53 National Archives, The Hague (henceforth NA), Koloniën 1850-1900, inv. no. 2362, Verbalen, no. 80,26 November 1870 . Due to the high import duties, imports from elsewhere were negligible in this period.

54 Van der Eng, “Why Didn't Colonial Indonesia”, pp. 1023-1024. Probably, Van der Eng consciously made conservative estimates to stay on the safe side, as I actually agree with his larger argument that - at least in the nineteenth century - deindustrialization of the Indonesian countryside should seriously be questioned. My figures are thus not intended to criticize Van der Eng's reasoning, but instead to take it a step further.

55 As noted in the margins of the report. NA, Koloniën 1850-1900, 2362, 26 November 1870.

56 NA, Koloniën 1850-1900, 2362, 26 November 1870.

57 Rouffaer, “De voornaamste industrieën”, pp. 21-22. 
and labour-extensive process of tjap became an almost exclusively male activity. This hitherto underresearched division of textile labour is explored below, but let us first look at developments in the Netherlands in the period up to 1873 .

\section{Successful industrialization? Production for the colonial markets and shifting labour relations in the Netherlands, 1824 to 1873}

The Netherlands was relatively late to industrialize. Before the secession of the southern provinces of the kingdom in 1830 - present-day Belgium - King Willem I had looked towards the south for the industrial project. Indeed, the increase in cotton goods imported into Java in the 1820 s had mainly come from the southern Netherlands. After the defeat by Belgian troops, new plans in this domain had to be designed. The proto-industrial region of Twente, in the east of the Netherlands, was specifically assigned to develop a modern industry. To discourage foreign textile imports, in 1824, the Dutch government set tariff barriers of 25 to 35 per cent, as opposed to only 6 per cent for Dutch textiles (this was raised to 12.5 per cent in 1836 after serious British protests).$^{8}$ Only in the late 1860 s were tariffs lowered, and were eventually equalized for Dutch and foreign imports in 1874 . However, from the onset, Dutch companies made secretive contracts with the NHM that refunded the import tariffs after the goods had arrived in the East Indies. These refunds were heavily subsidized by the Dutch government in the first decades of the NHM's existence..$^{59}$

In 1833, the NHM founded a weaving school in the Netherlands, where boys were taught by English weavers how to use the flying shuttle. ${ }^{60}$ Yarns were largely imported from England, which the first textile firms in Twente in the 1830 s and 1840 s still put out into the countryside to be woven on handlooms. Companies were still small and many survived only for a few years. In 1842, 103 firms delivered 205,000 pieces of bleached cotton cloth for the East Indies market: on average, almost 2,00o per firm per year. ${ }^{61} \mathrm{Nev}-$ ertheless, the first decades of textile production in Twente were relatively volatile. After a number of successful years, the annual reports of the NHM begin to mention overproduction and declining demand in the Javanese

$5^{8}$ Van der Eng, “Why Didn't Colonial Indonesia”, p. 1026.

59 Van Zanden and Van Riel, Strictures of Inheritance, pp. 114-119.

6o Van Nederveen Meerkerk, Heerma van Voss, and Hiemstra-Kuperus, "The Netherlands".

61 Willink, De textielbaronnen, p. 26. 
market in the $1850 \mathrm{os}$. This downturn was attributed to British competition, which led thousands of (male) handloom weavers in Twente to switch to agricultural work. ${ }^{62}$ Apparently, the report states, there were many more cotton textiles imported into Java than the NHM thought. However, import statistics show stagnation in the 1850 s, and a simultaneous upsurge of local production (compare Figure 5.1 and Figure 5.2). It can thus be concluded that Javanese textile production directly led to unemployment of Dutch weavers in this period.

The mechanization of Dutch spinning and weaving occurred slowly, but surely. Whereas Twente only counted six mechanized spinning mills and three weaving mills in 1857 , in the early 1870 s, there were countless factories in the region. ${ }^{6}$ These factories increasingly employed women and children as cheap wage labourers, to be as competitive as possible in the national and international market. While building on a tradition of female and child employment in the cottage industry, labour relations in the households nevertheless drastically changed, as the spheres of the home and the workplace became increasingly separated. ${ }^{64}$

Mechanization not only led to changes in the physical workplace, but also in the division of labour between men and women. Whereas hand spinning had traditionally been a job performed mainly by women and children, ${ }^{65}$ the spinning mills instead mainly employed adult men, who were generally assisted by boys. Women and girls were nevertheless also amply employed in the new factories, for tasks such as burling, darning, and roving. ${ }^{66}$ This was reflected in the labour-force participation of unmarried women. The percentage of women who stated an occupation at marriage in the town of Enschede - one of the major textile centres of Twente, after a steep decline in the first decades of the nineteenth century - shows a remarkable increase from the 1840 os onwards, reaching 75 per cent towards the end of the century. ${ }^{67}$ Married women, on the other hand - who had been very important in the protoindustrial textile industry - were not particularly welcome in the factories, although norms and values differed regionally. ${ }^{68}$

62 NA, Archives NHM, Inv. no. 5271. Verslagen van de Agent te Nijverdal, Reports 1855, 1856, and 1857 .

63 Plemp van Duiveland, Twentsche weefsels, pp. 19, 26.

64 Brouwer and Van Eijndhoven, "Fabrieksarbeidsters", pp. 83-84.

65 See, e.g., Van Nederveen Meerkerk, "Couples Cooperating".

66 Van Nederveen Meerkerk, Van Voss, and Hiemstra-Kuperus, "The Netherlands", pp. 379-38o.

67 Boter, "Before She Said “I Do"”, p. 10.

68 Janssens, "De rol van vrouwen", p. 94. 
Working conditions in the factories were harsher than in traditional home industry. Not only were the factory halls noisy, dark, and polluted, but the machines led to many accidents. Moreover, unlike domestic industrial workers, factory workers were unable to decide for themselves on the pace of their work and the length of their working days. Two contemporary inquiries into child labour showed that both in 1841 and in 1860 , children on average worked twelve to thirteen hours per day, and it remained at this high level, despite the fact that mechanization had raised labour productivity considerably over these two decades. ${ }^{69}$ Although there was a long way to go, the labour conditions in these factories led to growing societal indignation and concern, out of which the first Child Labour Law was eventually introduced in 1874 . These changes in social protection were thus a direct consequence of the "social question" arising during industrialization in the Netherlands, a process that was, in its first decades, stimulated by exports to the Dutch East Indies.

The textile market in the Dutch East Indies continued to fluctuate, leading the Dutch textile enterprises to redirect their attention to other markets, especially in the context of increasing English competition after the lowering of the tariffs in the 186os. In addition to growing European markets, some textile factories found alternatives in the African market, where the wax prints, which had not really satisfied Javanese consumers, became very popular. In 1873, the NHM agent noted this increasing globalization of the textile trade in his annual report:

Behold, who could have thought or predict, that in small-town Goor, where in 1834 the first flying shuttle buzzed through the warp, 40 years later, French merchants would come to buy its manufactures, and deliver it carriage-free to an English port, destined for the African Gold Coast and yet, it is indeed a fact. ${ }^{70}$

It can thus be concluded that Dutch textile exports to the East Indies were far from an outright success story in the nineteenth century, both in terms of competitiveness with British and with Javanese textiles, and in terms of constant employment in Twente. Nevertheless, the persistent attempts by the Dutch government to get industrialization off the ground, by implementing institutions such as import barriers in the colony for foreign traders, as well as hidden subsidies for Dutch colonial textile contracts, did 
in the end lead to rapid industrialization in the Netherlands. Consequently, this influenced labour relations in the metropole in the period until 1874, in the sense that the factories drew large numbers of women and children to perform wage labour, and moreover impacted on the gendered division of work in the textile industry.

\section{Coping with competition: Textile production and gender relations in Java, 1874 to 1914}

In the $1870 \mathrm{os}$, the transformation of the Netherlands from a pre-industrial to an industrial society gained full momentum, and the country would from then on approximately follow the European norms of sustained economic growth. The added value of industry compared with agriculture increased tremendously in this period, suggesting structural change in the economy. ${ }^{71}$ Moreover, real wages, which had been practically stagnant since the eighteenth century, started to rise rapidly between the 1860 os and the end of the nineteenth century. ${ }^{72}$ Whereas the Dutch metropolitan economy had already been following liberal policies since the 1840 s, this shift was only implemented in the East Indies in the 1870s. Due to increasingly heated debates about forced labour, the Cultivation System was abandoned.

Moreover, as mentioned, the preferential trading of the NHM was abolished in 1874, allowing for more competition in the realm of imports. With regard to textiles, this mainly implied the influx of British cotton in the Javanese market during this period, which affected the demand for Dutch textiles. ${ }^{73}$ Some historians have suggested that this policy of liberalization also drastically affected local textile production by hindering mechanization of the native industry, which had long-term effects reaching into the post-colonial period. ${ }^{74}$ However, the effects of liberalization should not be exaggerated. Indeed, textile imports rose drastically in the year 1874 (total value Dfl. 34,632,0oo) compared with the year before the equalization of import duties for Dutch and other importers, 1873 (total value Dfl. 20,508,000): a rise of 69 per cent. After that year, however, total textile imports more or less stabilized, at least until 1890 (see Figure 5.4). Moreover, although the share of Dutch textile imports declined somewhat

Dick, “Nineteenth-Century Industrialization", p. 137. 
Figure 5.4 Imported cotton cloth (left-hand y-axis) and cotton yarns (right-hand $y$-axis) in Java, 1874 to 1913 (in 1,000 1913-Dfl.)

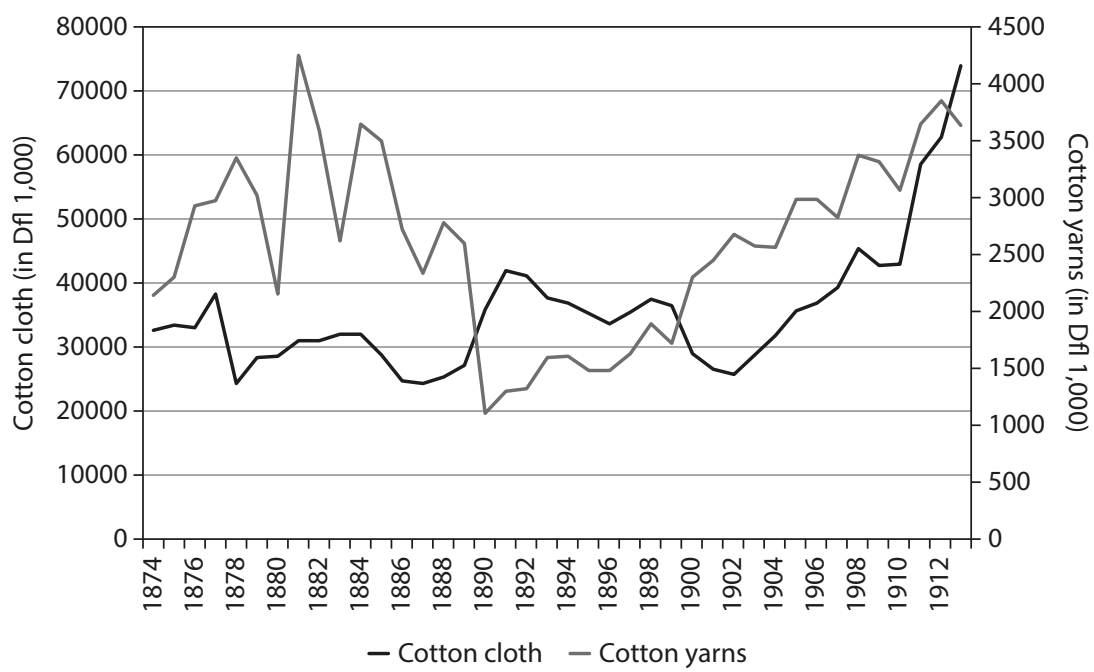

Source: Korthals Altes, General Trade Statistics, pp. 117-125

compared with the total textile imports, this decline was not spectacular before $1900 .^{75}$

From 1874 onwards, it is possible to distinguish between imported yarns and other cotton goods in the import statistics. The graph shows interesting contrasting trends in the imported volumes of yarns and woven cotton cloth, suggesting that the Javanese demand for foreign cloth may have responded quite flexibly to the supply of home-woven cloth from imported thread. Moreover, in a relative sense, the importance of textile imports in the total imports into Java seem to have diminished, which implies that, as Lindblad has remarked, "for the eastbound trajectory of the trade between motherland and colony the manufactures were a stable factor, but not a dynamic source of change" ${ }^{76}$ From this, it can be inferred that trade liberalization favoured other imports - especially rice, iron, and machinery - much more than the textile trade after $1874 .{ }^{77}$ As the Javanese population rose quite rapidly in this period, the relatively stable import of 
textiles either means that consumptive demand declined, or that the gap was filled by local textile production.

Data on the purchasing power of Javanese commoners in the colonial period is scarce and is heavily debated by historians. Overall estimates per twenty-year period suggest that between 1815 and 1913, GDP per capita grew in most periods, but only marginally so. Exceptions occurred in the 1840 s and 1860s, when GDP per capita had a negative annual growth rate of $0.4 .^{78}$ These are, of course, highly aggregated figures, both in terms of geography and of chronology, but even so, the period of the Cultivation System, in general, seems to have had the most negative consequences for Javanese living standards. According to Booth, the famines in the late $1840 \mathrm{~s}$ and 1850 s were caused not by food shortages, but by declining purchasing power. ${ }^{79}$ Boomgaard, too, has contended that food consumption in terms of quantity and quality was lower in the period from 1850 to 1880 than it had been before $18300^{80}$ However, other historians, such as Elson, are less pessimistic about the negative effects of the Cultivation System on Javanese living standards. ${ }^{81}$ Most certainly, the economic tide did change somewhat in the 186os, when per capita income grew. Rising standards of living probably enhanced the demand for textiles, which according to Van der Eng increased in this period to an annual average of 0.9 kilograms per capita (around two sarongs). ${ }^{82}$ As several authors have suggested, this change probably did not result from higher real wages, but from the increased time the different members of the Javanese household spent on labour due to the Cultivation System. ${ }^{83}$ Among these activities, hand weaving and - more crucially in the period after the 1860 s - the finishing of cotton cloth, were very important.

Indeed, multiple sources indicate that there was ample weaving activity in Java, although probably more concentrated in particular regions than earlier. This was a consequence of the development of (supra)regional markets, which in time made self-sufficiency in terms of textile production redundant, although spinning and especially weaving for household use remained existent well into the twentieth century. ${ }^{84}$ Typical textile centres

\footnotetext{
78 Van Zanden and Marks, An Economic History, p. $5^{0 .}$

79 Booth, The Indonesian Economy, p. 94.

8o Boomgaard, Children of the Colonial State, p. 202.

81 Ricklefs, A History of Modern Indonesia, pp. 116-117; Elson, Village Java, pp. 304-319.

82 Van der Eng, "Why did Colonial Indonesia", p. 1024.

83 White, "Labour in Childhood's Global Past", p. 485; Booth, The Indonesian Economy, p. 96.

84 Jasper and Pirngadie, De inlandsche kunstnijverheid in Nederlandsch Indië. Vol. II, p. 6; Dalenoord, “Textiel-nijverheid in Nederlandsch-Indië”.
} 
Figure 5.5 Imports of cotton yarns and volume of home-produced cotton, Dutch East Indies 1904 to 1913 (in tonnes)

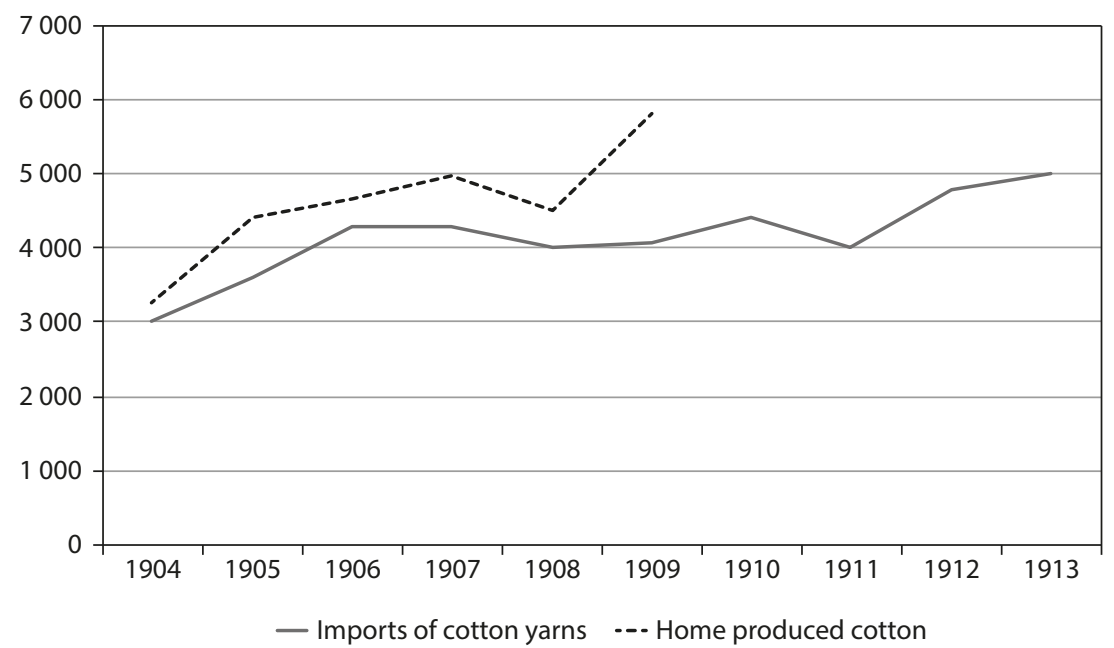

Sources: Dalenoord, "Textiel-nijverheid", p. 169; Matsuo, Javanese Cotton Industry, p. 12

around 1900 were Priangan, Krawang, Djapara, Bagelan, Yogyakarta, and Madiun. ${ }^{85}$ Colonial authorities noted around 1890 that in Priangan,

There is hardly a quarter, a hamlet or a house where the clattering of the loom does not resonate. That which the industrious mother of the house produces more than is needed for the clothing of the family, she brings to the market. Indeed, it is only a plain tissue, but due to the reliability of the good and its low price (Dfl. 1.50 à $\mathrm{f} 3 .^{-}$), this indigenous fabric can easily compete with the European calicoes, which testifies to the fact that cheap is expensive. ${ }^{86}$

Two decades later, researchers claimed that despite European competition, "there are still many regions in the Archipelago where the population for their clothing prefers domestically produced fabrics, which are generally much stronger than the imported tissues". ${ }^{87}$ In addition to weaving, domestic spinning was certainly not totally eradicated, as the cultivation of

85 Matsuo, Javanese Cotton Industry, p. 15.

86 Quoted in Rouffaer, “De voornaamste industrieën”, p. 12.

87 Jasper and Pirngadie, De inlandsche kunstnijverheid in Nederlandsch Indië. Vol. II, p. 2. 
Figure 5.6 Two Javanese women batiking, c. 1910

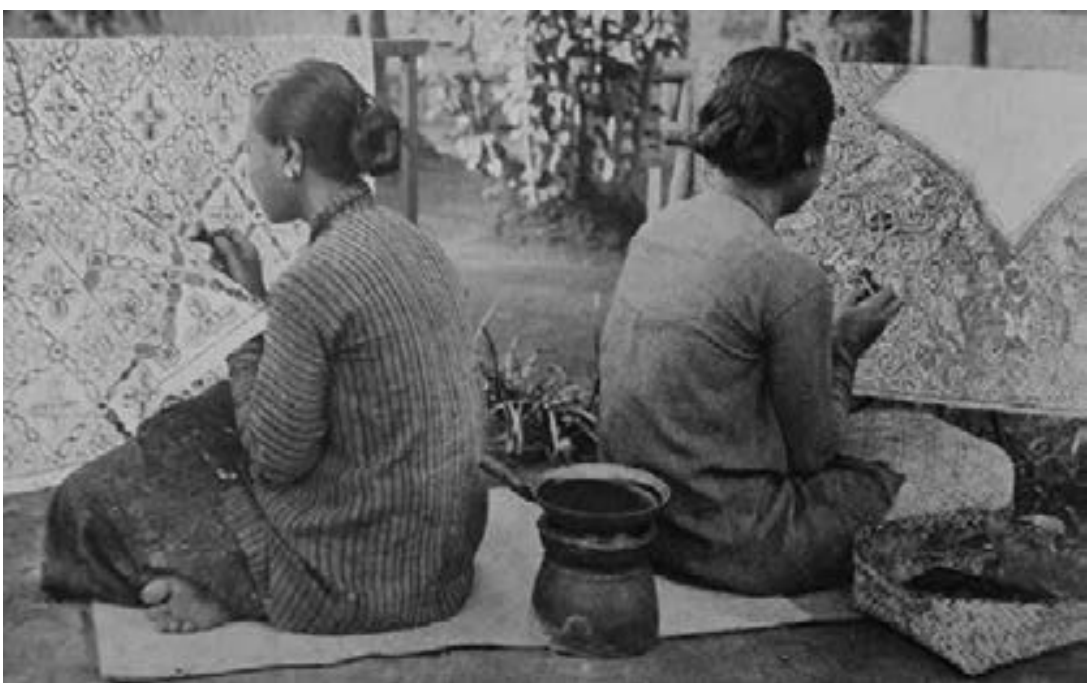

Source: Jasper and Pirngadie, De batikkunst, p. 58

local cotton in fact seems to have been growing alongside the increase in imported yarns (see Figure 5.5).

As well as spinning and weaving, the finishing of undyed cloth has traditionally been a Javanese specialty. Whereas weaving with coloured thread also constituted a longstanding practice, and increasing quantities of coloured yarns were imported from Europe ${ }^{88}$ a more refined traditional art of colouring white cotton tissues was the production of batiks.

As noted above, batik was a traditional form of handicraft, mainly performed by women. Originally, batik was particularly an art that was the prerogative of aristocratic women, who had the time to devote to the careful and labour-intensive process, which involved waxing and colouring with multiple dye baths. The batiks, depending on the quality of their maker, were relatively expensive, and they were particularly desired by the higher-ranked people in Javanese society. ${ }^{89}$

From around 1860 onwards, however, a new product emerged that was more affordable than batik, yet of higher quality than the imported

88 Only indigo dyeing was still widely practiced in Java around 1900, as the quality of European dyes for blue and black yarns could not compete with the indigenous indigo. Jasper and Pirngadie, De inlandsche kunstnijverheid in Nederlandsch Indië. Vol. II, p. 61.

89 Jasper and Pirngadie, De inlandsche kunstnijverheid in Nederlandsch Indië. Vol. III, pp. 3, 10. 
Figure 5.7 A Javanese man tjapping (block printing) cotton cloth, c. 1910

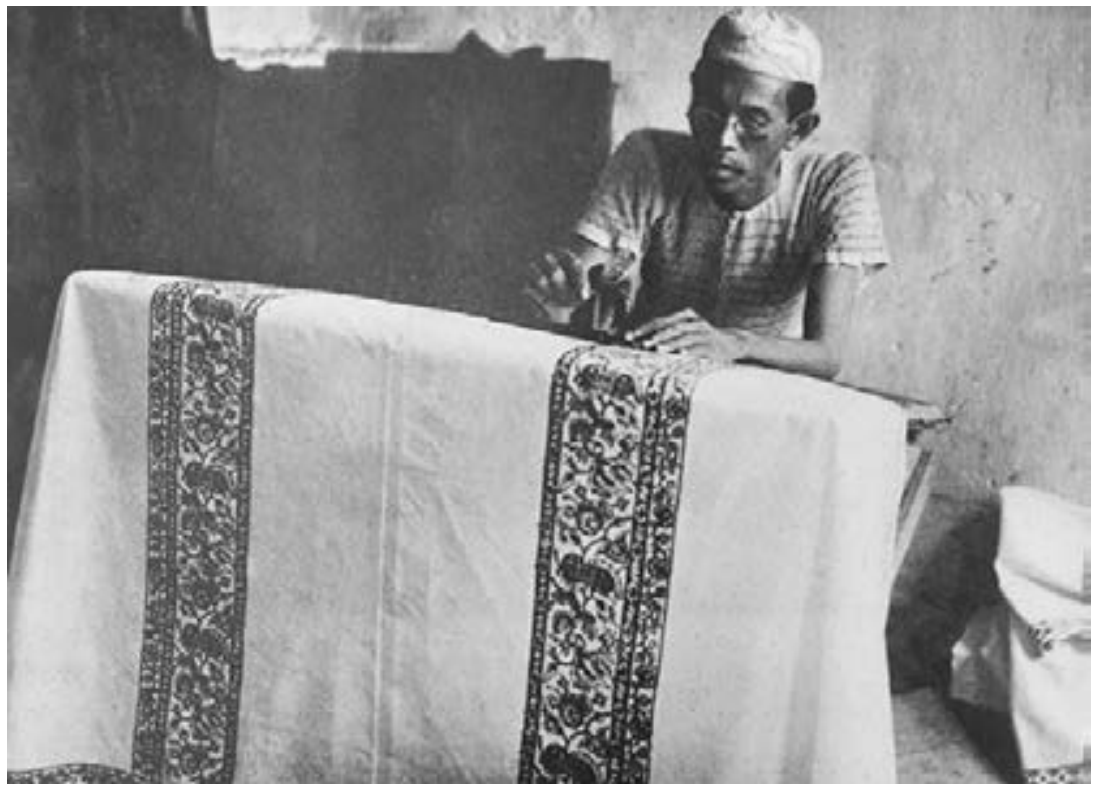

Source: Jasper and Pirngadie, De batikkunst, p. 74

European coloured cloth. The new product, probably adapted from blockprinting techniques in British India, was called tjap, which was produced in a more standardized fashion than batik. It was much cheaper than batik, because labour intensity was far lower: an experienced craftsman could produce almost twenty printed sarongs per day, whereas it took twelve to fifteen days to batik one piece of cloth..$^{90}$ Tjaps could compete favourably with European imports, and they were mainly processed by men instead of women. Again, local preferences played a large role in the demand for these textile goods. Around 1900, it was observed that "every native, who can somehow afford it, chooses the real batiks over the tjap, and the tjapped cloth over the factory-made ones". ${ }^{91}$ Other Dutch observers explicitly criticized the influence of European imports: "With their use of bright, gaudy colours, the import trade in some regions has unfortunately spoiled the want of the population for sober, warm dyes." However, as they more optimistically continued, traditional handicrafts such as coloured weaving and printing luckily persisted, "which, concerning their designs could educate European 
masters"..$^{2}$ These adherents to local culture mirrored similar enthusiasm for indigenous Indian textiles by the Arts and Crafts Movement in Great Britain at the time. ${ }^{93}$

What this all means in terms of production volumes and total labour force is of course an important question. Minimum estimates around 1900 suggest that in the two residencies of Sala (East Java) and Pekalongan (Central North Java) alone, the production of batiks and tjaps amounted to respectively five million and two million guilders on an annual basis. ${ }^{94}$

Table 5.1 Registered labour-force participation of the adult population, Java and Madura, 1905

\begin{tabular}{lrrrr}
\hline & \multicolumn{2}{c}{ Men } & \multicolumn{2}{c}{ Women } \\
& $n$ & $\%$ of all men & $n$ & $\begin{array}{c}\text { \% of all } \\
\text { women }\end{array}$ \\
& & & & $16.8 \%$ \\
Only agriculture & $4,229,606$ & $54.4 \%$ & $1,189,807$ & $9.9 \%$ \\
Only industry & 618,268 & $7.9 \%$ & 703,364 & $5.0 \%$ \\
Only service & 322,861 & $4.1 \%$ & 357,275 & $1.7 \%$ \\
Agriculture + industry & 333,545 & $4.3 \%$ & 123,164 & $0.7 \%$ \\
Agriculture + service & 561,185 & $7.2 \%$ & 50,021 & $0.3 \%$ \\
Agriculture + other & 126,794 & $1.6 \%$ & 17,839 & $4.9 \%$ \\
Other & 381,615 & $4.9 \%$ & 344,363 & $60.7 \%$ \\
Without recorded profession & $1,206,852$ & $15.5 \%$ & $4,305,685$ & $100 \%$ \\
Total & $7,780,726$ & $100 \%$ & $7,091,518$ & \\
\hline
\end{tabular}

Source: NA, Handelingen Staten Generaal, 368, Bijlage C, Koloniaal Verslag, 1907

Table 5.1 shows that according to the census of 1905 , about 85 per cent of all adult Javanese men were registered with an occupation, compared with about 40 per cent of all adult Javanese women. Of course, official census statistics are highly problematic, especially with regard to capturing economic activities in the non-formal sectors, and particularly for women's work..$^{95}$ Most probably, the percentage of women without a recorded occupation is too high. Despite these likely underestimates of women's work, the figures do give an indication of the minimum numbers of women involved in the different sectors of the economy. Although the

92 Jasper and Pirngadie, De inlandsche kunstnijverheid in Nederlandsch Indië. Vol. II, p. 2.

93 Haynes, Small Town Capitalism, p. 197.

94 Jasper and Pirngadie, De inlandsche kunstnijverheid in Nederlandsch Indië. Vol. III, p. 10.

95 See, e.g., Humphries and Sarasua, "Off the Record". 
Figure 5.8 Percentages of men and women working in different sectors, Java and Madura 1905

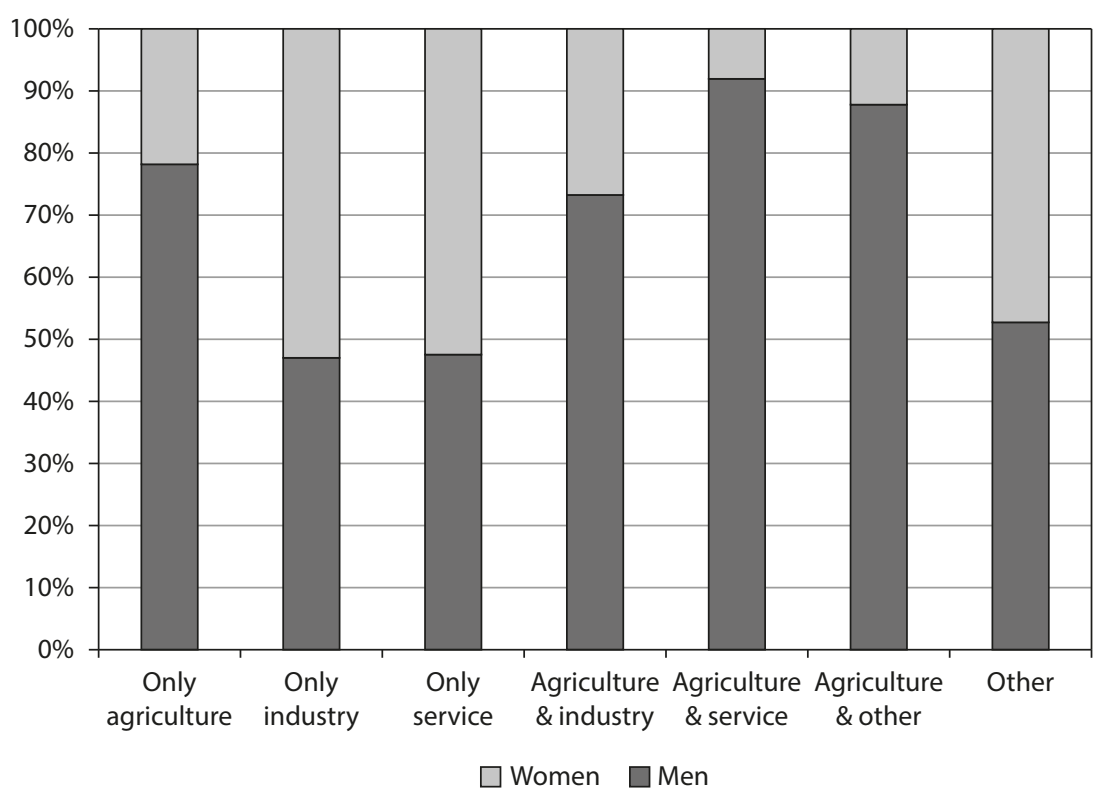

Source: See Table 5.1

1905 census does not differentiate between various branches of industry, we can see that about a quarter of all women officially registered in the labour market were active in industry. Moreover, another 4.5 per cent of them were registered as performing industrial activities alongside agricultural work. This implies that over 820,000 women were formally registered as industrial workers, the majority of whom will have been active in textile production.

Furthermore, if we compare the female with the male labour force (Figure 5.8), we can see that women comprised about half of the industrial labour force around 1900. As many men were active in a variety of industries around 1900, such as metalwork, construction work, and labouring in sugar mills, ${ }^{96}$ textile production, was - apart from tjapping - dominated by women and constituted a considerable share of the total labour force at the time. Most probably, the census left out all of those women who were still spinning and weaving for domestic use, activities that nevertheless contributed to the household income in kind, either as 
replacing expenditure for home use, or because surpluses yielded some profit in the market. ${ }^{97}$

\section{Changes in the Dutch textile labour market, 1874 to 1914}

In the meantime, the Dutch textile industry experienced fundamental changes. From the 1870 s onwards, the mechanization of the Dutch cotton industry, both in spinning and weaving, progressed spectacularly. In the early 1880 s, the last - predominantly male - cotton hand weavers disappeared. The lifting of import duties in 1874 meant that other players, mainly the British in this period, entered the East Indies market for textiles. The 188 os constituted a period of stagnation, in which overall growth rates in the Dutch textile industry were low or even negative..$^{8}$ Excess capacity in the 1870 os and 1880 s probably led to a loss of job security for many textile workers, as can be deduced from a fall in married women's labour-force participation in a textile town such as Enschede. Despite these problems, however, the Dutch textile industry was still able to stabilize its share in the East Indies market (around 5o per cent) after 1875, up to the First World War. ${ }^{99}$

After the difficult 1880 s, the Dutch textile industry grew: production capacity recovered, and almost doubled between 1890 and 1910. This development can be attributed both to expansion into the European market, ${ }^{100}$ and to an increase in domestic demand, reflecting the rising real wages of Dutch labourers after the 1860s. In the period from 1860 to 1913, the textile industry ranked third in value added in terms of overall national industrial production, which signifies its importance in this period despite some difficult years. ${ }^{101}$ When Dutch textile exports to the Indies, as well as to other countries, again expanded in the 189os, the number of young women working in textiles increased likewise. ${ }^{102}$ Indeed, it seems that in this period, children and women - and especially married women - formed a flexible pool of factory workers who could be hired and dismissed according to requirements. 
Figure 5.9 Men and women working in industry, the Netherlands 1899

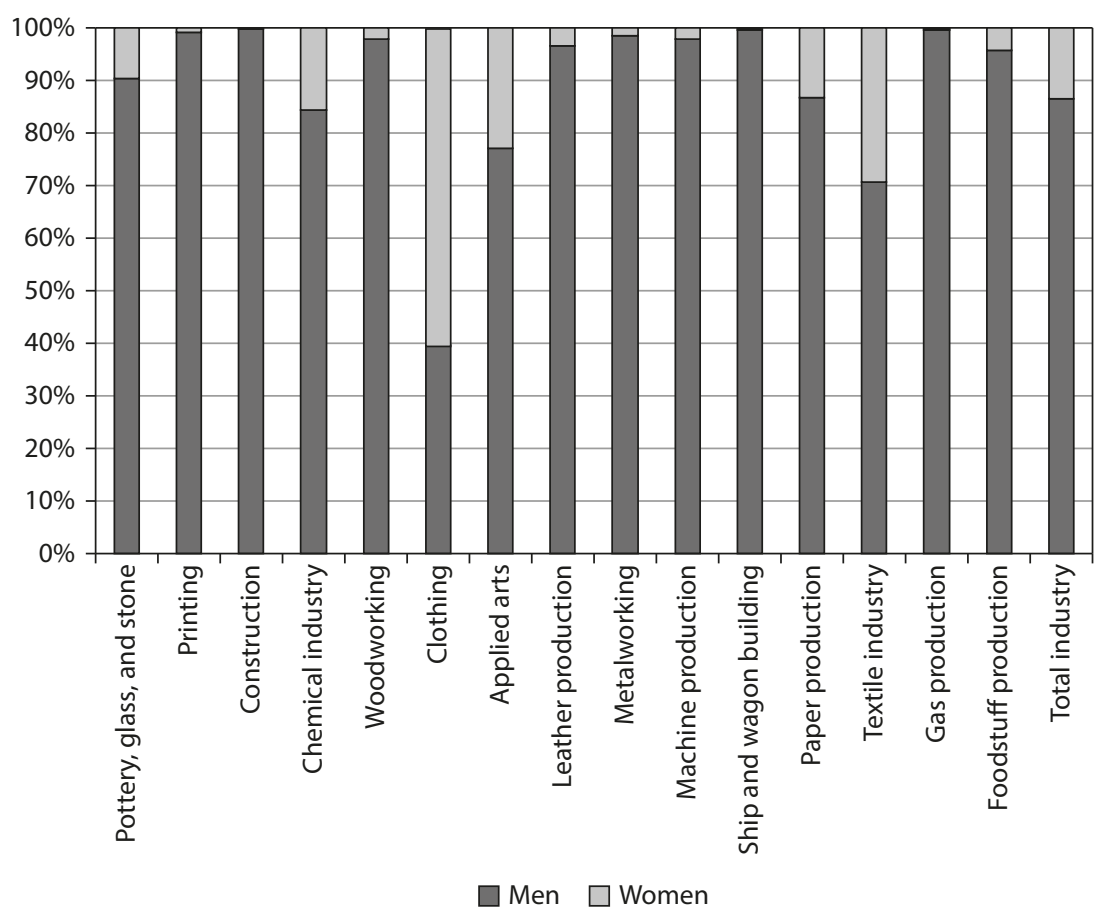

Source: CBS, Beroepentelling 1899

As Figure 5.9 shows, the census of 1899 reveals that in contrast to Java, the Dutch industry sector was dominated by men. Only the clothing and textile industries were very important industrial sectors in which Dutch women and girls worked, but nevertheless, the proportion of men compared with women in textiles was much higher: respectively 70 per cent and 30 per cent in 1899. Over 17 per cent of all the women and girls active in industry worked in textile production. On the other hand, its share only amounted to 5 per cent of all the girls and women with an occupational mention in the census, and moreover, only about 10 per cent of the women working in textiles were married. Compared with other western European countries, the participation of women in the labour market was low by 1900, whereas it had been approximately on par around $1850 .{ }^{103}$ Apparently, despite the upsurge of women's labour-force participation in textile regions in the 1840 s and 185 os, and again in the 189 os with the recovery of the Dutch 
textile industry, Dutch women's participation in the overall labour market declined faster than elsewhere in Europe. ${ }^{104}$ Only in the textile regions, most notably in the cotton factories, did the participation of both young unmarried and married women remain relatively high compared with the average participation of Dutch women. ${ }^{105}$

Historians of Dutch women's work have explored several explanations for this diverging trend in female labour-force participation, such as sociocultural roots in the seventeenth century, the Netherlands' late industrialization, and even its neutrality in the First World War. ${ }^{106}$ I would, however, like to point to another possible factor, which again leads us to colonial connections. Especially after the 1850 s, the Dutch economy profited immensely from the excessive gains from the Cultivation System, and after its abandonment in 1870, from other income derived from Java. Van Zanden and Van Riel have calculated that the Batig Slot (colonial surplus) from the Cultivation System amounted to over 50 per cent of all the tax income in the Dutch treasury, ${ }^{107}$ and also after that, the gains were considerable until deep into the $1870 \mathrm{os}$. Most probably, Dutch colonial extraction was relatively more stringent than that of other imperial powers in terms of shares of GDP and total tax income. ${ }^{108}$ Although historians and economists have intensely debated the effects of this colonial surplus in terms of the growth of Dutch public finances and national income, they can by no means have been negligible. For the late colonial period (1925 to 1940), contemporary economists Tinbergen and Derksen estimate the total income from the Dutch East Indies to have been about 14 per cent of the annual Dutch national income, and this will not have been less in the preceding period, which is known as even more extractive. ${ }^{109}$

Between 1860 and 1900, exactly in the period when the colonial surpluses had balanced the Dutch public debt, real male wages in the Netherlands rose significantly, by more than 150 per cent, and more than in other European countries (see Table 5.2). ${ }^{110}$ Not only did the prices of foodstuffs

104 Schmidt and Van Nederveen Meerkerk, "Reconsidering".

105 Brouwer and Van Eijndhoven, "Fabrieksarbeidsters", pp. 94-95.

106 For an overview of the literature, see Van Nederveen Meerkerk, "Vergelijkingen".

107 1831-1840: 150.6 million guilders; 1841-1850: 215.6 million guilders; 1851-1860: 289.4 million guilders. Van Zanden and Van Riel, Strictures of Inheritance, pp. 179-180.

108 Maddison, "The Colonial Burden", pp. 361, 367 .

109 Derksen and Tinbergen, Berekeningen, p. 17. Historians have debated whether this can be called a high percentage. See, e.g., Wesseling, Indië verloren, p. 296.

110 Frankema and Buelens, "Conclusion", p. 275; Van Zanden and Van Riel, Strictures of Inheritance, pp. $275^{-276}$. 
in the world market decline due to the agrarian depression, but coffee and tea - new working-class beverages in this period - and sugar also continued to be imported for relatively low prices from the East Indies. Because of the large revenues from the Dutch East Indies in the second half of the nineteenth century, excises on some basic consumption goods in the metropole could be lowered. ${ }^{111}$ Although perhaps not in the low-wage textile regions, this may have sped up material realization of the ideal of the male breadwinner in the Netherlands, according to which the housewife stayed at home to take care of the household, and children went to school. In more than one sense, colonial connections formed an important element in these developments.

Table 5.2 Indexed real wages in some Western European countries, 1850 to 1913 $(1860=100)$

\begin{tabular}{lrrrr}
\hline Year & Netherlands & England & France & Sweden \\
\hline 1860 & 100 & 100 & 100 & 100 \\
1870 & 110 & 105 & 116 & 108 \\
1880 & 144 & 115 & 123 & 109 \\
1890 & 160 & 145 & 143 & 131 \\
1900 & 190 & 163 & 164 & 159 \\
1913 & 200 & 175 & 167 & 179 \\
\hline
\end{tabular}

Source: Van Nederveen Meerkerk, "Vergelijkingen en verbindingen", p. 32

Colonial gains and imperial relations not only help to explain these latenineteenth-century changes in the labour allocation and purchasing power of Dutch households, but - and this is particularly interesting in the light of this chapter - colonial influences can also be seen in Dutch consumption habits for cotton cloth. Towards the end of the nineteenth century, more and more batik from the East Indies appeared in ordinary Dutch households, due to the intensified traffic of goods and people from and to the colony. ${ }^{112}$ Moreover, several prominent members of Dutch society actively propagated the consumption of batiks in the Netherlands, arguing that their elegance and class could ameliorate the tasteless cotton mass products that the Dutch urban working classes were used to wearing. In this sense, it was argued, Dutch consumers had much to learn from their

111 Vermaas, "Real Industrial Wages", pp. 147-149.

112 Legêne, Spiegelreflex, p. 135 . 
Javanese counterparts. Around 1880, Twente textile manufacturers even launched an initiative to transport 4,000 of their factory workers by train to a National Exhibition of Colonial Industry in Arnhem. Here they could see with their own eyes the finished batiks for which they had produced the white cloth in the factories. ${ }^{113}$ These are not only good examples of how textile production and consumption in different parts of the empire came together, but also a reminder of how entangled the metropole and colony in fact were around the turn of the twentieth century.

\section{Conclusion}

This chapter has aimed to highlight the interwoven histories of textile production in the Netherlands and Java. While the impact of colonial institutions on the colony seems obvious, I argue here that on the one hand, the economic position of the native population was affected in quite different ways than most historians have anticipated, and on the other hand, that colonial policies and connections in turn have affected the metropole in ways that have previously been underresearched.

In the pre-colonial period, global trade impacted on gendered labour relations in Java and the Dutch Republic. VOC institutions - such as the implementation of a cotton yarn tax - in combination with favourable market conditions, shifted Javanese women's labour allocation from subsistence agriculture to spinning and weaving for the market. Thus, a move from reciprocal to commodified labour relations had already started before 1800 . In addition to that, women traditionally worked as artisans in the batiking industry. In the Netherlands, the urge to compete with Asian cotton led to quality changes in woollen production, consequently stimulating women's participation in the labour market and their shift to wage labour, but in the lower value-added segments of textile production. While the grip of colonial institutions became firmer in the early nineteenth century, they did not always have the intended effects on the Javanese economy. Certainly, the Cultivation System again entailed a shift of women's labour to subsistence agriculture, but only for the first years. As only a few historians have noted before me, the Javanese textile industry recovered in the 1840 , and was able to hold its own against competition from foreign imports until the 1920 . Moreover, this industry was mainly in the hands of weaving and batiking women. In some ways, the shift from weaving with factory-made yarns 
and the batiking of factory-woven bleached cloth ensured the reallocation of local producers' time, who now engaged in higher value-added stages of the production process.

These changes involved the shift of women from more time-consuming hand spinning to cotton weaving. Probably, the time women saved by not having to spin was well compensated for by weaving: the surplus cloth that the household did not need could be sold in increasingly developing regional markets. This means that a further acceleration of commodified labour took place under the influence of colonial policies and institutions. Because the living standard debate has until now tended to focus on male real wages, including women's economic contributions in the picture may indeed solve part of the puzzle of how - despite the atrocities of colonial extraction in the form of forced cultivation and taxes - Javanese households were still able to survive and perhaps even somewhat expand their consumption. Moreover, from around 1860, new dyeing techniques emerged. In addition to the artistic and expensive batik, dominated by women, men started tjapping (block printing), which was less labour-intensive and thus more competitive with the factory imports from Europe. The consumer preferences of the Javanese population played an important role in all of this. Although information on the purchasing power of the native population is still inconclusive, it is clear that there was a huge market for domestic textiles, whose quality was generally more highly rated than that of the imported cloth from Europe.

Turning our gaze to the metropole, we find that colonial policies clearly had a direct as well as an indirect impact on textile production and the division of labour in the Netherlands. The preferential trading status of the NHM and interlinked state subsidies until the 1870s stimulated Dutch industrialization, starting with its textile industry. Although the profits may not have been as high as expected, state subsidies and tariff barriers favoured Dutch textiles, which slowly but surely led to a shift from cottage production by hand to factory production using machines. In the process, married women became first more, and towards the end of the century less, important in the production process of textiles, but children and young women were drawn to the factories in large numbers as cheap wage labourers.

These changes were accompanied by a rise in male real wages in the period from 1860 to 1900 , partly caused by the colonial revenues that flowed into the Dutch economy and society at that time. By indirect tax reform, these colonial gains partly trickled down to the lower classes. Although the reality of the male breadwinner society could only be fully attained after 
the First World War, and was certainly far away for the working classes in low-wage textile regions, the ideal had already firmly gained ground by around 1900. Interestingly, around this time, according to such ideals, the higher classes even sought to "educate" the lower classes in their consumer preferences, and tried to stimulate them to refine their consumption of textiles by buying batiks. In addition, prevailing norms were reflected in Dutch labour legislation as well as social practice. For women, factory work formed a stage in their life cycle, and if they kept working after marriage, it was in the informal sector, not in formal wage labour. Thus, in contrast to the - artistically and economically - highly valued textile work by Javanese women, the position of female textile workers in the Netherlands, which had already deteriorated with the guild exclusions in the early modern century, was very low, and factory work was increasingly seen as unfit for married Dutch women.

Institutions indeed interfered with colonial market relations, seemingly leading to deindustrialization in colonial Indonesia, as Williamson suggests, and industrialization in the Netherlands. However, indigenous economic adaptability, in combination with cultural values - such as the consumer preferences of the Javanese, or the rise of the male breadwinner ideology in the Netherlands - direct our attention to additional forces of change, such as the agency of both indigenous textile producers and consumers, the gendered division of labour, and the unintended consequences of colonial policies. In this way, the success story of the Dutch textile industry, as well as the presumed collapse of Javanese labour-intensive textile production, can and should be seen in a more nuanced perspective.

\section{Bibliography}

Acemoglu, Daron, Simon Johnson, and James Robinson, "The Colonial Origins of Comparative Development: An Empirical Investigation", American Economic Review, 91 (2001), pp. 1369-1401.

Allen, Robert C., et al., "Wages, Prices, and Living Standards in China, 1738-1925 in Comparison with Europe, Japan, and India", Economic History Review, 64 (2011), pp. 8-38.

Austin, Gareth, "Resources, Techniques, and Strategies South of the Sahara: Revising the Factor Endowments Perspective on African Economic Development, 1500-200o", Economic History Review, 61 (2008), pp. 587-624. 
Austin, Gareth, “The 'Reversal of Fortune' Thesis and the Compression of History: Perspectives from African and Comparative Economic History", Journal of International Development, 20 (2008), pp. 996-1027.

Austin, Gareth, and Kaoru Sugihara (eds), Labour-Intensive Industrialization in Global History (London, 2013).

Berg, Maxine, "What Difference Did Women's Work Make to the Industrial Revolution?", History Workshop, 35 (1993), pp. 22-44.

Bijdragen van het Statistisch Instituut (Amsterdam, 1887).

Boomgaard, Peter, Children of the Colonial State: Population Growth and Economic Development in Java, 1795-1880 (Amsterdam, 1989).

Boomgaard, Peter, "Female Labour and Population Growth on Nineteenth-Century Java", Review of Indonesian and Malayan Affairs, 15 (1981), pp. 1-31.

Boomgaard, Peter, and Gooszen, A.J., Population Trends 1795-1942: Changing Economy of Indonesia, vol. 11 (Amsterdam, 1991).

Booth, Anne, The Indonesian Economy in the Nineteenth and Twentieth Centuries: A History of Missed Opportunities (Basingstoke, 1998).

Boter, Corinne, "Before She Said 'I Do': The Impact of Industrialization on Unmarried Women's Labour Participation 1812-1932", CGEH Working Papers 56, 2014, available at: http://www.cgeh.nl/sites/default/files/WorkingPapers/cgehwp56_boter.pdf.

Broadberry, Stephen, and Bishnupriya Gupta, "The Early Modern Great Divergence: Wages, Prices and Economic Development in Europe and Asia, 1500-180o", Economic History Review, 59 (2006), pp. 2-31.

Broadberry, Stephen, and Bishnupriya Gupta, "Lancashire, India, and Shifting Competitive Advantage in Cotton Textiles, 1700-1850: The Neglected Role of Factor Prices", Economic History Review, 62 (2009), pp. 279-305.

Brouwer, Fenna, and Monique van Eijndhoven, "Fabrieksarbeidsters in de Twentse textiel 1890-1914", Textielhistorische Bijdragen, 22 (1981), pp. 83-116.

Centraal Bureau voor Statistiek, Beroepentelling 1899, Volkstellingen 1795-1971/ Dutch Censuses 1795-1971 website, available at: http://www.volkstellingen.nl/ nl/volkstelling/jaarview/1899/index.html, accessed 26 June 2014.

Chaudury, Sushil, "European Companies and the Bengal Textile Industry in the Eighteenth Century: The Pitfalls of Applying Quantitative Techniques", Modern Asian Studies, 27 (1993), pp. 321-340.

Clarence-Smith, William G., "The Production of Cotton Textiles in Early Modern South-East Asia", in Giorgio Riello and Prassanan Parthasarathi (eds), The Spinning World: A Global History of Cotton Textiles, 1200-1850 (Oxford, 2009), pp. 131-134.

Cooper, Frederick, Colonialism in Question: Theory, Knowledge, History (Berkeley, 2005) 
Crafts, Nick, "Review: Trade and Poverty: When the Third World Fell Behind", Economic Journal, 123 (2013), pp. F193-F197.

Dalenoord, G., “Textiel-nijverheid in Nederlandsch-Indië”, Koloniale Studiën (1926), pp. 169-170.

De Graaf, Ton, Voor handel en maatschappij. Geschiedenis van de Nederlandsche Handel-Maatschappij, 1824-1964 (Amsterdam, 2012).

De Jonge, J.A., De industrialisatie in Nederland tussen 1850 en 1915 (Nijmegen, 1976).

Derksen J.B., and J. Tinbergen, Berekeningen over de eonomische betekeenis van Nederlandsch-Indië voor Nederland (The Hague, 1941).

Dick, Howard, "Nineteenth-Century Industrialization: A Missed Opportunity?", in J. Thomas Lindblad (ed.), New Challenges in the Modern Economic History of Indonesia (Leiden, 1993), pp. 123-148.

Elson, Robert, Village Java under the Cultivation System, 1830-1870 (Sydney, 1994).

Fasseur, Cees, Kultuurstelsel en koloniale baten. De Nederlandse exploitatie van Java 1840-186o (Leiden, 1975).

Fernando, M.R., "Growth of Non-Agricultural Economic Activities in Java, 18201880", in J. Thomas Lindblad (ed.), New Challenges in the Modern Economic History of Indonesia (Leiden, 1993), pp. 89-109.

Fischer, E.J., "De ontwikkeling van de Twentse katoenindustrie en de toename van de arbeidsproductiviteit tussen 1800 en 1930", Textielhistorische Bijdragen, 22 (1981), pp. 3-38.

Fischer, E.J., Fabriqueurs en fabrikanten. Twente, Borne en de katoennijverheid 1800-1930 (Utrecht, 1983).

Frankema, Ewout, and Frans Buelens, "Conclusion", in Ewout Frankema and Frans Buelens (eds), Colonial Exploitation and Economic Development: The Belgian Congo and the Netherlands Indies Compared (London, 2013), pp. 274-280.

Hall, Kenneth R., "The Textile Industry in Southeast Asia, 1400-180o",Journal of the Economic and Social History of the Orient, 39 (1996), pp. 87-135.

Haynes, Douglas E., Small Town Capitalism in Western India:Artisans, Merchants, and the Making of the Informal Economy, 1870-1960 (Cambridge, 2012).

Humphries, Jane, and Carmen Sarasua, “Off the Record: Reconstructing Women's Labor Force Participation in the European Past”, Feminist Economics, 18 (2012), pp. 39-67.

Jansen, M., De industriële ontwikkeling in Nederland 1800-1850 (Amsterdam, 1999). Janssens, Angélique, "De rol van vrouwen in de eerste demografische transitie in Nederland. Een vergelijking van twee textielsteden”, Tijdschrift voor Sociale en Economische Geschiedenis, 6 (2009), pp. 87-114.

Jasper, J.E., and Mas Pirngadie, De inlandsche kunstnijverheid in Nederlandsch Indië. Vol. II, De weefkunst (The Hague, 1912). 
Jasper, J.E., and Mas Pirngadie, De inlandsche kunstnijverheid in Nederlandsch Indië. Vol. III, De batikkunst (The Hague, 1916).

Korthals Altes, W.L., General Trade Statistics 1822-1940: Changing Economy of Indonesia, Vol.12A (Amsterdam, 1991).

Legêne, Susan, Spiegelreflex. Culturele sporen van de koloniale ervaring (Amsterdam, 2010).

Lemire, Beverly, and Giorgio Riello, "East and West: Textiles and Fashion in Early Modern Europe", Journal of Social History (2008), pp. 887-916.

Lindblad, J. Thomas, “De handel in katoentjes op Nederlands-Indië, 1824-1939”, Textielhistorische Bijdragen, 34 (1994), pp. 89-104.

Lindblad, J. Thomas, "De handel tussen Nederland en Nederlands-Indië, 1874-1939", Economisch en Sociaal-Historisch Jaarboek, 51 (1988), pp. 240-298.

Maddison, Angus, “The Colonial Burden: A Comparative Perspective”, in M. Scott and Deepak Lal (eds), Public Policy and Economic Development: Essays in Honour of Ian Little (Oxford, 1990), pp. 361-375.

Matsuo, Hiroshi, The Development ofJavanese Cotton Industry (Tokyo, 1970).

Mokyr, Joel (ed.), The British Industrial Revolution: An Economic Perspective (Boulder, 1999).

Muller Szoon, Hendrik, De Nederlandsche katoennijverheid, en het stelsel van bescherming in Nederlandsch-Indië (Rotterdam, 1857).

Parthasarathi, Prasannan, "Rethinking Wages and Competitiveness in the Eighteenth Century: Britain and South India”, Past and Present, $15^{8}$ (1998), pp. 79-109.

Plemp van Duiveland, L.J., Twentsche weefsels, geschiedenis van de activiteiten van de NHM in Twente (n.p., 1957).

Pomeranz, Kenneth, The Great Divergence: China, Europe, and the Making of the Modern World Economy (Princeton, 2000).

Pott-Buter, Hettie, Facts and Fairy Tales about Female Labour: A Seven-Country Comparison, 1850-199o (Amsterdam, 1993).

Prakash, Om, The Dutch East India Company and the Economy of Bengal, 1630-1720 (Princeton, 1985).

Raffles, Thomas Stamford, The History ofJava, $2^{\text {nd }}$ ed., 2 vols (London, 1830).

Ricklefs, M.C., A History of Modern Indonesia (London, 1981).

Rouffaer, G.P., "Aanhangsel: de voornaamste industrieën der inlandsche bevolking van Java en Madoera", appendix to C. Th. Van Deventer, Overzicht van der economischen toestand der inlandsche bevolking van Java en Madoera (The Hague, 1904), pp. 1-128.

Roy, Tirthankar, Artisans and Industrialization: Indian Weaving in the Twentieth Century (Delhi, 1993). 
Schmidt, Ariadne, and Elise van Nederveen Meerkerk, "Reconsidering the 'First Male-Breadwinner Economy': Women's Labor Force Participation in the Netherlands, 1600-19oo", Feminist Economics, 18 (2012), pp. 69-96.

Seegers, W.A.I.M., Manufacturing Industry, 1870-1942: Changing Economy in Indonesia, vol. 8 (Amsterdam, 1988).

Stoler, Ann, “Class Structure and Female Autonomy in Rural Java”, Signs, 3 (1977), pp. 74-89.

Van der Eng, Pierre, “Why Didn't Colonial Indonesia Have a Competitive Cotton Textile Industry?”, Modern Asian Studies, 47 (2013), pp. 1019-1054.

Van Nederveen Meerkerk, Elise, "Couples Cooperating? Dutch Textile Workers, Family Labour and the 'Industrious Revolution', c. 1600-180o", Continuity and Change, 23 (2008), pp. 237-266.

Van Nederveen Meerkerk, Elise, "Segmentation in the Pre-Industrial Labour Market: Women's Work in the Dutch Textile Industry, 1581-1810", International Review of Social History, $5^{1}$ (2006), pp. 189-216.

Van Nederveen Meerkerk, Elise, "Vergelijkingen en verbindingen. De arbeidsdeelname van vrouwen in Nederland en Nederlands-Indië, 1813-1940", Low Countries History Review, 130 (2015), pp. 17-20.

Van Nederveen Meerkerk, Elise, Lex Heerma van Voss, and Els Hiemstra-Kuperus, "The Netherlands", in Lex Heerma van Voss, Els Hiemstra-Kuperus, and Elise van Nederveen Meerkerk (eds), The Ashgate Companion to the History of Textile Workers, 1650-200o (Aldershot, 2010), pp. 363-396.

Van Zanden, Jan Luiten, and Arthur van Riel, The Strictures of Inheritance: The Dutch Economy in the Nineteenth Century (Princeton, 2004).

Van Zanden, Jan Luiten, and Daan Marks, An Economic History of Indonesia, 18002010 (London, 2012).

Vermaas, Annelies, "Real Industrial Wages in the Netherlands", in P. Scholliers and V. Zagmani (eds), Labour's Reward: Real Wages and Economic Change in $19^{\text {th }}$-and $20^{\text {th }}$-Century Europe (Aldershot, 1995), pp. 138-150.

Verslag van den waters- en voedingnood te Semarang uitgebracht door de Commissie, ingesteld bij Gouvernements Besluit d.d. 2 Juli 1902 (Buitenzorg, 1903).

Watson Andaya, Barbara, "The Cloth Trade in Jambi and Palembang Society during the Seventeenth and Eighteenth Centuries", Indonesia, 48 (1989), pp. 27-46.

Watson Andaya, Barbara, The Flaming Womb:Repositioning Women in Early Modern Southeast Asia (Honolulu, 2006).

Wesseling, H.L., Indië verloren, rampspoed geboren en andere opstellen over de geschiedenis van de Europese expansie (Amsterdam, 1988).

White, Ben, "Labour in Childhood's Global Past: Child Work and Colonial Policies in Indonesia, 1800-1949", in Kristoffel Lieten and Elise van Nederveen Meerkerk (eds), Child Labour's Global Past (Bern, 2011), pp. 479-500. 
Williamson, Jeffrey G. Trade and Poverty: When the Third World Fell Behind (Cambridge, 2013).

Willink, Bastiaan, De textielbaronnen. Twents-Gelders familisme en de eerste grootindustrie van Nederland 1800-1980 (Zwolle, 2010).

\section{About the Author}

Elise van Nederveen Meerkerk is Associate Professor at the Department of History and Art History at Utrecht University and Professor of the Comparative History of Households, Gender and Work at Radboud University Nijmegen (The Netherlands). Her work is mostly in the field of comparative labour relations, gender, and households from the early modern period to the present. Publications include: "Challenging the De-industrialization Thesis: Gender and Indigenous Textile Production in Java under Dutch Colonial Rule, ca. 1830-1940", Economic History Review (2017); Towards a Global History of Domestic and Care Workers (Leiden, 2015) (co-edited with Dirk Hoerder and Silke Neunsinger).

E-mail: e.j.v.vannederveenmeerkerk@uu.nl 


\title{
6 The Triumph of the Peasant Option and the Parasitic Cotton Sector in Malawi, 1891 to $1995^{*}$
}

\author{
Elias C. Mandala
}

Hofmeester, Karin \& Pim de Zwart (eds.), Colonialism, Institutional Change, and Shifts in Global Labour Relations. Amsterdam: Amsterdam University Press, 2018

DOI: $10.5117 / 9789462984363 / \mathrm{CHo} 6$

\begin{abstract}
Malawi's colonial and post-colonial governments tried, without success, to create capitalist farmers out of the country's cotton-growing peasantry. The plan foundered under the weight of low producer prices resulting from high freight rates and systematic transfers of income from the cotton trade into non-peasant enterprises. Villagers were left with no money to specialize in cotton farming, and the industry survived as a smallholder undertaking only because it received the uncompensated labour of dependants and resources from other sectors. Cotton agriculture developed as a parasite, on economic and political grounds. It originated in, and was for a long time sustained by, the silent violence of the colonial tax code: to grow cotton was to venture beyond the boundaries of economic rationality.
\end{abstract}

Keywords: cotton, new imperialism, peasantry, second colonial occupation, World Bank, World War II

"Reducing it to its essentials the object must be to create a class of professional farmers [and] to encourage the individual, to develop his initiative and to evolve a class of yeoman farmer."

* I am grateful to Dean Miller and Louis Nthenda for their insightful comments and suggestions on an earlier draft and to Clement Ng'ong'ola for permission to use a figure from his dissertation.

1 Kettlewell, An Outline, p. 3. 
"And after selling a bag its [sic] never enough for buying a cloth or taxation [but only enough to buy] sweets [...] We want to be rich, therefore marketing system should be improved and price raised." ${ }^{2}$

"The Nyasaland native is conservative by nature and he has been slow to adjust his outlook to changed conditions." ${ }^{3}$

"It is remarkable that the decline of the European cotton industry or any other agricultural enterprise was tolerable if unremunerative prices were an important factor. Africans, however, were conservative if they showed the same sensitivity to market trends." ${ }^{\text {4 }}$

\section{Introduction}

The opening quotation captures in a nutshell the determination of colonial officials in Malawi to reshape the country's agrarian economy; to remake it in such a way that it would be able to subsidize Britain's reconstruction after World War II. In the second and third quotations, Mr Balandao and the acting governor outline different reasons why such a programme might not work. For Acting Governor K.L. Hall, the challenge lies in Africans' "natural conservatism", whereas Mr Balandao, a peasant farmer, signals low producer prices as the potential obstacle. Raised in the context of a small country, Malawi, the two perspectives were to inform much of the debate about Africa's economic crisis in the 1980 s. $^{5}$

Mr Balandao's criticism reverberates in the scholarly discussion informed by political economy, an approach that has allowed those trained in political science, economics, history, and in several other social sciences to join in the conversation about Africa's economic challenges. In his reference to prices as a factor in the behaviour of the cotton grower, Mr Balandao seems to have lifted a page from Robert Bates's influential book, States and Markets in Africa ${ }^{6}$ A unifying theme in political economy is the assumption that the same methods used to understand "successful" economies can

2 Oral Testimony: Balandao, TA Ngabu, Chikwawa District. Recorded by Symforiano Mwendo (SM) in 1996 on behalf of the author. These testimonies will hereafter be referenced as SM96/. Emphasis added by the author.

3 Ng'ong'ola, "Statutory Law", p. 272.

4 Ibid., p. 272.

5 Among others, see Ravenhill, Africa in Economic Crisis.

6 Bates, Markets and States. 
also illuminate the workings of underperforming systems; a very different starting point from that implicit in the acting governor's explanation. His theory prepares the reader to see Africa as a unique place; as the "other".

For some scholars, Africa's uniqueness is a product of its culture, whereas for others, it is its environment. Thus, the same African environment that has given the world and, particularly the West, diamonds, gold, oil, and resources for academic endowments, emerges from the work of many scholars as the principal obstacle to economic development. Eric Jones did not mince his words on this subject, confidently declaring "The defects of the [African] environment [...] did indeed strike so close to the heart of economic life that it is not clear what indigenous developments were possible." John Illife clarified the assertion about Africa's uniqueness, reminding his readers that while the inhabitants of "favoured" climates are heroes for building "civilizations", Africans "deserve admiration, support, and careful study" for the achievement of bodily survival. They "have been and are the frontiersmen who have colonized an especially hostile [sic] region of the world on behalf of the entire human race. That has been their chief [read "only"] contribution to history." ${ }^{\prime}$ And, perhaps seeing nothing particularly "salubrious" in the northern climates, some have blamed the same African environment for not being harsh enough to force its inhabitants to invent capitalism. The late Professor Ali Mazrui poetically called this particular deficiency the "winter gap". ${ }^{9}$ In sharp contrast, however, other scholars have looked to African culture to explain the continent's economic challenges.

Culture surfaces as an independent variable in, for example, discussions about the failure of export production to transform African agriculture. According to one authority, Sarah Berry, "The strategies used to pursue such struggles led to investment not in labour-saving innovations [...] but in the proliferation of patronage relations, as accumulators sought to protect their access to resources and markets by accumulating loyal subordinates. ${ }^{{ }^{\prime 10}}$ The processes of commercialization that have led to "development" in other parts of the world have been "compromised" in Africa "by the actions of social networks deeply rooted in African culture"."

7 Jones, The European Miracle, pp. 154-156.

8 Iliffe, Africans, p. 1.

9 Mazrui, The Africans, pp. 213-236. For among the latest and perhaps most radical versions of this environmental determinism, see Sangmpam, "Why the African Union".

10 Berry, "The Food Crisis", p. 96.

11 Vail, "Review”. Emphasis added. 
The argument in this contribution is that there is no need to invoke culture or the environment to explain history in Africa. As elsewhere in the world, in Africa culture and the natural setting become effective historical drivers only when coupled with specific political and economic relationships. The cultural argument ignores, for example, the fact that the ancestors of the farmers, who are supposedly busy acquiring dependents today, spent over three centuries after 1500 exporting their neighbours and relatives. In Malawi, the propensity of African cotton growers and European tea farmers to invest in social relationships was an effect, not a cause, of the fact that they could not afford machines or paid employees on a regular basis. The environment was equally neutral in its effects on the history of cotton farming.

The government's plans to create cotton-growing capitalist farmers crashed under the weight of low producer prices resulting from high freight rates and systematic transfers of surpluses from the cotton trade into nonpeasant initiatives. Villagers were left with little or no money to invest or specialize in cotton farming, and the industry could only survive as a smallholder venture mainly because, unlike capitalists, villagers could pump into it the uncompensated labour of their dependants, and money generated in other sectors. Cotton farming developed as a parasite, on economic and political grounds. It originated in, and until the mid-199os was sustained by, the silent violence of the country's tax legislation. European and Asian settlers, working in the same hot and humid Lower Tchiri Valley but free from the oppressive power of the colonial state that otherwise ruled village life, abandoned cotton agriculture in the early 1920 s because they could not run it on a rational basis.

The chapter addresses these issues in four parts. The first explores the rise and fall of the government's plan, from 1891 to 1923, to turn European settlers into capitalist cotton farmers supported by cheap African labour. The second part focuses on the fact that, under the prevailing economic and political conditions, peasants' success as cotton producers relied simultaneously on their powerlessness vis-à-vis the colonial state and their ability to control the labour of their dependents. The third section examines the dynamics of cotton markets and producer prices. The final part shows how - as a result of stagnation in rural incomes - on the one hand, villagers underutilized technology and wage labour and, on the other, spread their own labour over a wide range of activities, including those needed to keep cotton agriculture alive. The economics and politics of peasant cotton agriculture thus undercut any stirrings towards specialization and the possibility of a new class of "yeoman" farmers. 


\section{Cotton and the "new" imperialism}

The first British plan to establish a capitalist cotton economy based on the division between European owners of capital and African wage earners foundered, partly because of high freight costs, but mainly because the settlers could not secure labour cheaply enough to offset the disadvantages of the primitive transport system.

Coming at the height of the "new" imperialism, as they did elsewhere in Africa at the time, in 1891 the British annexed Malawi (also known as "British Central Africa" and "Nyasaland" from respectively 1891 to 1907 and 1907 to 1964) with two main objectives. The new territory was to export to the British Empire minerals, foodstuffs, "big fix" items (such as coffee, tea, and tobacco), and raw materials, particularly cotton. Malawi would in turn become a destination for British manufactures and British capital, the distinctly "new" feature of the imperialism of the period. This was a double-sided mission, some parts of which proved easier to accomplish than others.

With knowledge gleaned from missionaries and traders who had worked in the region since 1875 , the colonial regime ruled out the possibility of developing a mining industry in the country. ${ }^{12}$ The colony was to contribute to the wealth of Britain mainly as an exporter of agricultural products. Known as "economic" crops, all of these were initially to be grown in the Tchiri Highlands, where the climate was "healthy" enough for European settlers. However, after a few seasons of trials, it became obvious that although suitable for most crops, the Tchiri Highlands could not support cotton; cotton could only prosper in the humid and hot Lakeshore districts and the Lower Tchiri Valley: the focus of this chapter.

Long before identifying the locations for the different "economic" crops, officials had already determined the "appropriate" division of labour for the country. Given the absence of exploitable mineral resources, British investment in this country would be directed towards agriculture. European settlers were therefore to monopolize "economic" crops, with Africans contributing nothing to this privileged sector of the economy apart from their labour. Thus, when not working on European estates, villagers were to limit their agricultural activities to the cultivation of food crops, including maize, which would feed the Africans employed by Europeans. Governor George Smith was beholden to this division of labour as late as 1920: "I feel $[\ldots]$ it is to the European and European capital that we must look for any 
considerable and rapid expansion in the growth of cotton in Nyasaland, the native continuing in a large degree to fund the labour."13

The state and its European allies fought to the end to maintain this division of labour, which quickly assumed the character of a natural given. The government's resolve to make this plan work encountered many challenges, the most significant of which was its own failure to invest in a transportation system efficient enough to move the country's exports and imports. Head porterage was still a common method of moving commodities in Malawi when Governor Smith was declaring his commitment to the cause of British finance capital in 1920. Further, freight rates on the privately built railway system that replaced head carriers proved to be higher than on any of the other systems in the region, all of which were publicly financed. Not many entrepreneurs with resources looked to Malawi to start a business; they went to other British territories with better facilities. Only those with fewer options trekked to Malawi, attracted by news of cheap land and cheap labour. They would launch undercapitalized enterprises, relying on the hoe as their principal instrument of production, and offering poor working conditions and obscenely low wages. Africans did everything to avoid these labour camps and, through that process, turned the state into a labour-recruitment agent.

To meet the needs of its "investors", the government devised a labour tenancy system, known as thangata, which reduced to perpetual dependence those Africans who were on the land both before and after its seizure by the settlers. ${ }^{14}$ (These settlers saw the value of dependent workers without learning anything about African "culture"; indeed many despised it.) However, thangata became a useful tool of labour recruitment only on the Tchiri Highlands, where the expropriation of land and influx of immigrants from Portuguese-controlled Mozambique exacerbated the pre-existing high population densities. Refugees from Portuguese oppression underwrote the success of tea, tobacco, and coffee estates in the Tchiri Highlands. Thangata did not, however, work as planned in areas that, like the Lower Tchiri Valley, did not receive such an influx of refugees. To satisfy the labour requirements of European enterprises throughout the country, the colonial state complemented thangata with tax legislation.

Within ten years of assuming control of the country, the British had passed three pieces of tax legislation intended not only to raise revenue, but also to drive labour to European enterprises. In 1891, the government imposed

13 Governor Smith to Secretary of State for the Colonies, 16 August 1920, S1/557/20, Malawi National Archives [hereafter MNA]. See also Mandala, "Feeding and Fleecing".

14 Pachai, Malawi, pp. 99-109. 
a six-shilling poll tax on every adult male, and making any male fourteen years and older qualify as an adult. Three years later, in 1894, the government responded to protests by chiefs and missionaries about the high tax rate, by altering the unit of taxation from the poll to what was termed the "hut tax", and setting this tax at three shillings per year. ${ }^{15}$ However, continuing labour shortages forced the government to revise the tax code again in 1901, when the tax rate was quadrupled from three to twelve shillings per year and, even more tellingly, when officials introduced a rebate system allowing anyone who worked for a European for at least one month in a year to pay only half the maximum payable tax. ${ }^{16}$ Tax collection would turn into tax wars.

Unsure of their loyalties, the government relieved chiefs of their original responsibility as tax collectors during the annual tax campaigns. A European official, often the district administrator, who was now appropriately called the "collector", led the campaign. The expeditions would often turn violent during the two-month period between 31 December - when each year's taxes were payable - and 1 March. Tax offenders apprehended during the raids were not, however, sent to prison. Instead, they were "marched down hundreds of miles" from their homes to European enterprises on the Tchiri Highlands. Then, the houses of defaulters who managed to escape the collector were declared government property and subject to demolition. Sometimes whole "villages were burned down if chiefs or ordinary people raised the slightest demur". ${ }^{17}$ The tax wars brought home to the colonized the inherent violence of imperialism.

Malawians sometimes responded with violence to the organized violence of the state, as in 1915, when the anguish of those dispossessed of their land and forced to work on European estates in the Tchiri Highlands became the driving force behind the Chilembwe Uprising that sought to forcefully expel the British from the country. ${ }^{18}$ However, even after the defeat of the uprising, Malawians continued to resist, only this time employing the less spectacular but equally effective "weapons of the weak". At the same time that the violence of Portuguese rule in Mozambique flooded the Tchiri Highlands with desperate fugitives, thousands of able-bodied males - in a clear rebuke to the country's labour regime - headed to the mines of South Africa. This was the typical response in the northern part of the country. ${ }^{19}$

15 Sir Harry Johnston, Report on the First Three Years; Johnston to Secretary of State for Foreign Affairs, 22 January 1894; FO2/66, Public Record Office, British National Archives.

16 Pachai, Malawi, pp. 110-144

17 Ibid., p. 112

18 Shepperson and Price, Independent African; Mwase, Strike a Blow.

19 Pachai, Malawi, pp. 119-127. 
In the Lower Tchiri Valley, villagers resisted working on the European and Indian cotton estates by trying to grow their own cotton.

African cotton producers entered the archival records for the first time when they sold their product to Europeans, including in all likelihood some struggling European cotton farmers who were eager to make money by any means. News about these "hidden" transactions must have reached J.S.J. McCall, who arrived in Nyasaland in 1909, charged with the responsibility of establishing a Department of Agriculture. It speaks volumes about the department's financial capacity that even though committed to dependence on agriculture, it took Malawi two decades to establish this department.

Appalled by what he saw of European farms, with many overgrown by weeds due to lack of labour, McCall successfully lobbied for the passage of probably the first agricultural ordinance in the country, allowing African growers to pay their hut tax in cotton. Any head of household who produced thirty-six pounds (in the valley) or forty-two pounds (elsewhere in the country) of seed cotton and sold it to a European was entitled to a three-shilling tax rebate, the same as if they had worked one month in European employment. ${ }^{20}$ The colonial regime's commitment to the cause of the metropolitan textile industry did not exclude, in principle, an alliance with a productive peasantry.

Villagers seized the opportunity to work for themselves, and increased their cotton output every year after 1912. The partial collapse of the cotton trade during World War I proved to be only a temporary setback. Villagers redoubled their efforts and began to overtake settler production soon after the war. Several seasons of brilliant performance by the peasant sector undermined the government's support for the estate sector. Thus, after witnessing failing cotton estates in 1923, the Director of Agriculture removed the Lower Tchiri Valley from the list of areas to be "developed" by European enterprise. The capitalist route had reached a dead end:

In future the Lower Shire District (and parts of the Chikwawa District) should be regarded mainly as a Reserve for Natives and that Europeans or Asiatics should not be allowed to acquire further tracts of land except in very special circumstances [...] European efforts to develop this area of the Protectorate have been conspicuously unsuccessful. ${ }^{21}$

20 J.S.J. McCall, “Cotton Growing by Natives, 1909; Report on Nyasaland Cotton, April 24, 1909, A2/1/3", to British Cotton Growers Association [hereafter BCGA], 3 December 1910, A2/2/1, MNA. See also Mandala, Work and Control, pp. 108-132.

21 Department of Agriculture, Report on a Visit to the Lower Shire District, 1923, A3/2/68, MNA. Emphasis added. 
This was a courageous move on the part of the director; even though the last statement conveys the impression that European efforts to "develop" the colony through capitalist cotton agriculture had done well in other parts of the country (they had not). The plan failed in the Lakeshore region for the same economic reasons as it did in the Lower Tchiri Valley.

The Lower Tchiri Valley and the Lakeshore region were by nature the most suitable cotton-growing areas; both had grown cotton before colonial rule and would do so after colonialism under non-capitalist regimes of labour control. The capitalist experiment failed, partly because of the high freight rates on the country's primitive transportation network - as we shall see in section three of this chapter - but mainly because of rural resistance to wage employment on the undercapitalized farms. The end was also dramatic because Europeans were politically free to abandon undertakings that did not make economic sense. African farmers did not enjoy such freedom. They could not avoid both wage labour and cotton farming and remain British subjects, colonial power underwrote their cotton-growing activities, which verged on the margins of irrationality.

The collapse of the settler economy also shows that colonial officials could promote the interests of the metropolitan textile industry without at the same time serving the demands of finance capital. The two forms of capital could be separated. As in West Africa, colonial officials in Malawi came to serve the needs of Manchester through an alliance with the peasantry, an alliance that would moreover relieve officials from the politically risky task of labour recruitment.

\section{State power and the authority of village elders}

By the early 1920s, villagers had sabotaged not only the plantation cotton regime but also the earliest attempts by the colonial government to impose its own cotton-growing rules. There were limits to state power. Villagers did not follow the government's cotton-growing blueprint, but developed their own strategies to accommodate cotton within the existing systems of food production. These strategies proved so successful in delivering cotton that the government gave up its feeble attempts at intervention. However, in a colonial world in which cotton growing was also determined by political power, the successes of peasants' initiatives came at a price. Cotton farming exacerbated the plight of the youth, while exposing the food economy to new threats. Victories and setbacks were not always far from each other in the world of the colonized. 
Still exercising their partial independence as producers, villagers quietly ignored the government's cultivation blueprint that had accompanied the tax rebate regime, which allowed African growers to pay their hut tax in cotton. The blueprint required growers to raise cotton in its own separate field. I will refer to this method either as "pure" cotton culture or the "twofield" system; two, because cotton growers also continued to raise their own food crops. Afraid that the rules would place cotton cultivation in sharp conflict with the land and labour requirements of food cultivation, villagers invented two techniques to accommodate the cash crop.

For the first, peasants grew cotton on mphala drylands, where cultivation depended on rainfall. People planted cotton in the same field as, but immediately after harvesting, the early ripening varieties of maize, millet, and sorghum. In this way, villagers treated cotton the same way as they did their "secondary" crops, such as sweet potatoes and pigeon peas. Officials sometimes referred to such cotton as "late-planted cotton", because the cash crop followed the harvesting of major food crops. This is intra-seasonal rotation. The second technique also represented an adaptation of existing practice. ${ }^{22}$ In this method, villagers accommodated cotton by adjusting intercropping, a popular strategy some have called the jewel of peasant science in Africa. Under this regime, villagers raised cotton in the same field - and at the same time - as their maize, sweet potatoes, beans, and other food crops. Each area reproduced the biological diversity of the natural world. Moreover, villagers interplanted cotton with food crops not only on the mphala drylands as they did in intra-seasonal rotation, but also on the dambo floodplains bordering the Tchiri River. ${ }^{23}$

Because Malawi's popular cotton varieties during the colonial era were slow maturing, requiring at least five months to ripen, the possibility of raising cotton on the dambo floodplains, which was flooded every year, was influenced by the Tchiri River's flooding patterns. The river levels had started to drop in the mid-1880s, largely following a similar trend in Lake Malawi, which is the source of the Tchiri. The drop in the river's levels shortened the flood season, making it possible from about 1900 for villagers to grow the slow-maturing cotton in addition to fast-ripening food crops, such as maize and sweet potatoes, on dambo floodplains. They would sow cotton seeds at the

22 Port Herald District Annual Report, 1932, S1/43A/33; J.S.J. McCall, Director of Agriculture [hereafter, DA], 1910, A2/1/4, MNA.

23 E. Lawrence to DA, 8 January 1931, A3/2/109; Annual Agricultural Report, 1930, A3/2/183; 1933, A3/2/58; Monthly Agricultural Report, 1930-1932, A3/2/200; 1933-1935, A3/2/201; 1936-1938, A3/2/202, MNA. 
same times as their food crops, at the end of the flood season around June, and harvest the cash crop before the beginning of the flood season in December.

The competent use of the dambo floodplains and mphala drylands helped the Lower Tchiri Valley to emerge by the 1930s as the leading cotton-growing region in the country, which already had two major consequences. ${ }^{24}$ First, officials quickly dropped the original plan to force villagers to raise cotton in separate fields from food crops. Some even went so far as to admit the rationality of peasants' agricultural science: "The native methods of cotton cultivation", wrote the district commissioner for Nsanje in 1933, "appear to suit the Lower River conditions better than the methods employed on the experimental station judging by the yield per acre obtained from both". ${ }^{25}$ Peasants were thus able to organize their labour without outside interference. The second consequence was the region's emergence with a clean tax-payment record by the mid-1920s. Cotton growers made payment of the hut tax the first priority for money from cotton sales, and in that way removed the Lower Tchiri Valley from the list of places to be terrorized during the annual tax raids. ${ }^{26}$ The villagers had scored significant victories, but these came with significant losses for some sectors of the economy and some sections of the community, particularly those who had been powerless before colonialism.

The victories were possible mainly because heads of households were able to extract more labour than before from their male and female social juniors. With most of their income spent on taxes, elders were left with little or no money to pay regular wage labourers or invest in new technologies such as the plough. To meet the extra labour demands of the cash crop, they manipulated institutions such as marriage in order to keep youth labour in cotton agriculture. The initial impact of colonialism was not, as is often claimed, to liberate people from archaic family patterns of power.

The rise of export production in Malawi intensified the exploitation of those who were at the bottom of traditional society. Youth labour filled the gap between what merchants paid and what was socially necessary to raise cotton. Social juniors were the first to subsidize a parasitic sector that could not survive on its earnings and the dynamic of this process lay in the silent violence of British imperial control. ${ }^{27}$ Those, such as European settlers, who were not subject to such political violence did not turn their children into a

24 Production per Head of Export Crops, 1925, A3/2/233; BCGA Local Manager to DA, 19January 1926, A3/2/58, MNA.

25 Port Herald District Annual Report, 1933, NSP2/1/4, MNA.

26 Chikwawa District Annual Report, 1929, NSC2/1/3, MNA.

27 Chikwawa District Annual Reports, 1934, S1/88B/35; 1935, S1/79A/36, MNA; See South African General Mission (known today as African Evangelical Church), South African Pioneer, 45 (October 
free resource and did not therefore succeed as cotton farmers. Extra-economic pressure generated another contradiction: the same methods of cultivation villagers adopted to protect the food economy ended up harming it.

For example, to grow late-planted cotton on the mphala drylands, villagers had to abandon slow-maturing varieties of sorghum that could not fit into the cotton-growing schedule. However, this strategy had the effect of undermining food security. The late-maturing sorghums also happened to be the most drought-resilient food crops in this region of irregular and low rainfall. Droughts assumed a new meaning. ${ }^{28}$ Even more significant for the theme of this study were the contradictions of intercropping cotton with food crops on the dambo floodplains. To interplant cotton with food crops, villagers had to forego the possibility of several, consecutive maize cultures within a single growing season. This was a historic compromise, however, one that had little to do with the natural environment and everything to do with the organization of society.

In a powerful reminder that while offering opportunities, nature does not tell people what to do with their resources, the peasants in the northern or Chikwawa District exploited the same fertile dambo floodplains in a different way to those in the southern or Nsanje District. The system of intercropping cotton with food crops on the dambo floodplain described in the preceding pages was dominant only in the Nsanje District. In Chikwawa, villagers used the same fertile dambo to grow several successive maize crops during the same season. Economics determined the differing approaches. Unlike their neighbours in Nsanje, peasants in Chikwawa had a ready market for their maize in the neighbouring townships of Blantyre and Limbe, and they could use money from maize sales to pay their taxes. Those who grew cotton in Chikwawa raised the cash crop on the less-fertile mphala drylands. ${ }^{29}$

The differing use of the dambo in the Chikwawa and Nsanje Districts stands as a warning against reading the history of cotton agriculture in the Lower Tchiri Valley as a mere reflex reaction to the environment, particularly the Tchiri River. It was not. It was not so much the river, as the changing character of British imperialism, which determined the nature

1932), p. 127; 46 (August-September 1933); Port Herald District Annual Report, 1935, S1/79A/36, MNA.

28 Monthly Agricultural Report, February 1932; see also reports for November, December, 1929; January, February, 1930, A3/2/200; December 1935, A3/2/201; April 1937, A3/2/202, MNA.

29 Chikwawa District Annual Reports (Agriculture) 1952-1953 (1DCCK2/2/5); 1963-1965 (3.6.10R/16559, file Ag 3; Chikwawa District Monthly Reports (Agriculture), October 1955 (1DCCK2/2/5), MNA. 
of state intervention before and after World War II. As elsewhere in Africa, the colonial government in Malawi did not have the drive or resources to forcefully intervene in production before World War II. That situation changed after the war, when even the deficit-ridden colonial government in Malawi answered the call for colonies to bail out the devastated metropolitan economies. The Tchiri River region merely amplified global trends in both periods.

\section{The second colonial occupation}

The decline in cotton output, resulting from the permanent inundation of the marshes that started with the Bomani Deluge of 1939, strengthened the hand of the country's interventionists against the backdrop of a global campaign to make the colonized help to pay for the reconstruction of Europe after World War II. Colonial governments were now charged with the mission to extend their control of agriculture beyond the market and into the sphere of production. To do this, officials in Malawi passed the landmark agricultural legislation of $195^{1}$ that addressed both the social and technical conditions of peasant production. ${ }^{30}$ The implementation of this legislation placed the country on the same type of war footing as the tax campaigns of the early colonial era had done. The resulting resistance killed some but not all agricultural projects, and those that survived did so by raising the costs of production and, just as important, by sharpening peasants' awareness of those costs.

The technical component of the legislation of 1951 was two-sided. One part addressed general problems - such as soil erosion - that supposedly affected all farmers, regardless of whether or not they were engaged in export production. The other component dealt with the challenges facing munda (dry-land) cotton growers, particularly cotton pests. The legislation required peasants to uproot all cotton plants on the dry-lands by 31 July, burn them by 15 August, and plant new seeds in a field separate from food crops at the time of the first rains. ${ }^{31}$ Cotton was to be given as much attention as food cultivation, if not more. The two-field programme that villagers had successfully fought against at the beginning of the cotton era was back on the colonial agenda.

30 Mandala, The End of Chidyerano, pp. 137-163.

31 Chikwawa Cotton Development Project [hereafter CCDP], Project Manager (J.M. Hall) to Agricultural Extension Staff, 1, 28 August 1972 (14.1.2F/40365), MNA. 
Rural responses to the above measures were different in the two districts of the Lower Tchiri Valley; the Chikwawa (or northern) and Nsanje (or southern) districts. Resistance was fiercest in the more densely populated Nsanje District where, after losing the dambo marshes to cotton cultivation, peasants were eager to utilize the mphala drylands more carefully for food production. With little or no land to devote to the two-field system, and eager to restore the drought-resilient sorghums they had abandoned at the beginning of the cotton era, the villagers responded to the government's betterment programme on two fronts. Merging their protest with the national movement for political independence, most stopped growing cotton. Nsanje thus entered the post-colonial era as a diversified economy, featuring a dying cotton agriculture that competed with the more vigorous cattle keeping, fishing, and especially labour migration. The sparsely populated Chikwawa District became the new centre of the cotton economy in the country. The African-controlled government would launch the second agricultural campaign against cotton pests in that district.

The second campaign was more successful. For one thing, there was enough room in the Chikwawa District for people to practise the two-field system. However, even more significant was the altered political context. Resistance to the government's betterment programmes during the 1950s had been part of the struggle against British rule. The attainment of political independence in 1964 changed the balance of forces. African leaders were now in charge of the campaign, which they presented as part of their larger scheme to "develop" the country, although their ideas about the role of cotton in the economy did not differ from those of the British.

Thus, after securing the support of the World Bank, the new government launched the "Chikwawa Cotton Development Project" (CCDP) in 1968. Then, from 1973 - as the project expanded its stated mission to include other crops as well as cotton, and also incorporated the Nsanje District - the CCDP came to be known as the "Lower Shire Valley Agricultural Development Project" (SVADP) or "Project" for short, the terms used throughout this chapter to refer to the project both before and after 1973. The project was considered to have entered the era of so-called "integrated" development after 1973, but that was only on paper. Cotton growing in the Chikwawa District continued to dominate the organization and logic of the project, with one difference: instead of only requiring villagers to adopt the two-field system, SVADP officials also promoted spray technology.

The spray technology probably did not reduce the incidence of cotton pests, but it certainly helped to promote the cause of the two-field system, both directly and indirectly. It popularized the system directly when 
growers were required to adopt the regime in order to qualify for agricultural loans from the Project, as cultivators needed the loans to procure sprayers and pesticides. Indirectly, the spray technology helped propagate the two-field system because while trusting its effectiveness in the fight against cotton pests, villagers were also afraid of contaminating their food with pesticides. The result was a general adoption of the two-field system among Chikwawa's cotton growers, many of whom hoped to turn cotton farming into a profitable business. As Mrs Enifa Kwenje enthusiastically told my research assistant in the presence of two other ladies:

In munda [dry-land] farming, we grow cotton in its own garden; maize in its own garden; sorghum in its own garden [...] this is modern agriculture, not the traditional method, when they used to mix cotton with maize, groundnuts, and other food crops. Nowadays we follow the advice of agricultural instructors who are dead against intercropping and tell us never to mix crops [...] we raise each crop in its own field, be it cotton, maize, sorghum $[\ldots .$.$] millet. ^{32}$

These villagers were rural innovators, ready to assume new risks in production.

Most farmers today grow cotton as a pure culture in three alternative ways. Some separate cotton from food crops by alternating rows in the same field, some divide the same field into sections of cotton and of food crops, but most growers in the sparsely populated portions of the Chikwawa District raise the cash crop in its own field away from their food crops. In addition to the availability of land, the variations also reflect a household's labour and financial resources.

Although a major victory for agricultural interventionists in the postWorld War II era, the two-field system and spray technology imposed a significant financial burden on rural innovators. The technology was expensive, which was particularly true of the pesticides. According to one survey, on average, pesticides in the mid-1980s consumed about 27 per cent of the annual income of cotton farmers who owned and used their own spraying machines; the corresponding figure among farmers who also borrowed or rented the spraying machines from the rich was 33 per cent. ${ }^{33}$

32 Mrs Enifa Kwenje, Mrs Atafinu Petulo, Magret Jimu Mpheka, Tomali Village, TA Lundu, Chikwawa, 12 June 1996, SM96/16.

33 These figures are based on the following information: (1) Every sprayed acre among sprayer-owning and sprayer-borrowing farmers yielded $359 \mathrm{lbs}$. and $432 \mathrm{lbs}$., respectively (the corresponding yield among non-sprayers was $210 \mathrm{lbs}$.): Shire Valley Agricultural Development Project [hereafter SVADP], Cotton Survey, 1974/75, 49. (2) In 1983-1984, the credit price for a 
High-tech agriculture was also financially onerous because the SVADP did not subsidize the new technology; it only offered loans on which it moreover levied a 10 per cent interest charge. ${ }^{34}$ The new cotton regime fostered rural indebtedness.

From October to December 1970, 1,250 farmers applied for loans to buy sprayers, and the project's Loans Committee approved 1,178 and turned down 72 of those applications. ${ }^{35}$ Another survey concluded that during the first phase of the Project, from 1968 to 1973, peasants borrowed approximately 636,877 Malawian kwacha (MWK) (around $\$ 700,000$ ) for sprayers and pesticides. ${ }^{36}$ Poor growers, whose applications were rejected under the project's stringent eligibility requirements, ended up borrowing money and/ or technology from the wealthy who, by paying with cash, could buy it at a 10 per cent discount. The poor fell victim to money lenders, also because of the high labour demands of the new cotton regime.

Already labour-intensive even before World War II, when most growers intercropped cotton with their food crops in the marshes, the two-field system pushed household labour to its limits. Peasants needed to repeat in their cotton field nearly every major operation they performed in food production: garden preparation, burning of old stalks, sowing, weeding, and harvesting. While some operations, such as harvesting, were one-time procedures, others demanded the farmers' attention several times in each growing season. For example, peasants weeded their fields at least three times per growing season. ${ }^{37}$ Spraying was even more repetitive and labour consuming.

Villagers were expected to spray their cotton at least twelve times in a growing season..$^{3}$ Farmers began each round of spraying by mixing

complete package of pesticides for 0.4 hectare $(0.98$ acres) was in Malawi kwacha [hereafter MWK] 22.75 (Ngabu Agricultural Development Division [hereafter NADD], "Historical Statistics", [March 1984] Item 14), and in that year the price ofl kilogram of first-grade cotton was 42 tambala (or 19 tambala per lb.): see ibid., Item 13. (3) Lastly, the calculation assumes that all the cotton was first grade (which obviously it was not) among the two categories of spraying farmers (1983-1984); CCDP, Project Manager (J.M. Hall) to DC Chikwawa, Members and Chairman Liaison Committee, 11 May 1971 (14.1.2F/40365), CCDP, Monthly Reports, December 1970 (14.1.2F/40364), MNA.

34 NADD, "Historical Statistics" (March 1984, Item 14), MNA.

35 CCDP, Monthly Reports, December 1970 (14.1.2F/40364), MNA

36 CCDP, Monthly Reports, March 1974 (14.1.2F/40364), MNA.

37 Some villagers also thinned (kuzulira, kutengula, kupambula) their cotton during the initial phase in weeding: SM96/2, 13, 14, 17; CCDP, Monthly Reports, January 1971(14.1.2F/40364), MNA. 38 SVADP, Monthly Advice (February 1975), pp. 3, 582; see also ibid. (January, April 1974), pp. 311, 417. For similar struggles against cotton pests in the Old South, see Carter, An Hour Before Daylight, pp. 179-18o. Thanks to Dr Karen Fields for directing my attention to this important and fascinating account of rural life in the Old South. 
pesticides with water, often drawn a long way from the fields. They sprayed while walking at a specified pace in relation to the direction of the wind. After spraying the entire field, they cleaned and stored knapsacks and other tools ready for the next round, during which they would follow the same procedure except that the pesticides would change according to the age of the cotton crop. Spraying thus clashed with other farming operations, exaggerated the conflict between cotton and food, and encouraged the employment of extra-household labour.

According to one survey, during the 1971 to 1972 growing season, 88 per cent of "Type II" or "progressive" farmers - those who were supposedly becoming "yeoman" farmers - and 54 per cent of "Type I" or "traditional" cotton growers employed extra-household labour at some point during the season..$^{39}$ About seven years later, in 1979, it was reported that the region's cotton growers spent a total of MWK 714,000 (about $\$ 585,480$ ) on wages. ${ }^{40}$ Data also shows that a greater portion of the labour costs relate to casual or temporary workers, because even progressive farmers did not have the means to engage wage labourers on a regular basis. Regardless of the predominance of casual over regular wage earners, the labour costs and the expenditure for the spray technology combined to raise the expense of cotton agriculture, as well as the rural awareness of those costs.

\section{Stagnant incomes from cotton}

Rural incomes from cotton remained stagnant during the last three decades of the twentieth century, partly as a result of national policies and pressures that are documented in this section, and partly in response to fluctuations in world prices for the country's cotton; a subject that needs further investigation. The results of a survey I launched in 2014 to determine peasants' expenditures on cotton growing are not yet available. However, a combination of data used in the previous section (Table 6.1) and peasants' reports in the following pages, point to a widening gap between the costs and the rewards of cotton agriculture during the period under discussion.

As a result, perhaps, of their willingness to assume significant risks in production, peasants became very critical of the cotton market. Their grievances against the cotton buyer fall into three groups. First, villagers contended that cotton prices had not kept up with the rising cost of 
consumer goods. Headman Mafale of the Chikwawa District could not hide his frustration with producer prices when he addressed a public meeting attended by the leaders of the Malawi Congress Party in 1967:

My fellow friends and I are pleased of this sort of meeting and the speech of the Minister. From the time cotton was introduced in the country the price per lb. was in accordance with the economy of the country and all other things on sale in Malawi. For example it was a penny per lb. and at the same time things in stores and anywhere were also very cheap. A person could buy a 2/- shirt. Why then does the Government not raise price of cotton per lb. since the standard of living has gone high and everything is also very high, we are tired of $6 d$. per lb. of our cotton? ${ }^{21}$

Even though there is no data on consumer prices, Mafale's contention makes sense in view of the dominant trend in cotton prices, as represented in Table 6.1 below.

The second complaint contrasts income from cotton with the prices of the spray technology:

But we have only one major complaint, only one. You may grow and harvest a lot of cotton. But look at the prices they offer; only MWK4.50 [per kilo], which always comes as a surprise. No one expects such a [low] rate. People expect ten, eight, or fifteen [kwacha per kilogram], but we would always get MWK4.50 instead. And this would come after we had taken loans [to buy pesticides] at something like MWK $75^{\circ}$ per pack or bottle [...] Those who have many acres borrow up to four thousand, five thousand, and six thousand Kwacha. ${ }^{42}$

Statistical evidence presented in the foregoing section confirms the general sentiment conveyed by the above anecdotes. During the early 1980s, villagers spent between 27 and 33 per cent of their income from cotton on pesticides. ${ }^{43}$

41 Headman Mafale of T.A. Lundu (Chikwawa) at "The Agricultural Meeting Called and Conveyed [sic] by Malawi Congress Party Leaders in Lower Shire on $29^{\text {th }}$ December, 1967", Cotton File (17.16.2R/40370, Agr. 5), MNA. Emphasis added.

42 Bonjesi Binzi Namizinga, J.V. Ngalu, Mandere Village, TA Ngabu, Chikwawa, 25 May 1996 (SM96/10). The same complaint was voiced by Village Headman Daison House, Willasi Kacholola, David Nsabwe, Mbaenderana Village, TA Kasisi, Chikwawa, 17 May 1996 (SM96/4).

43 Calculation is based on figures found in SVADP, Cotton Survey, 1974/75, 49; NADD, "Historical Statistics", [March 1984] Item 14 CCDP, Project Manager (J.M. Hall) to DC Chikwawa, 
The third source of growers' dissatisfaction was indebtedness. This was a new form of indebtedness villagers incurred in their pursuit of spray technology, as was pointed out in the foregoing section. In 2002, villagers brought this issue to the attention of officials from the government and the country's textile industry during a campaign to revive cotton:

During the meeting farmers alleged that major cotton buyers, ADMARC and Great Lakes, are exploiting them by offering low prices, saying there are no profits gained from their sales. The farmers also said they spend all the money realized from cotton sales in settling debts which they get from money lending institutions at high interest rates. This is what leads to the collapse of the farming industry, they said. ${ }^{44}$

The campaign could not succeed without raising producer prices, officials were told. Another grower had expressed a similar frustration in 1996: "How can people pay back the money they owe when they received only MWK4.50 [per kilo]? How can we pay back our loans?"'5

The current study treats the above criticisms seriously because, if nothing else, they indicate the level of the villagers' willingness to invest in the cotton enterprise. It is therefore unfortunate that the current study has not completed collecting data either on peasants' expenditures or on world cotton prices for the country's cotton during the period under investigation. However, the figures on producer prices between 1950 and 1995, which are detailed in Table 6.1, show that the villagers' criticisms were well founded.

Table 6.1 Price per kilogram of first grade cotton in British, Malawi, and US currencies

\begin{tabular}{lrrrrrrr}
\hline \multirow{2}{*}{ Year } & \multicolumn{2}{c}{ Exchange rates } & & \multicolumn{2}{c}{ Prices (current) } & Prices \\
\cline { 2 - 3 } & E=US\$ & MWK=US\$ & & Pence $(£)$ & MWK & Cents (US\$) & 1950 \\
\hline 1950 & 2.80 & & $\mathbf{6 . 6}$ & $\mathbf{9 1}$ & $\mathbf{1 0 0}$ \\
1951 & 2.80 & & $\mathbf{8 . 8}$ & $\mathbf{1 2 1}$ & $\mathbf{1 3 5}$ \\
1952 & 2.80 & & $\mathbf{1 1}$ & $\mathbf{1 5 4}$ & $\mathbf{1 6 9}$ \\
1955 & 2.80 & & $\mathbf{1 1}$ & $\mathbf{1 5 4}$ & $\mathbf{1 6 9}$
\end{tabular}

Members, and Chairman Liaison Committee, 11 May 1971 (14.1.2F/40365), CCDP, Monthly Reports, December 1970 (14.1.2F/40364), MNA.

44 "Farmers Revive Cotton Growing", MNA.

45 Bonjesi Binzi Namizinga and J.V. Ngalu, Mandere Village, TA Ngabu, Chikwawa, 25 May 1996 (SM96/10). The same complaint was voiced by Daison House (VH), Willasi Kacholola, David Nsabwe, Mbaenderana Village, TA Kasisi, Chikwawa, 17 May 1996 (SM96/4). 


\begin{tabular}{|c|c|c|c|c|c|c|}
\hline \multirow[t]{2}{*}{ Year } & \multicolumn{2}{|c|}{ Exchange rates } & \multicolumn{3}{|c|}{ Prices (current) } & \multirow{2}{*}{$\begin{array}{r}\text { Prices } \\
1950\end{array}$} \\
\hline & $£=$ US\$ & MWK=US\$ & Pence (£) & MWK & Cents (US\$) & \\
\hline 1957 & 2.80 & & 13.2 & & 184 & 203 \\
\hline 1958 & 2.80 & & 13.2 & & 184 & 203 \\
\hline 1959 & 2.80 & & 13.2 & & 184 & 203 \\
\hline 1960 & 2.80 & & 13.2 & & 184 & 203 \\
\hline 1967 & 2.76 & & 13.2 & & 182 & 200 \\
\hline 1970 & 2.4 & & 13.2 & & 158 & 173 \\
\hline 1971 & & 1.20 & & 17.0 & 20 & 22 \\
\hline 1972 & & 1.25 & & 12.1 & 15 & 17 \\
\hline 1973 & & 1.22 & & 12.1 & 15 & 16 \\
\hline 1974 & & 1.19 & & 15.4 & 18 & 20 \\
\hline 1975 & & 1.16 & & 17.6 & 20 & 22 \\
\hline 1976 & & 1.09 & & 18.7 & 20 & 22 \\
\hline 1978 & & 1.19 & & 23.1 & 27 & 30 \\
\hline 1979 & & 1.22 & & 23.1 & 28 & 31 \\
\hline 1980 & & 1.23 & & 23.0 & 28 & 31 \\
\hline 1981 & & 1.11 & & 28.5 & 32 & 35 \\
\hline 1982 & & 0.92 & & 32.5 & 30 & 33 \\
\hline 1983 & & 0.85 & & 38.0 & 32 & 35 \\
\hline 1984 & & 0.85 & & 42.0 & 36 & 39 \\
\hline 1995 & & 0.07 & & 450 & 32 & 35 \\
\hline
\end{tabular}

Notes: (1) The original figures are in pounds (lb), converted to kilograms by multiplying by 2.2 . Columns 2 and 3 represent the original figures in British pounds ( $£$ ) and Malawi kwacha (MWK), respectively. I have converted British pounds into US dollars directly using data provided by the Pacific Exchange Rate Service at http://fx.sauder.ubc.ca.

I have used a variety of sources, including my own memory, to convert the Malawian kwacha into US dollars. Original figures can be found in Nyasaland Government, Annual Report of the Department of Agriculture for 1950 (p. 10), 1951 (p. 10), 1952 (p. 6), 1955 (p. 11), 1957 (p. 7), 1958 (p. 10), 1959 (p. 10), 1960 (p. 9); The Agricultural Meeting Called and Conveyed [sic] by Malawi Congress Party Leaders in Lower Shire on 29th December, 1967", Cotton File (17.16.2R/40370, Agr.5); District Commissioner (Chikwawa) to All Chiefs (Chikwawa), 24 April 1970 (17.16.2R/40370, file Agr.5/162); SVADP, Monthly Advice (January 1975), 574; NADD, Historical Statistics" (March 1984), Item 13 (for the years 1972-1984), MNA. Bonjesi Binzi Namizinga, J.V. Ngalu, Mandere Village, TA Ngabu, Chikwawa, 25 May 1996 (SM96/10).

The table of producer prices reflects, in broad terms, trends in world commodity prices immediately following World War II. The spike in Malawi's cotton prices at the beginning and end of the 1950s mirrored Europe's growing demand for African products during the era of reconstruction. Similarly, the drop in real prices in the early 1970 echoes the worldwide plunge in commodity prices at the end of the reconstruction era in Western Europe. However, even though this researcher does not yet know the prices that the country's cotton fetched on the world market, it is clear from other sources that Table 6.1 
also tells the story of a particular country's experiences of fluctuations in global prices. In addition to the continuing weight of extra-economic pressures, direct and indirect forces help to explain the sharpness of the decline in rural incomes in 1971 and their relative stagnation after that date.

One group of economic pressures takes the reader to the origins of the area that would become Malawi in 1964. When it annexed the territory in 1891, London had little interest in it. The annexation was done reluctantly, and mainly to appease Scottish nationalists. Scottish missionaries and traders, who had settled in the area after 1875 as a tribute to their national hero, Dr David Livingstone, did not want to come under Portuguese rule or John Cecil Rhodes' British South Africa Company. They instead clamoured for Her Majesty's protection and, through their allies in the House of Commons, pressured the British government until the Foreign Office appointed Sir Harry Johnston in 1891 as the Protectorate's first High Commissioner (future governor). However, as if to signal their lack of enthusiasm for this particular imperialist venture, the British Treasury reputedly gave Johnston a mere $£ 20,000$ to establish and run the Protectorate for the three years from 1891 to $1893 \cdot{ }^{46}$ The small community of Scots in the Protectorate got their "new Scotland", with its own capital of Blantyre, but the Africans would pay a heavy price. The country started with a budget deficit it has never been able to close to this day, with two immediate consequences for the story of cotton agriculture.

First, the British and their African successors taxed everything they could lay their hands on, and cotton became an easy target. Second, the government had no resources to build an efficient and affordable transportation system. ${ }^{47}$ Head porterage was still a common means of moving the country's exports and imports during the interwar period, and without sufficient funds, the government turned to private enterprise to build the country's railway system. Malawi's was the only privately financed railway system in the region and, as expected, it proved to be the most expensive. Freight charges on this system were higher than those on the publicly financed railways of Southern Rhodesia (Zimbabwe) and Uganda. Peasants paid for

46 As a result, the protectorate began as an aid-dependent country. Sir Harry Johnston financed his young administration and its wars of "pacification" with money from John Cecil Rhodes's British South Africa Company. Between 1891 and 1895, the company provided the government an annual subsidy of $£_{17,500}$ and received, in return, the "right to acquire [...] concessions of land and minerals both within and without the protectorate." (Pachai, Malawi, pp. 82, 57, 77). With its large tracts of prime land, the Chartered Company became a key player in the country's economic development and policies.

47 Mandala, "Feeding and Fleecing"; Vail, "The Making"; Vail, "Railway Development". 
the high transport costs. According to one estimate, Malawi's railways absorbed 40.66 per cent of the money that cotton growers at Chiromo market would have received for their product in $1930 .{ }^{48}$ Merchants always referred to the high freight rates when resisting any increase in producer prices. ${ }^{49}$

While the transportation hurdles affected both peasant and capitalist producers, other pressures were specifically designed to depress the incomes of peasant growers, a policy that held true during both the colonial and post-colonial eras.

According to Dr Clement Ng'ong'ola, who is my principal authority on statutory law affecting agriculture in Malawi and the author of the fourth quotation opening this chapter, the country's marketing system, during both the colonial and post-colonial periods, distinguished between those crops raised by Africans on "Customary" (public) land and those grown on private land, owned or leased by Europeans and Asians during the colonial era, and by tobacco-growing African politicians and their associates after independence..$^{\circ}$ Leaseholders sold their coffee, tea, and flue-cured tobacco by auction at the prevailing world prices. By contrast, the government deployed a barrage of ordinances to govern the sale of peasant-grown groundnuts, maize, rice, and especially the more lucrative cotton and fire-cured tobacco crops.

The legislation was intended to accomplish three related objectives. The first was to stifle and drive out competition from the markets of peasant produce. Thus, after a few years during which the cotton market was open to European as well as Indian buyers, the British Cotton Growers Association (BCGA) won the right to act as the country's sole buyer of peasant-grown cotton in $1923 .{ }^{51}$ The Association lost this monopsony at the end of the Great Depression, but that did not lead to an open market. After a short interval, when the state itself purchased cotton directly and through individuals appointed as its agents, came the marketing boards in the period after World War II. There were initially crop-specific boards, such as the Cotton

48 BCGA Manager, The Native Cotton Industry, Nyasaland, 1931, A3/2/56, MNA. The subsequent liberation and civil wars in Mozambique between the late 196os and early 1990s only worsened the situation for Malawi's exporters, who had to send their goods through Tanzanian and South African (through Zambia and Zimbabwe) ports.

49 See, for example, BCGA to DA, 19 April 1911 (A1/1/2); BCGA to [?], 3 December 1912 (A1/1/3); Acting Chief Secretary to BCGA, 3 January 1913 (A1/1/4); BCGA to DA, 26 April 1934 (A3/2/53); Director, Liverpool-Uganda Cotton Company, to Chief Secretary, 7 June 1934 (S1/269/34), MNA. 50 Ng'ong'ola, "Statutory Law".

$5^{1}$ Agreement with the BCGA, 1922, A3/2/55; Development of the Native Cotton Industry, 9 May 1923 (A3/2/68), MNA. The initial contract was for five years and was to be renewed every three years afterwards. 
Marketing Board (1951) and the Tobacco Marketing Board (1951), but they were later amalgamated into one, beginning with the Agricultural Produce and Marketing Board (1955), the forerunner to, first, the Farmers Marketing Board (FMB) in 1962, and then, the Agricultural Development and Marketing Corporation (ADMARC) in $1970 .^{5^{2}}$

The second purpose of the legislative frenzy was to give the government and its agencies the power to extract and keep the difference between the money that the country's crops fetched on the world market and the amount that officials decided to give the growers. The surpluses generated in this way kept rising as the ordinances became more successful in driving out competitors from the market. In 1966, the FMB's net profit (after deducting its expenses in buying crops from peasants and selling them abroad) represented only 0.09 per cent of the total international value of the country's peasant-grown cotton, tobacco, and a few other crops. That figure rose to about 12.77 per cent in 1971, when ADMARC announced its first earnings as a corporation. However, by 1977 , the figure had more than trebled to 38.76 per cent. As Table 6.2 shows, ADMARC's profits kept growing during the same period that producer prices were stagnant (Table 6.1).

Table 6.2 ADMARC Crop Trading Accounts, 1966 to 1977 (in MWK1,000)*

\begin{tabular}{lrrr}
\hline Year ending & 31 December 1966 & 31 March 1971 & 31 March 1977 \\
\hline Net sales value of crops & 15,556 & 20,833 & 58,520 \\
purchased & & & 2660 \\
Net profit/loss on crop trading & 14 & 12.77 & 38.76 \\
Net profit on crop trading as a & 0.09 & & \\
percentage & & & \\
\hline
\end{tabular}

*Adapted from Ng'ong'ola, "Statutory Law", ch. 6, Table 13

The third and probably most important objective of the legislation, in terms of the long-term development of peasant cotton agriculture, was to give the state and its boards the freedom to spend the surpluses from peasant produce as they saw fit.

Before the 1950s, government officials loudly proclaimed their intention to use surpluses from the peasant sector to subsidize producer prices in the event of a collapse in world prices. It did not take long before events proved the hypocrisy of that claim. When the Great Depression came in

52 Nyasaland Government, Annual Report of the Department of Agriculture 1955, p. 11; Nyasaland Government, Annual Report of the Department of Agriculture 1960, p. 9. 
the early 1930s, the government had accumulated some $£ 17,300$ as part of its share of the BCGA's profits, yet not a penny of this went to assist suffering cotton producers. ${ }^{53}$ Later, the deficit-ridden Malawi government seized every opportunity to declare its intention to subsidize peasant production, but it never saw an occasion to implement that policy. Nevertheless, the same officials always did what they said they would when it came to the second use of peasant surpluses. ${ }^{54}$

Starting in the 1950s, marketing boards were tasked to join the government in "developing", the country. This role required the boards to invest their profits from peasant agriculture in private ventures and statutory corporations. The old rhetoric of price stabilization began to disappear after the formation of the FMB and especially ADMARC, which like any other corporation, measured its success by the size of its profits. In 1977, ADMARC invested in about forty private and state enterprises in the country, enterprises that were beholden to urban welfare, and thus diverting surpluses from rural labour to subsidize urban development and lifestyles. ${ }^{55}$

One agricultural sector that benefited from ADMARC's role as an investor was the estate-based tobacco industry of political elites, including Life-President Banda himself. Peasant producers, who created the surpluses with their sweat, received no such assistance. There was no ADMARC or government to help cotton growers who needed money to pay labourers or purchase spray technology; most growers met those expenses through loans that carried high interest rates. It seems that the more resources growers put into the cotton industry, the less they got out of it.

\section{Implications of the gap between producer prices and inputs}

The widening gap between inputs and producer prices severely limited the possibilities for capitalist agriculture in Malawi, as peasants not only underutilized spray technology and wage labour, but also spread their energies across different economic enterprises. Villagers did not specialize in cotton farming, but combined the cash crop with food production, fishing, cattle keeping, wage employment, and other activities. They diversified their efforts partly because they could not live on cotton alone (just as they could not survive on any of the alternatives alone) and partly because they 
needed these other sectors to finance their cotton operations. Cotton had become a parasite.

Persistently low producer prices led both rich and poor farmers to use the expensive and unsubsidized spray technology sparingly; the poor because they could not afford the amounts they needed, and the rich because - to ward off the possibility of loss in the event of really low prices - they sold some of their pesticides to the poor. In the end, no one applied the technology as recommended. Many did not spray at all in the event of a drought. ${ }^{6}$ Rain shortage not only augured the possibility of a bad harvest, but also raised the cost of labour by increasing the distances people had to walk to obtain water for spraying. ${ }^{57}$ Thus, a large amount of the pesticides used in 1995 to 1996 came from 1994 to 1995, a season of drought.

It was not, however, only in times of drought that growers tried to minimize the cost of spraying. Farmers tried to cut expenses on a regular basis. For instance, they often increased the water-to-pesticide ratio, mixing one packet of Carbaryl with six gallons of water, instead of the recommended three. At other times they split one packet into two, mixing each half with three gallons of water.$^{8}$ Other villagers sprayed two rows of cotton with the dosage recommended for one. ${ }^{59}$ However, the most common method of reducing the cost of spray technology was also a labour-saving strategy: Villagers simply reduced the frequency of spraying. In one sample, they applied insecticides on average about five times instead of the recommended frequency of twelve to fourteen applications per season. ${ }^{60}$ Financial considerations also led cotton growers to underutilize wage labour.

When the need arose to engage extra-household labour, as during the weeding and harvesting seasons, most growers could only afford "casual" (waganyo) rather than the more expensive "regular" (wanchito) workers. The casual labourer would supplement the farm's stable workforce, consisting of the wife, husband, children, and dependent relatives. The children and

56 SM96/8, 13, 14, 17, 19. They did this during the droughts of 1964, 1970, 1980, and 1994: Chikwawa District Monthly Reports (Agriculture), March 1964 (3.5.10R/16559), February 1980 (11.4.9F/40352); Northern Chikwawa District Monthly Reports (Agriculture), March 1970 (14.1.2F/40362), MNA.

57 Ibid.; Chikwawa District Monthly Reports (Agriculture), January 1980 (11.4.9F/40352), MNA.

$5^{8}$ SVADP, Monthly Advice (April 1974), pp. 416-417, MNA.

59 SVADP, Monthly Advice (February 1975), MNA.

6o SVADP, Monthly Advice (February 1974), p. 36o. I arrived at this figure on the basis of the information that each season, rich and poor peasants sprayed, on average, 6.2 and 4.1 times, respectively. See also SVADP, Monthly Advice (April 1974), p. 417, MNA. 
dependent relatives supported the peasant farm's regular operations, as did thangata tenants on the "successful" European tea and tobacco plantations in the Tchiri Highlands. Despite their differing cultural backgrounds, both European and African farmers courted dependent workers, as an effect rather than a cause of their inability to employ wanchito workers as the backbone of their operations or to acquire ploughs and other agricultural technologies. For the same reason, cotton farmers continued to straddle different economic endeavours.

Because they could not live on their cotton proceeds alone, all cotton growers also regularly raised food for their own consumption, although the poor devoted more of their energies to food than the rich $\operatorname{did} .{ }^{6}$ Some extended their non-cotton operations beyond food, to include fishing, cattle keeping, and wage employment. They divided their efforts among these operations because neither cotton, food production, nor any of their competitors could fully support a household's needs in the partially commercialized village economy. From this perspective, cotton growing and its alternatives were functionally equivalent; none could be relied upon as the only source of income. Both non-cotton growers and cotton farmers straddled over several economic activities to support their main productive enterprise. But cotton was a parasite for economic as well as political reasons. Villagers pumped resources into cotton agriculture from other sectors of the economy because there was always a market for the cash crop. In this respect, Malawi's cotton economy was no different from that of Georgia during the 1940s when, according to the former US president, Jimmy Carter, "there was always a cash market at the prevailing price". ${ }^{62}$ No other product of the peasant sector in Malawi enjoyed such a privilege, and as we have seen earlier in this chapter, cotton enjoyed such favour because of its origins in the violence of the tax legislation. Extra-economic pressures were key to the development of the peasant cotton regime as a parasite.

Peasant cotton agriculture passed through two phases on its journey as a parasite. The first stretched from the first to the fifth decade of the twentieth century, when - under the popular methods of intercropping and intra-seasonal rotation - the unpaid labour of oppressed members of the household closed the gap between what merchants paid and the actual costs of producing the crop. Cotton acted mostly as an "invisible" parasite

61 NADD, "Garden Survey", ch. 5. The survey shows that cotton occupied 12 per cent of the smallest gardens but up to 40 per cent of the largest fields. See also NADD, "Garden Survey", ch. 4, MNA. 62 Carter, An Hour Before Daylight, p. 178. 
during this period, compared with what came in the second phase, running from the late 1940 s to the present.

As a result of its rising labour demands and the high cost of the spray technology, cotton agriculture began to absorb resources from entire sectors of the economy during Africa's second colonial occupation in the late $1940 \mathrm{~s}$. For example, many farmers used food to pay waganyo casual labourers, but even more significant was the support cotton received from wage employment outside peasant agriculture.

Having started as an alternative in the country's tax regime, wage employment beyond the valley started to prop up cotton agriculture in the 1950s under the colonial government's Master Farmers Scheme (MFS). A countrywide drive to create yeoman farmers, this programme recruited its candidates from those who were already rich. Cotton farming could not produce its own candidates for the scheme. The project instead relied on villagers who had made money in fishing, cattle keeping, food production, and especially as migrant workers. As one researcher aptly concluded, the MFS did not create rich peasants; it only assisted those who were already rich. ${ }^{63}$

The SVADP followed the same path as the MFS. Well over 68 per cent of the project's Type II or "progressive" growers during the 1970s had worked and saved money outside the country as migrant workers. ${ }^{64}$ Further, a common strand in the testimonies collected during the late 1990s is the story of a husband or son who, as a wage earner, sent money home for cotton cultivation. With this money, the wife or parent could procure sprayers, insecticides, and labour. ${ }^{65}$ Thus, in sharp contrast to the prosperous cotton centres of the first four decades of the twentieth century, the new epicentre of cotton agriculture in the country, the Ngabu Chiefdom of Chikwawa District, sent large numbers of its youths into wage employment within and beyond the district. ${ }^{66}$ Cotton "needed" the extra income to survive as an enterprise, in much the same way as the South African mines "needed" the "reserves" to reproduce their workforce. Students of export production can learn something from the vigorous debates about circulatory labour migration in southern Africa. ${ }^{67}$

63 Kalinga, "The Master Farmers' Scheme", p. 378.

64 CCDP, "Farm Survey, 1970-71", MNA.

65 Wikika Mbayenderana, Mbayenderana Village, TA Kasisi, Chikwawa, 16 May 1996 (SM96/2); May 1996 (SM96/4); MagretJongesi, Mphamba Village, TA Ngabu, Chikwawa, 20 May 1996(SMg6/6). 66 SVADP, “Cotton Survey, 1974/75," p. 17 (Table 2L), MNA.

67 See, for example, Wolpe, "Capitalism"; First, Black Gold. 


\section{Conclusion}

As an agent of Britain's ruling classes, the colonial state in Malawi was quite effective in shaping the labour relations of cotton agriculture. It not only elevated smallholder cotton farming to a pillar of the colonial relationship, but also successfully directed surpluses from the peasant sector to support other classes within and beyond the country. These transfers of wealth and the power regime that backed them, rather than the natural environment or culture, were the decisive factors in the failure of cotton agriculture to transform peasants into capitalist farmers.

Africans' incomes from cotton subsidized the needs of several non-peasant groups, starting with the state itself in its role as a tax collector. Other claimants on the same incomes included merchants, railway companies, African tobacco farmers, and metropolitan textile industrialists. As a result, there was always a wide gap between producer prices and what the country's cotton fetched on the world market. Cotton agriculture turned out to be unprofitable among European farmers, because they were also affected by some of the transfers, particularly the high freight rates charged by the country's railways. However, settlers and peasants reacted differently to their common plight.

Africans continued to grow cotton, while European farmers abandoned the enterprise, bringing an end to the government's first and preferred experiment in capitalist cotton farming. The fact that in their explanations of the fiasco, government officials in Malawi placed the blame on the environment only proves Andrew Sayer's point that: "For too long the ruling classes have attributed to 'Nature' [...] the iniquities and sufferings for which the organization of society is responsible." ${ }^{68}$ Nature did not conspire against European farmers; nor did it favour African growers. European and African cotton growers operated under the same hot and humid environment of southern Malawi; they reacted differently because they belonged to different classes in the colonial pyramid of power. Settlers were "free" agents whereas the colonized Africans were not.

African producers could not quit the unprofitable enterprise, because as British subjects they had to earn cash, even if only in order to pay their taxes. Extra-economic pressures were in full force in the peasants' engagement with the world economy. For the inhabitants of the Lower Tchiri Valley at the beginning of colonial rule, participation in the world economy meant either wage employment on European enterprises, or smallholder cotton 
agriculture. However, after their successful resistance to wage labour, villagers were left with no alternative other than to grow cotton. They could not withhold labour from wage employment and smallholder cotton agriculture, and remain British subjects. Under British power, successful resistance to wage labour implied submission to cotton merchants and the textile industry.

To raise cotton under the above conditions was to venture beyond the margins of economic rationality. This was precisely what the engineers of the colonial agenda had sought from the beginning: to compel Africans to produce for the world market, even when it did not make economic sense. The cotton industry thus developed as a parasite, feeding on the uncompensated labour of social juniors and other dependents, within and beyond agriculture. Britain's cotton project in Malawi provides a revealing case study in the reorganization of rural labour relations under colonialism.

As elsewhere, cotton agriculture in Malawi was labour-intensive. The pressure on household labour was particularly acute, because given their low incomes from cotton, most cultivators also grew their own food. The labour demands of the food economy collided further with those of cotton, because the cash crop did not come with new technologies: Africans entered and came out of the colonial period with nothing but the hoe. There were severe labour bottlenecks during the growing season, and heads of households and other farming enterprises looked for help through dependent relations.

It is therefore true, as some have observed, that the rise of export agriculture in Africa witnessed a "proliferation of patronage relations". In Malawi, both cotton-growing peasants and European tea planters deployed different types of semi-servile labour relations, ranging from social juniors to thangata tenants. However, as I have insisted in this chapter, the courtship with dependent labour was an effect, not a cause, of the farmers' inability to engage regular wage labourers or make use of advanced technologies.

In the end, what killed the dream of both colonial and post-colonial governments in Malawi to turn cotton growers into "yeoman" farmers was not some ill-defined African "conservatism", the "hostile" environment, or "unchangeable" cultural traits. The forces that guaranteed the triumph of the peasant option and the country's grinding poverty were much closer to home: the labour relations that evolved as part of British colonialism. 


\section{Bibliography}

Bates, R., Markets and States in Tropical Africa (Berkeley, 1981).

Berry, S., "The Food Crisis and Agrarian Change in Africa: A Review Essay", African Studies Review, 27 (1984), pp. 59-112.

Carter,Jimmy, An Hour Before Daylight:Memories of a RuralBoyhood (New York, 2001). "Farmers Revive Cotton Growing", Nation (Malawi), 10 January 2002.

First, R., Black Gold: The Mozambican Miner, Proletarian and Peasant (Brighton, 1983). Iliffe, John, Africans: The History of a Continent (Cambridge, 1995).

Jones, E.L., The European Miracle: Environments, Economics and Geopolitics in the History of Europe and Asia (Cambridge, 1981).

Kalinga, O.J., "The Master Farmers' Scheme in Nyasaland, 1950-1962: A Study of a Failed Attempt to Create a 'Yeoman' Class", African Affairs, 92 (1993), pp. 367-387. Kettlewell, R.W., An Outline of Agrarian Problems and Policy in Nyasaland (Zomba, 1955).

Macmillan, H.W., "The Origins and Development of the African Lakes Company, 1878-1908" (PhD diss., University of Edinburgh, 1970).

Mandala, Elias, The End of Chidyerano: A History of Food and Everyday Life in Malawi, 1860-2004 (Portsmouth, 2005).

Mandala, Elias, "Feeding and Fleecing the Native: How the Nyasaland Transport System Distorted a New Food Market, 189os-1920s", Journal of Southern African Studies, 32 (2006), pp. 505-524.

Mandala, Elias, Work and Control in a Peasant Economy: A History of the Lower Tchiri Valley in Malawi, 1859-196o (Madison, 1990).

Mazrui, Ali A., The Africans: A Triple Heritage (Boston, 1986).

McCracken, K.J., "Livingstonia Mission and the Evolution of Malawi, 1873-1939" (PhD diss., Cambridge University, 1967).

Mwase, G.S., Strike a Blow and Die: The Classic Story of the Chilembwe Rising (London, 1970).

Ng'ong'ola, Clement, "Statutory Law and Agrarian Change in Malawi” (PhD diss., London University, 1983).

Nyasaland Government, Annual Reports of the Department of Agriculture (Zomba, 1950-1959).

Pachai, B., Malawi: The History of the Nation (London, 1973).

Ravenhill, N.J. (ed.), Africa in Economic Crisis (New York, 1986).

Sangmpam, S.N., "Why the African Union Should Be Disbanded", African Technopolitan, 3 (2015), pp. 106-121.

Sayer, Andrew, "Epistemology and Conceptions of People and Nature in Geography”, Geoforum 10 (1979), pp. 19-41. 
Shepperson, G., and T. Price, Independent African:John Chilembwe and the Origins, Setting and Significance of the Nyasaland Native Uprising of 1915 (Edinburgh, 1958). South African General Mission, South African Pioneer, 45 (October 1932), p. 127; 46 (August-September 1933).

Vail, Leroy, "The Making of an Imperial Slum: Nyasaland and Her Railways, 18951935", Journal of African History, 16 (1975), pp. 89-112.

Vail, Leroy, "Railway Development and Colonial Underdevelopment: The Nyasaland Case", in R. Palmer and N. Parsons (eds), The Roots of Rural Poverty in Central and Southern Africa (Berkeley, 1977), pp. 365-395.

Vail, Leroy, "Review of 'Sara Berry, No Condition is Permanent:The Social Dynamics of Agrarian Change in Sub-Sahara Africa”, American Historical Review (1995), p. 201.

Wolpe, H., "Capitalism and Cheap Labour-Power in South Africa: From Segregation to Apartheid", Economy and Society, 1 (1972), pp. 425-456.

\section{About the Author}

Elias Mandala teaches African history at the University of Rochester, New York (United States). His major publications include Work and Control in a Peasant Economy: A History of the Lower Tchiri Valley in Malawi, 1859-196o (Madison, WI, 1990) and The End of Chidyerano: A History of Food and Everyday Life in Malawi, 1860-2004 (Portsmouth, NH, 2005). He is now working on a political and environmental history of the Magololo Chiefs of southern Malawi and former servants of Dr. David Livingstone.

E-mail: elias.mandala@rochester.edu 



\section{Part II}

Changing Labour and Land Market Institutions 



\title{
$7 \quad$ Extractive Economy and Institutions?
}

\author{
Technology, Labour, and Land in Potosí, the Sixteenth to the \\ Eighteenth Century*
}

Rossana Barragán

\begin{abstract}
Hofmeester, Karin \& Pim de Zwart (eds.), Colonialism, Institutional Change, and Shifts in Global Labour Relations. Amsterdam: Amsterdam University Press, 2018
\end{abstract}

DOI: $10.5117 / 9789462984363 / \mathrm{CHo} 7$

\begin{abstract}
The mita is frequently seen as a paradigmatic example of an extractive economic and political institution of the Spanish Empire. This chapter first provides an overview of the complex process to obtain silver, showing it is more than mere extraction. The second part delineates a complex picture of extraction based on unfree ( $m i t a$ ) and free labour, at the same time. A close analysis of the mita reveals changes, reminding us that institutions have a transformative history. Behind the continuity of the mita, there were far-reaching changes like the emergence of an important group of self-employed workers (kajchas) who were processing ores. In the third part, labour relations are linked to the institutions of land and mine ownership within the Spanish Empire.
\end{abstract}

Keywords: institutional perspectives, silver mines, extraction, land and property

In La Virgen del Cerro, a painting of the mountain of Potosí represented as Virgin Mary, the world is in the foreground. To the right is the great Emperor Charles V (1500-1558), to the left the Pope, and behind them, in the distance,

* I would like to thank Karin Hofmeester and Marcel van der Linden for their comments. This chapter is based on my research over the last four years in the Archives of Potosí, Sucre (Bolivia), Buenos Aires, and Seville. The first results are three articles: “'Indios Esclavos', "Dynamics of Continuity and Change", and "Working Silver". 
Figure 7.1 Painting of Cerro Virgen

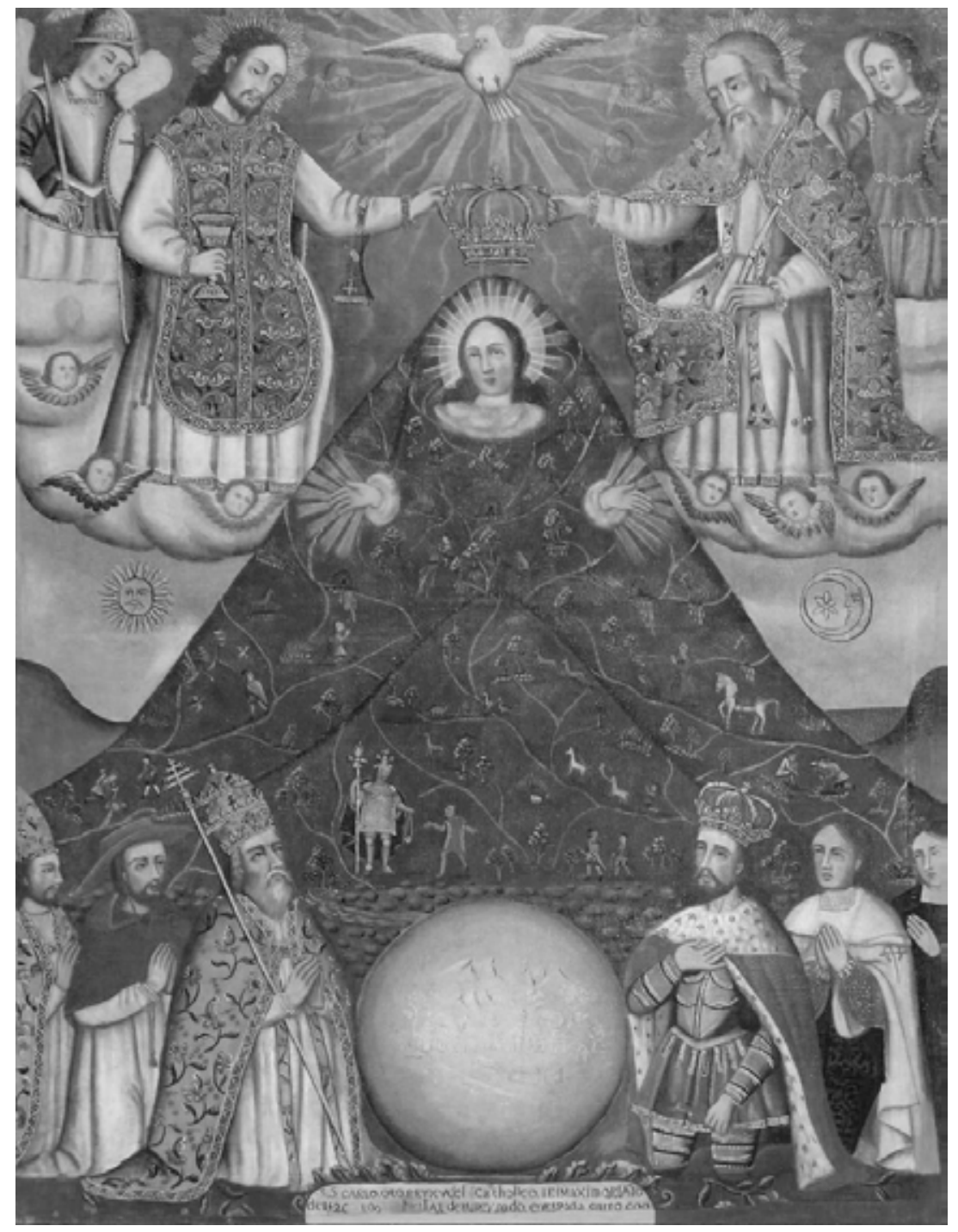

the Inca with his sceptre. ${ }^{1}$ The world has been reorganized, starting from the mining of silver that gave rise to a long production chain and to global trade, allowing the connection of all the continents from the end of the sixteenth century, when Potosí accounted for between 60 and 70 per cent

1 The author of this eighteenth-century work is unknown. The painting is in the Museum of the House Mint of Potosí. There are also other anonymous paintings with the same topic. 
of the entire world's silver production. ${ }^{2}$ The non-mining sector - mainly comprising cochineal, indigo, wood, pearls, silk, medicinal plants, and sugar - represented 14 per cent of the total exports between 1561 and 1650 , while around 90 per cent of the silver was destined for the metropolis. ${ }^{3}$

Production in the Potosí silver mines boomed spectacularly, giving rise to a "silver age" (instead of a "golden age") between 1549 and the early 16oos, followed by a decline during the long seventeenth century and a recovery between the 1720 s and the $1790{ }^{4}{ }^{4}$ Throughout this period, the mines were worked by the indigenous population. Although the system of work was based on both unfree and free labour, the emphasis in literature, particularly from the point of view of the economic institutional perspective, is on the mita or unfree labour. The mita became a paradigmatic example of an economic and political institution of the Spanish Empire that explains the differences in "power, prosperity and poverty", or "why some nations fail" and others do not, in the words of Daron Acemoglu and James Robinson. ${ }^{5}$ They speak in terms of inclusive economic and political institutions versus extractive economic and political institutions. The former should secure private property, an unbiased system of law, and

2 Silver fuelled the "birth of world trade", allowing continuous and constant exchange among the Americas, Europe, Asia, and Africa. It is estimated that Latin America produced approximately 150,000 tons of silver between 1500 and 1800 , some 80 per cent of the entire world's production in this period, from which 60 per cent came from Potosís mines in the second half of the sixteenth century. For Arturo Giráldez, global trade "emerged when all important populated continents began to exchange products continuously and in values sufficient to generate crucial impacts on all the trading partners." Giráldez, "Born with a Silver Spoon", pp. 31, 32, 40.

3 Assadourian, Elsistema, pp. 211, 216. Garner stated, following data from Sluiter, that between 1575 and 1650, 83 per cent of silver left America: 76 per cent went to Europe and 7 per cent to the East. Garner, "Where Did All the Silver Go?".

4 For Richard Garner, Potosí had growth (1549-1605), decline (1606-1723), revival (1724-1783), and finally decline (1784-1810). Garner, "Long-Term Silver Mining Trends", p. 908. For Enrique Tandeter, the revival went from 1731 until 1800 . The source for Tandeter is J.J. Te Paske. Even with a somewhat diminished role, towards the 1770s, Potosí accounted for 40 per cent of the silver from the Viceroyalty of Peru and after its separation from the Viceroyalty of Peru it accounted for 65 per cent of the production of the new Viceroyalty of the Río de la Plata. See Tandeter, "Forced and Free Labor", p. 10o. According to Garner, the annual growth rate of Potosí was 1.8 per cent in this last period. "Output was as high in the last quarter of the eighteenth century as at any time since the middle of the seventeenth century, but it was still only half of what it had been at the end of the sixteenth century and the beginning of the seventeenth century [...] Without Potosís eighteenth century revival, both the mining economy and the general economy might have remained stalled down to the end of the colonial period, or at the very least, until the reorganization of the viceroyalty in 1778": Garner, "Long-Term Silver Mining Trends", pp. 910-911. 5 Acemoglu and Robinson, Why Nations Fail. 
freedom to contract and exchange ${ }^{6}$ - a model that seems to fit the United States, a former British colony. The latter is the opposite, and applies to the Spanish colonies. This position also assumes that the exploitation of silver is an extractive process.

Acemoglu and Robinson are also very well known for their thesis about the "reversal of fortunes", or the process by which countries that were rich became poor or vice versa. This situation too is explained by the role of institutions. The authors claim there are societies that provide incentives for investments, called institutions of private property, allowing for better economic performance. By contrast, extractive institutions concentrate power in the hands of a small elite, create risks for expropriation, and discourage investment. ${ }^{7}$

In a previous work, Acemoglu, Robinson, and Simon Johnson point out that inequalities were determined not by factor endowments, as Stanley Engerman and Kenneth Sokoloff argued, but by colonial rule, the political economy of conquest, and enslavement. ${ }^{8}$ Very few people could disagree with this statement because colonialism, by definition, concerns unequal relationships between a colonial power and subordinated colonized territories and peoples. The issue becomes problematic when the authors introduce their examples. Engerman and Sokoloff underline the importance of two linked elements: the institutions and the concentration of wealth. They state that institutions included not only formal political and legal structures, but also culture. ${ }^{9}$ The Spanish practices "of awarding claims on land, native labour, and rich mineral resources to members of the elite encouraged the formation of highly concentrated landholdings and extreme inequality", in contrast to the British colonies. ${ }^{10}$ The same antinomy is present in the distinction between a mercantilist model and a liberal one. The Spanish colonies fit the first model, producing predatory,

6 Ibid., p. 75 .

7 Acemoglu, Johnson, and Robinson, "Reversal of Fortune". With regard to the mita as a clear example of an economic and political institution where forced workers could not choose (also implying the development of systems of the concentration of power in the hands of a narrow elite), see Acemoglu and Robinson, Why Nations Fail, pp. 77, 81.

8 See Acemoglu, Johnson, and Robinson, "Colonial Origins", and Engerman and Sokoloff, "Factor Endowments".

9 Engerman and Sokoloff, "Factor Endowments", p. 261.

10 "In contrast, small family farms were the rule in the northern colonies of the North American mainland that favored a more equal distribution of wealth, more democratic political institutions, more extensive domestic markets, and the pursuit of more growth-oriented policies than did those in the former." Engerman and Sokoloff, "Factors Endowments", p. 262. See also Sokoloff and Engerman, "History Lessons". 
patrimonial states, and dysfunctional markets, whereas the British colonies are seen as liberal, with a settled population, smallholders, and free markets. ${ }^{11}$

There are some general and specific problems in the historical institutional perspective that suggests, as we have seen, an opposition between good and successful institutions and bad and failed institutions. First, as Regina Grafe and María Alejandra Irigoin point out, the Spanish Empire is reduced to an absolutist, interventionist, centralist, statist empire that was disinclined to grant its subjects local government, whereas the British Empire in North America is depicted as having a parliamentary government and of granting self-government. ${ }^{12}$ Second, as Gareth Austin states, the thesis of the reversal of fortunes implies a compression of history horizontally (through space) and vertically (through time), oversimplifying the issue of causation. ${ }^{13}$ Third, it would be important to include the treatment and position of Native Americans ${ }^{14}$ and the question of slavery through the seventeenth and eighteenth centuries - particularly in Virginia and Carolina.

There are more specific issues in the accounts of the exploitation of silver, labour, and land in the Spanish Empire. Here again, the analysis is reductionist and equivocal, because Spanish colonial reality was much more complex than described by the authors. Silver is not obtained as a "fruit" ready to pick in the mines, but as ores, which have to be treated involving a long process that cannot be underestimated. In the case of labour in Potosí, we are faced with the extraction of a worldwide commodity, silver, which was based on unfree (mita) and free labour, at the same time. A close analysis of the mita furthermore reveals changes, reminding us that institutions have a transformative history. Behind the continuity of the mita over more than two and a half centuries, there were far-reaching changes, obliterated in general accounts. It is also important to consider that the labour system in Potosí was partly the result of the agency of workers. Lastly,

11 Lange, Mahoney and Vom Hau, "Colonialism and Development".

12 Grafe and Irigoin, "The Spanish Empire", p. 243. Both have criticized New Institutional Economics and opposed the factor endowments perspective, arguing that these points of view present a simplistic portrayal of the Spanish Empire. They claim that the Spanish fiscal system did not "aim at the extraction of resources or revenues from the colonies for the benefit of the metropolis. Instead it aimed at making the colonies self-sufficient." They opposed "extractive institutions", which "concentrate power in the hands of a small elite" to "institutions of private property" seen as essential for investment and successful economies: Irigoin and Grafe, "Bargaining for Absolutism".

13 Austin, "The 'Reversal of Fortune' Thesis".

14 See Reséndez, The Other Slavery. 
with regard to land, it is well known that the phenomena of large landed estates or latifundia was not a feature of the Spanish Empire, but much more of the post-colonial period, and that the distribution was not more concentrated in Latin America than in the British colonies, as Coatsworth points out. ${ }^{15}$ In the Andean region, the Indian communities disposed of their lands, and community members were recruited as part of the draft system to work in the mines (as mita labourers). Accordingly, work also has to be related to the new property rights for land and mines, an important topic that is not always present in labour historiography.

In the first part of this chapter, I provide an overview of the complex process to obtain silver, in contrast to the perspective that assumes it to be mere extraction. The second part delineates a much more complex picture of the different labour relationships in Potosí. I argue that there was a system of work that articulated unfree ( $m$ ita) and free ( $m$ inga) labour, rather than two separate categories of labourers (mitayos and mingas). ${ }^{16}$ In line with the taxonomy of the Global Collaboratory of the IISH, the mita was tributary labour during the Inca period, converted under Spanish rule into a combination of features of tributary and commodified labour. Tributary in the sense that workers were obliged to work by the state, but for private Spanish mine and mill owners. ${ }^{17}$ Commodified, because the mita workers received a wage, but also because the product of their work, silver, was at the birth of global trade.

15 Coatsworth, “Structures”, p. 139.

16 A mitayo was a worker in the mita system. Viceroy Francisco de Toledo implemented the colonial mita system, an Indian draft labour system in the mines, in 1573. The classic studies of Potosí and Indian labour remain, for the early period, Crespo Rodas, "La mita de Potosí"; Bakewell, Miners of the Red Mountain; and Cole, The Potosi Mita. For the later periods, see Buechler, Gobierno, minería y sociedad; Tandeter, "Forced and Free Labor"; and Tandeter, Coacción y mercado. For the early period, see also Platt, Bouysse-Cassagne, and Harris, QaraqaraCharka. A full account of the historiography on the mita is not possible here. For an interesting overview, see the introduction (pp. xiv-xxix) in González Casasnovas, Las dudas de la corona, and Barragán "Working Silver". One salient issue that remains under discussion is whether or not there was continuity between the Incaic and Spanish mita systems. Barnadas and Tandeter argue that these were two distinct systems. See Josep Barnadas, Charcas, p. 262, and Tandeter, Coacción y mercado, p. 44. Tristan Platt, in contrast, argues that "The mita represented a major element of continuity with the Incaico because the Incas had demanded labor rather than goods from the subjects incorporated into Tawantinsuyu": Platt, "Señorío Aymara". The term minga is a hispanization of the Aymara word mink' $a$ and of the Quechua word minq'ay still in use today to describe an agricultural wage labourer or a person who works for payment in kind rather than money. Paula Zagalsky is preparing a book on the early mita. See "La mita de Potosí: una imposición colonial invariable en un contexto de múltiples transformaciones (siglos XVI-XVII; Charcas, Virreinato del Perú), Chungará, Vol. 46, No. 3., pp. 375-395.

17 Hofmeester et al., "The Global Collaboratory". 
The mita itself went through important changes, which transformed it over its two centuries of existence. The analysis shows the important changes that transmuted the mita service into a payment in money. Nevertheless, the most important transformation was the emergence and consolidation of an important group of self-employed workers (k'ajchas) who were processing ores in the trapiches or rudimentary mills in the eighteenth century. ${ }^{18}$ For the mine owners, the k'ajchas were simply thieves who stole their ore. These self-employed workers challenged and questioned the practice, ownership, and exploitation of the ores. Accordingly, in the third part of this chapter, labour relations are linked to the institutions of land and mine ownership within the Spanish Empire. On the one hand, land access of indigenous workers explains why there was never a shift from "unfree labour" to "free labour" or a formation of proletarians. On the other hand, the importance that the self-employed acquired in the eighteenth century reveals that the workers did not completely accept the distribution of property rights, and claimed to exploit the minerals as their own right and for their own benefit.

Lastly, I address how this complex picture has consequences for the institutionalist interpretation of the Spanish Empire.

\section{Extractivism? The industry of silver}

Extractivism is a term that describes an economic model dependent on the removal of natural raw materials. This action on natural resources is perceived without any added value, in contrast to the production of manufactured goods. The exploitation of minerals is considered an example of extractivism. ${ }^{19}$ The case of silver from Potosí during the colonial period - the sixteenth to the eighteenth century - is a good example with which to

18 K'ajcha, the current spelling of this term, refers to the practice of mine raiding or Indians called "mineral thieves" by mining industrialists and other authorities, because they entered the mines on weekends to take ore for themselves. In documents, they also appear as cacchas, calchas, capchas, or cagchas. There are different accounts of the etymology. A 1759 document states that k'ajcha was a Quechua word, meaning the sound of the sling (honda in Spanish) thrown by the k'ajchas to scare off people who dared approach them inside the mines: "Descripción del terreno y lugares comarcanos de Potosi”" (1759), in "Tracts Relating to the Provinces of Buenos Ayres and Patagonia," 1756-1802, British Library [hereafter, BL], London, Add Ms. 17605 (hereafter cited as "Descripción"), fol. 265. A copy of this document is available at the Archivo y Biblioteca Nacionales de Bolivia. The trapiches were mills that allowed for a process of dry grinding ore.

19 Acosta, "Extractivism and Neoextractivism", pp. 61-62. Speaking about the natural resource wealth, we found this statement: "it is not a result of a production process": Humphreys, Sachs, and Stiglitz, "Introduction", p. 6. 
examine this perspective, because the ore went through a process requiring several months before it was transformed into pure silver. It is clear that we are dealing with an industrial process.

There were two main ways to obtain silver: through a smelting process or through amalgamation. The first was pre-colonial, and was used mainly when the ores contained high proportions of silver. In this case, the extraction process, smelting, and casting, was carried out using wind-blown furnaces (a traditional pre-Hispanic technology called huayras). Before 1585 there were around 6,00o huayras in use in Potosí. ${ }^{20}$

The amalgamation process introduced in the mid-1570s was used for more than two centuries, and was crucial when the content of silver in the ores declined. It is possible to distinguish at least six stages in this process: ore extraction, selection, trituration of minerals, amalgamation, washing of the mixed minerals, and distillation. ${ }^{21}$ In all these steps, the work was in the hands of the Indian population, some unfree and others free. The work was done in the mines in the mountain of Potosí, where they had to obtain the ores, and within the refining mills owned by Spaniards, where the ores were transformed into silver (see Image 1). Most of the Indian people working in the mines and in the mills received a name related to the activity for which they were responsible.

In the first stage, inside the mines, there was a division of work between those who cut the ore (barreteros) who were free wage workers (minga), and those who carried out the ore from the mines in leather sacks or reed baskets (apiris) who were unfree workers (mita). Immediately after, people known as palliris, who were also free workers, selected the ore. The selected ore was prepared and transported by llamas, controlled by their owners (cumiris), from the mountain to the refining mills (ingenios), where all the processes of amalgamation took place. To maximize the amalgamation of ore with quicksilver (mercury), it had to be pulverized, a task that was accomplished within the refining mills in ingenios. The ingenios were rectangular constructions that enclosed the rooms necessary for storage, the mill, and the open spaces used in the different stages in the process of converting the ore into silver.

Although there were mills driven by human power, by mules, or by horses, the water-driven mill became the centrepiece of the ingenio after

21 Garavaglia speaks of five stages, to which I added one. See Garavaglia, "Plata para el Rey", p. 129 . 
Figure 7.2 An ingenio in 1585

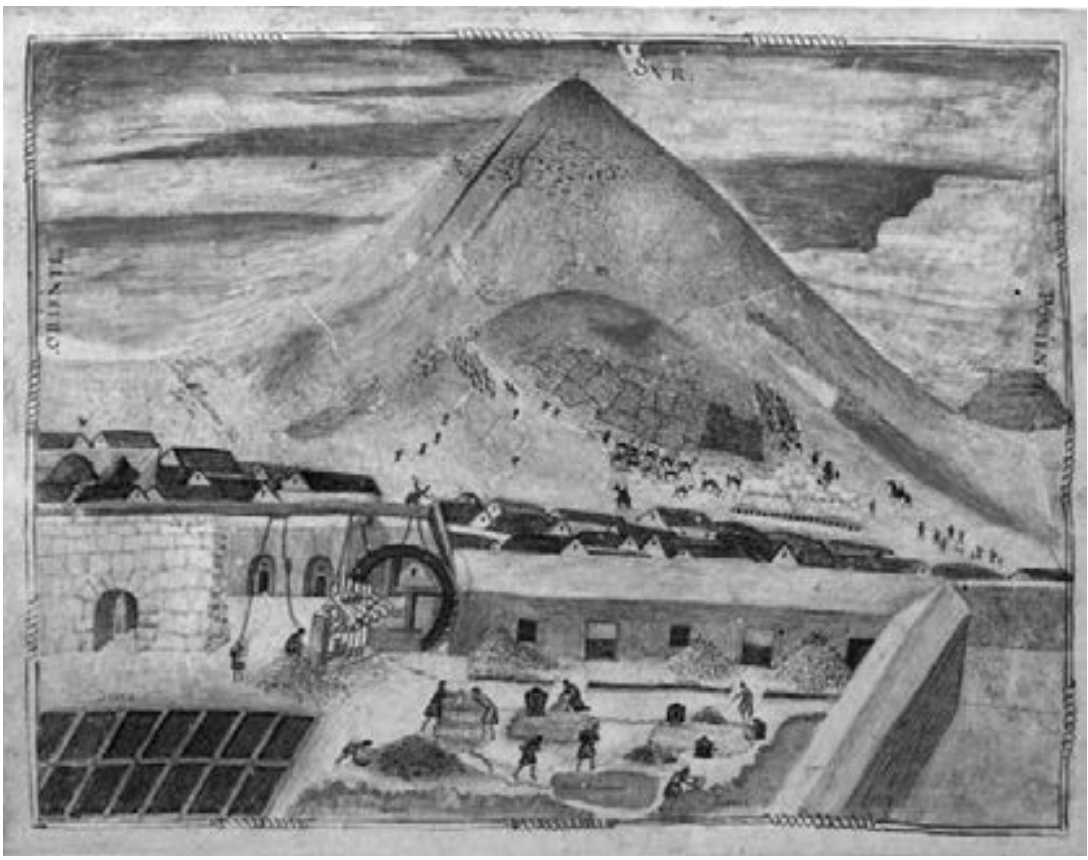

Source: The Hispanic Society of America

the 1570 . To construct them, dams and aqueducts were also necessary. ${ }^{22}$ The water was conducted through aqueducts towards the stream that ran under the mountain and through the city, becoming the industrial axis of all the water-driven mills, and what was called the Ribera of Potosí. The city's stream was also canalized in a five-kilometre course. The water used in one refining mill was returned to the channel to be used in the next one. ${ }^{23}$

The water-driven mills consisted, as Peter Bakewell describes them, of massive machinery: a waterwheel some eight metres (twenty-six feet) tall, with iron stamping shoes that weighed over forty-five kilograms each (and even larger after the mid-1570s). In 1603 there were forty-eight ingenios,

22 In some cases the dams used existing lakes, but it was necessary to build other reservoirs in order to increase the volume of water. This work was driven by Viceroy Toledo (around 1577) using the Indian labour force. See Gioda, Serrano, and Frey, "L'Eau et l'Argent à Potosí". In the 1580 s, seven dams had already been built, and in 1621 there were thirty-two water reservoirs. 23 Bakewell, Miners of the Red Mountain, p. 13. See also Garavaglia, "Plata para el Rey". 
Figure 7.3 Instruments used in the oven to distil mercury according to Alonso Barba, 1640*

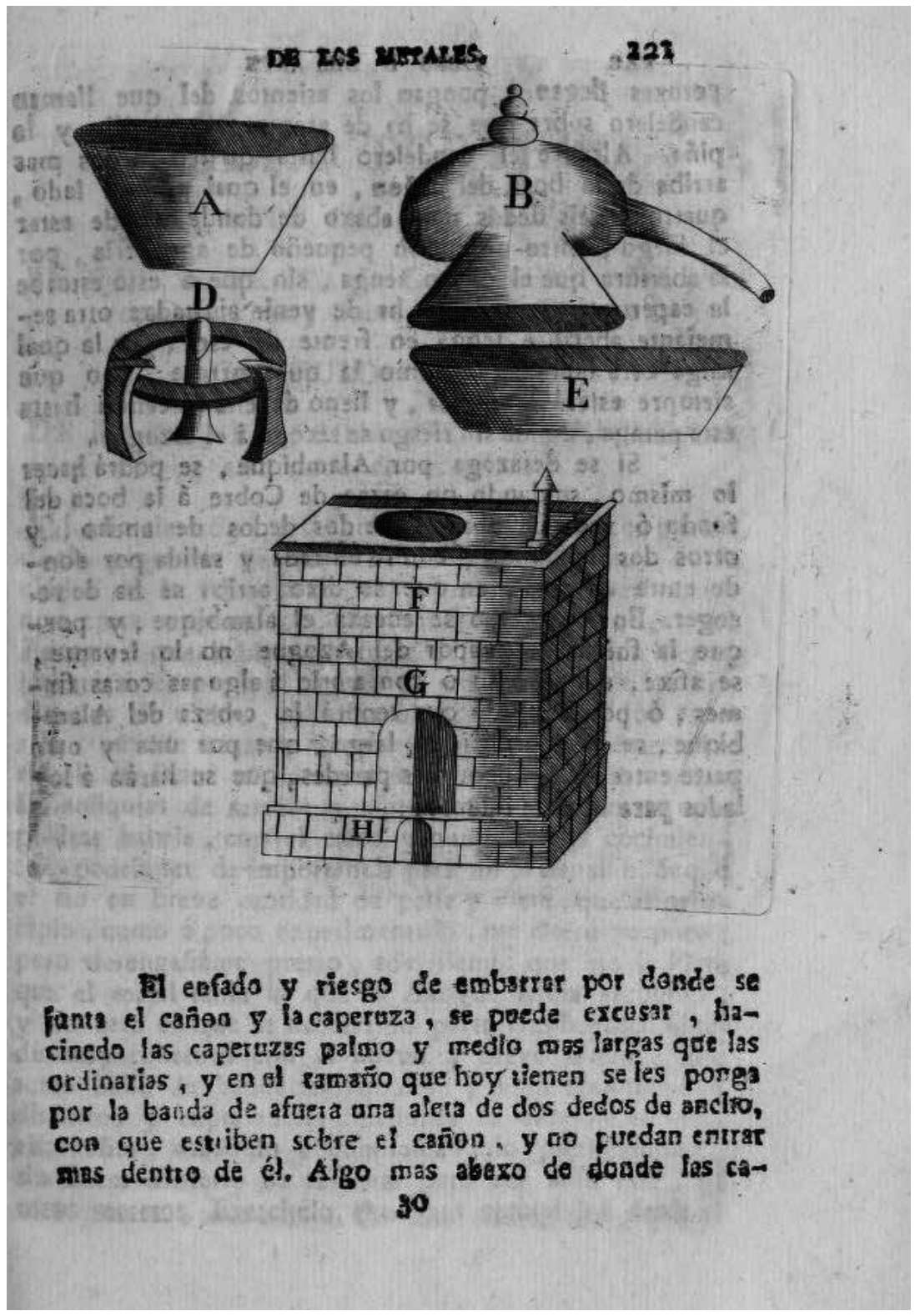

* Barba, Arte de los metales. 
some of which had two milling assemblies (cabezas), and by 1610 there were around 140 cabezas. ${ }^{24}$ Unfree mita workers known as indios morteros "fed the stamps of the mill and its mortar block". ${ }^{25}$

The amalgamation could then start. Water was key to this process, and the amount of every element to be blended was the responsibility of the refiner; a Spaniard or a mestizo. The mixing in Potosí was frequently carried out using special boxes. Each box (cajón) held fifty quintales of flour $(5,000$ pounds) and five of salt, mercury (six to ten pounds per quintal of ore), copper sulphate (magistral), and iron. ${ }^{26}$ The "dough" was removed and mixed by the feet (pisada) of the free workers or mingas (repasiris) for several weeks (three weeks or more) until the mercury was completely incorporated in the mixture. ${ }^{27}$

After amalgamation, the fifth stage could start. This was the washing process, which used a stream of water. The light particles were washed away, while the heavy parts of the mix - consisting of the amalgam of mercury and silver - settled, constituting the pella. Habitually, several vats and settling pools were used in series to maximize the recovery of the mercury amalgam.$^{28}$ The pella was then squeezed into bags to obtain a solid dough.

The last stage consisted of the distillation of mercury. The dough was placed into conical shapes that were heated for eight to ten hours, until the mercury had been completely distilled. The conical silver pieces were then sent to the Mint House to pay tax (20 per cent) to the Crown.

Technology was important throughout the process, but so was the organization and division of labour. There was certainly a significant investment at the end of the sixteenth century that allowed water to be supplied almost all year, using it as power for the process of amalgamation. Undoubtedly, the division of labour was also very striking. The terminology of the different types of work that the mine demanded, such as the unfree labour of mitayos apiris (carriers), and the free labour of mingas or palliris (selectors of metal), cumuris (those that brought the ore down from the mine to the refinery), and repasiris (those that trampled the amalgam) was in native languages. This reflects the magnitude of the native population's participation and their expertise. Last but not least, there were also shifts between different categories of workers: unfree and free. 


\section{Labour relations in Potosí ${ }^{29}$}

Historiography has established a period prior to 1573 , and a subsequent period marked by the policies of the Viceroy Francisco de Toledo. Carlos Sempat Assadourian, a historian who criticized the notion of enclave, proposed the concept of a "colonial system" that emerged with the restructuration of the economic and political space. In the mines, this involved relaunching Potosí mining, introducing technological changes, and imposing rules for the continuous provision of labour, the mining mita. ${ }^{30}$

During the period prior to 1574 , the indigenous population carried out the extraction using their own means of production, exploiting part of the mines at their own cost ${ }^{31}$ and largely for their own benefit. They even controlled the sale in local markets. ${ }^{32}$ In other words, it seems that the Spaniards - who were the mine owners - had only a small part in the extraction and processing of ore. They assigned a certain number of varas (o.8 metres) in the mines to Indian workers to exploit minerals, and in exchange, the workers gave the owner part of the ores, which were sold - again and immediately - back to the same workers for the smelting process. ${ }^{33}$ Although no name has been given to these labour relations, it is clear that many workers exploited the mines in a system of sharecropping or a form of lease of the property. A single but exceptional testimony from 1551 states that the Indians of Collao wanted to obtain a "license to extract silver but without the intervention of the Spanish" ${ }^{34}$ Starting from 1574 , however, the situation would be very different.

Significant changes were introduced between 1572 and 1576 as a result of reduced production due to the scarcity of high-grade ores. The amalgamation process became the main procedure for refining, replacing the indigenous smelting and casting technique. This technology, as we have seen, required the provision of mercury, coming from the mine of Huancavelica (in central Peru), water for the refining mills, and an important contingent of labour power.

These changes led to an "almost absolute concentration of the means of production in the Spanish group” (the Spanish people) as regards both the

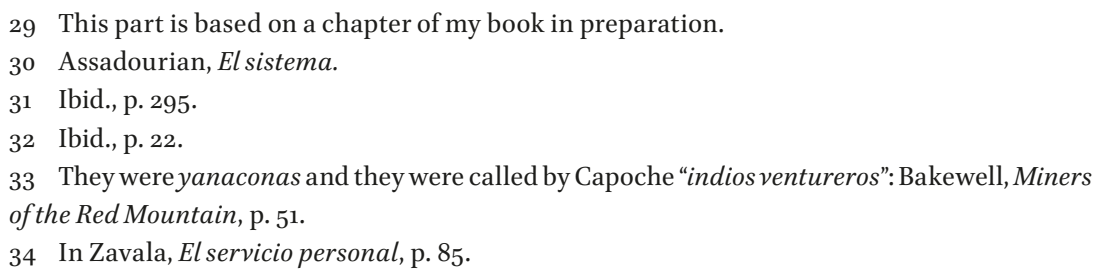


extraction and the refining process. ${ }^{35}$ Referring to the writings of Capoche (a Spaniard owner of some mines and mills, and one of the most valuable sources) from the sixteenth century, ${ }^{36}$ Assadourian considered that the indigenous population suffered from degradation because they began to be subordinated to a wage system. Capoche wrote that "the invention of [the procedure of amalgamation with] quicksilver deeply saddened them [...] as it deprived them of their profit, and the only possibility they had to sustain themselves and to pay their rent was with daily paid labour, having owned all the past wealth". ${ }^{37}$

The constant supply of mita labour was based on an old and sophisticated Inca system of work organization. The term mita in Quechua and Aymara languages means "turn" or "to work in their turn", and was used for different kinds of labour that people carried out for the state or their authorities. The mita in the mines involved an Indian population of upwards of 14,000 males between eighteen and fifty years of age coming (with their families) to work in Potosí from different villages in seventeen provinces. This magnitude in the mines was certainly new. The people had to go to the mines and mills of Potosí for a period of one year under the leadership of local Indian authorities (caciques or curacas), directed by mita captains (first six and later eleven) who were also Indians working under the control of Spanish authorities.

From the beginning, the mita raised the problem of "personal service", that is, the tension between the freedom of the Indians considered (as was any subject under the Spanish Crown) as vassals, and the obligation to work in the mines, considered as a sign of unfree men. ${ }^{8}$ Coercion was based on two articulated reasons. First, in name of the public good, and more specifically, the importance of the industry for the economic support of the monarchy. In 1647, in his book Política Indiana, the jurist Juan de Solórzano Pereira suggested that the princes had coercive powers over their vassals whenever the latter understood that this was for the universal good. Second, the obligation that the members of the republic, all vassals of the Crown,

35 Assadourian, "La producción”, p. 32.

36 Capoche wrote the Relación general de la Villa Imperial de Potosí (1585) that described Potosí after 1545 . He himself was involved in the production of silver.

37 Assadourian, "La producción", p. 29.

$3^{8}$ In the background of these considerations were the debates in the early sixteenth century about the colonization of America and the situation of Indians. Juan Ginés de Sepúlveda, influenced by Aristotle, asserted that Indians were not capable of self-government and could be subjected to bondage or slavery, while Bartolomé de las Casas was opposed to this position. 
had to help each other much like the parts of a human body. In this context, the Indians were considered the feet of the republic. ${ }^{39}$

The conditions of the mita work were clearly defined. First, the 12,00o to 14,000 workers (mita gruesa; the number could change from one year to the other) were divided into three regiments of labourers (mita ordinaria) to allow shifts between them. Second, every mitayo or labourer had to work for one week and not work during the following two weeks (those not working were considered to be resting or in "huelga"). On the third week, they had to start working again.

Table 7.1 Regiments and shifts of work

\begin{tabular}{|c|c|c|c|c|c|}
\hline 1st week & 2nd week & 3rd week & 4th week & 5th week & 6th week \\
\hline \multicolumn{6}{|l|}{$\begin{array}{l}1^{\text {st }} \text { regiment } \\
\text { of labourers }\end{array}$} \\
\hline & \multicolumn{5}{|c|}{$\begin{array}{l}2^{\text {nd }} \text { regiment } \\
\text { of labourers }\end{array}$} \\
\hline & & \multicolumn{4}{|c|}{$\begin{array}{l}3^{\text {rd }} \text { regiment } \\
\text { of labourers }\end{array}$} \\
\hline \multicolumn{6}{|l|}{ Working } \\
\hline Non-working: & & & & & \\
\hline
\end{tabular}

At the same time the mita labour was organized, ${ }^{40}$ there was a change from the payment of tax in kind to a cash tax system, which obliged the indigenous population to be more involved in the trading circuits (sale of products), and the sale of their labour in mines and in agricultural companies.

The mita workers (or draft labour) were one part of the labour system of Potosí and the others were the minga workers. Both received a salary, and in this sense both were wage workers. To the extent that the mita was considered as unfree labour (it was obligatory work organized by the state) the mingas appear in literature as free labour. This opposition between "free" and "unfree" is not completely appropriate, however, because the etymology 
of minga is related to workers paid by the day (like jornaleros) ${ }^{41}$ and because they might have been less "free" than we thought. The research that I have been carrying out has led me to establish that we should speak of a single system of work, particularly for the eighteenth century, the mita-minga system, instead of two separate and opposed categories of labourers. In order to understand this proposal, we need to consider again the coexistence of the three regiments of labourers and the rhythm of work. The labourers who were not working as mitayos or unfree workers could be engaged in other enterprises during the two weeks that they were not working. Some sources indicate that the free workers or mingas were hired precisely from among the men who were "de huelga", for example, the mitayos. ${ }^{42}$ If so, free workers or mingas could also be unfree workers or mitayos. In other words, there was a combination of different labour relations realized by the same people in different weeks and months.

\section{Table 7.2 Workers' changing between different categories in a month}

$\begin{array}{llll}\text { Unfree labour } & \text { Freelabour } & \text { Freelabour } & \text { Unfree labour } \\ \text { Mitayo } 1^{\text {st }} \text { week } & \text { Minga } 2^{\text {nd }} \text { week } & \text { Minga } 3^{\text {rd }} \text { week } & \text { Mitayo } 4^{\text {th }} \text { week }\end{array}$

Taking into account the relationship between the mita and the minga workers has important consequences. If the mita system consisted of three shifts combined with the work of the mingas, it becomes clear that we cannot study mitayos without studying mingas and vice versa. Nor can we conclude that there was a transition from a system of unfree labour to a system of free labour, because the two were completely intertwined. The ensemble as a whole can thus be understood as a system that combined a low-wage

41 Bakewell used the term "forced workers" and draft system for the mitayos, although he reminds us that the word in Quechua means a turn at some task: Bakewell, Miners of the Red Mountain, p. 197. The opposition between forced work labour and free labour ("trabajo forzado" versus "trabajo libre") comes from Tandeter, "Forced and Free Labor" and Tandeter, Trabajo forzado. See also note 16.

42 Cole, The Potosí Mita, pp. 9, 12, 14. Wages were four reales (half a peso) per day plus ore compared with 3.5 reales for mitayos and 4.5 reales per day plus coca for refining, and compared with 2.75 for mitayos. Bakewell, Miners of the Red Mountain, pp. 123-124. Even Tandeter (who states that the mitayos were worse off than slaves) recognizes that initially mitayos' work as mingas during their rest weeks compensated for the week of hard work as mitayos at low wages. In 1793, Sanz, the governor of Potosí, explained that the mitayos could choose in their weeks of rest to work where they wanted, in the mines, in the refineries, or in other jobs, earning from 4 to 8 reales per day. "Sobre la mita de Potosí", Archivo General de la Nación [hereafter, AGN] Colonia Gobierno 1488, Quaderno No. 1, f. 89-9o. 
corvée or mita with the well-paid minga work. Lastly, as Peter Bakewell argued a long time ago, if all the mingas came from the mita ordinaria, minga labour then became "informally obligatory". ${ }^{43}$

Mitayos (corvée workers) and minga workers (workers paid by the day) were present from the sixteenth to the eighteenth century, but the continuity of terms can obscure changes that are analysed in the next part.

\section{Changes in the mita: Behind its continuity, Indios de faltriquera, Indios colquehaques}

The number of mitayos was reduced from 14,000 - established by Toledo in 1573 to 1575 - to no more than 4,000 by the end of seventeenth century (a decline of more than 70 per cent), and to around 3,000 in the eighteenth century $^{44}$ (Graph 1). Several factors may have contributed to this decrease, such as disease and bad working conditions, but internal migration was certainly one of the main causes. ${ }^{45}$ The flight of people from their villages to other places and provinces was one of the easiest ways to escape from the mita.

Another important change was the fulfilment of mita obligations through cash payments, or the "metamorphosis of the mita". According to Jeffrey Cole, the changes were so great that the system was totally different from that in Toledo's time. In this new arrangement, already present in early 160o, the mitayo workers paid money to avoid going to the mines, subsidizing the hiring of mingas to take their place. The terms used to name this situation are Indios de faltriquera and Indios colquehaques, with some differences between them. "Indio de faltriquera" literally means a "pocket Indian" and refers to the payment received by an employer to replace the draft worker or mitayo, although the money was not always used to hire their replacements.

43 Bakewell, Miners of the Red Mountain, p. 132.

44 The mitayos or workers were nevertheless only 3,199 each year instead of 17,000: Decree of Viceroy Castelfuerte, 1736: Tandeter, "Forced and Free Labour", pp. 102-103.

45 Thanks to studies by Sánchez-Albornoz, Assadourian, and Saignes, we know that these migrations were part of indigenous strategies to escape from the mita, by settling in other towns and communities as "outsiders" (forasteros) or in landed estates (haciendas) as tenant labourers (yanaconas). See Sánchez-Albornoz, Indiosy tributos; Assadourian, El sistema; Saignes, Caciques. There was, then, a far-reaching redistribution of the Andean population, which took place fundamentally in the seventeenth century. This is the process of "forasterización". The forasteros were more numerous than the "originarios" or people born in the community who would pay tribute and go to the mita. The forasteros paid just tribute. The authorities tried to include the forasteros into the mita, particularly in 1683 , with the Viceroy of La Palata, but they did not succeed. 
Figure 7.4 Evolution of the number of mitayos arriving in Potosi

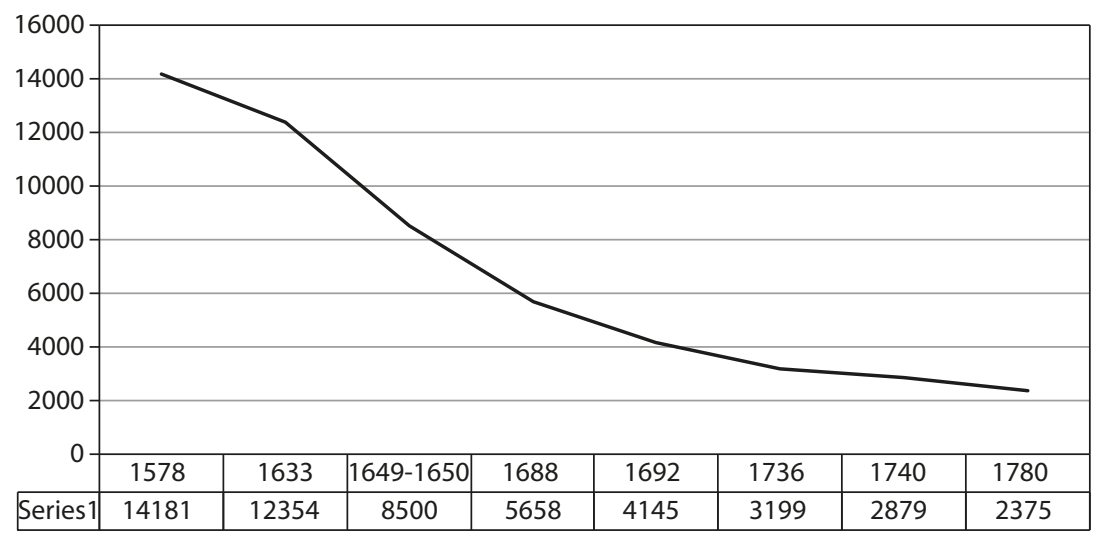

Source: Tandeter, Coacción y mercado, pp. 48, 56

Indios colquehaques (also called tasa-runas, or colque-runa-haques), meaning people who have "money", ${ }^{6}$ were those who gave an amount of money to their caciques or the authorities, in order to avoid going to the mines to work as mitayos or to help to pay for the runaways of the mita from their villages. ${ }^{47}$ They were without doubt the wealthiest members of their communities. ${ }^{48}$

To pay money in order to avoid working in Potosí would mean that the labour corvée was transformed into a monetary corvée, implying an important monetization of the members of the Andean communities through other market mechanisms. The amount paid in money also implies important economic and social differentiations within communities.

Payment in cash that grew over time could be an attractive option for employers, who could divert these sums to other economic activities. It is estimated that half of mita obligations were met through payments of silver and the other half through personal labour, with one-eighth or one-ninth of the annual draft obligations not met at all in the seventeenth century. ${ }^{49}$ This meant that the substitute minga could expect a higher wage than the mitayo.$^{50}$ At the beginning of the eighteenth century, it seems that payment

46 Qullqijaqi, Hispanicized as colquehaque; literally, in Aymara, "money people", colque runa in Quechua.

47 See also Sánchez-Albornoz, Indios y tributos.

48 See Bakewell, Miners of the Red Mountain, p. 197, and Cole, The Potosí Mita, p. 57. Tandeter, Coacción y mercado, p. 88.

49 Zavala, cited in Cole, The Potosí Mita, pp. 37-38, 57.

$5^{0}$ Bakewell, Miners of the Red Mountain, pp. 121, 123-125. 
in lieu gradually disappeared due to the critiques that this practice received in the second half of the seventeenth century, and to the upturn in mining activity starting from $1730 . .^{11}$

The practice of appropriation of minerals by workers existed throughout the Americas under different names. In Potosí it goes back to the early days (after 1550), when almost all the metal that was exploited and cast passed through the hands of the workers. At the end of the sixteenth century, after the technological transformations and the introduction of wages, the workers were allowed to enter the mines for their own benefit from Saturday to Monday morning. In the eighteenth century, these workers were known as k'ajchas. Nevertheless, the terms k'ajchas, and the trapiches associated with them, were not listed among the most important mining terms and definitions in the seventeenth century..$^{52}$ This could mean that the practice was not as widespread as it became later on. Three facts reveal that we are faced with a new labour relationship, which was established in the mines and continued for a long time. In $175^{1}$ and $175^{2}$, more than 2,000 k'ajchas succeeded in their opposition to the local authorities who were trying to expel them from the Potosí mines. This situation triggered intense discussions and disputes between miners and local and regional authorities in Potosí over the following years. ${ }^{53}$ Another indication is that - probably due to the number of people and the quantity of silver that they sold - from 1754, the bank that used to buy the ore (Banco de Rescates, which became Banco San Carlos), separated the provenance of silver into two categories and groups: on the one hand the Gremio de Azogueros (mining guild), the traditional Spanish and Creole owners of the mines, on the other hand, the trapicheros, k'ajchas and workers outside the provinces. ${ }^{54}$ The trapicheros were the owners of the rudimentary mills, and the k'ajchas could work in the trapiches (in a kind of sharecropping), but could also own one of them. Finally, a series of reports and visits speak about them, especially from 1760 onwards.

$5^{1}$ In 1793, the Governor of Potosí, Sanz, replying to the Discourse against the mita (The Discourse is in AGN Colonia Gobierno 1488. Quaderno No. 1. Sobre la mita de Potosí; Ricardo Levene published this document in Vida y Escritos de Victorián de Villava, Pruse, S.A.: Buenos Aires, 1946), explained that the "abuse" that existed before was also due to the fact that at that time the mines were only exploiting the waste and remains that had accumulated (AGN Colonia Gobierno 1488. Quaderno No. 1. Sobre la mita de Potosí, f. 89-9o).

52 Llanos, Diccionario.

53 See Barragán, "Working Silver".

54 See Annexes, Table I, Buechler, Gobierno, minería y sociedad, vol. 2, p. 473. There were also complaints against the governor-corregidor Santelices, blaming him for authorizing the recognition of the k'ajchas. Ibid., vol. 2, p. 297. 
K'ajchas, trapiches, and trapicheros, entailed the emergence of workers' independent activity for their own benefit, meaning that they no longer worked for someone else $\mathrm{e}^{55}$. The k'ajchas were producing ore while the trapicheros were refining it. In 1759 a trapiche was described as the place of grinding ore by large rocks, ${ }^{56}$ as opposed to the massive machinery consisting of a trituration mill and a water mill of the traditional ingenio or refining mill (ore mill). ${ }^{57}$

The inspection of the trapiches of $1761-1762^{58}$ shows that they were experiencing a boom: of the total of 220 trapiches, some forty had been established over the previous two years while only twenty-two were more than fifty years old. Most of them - ninety-four trapiches (42 per cent) - began operation between 1742 and 1758 , though only sixty-four had permission given by the authorities.

Some historical sources indicate that the people working in the trapiches were related to people working in the mines and could, in some cases, be the same. A document pointed out clearly that the "yndios trapicheros" were also employed as k'ajchas, pongos (Indian supervisors of work inside the mines), palliris (workers collecting ores in the piles of discarded material), and barreteros (pick workers and faceworkers) inside the mines. ${ }^{59}$

The log books of the San Carlos Bank, which show the sale of silver to the bank by the trapicheros and k'ajchas on the one hand, and by the azogueros on the other, present new and important information. We know that the azogueros were limited in number. In fact, for 1762 there were only

55 In some cases they could have some agreements of sharecropping although we do not have the evidence.

$5^{6}$ The trapiche consisted of two large stones, the first one- to two-metres long, the upper surface of which was worked flat and upon which another stone called a flying wheel rested and moved fast enough to grind the ore. The "Descripción" stated that one or two workers placed an arroba (approximately $11.5 \mathrm{~kg}$ ) of metal on the flat stone and moved the flying wheel at great speed, grinding twenty boxes a week of choice metal that was brought down from the mountain to the trapiches. The metal was then mixed with mercury and other substances in cow leatherand finally washed in a large mud tub with spring or canal water. All of this work was carried out by hand with the exception of the "repaso" or mixing that involved workers stamping the mixture with their feet. "Descripción", BL, f. 278-279.

57 Bakewell, Miners of the Red Mountain, p. 198. It seems that this stone was like the native and Inca practice of grinding ores that the Spanish called quimbalate, a boulder described as having a "half-moon shape [...] to the upper, flat, edge of which is lashed a beam. The projecting ends of the beam are alternately pushed down by a worker on each side. The boulder rocks to and fro, crushing the ore placed beneath it."

58 "Report by Saint Just on azogueros and k'ajchas", Archivo General de Indias, [hereafter, AGI], AGI Charcas 481, No. 19, 1763-1769.

59 Ibid., AGI Charcas 481, No. 19. 
thirty-nine of them. By comparison, k'ajchas and trapicheros reached a total of over 500 people who made more than 1,500 transactions amounting to a total of 19,628 pesos. $^{60}$ In general, a large number of the k'ajchas made only one transaction ( 327 people or 63 per cent), so we assume that they were fundamentally regular workers in the mines who were generating additional income.

This overview allows us to understand the reasons why the k'ajchas gave rise to intense and heated debates between the different actors involved in the mines, over the competition that the practice implied for the traditional azoguero miners. The k'ajchas were not just "thieves" as the authorities considered them. They were bringing into question the legitimacy of the property.

\section{The relationship between the labour system and the property institutions of land and mines in Potosí}

In 1980, Assadourian indicated a process of land redistribution and reorganization at the end of the sixteenth century, after the destruction of the Inca state and its depopulation, which in turn led to a decline in the agricultural area. After this reorganization, the land tenure consisted of indigenous territories, communities, and other territories in which Spanish landed estates could be constituted. In the first case, the land was owned by the whole community, but within each territory, every family had its family plots of land plus community lands where there was collective management of different crops on a rotating basis for the benefit of all the households. The communities had then to ensure the process of peasant reproduction in order to allow the use of their labour force in mining, in agriculture, and in other activities ${ }^{61}$

The establishment of boundaries for indigenous territories allowed, simultaneously, the free disposal of other lands for the Spanish Crown's use ("realengas" land). The Royal Decree of 1591 stipulated carrying out visits to rural areas to offer land for sale. This practice began when the Spanish

6o For 1761-1762, see Libro donde se sientan los marcos que se traen al rescate de los trapicheros de esta rivera, 1761-1764, Archivo Histórico de Potosí [hereafter, AHP], Banco de San Carlos BSC 313 , f. 155 . For 1788 , the book title is Libro de compras de piñas de trapicheros y ccachas, AHP BSC 383 . We have the same information for the azogueros: Libro donde se asientan los marcos de plata que los señores Azogueros de esta Villa traen a rescatar a este Banco y mercadería que corre a cargo del Maestre de Campo, 1759-1762, AHP BSC-36o.

61 Assadourian, El sistema, pp. 294, 297, 301, 303. 
Crown was hard-pressed due to the war with England, and due to the need to protect the royal fleet returning with precious metals. ${ }^{62}$ Glave rightly points out that from then on, the king appeared as the owner of the land. ${ }^{63}$ This marked "the history of expropriation of the natural resources of the Indians and of the formation of a new form of possession, ownership and exploitation of the land [...] in the hands of the colonizers" ${ }^{64}$ As agricultural markets were formed, interest in owning land also increased. ${ }^{65}$

Legal property rights were given to the Spaniards and the indigenous people through the payment of a fee in these visits to the rural areas (composiciones). The Spaniards then became owners of ranches, farms, and estates. The indigenous population also received delineated territories, and within them, had their own authorities, and important degrees of economic and political autonomy. The Spanish Crown granted legal land rights in exchange for a sum of money. Whenever there were fiscal needs, the Crown carried out new visits that often legalized prior property land rights, and in many cases, also represented modifications to the boundaries and limits. ${ }^{66}$

Although it was the king who was entitled to distribute and sell the land, the indigenous population considered it was entitled to its own land, which it requested and defended throughout the colonial period and even during the nineteenth century. ${ }^{67}$

62 Glave "Propiedad de la tierra", p. 353.

63 Glave, "El arbitrio de tierras", pp. 82-83, and Glave, "Propiedad de la tierra", p. 353.

64 Glave, "Propiedad", p. 313.

65 Ibid., p. $35^{2}$.

66 The mainland visitors and compositores in the Andean region were:

1591: Obispo de Quito, Fray Luis López. Charcas: Cochabamba, Oruro, Sucre

1594: Alonso Basquez Dávila

1596: Gonzalo Gutiérrez de Figueroa

1618-1619: Alonso Ibañez de Lobera y Alonso de la Torre: Omasuyos. La Paz, Larecaja, Pacajes, Paucarcolla, Sicasica

1647-1649: Francisco Antonio de la Masueca Alvarado: Larecaja, Cochabamba, Pilaya, Paspaya, Tomina, Misque; Joseph de la Vega Alvarado: Valle de Chillón, Chayanta, Porco, Oroncota, Mataca, Chichas; Joseph [Tello] de Meneses - Canas, Canches, Cavana, Cavanilla, Asángaro, Asillo, Chucuito, Paucarcolla

1656-1659: Gerónimo Luis de Cabrera: Laja, Guarina, Achacachi, Ancoraimes y Pucarani

1659: Fray Juan Rondón

1674: Don Pedro Luis Enriquez: Sicasica y Pacajes

1718: Juan Bravo de Rivera: Inquisivi, Sapahaqui

1724: Joseph de Lerma y Salamanca

1744: Cristóbal de Borda Palca, Lambate

See Barragán, “¿Categoría Fiscal o Categoría Social?”.

67 Barragán, "Los títulos". See also Taller de Historia Oral Andina, El ndio Santos Marka T"ula; Gotkowitz, A Revolution for Our Rights. 
The recognition of indigenous land rights was one of the pillars of the tax system and the administration of draft labour. This situation avoided the formation of an army of proletarians, who had nothing to sell other than their own labour force. Thanks to the system of agricultural and livestock ownership, they could escape from the process of proletarianization and were not obliged to sell their labour force as "free workers".

But what happened to the ownership of the mines? The legislation in the Spanish Americas maintained the legal doctrine of royal ownership of the subsoil, allowing it to be exploited by individuals in exchange for a tax on production. ${ }^{68}$ In particular, the rules for the mines of Potosí and Porco in 1574 established (in Ord. 1, Title 1, "On Discoverers, Records and Concessions") the royal right: a legal principle that allowed the king to grant permissions over the mines to his vassals and subjects, whatever their situation. ${ }^{69}$

This meant that the Indians could receive these grants as vassals of the king. ${ }^{70}$ It was also explained that the Indians could hold and exploit gold and silver mines in the same way as the Spaniards. ${ }^{71}$ Viceroy Toledo went even further. He granted a concession to operate a mine of sixty varas "held in common" for the caciques and for the communities destined to pay the taxes and expenses in mita labouring. The caciques were granted an additional eighty varas. This same provision applied to the ordinary Indians, although at the same time, it established that "more Indians cannot be granted concessions" without there being enough for the Spaniards. ${ }^{72}$ The mineral tailing was moreover designated as common property and the legal norms established that no one could prevent free access to it, prohibiting its fencing off. ${ }^{73}$

What information do we have about Indians who exploited the mines on their own behalf and who were registered as discoverers receiving concessions? In 1585, Capoche listed more than ninety-three seams in the mountain of Potosí, and in each one there were a variable number of people,

68 The Rules of La Gasca in $155^{\circ}$ in Potosí sanctioned by the Audiencia of Lima; the Rules of Polo de Ondegardo in 1562, and those of Toledo in 1574, ratified these principles, introducing a series of regulations. Martinez, "Legislación minera colonial”, pp. 1014-1015.

69 Toledo, Disposiciones gubernativas, “Título I, Ordenanza I", p. 305.

70 "Es nuestra merced y voluntad que todas las personas de qualquier estado, condición, preeminencia, o dignidad, españoles e indios, nuestros vasallos, puedan sacar oro, plata, azogue y otros metales por sus personas, criados o esclavos en todas las minas [...] que hallaren”. Leyj. Tit. XIX, Recopilación, vol. 2, p. 68.

71 Lex XIIIJ, p. 1551, 1563, 1575; Recopilación, vol., 2, p. 71.

72 Toledo. Disposiciones gubernativas, “Título I, Ordenanza V”, p. 307.

73 Toledo, Relaciones de los virreyes, “Ordenanza I”, p. 340. 
from seventy-eight in the seam named Veta Rica, for example, to just one person in some other seams. Therefore, in general, there were a high number of miners recorded, over 500. At least twenty-three Indians are mentioned among them, including some Incas and other people from Cuzco and the surrounding areas.

This panorama contrasts with what we know for the eighteenth century, when there were between twenty-seven ${ }^{74}$ and forty-four refineries, ${ }^{75}$ and mill owners who also owned the mines. No indigenous people appear among these concession holders and owners.

The Carolino Code, drafted by Pedro Vicente Cañete in 1794 but never ratified, provides interesting information about the perspectives and proposals of the authorities and azogueros of that time regarding ownership and concessions. Cañete accepted that the mines could be exploited by all vassals, ${ }^{76}$ as indicated in the Laws of the Indies. There were, however, some clauses that restricted this unlimited access. The "miners" had to be people with more than ten years of experience and they had to be "Spaniards, mestizos or Indians or nobles without the race of blacks or mulattos".77 They also had to be registered with the governor-intendants, who granted them licenses and rights $^{78}$ to two or a maximum of three seams. ${ }^{79}$ There was, nevertheless, another legal norm which directly prohibited any "servant or operator of the azogueros and owners of mines and refineries" from being able to acquire their own mines or to work in a refinery in the place where they were serving. ${ }^{80}$ It is therefore possible to think that the Spaniards were afraid of a conflict of interests.

Consequently, although it is accepted that the Indians could be owners, none of them appear as such in this period in Potosí and the articles of the code proposed by Cañete show us that not only was the registration process complicated, but also that the Indians could be denied ownership by arguing that they had "served" or worked for a mine or refinery owner.

There was, however, as already mentioned, a tradition of relatively free access to the ores in the first decades of Potosís mine exploitation. Viceroy Toledo himself, who established the mita for the mines and the amalgamation process, stated in his legal norms that the owners of the 
mines ("lords of mines") were obliged to give the workers a quarter of the mine's seams as "was done until then", under the condition that they had to sell the ore that they obtained to the owners of the mines and refineries. ${ }^{81}$ The tolerance shown to the indigenous population working on Potosí, by allowing them to take ores for their own benefit during the weekends, was therefore compensation - or at least a concession - possibly introduced at the time when the population was gradually losing freer access to the ore. What appeared as permissiveness was consequently, and at the same time, an indigenous right lost in the sixteenth century. The existence of the k'ajchas in the eighteenth century means, therefore, that the ownership of the mines and the exclusive property rights of the Spanish mine owners were not completely accepted by the workers, who insisted on their rights to access the silver mines they had benefitted from since early times.

The economy of the k'ajchas and trapicheros of the eighteenth century is a clear example of a practice that had a long history, but was reaffirmed in the eighteenth century. Indigenous people could then take advantage of the mines for themselves, even if they were not recognized as the owners.

\section{Conclusion}

It is time to return to the institutional perspective and to the analysis about Potosí and the Spanish Empire. On the one hand, in the study of the economy, the role of institutions - defined by Douglass North as "the humanly constraints that shape human interaction" ${ }^{\prime 2}$ - is certainly important. On the other hand, it is equally relevant to include the experiences of colonialism and institutions, as did Acemoglu and Robinson. Nevertheless, this chapter disagrees about their perspective on the mita and on Spanish colonialism.

I began with the description of ore's transformation into silver, questioning the view of extraction that ignores processes involving technology, labour, a complex system of coordination, and expertise. It is certainly essential not to underestimate this process, because there was evidently an early silver industry that involved at least 15,000 people at the end of the sixteenth century.

Another problem in institutional literature is the construction of a dichotomy between Spanish extractive colonialism in Latin America and

81 Toledo, Relaciones de los virreyes, “Ordenanza X”, p. 357.

82 North, Institutions, p. 3 . 
British colonialism that, in the US, produced a free market, growth, equality, and democracy. This dichotomy is thus a contrast not only between good and bad institutions, but between good colonialism and bad colonialism. In one case, coercion regarding the indigenous people is stressed, implying North America would have been a terra nullias with benign colonialism without Indians and without slavery.

Acemoglu and Robinson, in their famous and critically acclaimed book of 2012, wrote:

Throughout the Spanish colonial world in the Americas, similar institutions and social structures emerged [...] The Spanish created a web of institutions designed to exploit the indigenous peoples [...] and extract all income in excess [...] for Spaniards. This was achieved by expropriating their land, forcing them to work, offering low wages for labor services, imposing high taxes, and charging high taxes [...] Though these institutions generated a lot of wealth for the Spanish Crown [...] they also turned Latin America into the most unequal continent in the world and sapped much of its economic potential. ${ }^{83}$

It is clear, now, that these statements are not false. However, they are not entirely accurate with regard to the two topics analysed here: labour and land. The authors reduce Spanish colonial reality by disregarding studies that show more complex forms of colonial institutionalism. The present case study reveals, first, that the indigenous people received title to their lands from the Spanish Crown, through their communities, and throughout the colonial period there was not a mass process of dispossession of land in the "two hundred thousand square miles" of the "largest and most onerous scheme of labour exploitation in the Spanish colonial period" as Acemoglu and Robinson have framed it. ${ }^{84}$ My hypothesis is that access to land explains why there was no transformation in the colonial period from unfree labour to free labour in almost three centuries, nor was there a process of proletarianization. Nevertheless, at the same time, the rights to the ownership of the mines were redefined and established, and although indigenous people were not completely excluded in the distribution, they were clearly reduced to a handful of beneficiaries. The great majority were converted to temporary labourers in the mines through a complex draft system of supply (mita) coming from different villages in the countryside within a radius of 500 kilometres. 
Second, the case study shows that mita was not the same throughout the colonial period. Together with the reduction in the number of mitayos in the seventeenth century, the custom of paying "not to go to the mita" was established. This meant, on the one hand, a high degree of monetization of the indigenous population, and on the other hand, growing inequality among them.

Third, the analysis of labour relations in Potosí - and their main shifts - also shows how the agency of people involved could modify the policy of the colonial government and the structure of the labour force. The emergence of the self-employed or k'ajchas in the exploitation and transformation of the ores is the best example of the agency of workers who were not just "resisting", but struggling for what they seem to have considered their right to participate in the new economy for their own benefit. This is why I consider that we cannot label them as "thieves". The k'ajchas, together with the trapiches, maintained a quasi-parallel economy that burst onto the scene with considerable energy in the middle of the eighteenth century.

Last but not least, the case of Potosí confurms what the historiography of the last few decades on free and unfree labour has shown: that unfree labour does not imply an absence of wages, that there is not always a sharp contrast between free and unfree labour, and that there are many intermediate forms between them. ${ }^{85}$ In this context, Potosí seems to be an extreme case of intermingling categories of work. Here, workers fulfilled their compulsory work for one week, being able to become "free" workers or labourers for the following two weeks. This means that people could be involved in different labour relations at different times. Unfree labour and free labour were categories related to tasks performed largely by the same people in the same month. In addition, we should not forget that the same mitayos were mining workers for one year, becoming peasants and shepherds again when their year of service in Potosí ended. Lastly, the mitayos or the unfree labour could be, to a large extent, free labourers or mingas and k'ajchas, although not all the k'ajchas or mingas could be mitayos.

85 See, in the, 1990s, Brass and Van der Linden, Free and Unfree Labor. Marcel van der Linden wrote in that book that contrary to what Marx and Marxists have argued, unfree labour and slavery are compatible with capitalism. Van der Linden, "The Origins", p. 503. Van der Linden stated also that the intermediate forms between different categories are fluid rather than sharply defined: Van der Linden, Workers of the World, p. 22. Finally, Bosma pointed out that wage labour is not necessarily "free labour": Bosma, "Dutch Imperial Anxieties". 
The analysis of property rights to land and seams, and the labour relationships in Potosí, show the importance of case studies that allow us to understand the complexity of the situation. However, it is not just a claim of greater accuracy. In the end, the main issue is how this analysis of silver production brings into question generalizing overviews and theoretical explanations about poverty and prosperity. Inequalities were and are undoubtedly present in Latin America, but their history and causes are not just rooted in "bad Spanish institutions". It is worthwhile to remember that silver left Potosí for centuries to fuel the trade of the global world.

\section{Bibliography}

Acemoglu, Daron, and James A. Robinson, "The Colonial Origins of Comparative Development: An Empirical Investigation”, American Economic Review, 91 (2001), pp. 1369-1405.

Acemoglu, Daron, and James A. Robinson, Why Nations Fail: The Origins of Power, Prosperity and Poverty (Great Britain, 2012).

Acemoglu, Daron, Simon Johnson, and James A. Robinson, "Reversal of Fortune: Geography and Institutions in the Making of the Modern World Income Distribution", Quarterly Journal of Economics, 117 (2002), pp. 1231-1294.

Acosta, Alberto, "Extractivism and Neoextractivism: Two Sides of the Same Curse", in Miriam Lang and Dunia Mokrani (eds), Beyond Development: Alternative Visions from Latin America (Quito, 2013), pp. 61-86.

Assadourian, Carlos Sempat, El sistema de la economía colonial. Mercado interno, regiones y espacio económico (Lima, 1982).

Assadourian, Carlos Sempat, "La producción de la mercancía dinero en la formación del mercado interno colonial”, Revista Economía, 1 (1978), pp. 9-56.

Austin, Gareth, "The 'Reversal of Fortune' Thesis and the Compression of History: Perspectives from African and Comparative Economic History", Journal of International Development, 20 (2008), pp. 996-1027.

Bakewell, Peter, Miners of the Red Mountain: Indian Labor in Potosí, 1545-1650 (Albuquerque, 1984).

Barba, Alonso, Arte de los metales (Lima, 1817).

Barnadas, Josep, Charcas 1535-1565: Orígenes de una sociedad colonial (La Paz, 1973). Barragán, Rossana, “¿Categoría fiscal o categoría social?”, in Hans Joachim König, Tristan Platt, and Colin Lewis (eds), Cuadernos de Historia latinoamericana No. 8. Estado-nación, comunidad indígena, industria. Tres debates al final del milenio (AHILA, 2000), pp.143-168. 
Barragán, Rossana, "Dynamics of Continuity and Change: Shifts in Labour Relations in the Potosí Mines (1680-1812)", International Review of Social History, 61 (2016), pp. 93-114.

Barragán, Rossana, “'Indios Esclavos': en torno a la mita minera y los servicios personales, 1790-1812”, in Clément Thibaud, Federica Morelli, Alejandro Gomez, and Gabriel Entin (comps.), Les révolutions des empires Atlantiques: Une perspective transnationale (Rennes, 2013), pp. 151-178.

Barragán, Rossana, "Los títulos de la Corona de España de los indígenas: para una historia de las representaciones políticas, presiones y negociaciones entre Cádiz y la República liberal”, Boletín Americanista, 65 (2012), pp. 15-37.

Barragán, Rossana, "Working Silver for the World: Mining Labor and Popular Economy in Colonial Potosí”, Hispanic American Historical Review, 72:1 (2017), pp. 193-222.

Bosma, "Dutch Imperial Anxieties about Free Labour, Penal Sanctions and the Right to Strike", in Alessandro Stanziani (ed.), Labour, Coercion and Economic Growth in Eurasia, $17^{\text {th }}-20^{\text {th }}$ Centuries (Leiden, 2013), pp. 63-86.

Brass, Tom, and Marcel Van der Linden (eds), Free and Unfree Labor: The Debate Continues (New York, 1997).

Buechler, Rose Marie, Gobierno, minería y sociedad: Potosí y el "Renacimiento" Borbónico, 1776-1810, 2 vols (La Paz, 1989).

Capoche, Luis, Relación general de la Villa Imperial de Potosí (Madrid, [1585] 1959).

Coatsworth, John, "Structures, Endowments, and Institutions in the Economic History of Latin America”, Latin American Research Review, 40 (2005), pp. 126-144.

Cole, Jeffrey, The Potosi Mita, 1573-1700: Compulsory Indian Labor in the Andes (Stanford, 1985).

Crespo Rodas, Alberto, “La mita de Potosí”, Revista Histórica, 22 (1955-1956), pp.169-182. Engerman, Stanley, and Kenneth Sokoloff, "Factor Endowments, Institutions, and Differential Paths of Growth among New World Economies", in Stephen H. Haber (ed.), How Latin America Fell Behind: Essays on the Economic Histories of Brazil and Mexico, 1800-1914 (Stanford, 1997), pp. 260-304.

Garavaglia, Juan Carlos, "Plata para el Rey. Tecnología y producción en el Potosí colonial”, in Juan Marchena (ed.), Potosí, plata para Europa (Seville, 200o), pp. 127-140.

Garner, R.L. "Long-term Silver Mining Trends in Spanish America: A Comparative Analysis of Peru and Mexico", American Historical Review, 93 (1988), pp. 898-935.

Garner, R.L. "Where Did All the Silver Go? Bullion Outflows, 1570-1650: A Review of the Numbers and the Absence of Numbers" (21 October 2006), available at: www.insidemydesk.com/lapubs/NetDraft-SilverGoRev.pdf. 
Gioda, Alain, Carlos Serrano, and Markus Frey, "L'eau et l'argent a Potosí (ancient Haut-Pérou, puis Bolivie)", La Houille Blanche, 7 (1998), pp. 65-75.

Giráldez, Arturo, "Born with a Silver Spoon: China, American Silver and Global Markets During the Early Modern Period" (PhD diss., Universiteit van Amsterdam, 1999).

Glave, Luis Miguel, "El arbitrio de tierras de 1622 y el debate sobre las propiedades y los derechos coloniales de los indios", Anuario de Estudios Americanos, 71 (2014), pp. 79-106.

Glave, Luis Miguel, "Propiedad de la tierra, agricultura y comercio, 1570-1700: el gran despojo", in Carlos Contreras (ed.), Compendio de Historia Económica del Perú. Economía del período colonial temprano (Lima, 2009), pp. 313-446.

González Casasnovas, Ignacio, Las dudas de la corona. La política de repartimientos para la minería de Potosí (1680-1732) (Madrid, 2000).

Gotkowitz, Laura, A Revolution for Our Rights: Indigenous Struggles for Land and Justice in Bolivia, 1880-1952 (Duke, 2008).

Grafe, Regina, and María Alejandra Irigoin, “The Spanish Empire and Its Legacy: Fiscal Re-distribution and Political Conflict in Colonial and Post-Colonial Spanish America", Journal of Global History 1 (2006), pp. 241-267.

Hofmeester, Karin, Jan Lucassen, Leo Lucassen, Rombert Stapel and Richard Zijdeman, "The Global Collaboratory on the History of Labour Relations, 1500-2000: Background, Set-Up, Taxonomy, and Applications" (2015), available at: http:// hdl.handle.net/10622/4OGRAD.

Humphreys, Macartan, Jeffrey D. Sachs, and Joseph E. Stiglitz, "Introduction: What Is the Problem with Natural Resource Wealth?", in Macartan Humphreys, Jeffrey D. Sachs, and Joseph E. Stiglitz (eds), Escaping the Resource Curse (New York, 2007), pp. 1-20.

Irigoin, Alejandra, and Regina Grafe, "Bargaining for Absolutism: A Spanish Path to Nation-State and Empire Building”, Hispanic American Historical Review, 88:2 (2008), pp. 173-209.

Lange, Matthew, James Mahoney and Matthias vom Hau, "Colonialism and Development: A Comparative Analysis of Spanish and British Colonies”, American Journal of Sociology, 111:5 (2006), pp. 1412-1462.

Llanos, García de, Diccionario y maneras de hablar que se usan en las minas y sus labores en los ingenios y beneficios de los metales (1609) (La Paz, 1983).

Martinez, Molina "Legislación minera colonial en tiempos de Felipe II", in Francisco Morales Padrón (ed.), XIII Coloquio de Historia Canario-Americana, VIII Congreso Internacional de Historia de América (AEA) (1998).

Martiré, Eduardo, El Código Carolino de Pedro Vicente Cañete (Buenos Aires, 1973-1974). 
North, Douglass C., Institutions, Institutional Change, and Economic Performance (Cambridge, 1990).

Platt, “Señorío Aymara y trabajo minero: De la mita al k'ajcheo en Potosí (15451837)", in Juan Marchena (ed.), Potosí: Plata para Europa (Sevilla, 200o), pp. 189-211.

Platt, Tristan, Therèse Bouysse-Cassagne, and Olivia Harris, Qaraqara-Charka: Mallku, Inka y Rey en la Provincia de Charcas (Siglos XV-XVII): Historia antropológica de una confederación Aymara (La Paz, 2006).

Recopilación de leyes de los reinos de las Indias, 3 vols (Madrid, 1791).

Reséndez, Andrés, The Other Slavery: The Uncovered Story of Indian Enslavement in America (Boston, 2016).

Saignes, Thierry, Caciques, Tribute, and Migration in the Southern Andes: Indian Society and the Seventeenth-Century Colonial Order (London, 1985).

Sánchez-Albornoz, Nicolás, Indios y tributos en el Alto Perú (Lima, 1978).

Sokoloff, Kenneth L., and Stanley L. Engerman, "History Lessons: Institutions, Factor Endowments, and Paths of Development in the New World", Journal of Economic Perspectives, 14:3 (2000), pp. 217-232.

Solórzano Pereira, Juan de, Política indiana (Amberes, 1703).

Tandeter, Enrique, Coaccióny mercado: La minería de la plata en el Potosí colonial, 1692-1826 (Buenos Aires, 1992).

Tandeter, Enrique, "Forced and Free Labor in Late Colonial Potosí", Past and Present, 93 (1981), pp. 98-136.

Tandeter, Enrique, Trabajo forzadoy trabajo libre en el Potosí colonial tardío (Buenos Aires, 1980).

Taller de Historia Oral Andina, El indio Santos Marka T'ula, cacique principal de los ayllus de Qallapa y apoderado general de la comunidades originarias de la República (La Paz, 1986).

Toledo, Francisco de, Disposiciones gubernativas para el Virreinato del Perú, 15691574 (Sevilla, 1986).

Toledo, Francisco de, Relaciones de los virreyes y audiencias que han gobernado el Perú, Tomo I: Memorial, and ordenanzas de D. Francisco de Toledo (Lima, 1867).

Van der Linden, Marcel, "The Origins, Spread and Normalization of Free Wage Labour", in Tom Brass and Marcel van der Linden (eds), Free and Unfree Labor: The Debate Continues (New York, 1997), pp. 501-523.

Van der Linden, Marcel, Workers of the World: Essays toward a Global Labor History (Leiden, 2011).

Zavala, Sylvio, El servicio personal de los indios en el Perú (extractos del siglo XVII), Tomo I (México, 1979). 


\section{About the Author}

Rossana Barragán is Senior Researcher at the International Institute of Social History in Amsterdam (The Netherlands). Among her most recent articles are "Dynamics of Continuity and Change: Shifts in Labour Relations in the Potosí Mines (1680-1812)", International Review of Social History, 61 (December 2016); "Working Silver for the World: Mining Labor and Popular Economy in Colonial Potosí", Hispanic American Historical Review, 97:9 (May 2017). Focused on the dynamics of labour in the colonial period in Latin America, she is writing a new book on the colonial mining industry in Potosí.

E-mail: rba@iisg.nl 



\title{
8 Changing Tides
}

\section{Maritime Labour Relations in Europe and Asia*}

\author{
Matthias van Rossum
}

Hofmeester, Karin \& Pim de Zwart (eds.), Colonialism, Institutional Change, and Shifts in Global Labour Relations. Amsterdam: Amsterdam University Press, 2018

DOI: $10.5117 / 9789462984363 / \mathrm{CHo} 8$

\begin{abstract}
This chapter explores and explains the character and impact of the "long" internationalization of maritime labour markets in Europe and Asia, from 1500 to 2000 . The maritime sector provides an interesting perspective on changing global labour relations. The chapter explores the development of maritime labour relations and segmented labour markets in international shipping by studying the Dutch maritime experience from a comparative perspective. Doing so, it shows the double effect of colonialism, simultaneously integrating Asian and European maritime labour markets, while severely constraining Asian maritime labour through the rise of restrictive labour contracts and differentiating and unequal recruitment regimes.
\end{abstract}

Keywords: sailors, Asia, Europe, globalization, colonialism, segmentation, inequality

\section{Introduction}

Shipping was crucial to early modern and modern global trade. The international and mobile character of the industry had an important impact on maritime labour in various ways. The international character of the sector affected more than just maritime culture and sailors' cosmopolitan

* This chapter originates from a paper for the workshop "Economic Institutional Change and Global Labour Relations" (International Institute of Social History [IISH], Amsterdam, September 2014). 
worldview. With shipping becoming increasingly global, different local and regional maritime labour markets became entangled from the start of the early modern period onwards. European shipping companies operating in the intercontinental and overseas trade were able to use European, Asian, and Atlantic maritime labour markets. From the mid-nineteenth century onwards, renewed waves of internationalization increased this process. The maritime sector - shipping and its adjoining industries - not only brought together sailors of different origins, but also linked groups working under different labour relations.

Over the centuries, the internationalization of competition for both employers and employees interacted with changing patterns of recruitment and the institutional solutions to the complex or "imperfect" character of the maritime labour market (referring to the difficulties of matching supply and demand in (long-distance) shipping). The globalizing maritime labour market is, therefore, an interesting case with regard to understanding the development of labour relations and global entanglements over time. This chapter contributes to the aims of the current volume by analysing and explaining the character and impact of the "long" internationalization of maritime labour markets in Europe and Asia, from 1500 to 2000. This contributes to our understanding of changing labour relations in different parts of the world - and how these were connected - through a global, comparative, and sectoral approach. It explores and explains the development of maritime labour relations and segmented labour markets in international shipping by studying the Dutch maritime experience from a comparative perspective. In doing so, it indicates that the forces of European colonial expansion were not only crucial in integrating labour markets globally, but perhaps even more so in the increasing segmentation of these labour markets. This is not the history of "different" (or exploitative) economic institutions changing the historical trajectory of the non-West, because it was precisely the European "inclusive" economic institutions that were imposed that resulted in rearranging market exchange and safeguarding contractual exploitation of (Asian) labour in favour of European capital, and in its shadow, European labour.

\section{All that glitters...}

The development of markets and market institutions is generally considered to have been a stimulus for the development of wage labour, either for 
private companies or for the state. ${ }^{1}$ The development of market economies could also result in "an increase of self-employment, flexibilization of the labour market that might result in various combinations of waged work" and other constellations of labour relations. ${ }^{2}$ Increasingly, however, it is recognized that production for the market and the development of market economies can easily be combined with various forms of unfree or coerced labour, for example, slavery, indentured labour, etc. ${ }^{3}$

We should try to disentangle this a little further. Labour relations are solutions for the allocation of labour that are shaped by various forms of compensation and coercion. Labour relations, therefore, can entail the exchange of labour effort (or labour power) for protection, money, or something else. Markets gain a role in the allocation of labour in situations where labour power is sold in return for monetary or other forms of compensation, and where there are multiple sellers and buyers. In that sense, labour markets exist when multiple potential transactions of labour power are brought together. This can happen in either a physical (real) sense, through simultaneous and direct presence, for example, in a village square or in a pub, or in an abstract sense, through the notion that there are other options that (could) act as an alternative for the proposed exchange of labour in a certain place and time.

Although markets are based on the principle of exchange, this does not mean that the labour power involved is always completely free or that the worker is always the seller or even the owner of the labour power. Marx pointed this out, referring to the shortages in the English labour market in 1834 that were solved through the forceful recruitment of land labourers for the Manchester industries. "These people were bought and sold by the agents in Manchester to the producers in Manchester, just as easy as the slaves to the cotton planters in the southern states [of the United States of America]." If "free" labour markets are markets in which free workers engage in wage labour relations through engagements that are completely without coercion, the comparison made here refers to the opposite extreme end of the range of possibilities. Slave markets can be seen as capital markets, but are labour markets as well.

From that perspective, labour markets involving coerced labour might not be considered as markets of labour (where workers sell their own labour

1 International Institute of Social History, "Global History", p. 12.

2 Ibid., p. 12.

3 For example, Van Zanden, Arbeid tijdens het handelskapitalisme; Banaji, Theory as History; Van der Linden, Workers of the World.

4 Marx, Het Kapitaal, p. 250. 
effort), but as markets for labour power in a different sense (where the labour effort is sold, sometimes even - as in the case of slave markets - including its human carrier). These distinctions, however, are gradual. The range of historical possibilities can vary from workers selling their own labour power directly, to workers selling their own labour power through intermediaries (who might influence and even determine the conditions and buyers of the labour power to varying degrees), to workers who are to some degree forced to sell their labour power (directly or through intermediaries). ${ }^{5}$

It is possible that different workers under these different conditions compete - or are made to compete - in the same labour market. For example, in the labour market for local transport work in the city of Batavia in the eighteenth century, one could hire workers who were free citizens of the city, but also slaves who were hired out directly by their masters, and even slaves who were (temporarily) allowed by their master to look for so-called coolie labour. ${ }^{6}$ Nowadays, the Netherlands witnesses the introduction of involuntary labour by the unemployed, as they are being made to work (mainly in low-skilled positions) under the threat of losing social benefits. Simultaneously, there are debates around the increased employment of voluntary workers (without compensation) in positions where free wage workers were previously employed, for example, as bus drivers on local public transport routes that are considered unprofitable. ${ }^{7}$ Other recent examples can be seen in the use of forced labour by prisoners in the US, and also in cases concerning the exploitation of migrant workers who are bound by legal restrictions or through (illegal) practices, where their passports are taken away. ${ }^{8}$

These contingencies are a reminder, first, that markets are not dependent on complete freedom, but can function fairly well with elements of coercion. Second, that what happens as a result of the development of market economies or simply within markets seems to be less the product of a certain economic rationality, but appears more shaped by the actors

5 Examples of slaves hiring themselves out or being hired out as coolies were common in eighteenth-century Batavia. Examples of recruitment through intermediaries were not uncommon in the Dutch Republic. See Van Rossum, Werkers van de wereld.

6 Van der Chijs, Nederlandsch-Indisch Plakaatboek, vol. 5, p. 379. More information can be found in my paper "Transforming the Coolie".

7 See the recent debates on displacement (verdringing) and "forced" labour in the Netherlands. There are similar debates in Germany.

8 Examples come from around the globe, but a striking recent example is the allegations against the conditions of workers in Amazon distribution centres in Germany: BBC, "Germany Probes"; Bennett, “Amazon Warehouse Staff”; Van Rossum, “Redirecting”. 
involved, their ideas, their organizations, their actions to represent their interests, and their formal and informal agreements. ${ }^{9}$ It problematizes the often idealized free basis of "inclusive economic institutions", securing "property rights", market transactions, and contractual agreements. All these insights are not necessarily new, but remind us that we need to look at markets as "constituted by the law that enforces the bargains made in them", as well as shaped by the informal rules of engagement. ${ }^{10}$

\section{Hoisting for wages}

Maritime labour for long-distance shipping is an interesting case, as it seems to have been characterized by employment through wage labour relations and internationalization from early on. ${ }^{11}$ In this sense, the international character of the occupation, and the level of predominance of wage labour, might be compared with the case of military labour, although some groups of mobile workers might also be considered, such as maids and artisans in early modern Europe. ${ }^{12}$

Wage labour, of course, was not the only possible labour relation under which maritime labour could be employed. Several examples point to the possibility of using slave labour. In most of these instances, however, slaves employed as sailors seem to have been a small and controllable minority amongst a crew mainly consisting of wage workers (in the case of nineteenthcentury Arabian Seas steam and local dhow shipping) or local war bands (in the case of Balangingi slave raiders). ${ }^{13}$ One of the main exceptions may have been rowing galleys, where rowers could be easily controlled and disciplined. Especially on board sailing, and later steam and motor, vessels engaged in long-distance shipping, however, employing slave labour for maritime work on board ships was problematic, as it resulted in too many problems with controlling the labour force and too many opportunities for

9 Tilly provides an important framework on the societal and economic game involved: Tilly, Durable Inequality.

10 Hay and Craven, "Introduction", p. 26. Quoted in Banaji, Theory as History, p. 43.

11 See, for example, Van Royen, Bruijn, and Lucassen "Those Emblems of Hell"?; Van Rossum, Werkers van de wereld.

12 Zürcher, Fighting for a Living.

13 Warren, The Sulu Zone, p. 188; Sheriff, Dhow Culture, pp. 99-100; Ewald, "Crossers of the Sea". The examples provided by Winterbottom for the East India Company do not convince us that the EIC employed slaves on board their ships for maritime work on a large scale: Winterbottom, "From Hold to Foredeck". 
flight and insurrection. The disastrous experiment of the Dutch East-India Company (VOC) with slave sailors on the Mercuur in 1782, ending in a mutiny and successful escape by most of the slaves, illustrates this point well. ${ }^{14}$ It must be noted that the VOC had already anticipated the problematic nature of employing slaves as sailors, by promising them monthly payment for their work and the prospect of gaining their freedom after several voyages.

Another possibility sometimes hinted at may have been the option of sailing ships with merchant sailors, who work together on voyages, each with their own share in the cargo. This notion of "shipper-passengers", introduced by Van Leur as part of the concept of "peddler trade", may have been the case amongst certain local communities, but there is very little evidence for the widespread use of this model, as has been discussed on previous occasions. ${ }^{15}$

In early modern Asia, just as in Europe, sailors mainly seem to have been engaged in wage labour relations. As one of the first global companies to have heavily invested in both shipping between Asian destinations and in intercontinental shipping between Europe and Asia, the VOC found it relatively easy to recruit sailors in various Asian regions. In different periods, they recruited in and around Java, Formosa (present day Taiwan), Malacca, the Coromandel and Malabar coasts, Bengal, and Surat. ${ }^{16}$ By the time the VOC was interfering in maritime Asia, Asian sailors themselves often referred to their work - on ships of European companies but also explicitly on Asian ships - as being "hired" men, having "engaged in the service" of a captain, and the like. ${ }^{17}$ Recruitment was often carried out per voyage, and labour conflicts arose when payment or the time or place of disengagement seemed not to match the agreements. ${ }^{18}$

The existence of wage labour in maritime Asia was not an isolated phenomenon. It seems to have been part of larger developments related to the development and presence of market economies in Asia well before the arrival of European maritime powers, for example, in military and other labour markets in parts of Java and India. ${ }^{19}$ This reminds us of the important insight that labour markets and market economies "have come into

\footnotetext{
14 Van Rossum, “'Amok!”.

15 Van Rossum, “The Rise of the Asian Sailor?”, esp. pp. 182-183, 189-192. More elaborate explanations can be found in Van Rossum, Werkers van de wereld.

16 Van Rossum, Werkers van de wereld; Van Rossum, “A 'Moorish World”.

17 Van Rossum, "The Rise of the Asian Sailor?"

18 See, for example, the conflict preceding the mutiny on an Asian vessel in 1784: Van Rossum, Werkers van de wereld, pp. 360-362.

19 Lucassen, "Deep Monetization, Commercialization, and Proletarization"; Gommans, Mughal Warfare, pp. 69, 83; U. Bosma, "Database 1650-190o" and "Methodological paper".
} 
existence not once, but several times throughout history and in multiple regions of the world, and have in many cases also disappeared". ${ }^{20}$

The slow decline of wage labour and labour markets in parts of Asia after the arrival of European imperial powers is important to note here. Recent estimates by Ulbe Bosma show a decline of the share of commodified labour from 53 per cent in 1650 , to 38 per cent in 1800 and 36 per cent in $1900 .{ }^{21}$ In a recent critique of colonial history (and historiography) of the Dutch East Indies, Jan Breman also points out the coercive effects of colonial policies, isolating agrarian production areas and introducing obligated labour services. ${ }^{22}$

So, what are the implications of all this? Wage labour seems an old phenomenon, a solution to the problem of allocation of labour that has been employed many times in the history of complex human societies, especially for workers in specific occupations, including sailors. Being recruited per voyage or for multiple years, sailors gained rights (such as receiving wages and food), but also had duties and obligations (such as having to stay in service for a certain amount of time). The contract these wage workers engaged in could often be enforced by physical or legal violence. $^{23}$

At the same time, it seems clear that if being a wage worker is just another way of ensuring a livelihood, it becomes obvious that workers do not necessarily limit themselves to wage work alone (and where possible or needed, combine it with other strategies) or for their entire lives (so they can shift to different labour relations or strategies during their life). Sailors in particular - as becomes clear from the histories of European and Asian sailors from the eighteenth into the twentieth century - often try to profit from the opportunities provided by the mobile character of their work, through legal or illegal forms of private trade. This seems to have been done both by European VOC sailors and by Asian sailors. It is important, therefore, not to reify this as a characteristic of either Asian or European labour relations, as seems to be the tendency in literature on, for example, Chinese sailors.

All of this also suggests that if wage labour was a normal and long-lasting solution for the allocation of labour, it is no longer one unique transition to

20 Lucassen, "Een geschiedenis" (translated as Lucassen, "Outlines of a History of Labour").

21 Lucassen, “Deep Monetization, Commercialization, and Proletarization”; Gommans, Mughal

Warfare, pp. 69, 83; Bosma, "Database 1650-1900" and "Methodological paper".

22 Breman, Koloniaal profijt.

23 As in the case of the VOC: see Van Rossum, "Claiming Their Rights?". 
wage labour that should be explained. It becomes important to look at the multiple ways in which labour markets developed, rose, and sometimes declined. It also becomes crucial to look at the different possible transitions of labour relations in the long term. Of course, it becomes important to try to understand how wage labour relations related to other labour relations, and how this affected the positions and relations of workers. In essence, the question shifts from the problem of where and when wage labour arose - and whether this transition was complete or not - to where and when wage labour was in use, in what specific context, and under what conditions.

\section{Not perfect, but how does it work?}

An important starting point is the observation that the mobile and global character of the maritime industry ensured that maritime labour markets were "imperfect". This was especially the case in the age of sail, with seasons and monsoons dictating the rhythm of shipping, but it still characterized the maritime industry in the age of steam and motor engines, with economic flows dictating the need for transport and shipping. The difficulty and irregularity in the way that supply of and demand for labour were adjusted, was important in shaping the organization of and mediation in labour markets. This "imperfect" character might be seen as distinguishing for maritime labour markets, although one could wonder whether "perfect" labour markets actually ever really exist or existed. A crucial question, therefore, is what solutions are created by the actors involved, and how these solutions shape the relations between employers, intermediaries, workers, and their organizations.

There are a number of solutions for such imperfect labour markets. Three hypothetical options might be identified:

1. A completely casual situation: individual crew members are employed wherever they are needed and potential employers take whomever they can find. A casual labour market can function when there are enough sufficiently skilled workers around in the places where labour might be needed, such as overseas port cities. All this can be supported by intermediaries who do not have an influential role in the recruitment process, but merely facilitate the lodgings and bars where workers and employers meet. 
2. A completely mediated situation: entire crews or individual crew members find work (or are supplied) through recruitment intermediaries who make sure that workers are available at the time they are needed. This seems to occur when there is a shortage of (sufficiently skilled) workers or a shortage of work. Intermediaries assume an influential role, steering the conditions under which and employers for whom workers will be recruited, controlling workers when they are still potential recruits, indebting them, etc.

3. A completely formalized situation: individuals find work through (official) government or labour union recruitment bureaus, which ensure recruitment through procedures that offer workers more or less equal opportunities to find work, ruling out intermediaries and particularism.

None of these situations, of course, occur in such a "pure" form. Most of the time, there are combinations of these solutions at work, or competing. In the case of long-distance shipping in early modern Europe and Asia, maritime labour markets seems to have been characterized by intermediate forms of casual and mediated solutions, as the two following cases show.

\section{Case I: Recruitment in South and Southeast Asia, the eighteenth century}

Not much is known (yet) about recruitment in early modern Asia, but the available evidence seems to indicate a situation in the labour market that was marked more by casual solutions than by heavily mediated ones. Asian sailors could be recruited as individuals - possibly also through direct recruitment by European or Asian ship officers - being engaged mainly in wage labour relations. This seems to have been at least the case in Surat, as well as in Bengal, Malacca, Batavia, and other parts of Java. ${ }^{24}$

An incident in Malacca in February 1735 is intriguing in this regard. ${ }^{25}$ Lying at the port of Malacca, the Batavian burger Gidion Schrijver had sent out his "moor bootsman" Aldsie with "40 rijksdaalder en 12 stuivers"

24 Van Rossum, Werkers van de wereld.

25 Please note that the following paragraphs are taken from a previous paper, "The Rise of the Asian Sailor?", published as Van Rossum, “The Rise of the Asian Sailor". This example is one of the few cases with elaborate historical evidence of recruitment practices. It has therefore been included in this chapter in order to emphasize the seemingly more casual and less mediated nature of Asian maritime labour markets in comparison with early modern Europe. 
to recruit ten new Moor sailors in Malacca. Once employed on the ship, however, one of the sailors was discovered to be the inland soldier Joan de Choisa, who had fled the service of the Dutch East India Company. ${ }^{26}$

Both soldier De Choisa and foreman Aldsie were taken into custody, and before the Raad van Justitie (High Court) an interesting controversy developed around the recruitment of De Choisa by Aldsie. Joan de Choisa claimed that Aldsie had been aware of him being a soldier. The two would have met in a Chinese bar in Malacca and it was the foreman - according to De Choisa - who told him to meet again in the same bar two days later. Aldsie assured De Choisa that he could arrange transport away from Malacca and Aldsie took the soldier to the house of "Moor Aboe Backar". There they cut off his hair and Aldsie gave him sailors' clothes to the value of nine rupees. ${ }^{27}$ In the evening, they took him on board the ship of Gidion Schrijver as a sailor, where he was discovered to be a deserting soldier within two days.

The Moor foreman Aldsie was also taken into custody after Joan de Choisa was interrogated. Aldsie, however, denied the charges of having consciously recruited a deserting soldier. Being interrogated with force ("ad torturam"), Aldsie persisted that he had met Joan de Choisa in no other place than the house of Aboe Backar. Contrary to the claims of De Choisa, Aldsie stated that he had not met the soldier earlier (in a Chinese bar) and had not made any agreement regarding his transport. Aldsie did not deny having bought De Choisa his clothes and recruiting him as a new sailor (" $a$ ls een nieuw aangeworben matts"), but maintained his declaration that he did not know that De Choisa had been in the service of the company ("sonder kennisse bevoorens gehad te hebben dan den selve ten dienste der E: Comp: is geengageert geweest ${ }^{\prime \prime} .^{28}$

The example is an illustrative incident. It shows an instance of the easy recruitment of "Moor" - probably Indian - sailors in one of the main ports of the Malaysian peninsula. It shows a European captain employing European and Asian labour, and thus making good use of the local maritime labour markets. Furthermore, what is interesting is that the foreman and sailor might have met either at a Chinese bar or at the house of the Moor, Aboe

26 "door een van zijn mattroosen in presentie van zijn schrijver en stuurm: wierd g'rapporteert dat zig aan boord op hield een zoldaat in dienst der E: Comp", National Archives [NA], VOC, 9373 .

27 "dat hij gev: voorm: bootsman verzorgt heeft om hem van hier te vervoeren als dat niet konde doen hij gev: weder naar zijn post zoude gaan dat die bootsman hem gev: verzekering deede van hem gev: weg te zullen helpen gaande", NA, VOC, 9373.

28 NA, VOC, 9373. 
Backar. There seems to have been no established relation between the recruited (De Choisa) and the foreman (Aldsie) in the sense of social or financial bonds (debts, family ties, regional connections, etc.). The advance or investment provided to the new recruit, in the form of a haircut and sailors' clothing, is somewhat similar to the patterns of recruitment known for European sailors. As far as the role of the middleman - Aboe Backar - is described, this seems to have been limited to perhaps providing clothing (De Choisa's version) or temporary lodging (as might be the conclusion from the version of Aldsie, claiming to have met De Choisa at Aboe Backar's house).

The case of De Choisa in Malacca occurred around the time that the maritime labour market in the Dutch Republic seems to have taken a completely different turn. With regard to recruitment by the VOC in Asia, there are few indications that recruitment patterns changed significantly during the eighteenth century. It was only towards the end of the century, after and around the Fourth Dutch-Anglo War, that labour shortages and pressures for the recruitment of Asian sailors seem to have made the role of intermediaries more important. At the same time, however, payments for Asian sailors could have risen significantly as well. ${ }^{29}$

\section{Case II: Recruitment in the Dutch Republic, circa $1740^{30}$}

In the Dutch Republic, the maritime labour market seems to have undergone important changes around the middle of the eighteenth century. An interesting indication for this is the absence of new recruits at the time of departure of the VOC fleet leaving the republic to go to Asia. In the Dutch Republic, absentie had a specific meaning in the context of the Dutch East India Company. For the crews ready for ships to Asia, this was not a temporary absence from the work place, but absence at the time of the departure of the fleet. This meant that absent workers destined for the service in Asia missed their ship. This made absence at the time of departure effectively an act of desertion. The absence of recruits at the departure of the fleet to Asia was therefore taken very seriously. For example, a quartermaster, who had decided to take his recruitment bonus - worth two months of wages - and run away, was caught and imprisoned. According to Bicker Raije, who mentions the incident in his diaries, a woman came by the prison

29 Van Rossum, Werkers van de wereld, ch. 5 .

30 The following paragraphs are based on the paper "Desertion by Sailors, Soldiers, Slaves and Convicts in the Eurasian Empire of the Dutch East India Company", presented at the ENIUGH Conference in Paris (September 2014) and published as Van Rossum, “'Working for the Devil'”. 
Figure 8.1 Absence of VOC workers at departure from the republic, per origin, percentages per year

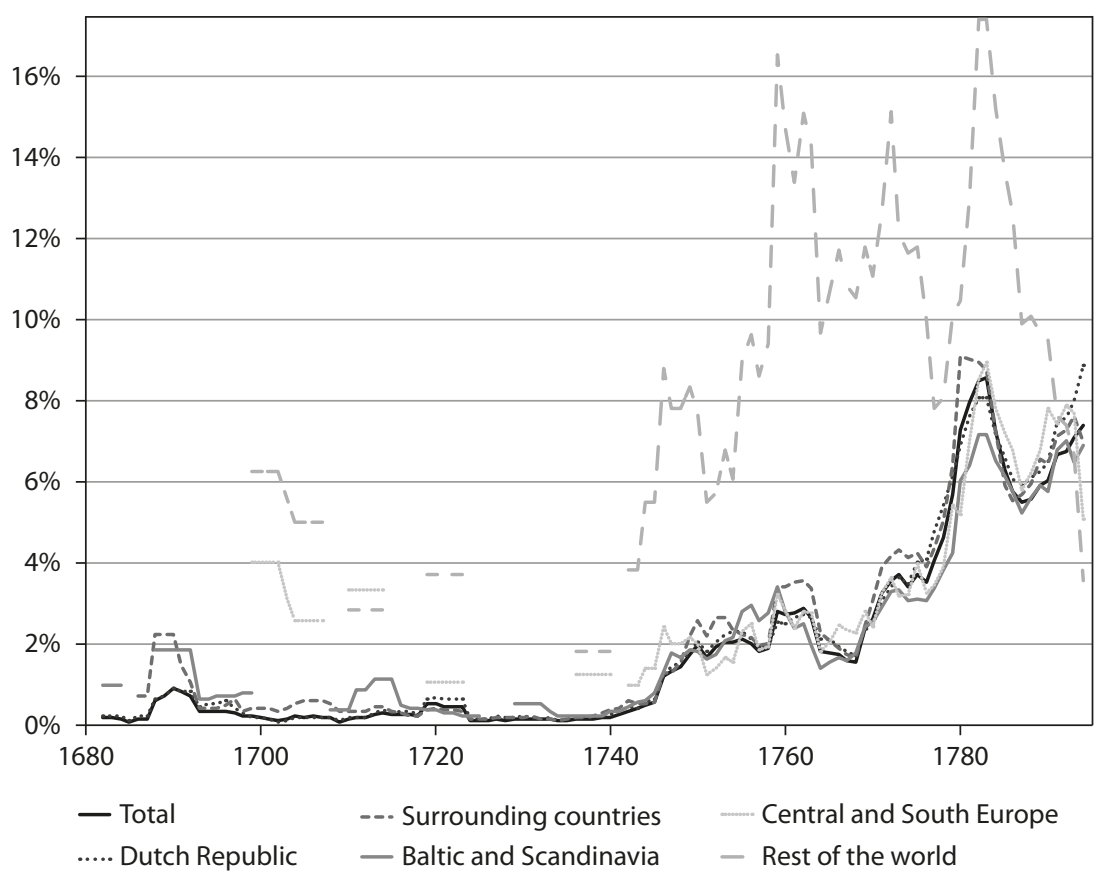

Source: VOC Opvarenden; place names categorized according to Hart

and claimed that they had exchanged wedding vows and that she was pregnant with his child. There was no clemency; the quartermaster was to marry the woman while remaining in chains and then taken on board the next departing ship to work as a sailor without wages..$^{31}$

The absence of VOC employees ready for departure in the Dutch Republic was strongly on the increase from 1745 onwards. Absence was at times linked to the origin and occupation of the worker. There had been a temporary rise of the level of absence between the years 1687 and 1694, especially among workers originating from the regions directly bordering the Dutch Republic, Scandinavia, and the Baltic area. In general, however, the levels of absence do not seem strongly related to the regions of origin of the absentee workers from Europe. For workers originating from the rest of the world,

31 Bosman, De polsslag, p. 129. Original: "veroordeeld om eerst in de Boeien met die vrouw te trouwen, dan binnenskamers gegegeseld te worden, en dan geboeid aan boord gebracht te worden om als matroos voor de hoofdofficier te varen." 
often the West and East Indies, the level of absence at the time of departure in the Dutch Republic was actually much higher. The relationship between occupation and absence is also stronger. Workers recruited for lower occupations, such as soldiers, young sailors, sailors, and boys in particular were absent at the time of departure. Compensation and career opportunities were an important factor: workers in higher occupations, such as officers, petty officers, artisans, and so on, were less likely to be absent.

Most important, and providing a better explanation for the increase in absence from the 1740 s onwards, might be the strong relationship between absence and debt. This, however, was not similar to the impact of debt on desertion oversees, where increasing debts would lead to increasing levels of desertion. In the case of absence in the Republic, the occurrence of workers' absence seems to have been lower for workers with debts that had been arranged via the company. Some elaboration is important here.

At their recruitment in the Dutch Republic, workers could sign a maandbrief, a letter entitling relatives to a regular payment of a part of the workers' wages while he was overseas, and a transportbrief, a letter of debt which arranged the payment of one specific sum of money from the wage account of the worker to either a relative or someone else. Both payments would only be effected after the VOC employee had earned enough money through service overseas. The transportbrief had priority over the maandbrief. In a case where workers had both a maandbrief and a transportbrief, it was possible that the transportbrief was assigned to either family or to debtors, such as intermediaries in the process of recruitment and the provisioning of clothing and equipment.

The transportbrief was mainly used as a payment for debts accrued by the worker before departure. Recruitment intermediaries, such as boarding house masters, hawkers, and provisioning specialists, would make sure to appropriate the transportbrief of the worker after (or before) providing the worker with the necessary equipment and services. The transportbriefserved as payment for this, and was sold by boarding house masters for a price that was lower than the actual value of the letter, but high enough to compensate for the costs and to profit from it. The buyers of the transportbrief, so-called ceelkopers, speculated on a reasonable return rate from the payments on these letters of workers. For workers who only signed the transportbrief, it seems to have served only as a way to pay off debt, and not as a payment for relatives, as they did not sign the maandbrief, meant as a service exclusively for relatives. The need to pay off debts through a transportbrief without assigning money to relatives through a maandbrief indicates the involvement of intermediaries in the recruitment process and the dependence on 
the services of these intermediaries at the time of recruitment. Of course, foreign workers, often arriving in Amsterdam and other chamber cities without the necessary contacts and knowledge, were more dependent on such intermediaries and were more vulnerable to the possible malpractices that accompanied them.

Table 8.1 Share of absent VOC employees with a transportbrief, but without a maandbrief (percentages)

\begin{tabular}{rrrr}
\hline & All recruits & Absent in Republic & Deserted overseas \\
\hline $1680-1700$ & $53 \%$ & & $61 \%$ \\
$1700-1720$ & $57 \%$ & $50 \%$ & $74 \%$ \\
$1720-1740$ & $65 \%$ & $61 \%$ & $82 \%$ \\
$1740-1760$ & $76 \%$ & $10 \%$ & $91 \%$ \\
$1760-1780$ & $81 \%$ & $5 \%$ & $96 \%$ \\
$1780-1800$ & $60 \%$ & $1 \%$ & $80 \%$ \\
\hline
\end{tabular}

Source: VOC Opvarenden

The functioning of this system of debts and transportbrieven, however, does not offer sufficient explanation for the absence of workers. During the eighteenth century, there was both a strong increase in the level of absence and in the level of workers with a transportbrief and no maandbrief, rising from 50 to 60 per cent around 1700 , to 75 to 85 per cent in the period from 1740 to $17800^{32}$ The simultaneous rise of the levels of absence and debt, despite the paradox that debt had a limiting effect on absence, indicates an increase of the role of recruitment-related intermediaries, as well as an increase in the character of the recruitment process, entailing more control over the recruit. Up to 1740, the levels of debt of absent workers - as indicated by the transportbrieven - were fairly similar to the average. This changed, however, in the 1740s, as the level of absentees with debts dropped significantly at the same time that the level of overall absence increased. The increased role of recruitment intermediaries must have coincided with the increased control of these intermediaries over the workers who signed the transportbrieven that formed their payment. The fact that indebted recruits who can be traced through the transportbrieven had a relatively high level of presence, must have been the result of boarding house masters and other intermediaries

32 The percentage of workers with a transportbrief, but no maandbrief remained between $5^{0}$ and 65 per cent in the period up to 1733 . It then rose in the period $1734-1742$, to between 65 and 70 per cent, and fluctuated between 75 and 85 per cent in the period 1743-1780:VOC Opvarenden. 
making sure that their indebted workers would be on board at the time of departure; securing their payment through the transportbrief. ${ }^{33}$

In his study into the personnel of the VOC, J.R. Bruijn signalled the increasing scarcity of qualified sailors for the VOC and the Dutch Navy in the 1740 s and 1750 s. $^{34}$ The crisis of recruitment in the 1740 s was not only a question of the shortage of skilled labour. More importantly, the recruitment system in chamber cities, such as Amsterdam, underwent a change in character, developing into a system with more deceptive and violent characteristics, resulting in rising levels of both absenteeism and debt. ${ }^{35}$ Examples of riots related to the recruitment of sailors and soldiers show the large scale of the recruitment industry and the sometimes violent ways in which boarding house masters secured their business. The volkhouder (boarding house master) Jan van Swol had around 300 people in his boarding house at the Zeedijk in Amsterdam in 1754. A fight broke out between the men of the boarding house master and his "clients", who complained about the food. Some of the angry recruits were arrested, but the others took over the boarding house and declared that "they had made the house into an imperial free city, and that everyone was allowed to enter and leave freely" ${ }^{16}$ This was a reference to the coercion and control that were inherent to many of the boarding houses. Walking away was not simply allowed. Some boarding houses may have had a closer resemblance to a prison than to a guest house. A few years later, "a few hundred Noors or Juts" attacked a boarding house in Amsterdam, because the boarding house master "did not want to release some of their mates". They confronted the "servants or overseers" who worked for the widow who owned the house. After that, "zielverkopershuis at the Zeedijk was completely plundered, everything in the house was destroyed, the porcelain cabinet thrown on the ground, a clock smashed, and even the parrots were killed". Furthermore, the sailors "freed everyone who were locked up there and chased them out of the house". ${ }^{37}$

33 One might argue that it is not the intermediary retrieving the transportbrief who has a stake in making sure that the recruit is actually on board during departure, but the buyer of the transportbrief. However, this might underestimate the role of personal contacts and credibility in the buying and selling of the transportbrieven, or to rephrase this, the boarding house master who did not prevent their recruit from fleeing before departure may have a hard time selling his transportbrieven or may have seen their value drop significantly.

34 Bruijn, "De Personeelsbehoefte".

35 Gaastra, "The Recruitment of Soldiers".

36 Bosman, De polsslag, p. 154. Original: "dat zij nu van het huis een keizerlijke vrijstad hadden gemaakt, en dat iedereen er naar believen in en uit mocht gaan."

37 Ibid., pp. 196-197. Original: “door honderden Jutten of Noren, hun maten, niet meer wilde overdragen of loslaten, zielverkopershuis op de Zeedijk geheel geplunderd; Alles in huis was 


\section{From Europe to Asia, and back ${ }^{38}$}

The labour markets in Europe and Asia became increasingly entangled from 1500 onwards. This was not a process initiated one-sidedly from Europe and radiating outwards. The process of the internationalization of labour markets developed independently in different parts of the maritime world. For early modern Europe, three regions have been distinguished in the way that maritime labour markets functioned. ${ }^{39}$ First, regions where maritime labour was employed through international recruitment of "free" labour, as was the case mainly in the Dutch Republic, recruiting sailors from Northwestern Europe. ${ }^{40}$ Second, regions where sailors were mostly employed from within "national" boundaries, sometimes with a small amount of additional international recruitment. This was the case, for example, in Denmark, France, England, and Spain, where recruitment was mainly free, with the exception of periods of war. Third, regions where both free and unfree recruitment took place from within and outside "national" borders, mainly in the regions around the Baltic and Mediterranean. ${ }^{41}$ Similar recruitment patterns developed in Atlantic shipping. In the Atlantic region, however, the levels of international recruitment, perhaps due to the long distances involved, were higher than in European shipping, especially for shipping from regions in Northern Europe, such as Denmark, Hamburg, Prussia, and Bremen. ${ }^{42}$ French, Spanish, and English vessels were often still manned by "nationals", but here as well, there tended to be more non-nationals on board. National regulations, such as the English Navigation Acts (1651) and the laws regulating the Spanish Atlantic trade route (the Carrera de Indias) (1658), officially limited the number of "foreign" sailors that Spanish and English ship owners were allowed to employ on board their ships. In practice, these regulations were often ignored or circumnavigated, leading to the recruitment of Portuguese, Italian, Flemish, Dutch, and German sailors. ${ }^{43}$ Shipping in the Atlantic was marked by another important development. In addition to the international recruitment of

vernield, een porseleinkast met porselein omvergesmeten, een staande klok verpletterd, zelfs een papegaai en de kanaries waren vermoord, haar knechten of toezichthouders; Ze hebben iedereen die daar opgesloten zat laten lopen en het huis uit gejaagd."

38 This paragraph can also be found in the paper "The 'Yellow Danger'?".

39 Van Lottum, Lucassen, and Van Voss, "Labour Markets”.

40 Van Lottum, Across the North Sea, pp. 136-137.

41 Van Lottum, Lucassen, and Van Voss, "Labour Markets", pp. 336-338.

42 Van Rossum et al., "National and International Markets", p. 57.

43 Rediker, Between the Devil and the Deep Blue Sea, pp. 19-2o, 80; Pérez-Mallaína, Spain's Men of the Sea, pp. 56-57. 
"white" European and American sailors, shipping in the Atlantic increasingly witnessed the recruitment of crew members of African or African-American origin. Sometimes, these sailors were slaves, working for their owner as a sailor, for example, on vessels from the Caribbean, North America, and Brazil. ${ }^{44}$ More often these sailors could be free black men, sometimes freed slaves, earning a living through maritime work in the Atlantic. ${ }^{45}$

The developments in maritime Asia did not, as could be argued for the Atlantic, only result from the European expansion and the developments in European shipping. Recruitment of maritime labour outside ethnic or national (group) boundaries was not an exclusively European phenomenon, but seems to have been common in Asia as well. Internationalization in Asian maritime labour markets outside and before the arrival of the Portuguese, the VOC, and other European trading companies, is more difficult to trace and leaves much room for future research. ${ }^{46}$ The various regions of maritime Asia, however, had already been connected by intensive long-distance shipping long before the arrival of Europeans. There is evidence that the same can be said for the maritime labour markets in Asia. Recent studies indicate that shipping with crews of mixed origin was a common phenomenon in Asia. ${ }^{47}$ For shipping over long distances and regional routes in the Indonesian archipelago and the Indian Ocean, in particular, maritime labour could be recruited from the many different port cities of maritime Asia.

The maritime labour markets of Europe and Asia were related from the moment that structural maritime connections between the two regions came into existence. With European maritime expansion, however, maritime labour markets throughout the globe increasingly became entangled. The changing character of the relations between these markets can be roughly divided into five stages. Partly overlapping, these range from more or less separate maritime worlds around 1500 to almost completely interconnected markets. The stages are:

1. Almost entirely separated labour markets in maritime Europe and maritime Asia (before 1500).

2. Increasing connection between Asian and European maritime labour markets as a result of the introduction of European labour supply and

44 Bolster, BlackJacks, pp. 84-86.

45 Christopher, Slave Ship Sailors.

46 Although lack of sources seems to be a problem here.

47 Van Rossum, “The Rise of the Asian Sailor?"; Van Rossum et al., "National and International Markets". 
demand in Asian maritime labour markets. The European and Asian maritime labour markets become intertwined in Asia; only really small numbers of Asian slaves and sailors make it to Europe, mainly through Portuguese shipping (1500-1750).

3. Increasing integration in intercontinental shipping between Asia and Europe, especially from the early eighteenth century onwards, through recruitment of Asian sailors for shipping from Asia to Europe by East India companies and the settlement of Asian sailors, notably in London. The VOC is somewhat late in employing Asian sailors for intercontinental shipping and puts up barriers against the settlement of Asian sailors in the Dutch Republic (1700-1800).

4. Increased and accelerated internationalization of the recruitment of maritime labour in shipping in Asia (from the late eighteenth century onwards) and in intercontinental shipping (from the 1830 s onwards). Simultaneously, a breaking down of barriers to the employment of "foreign" crews and increased regulation of colonial recruitment, ensuring the supply of (increasingly cheaper) Asian maritime labour (1800 onwards).

5. Near complete integration of European and Asian maritime labour markets, movement and settlement of Asian and European sailors in both Asia and Europe (now also outside London) (1870 onwards). ${ }^{48}$

\section{From internationalization to segmentation}

The concise overview of Eurasian maritime labour and its labour relations and recruitment, especially in the early modern period, indicates that wage labour was the dominant mode of employment for sailors in both Europe and Asia. Case studies into the work and lives of European and Asian sailors in the service of the Dutch East India Company suggest that throughout the seventeenth and eighteenth centuries, Asian and European sailors performed similar work for similar wages. Although a European company, framing its Asian environment in its rather "Dutch" world view, the VOC provides an important example, as throughout almost the entire seventeenth and eighteenth centuries, it was the largest trading organization active throughout Asian waters working with European and Asian sailors. The bargaining position of Asian sailors seems to have been somewhat better than that of

48 Figures for Asian and European sailors on European merchant fleets are available in Van Rossum, Werkers van de wereld, at the beginning of chapter 3 . 
European sailors. In the second half of the eighteenth century, this resulted in better regulations in the sphere of health care, lower punishments, lower debts, and attempts to prevent maltreatment by company authorities. ${ }^{49}$

Recruitment patterns were mainly intermediate forms between the "casual" and "mediated" modes, but an important distinction seems to have been that whereas Asian maritime labour markets may have been more characterized by casual recruitment patterns, the maritime labour market in the Dutch Republic became characterized more by mediated, often more coercive, recruitment patterns from 1740 onwards.

This all changed rapidly from the early nineteenth century. Increased European colonial interference in Asian societies, and especially Asian labour markets, resulted in changing recruitment patterns, the breakdown of negotiating positions, and the lowering of wages and working conditions for Asian sailors. Diverging wages, and therefore diverging costs of European and Asian labour, changed the relation between European and Asian sailors drastically. Colonialism and the reform of Asian labour markets undermined the position of Asian sailors and advanced the position of employers and intermediaries, and their control over the (Asian) workforce..$^{\circ}$ Colonialism, in that respect, was not only an important factor in the increasing integration of labour markets, but at the same time in the increasing segmentation of these labour markets.

On the rapidly expanding British merchant fleet, Asian sailors were forced to be engaged under so-called "lascar articles" from the $1820 \mathrm{~s}$ onwards. These articles contained separate conditions of engagement for sailors from the British Asian colonies, including contract durations of several years, but also prohibitions to be discharged in Britain and other restrictions. These regulations were accompanied by fundamental changes under expanding colonialism in the first half of the nineteenth century. Recruitment practices in British India were re-organized through (colonial) recruitment offices, backing up the employers' interests. Simultaneously, colonial maritime employers were successful in 'reinventing 'traditional' recruitment practices" to exert control over their (colonial) labour force, reviving traditions that had not been around in this form during the "more than two centuries [in which] 'lascars' had been employed on European vessels".$^{51}$ Under the influence of rising colonialism, early in the nineteenth

49 Again, this becomes clear from Van Rossum, Werkers van de wereld.

$5^{0}$ Balachandran, Globalizing Labour?. This has also been pointed out in reviews of this book, including my review in Indian Historical Review, 41 (2014), pp. 357-36o.

$5^{1} \quad$ Balachandran, Globalizing Labour?, p. 18. 
century, maritime recruitment patterns in Asian seem to have changed from "casual" to "mediated".

Simultaneously, European sailors - who had experienced this shift, at least in the Dutch Republic, but presumably also elsewhere, almost a century earlier - gained the increasing attention of political reformers and labour unions, striving for the improvement of their working conditions and their position in the labour market (from the late nineteenth to the early twentieth century). With the rise of labour union organization, this led to attacks on the "mediated" recruitment systems for European sailors - in the early twentieth century in the Netherlands - and recruitment became increasingly organized through bureaus of maritime employers and sometimes through bureaus of governments or labour unions. The "formalization" of European sailors' recruitment was in sharp contrast with the continuation of the "mediated" recruitment of Asian sailors, creating a division between better-paid European workers and their lower-paid Asian counterparts. These groups partly competed, as they were employed in the same occupations.

If we are to understand "institutions" as humanly devised constraints that structure political, economic, and social interactions, the global history of the maritime sector shows the simultaneous integration of Asian and European maritime labour markets with increasing constraints on Asian maritime labour resulting from colonial (and Western capitalist) powers. Crucial to this process were both (penalized) labour contracts and differentiating recruitment regimes. It is important to note that these could be considered "inclusive" economic institutions, organizing market exchange and safeguarding contractual agreements. These contracts, however, were extremely unbalanced, favouring the claims of employers on (contracted) labour power over (the protection of) the rights of the workers. Similar to the Dutch and other European maritime and military labour contracts of the early modern period, sailors were obliged to serve for years once they had signed a contract. Systems of penalties, criminal punishment, and the restriction of mobility bound workers severely.

Between the mid-nineteenth and early twentieth century, a fully globalized maritime labour market emerged that was marked by large inequalities and tense conflicts between employers, workers, and different groups of workers. Under the pressure of the destructive effects of colonialism - actively breaking down well-established labour markets and demolishing the position of colonial workers - and the mobilizing effects of mass ideologies, rallying around nationality, race, and class, European and 
Asian sailors were set against each other. ${ }^{52}$ Class ideology created a clear division between workers and employers, pushing for solidarity amongst divided groups of workers, but at the same time problematizing the role of groups of workers that had not (yet) organized and participated in this struggle. Colonialism, at the same time, had made Asian sailors colonial "subjects", who were paid less and were perceived to be "inferior" and "less capable" workers. The colonialism and global capitalism nexus, and the wave of economic-institutional changes it forced upon the world, pushed Asian sailors into a specific "inferior" position.

The consequent explicit competition between Asian and European sailors resulted in two distinct strategies to cope with this division in one of the first real global workforces. European - especially social-democratic labour unions opted for nationalist strategies in which the role of Asian sailors was seen as that of obstructors of what was perceived by European workers as "their" more "developed" class struggle. This resulted in explicit racist campaigns against Chinese and Indian sailors in the $1920 .^{53}$ Other groups, often revolutionary organizations of European and Asian sailors, opted for the opposite strategy of internationalist solidarity by attempting to organize and create links between European and Asian sailors. These conflicts echoed into the Second World War, after which the scene would again change drastically as result of decolonization and changing regulation, but also maritime industries becoming unrestricted by using flags of convenience.

\section{Conclusion}

This chapter traces the "long" internationalization of maritime labour markets in Europe and Asia (1500 to 2000) and tries to explore and explain developments in maritime labour relations and the segmentation of maritime labour markets through the Dutch case. It indicates that wage labour was a normal and long-lasting solution for the allocation of labour in the maritime sector across the globe. The chapter, therefore, does not try to explain a transition to wage labour, but points out that the question must be shifted from the problem of where and when wage labour arose - and whether this transition was complete or not - to where and when wage labour was in use, in what specific context, and under what conditions. 
Historical evidence for the functioning of maritime labour markets in Europe and South and Southeast Asia indicates that in the case of longdistance shipping, maritime labour markets in these different parts of the world were characterized by intermediate forms of casual and mediated wage labour relations.

The labour markets in Europe and Asia became increasingly entangled from 1500 onwards. This happened in partly overlapping stages: from almost entirely separated labour markets in maritime Europe and maritime Asia (before 1500); increasing connections between Asian and European maritime labour markets through intensified intra-Asiatic shipping (15001750); increasing integration in intercontinental shipping between Asia and Europe, including the recruitment of Asian sailors (1700-1800); increased and accelerated the internationalization of recruitment of maritime labour in shipping in Asia (from the late eighteenth century onwards) and in intercontinental shipping (from the 1830 s onwards); and finally, near-complete integration of European and Asian maritime labour markets, and the movement and settlement of Asian and European sailors in both Asia and Europe (1870 onwards).

In this process of globalizing maritime labour markets, the position of European and Asian sailors - and as a result also the relations between these workers - changed drastically. In the eighteenth century, Asian sailors seem to have had a relatively good bargaining position, apparently better than that of European sailors. From the early nineteenth century onwards, increased European colonial interference in Asian societies - and especially in Asian labour markets - resulted in changing recruitment patterns, the breakdown of the negotiating positions, and the lowering of wages and working conditions for Asian sailors. Undermining the position of Asian sailors, colonial reforms advanced the position of employers and intermediaries, and increased their control over the Asian workforce. Under the influence of rising colonialism, early-nineteenth-century maritime recruitment patterns in Asia seem to have changed from "casual" to "mediated". Under the pressure of political reformers and labour union organizing, the mediated recruitment systems were in decline for European sailors, and recruitment was increasingly formalized through bureaus of maritime employers and sometimes through bureaus of governments or labour unions.

The global history of the maritime sector, therefore, is a key example of the double effect of colonialism, simultaneously integrating Asian and European maritime labour markets, while severely constraining (or even "binding") Asian maritime labour through (penalized) labour contracts and 
differentiating recruitment regimes. Colonialism, in that respect, was not only an important factor in the increasing integration of labour markets, but at the same time in the increasing segmentation of these labour markets. It must be noted that this is not just the history of "different" economic institutions altering the history of the non-West. The institutions enforced on Asian (maritime) labour markets can be considered "inclusive" economic institutions, organizing market exchange and safeguarding contractual agreements. These contracts, however, safeguarded deals made in power relations that were extremely uneven, almost solely focusing on the employers' rights to the exploitation of and control over (Asian) workers, by the claim of employers on (contracted) labour power over (the protection of) the rights of the worker. As a result, the interplay of colonial and global capitalistic expansion pushed Asian sailors into an "inferior" position, leading to explicit and racialized competition between Asian and European sailors.

\section{Bibliography}

Balachandran, G., Globalizing Labour? Indian Seafarers and World Shipping, c. 1870-1945 (New Delhi, 2012).

Banaji, J., Theory as History: Essays on Modes of Production and Exploitation (Chicago, 2011).

BBC, "Germany Probes Amazon Warehouse Conditions after Film", BBC, 16 February 2013, available at: http://www.bbc.com/news/world-europe-21488816.

Bennett, Asa, “Amazon Warehouse Staff in 'Slave Camp' Conditions, Workers Say", Huffington Post United Kingdom, 25 November 2013, available at: http://www. huffingtonpost.co.uk/2013/11/25/amazon-staff-investigation_n_4335894.html. Bolster, W.J., BlackJacks: African American Seamen in the Age of Sail (London, 1997). Bosma, U., "Database 1650-19oo" and "Methodological Paper" (2011), The Global Collaboratory on the History of Labour Relations 1500-2000, available at: https:// collab.iisg.nl/group/labourrelations/.

Bosman, Machiel, De polsslag van de stad. De Amsterdamse stadskroniekvanJacob Bicker Raije (Amsterdam, 2009).

Breman, J., Koloniaal profijtvan onvrije arbeid: het Preanger stelselvan gedwongen koffieteelt op Java, 1720-1870 (Amsterdam, 2010).

Bruijn, J.R., "De Personeelsbehoefte van de VOC overzee”, Bijdrage en Mededelingen betreffende de Geschiedenis der Nederlanden, 91 (1976), pp. 218-248.

Christopher, E., Slave Ship Sailors and Their Captive Cargoes, 1730-1807 (Cambridge, 2006). 
Ewald, J.J., "Crossers of the Sea: Slaves, Freedmen, and Other Migrants in the Northwestern Indian Ocean, c. 1750-1914", American Historical Review, 105 (2000), pp. 69-91.

Gaastra, F.S., "The Recruitment of Soldiers by the VOC in the $18^{\text {th }}$ Century", in W. Klooster (ed.), Migration, Trade and Slavery in an Expanding World (Leiden, 2009), pp. 101-114.

Gommans, J., Mughal Warfare: Indian Frontiers and High Roads to Empire, 1500-1700 (New York, 2002).

Hay, Douglas, and Paul Crave, "Introduction", in Douglas Hay and Paul Crave (eds), Masters, Servants and Magistrates in Britain and the Empire, 1562-1955 (Chapel Hill, 2004), pp. 1-58.

International Institute of Social History, "Global History from Below: Explaining and Connecting Shifts in Labour Relations, 1500-2000”, available at: https:// collab.iisg.nl/c/document_library/get_file?p_l_id=273223\&folderId=338337\& name=DLFE-171701.pdf.

Lucassen, J., "Deep Monetization, Commercialization, and Proletarization: Possible Links, India 1200-190o", in S. Bhattacharya (ed.), Towards a New History of Work (New Delhi, 2014), pp. 17-55.

Lucassen, J., "Een geschiedenis van de arbeid in grote lijnen" (Amsterdam, 2012). https://socialhistory.org/sites/default/files/docs/publications/geschiedenisarbeid-grote-lijnen_.pdf

Lucassen, J., “Outlines of a History of Labour”, IISH Research Paper 51, Amsterdam, 2013. https://collab.iisg.nl/c/document_library/get_file?p_l_id=273223\&folderI $\mathrm{d}=338337$ \&name=DLFE-174901.pdf.

Marx, K., Het Kapitaal. Kritiek van de politieke economie (Amsterdam, 2010).

Pérez-Mallaína, P.E., Spain's Men of the Sea: Daily Life on the Indies Fleets in the Sixteenth Century (Baltimore, 1998).

Rediker, M., Between the Devil and the Deep Blue Sea:Merchant Seamen, Pirates and the Anglo-American Maritime World, 1700-1750 (Cambridge, 1987).

Sheriff, A., Dhow Cultures of the Indian Ocean: Cosmopolitanism, Commerce and Islam (London, 2010).

Tabili, L., "The Construction of Racial Difference in Twentieth-Century Britain: The Special Restriction (Coloured Alien Seamen) Order, 1925",Journal of British Studies, 33 (1994), pp. 54-98.

Tilly, C., Durable Inequality (Berkeley, 1998).

Van der Chijs, J.A. (ed.), Nederlandsch-Indisch Plakaatboek 1602-1811, 17 vols (Batavia, 1885-1900).

Van der Linden, M., Workers of the World: Essays toward a Global Labor History (Leiden, 2011). 
Van Lottum, J., Across the North Sea: The Impact of the Dutch Republic on International Labour Migration, c. 1550-1850 (Amsterdam, 2007).

Van Lottum, J., J. Lucassen, and L. Heerma van Voss, “Labour Markets and National Identity, 1600-1850", in R.W. Unger (ed.), Shipping and Economic Growth, 1350-1850 (Leiden, 2011), pp. 309-352.

Van Rossum, M., 'AAmok!' Mutinies and Slaves on Dutch East Indiamen in the 1780's", International Review of Social History, 58 (2013), pp. 109-130.

Van Rossum, M., "Claiming Their Rights? Indian Sailors under the Dutch East India Company (VOC)", in Maria Fusaro, Bernard Allaire, Richard Blakemore and Tijl Vanneste (eds), Labour, Law and Empire: Comparative Perspectives on Seafarers, c. 1500-180o (London, 2015), pp. 263-277.

Van Rossum, M., Hand aan Hand (Blank en Bruin). Solidariteit en de werking van globalisering, etniciteit en klasse onder zeelieden op de Nederlandse koopvaardij, 1900-1945 (Amsterdam, 2009).

Van Rossum, M., "A 'Moorish World' within the Company: The VOC, Maritime Logistics and Subaltern Networks of Asian Sailors", International Journal on the History of European Expansion and Global Interaction, 36 (2012), pp. 39-6o.

Van Rossum, M., "Redirecting Global Labor History?", in C. Antunes and K. Fatah-Black (eds), Explorations in History and Globalization (London, 2016), pp. 47-62.

Van Rossum, M., "Book Review: G. Balachandran, Globalizing Labour? Indian Seafarers and World Shipping, c. 1870-1945", Indian Historical Review, 41 (2014), pp. 357-36o.

Van Rossum, M., "The Rise of the Asian Sailor? Inter-Asiatic Shipping, the Dutch East India Company and Maritime Labour Markets (1500-1800)", in S. Bhattacharya (ed.), Towards a New History of Work (New Delhi, 2014), pp. 180-213.

Van Rossum, M., "Transforming the Coolie: Changing Coolie Labour Relations in the Dutch Empire", presented at the workshop Forms of Bonded Labour: Conceptual Approaches towards a New Comparative Research Framework, 23/24 June 2014, Cologne.

Van Rossum, M., Werkers van de wereld. Globalisering, arbeid en interculturele ontmoetingen tussen Aziatische en Europese zeelieden in dienst van de VOC, 1600-180o (Hilversum, 2014).

Van Rossum, M., "'Working for the Devil': Desertion in the Eurasian Empire of the VOC", in M. van Rossum and J.M. Kamp (eds), Desertion in the Early Modern World: A Comparative History (London, 2016), pp. 127-16o.

Van Rossum, M., “The 'Yellow Danger'? Global Forces and Global Fears in the North Sea and Beyond (1600-1950)", presented at the $11^{\text {th }}$ North Sea History Conference, Scheepvaartmuseum, Amsterdam, September 2014. 
Van Rossum, M., L. Heerma van Voss, J. van Lottum, and J. Lucassen, "National and International Markets for Sailors in European, Atlantic and Asian Waters, 1600-1850", in M. Fusaro and A. Polonia (eds), Maritime History as Global History: Research in Maritime History (St. John's, 2010), pp. 47-72.

Van Royen, P.C., J.R. Bruijn, and J. Lucassen (eds), "Those Emblems of Hell”? European Sailors and the Maritime Labour Market, 1570-1870 (St. Johns, 1997).

Van Zanden, J.L., Arbeid tijdens het handelskapitalisme (Bergen, 1990).

VOC Opvarenden, database, available at: http://www.gahetna.nl/collectie/index/ ntoo444, accessed January 2012.

Warren, J.F., The Sulu Zone, 1768-1898: The Dynamics of External Trade, Slavery, and Ethnicity in the Transformation of a Southeast Asian Maritime State (Singapore, 2007).

Winterbottom, A., "From Hold to Foredeck: Slave Professions in the Maritime World of the East India Company, c. 1660-1720", in M. Fusaro and A. Polonia (eds), Maritime History as Global History: Research in Maritime History (St.John's, 2010), pp. 95-124. Wubben, H.J.J., "Chinezen en ander Aziatisch ongedierte": lotgevallen van Chinese immigranten in Nederland 1911-1940 (Zutphen, 1986).

Zürcher, E.J. (ed.), Fighting for a Living: A Comparative History of Military Labour, 1500-2000 (Amsterdam, 2013).

\section{About the Author}

Matthias van Rossum is Senior Researcher at the International Institute of Social History in Amsterdam (The Netherlands). He works on global labour history with a special interest in maritime labour history, coercion in labour relations, and the dynamics of labour conflicts and social relations. He was awarded a NWO Veni Grant for research on the history of slavery and slave trade in early modern Dutch Asia (2016-2019). His publications include Desertion in the Early Modern World (co-edited with Jeannette Kamp) (London, 2016). More information: https://socialhistory.org/en/staff/ matthias-van-rossum.

E-mail:mvr@iisg.nl 


\title{
$9 \quad$ Wage Labour and Slavery on the Cape Frontier
}

\author{
The Impact of the Abolition of Slave Imports on Labour \\ Relations in the Graaff-Reinet District ${ }^{*}$
}

Johan Fourie and Erik Green

Hofmeester, Karin \& Pim de Zwart (eds.), Colonialism, Institutional Change, and Shifts in Global Labour Relations. Amsterdam: Amsterdam University Press, 2018

DOI: $10.5117 / 9789462984363 / \mathrm{CHog}$

\begin{abstract}
The 1807 ban on the importation of slaves is said to have had severe consequences for farmers in South Africa's Southwestern Cape, an area of wheat and wine farming that used large numbers of slave labourers. The ban resulted in a rapid rise in slave prices, which significantly increased input costs. In contrast, the effect of the ban was apparently much more moderate in the eastern parts of the colony, where stock farmers used predominantly Khoesan labour. We use six tax censuses from the easternmost district in the Colony, Graaff-Reinet, to show that the ban on importing slaves did indeed have important consequences for farmers, even on the colony's distant frontier. The ban affected not only the composition of labour but also its productivity.
\end{abstract}

Keywords: slavery, abolition, Graaff-Reinet, labour, tax censuses

* This chapter is based on a paper prepared for the Workshop on Economic Institutional Change and Global Labour Relations, IISH Amsterdam, 26-27 September 2014. We want to thank the participants of this workshop, and in particular Pim de Zwart and Karin Hofmeester, for their valuable comments on an earlier version. We would also like to thank members of the Laboratory for the Economics of Africa's Past (LEAP) seminar series for their valuable feedback. We further thank Elsje Kemp, Chris de Wit, and Linda Orlando for research assistance, and Erika le Roux for archival support. 


\section{Introduction}

When the Cape Colony became part of the British Empire in the early nineteenth century, its main agricultural products were wheat and wine from the fertile region close to Cape Town, and cattle and sheep from the drier interior. This geographical specialization divided eighteenth- and nineteenth-century Cape production into two distinct types, with wheat and wine farmers mostly using slave labour, and cattle farmers mostly employing the indigenous people, the Khoesan, either as free wage labour or under semi-bonded contracts. ' Consequently, it seems reasonable to assume that the 1807 British ban on slave importation was a major shock to the wheat and wine farmers, whereas farmers in the interior would have been much less affected, everything else being equal. However, this generalized view ignores the nuances of labour relations on Cape Colony farms. In an earlier work, we have shown that the Khoesan played an important role in the wine and wheat farms of the Southwestern Cape, ${ }^{2}$ and in this chapter we show that slaves played a similarly important role as farm labourers in the interior.

This chapter details the first systematic quantitative analysis of labour relations in the nineteenth-century Cape that includes the contribution of Khoesan labour. Our analysis uses newly transcribed tax censuses of frontier farmers over the first twenty-five years of the nineteenth century, the original records of which are housed in the Cape Town Archives Repository. In particular, we show how farmers were affected by the legal changes that were set in motion by the 1807 ban on slave importation. We use the frontier district of Graaff-Reinet as an in-depth case study, but we also relate this to general developments in the Cape Colony. We argue that although the changes certainly affected the settler farmers, the effect was not as straightforward as is commonly assumed. To show this, we exploit the fact that the Hottentots, as the Khoesan were then called, appear as a separate labour category in the tax censuses of settler farmers in the Graaff-Reinet district, on the eastern border of the colony. This district provides us with an interesting case because its settler farming history differs considerably from that of the Southwestern Cape, where slavery was more widespread and slaves were the only labour supply enumerated in the tax record. The fact that Graaff-Reinet farmers relied predominantly on Khoesan labourers - and that these labourers are included in tax records for the period - enables us to compare the productivity

1 Worden, Slavery; Penn, "Pastoralist and Pastoralism"; Scully, Liberating the Family?; Ross, "The Origins".

2 Fourie and Green, "The Missing People”. 
of slave and Khoesan labourers, something that we cannot do for the more well-researched districts of Cape Town, Stellenbosch, and Swellendam. ${ }^{3}$

\section{Farm labour in the eighteenth- and early-nineteenth-century Cape}

The Cape was settled in $165^{2}$ by the Dutch East India Company, the VOC (Verenigde Oost-Indische Compagnie), as a refreshment station for passing ships. The first commander of the station, Jan van Riebeeck, soon reported back to the directors of the VOC that he needed more Europeans to settle as farmers in order to ensure a sufficient supply of food for the passing ships. The inflow of settlers, however, remained modest until the late seventeenth century, when European settlement began to expand and a small but scattered free settler society was established, supplying the town primarily with wheat, wine, and cattle. ${ }^{4}$ The increased commercialization of settler farming helped to reproduce a prosperous agrarian elite, ${ }^{5}$ although it did not lead to a monocultural plantation system supplying the metropolitan market, as was the case with West Indian sugar and Brazilian coffee. ${ }^{6}$

The settler farmers faced two major economic constraints: lack of capital and shortage of labour. Land tenure was initially offered free of charge, which considerably reduced the drain on capital. The VOC further granted farmers start-up capital loans, often in the form of seed or equipment that helped them set up their operations. The large credit market that developed in the colony also helped farmers to get started. ${ }^{7}$ However, the shortage of labour proved particularly troublesome.

At first, the VOC suggested that European immigrants, who could be employed as indentured labourers, would ensure the supply, but the number of these immigrants arriving in Table Bay was never sufficient to satisfy the farmers' requirements. Another solution was to employ knechts (company servants), but they were also few in number, and because of their scarcity

3 In this chapter we use the term "Khoesan" while acknowledging that this was not a homogeneous group. The settlers at the Cape encountered diverse groups of peoples whom they identified as "Bushmen" (San), the hunter-gatherers, and "Hottentots" (Khoe, also Khoi or Khoikhoi), a nomadic, pastoral people. Anthropological research shows that the two groups are not discrete ethnic categories. The Dutch differentiated them not by physical appearance, but socioeconomically: the cattle owners were classified as Khoe and the non-cattle owners as San. A comprehensive discussion can be found in Elphick, Kraal and Castle.

4 Fourie and Von Fintel, "The Dynamics of Inequality”.

5 Williams, "Who, Where, and When"; Fourie, "The Remarkable Wealth".

6 Worden, Slavery, p. 19.

7 This credit market is the focus of ongoing research; Swanepoel and Fourie, “'Impending Ruin”". 
they could command higher prices than many farmers could afford. Van Riebeeck suggested employing Chinese immigrants, as were used in Batavia, but this plan was abandoned because the cost of their passage was too high. The colony thus turned to using slaves from Africa and the East Indies. Slaves from West Africa could be bought with the help of the Dutch West India Company, and the VOC had contacts with Asian slave traders bringing slaves from the East. The company initially offered slaves on credit to the farmers in order to stimulate production, and in the 1680 s the number of slaves at the Cape began to rise steadily. ${ }^{8}$

By 1800 , about 90 per cent of the Cape settler farmers owned slaves. Historians are in agreement that slaves were a major input for farmers in the colony's southwestern region. Armstrong and Worden suggest a strong positive correlation between slave ownership and yields of wine and wheat, ${ }^{9}$ and this view is confirmed by earlier observers. In the 1730 s, for example, Mentzel, a visitor to the Cape, said that "the expansion of the colony demands an ever increasing number of slaves" and that "every farmer requires many more slaves than members of his own household to grow his crops and develop his land". ${ }^{10}$

In the interior, where the harsher environment and lack of infrastructure made large-scale wine and wheat farming difficult, settlers established pastoral farms. Why they moved into the interior remains a matter for debate. The economic historian Neumark attributes this largely to the attraction of financial opportunities for raising stock and trading with the indigenous people, whereas historians such as Guelke argue that the pressure of the expanding population in the Southwestern Cape forced young settlers to make this move. ${ }^{11}$ Guelke's view is supported by Shell, who dismisses the popular belief that European immigration to the Cape ended in 1717, and makes the case that the boundaries of the colony expanded as Europeans continued to move to the Cape throughout the eighteenth century. ${ }^{12}$

The first settler farmers adopted the indigenous people's system of taking sheep and cattle out to pasture during the day and returning them to the kraalin the evening for fear of thieves, a system that made pastoral farming in the Cape quite labour-intensive. ${ }^{13}$ The farmers in the interior used slaves less than the farmers of the Southwestern Cape. As has been pointed out

8 Worden, Slavery, pp. 7-9.

9 Armstrong and Worden, "The Slaves".

10 Worden, Slavery, p. 10.

11 Neumark, Economic Influences; Guelke "Frontier Settlement".

12 Shell, "Immigration".

13 Beinart, The Rise of Conservation; Penn, "Pastoralist and Pastoralism". 
by a number of historians, the indigenous Khoesan were a crucial source of labour in the interior. ${ }^{14}$ P.J. van der Merwe, one of the first historians of the frontier farmers known as the trekboers, argued that "the KhoiKhoi presence in the interior undoubtedly contributed much to making migration into the countryside possible". ${ }^{15}$

The Southwestern Cape and the interior certainly used different labour sources, but it would be a mistake to assume that the former relied solely on slaves and the latter solely on indigenous labour. Slaves undoubtedly played a large role as farm labourers in the Southwestern Cape, but our own estimates, as well as a sizeable quantity of anecdotal evidence, indicate that indigenous labour was also of importance here. It is also true that most settler farmers in the Southwestern Cape owned slaves, but the average number of slaves per farm remained low throughout the eighteenth century. By the mid-eighteenth century, more than $5^{\circ}$ per cent of the settlers held fewer than five slaves, and in 1774, 24 per cent held no slaves at all. ${ }^{16}$ This clearly indicates that a large proportion of farmers in the Southwestern Cape could not have relied on slaves alone.

There is ample anecdotal evidence to support the claim that Khoesan labourers played a significant role in farming in the eighteenth-century Cape. Settler farmers periodically complained that the VOC employed a large number of Khoesan, reducing the number who could work for farmers. In 1744, large-scale wheat farmers complained that they were forced to limit the size of their crops because of shortages of Khoesan labour. ${ }^{17}$ In previous research, combining traveller accounts with household-level tax records to quantify the role of the Khoesan as farm labourers in the eighteenth-century Cape Colony, we have found that the number thus employed increased throughout the eighteenth century. ${ }^{18}$ This shows that the demand for various forms of farm labour increased with the expansion of settler agriculture, and supports the view of historians who argue that the expansion of settler agriculture was accompanied by a process of primitive accumulation, reducing the Khoesan pastoralists to a rural proletariat. ${ }^{19}$

16 This situation could be compared with that of the "median sugar estate" in Jamaica, which between 1741 and 1745 held an average of ninety-nine slaves, increasing to 204 for the years 1771 to 1775 : Fourie, "Slaves".

17 Worden, Slavery, pp. 33, 36 .

18 Fourie and Green, "The Missing People".

19 Penn, "Pastoralist and Pastoralism", p. 4; Scully, Liberating the Family?, p. 20. 
The 1807 ban on importing slaves, unsurprisingly, increased the price of slaves in the Cape. In 1808, the average price of an adult male slave was $£ 60$, and by 1826 it had increased to $£ 150$. The increase would have been even more dramatic had it not been for the fact that the slave population was reproducing itself by the turn of the century. ${ }^{20}$ Nevertheless, scholars are of the opinion that the ban was a serious setback for settler farmers, particularly those employing large numbers of slaves. ${ }^{21}$ Dooling, for example, concludes that "[in] the absence of price regulation, state protection and massive labour coercion the Western Cape's farmers were clearly unable to make substantial profits by means of agricultural production alone". ${ }^{22}$ Other studies suggest various ways that farmers would have reacted to the price increase, such as using a greater number of female and child slaves (earlier employed as domestic workers) as farm labourers or using more semi-bonded labour. Throughout the eighteenth century, farmers in all regions of the Cape had used a system of indentured labour. Originally they employed former knechts on a contractual basis, but by the mid-eighteenth century, a new system - known locally as inboekstelsel - had become more common. Under this system, a child of a slave woman and a Khoesan man was obliged to stay on the farm and work until he or she reached the age of eighteen. ${ }^{23}$

Labour relations underwent a change in the early nineteenth century, described by Ross as "contrasting developments". While slavery declined, coercion increased, most notably in the interior of the country, where there were stories of brutality towards the indigenous populations. ${ }^{24}$ The British government, aware that the ban on slave imports would cause a labour shortage, set limits on the freedom of movement for Khoesan labourers, issuing a code of labour legislation in 1809 that enabled the farmers to tie Khoesan children (and by extension the whole family) to the farm until they were twenty-five years old. This was a system of apprenticeship that stemmed from the practice of the inboekstelsel, but now with legal recognition. The modified system meant that the farmers, on paper, were charged with providing the Khoesan child with food and housing (and occasionally basic education) in exchange for labour. ${ }^{25}$

21 Ross, Status; Dooling, "The Making of a Colonial Elite"; Feinstein, An Economic History of South Africa.

22 Dooling, "In Search of Profitability", p. 105.

23 Green, "The Economics of Slavery"; Malherbe, "Indentured and Unfree Labour".

24 Ross, "Emancipation", p. 133.

25 Ibid., p. 134. 
Worden argues that neither the use of female and child slaves nor the restrictions on the mobility of Khoesan labourers could have compensated for the increased cost of slaves, since the supply of female and child slaves and Khoesan was insufficient. Scattered evidence provided by Dooling, based on farm expenditures from the immediate post-emancipation period, supports this view. Dooling shows that Cape farmers' labour costs in the 1840 s and 1850 s accounted for 25 to 30 per cent of their total income. By comparison, labour on plantations in eighteenth-century Mexico accounted for 5 to 10 per cent of total income, and on East Anglian farms in England, 2 to 3 per cent. ${ }^{26}$ This indicates that labour shortages were a serious problem for the farmers, but we need a more direct measurement, as Doolings' figures are not only a function of labour costs, but also depend on the profits made.

How severe then, were the labour shortages that the Cape farmers faced? The problem has so far not been dealt with systematically, and previous research provides contradictory answers. The ban on slave importation increased the price of slave labour, while alternative forms of labour were still in short supply. But how short was this supply? To answer this question, we would need to establish the size of the Khoesan population in the early-nineteenth-century Cape. Unfortunately, we lack any reliable primary sources, and the available estimates provide contradictory answers. Guelke says that by 1780 , the number of Khoesan living within the Cape boundaries had been reduced to 23,000 , and Scully says that by 1830 the figure was 42,000 , which would mean that the Khoesan outnumbered the slaves, of whom there were 33,583 at that time. ${ }^{27}$

However, using quantitative data, we can now show that the role of slaves was not as negligible in the interior as historians have tended to argue. We do this by analysing in detail the shifting labour relations in a specific district, Graaff-Reinet, in the early nineteenth century.

\section{Graaff-Reinet, labour mobility, and the ban on slave imports}

Graaff-Reinet was founded in 1786, and was to become the centre for wool production by the middle of the nineteenth century. ${ }^{28}$ Sales oflivestock were the district's main source of income in the eighteenth and early nineteenth century, mostly in the form of small numbers of cattle and sheep sold to 
intermediaries who were responsible for driving them to Cape Town, a journey that could take up to three months. ${ }^{29}$ The distance from the market was not the only difficulty the Graaff-Reinet settler farmers faced. A Swedish traveller, Sparrman, reported in 1770 that the land was fairly dry, and thus unsuitable for large-scale cattle farming, but surprisingly suitable for sheep, and that the northern parts of Graaff-Reinet became so cold during winter that it "sometimes snow[ed] to a man's length", forcing the farmers to move the sheep and cattle to the drier plains south of the settlement. The dry climate not only prevented investments in large herds of cattle, it also limited the possibility of trade. The farmers could only move their sheep and goods to the Cape Town market during the rainy season, when there was enough water and pasture for the animals. In very dry years, of which there were many in the first two decades of the nineteenth century, wagon traffic between Graaff-Reinet and Cape Town almost came to a standstill. ${ }^{30}$

When Britain took formal control over the colony in 1795 , immigration and military expansion boosted the growth of Graaff-Reinet. This growth was further boosted by the establishment of a government office in 1803 and the inflow of military personnel. ${ }^{31}$ British migration to the Cape increased significantly, notably after 1820 . Some of the British moved to Graaff-Reinet, bought land from the Boers, and were soon at the forefront of sheep farming and wool production in the Cape Colony. Their arrival in Graaff-Reinet marked the beginning of the long-term expansion of wool production in the Cape. The British invested in irrigation, enabling a more intensive settlement in the semi-arid interior..$^{22}$

Labour demands were high. A farmer could, even before wool production took off in the 1820 s, own up to 10,000 or 12,000 head of livestock. Family members and the Khoesan were the two most important sources of labour. Eldredge, like Guelke, states that the reason for this was that slaves were far too expensive for the average farmer. In 1790, there were about 600 slaves in the district, the equivalent of one per farm, whereas 10,000 Khoesan were employed. ${ }^{33}$ The lack of reliable, detailed information makes it difficult to classify accurately the various ways the Khoesan were employed. Qualitative sources commonly refer to the use of apprenticeship, but also

Muller “The Economic Awakening”, p. 48.

30 Beinart, The Rise of Conservation, pp. 39-43; Muller, "The Economic Awakening”, p. 26; Ballard, "Drought", p. 361.

31 Muller, "The Economic Awakening", p. 30.

32 Beinart, The Rise of Conservation, p. 57.

33 Eldredge, "Slave Raiding”, pp. 93-126, 94, 96. 
of Khoesan moving from farm to farm in organized work gangs. ${ }^{34}$ Coercion was undoubtedly involved, and stories of the brutal treatment of Khoesan are widely confirmed, not least by the Khoesan rebellion of $1799 \cdot{ }^{35}$ On a number of occasions, the Khoesan complained to local authorities that they had not received payments or that they were beaten by their employers..$^{36}$

What makes the Eastern frontier an interesting case is that developments there were very different from those of the Southwestern Cape in the first two decades of the nineteenth century. Whereas slavery was on the decline in the Southwestern Cape, it increased in the Graaff-Reinet district, and in 1820 about 5,000 slaves were being used there. While the ban was making it more expensive to buy slaves, there was a regional shift, with slaves being transferred from west to east. ${ }^{37}$ Whether this shift was a response to Western Cape farmers employing larger numbers of Khoesan labourers is difficult to determine, as Khoesan are not included in the tax records of the Southwestern Cape districts. For this reason, we need to document the experience of Graaff-Reinet households and their labour relations on the Cape frontier, not only to improve our understanding of the frontier experience but also to pave the way for a reinterpretation of labour relations closer to Cape Town.

The use of Khoesan labour on individual farms began to be documented in the nineteenth century. The documentation of the Khoesan employed by farmers in the Graaff-Reinet district was part of the larger project of trying to control the mobility of the indigenous populations in an attempt to curb the social tension between the indigenous populations and the colonists. ${ }^{38}$ However, the numbers reported probably still underestimate the number of Khoesan employed, as they only include those who lived on the farms or who were employed as permanent wage labourers. The documents thus exclude Khoesan employed as day labourers, and it is difficult to estimate their numbers, given the available sources.

\section{The tax censuses}

The Graaff-Reinet district's tax censuses during the early nineteenth century include the number of Khoesan employed by each farm. Each of 
the several districts of the Cape Colony compiled its own tax census. We used the records from the Graaff-Reinet district, because this is the only district that listed Khoesan separately from other sources of labour. Each census includes the number of settler men and women and their sons and daughters in a household, the number of slaves used (split by gender and age), the number of Khoesan employed (split by gender and age), the number of wagons and carts owned, and several output variables, including the number of cattle, sheep, horses, and pigs owned, and the amounts of wheat, barley, rye, oats, wine, and brandy produced. Table 9.1 shows the size of some of these variables between 1790 (the first census for Graaff-Reinet) and 1828 (the last that includes all the variables). ${ }^{39}$

Table 9.1 Totals of tax census variables, Graaff-Reinet, 1790-1828

\begin{tabular}{lrrrrr}
\hline Variable & 1790 & 1800 & 1810 & 1820 & 1828 \\
\hline Settler men & 719 & 886 & 1388 & 1257 & 1426 \\
Settler women & 502 & 634 & 1022 & 966 & 1186 \\
Settler sons & 800 & 1073 & 1848 & 1414 & 1904 \\
Settler daughters & 776 & 1062 & 1672 & 1474 & 1886 \\
Knechts & 8 & 5 & NA & NA & NA \\
Slaves & 340 & 419 & 889 & 627 & 733 \\
Slave women & 227 & 368 & 546 & 468 & 514 \\
Slave sons & 19 & 94 & 172 & 289 & 329 \\
Slave daughters & 11 & 81 & 165 & 195 & 300 \\
Khoesan men & NA & 3099 & 2808 & 2644 & 2010 \\
Khoesan women & NA & 3288 & 3019 & 2915 & 1900 \\
Horses & 1424 & 4208 & 8723 & 8165 & 9458 \\
Cattle & 33,375 & 74,412 & 65,530 & 68,330 & 48,039 \\
Sheep & 250,500 & 735,676 & $1,132,019$ & 683,051 & 711,174 \\
Pigs & 33 & NA & 123 & 49 & 12 \\
Wheat sown & NA & NA & 289.25 & 442.25 & 492.5 \\
Wheat reaped & NA & 3158 & 7894 & $10,399.38$ & 6073.5 \\
Vines & NA & NA & 38,2269 & 47,0874 & 59,7026
\end{tabular}

39 Transcribed from sources J 109, J118, J133, J145, J155, J165 and J 167 in the Cape Town Archives Repository, Cape Town, South Africa. The authors would like to thank Erika le Roux, Chris de Wit, and Linda Orlando for their kind assistance. The transcribed files are in the possession of the authors and may be made available to researchers with specific requests. 


\begin{tabular}{lrrrrr}
\hline Variable & 1790 & 1800 & 1810 & 1820 & 1828 \\
\hline Wine & NA & 122.75 & 141.875 & 240.125 & 128.375 \\
Wagons & NA & NA & 1181 & 1074 & 1099 \\
Carts & NA & NA & 20 & 18 & 45 \\
\hline
\end{tabular}

Notes: "NA" denotes categories that were not available in that census year. "Wheat sown" and "wheat reaped" are enumerated in muids. "Wine" is measured in leaguers.

To obtain consistent data, we transcribed six of these censuses -1800 , $1805,1810,1815,1820$, and 1825 - to cover the period before and after the ban on slavery..$^{40}$ Table 9.2 provides the summary statistics - the average of each variable, by year - of the six censuses. Some variables that were not included in the 1800 census have been marked as "not available". ${ }^{41} \mathrm{We}$ also constructed a "value" variable, disaggregated by type of production. This indicates the market prices of output from the Graaff-Reinet district, obtained from prices listed in probate inventories..$^{42}$ What is important here is not so much the actual prices, as the relative prices of the various goods. We assume that these levels stayed constant for the period between 1800 and $1825 \cdot{ }^{43}$

40 We selected these years because of the consistency of five-year intervals and the perceived accuracy of the micro-level data. Transcribed from sources J118, J133, J145, J155, and J165 in the Cape Town Archives Repository.

41 On the other hand, the 1800 census includes the number of European servants (knechts) working on Graaff-Reinet farms, although only seven such apprentices appear in the records. This variable is therefore excluded.

42 These inventories were from the MOOC 8-series of the Transcription of Estate Papers at the Cape of Good Hope: TEPC Transcription Project, Inventories of the Orphan Chamber: http:// databases.tanap.net/mooc/. See Liebenberg et al., "The Inventories".

43 The prices of horses (Rds 8) and sheep (Rds 2) are obtained from MOOC 8/31.55, the price of cattle (Rds 5) from MOOC 8/33.11, the price of wine (Rds 75, calculated by multiplying the half-aam price of Rds 10 by 7.5 to convert to leaguers) from MOOC $8 / 36.7$, the price of brandy (Rds 75 per leaguer) from MOOC 8/32.22, and the price of wheat (Rds 6 per muid) and barley (Rds 4 per muid) from MOOC 8/34.5, MOOC 8/39.6 and MOOC 8/39.17. The "stock value" includes only cattle and sheep, while the "total value" also includes horses. 
Table 9.2 Average per household across six tax censuses, 1800-1825

\begin{tabular}{|c|c|c|c|c|c|c|c|c|}
\hline & Unit & 1800 & 1805 & 1810 & 1815 & 1820 & 1825 & Total \\
\hline Settler men & Count & 0.97 & 0.99 & 0.96 & 0.96 & 0.96 & 0.95 & 0.96 \\
\hline Settler women & Count & 0.69 & 0.72 & 0.71 & 0.75 & 0.73 & 0.76 & 0.73 \\
\hline Settler children & Count & 2.37 & 2.45 & 2.36 & 2.25 & 2.19 & 2.39 & 2.34 \\
\hline Khoesan men & Count & 3.25 & 1.79 & 1.86 & 1.49 & 2.05 & 2.02 & 2.04 \\
\hline Khoesan women & Count & 3.48 & 2.06 & 2.06 & 1.49 & 2.18 & 2.07 & 2.18 \\
\hline Khoesan & Count & 6.72 & 3.85 & 3.92 & 2.98 & 4.23 & 4.10 & 4.23 \\
\hline Slaves men & Count & 0.55 & 0.75 & 0.73 & 0.67 & 0.68 & 0.69 & 0.68 \\
\hline Slaves women & Count & 0.38 & 0.53 & 0.49 & 0.45 & 0.49 & 0.51 & 0.48 \\
\hline Slaves & Count & 0.93 & 1.28 & 1.23 & 1.11 & 1.16 & 1.19 & 1.16 \\
\hline Horses & Count & 6.22 & 5.81 & 5.94 & 4.49 & 6.09 & 6.06 & 5.78 \\
\hline Cattle & Count & 78.34 & 46.45 & 42.78 & 36.45 & 51.62 & 42.75 & 48.62 \\
\hline Sheep & Count & 756.0 & 701.1 & 764.4 & 426.7 & 522.2 & 523.9 & 611.2 \\
\hline Pigs & Count & NA & 0.14 & 0.12 & 0.04 & 0.04 & 0.02 & 0.06 \\
\hline Wheat sown & Muids & NA & 0.25 & 0.24 & 0.25 & 0.32 & 0.37 & 0.25 \\
\hline Wheat $r$ & Muids & 9.82 & 5.08 & 6.08 & 7.50 & 7.95 & 5.02 & 6.77 \\
\hline Barley sown & Muids & NA & 0.14 & 0.18 & 0.15 & 0.18 & 0.15 & 0.14 \\
\hline Barley reaped & Muids & 4.32 & 2.80 & 3.70 & 3.52 & 3.90 & 1.80 & 3.28 \\
\hline Rye sown & Muids & NA & 0.00 & 0.00 & 0.00 & 0.00 & 0.00 & 0.00 \\
\hline Rye reaped & Muids & 0.00 & 0.07 & 0.00 & 0.01 & 0.00 & 0.06 & 0.02 \\
\hline Oats sown & Muids & NA & 0.00 & 0.03 & 0.00 & 0.00 & 0.00 & 0.01 \\
\hline Oats reaped & Muids & 0.00 & 0.00 & 0.00 & 0.00 & 0.02 & 0.01 & 0.01 \\
\hline Vines & Count & NA & 263.3 & 328.7 & 321.1 & 335.0 & 351.8 & 279.2 \\
\hline Wine & Leaguers & 0.12 & 0.09 & 0.13 & 0.15 & 0.15 & 0.06 & 0.12 \\
\hline Brandy & Leaguers & NA & 0.02 & 0.03 & 0.04 & 0.05 & 0.04 & 0.03 \\
\hline Wagons & Count & NA & 0.89 & 0.94 & 0.74 & 0.81 & 0.83 & 0.73 \\
\hline Carts & Count & NA & 0.01 & 0.01 & 0.01 & 0.01 & 0.02 & 0.01 \\
\hline Value stock & Rds & 1903.8 & 1634.5 & 1742.6 & 1035.6 & 1302.5 & 1261.5 & 1465.4 \\
\hline Value grain & Rds & 76.21 & 41.69 & 51.27 & 59.08 & 63.32 & 37.29 & 53.71 \\
\hline Value viti & Rds & 9.21 & 7.94 & 12.06 & 14.28 & 15.23 & 7.06 & 10.96 \\
\hline Value total & Rds & 2021.7 & 1719.4 & 1838.7 & 1130.9 & 1414.3 & 1347.1 & 1563.3 \\
\hline
\end{tabular}

Notes: "NA" denotes categories that were not available in that census year. Rds is rijksdaalders/ rixdollars. 
The descriptive evidence in Table 9.2 allows for several important observations. We can see that the first two decades of the eighteenth century appear to have been unfavourable for frontier farmers. Output fell from a high of rixdollars (Rds) 2,021 per farmer in 1800 to Rds 1,131 in 1815, a drought year, after which output recovered to Rds 1,347 in 1825, although that was still significantly below the 1800 and even the 1810 level.

Historical documents show that weather conditions in Graaff-Reinet in the early nineteenth century were indeed troublesome, with recurrent droughts and unusually cold winters. ${ }^{44}$ However, we suggest that another reason for the decrease in output may have been the increasing scarcity of labour because of the slave ban. This suggestion contradicts much previous research, which has argued that farmers in Graaff-Reinet did not face an immediate shortage of labour, partly because of the intensified use of semi-bonded labour, a practice sanctioned by the state from 1809 onwards. ${ }^{45}$ Nevertheless, to date the lack of data has made it impossible to verify either of these conflicting claims about labour supply. Our summary statistics can help us assess these claims, especially if we consider the two periods, 1800 to 1810 and 1815 to 1825 , separately. Between 1800 and 1810 , the average number of Khoesan per farmer declined significantly, from 6.7 to 3.9. This is in contrast to an increase in the average number of slaves, from 0.9 to 1.2. Household labour remained the same at four individuals per farm. The increase in slave ownership should not be surprising: the international ban was only announced in 1807 and it would have taken several years for it to filter through to the farmers on the frontier.

What is perhaps surprising, however, is the rapid decline in the Khoesan population formally employed on Graaff-Reinet farms. There are two possible and not necessarily mutually exclusive explanations for this. The first is that there were simply fewer Khoesan in the area. Having lost access to grazing land in the interior, many Khoesan are reported to have moved southwest in search of employment in the wheat and wine farms of the Stellenbosch and Drakenstein districts. It is perhaps for this reason that the Cape government imposed a restriction on the movement of Khoesan labour. The second reason for the decline may have been changes in sheep farming methods when British settlers bought farms from the Boers. Unlike the Boers, who followed local, indigenous practices, the British farmers enclosed their flocks rather than bringing them back to the kraal every 
evening and this reduced the demand for labour significantly. ${ }^{46}$ It is hard to disentangle cause and effect here, but it seems plausible that changes in herding practices occurred because of a shortage of labour rather than the reverse.

The legal changes aimed at limiting the mobility of the Khoesan seem to have had only a minimal effect on increasing the labour supply at first. In addition, we find that between 1810 and 1815, the number of Khoesan employed on farms in fact declined further, from an average of 3.92 to 2.98 . It is only after 1815 that it began to increase. By 1820 it reached its highest level after 1800, an average of 4.23 Khoesan per farm. The average number of slaves per farmer, on the other hand, decreased between 1800 and 1810 , and remained at a level below that of 1805 . Even just from the descriptive evidence (Table 9.2), it appears that the ban on importing slaves increased the role of Khoesan labour relative to slave labour.

\section{Productivity of slave and Khoesan labour}

The trends in the average numbers of slaves and Khoesan on the GraaffReinet farms may mask changes in the productivity of these different types of labour. To investigate this, we ran a basic Ordinary Least Squares production function with the value of production as the dependent variable and the labour types as explanatory variables. This production function allows us to ascertain which inputs were most important in creating the outputs. 


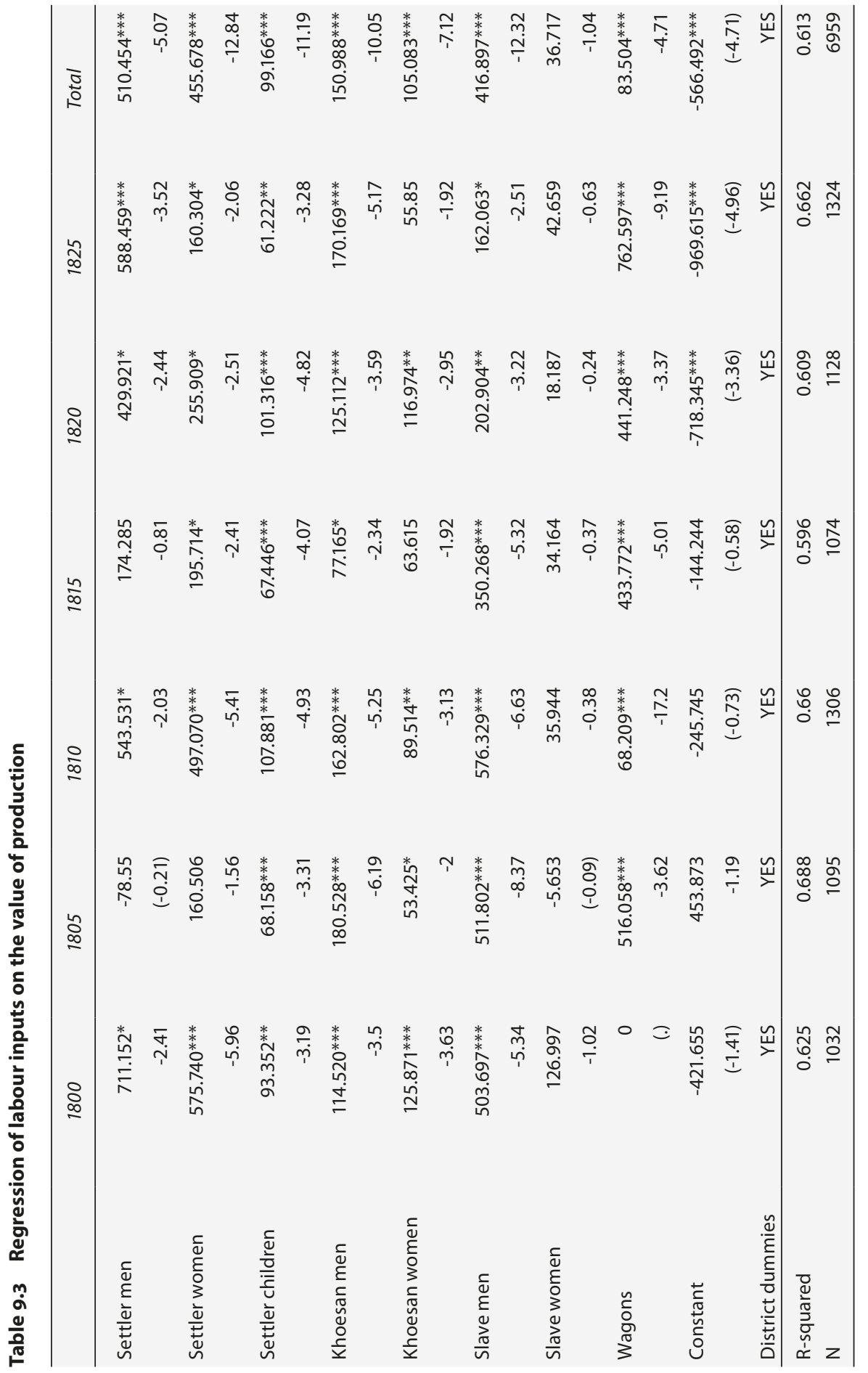


Figure 9.1 Coefficients of male Khoesan and male slaves, 1800-1825

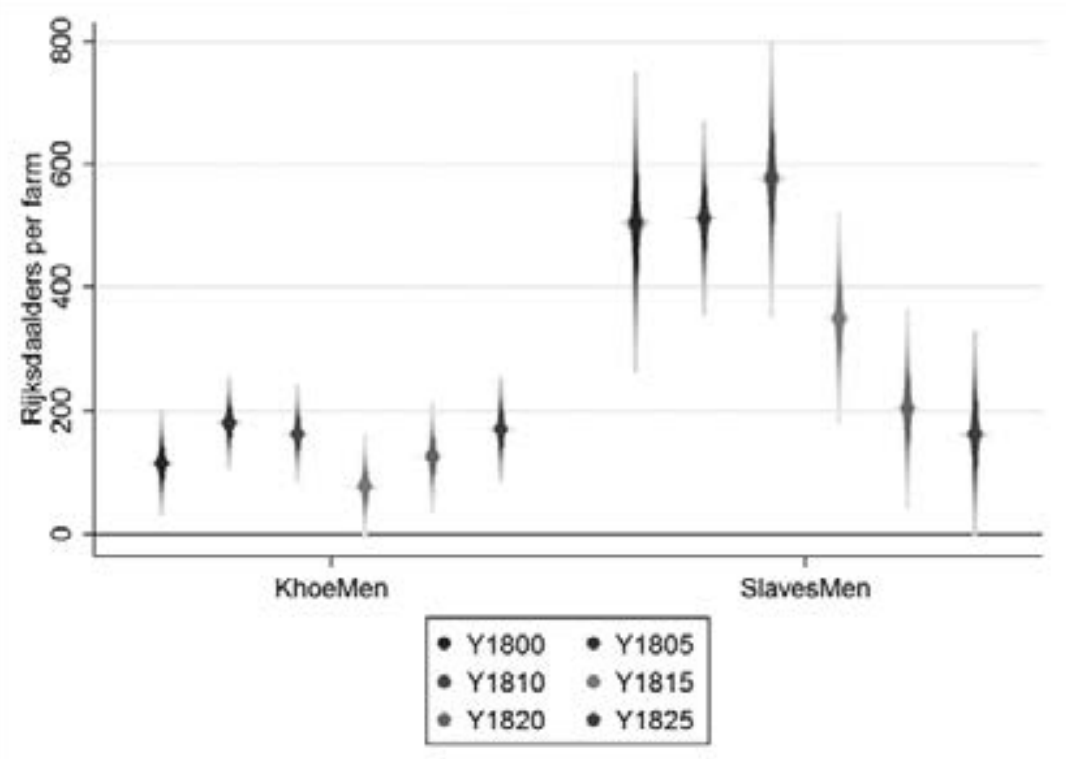

Figure 9.2a Coefficients of male slaves for stock farming, 1800-1825

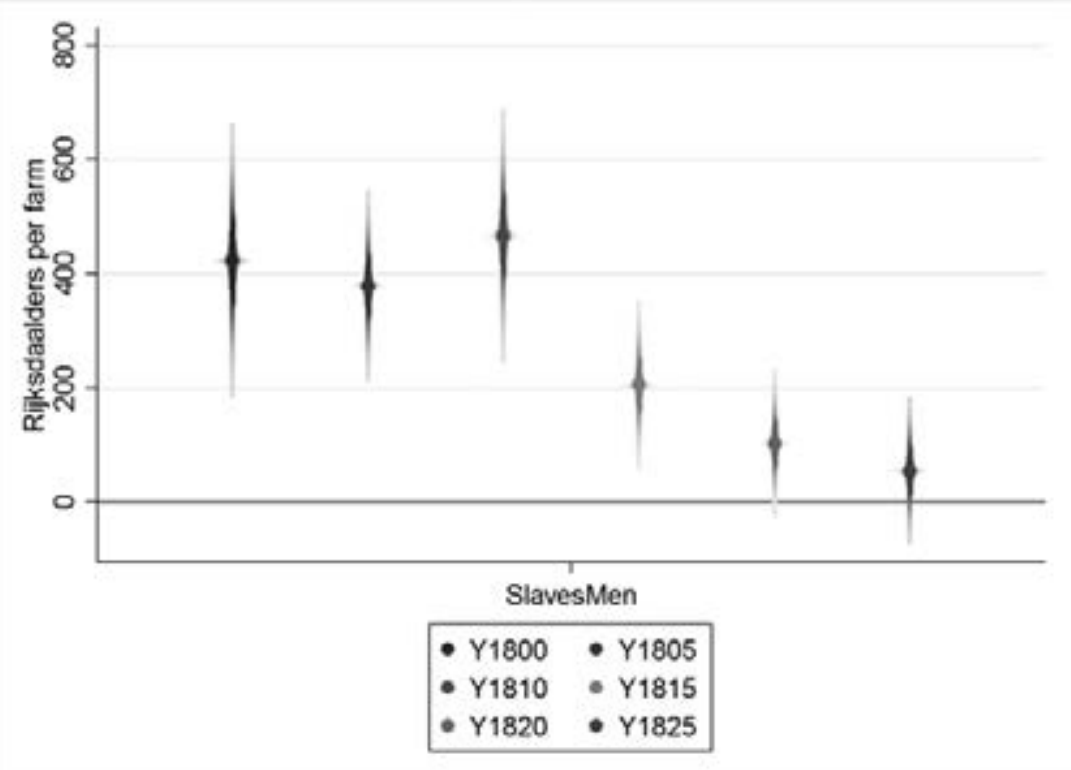


Figure 9.2b Coefficients of male slaves for grain farming, 1800-1825

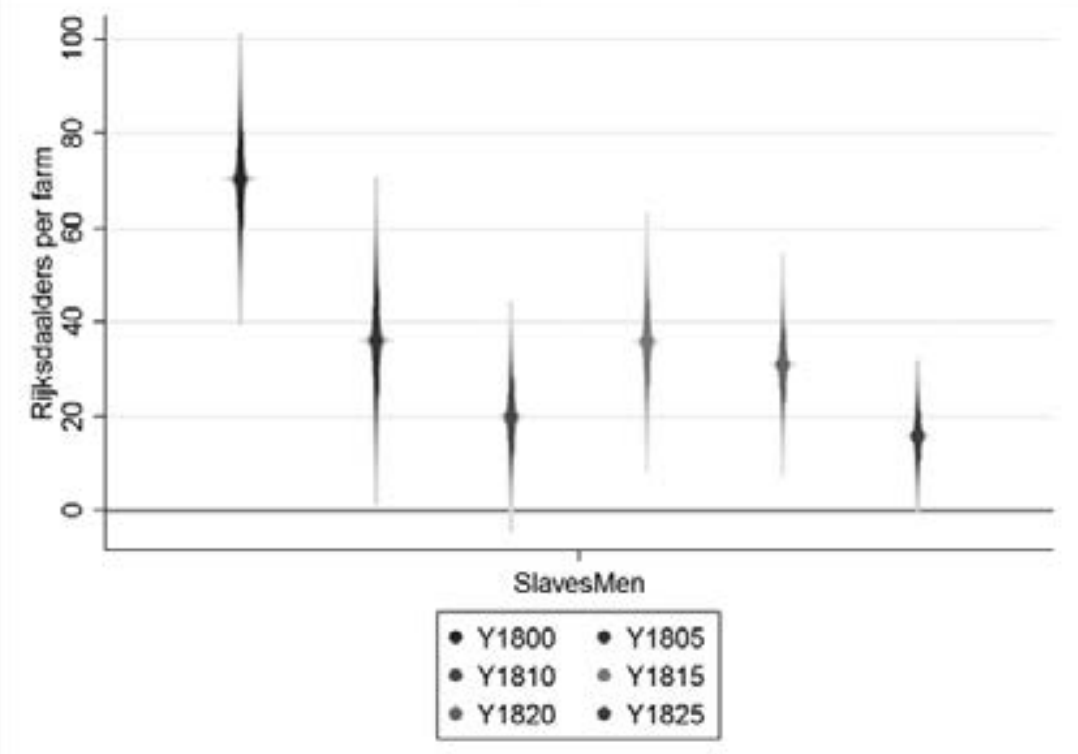

Figure 9.2C Coefficients of male slaves for viticulture, 1800-1825

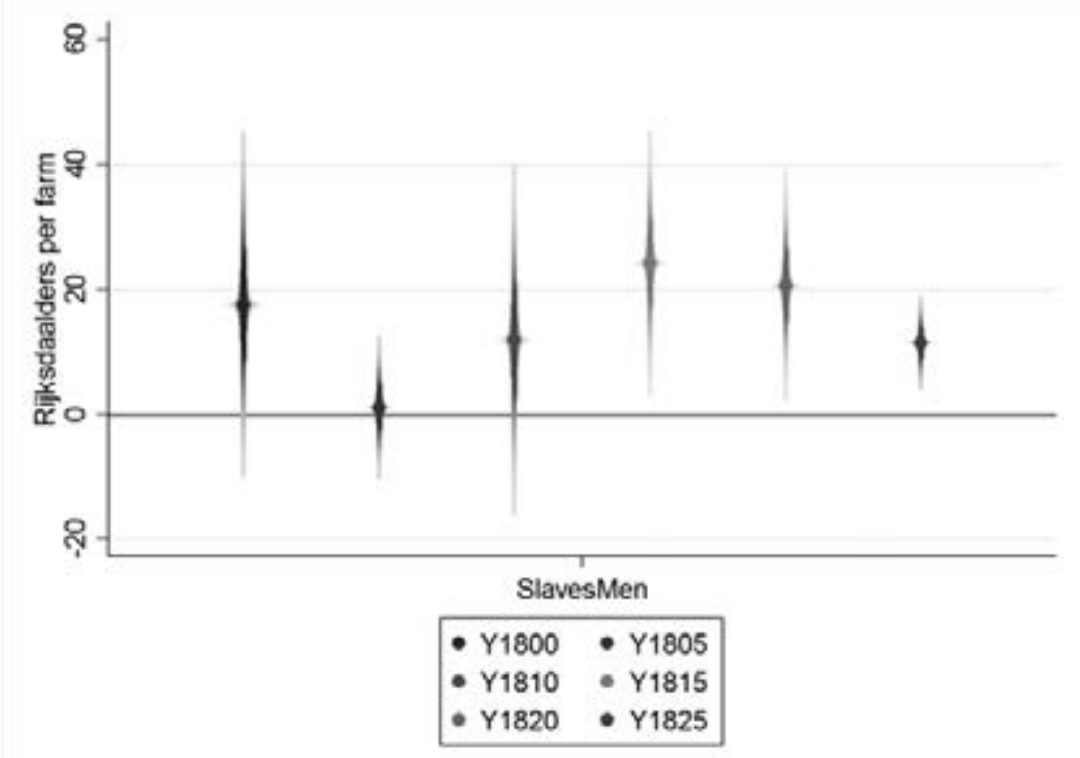


The results presented in Table 9.3 reveal important productivity trends by gender. Looking at the coefficients over the entire sample shown in the "total" column, we can see immediately that both men and women contributed to total production. There is, however, significant variation over the period examined. In some years, notably 1800 and 1810 , women have a large and statistically significant coefficient, meaning that we can be certain they made an important contribution to production in those years. In others, although the coefficient is still positive, its size is diminished to the extent that it has no statistical significance. Settler children contributed on average less than other types of labour.

More importantly for our story, a coefficient of Rds 150 is calculated for male Khoesan. This is less than half the coefficient for male slaves, suggesting that male slaves were in general much more productive than male Khoesan. However, there are important changes in the trend of these coefficients over the period under investigation. These changes are better reflected in Figure 9.1, which shows the size of the male Khoesan and male slave coefficients for each of the six censuses. Note the considerable decline in the coefficients of slave labour over the period, from a high of 503 to a statistically insignificant 81 by 1825 . Also note that, as explained earlier, this was a period when slave prices increased markedly. It is puzzling that these move in opposite directions. Why would an exogenous shock in the supply of slaves cause a decline in their individual productivity?

We may find an answer by considering the coefficients for each of the output types separately. To do this, we repeated the exercise above but changed the dependent variable to represent the value of stock farming, grain farming, and viticulture separately. From Figure 9.2, it is abundantly clear that the decline in the overall level of productivity was as a result of the decline in productivity for stock farming. This should not surprise us, as stock farming was by far the largest category.

What explains this decline in the productivity of slaves in stock farming? It is far from obvious which form of labour should be the most productive, and we need to consider which was best suited to stock farming. Given that herds were dispersed over a fairly large geographical area, it would have made little sense to use slaves, as the cost of monitoring them would have been relatively high. However, the problem of runaway slaves seems to have been minimal. An 1834 account stated that only 1 per cent of the slaves in the whole of the Cape Colony had escaped and in the Cape papers, runaway 
slaves are not discussed at all. ${ }^{47}$ We must take into account the fact that labour demands in sheep farming are more or less constant over the year, which means that employers tend to avoid short-term labour contracts. We would thus expect the employment of work gangs and of Khoesan day labourers to have played a minor role on Graaff-Reinet sheep farms, while indentured Khoesan labour would have increased, which Giliomee also argues is what happened..$^{8}$ We might also reasonably assume that after the ban on slave imports, the farmers' use of labour would become increasingly specialized. This fits the general story of British settlers. Instead of "wasting" expensive slaves on sheep farming, farmers might instead have used them in those industries where slaves had, for whatever reasons, a comparative advantage over Khoesan, particularly in wheat and wine farming.

The problem with this interpretation is that it does not accord well with the available evidence. Consider Figure 9.2, for example. Here we see that slave productivity in the other sectors, although above that of the Khoesan, was also in decline towards the end of the period. Therefore, the specialization of slave usage into other modes of agriculture does not seem to be a sufficient answer.

This specialization may not only have been into other types of agriculture, but also into other types of production and other uses entirely. One hypothesis runs as follows: as the price of slaves started to increase because of the ban on slave trading, and the mobility of Khoesan labour was restricted, male Khoesan began to replace male slaves on frontier farms. Male slaves were now seen as luxury items, owned by the wealthy and used to transport people from farm to town or simply around town. Another hypothesis is that slaves were bought by townspeople who used them in sectors outside agriculture, for example, in proto-factories. ${ }^{49}$ Given the lack of adequate data on non-farm production, this is a difficult hypothesis to test. However, by looking at the proportion of slaves concentrated in the town of Graaff-Reinet over the period, we might be able to identify whether this effect is large enough to explain the declining productivity of slaves. Table 9.4 suggests that it is not. Although the townspeople clearly owned more slaves than the farmers, there are no clear time trends in either the average number of slaves

47 Mason, "Fortune Slaves", p. 74. Of course, 1834 may not be a very representative year, given that slavery had been formally abolished. However, we find little anecdotal evidence of high desertion rates.

48 Giliomee, "Processes", p. 85.

49 Fourie, "Slaves". 
per household or the ratio of town averages to farm averages. Specialization in non-farm production does not seem to explain the decline in the productivity coefficient. ${ }^{50}$

Table 9.4 Urban and rural slave ownership

\begin{tabular}{cccc}
\hline & Town & Farms & Town to farm ratio \\
\hline 1805 & 1.42 & 0.71 & 1.98 \\
1810 & 0.61 & 0.75 & 0.81 \\
1815 & 1.02 & 0.62 & 1.65 \\
1820 & 0.96 & 0.63 & 1.52 \\
1825 & 1.14 & 0.62 & 1.83 \\
\hline Total & 0.99 & 0.65 & 1.52 \\
\hline
\end{tabular}

Source: See above. No district dummy is available for the 1800 census.

Perhaps the ban on slavery forced settler farmers to increasingly use male slaves in a supervisory role on farms? Male slaves and male Khoesan should then have become increasingly complementary in producing output. We tested for this by including an interaction term in our standard model. An interaction term combines two variables to ascertain what the unique effect of these two variables is, over and above their individual effects. Table $9 \cdot 5$ shows the results. Except for the small, negative, but statistically significant coefficient in 1810, all other coefficients are very small and insignificant. There seems to have been very little complementarity between male slaves and male Khoesan, and certainly no trend over the period that could explain the decline in the coefficient (which is still visible in Table 9.5).

50 In separate regressions, we attempted to identify the factors that contributed to male slave and male Khoesan productivity. As explanatory variables, we used the different inputs into stock farming. The only coefficient that was significantly different between the two labour units is carts. The slaves (men) and carts interaction is large, negative, and statistically significant. This suggests that slaves may have been used to transport people or perhaps as luxury goods (as carts were luxury goods too). However, when we ran these regressions separately for each year, we found no pattern over the period. In fact, the largest effect seems to be from 1805 , which suggests that this cannot explain the decline in the slavery coefficient. 


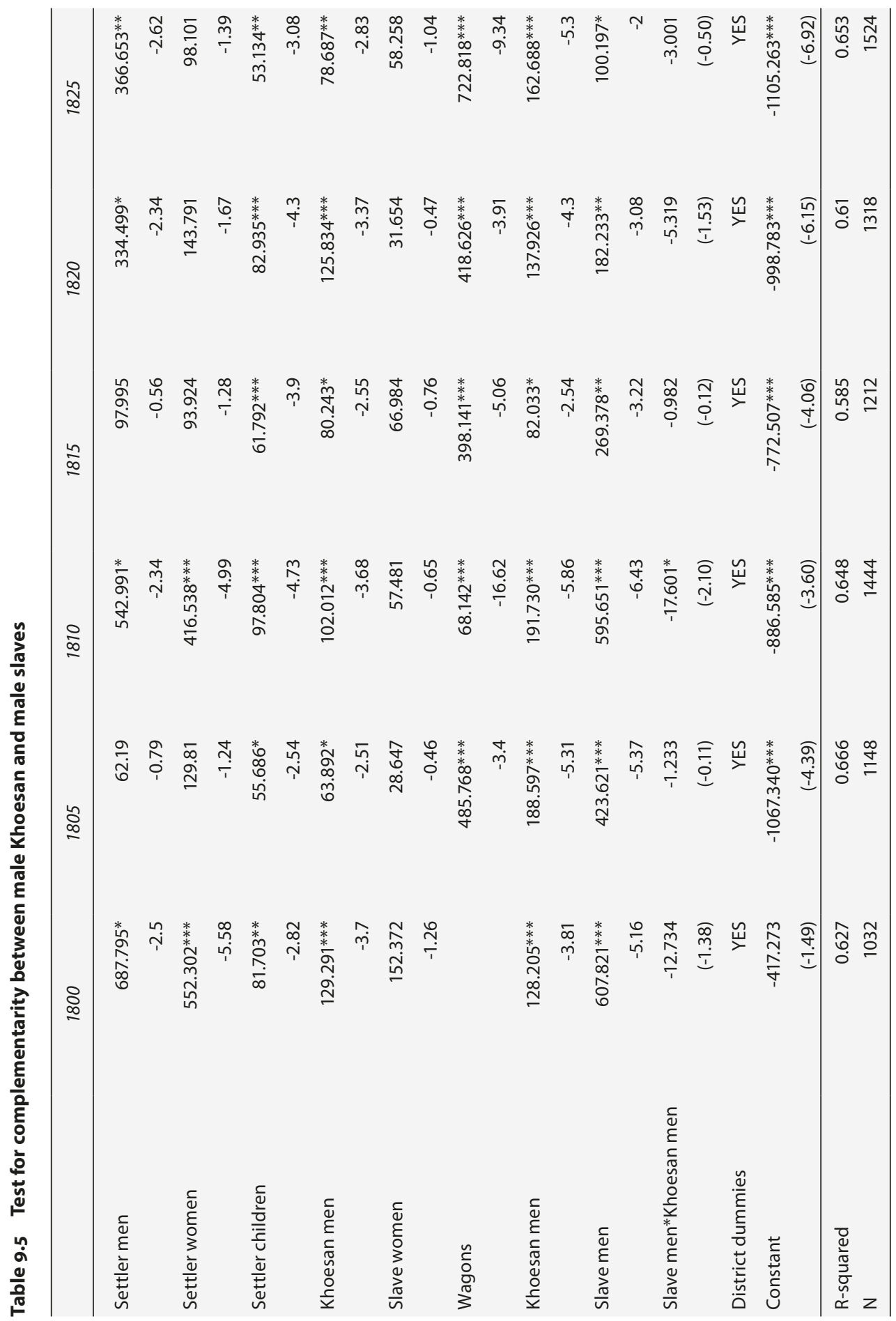


Figure 9.3 Kernel density estimates of male slaves by year

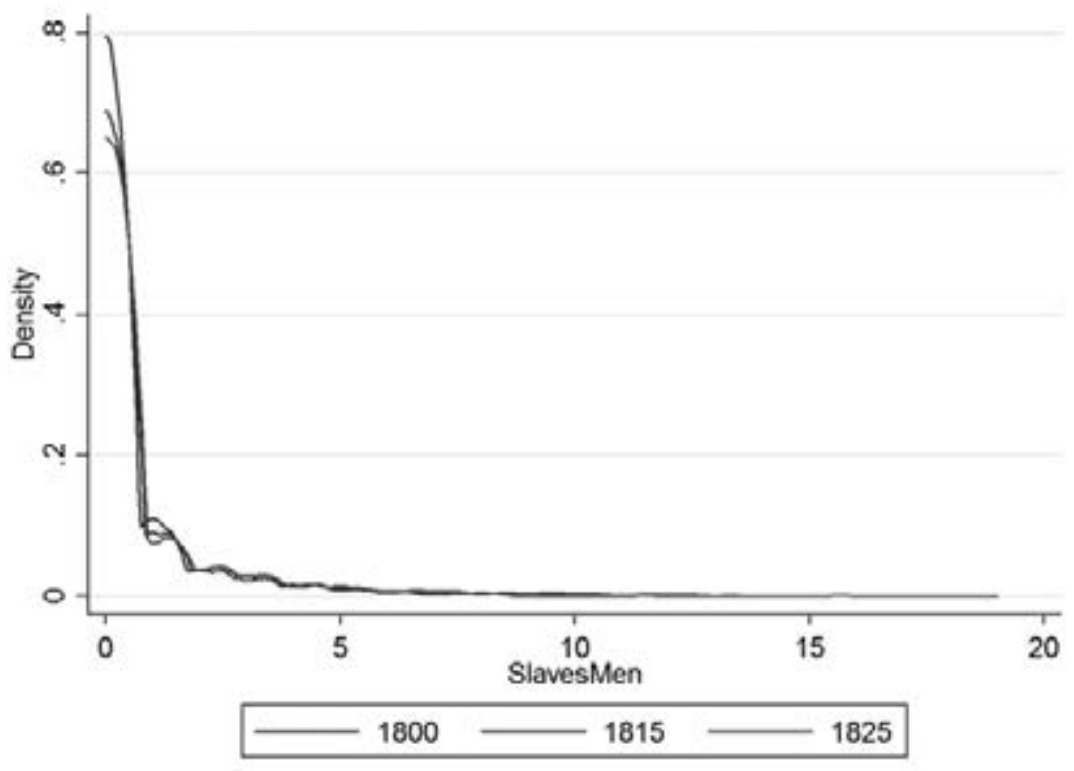

Another possible explanation for the decline in the male slave coefficient is that slaves became increasingly concentrated on wealthy farms. A greater concentration of slaves on wealthy farms could result in diminishing marginal returns on slave labour, which could possibly explain the fall in the marginal product of labour.

Table 9.6 shows the distribution of male slave ownership for households with more than two slaves. This is a snapshot of the concentration of slaves over time. At first glance, we can see there is indeed an increase in the concentration levels, notably in the increase at the ninetieth percentile. The maximum number of slaves owned also rises from fifteen in 1800 to nineteen by 1825 . A statistical analysis of 1800,1815 , and 1825 - showing the greater concentration of male slaves in affluent households - is also provided in Figure 9.3. 
Table 9.6 Concentration of slave ownership over time

\begin{tabular}{lllllll}
\hline & p10 & p25 & p50 & p75 & p90 & max \\
\hline 1800 & 3 & 3 & 4 & 6 & 8 & 15 \\
1805 & 3 & 4 & 4 & 6 & 8 & 14 \\
1810 & 3 & 3 & 5 & 7 & 10 & 17 \\
1815 & 3 & 3 & 4 & 7 & 9 & 14 \\
1820 & 3 & 4 & 5 & 7 & 10 & 18 \\
1825 & 3 & 3 & 5 & 7 & 11 & 19 \\
\hline
\end{tabular}

However, it is unclear whether this effect is large enough to explain the pronounced fall in male slave productivity. It is more likely that other, unobservable, farm characteristics explain the sudden decline. To investigate this we need a panel dataset - linking families between the different censuses - and more advanced estimation techniques, notably fixed-effects models. To produce these will be a costly exercise, but it is necessary if the decline in the productivity of slave labour following the ban on slavery is to be better understood.

\section{Conclusion}

The availability of large, historical datasets, such as the newly transcribed tax censuses used in this study, allows economic historians to both identify new long-term historical patterns and, in combination with stronger analytical tools, test new causal relationships. This is particularly relevant for regions often neglected in scholarly literature, such as Sub-Saharan Africa..$^{51}$ Although the complete series of tax censuses are still being transcribed, they will ultimately be made available online through global data platforms, including the Global Collaboratory on the History of Labour Relations and the Clio-Infra project..$^{52}$ These platforms not only increase accessibility and the dissemination of research results, but allow for greater cross-region standardization and comparison; for example, to test the effect of the ban on slave imports across the British Empire.

51 Fourie, "The Data Revolution".

$5^{2}$ See Global Collaboratory on the History of Labour Relations, https://collab.iisg.nl/web/labourrelations/about, or Clio-Infra: Reconstructing Global Inequality, https://www.clio-infra.eu/. 
In this study, however, our focus on the Graaff-Reinet district of the Cape Colony already offers some insights. The introduction of a ban on slave importation across the British Empire in 1807 had a marked effect on the Cape economy. Not only did prices increase, as historians note and contemporary policymakers were well aware of, but even on the Cape's eastern frontier, far from the bustling market town in Table Bay, production decisions were affected.

Historical literature suggests that labour relations underwent a change in the early nineteenth century. Slavery declined and the coercion of indigenous populations increased. The British government, aware that the ban on slave imports would cause a labour shortage, set limits on the freedom of movement for Khoesan labourers, issuing a code of labour legislation in 1809 that enabled farmers to tie Khoesan children (and by extension the whole family) to the farm until they were twenty-five years old.

We argue, using a new dataset of six censuses of the Graaff-Reinet district, that slaves had a large initial advantage over Khoesan labour; on most farms, slaves were on average more than three times as productive as male Khoesan. It is therefore reasonable to expect slaves to be the preferred form of labour on farms in the interior, even given the availability of an indigenous labour force.

Our results show, however, that this productivity changed after the introduction of the ban. Male slaves' productivity began to fall. By 1825 , estimates show that their productivity was at the same level as that of male Khoesan. We thus provide quantitative evidence to support historians' claims that labour relations changed after the abolition of slavery. The Khoesan clearly became more productive after the imposition of the 1809 labour legislation restricting their movement.

There are several plausible explanations for this effect, although all of them are difficult to test using the data that is currently available. We find little proof that slaves became increasingly specialized in non-agricultural production or that they began to take on a more supervisory role that was complementary to Khoesan labour. Instead, we argue that at least part of the decline in slave productivity has to do with the concentration of slaves on wealthier farms. As more slaves moved to a few large farms, diminishing marginal returns reduced the productivity of slaves in the Graaff-Reinet district. The reason for the concentration of slaves on larger farms remains unclear, but this hypothesis fits quite well with previous research that emphasizes the changes in farm ownership in general and the expansion of wool production in particular. This hypothesis, we must stress, is still very tentative and will need further investigation, especially using a larger 
number of census records. Nevertheless, what is clear from our results is that, contrary to what Cape historians have emphasized previously, slaves played an important role, even in the frontier economy. Khoesan and slave labour were subject to the supply and demand of the colonial economy. The economic aspect of these labour relations deserves more attention than it has hitherto received.

\section{Bibliography}

Armstrong, J.C., and N. Worden, "The Slaves, 1652-1834", in R. Elphick and H. Giliomee (eds), The Shaping of South African Society, 1652-1840 (Middletown, 1988), pp. 109-183.

Ballard, C., "Drought and Economic Distress: South Africa in the 180os", Journal of Interdisciplinary History, 17 (1986), pp. 359-378.

Beinart, W., The Rise of Conservation in South Africa: Settlers, Livestock, and the Environment, 1770-1950 (Oxford, 2003).

Cape Town Archives Repository, The House of Commons Papers of the Native Inhabitants of Southern Africa, Part I: Hottentotts and Bosjmen, Caffres, Griquas (Cape Town, n.d.).

Dooling, W., "In Search of Profitability: Wheat and Wine Production in the PostEmancipation Western Cape", South African HistoricalJournal, 55 (2006), pp. 88-105

Dooling, W., "The Making of a Colonial Elite: Property, Family and Landed Stability in the Cape Colony, c. 1750-1834", Journal of Southern African Studies, 31 (2005), pp. 147-162.

Eldredge, E., "Slave Raiding across the Cape Frontier", in E. Eldredge and F. Morton (eds), Slavery in South Africa: Captive Labor on the Dutch Frontier (Bloomington, 1994), pp. 93-126.

Elphick, R., Kraal and Castle: Khoikhoi and the Founding of White South Africa (New Haven, 1977).

Feinstein, C., An Economic History of South Africa: Conquest, Discrimination and Development (Cambridge, 2005).

Fourie, J., "The Data Revolution in African Economic History", Journal of Interdisciplinary History, 47:2 (2016), pp. 193-212.

Fourie, J., "The Remarkable Wealth of the Dutch Cape Colony: Measurements from Eighteenth-Century Probate Inventories", Economic History Review, 66 (2013), pp. 419-448.

Fourie, J., "Slaves as Capital Investment in the Dutch Cape Colony, 1652-1795", in E. Hillbom and P. Svensson (eds), Agricultural Transformations in a Global History Perspective (London, 2013), pp. 136-159. 
Fourie, J., and D. von Fintel, "The Dynamics of Inequality in a Newly Settled, PreIndustrial Society: The Case of the Cape Colony", Cliometrica, 4 (2010), pp. 229-267. Fourie, J., and E. Green, "The Missing People: Accounting for the Productivity of Indigenous Populations in Cape Colonial History", Journal of African History, 56 (2015), pp. 195-215.

Giliomee, H., "Processes in Development of the Southern African Frontier", in H. Lamar and L. Thompson (eds), The Frontier in History: North America and Southern Africa Compared (New Haven, 1981), pp. 76-122.

Green, E., "The Economics of Slavery in the Eighteenth-Century Cape Colony: Revising the Nieboer-Domar Hypothesis", International Review of Social History, 59 (2014), pp. 39-70.

Guelke, L., "Frontier Settlement in Early Dutch South Africa", Annals of the Association of American Geographers, 66 (1976), pp. 25-42.

Liebenberg, H., F. Clayton, K. Faasen, E. van As, J. van der Merwe, M. Rall, and I. Meyer, "The Inventories of the Orphan Chamber of the Cape of Good Hope", in N. Worden (ed.), Contingent Lives: Social Identity and Material Culture in the VOC World (Cape Town, 2007), pp. 3-22

Malherbe, V.C., "Indentured and Unfree Labour in South Africa: Towards an Understanding", South African Historical Journal, 24 (1991), pp. 3-30.

Mason, E.J., "Fortune Slaves and Artful Masters: Labor Relations in the Rural Cape Colony during the Era of Emancipation, ca. 1825 to 1838 ", in. E. Eldredge and F. Morten (eds), Slavery in South Africa: Captive Labor on the Dutch Frontier (Bloomington, 1994), pp. 67-92.

Muller, A.L., "The Economic Awakening of the Eastern Cape, 1795-1820", South African Journal of Economics, 1 (1987), pp. 41-53.

Neumark, S.D., Economic Influences on the South African Frontier, 1652-1836 (Stanford, 1921).

Penn, N.G., "Pastoralist and Pastoralism in the Northern Cape Frontier Zone during the Eighteenth Century", Prehistoric Pastoralism in Southern Africa, 5 (1986), pp. 62-68.

Ross, R., "Emancipation and the Economy of the Cape Colony", Slavery \& Abolition: A Journal of Slave and Post-Slave Studies, 14 (1993), pp. 131-148.

Ross, R., "The Origins of Capitalist Agriculture", in P. Delius and S. Trapido (eds), Putting the Plough to the Ground:Accumulation and Dispossession in Rural South Africa, 1850-1930 (Johannesburg, 1986), pp. 56-100.

Ross, R., Status and Respectability in the Cape Colony, 1750-1870 (Cambridge, 1999). Scully, P., Liberating the Family? Gender and British Slave Emancipation in the Rural Western Cape, South Africa, 1823-1853 (Oxford, 1997).

Shell, R., "Immigration: The Forgotten Factor in Cape Colonial Frontier Expansion, $165^{8}$ to 1817", Journal of South African and American Studies, 6 (2005), pp. 1-38. 
Swanepoel, Christie, and Johan Fourie, “'Impending Ruin' or 'Remarkable Wealth'? The Role of Private Credit Markets in a Settler Colony”, Economic Research Southern Africa Working Paper 517, May 2015, https://econrsa.org/system/files/ publications/working_papers/working_paper_517.pdf.

Williams, G., "Who, Where, and When Were the Cape Gentry?", Economic History of Developing Regions, 28 (2013), pp. 83-111.

Worden, N., Slavery in Dutch South Africa (Cambridge, 1985).

\section{About the Authors}

Johan Fourie is Associate Professor of Economics at Stellenbosch University (South Africa). His publications include studies using colonial probate inventories (Economic History Review, 2013), population estimates (Journal of African History, 2015, with Erik Green), and credit records (Journal of Southern African Studies, 2017, with Christie Swanepoel). His contribution to this volume is the first chapter of a new project - The Cape of Good Hope Panel - in which a panel dataset of Cape settler households spanning more than a century will be created.

E-mail:johanf@sun.ac.za

Erik Green is an Associate Professor of Economic History at Lund University (Sweden) and a Research Fellow at the Department of Economics, Stellenbosch University (South Africa). His main research interest is agricultural history and labour history. His recent publications include studies of wage shares in Malawi (Journal of African History, 2015, with Jutta Bolt), involutionary growth in Ghana (Journal of Agrarian Change, 2016), labour and land tenure changes in Zambia (Journal of Southern African Studies, 2017, with Milja Norberg), and slavery and the Nieboer-Domar hypothesis in South Africa (International Review of Social history, 2014).

E-mail:Erik.Green@ekh.lu.se 



\section{Part III}

Monetization and the Payment of Work 



\title{
10 Paying in Cents, Paying in Rupees
}

\author{
Colonial Currencies, Labour Relations, and the Payment of \\ Wages in Early Colonial Kenya
}

Karin Pallaver

\begin{abstract}
Hofmeester, Karin \& Pim de Zwart (eds.), Colonialism, Institutional Change, and Shifts in Global Labour Relations. Amsterdam: Amsterdam University Press, 2018
\end{abstract}

DOI: $10.5117 / 9789462984363 / \mathrm{CH} 10$

\begin{abstract}
This chapter focuses on labour relations and the payment of wages in early colonial Kenya. It looks at how colonial money was obtained, saved, and spent by African labourers, and it argues that the circulation and use of different currency denominations was connected to the rhythms of wage and tax payments. The chapter contends that the supply of labourers in the early colonial period was partly determined by the type of currency denominations in which labour was paid and by the ways in which cash earned through waged work was used.
\end{abstract}

Keywords: Kenya, labour, money, wages, colonialism

\section{Introduction}

The history of labour in Kenya has been the subject of numerous studies. ${ }^{1}$ As Bruce Berman pointed out, "few historical arenas offer a clearer view of the intersection of powerful social forces with the subjective decisions of determinate actors creating a new and recognizable social and political entity such as "Kenya". ${ }^{2}$ The establishment of white settlers' plantations,

1 The key works are: Clayton and Savage, Government and Labour; Van Zwanenberg, Colonial Capitalism; Tignor, The Colonial Transformation; Cooper, From Slaves to Squatters; Stichter, Migrant Labour; Mosley, The Settler Economies; Berman, Control \& Crisis; Berman and Lonsdale, Unhappy Valley; Okia, Communal Labor.

2 Berman, Control \& Crisis, p. 49. 
together with the demand for workers coming from the colonial state, produced a "perpetual search for labour"3 that lasted from the early twentieth century until the $195 \mathrm{os}^{4}{ }^{4}$ During the early colonial period, the main concern of the embryonic colonial state was to find cheap labour and to create the conditions for colonial development. In order to control the sources of uncertainty and instability in the labour supply, the colonial state used coercion and expanded the scope and intensity of its intervention. ${ }^{5}$ However, this could not suffice to mobilize the required number of workers. The availability of labourers was connected to the level of taxation, the rhythms of the subsistence agricultural production, and the attractiveness of wages. For African workers, waged labour was a way to access colonial money, and the availability of labourers was therefore largely connected to what they wanted to do with the cash earned. Money, and the ways to obtain it, can therefore provide an analytical tool to explore the development of the colonial economy and of labour relations in early colonial Kenya.

The introduction of a new currency system was one of the most important institutional changes of the early colonial period. It was driven by various economic motivations, including the reduction of transaction costs, the construction of colonial economies, and the increase in control over macroeconomic conditions. ${ }^{6}$ At the same time, it was a way to create a new relationship with the colonial state: the daily use of coins and notes was instrumental in the establishment of a link of authority between the colonial state and its subjects. ${ }^{7}$ Crucial in this process were the imposition of taxes and the payment of wages in the new currency, as well as the monetization of marriage payments and of the ways of accumulating and storing wealth.

This chapter looks at how colonial money was obtained, and then saved or spent in early colonial Kenya. It focuses on how wages were paid and in what currency denomination, on the connection between monetization and the supply of labour, and on the link between colonial taxation and the development of wage labour. It looks at which groups used which means of exchange, for what type of transaction, and at how often wages were paid and in which coins. It argues that the supply oflabourers in the early colonial 
period was also the result of the ways in which the cash earned through waged work was used. The chapter also contends that the circulation of different currency denominations was connected to the rhythms of wage and tax payments.

\section{Rupees, cents and shillings: The introduction of colonial money in the East Africa Protectorate}

In the nineteenth century, the area that later became the East Africa Protectorate (EAP) was part of the commercial hinterland of Zanzibar, the development of which had been the result of the commercialization of two main commodities: ivory and slaves. Patterns of trade became highly complex, involving the use of imported currencies at the "interface" ${ }^{8}$ between regional economies and the commercial world of Zanzibar. On the coast, the currencies in use were the Maria Theresa thaler and the Indian rupee, and commodity currencies in the interior were mainly glass beads, imported cloth, and metal wire. ${ }^{9}$ At the time of the establishment of the EAP in 1895 , the area was therefore already monetized, and people had developed specific ways to evaluate and exchange goods and services.

However, the British wanted to introduce a currency that could be issued and centrally controlled by the government, and that could mediate the transactions between the colonial state and its subjects, such as the payment of wages and taxes. After many discussions, it was decided that the Indian rupee was the best option for the EAP. Its choice as the currency of both Uganda and the EAP was considered as a natural consequence of the pre-existing trade relations with the Indian Ocean commercial world, and especially with Zanzibar, that had become the basis of the British commercial interests in the area. In May 1898, the Indian rupee became together with its fractional coins, annas and pice - the official currency of the EAP. ${ }^{10}$

In the first years of colonial rule, the rupee was used for the payment of taxes and wages. Copper pice, instead, thanks to their small value, became the chief form of currency in the markets of the coastal areas. In the

8 Jane Guyer introduced the concept of the currency "interface", a point of meeting where difference was maintained, albeit on changing terms. See Guyer, Money Matters, p. 8.

9 For an overview on the use of imported commodities as currencies in nineteenth-century East Africa, see Pallaver, "A Recognized Currency".

10 "Order in Council. East Africa Currency", May 19, 1898, The National Archives, London [hereafter, TNA], FO $8817027 \mathrm{X}$. 
interior, however, colonial currencies had very little circulation, with the exception of the neighbourhood of government stations. ${ }^{11}$ With no means of transport other than human porters, carrying coins into the interior was too expensive. It was only after the opening of the Uganda railway in 1902, that colonial coins, and especially the copper pice, were gradually introduced into the interior and had a wider circulation. ${ }^{12}$

The circulation of copper pice in the coastal areas presented, however, some problems, especially because of its fluctuating value. The pice was officially sixty-four to the rupee, but from 1898 to 1902 its value fluctuated between sixty-five and eighty-two to the rupee. In order to solve this problem, to limit the circulation of commodity currencies (especially in Uganda, where cowrie shells were the chief currency), and to assist the development of the internal exchange economy, a new monetary system was discussed in the early 1900 and introduced in $1905 \cdot{ }^{13}$

The 1905 East Africa and Uganda (Currency) Order in Council, introduced the subdivision of the Indian rupee into cents, and sanctioned, for the first time, the introduction of paper notes. The coins introduced were fifty and twenty-five silver cents, ten and five copper cents, and one and one-half aluminium cents. ${ }^{14}$ When changes in currency were made, the Treasury in London considered issues of profits, seigniorage, design, and composition, but local administrators were perfectly aware that "complications of currency in the eyes of the natives" could easily hinder the effectiveness of currency policies. ${ }^{15}$ The circulation and acceptance of colonial money could be made effective only by the gradual transformation of local economic practices and payments. Workers often refused to be paid in a new denomination when a currency change occurred. In 1909, for example, L. Besson \& Co. - a company that ran the Uyombo Mangrove Concession in Mombasa - complained that local workers did not want cents and only wanted pice, and asked for the help of the government in order to make the Currency Order in Council effective. ${ }^{16}$

14 TNA FO 881/7027X. The 1905 Order in Council regulated the currency situation in the EAP and, for the first time, Uganda. It was aimed at limiting the circulation of cowries in Uganda, as well as the fluctuating value of Indian copper pice in the EAP.

15 Bowring to Undersecretary of State, July 3, 1905, TNA CO 533/9.

16 L. Besson to Provincial Commissioner Mombasa, Mombasa, January 9, 1909, Kenya National Archives, Nairobi [hereafter KNA] PC Coast 1/1/150. 
Colonial money was rejected for various reasons. New currencies were invariably in short supply after their introduction and, generally, they had too high a denomination value to be used in local small transactions. ${ }^{17}$ In the case of the East African cents, there were two main problems: the material from which the one and the half-cent coins were made, and the design and exchange rate of the ten-cent coin. Soon after the introduction of the new cents, it was discovered that the aluminium one-cent coins corroded, especially in the coastal areas, "to such an extent as in some cases to be hardly recognizable as coins". ${ }^{18}$ In March 1908, the minting of aluminium coins for the EAP was therefore suspended and new one and half-cent nickel-bronze coins were approved. ${ }^{19}$

Another problem with cent coins was that people, who had been using Indian currencies for many years, continued to calculate in the more familiar pice instead of in tens and multiple of tens. According to the new convertibility of cents into pice, it was not convenient to carry out transactions with some cent denominations. The basis for every calculation was three cents equalling two pice. In this way, nine cents corresponded to six pice, and twelve cents to nine pice. When someone exchanged his or her ten-cent coin to pice, what they obtained back was six pice, the value of which was actually nine cents. It goes without saying that in these sorts of transactions, one cent was always lost. The only coin that could be exchanged for its exact value was the one-cent piece. ${ }^{20}$ That is why, as shown below, this was the currency that was most in demand in the protectorate.

The last important change in the monetary history of the protectorate happened after the end of the First World War, and was determined by the post-war increase in the value of silver and, consequently, of the value of the silver Indian rupee against sterling. As a consequence, from 1919 to 1923 , Kenya saw three different currency changes: from the Indian rupee to the East African rupee, to the East African florin, and finally, to the East African shilling, which remained the official currency until independence. $^{21}$

17 Ekejiuba, “Currency Instability and Social Payments", p. 142.

18 "Extract from a Despatch by the Governor of the East Africa Protectorate to the Secretary of State for the Colonies", July 24, 1908, TNA CO 533/46.

19 MacCartney to Under Secretary of State, August 27, 1908, TNA CO 33/52. Aluminium coins continued to circulate in the EAP and they ceased to be accepted only after 1 October 1913 . See Nairobi, 30 June 1913, KNA PC COAST 1/6/38; Isaac to Mombasa District Commissioner [hereafter DC], Mombasa, December 16, 1909, KNA PC Coast 1/1/154.

20 Kikuyu Quarterly Report, June 1911, KNA DC KBU/1/3.

Maxon, "The Kenya Currency Crisis"; Mwangi, "Of Coins and Conquest". 


\section{Porters, squatters, and government workers: An overview of labour relations in early colonial Kenya}

The group working on Africa in the framework of the Global Collaboratory on the History of Labour Relations at the International Institute of Social History, Amsterdam, has highlighted the paucity of sources on labour relations, especially for the period before 1900. The sources for the colonial period, even if more abundant, are often incomplete and provide information on wage workers only. Nonetheless, these sources provide information on the structure of the labour market and a general context for highlighting shifts in labour relations. ${ }^{22}$

On the basis of methodological discussions, as well as the collection of data for several African countries, the group has highlighted how, although important changes in labour relations were triggered by the development of the colonial economy, reciprocal labour remained the dominant labour relation in many African countries after 1800 . Another important point that has emerged from the discussion is the development in many African countries of a combination of labour relations, generally reciprocal and commodified labour, which was particularly promoted by the establishment of the colonial economy. In Kenya, the changes in labour relations were a consequence of the development of the settlers' plantation economy after the beginning of the twentieth century, as we will see in this section. ${ }^{23}$

At the time of the establishment of the EAP in 1895, the majority of the local population was engaged in reciprocal labour. Wage labour existed, mainly in the coastal towns, where there were tradesmen and artisans very often slaves - who were usually paid by the job or daily. Given that there was no transport infrastructure, porters formed another class of wage labourers. There were about 10,00o regular porters in the Mombasa area in 1895. Slave labour was used in the coastal plantations. ${ }^{24}$

With the British occupation, an increasing number of workers were needed to support the government administration and the first colonial commercial ventures. Workers were required as "government stations' hands", soldiers, and porters, as well as in the building of the protectorate's infrastructures, especially the Uganda railway. This was the biggest project

22 Pallaver, "Labor Relations", p. 315.

23 For an overview of the first results of the research of the Africa group, see the Special Issue of History in Africa, 41 (2014), and especially the introduction: Hofmeester, Lucassen, and Ribeiro da Silva, "No Global Labour History".

24 Stichter, Migrant Labour, p. 1; Cooper, From Slaves to Squatters. 
undertaken by the British in East Africa in the early colonial period, and was aimed at connecting the Uganda Protectorate with the coast, in order to reduce transport costs and make the administration feasible and less expensive. ${ }^{25}$

When the construction work started in 1896, very few African labourers volunteered for employment, and those who did, often only for short periods. The Kamba, for instance, worked on three-month contracts, and when the contract expired they generally did not enrol again, preferring to work in their fields or to be employed as porters. ${ }^{26}$ The limited availability of labourers depended on a variety of issues. According to Sharon Stichter, access to land in this period was relatively egalitarian, as was the distribution of products. The groups who were rich in foodstuff or cattle had much less material incentive to take up wage work. ${ }^{27}$ Periods of crises could increase the availability of labourers, as in the case of the famine that hit the eastern part of the protectorate in 1899, but generally the incentives offered by the British were not enough to mobilize the needed number of workers. ${ }^{28}$

In order to obtain the manpower needed for the railway project, the colonial administration decided to recruit workers from India, although Indian labourers were definitely more expensive than local workers. Unskilled Indian labourers were paid twelve rupees per month, whereas local labourers only received four. ${ }^{29}$ The main advantage of using Indian labourers was that they worked for longer periods and could therefore guarantee a constant labour supply. In 1896, there were 3,948 Indians employed by the railway, in 1897 there were 6,086 , in $1898,13,003$, and in $1901,18,182.3^{30}$ With the progress of the railway inland, the number of African labourers increased, from about 1,400 in 1897, to 2,650 in 1898, and slightly decreasing to 2,506 in $1901 .^{31}$ The railway connecting Mombasa to Kisumu, on Lake Victoria, was opened in 1902. After the completion of railway works, about 6,500 Indian labourers remained in the protectorate and many of them opened small bazaars along the railway, forming the nucleus of a class of

25 For the Uganda railway, see Hill, Permanent Way; Hardy, The Iron Snake; Miller, The Lunatic Express; Sood, Victoria's Tin Dragon.

26 Whitehouse to O'Callaghan, Mombasa, February 26, 1897, TNA FO 403/258.

27 Stichter, Migrant Labour, pp. 9, 17-18.

28 Ibid., p. 16.

29 Mombasa, February 28, 1896, TNA FO 403/224.

30 Hill, Permanent Way, pp. 183, 189.

31 G. Molesworth, "Report on the Uganda Railway", March 28, 1899, TNA FO 881/7120; see also "Uganda Railway: History of the Undertaking", TNA FO 403/339. 
small traders that developed in later years and controlled the import and export trade in the interior regions..$^{22}$

In the early colonial period, Africans also found employment in commercial and government porterage. Porters were essential for the colonial enterprise, because they were the only means of transport to carry supplies to the government stations in the interior, as well as to carry commercial goods from Uganda to the coast. Porterage was a quite popular occupation, because of both the level of wages and the good conditions of caravan work. Wages were ten rupees per month with food for porters carrying loads from the coast to Uganda, and five rupees for inland porters. ${ }^{33}$ Porters also benefited from a host of regulations introduced by the colonial government in 1896, 1902, and 1910. These, among other things, sanctioned the obligation for a caravan master to take care of sick porters, to give employees a blanket, and to register them. ${ }^{34}$

The most important turning point in the history of labour in early colonial Kenya was the decision taken by the protectorate's commissioner from 1901 to 1904, Sir Charles Eliot, to encourage white settlement. The establishment of farms run by settlers created a tension that remained at the basis of the Kenyan economy for the following years: the conflicting co-existence of African peasant production with the settlers' demand for cheap African labour. ${ }^{35}$

Settlers were convinced, given that the government had "invited" them to East Africa, that it was its duty to provide labourers for their undertakings. Therefore, one of the main concerns of the government became to find labourers for the white settlers. ${ }^{36}$ Coercion has been identified as one of the chief tools employed by the colonial government to obtain labour. This led to a system of state control on labour that by the 1920 s was, in its scope and intensity, greater than in any other British colony in Africa. ${ }^{37}$

After 1910, as (globally) conditions of world trade prospered, and (locally) investments increased, more settlers arrived in East Africa. The favourable price of coffee and the expansion of sisal and maize production increased the required number of farm labourers to $100,000.3^{8}$ This,

Spencer, "The First Assault".

Clayton and Savage, Government and Labour, pp. 6-10.

Ibid.

White settlers' farming fully developed only after WWI. By 1913, three-quarters of export nings still came from African produce. See Berman, Control \& Crisis, p. 54.

Clayton and Savage, Government and Labour, p. 10; Berman, Control \& Crisis, p. 129.

Berman, Control \& Crisis, p. 143; Berman and Lonsdale, Unhappy Valley, p. 116.

Clayton and Ehrlich, "Introduction", p. 1. 
together with the development of various government projects, such as the extension of the Uganda railway and the building of piped water delivery system in Mombasa, created one of the first labour crises in the EAP. ${ }^{39}$ A Labour Commission was established to investigate the reasons behind the labour shortage and, as we will see in the next section, it was discovered that the problem was not only determined by the demand exceeding the supply. ${ }^{40}$

Quantitative sources of data about labour are limited, especially for the period before 1921, but they can nonetheless give an idea of the general magnitude of the wage labour force in relation to the total population. Before the outbreak of the First World War, the total number of workers employed by white farmers was 110,00o in the East Africa Protectorate (or in "the EAP"), whereas the number of people employed by the polity was 3,000 to 5,000 by the Public Works Department and 7,000 by the railway. ${ }^{41}$ In 1914, 24 per cent of the adult male population between the ages of fifteen and forty were in wage employment, but this reached 32 per cent in the South Nyanza province, near to Nairobi. ${ }^{42}$

The First World War was a watershed in the economic history of Kenya, as it created a more favourable situation for the white settlers, and at the same time caused a closer incorporation of African peasants into the colonial economy. The value of settlers' exports, especially coffee, sisal, and flax, recovered in 1915 and 1916, compared with the declines of 1913 and 1914. ${ }^{43}$ African local production of foodstuff came under the control of the state, owing to the enormous demand for food for troops and porters engaged in the East African Campaign. ${ }^{44}$

The beginning of military operations in East Africa saw a steady increase in compulsory labour, due to the recruitment of soldiers and carriers for the campaign in neighbouring German East Africa. A total of 201,431 military labourers were employed during the war. ${ }^{45}$ The peak for the

Okia, Communal Labor, p. 48.

40 The Native Labour Commission interviewed 284 witnesses, among which were 205 Europeans, 64 Africans, and ${ }_{15}$ Asians. It is one of the richest sources of data on the history of labour in early colonial Kenya.

41 Clayton and Savage, Government and Labour, p. 65; Berman and Lonsdale, Unhappy Valley, p. 107.

42 Berman, Control \& Crisis, p. 66.

43 Strachan, The First World War, p. 115.

44 Overton, "War and Economic Underdevelopment?"; Overton, "War and Economic Development".

45 Including 26,193 known dead and 14,000 deserters presumed dead; see Clayton and Savage, Government and Labour, p. 88. 
employment of compulsory labour was reached in 1918, when 77 per cent of the able-bodied male population in Machakos district, 75 per cent in Kitui, and 54 per cent in Kiambu, had been enrolled. ${ }^{6}{ }^{6}$ The demobilization started in March 1918, and between 1 April 1918 and 31 March 1919, 73,057 men returned home. ${ }^{47}$ It has been calculated that the British employed a total of 1,000,000 porters in the East African Campaign, of whom 200,000 were from the EAP. ${ }^{48}$ The war showed that coercion was an effective way to obtain labourers. State conscription provided a supply of porters and soldiers, but at the same time it increased the number of labourers available for the settlers' plantations. If labourers had regular employment, they could avoid conscription. ${ }^{49}$

During the war, the development of squatter labour on settlers' farms became one of the chief features of Kenyan labour relations. Labourers, for the most part Kikuyu, were allowed to settle on a farmer's land with their families, to cultivate a small plot of land, and to herd their cattle. In exchange, they had to provide a certain amount of labour for the white settlers, or services or rent in kind. Following the work of the 1917 Commission, in December 1918, the government introduced a new regulation to control and encourage resident African labour. In order to be entitled to land use, men had to work for the farmer for 180 days per year. The average wage was three rupees per month with rations, corresponding to the lower wage paid to migrant labourers. ${ }^{50}$ This system was convenient for employers, who could obtain the labour needed, especially during the harvesting season, and profitable for the labourers, who could leave the reserves and cultivate their own plot of land. ${ }^{11}$ In those early years, many of the Kikuyu squatters became very wealthy in the traditional terms of wives, sheep, cattle, and goats..$^{22}$ By the early 1920s, there were about 130,000 wage workers in the colony, and 100,000 others were squatters. By the 1930s, the number of squatters had increased to $150,000 . .^{53}$

The period between 1919 and 1921 witnessed the most serious crisis in the labour supply in Kenyan history. This was partly due to war conditions, such as the demobilization of porters and carriers, casualties from the

Stichter, Migrant Labour, p. 38 .

On carriers, see Hodges, The Carrier Corps.

8 Strachan, The First World War.

49 Berman, Control \& Crisis, p. 145.

Anderson, "Master and Servant", p. 476. 
conflict, and the Spanish influenza virus that followed the war. It was also the result of the expansion of local agricultural production, which made Africans less willing to leave their fields for wage labour. This occurred at the same time as a significant expansion of production by settlers, ${ }^{54}$ which created a huge demand for labourers, ${ }^{55}$ and in turn led to increased state control over the labour system. This had started to emerge before 1914 and culminated in the early 1920 s in a massive application of state coercion to favour labour recruitment. ${ }^{56}$

In response to the crisis, Governor Northey, pushed by the settlers, issued a new regulation on labour. ${ }^{57}$ The 1919 Native Authority Amendment Ordinance, known as the Northey Circular, provided for the use of compulsory recruitment of labourers for government works, such as porterage and road construction, for up to sixty days per annum..$^{8}$ Government forced labour was paid, but at wages lower than those prevailing in the private sector, in order not to compete with the settlers. ${ }^{59}$ In the interwar years, the number of forced workers employed under this ordinance averaged 13,693 per annum during the 1920 , and 4,421 in the $1930{ }^{60} .^{60}$ The 1919 circular also introduced twenty-four days per year of compulsory communal labour. This was work performed for the benefit of local communities, such as the maintenance of roads, and was seen by the colonial government as a form of continuing the traditional duties that Africans owed to their chiefs. ${ }^{61} \mathrm{Communal}$ and forced labour remained instrumental to the colonial state until independence. ${ }^{62}$

Children were found in great numbers in many communal labour work projects. In addition to communal labour, they were employed in coffee picking, on sisal estates, and in fuel and ballast camps. Children over the age of nine could be employed only with their parents' authorization and

54 Especially sisal, coffee, tea, cattle and sheep, and maize.

55 Tignor, The Colonial Transformation, p. 147; Berman, Control \& Crisis, p. 145.

56 Berman, Control \& Crisis, p. 129; Berman and Lonsdale, Unhappy Valley, p. 118.

57 Berman, Control \& Crisis, p. 145; Okia, Communal Labor, pp. 63ff.; Berman and Lonsdale, Unhappy Valley, pp. 10-11.

58 Forced labour for private purposes had been forbidden since 1908, but the government could employ compulsory labourers for public purposes. Under the 1912 Native Ordinance, all Africans were declared liable for sixty days of compulsory labour per year; Stichter, Migrant Labour, p. 37 .

59 Okia, Communal Labor, p. 15.

6 o Anderson, "Master and Servant", pp. 463-464; Clayton and Savage, Government and Labour, p. 153, 200; see also Stichter, Migrant Labour, p. 82.

61 Okia, Communal Labor, p. 65; see also Berman and Lonsdale, Unhappy Valley, pp. 110-111; Stichter, Migrant Labour, p. 66.

62 Okia, Communal Labor, p. 115 . 
a certificate from the local district commissioner. They could be employed in industrial work only once they had reached twelve years of age, and they had to be fourteen to be allowed to work on machinery. ${ }^{63}$

The period from 1918 to 1923 was one of coercion by the state, during which the recruitment of labourers was helped by an increase in the population that created population pressures in the reserves, especially in the Kikuyu area ${ }^{64}$ In the two decades from 1903 to 1923 , the number of male African wage workers increased from 5,000 to 120,000, with an average increase of about 100 per cent per year. ${ }^{65}$ It then increased to 169,000 by 1926 , equating to 33.8 per cent of adult African men between the age of fifteen and forty. In the first three months of 1927, there were 185,409 Africans in European employment, or 34 per cent of the men between the age of fifteen and forty. There were also 30,000 women and children employed in coffee harvesting. In 1929, there were 160,000 wage workers. ${ }^{66}$ Half of these were employed in commercial agriculture, the rest worked for the state and the railway. The vast majority of them were temporary and unskilled labourers, who worked for a period ranging from three to six months per year.

At the end of the period under examination, labour relations in the EAP were still characterized by the majority of people being employed in reciprocal labour. Many of the labourers employed in the European plantations were combining labour relations, as they were migrant or squatter labourers for a period of three to six months, but worked in their fields for the rest of the year. Compulsory labour was still largely used by the government, but started to decline in the late 1920 .

Despite the coercive role of the state, labour shortages remained endemic in Kenyan history, and became particularly serious after the end of the First World War. ${ }^{6}$ Labour shortages were commonly explained as a consequence of demand exceeding supply, or with the common stereotype of the lazy or idle "native" that became a basic European belief. However, as we will see in the next section, the attractiveness of wage labour was limited, not only because of the low level of wages and poor working conditions, but also owing to the uses that were made of the colonial money obtained through wages.

63 Stichter, Migrant Labour, p. 102.

64 Berman and Lonsdale, Unhappy Valley, p. 116.

65 Stichter, Migrant Labour, p. 30. They worked for an average of six months per year. A series of regulations were introduced by the government from 1910 to 1939 to secure labour. For this, see Anderson, "Master and Servant".

66 Berman and Lonsdale, Unhappy Valley, pp. 106-107.

67 Van Zwanenberg, Colonial Capitalism, p. 48. 


\section{Earning money in early colonial Kenya}

In the EAP, Africans could obtain colonial money in three main ways: through wage labour, through the sale of produce, and through the sale of livestock.

Data on wages is sparse and difficult to reconstruct over time. ${ }^{68}$ However, there is a general consent among historians that the rate of wages in Kenya was not a sufficient incentive to make people leave the reserves or their fields for settler plantations or government works. At the time of the Native Labour Commission Enquiry in 1912-1913, the average wage for thirty days of work in the plantations varied from three rupees with food to six rupees without food, depending on the area. Kikuyu residents on the settlers' land received a wage without food, whereas those coming from the reserves were given one extra rupee per month for food. Skilled workers, such as drivers, could earn seven to ten rupees per month. ${ }^{69}$ Masai herders earned six rupees per month with food..$^{70}$ There were regional variations in the level of wages. Inland plantation workers received between three and five rupees (with or without food), whereas on the coast, the average wage was eight to ten rupees with food. ${ }^{71}$ This was due to the fact that coastal people, including the Giriama, did not generally work for wages. Migrant labourers, for the most part Kikuyu, therefore went to the coast, in this way obtaining higher pay. ${ }^{72}$

Wages were generally better when working for African employers. The Kamba, for instance, very rarely worked for Europeans. Instead, they employed Kikuyu labourers to cultivate their own plantations and fields. At the beginning of the colonial period, they paid their labourers with one sheep or goat per month. ${ }^{73}$ The Kikuyu then took the sheep or goat back to the Kyambu district, where it could be sold for six rupees. Considering that the average wage in the Kyambu area settlers' farms was four rupees, it was better to work for the Kamba than to be employed locally by the settlers. ${ }^{74}$

68 Ibid., p. 36 .

69 East Africa Protectorate, Native Labour Commission [hereafter $N L C$ ], various entries.

$70 \quad N L C$, Witness no. 8, W. Russel Bowker, $N L C$, pp. 13-15.

$71 \quad N L C$, various entries.

72 Witness no. 4, P.E. Watcham, NLC, pp. 8-9; Witness no. 28, W. McGregor Ross, NLC, p. 44. From November 1911 and May 1912, about 6000 Kikuyu went to the coast and 3000 worked for Europeans. See Witness no. 16, G.K. Watts, NLC, pp. $26-28$.

73 Witness no. 214, C.R.W. Lae, $N L C$, p. 196; Witness no. 10, G.H. Osborne, $N L C$, pp. 17-19; Witness no. 12, A.C. Hill, $N L C$, pp. 20-22; Witness no. 58, G.M. Dean, $N L C$, pp. 8o-81.

74 Kyambu Quarterly Report, June 1912, KNA Microfilm [hereafter, MF]. There is also evidence of Masai employing Kikuyu as herders, see Witness no. 214, C.R.W. Lae, NLC, p. 196. 
Wages in government work were generally lower than those paid in the private sector. In 1914, the Public Works Department paid its employees an average wage of two rupees per month. Working conditions were also reported to be very bad. Working for the railway was more profitable. In 1908 , the 3,500 labourers working in the construction of the Magadi railway received eight rupees per month. ${ }^{75} \mathrm{~A}$ favourable aspect of government work was that the monthly wage was paid after around twenty-five days, whereas in the plantations, workers had to work for a full thirty-day month before being paid.

Porters were paid reasonably well. In 1908, there were 4,000 porters employed by safari firms at ten rupees per month. ${ }^{76}$ After the outbreak of the First World War, porters became essential for the war effort. In order to attract a sufficient number of them, the government paid carriers at coast rates, between ten and fifteen rupees with rations (which was a rate considerably higher than farm labour). However, as the war progressed, the lack of government funds led the administration to officially reduce the rate to five rupees with rations for the first three months, and six rupees with rations thereafter. ${ }^{77}$

Wages increased slightly at the end of World War I, owing to the acute shortage of labour mentioned above. Unskilled farm labour was paid five rupees on engagement and six to eight rupees after two months, an increase of one to two rupees over 1914 wages. Railway or private wood cutters received from six to ten rupees, cart drives twenty rupees, sweepers and road gangs five rupees, and domestic servants were paid eleven to twelve rupees if employed as garden workers, or twenty rupees as house servants. ${ }^{78}$ However, the purchasing power of these wages was decreasing very rapidly. Together with an increase in the hut and poll tax, the increased wartime prices of consumer goods made them unattainable for Africans, and such goods ceased to provide an incentive to work for some considerable time. ${ }^{79}$ In 1921, wages were nine to eleven shillings ( 4.5 to 5.5 rupees) per month; they reached twelve to fourteen shillings in 1923, and sixteen to eighteen shillings by the end of the decade. ${ }^{80}$ Women and children received two to four shillings less than male labourers, and squatter labourers earned less than half the wages paid to migrant labourers. The purchasing power of 
these wages was very limited, and with ten shillings per month, there was very little that a labourer could buy. ${ }^{81}$ Working for wages, as we will see below, was generally only a way to obtain colonial money to pay taxes or buy livestock, and there was little left over for consumption or saving. ${ }^{82}$

In the interwar period, wages and their purchasing power remained low. ${ }^{83}$ In 1939, in Nairobi - where wages were some of the highest in the colony - the average wage was less than twenty shillings for thirty days of work. It was estimated that at the time, the basic minimum to live in the city was twenty-one shillings per month for a single man and thirty-eight shillings for a married man with two children. Men preferred to work in the rural areas rather than working for such low wages, or they combined labour relations, working in part for wages and in part in the fields ${ }^{84}$ The Elgeyo district commissioner noted in 1937 that wages were so meagre that a man went out to work only because of the need for cash to pay bridewealth or tax. ${ }^{8_{5}}$ As we discuss in the next section, cash obtained through wage work was not generally the way to provide for a family, but was instead a way to obtain rapid access to colonial money.

An important point to make is that the money earned from wage labour was very often not comparable with that obtainable from selling produce or stock. It was calculated that in 1903 , by growing an acre of potatoes a Kikuyu could earn over ten times what he could if he spent the same time in wage labour. After 1903, with the decrease in produce prices, he could still earn three times as much. ${ }^{86}$ Many witnesses to the 1912 Native Labour Commission (NLC) reported that Africans made more money from their shambas (fields) than from working for Europeans. ${ }^{87}$

In the Nyanza Province, a man could make ten rupees per month by selling his agricultural produce, thanks to the seed distributed by the government. ${ }^{88}$ Many of the chiefs of the province who gave evidence to the NLC reported, in fact, that more people were earning money from the sale of produce than from wage work, and that the number of those engaged in cultivating had greatly increased in the previous years. According to one labourer, Onyanga Omolo, few Kavirondo were working for Europeans,

Van Zwanenberg, Colonial Capitalism, pp. 36-37.

3 Van Zwanenberg, Colonial Capitalism, p. 36.

84 Ibid., p. 40.

85 Ibid., pp. 80-81.

86 Stichter, Migrant Labour, p. 32.

87 Witness no. 13, A.L. Block, NLC, pp. 21-22; see also Berman, Control \& Crisis, p. 59.

88 Witness no. 1, A.C. Hollis, NLC, p. 1; see also Stichter, Migrant Labour, pp. 44-45. 
because they were working in their shambas, and "if a man made good profit out of his produce he spent the money on stock, and started a new shamba to get more money". ${ }^{89}$ It was noted that "those who cultivated their own shambas made more money than wage earners, for a man could get 30 Rs per month by selling bananas at 25 cents a bunch". ${ }^{\circ}$ Those who earned enough money through the sale of produce often employed other people to work for them, in this way further decreasing the number of available labourers..$^{91}$ Chief Amiena noted that the majority of his people owned shambas and made a large amount of money, with which they paid their taxes as well as the people working for them..$^{92}$

Many of the people interviewed by the NLC attributed the recurrent lack of labourers to the "wealth of the natives", measured by the stock they possessed. ${ }^{93}$ According to a missionary, people living in the Nyanza Province had increased their wealth in stock ninefold in a few years. ${ }^{94}$ In 1912, the secretary of native affairs estimated that if the wealth of the Masai was divided among every Masai man, woman, and child, each would have possessed stock worth at least one hundred pounds. According to him, there was no reason why such wealthy people would work for white settlers. ${ }^{95} \mathrm{Mr}$ Stone, acting district commissioner in Fort Hall, underlined that every penny coming from wages was invested in cattle, "because they knew that by that means their wealth would increase itself. The natives were rich now." ${ }^{\prime 6}$

The rhythms of African agricultural production often conflicted with the demand for labour by the state and the settlers, and were one of the main reasons behind the lack of manpower. ${ }^{97}$ Fewer workers were obtainable with the approach of the rainy season, when work was required to clear and till the fields. ${ }^{9}$ Moreover, when the harvest was good, the number of available labourers declined. ${ }^{99}$ The recurrent lack of workers was therefore also connected to the seasonality and success of agricultural production.

89 Witness no. 123, Onyanga Omolo, NLC, p. 131.

90 Witness no. 147, Malama wa Shundu, $N L C$, p. $15^{\circ}$.

91 Witness no. 157, Chief Siwachi, NLC, pp. 156-157.

92 Witness no. 164, Chief Amiena, $N L C$, pp. 160-161.

93 See, for example, Witness no. 131, M. Reynolds; Witness no. 140, A.A. Carscallan; Witness no. 141, Rev. Father Bouma; Witness no. 143, T.W. Wardle; Witness no. 214, C.R.W. Lae, etc., NLC.

94 Witness no. 140, A.A. Carscallan, pp. 146-147.

95 Witness no. 1, A.C. Hollis, NLC, p. 2.

96 Witness no. 253, Chief Kioi wa Nogi, $N L C$, p. 231.

97 Okia, Communal Labor, p. 62.

98 Witness no. 28, W. McGregor Ross, $N L C$, p. 44.

99 Witness no. 3, Fletcher, $N L C$, pp. 6-7. 
According to the final report of the NLC, wages were too low to make African labourers willing to work for Europeans. ${ }^{100}$ Nonetheless, the settlers were convinced that higher wages would not increase the labour supply, because a higher wage merely meant that a labourer could earn in one month what he previously could have earned in two months. ${ }^{101}$ People could easily earn the cash that they needed through the sale of livestock or agricultural produce, as their "requirements were very small". ${ }^{102}$

Africans were, in fact, considered as "target labourers", as they worked only to meet some specific requirements, such as the payment of taxes, the purchase of particular consumer goods, or the payment of a bridewealth. ${ }^{103}$ Once the tax or the bridewealth had been paid, Africans did not offer themselves for wage work again.

\section{Saving and spending money: Bridewealth and taxes}

The first report on labour in the EAP, compiled in 1903, already noted that wages paid in cash were immediately spent on stock or to obtain new wives, whereas small amounts were used to buy cloth, beads, and metal wire. ${ }^{104}$ Almost every witness giving evidence to the NLC - settlers, workers, chiefs, and colonial officials - agreed on the ways in which money earned through wage labour was spent: cattle and wives. Labourers accepted work far away from their home in order to earn money, which was then sent to their parents or relatives and invested in cattle and other stock. In this way it was possible to save the amount required for bridewealth payments.

Many workers were unmarried, but once married they no longer needed to work, unless they wanted to marry another wife. ${ }^{105}$ Young unmarried men were sent out by the chiefs to work, whereas married ones stayed at home and worked in their shambas to support their families. ${ }^{106}$ According to A.L. Block, a white farmer in Kyambu:

100 Witness no. 16, G.K. Watts, $N L C$, pp. 26-28.

101 Witness no. 21, F.O.B. Wilson, $N L C$, pp. 35-36.

102 Witness no. 8, W. Russel Bowker, NLC, pp. 13-15; see also Stichter, Migrant Labour, p. 133. 103 Berman calls this the myth of "target labour", which was used as a justification for coercion in order to obtain labour: see Berman, Control \& Crisis, p. 144. See also Berman and Lonsdale, Unhappy Valley, p. 106. Van Zwanenberg points out that these were not target labourers, but instead "welfare maximizers": see Van Zwanenberg, Colonial Capitalism, p. 39.

104 East Africa Protectorate, Report on Slavery, KNA AG 1/437.

105 Witness no. 91, Lord Delamere, NLC, pp. 108-111; Witness no. 103, W.M. Griess, NLC, p. 103. 106 Witness no. 121, Onyango Ojola, $N L C$, p. 130. 
In the Kikuyu reserves there were three classes of natives: those who spent their time drinking beer, the youths from 16 to 20 years old who have to work in order to provide themselves with money with which to buy sheep and wives, and those over 20 who never did anything. ${ }^{107}$

Bridewealth was usually paid with stock, although there is evidence of some payments made in cash. Chief Ndeda noted that,

Some married men went out to work for two or three months if not particularly well off. The marriage bridewealth was now being paid in money, instead of stock, varying from 300 Rs to 500 Rs. There were no really poor men in his district, all being cultivators, and a poor man could always make money by working on other people's shambas. ${ }^{108}$

A Kikuyu named Karanja wa Kimani, who earned ten rupees per month, said that he was working in order to buy goats, thirty to forty being needed to pay for bridewealth. ${ }^{109}$ Wambura wa Ngai, from Dagoretti District, first went out to work in order to be able to buy goats, and paid the bridewealth for one wife with forty goats and three cows, equal in total to seventy goats. When he was interviewed, he was working in order to pay the hut tax for himself and his mother. After paying it, he said he wanted to spend his earnings on goats and cattle, and if he received sufficient in exchange, he wanted to marry another wife. ${ }^{110}$

Farm labourers, who were generally unmarried and did not have to support a family, could save large amounts of the rupees they earned, as little money was spent while working in the plantations. Food was generally provided by the employer, equal to the amount of one rupee per month. Little was spent on imported goods, with the exception of blankets, cloth, hoes, knives, wire, beads, sugar, tea, and salt. ${ }^{111}$ Some labourers reported having saved 75 to 90 per cent of their salary, which they had sent home to buy cattle, sheep, and goats for bridewealth payments. ${ }^{112}$ Onyanga Omolo had been working for five months when he gave evidence to the NLC, and said that he had been able to send twenty-four rupees to his mother in

107 Witness no. 13, A.L. Block, NLC, p. 22.

108 Witness no. 158, Chief Ndeda, NLC, pp. 156-157.

109 Witness no. 126, Karanja wa Kimani, $N L C$, p. 133 .

110 Witness no. 258, Wambura wa Ngai, $N L C$, pp. 232-233.

$111 N L C$, various witnesses.

112 Witness no. 8o, J.M. Pearson, NLC, pp. 102-103; Witness no. 91, Lord Delamere, NLC, pp. 108-111. 
order to pay bridewealth. ${ }^{113}$ A Kavirondo was reported to have taken home 150 rupees after a long period of work. ${ }^{114}$

According to the Kyambu assistant district commissioner, the Kikuyu were marrying earlier than before. This was attributed to the "peaceful situation of the country", but it is reasonable to believe that this was also due to the fact that money was more easily obtainable by young Kikuyu men through wage labour. ${ }^{115}$ Wage labour could be attractive for young men, who left the reserves in order to acquire stock to start their own family. As a consequence, young men could marry earlier, without help from their families to pay bridewealth. ${ }^{116}$

Another use of cash was for the payment of taxes. Taxes were seen by the colonial administration as one of the most effective incentives to induce Africans to leave the reserves for European plantations or government work.

A hut tax was first introduced in the coastal areas in 1901, at the rate of one rupee per hut. Initially, the tax could be paid in labour, livestock, or trade goods, but later it had to be paid in cash. The hut tax was increased to three rupees in the Kikuyu and Ukamba districts in 1903, and in the coastal areas in $1905 .{ }^{117} \mathrm{~A}$ three-rupee poll tax began to be collected from 1910, and had to be paid by all men over sixteen not liable to pay the hut tax (those who were not married). The poll tax was first applied in the labour-producing areas, with the eventual aim of increasing the labour supply. ${ }^{118}$ In 1915 , taxes were increased to five rupees as a consequence of the need to obtain funds for the East African Campaign. At the end of the war, they were increased again, this time reaching eight rupees (sixteen shillings) ${ }^{119}$ Following African protests against this increase, the tax was reduced to twelve shillings, which remained the tax rate for almost the whole interwar period. ${ }^{120}$

From 1901 to 1921, taxes and wages increased almost concomitantly, with approximately one month's work needed in order to pay the tax. The starting wage for an unskilled labourer was four to five rupees before 1912, and by 1918-1919 it was five to eight shillings. Before 1925, only one month of work

113 Witness no. 119, Onyanga Omolo, NLC, p. 129.

114 Witness no. 134, C.B. Clutterbuck, NLC, pp. 141-142.

115 Witness no. 42, C. Dundas, NLC, p. 242.

116 Berman and Lonsdale, Unhappy Valley, p. 92; Stichter, Migrant Labour, p. 51.

117 Berman and Lonsdale, Unhappy Valley, p. 104.

118 Berman and Lonsdale, Unhappy Valley, p. 42; Stichter, Migrant Labour, p. 35. It was extended to the Nyanza province in 1912-1913.

119 Stichter, Migrant Labour, p. 35.

120 Berman, Control \& Crises, p. 149. 
was therefore required to pay the hut or poll tax,,$^{121}$ and after 1925 even less, as tax remained twelve shillings during the 1920 and 1930 s whereas wages increased from sixteen to eighteen shillings in $1929 .{ }^{122}$ However, according to Berman and Lonsdale, the amount of tax equated to more than one month of wage work. Very often, in fact, a man had to pay the hut tax for more than one wife, and also for kin unable to pay the tax on their own. According to the report of the 1927 Labour Commission, the average annual family income in the reserves was 9o to 110 shillings, of which twenty-eight shillings were paid in direct taxes. ${ }^{123}$

The tax burden made it difficult for married wage labourers to accumulate savings, and ensured that their net income could only supply a subsistence living for their family if they maintained access to land or squatting land. This favoured a combination of labour relations. Contrary to the colonial government's expectations, taxes were therefore not very effective in increasing the number of permanent labourers, as a tax obligation produced only a temporary increase in the labour supply. When it was time to pay the tax, more labourers were available for government or plantation work, but once the tax had been paid, workers disappeared and rarely came back to work. ${ }^{124}$ The wali (chief) of Kisumu reported that "the majority of workers only worked for two months in a year and when they earned sufficient with which to pay their taxes they returned to the reserves". ${ }^{125}$ It was reported that "six sittings of eggs or the sale of a few fowls sufficed to pay the Hut Tax". ${ }^{126}$ Especially in the vicinity of towns, such as Nairobi and Mombasa, people could make enough money for the tax by selling food to town dwellers. ${ }^{127} \mathrm{~A}$ farmer and trader, Mr J. Drought, sarcastically gave this example:

Consider the case of one of Mr Beech's Kikuyu who has to pay a tax of Rs 3/- per annum. In order to pay the tax he has only to stroll into Nairobi with six live fowls for which if lucky he can secure a rupee a piece or if the market is temporarily glutted he is sure of Rs $3 /$ - for the lot. Is the

121 The hut and poll tax had the same rate; the hut tax was paid by married men, the poll tax by unmarried men between fifteen and forty years old.

122 Stichter, Migrant Labour, p. 35; Clayton and Savage, Government and Labour, p. 28.

123 Berman and Lonsdale, Unhappy Valley, p. 114. See also Tignor, The Colonial Transformation, pp. 183-185; Berman, Control \& Crisis, p. 150.

124 Witness no. 3, Fletcher, $N L C$, pp. 6-7; Witness no. 4, P.E. Watcham, $N L C$, pp. 8-9.

125 Witness no. 153, Walli Hassan, NLC, pp. 153-154.

126 Witness no. 9, J. Stocker, $N L C$, p. 15; Witness no. 69, Sheikh Ali bin Salim, Mombasa, NLC, p. 95. 127 Witness no. 44, W. Hall, $N L C$, pp. 65-66. 
country any better off because a Kikuyu has sold three or six fowls, the bearing of which has been entirely left to the native fowl responsible for the production of the eggs? ${ }^{128}$

Another common way to meet tax requirements was from the sale of stock. ${ }^{129}$ When the end of tax-collecting time was approaching (taxes had to be collected before the end of the financial year, on 31 March), cattle suddenly became very cheap on the local markets, as people sold cattle to obtain the rupees to pay tax. ${ }^{130}$ The Kamba did not willingly work for wages, and when it was time to pay the tax, they obtained their money through selling cattle, goats, and sheep. In 1920 to 1921, a local administrator lamented that the increase in the poll tax to eight florins did not have the effect of making the Kamba more willing to work for wages, as they continued to obtain the necessary money through the sale of stock. ${ }^{131}$ The same happened in other districts, such as Baringo and Turkana..$^{132}$ The 1923 Annual Report for Kecheliba District, stated that "As in previous years money for the payment of hut tax was obtained almost entirely by the sale of goats and sheep and this continual drain on the stock can not go on infinitely". ${ }^{133}$ Archbishop Owen noted that in the early 1930s, the value of cattle, goats, and sheep had dropped by one-fifth, as a consequence of the forced sales to obtain cash for the hut tax. ${ }^{134}$ In 1936 , a Luo chief noted that his people called the tax a "cattle tax", because they always had to dispose of their cattle to pay it. ${ }^{135}$

Before the war, in many areas of Kenya the cash needed to pay tax could be made through the sale of produce, such as in the Nyanza province, or of livestock, as did the Masai, Kamba, and Gissi. ${ }^{136}$ Berman argues that taxation had a neutral effect: it prompted a rise in domestic production as much as it stimulated wage employment. ${ }^{137}$ Taxation could, in fact, be a stimulus for wage work in the reserves, or in those areas where production

128 Witness no. 187, J. Drought, NLC, pp. 171-187.

129 Witness no. 52, J. Johnston, $N L C$, pp. 75-76.

130 Kitui District Political Record Book [hereafter PRB] December 16, 1909 KNA PC/CP/172/1-2; Baringo District PRB, KNA DC/BAR/3/1.

131 Kitui District Annual Report [hereafter AR] 1920-1921, KNA PC/CP/172/1-2.

132 Baringo PRB, KNA DC/BAR/3/1; Kacheliba District AR 1923, KNA DC/WP/1/1.

133 Kacheliba District AR 1923, KNA DC/WP/1/1. For the Masai, see Report by R.W. Homsted, March, 13, 1918, TNA CO/533/194; Laikipia District Quarterly Report, 1909-1910, KNA MF.

134 Quoted in Van Zwanenberg, Colonial Capitalism, p. 95.

135 Van Zwanenberg, Colonial Capitalism, pp. 93-94.

136 Berman and Lonsdale, Unhappy Valley, p. 92; Van Zwanenberg, Colonial Capitalism, p. 75.

137 Berman, Control \& Crisis, p. 59. 
could not be increased owing to various constraints. ${ }^{1{ }^{8}}$ Or during economic crises, such as those occurring in 1921-1922 and 1930-1935, when taxation became a real hardship and more young men left the reserves and looked for wage labour. ${ }^{139}$ However, there is a general consent by economic historians regarding the limited effect of taxation in mobilizing wage labour.

As mentioned above, wages were too low compared with the money obtainable through the sale of produce or stock. Wage work was instead a way to obtain a lump sum in cash in a relatively short time, without disposing of the accumulated wealth in cattle. Monthly wages were generally paid by the government or the settlers in rupees, which were then used to pay tax or to buy cattle. Low denomination coins, such as cents, were instead used in the payment of casual labour and for small daily spending. As we will see in the next section, this produced a form of disconnection in the ways in which cents and rupees circulated.

\section{Daily and monthly labour: Paying in cents, paying in rupees}

In the early decades of colonial rule, the processes of integrating indigenous modes of production and the Kenyan economy into the metropolitan economy were achieved through the gradual transformation of African households into peasant commodity producers, and the increasing number of Africans employed for wages by British settlers, Indian traders, and the colonial government. ${ }^{140}$ The sale of produce and the payment of wages transferred cash from the government, the traders, and the settlers into the hands of Africans. Rupees were associated with government transactions. They were used to pay monthly wages and were the coercive currency of taxes. ${ }^{141}$ The rupee was the link between two regimes of value: one originating from the colonial power, which used rupees in assessing the value of labour and in establishing a link of authority over its subjects through taxation, and another originating from inside the colonized society, which used different forms of value in a new monetary setting. Wealth was invested in cattle, whereas rupees mediated between two orders of worth. ${ }^{142}$

138 Stichter, Migrant Labour, p. 34. See also Berman and Lonsdale, Unhappy Valley, p. 92; Okia, Communal Labor, p. 10.

139 Stichter, Migrant Labour, p. 35 .

140 Maxon, "The Establishment", p. 64.

141 Comaroff and Comaroff, "Colonizing Currencies", p. 170.

142 For the role of cattle as a way of saving money, see Schneider, Livestock and Equality, pp. 60-104. 
As discussed at length above, rupees from wages or obtained through the sale of produce were invested in cattle, in order to accumulate wealth or to gain enough money to pay for bridewealth. It was for this reason that migrant farm labourers wanted to be paid with rupee coins, and not with cents. According to some witnesses reporting to the NLC, migrant labourers who were working to accumulate money for bridewealth, preferred to be paid at the end of the month, so that they could have a lump sum with which to buy cattle, sheep, and goats. ${ }^{143}$ They very rarely broke up their rupees before going home or during the return journey from the coast. Cases were reported of labourers who even died of starvation while returning home from coastal plantations, because they did not want to break up their rupees. T. Howitt, a farmer in Kyambu, referred the case of a labourer who, going back home after one month of work, had died of starvation rather than breaking up his four rupees to buy food. ${ }^{144}$ Problems of this kind led the government to investigate the matter and sanction that people were provided with food, or cents to buy it, when they left the plantations. ${ }^{145}$

Colonial officers were aware of the opportunities offered by the different uses that were made of rupees and cents. The commissioner for public works, G.K. Watts, underlined that workers tended to hoard rupees, whereas they were more willing to spend cents for their daily needs. He suggested that paying workers in small coins could have resulted in the increase of "natives' wants", and therefore, in the long term, of the labour supply. ${ }^{146}$ Many settlers were also convinced that employing workers on a daily or weekly basis, rather than monthly, could be an effective way to increase the number of labourers and therefore reduce labour shortages. ${ }^{147}$ Those settlers who experimented with the payment of daily wages, seemed, in fact, to be particularly successful in finding labourers. C. Hirtzel, a farmer in Limoru who employed about 300 people, explained that he "had been very successful in getting the labour he required by paying wages daily at the rate of 10 cents. The natives were constantly changing, but they invariably brought substitutes." ${ }^{148}$ This created some practical problems. Hirtzel, again, noted that "The drawback to the system had been the necessity of arranging

143 Witness no. 13, A.L. Block, NLC, pp. 21-22; J. Boyes, a farmer in Kyambu, said that his labourers wanted to be paid only in rupees and not in cents: Witness no. 24, J. Boyes, NLC, pp. 61-62.

144 Witness no. 18. T. Howitt, NLC, pp. 31-32. This was confirmed by witness no. 42, O. Dundas, $N L C$, pp. 61-62, and by witness no. 231, R.G. Stone, $N L C$, pp. 211-213.

145 Witness no. 230, Kogi wa Manyingi, $N L C$, pp. 210-211.

146 Witness no. 16, G.K. Watts, NLC, pp. 26-28.

147 Witness no. 69, Sheikh Ali bin Salim, Mombasa, NLC, p. 95.

148 Witness no. 6o, C. Hirtzel, NLC, pp. 82-84. 
for the transport of practically cartloads of nickels with which to pay the labour." ${ }^{\prime 149}$ Even if the payment of cents was more effective in attracting labourers, transport problems and costs rendered it largely impracticable for the settlers. By contrast, Indian traders - who could more easily obtain cents through petty trade - generally paid their labourers in cents on a daily basis. ${ }^{150}$ Porters employed on a daily basis by the government were also paid in cents. After the building of the railways, porters continued to be widely employed to reach government stations situated far from the main roads. The wages for camp to camp porters were paid daily in cents..$^{51}$

Casual labour was therefore a way to get access to small amounts of colonial money, in the form of cents, which were then used for minor daily transactions. People who worked for longer periods were unmarried men (or married men who wanted to marry another wife), who wanted to obtain rupees to buy cattle to pay for bridewealth.

The employment of daily instead of monthly labourers became widespread during the years of the Great Depression in the 1930s. Employers had to compete with each other over labour, and one method was to take on men by the day instead of by the thirty-day month. ${ }^{152}$ The employment of labour on a daily basis was used particularly during the harvesting season in the coffee plantations. ${ }^{153}$ Many Kikuyu women and children, as well as some men, went out from their villages to the farms and returned home at night. These daily labourers were paid by the debbi, ${ }^{154}$ a tin full of coffee. ${ }^{155}$ The practice of paying by the debbi was particularly beneficial for the labourers. The Thika and Ruiru Farmers' associations noted that in 1925 on the same estate a casual labourer was earning up to fifty shillings per month - twice the average wage - due to the practice of paying by the debbi. ${ }^{15^{6}}$

Female labourers were also generally employed on a temporary basis, and were usually paid daily or on the basis of piece-work. ${ }^{157} \mathrm{Mr}$. T. Howitt,

149 Ibid.

$15^{\circ}$ Clayton and Savage, Government and Labour, p. 30.

151 Acting Provincial Commissioner, Northern Province to Chief Secretary, Entebbe, Masindi, April 4, 1921, Uganda National Archives, Entebbe, A/46/2195.

$15^{2}$ Van Zwanenberg, Colonial Capitalism, p. $5^{2}$.

153 Ibid., p. $5^{0 .}$

154 Elspeth Huxley describes the debbi in this way: "It is an oblong tin, fourteen inches high by nine inches square [...] It holds four Imperial gallons of petrol or paraffin and has become the standard measure for the sale of linseed oil, plough oil, lard, ghee and honey [...] Coffee pickers are paid by the tin-full." Huxley, Nine Faces of Kenya.

155 Tignor, The Colonial Transformation, p. 176.

156 Van Zwanenberg, Colonial Capitalism, p. $5^{0 .}$

157 Witness no. 7 , W.H.A. Caine, $N L C$, pp. 11-13. 
owner of a farm in Kyambu, employed 135 men at five rupees per month with food and a blanket. He also employed women, but only on a temporary basis: they came from the reserves at eight in the morning and left again at mid-day with a load of firewood each for payment. ${ }^{158}$ Women were very rarely hired for long periods, and therefore were generally paid in cents. In the port of Mombasa, women carrying baskets of coal earned one cent per trip. In the coffee plantations, the wives of residential labourers could earn twelve cents per day picking coffee. ${ }^{159}$ Women clearly did not need to save money for the same reasons that men did. They earned some money to contribute to the family income and for small daily expenses. ${ }^{160}$

Different layers of society used different denominations and types of coins, not only depending on their wealth but also on the type of transactions. ${ }^{161}$ Women and casual labourers were paid in cents, whereas workers hired by the government or the farmers for longer periods, for the most part unmarried men or tax target labourers, were paid in rupees. Rupees were used only for some types of transactions, and cents for others, and it was as if people did not consider them as part of the same monetary system. This is exemplified by this quotation by Partington, who writing about the Lumbwa noted that:

They appreciate rupees as being able to buy with them cattle, sheep and pay taxes. They also appreciate to a certain extent cents being able to buy with them meat in the market or salt or beads. But many of them do not connect the two nor do they realise that cents if a hundred strong are equal to a rupee. ${ }^{162}$

Small coins are generally more useful than larger ones. As a consequence, demand for small-denomination coins is relatively stronger, and hence they tend to be relatively scarce. ${ }^{163}$ In the EAP, rupees were used when trading high value goods, such as livestock or hides, but in the markets

158 Witness no. 18, T. Howitt, NLC, pp. 31-32.

159 Clayton and Savage, Government and Labour, pp. 92, 97.

16o Wages could be also paid in cattle. In the South Nyeri district, labourers were paid in advanced grants of stock. The employee worked until the advanced grant was paid off, on the condition that the employer paid his tax in cash, and "in certain cases the native employee has neither seen, nor can hope to see, any actual cash reward for his work." South Nyeri AR, 1934, as quoted in Van Zwanenberg, Colonial Capitalism, p. 54.

161 Lucassen, “Deep Monetisation”, p. 78.

162 H.B. Partington, Lumbwa Kericho District PRB, KNA MF.

163 Lucassen, “Deep Monetisation”, p. 85. 
"a small coin like the (1) cent is found by the inhabitants to answer their humble needs better than any other" ${ }^{164}$ Cents circulated more easily than rupees, but they tended to be scarce. Many colonial sources addressed the problem of the continuous lack of cents: they continued to be issued, but there was nonetheless always a shortage. ${ }^{165}$ Sources of the period commonly refer to the fact that people "buried" cents, as there was no other way of explaining them vanishing. Complaining about the fact that people in the interior did not want currency in notes, a local administrator said that continuous orders for new cents had to be placed as "it has been found that once cents leave the Office they never return" ${ }^{166}$ Cents seemed to disappear once they left the treasury, and unlike rupees, they rarely went back to the government in the form of taxes and fees. Over 100,000,000 one-cent coins were issued between 1906 and 1921 (see Table 10.1), and it was estimated that of the total number of cents issued for the EAP from 1906 to 1921, at least half were "lost". ${ }^{167}$

Table 10.1 Value in rupee of the coins in circulation in Kenya and Uganda, 15 February 1921

\begin{tabular}{rr}
\hline Indian rupees & $\begin{array}{r}\text { Cannot be ascertained. Over } 50,000,000 \\
\text { introduced by banks }\end{array}$ \\
\hline Silver florins & 4,000 \\
50 -cent pieces & $1,178,600$ \\
25 -cent pieces & $1,392,000$ \\
10-cent pieces & $4,250,000$ \\
5-cent pieces & $1,740,000$ \\
1-cent pieces & $103,200,000$ \\
\hline
\end{tabular}

Source: TNA CO 533/257

The wide distribution of low denomination currencies, used for frequent weekly and daily exchanges, can be called "deep monetization", that is, a substantial stock of currency per capita in circulation, consisting of denominations equalling the value of one hour or less of wage work. ${ }^{168} \mathrm{As}$ cents were used for the payment of daily and female labour, the

164 R. Skene to Provincial Commissioner Mombasa, Malindi, September 23, 1913, KNA PC Coast $1 / 6 / 23$.

165 See for instance, 'Circular no. 47. Currency Questionnaire', 29 April 1911, KNA DC EBU/1/5/4. 166 Shimoni, January 9, 1922, KNA PC COAST 1/6/65.

167 Mwangi, "Of Coins and Conquest", p. 783.

168 Lucassen, “Deep Monetisation”, p. 73. 
reconstruction of the yearly circulation of small denomination coins, or of the deep monetization in the colony, could provide information on the development and extent of child and female labour as well as of temporary labour.

\section{Conclusion}

The introduction of a colonial currency was one of the most important institutional changes of the colonial period. However, as Anthony Hopkins has recently pointed out, institutional change under colonial rule was not solely in response to colonial policies. Colonial rule was negotiated as well as imposed, and institutional change was the product of African initiatives as well as of exogenous causes. ${ }^{169}$ The availability of labourers in early colonial Kenya was not only connected to conditions deriving from the colonial state and the economy, such as the attractiveness of wages or the conditions of employment. It was also a consequence of the various motivations that made African workers willing to leave their fields, villages, or reserves in order to obtain cash. More permanent labourers were those who needed colonial money to pay tax or bridewealth. They were for the most part unmarried men, who wanted to obtain cash to buy cattle to pay bridewealth, or men who needed colonial money to pay tax, because they could not increase their agricultural production or sell cattle in order to obtain the money required. For everyday needs, it was sufficient to work daily and to obtain cents. These were then used in the local markets. Women, who worked for wages only for very short periods, were instrumental in favouring the circulation of cent coins, as were casual labourers.

The ways in which colonial money was obtained, accumulated, and spent were connected to economic exchanges deriving from the colonial state and its policies. In the early decades of colonial rule, wages paid in colonial money were not a sufficient incentive to provide the necessary number of labourers for the colonial economy. The availability of wage labour was connected to the specific purposes for which colonial money was earned. The low level of wages, together with the use that was made of colonial money, favoured the development of a combination of commodified and reciprocal labour, as the research carried out by the Global Collaboratory on the History of Labour Relations has also highlighted for other African 
countries. ${ }^{170}$ State coercion was initially employed to guarantee an adequate supply of labourers, and by the latter half of the 1920s, economic crises, growing population pressure in the reserves, and a growing African taste for consumer imports, ensured an adequate flow of labourers without further state coercion. ${ }^{171}$ Tributary labour therefore gave way to commodified labour, with workers employed both in the settlers' plantations and in public works. However, wage labour remained mostly impermanent, as African workers were available only for certain periods of time. The group working on Africa in the Global Collaboratory on the History of Labour Relations, has added a $195^{\circ}$ cross-section to those available, in order to provide a better analysis of the changes in labour relations during colonial rule. In the case of the Kenya colony, it was around this cross-section that the labour class was stabilized. ${ }^{172}$

The increased circulation of small-denomination coins is an indication of the growing importance of small producers and traders in the new colonial economy, as well as of the expansion of a casual labour force. It also suggests that African consumers had started to use colonial money to buy imported goods, including lamps, bicycles, blankets, enamelled wares, and European-style clothes. Further research regarding the circulation of the different currency denominations per year could provide a better understanding of the development of female, child, and casual labour in early colonial Kenya, that is, those forms of labour that are not generally included in the official colonial statistics.

\section{Bibliography}

Anderson, David M., "Master and Servant in Colonial Kenya", Journal of African History, 41 (2000), pp. 459-485.

Berman, Bruce, Control \& Crisis in Colonial Kenya: The Dialectic of Domination (Oxford, 1990).

Berman, Bruce, and John Lonsdale, Unhappy Valley: Conflict in Kenya and Africa, Book One: State \& Class (Athens, 1992).

Clayton, A.D., and C. Ehrlich, "Introduction", in The East Africa Protectorate: Report and Evidence of the Native Labour Commission 1912-13 (Nairobi, 1914), pp. 1-19.

170 See History in Africa, 41 (2014).

171 Berman and Lonsdale, Unhappy Valley, p. 112.

172 Stichter, Migrant Labour, p. 133. 
Clayton, Anthony, and Donald C. Savage, Government and Labour in Kenya, 18951963 (London, 1974).

Comaroff, John, and Jean L. Comaroff, “Colonizing Currencies: Beasts, Banknotes, and the Colour of Money in South Africa", in W. van Binsbergen and P. Geschiere (eds), Commodification, Things, Agency and Identity (The Social Life of Things Revisted) (Leiden, 2005), pp. 145-174.

Cooper, Frederick, From Slaves to Squatters: Plantation Labor and Agriculture in Zanzibar and Coastal Kenya, 1890-1925 (New Haven, 1980).

East Africa Protectorate, Economic Commission: Evidence (Nairobi, 1917).

East Africa Protectorate, Native Labour Commission: Evidence and Report (Nairobi, 1912-1913).

East Africa Protectorate, Report on Slavery and Free Labour in the British East Africa Protectorate (Nairobi, 1903).

Ekejiuba, Felicia, "Currency Instability and Social Payments among the Igbo of Eastern Nigeria”, in Jane Guyer (ed.), Money Matters: Instability, Values and Social Payments in the Modern History of West African Communities (Portsmouth, 1995), pp. 133-161.

Guyer, Jane (ed.), Money Matters: Instability, Values and Social Payments in the Modern History of West African Communities (Portsmouth, 1995).

Hardy, Ronald, The Iron Snake (London, 1965).

Helleiner, Eric, The Making of National Money: Territorial Currencies in Historical Perspective (Ithaca, 2003).

Herbst, Jeffrey, States and Power in Africa: Comparative Lessons in Authority and Control (Princeton, 2000).

Hill, M.F., Permanent Way: The Story of the Uganda and Kenya Railway (Nairobi, 1961). Hodges, Geoffrey, The Carrier Corps: Military Labour in the East African Campaign (New York, 1986).

Hofmeester, K., J. Lucassen, and F. Ribeiro da Silva, "No Global Labour History without Africa: Reciprocal Comparison and Beyond”, History of Africa, 41 (2014), pp. 249-276.

Hopkins, Anthony, "The Creation of a Colonial Monetary System: The Origins of the West African Currency Board", African Historical Studies, 3 (1970), pp. 101-132.

Hopkins, Anthony, "The New Economic History of Africa”, Journal of African History, $5^{0}$ (2009), pp. 155-177.

Huxley, Elspeth, Nine Faces of Kenya (London, 1990).

Ittmann, Karl, Dennis D. Cordell, and Gregory H. Maddox (eds), The Demographics of Empire: The Colonial Order and the Creation of Knowledge (Athens, 2010).

Lucassen, Jan, "Deep Monetisation: The Case of the Netherlands 1200-1940", Tijdschrift voor Sociale en Economische Geschiedenis, 11 (2014), pp. 73-121. 
Maxon, Robert M., "The Establishment of the Colonial Economy", in W.R. Ochieng and R.M. Maxon (eds), An Economic History of Kenya (Nairobi, 1992), pp. 63-74.

Maxon, Robert M., "The Kenya Currency Crisis, 1919-21 and the Imperial Dilemma”, Journal of Imperial and Commonwealth History, 17 (1989), pp. 323-348.

Miller, Charles, The Lunatic Express (Nairobi, 1987).

Mosley, Paul, The Settler Economies: Studies in the Economic History of Kenya and Southern Rhodesia, 1900-1963 (New York, 1983).

Mwangi, Wambui, "Of Coins and Conquest: The East African Currency Board, the Rupee Crisis and the Problem of Colonialism in the East African Protectorate", Comparative Studies in Society and History, 43 (2011), pp. 763-787.

Okia, Opolot, Communal Labor in Colonial Kenya: The Legitimization of Coercion, 1912-1930 (Basingstoke, 2012).

Overton, John, "War and Economic Development: Settlers in Kenya, 1914-1918", Journal of African History, 27 (1986), pp. 79-103.

Overton, John, "War and Economic Underdevelopment? State Exploitation and African Response in Kenya 1914-1918”, InternationalJournal of African Historical Studies, 22 (1989), pp. 201-221.

Pallaver, Karin, "Labor Relations and Population Developments in Tanzania: Sources, Shifts, and Continuities from 1800 to 2000", History in Africa, 41 (2014), pp. 307-335.

Pallaver, Karin, "A Recognized Currency in Beads: Glass Beads as Money in $19^{\text {th }}$ Century East Africa: The Central Caravan Road", in Catherine Eagleton, Harcourt Fuller, and John Perkins (eds), Money in Africa (London, 2009), pp. 20-29.

Schneider, Harold K., Livestock and Equality in East Africa: The Economic Basis for Social Structure (Bloomington, 1979).

Sood, S.V., Victoria's Tin Dragon: A Railway That Built a Nation (Cambridge, 2007). Spencer, I.R.G., "The First Assault on Indian Ascendancy: Indian Traders in the Kenya Reserves, 1895-1929", African Affairs, 8 o (1981), pp. 327-343.

Stichter, S., Migrant Labour in Kenya: Capitalism and African Responses, 1895-1975 (London, 1982).

Strachan, Hew, The First World War in Africa (Oxford, 2004).

Tignor, Robert L., Colonial Transformation of Kenya: The Kamba, Kikuyu, and Maasaifrom 1900-1939 (Princeton, 1979).

Van Zwanenberg, R., Colonial Capitalism and Labour in Kenya, 1919-1939 (Nairobi, 1975). 


\section{About the Author}

Karin Pallaver is Associate Professor at the Department of History and Cultures, University of Bologna (Italy), where she teaches African History and Indian Ocean History. Among her recent publications: "From Venice to East Africa: History, Uses and Meanings of Glass Beads", in Karin Hofmeester and Bernd-Stefan Grewe (eds), Luxury in Global Perspective: Commodities and Practices, c. 1600-200o (Cambridge, 2016), "The African Native Has No Pocket': Monetary Practices and Currency Transitions in Early Colonial Uganda", International Journal of African Historical Studies, 48:3 (2015); "Population Developments and Labor Relations in Tanzania: Sources, Shifts and Continuities from 1800 to 2000", History in Africa, 41 (2014).

E-mail:karin.pallaver@unibo.it 



\title{
11 Labour and Deep Monetization in Eurasia, 1000 to $1900 *$
}

\author{
Jan Lucassen
}

Hofmeester, Karin \& Pim de Zwart (eds.), Colonialism, Institutional Change, and Shifts in Global Labour Relations. Amsterdam: Amsterdam University Press, 2018

DOI: $10.5117 / 9789462984363 / \mathrm{CH} 11$

\begin{abstract}
The production and circulation of coins may be conceived as an important institution for the development of commodified labour. In Eurasia between 1000 and 1900 the degree to which people participate in a market economy is reflected in the frequency of exchanges of small denominations of currency. Long-term developments in deep monetization levels (DMLs) in Western Europe (England, the Low Countries, and France), South Asia and China enable us to trace shifts in labour relations. Explanations for changing DMLs may be found in the demand for small denomination coins (due to, e.g., increasing levels of commodification or a rise in wage labour) as well as in changing practices in payment frequencies and thus in credit relations of workers, which could determine their power relations.
\end{abstract}

Keywords: deep monetization, coin circulation, wage labour, credit, Eurasia

* This chapter has grown out of one conference paper, written for two different conferences. First, the workshop on Economic Institutional Change and Global Labour Relations at the IISH in Amsterdam (26-27 September 2014), and second, the conference "How Do Monetary Systems Affect Economic Crises?” at the Vrije Universiteit in Amsterdam (12-13 December 2014). I thank the participants of these conferences and of two meetings where I also could present these findings (Osaka, 3-4 March 2015, and Utrecht, 29 June 2015) for their input. In this new version, the labour aspects have been elaborated on more fully, in another chapter the monetary aspects are central: Lucassen, "Deep Monetization in Eurasia”. Both chapters refer to each other and some overlap is unavoidable. 
The efficiency of economic institutions has been an inspiring topic for many economic historians. ${ }^{1}$ Labourers, among the most important actors in economic life, shape and are also shaped by several institutions. Most labour historians concentrate on institutions regarding basic freedoms, such as freedom of employment, freedom of organization, and freedom to organize collective action. In addition, protective legislation regarding working hours, age at work, dangerous circumstances, and the like, are part and parcel of labour history. ${ }^{2}$

To date, modalities of payment and means of exchange have attracted barely any interest from this field, nor from monetary history or numismatics. ${ }^{3}$ Nevertheless, the institutions involved in producing and circulating currencies suitable for use in wage payments and for the daily expenses of workers do matter. This applies to all societies where currencies are used as means of exchange to pay for labour and services performed, which implies major parts of Eurasia and Northern Africa for the last two and a half millennia, and for the rest of the world for the last five hundred years. In this contribution, a brief introduction is provided, detailing the usage of currencies for paying wages and of the concomitant small change. It also follows, turning the argument around, that changes in circulation patterns may point to changes in labour relations. A more extended overview is provided of the implications of currency circulation for labour conditions and the welfare of workers - both as objects and as subjects - as we will see from several examples of labour protest against failing small-denomination coin circulation. This overview can only be tentative, and more suggestive than conclusive, not only because it covers such a large field, but also because of a lack of data and secondary literature.

The structure might accordingly appear a little strange at first sight. After an introduction about the usage of currencies by workers, and more specifically about their need for small change ("deep monetization"), I will proceed in three steps. I start with a comparative overview of monetization in Western Europe and surrounding countries, as this is the first occasion when such an overview has been possible. These insights are then used in an inductive way to paint a diachronic picture, using data for Britain, the

$1 \quad$ E.g., Van Zanden, "The Road".

2 E.g., Steinfeld, The Invention of Free Labor; Biernacki, The Fabrication; Lucassen, Global Labour History; Van der Linden, Workers of the World.

3 Interesting for linking money (though not currencies) and labour is Reddy, Money and Liberty; see also Biernacki, The Fabrication, ch. 8. 
Low Countries, and France. These long-term insights into the European situation are necessary in order to be used as input for the examination of two case studies outside Europe: India and China, to draw an overall picture of Eurasia from 1000 to 1900.

\section{Why remunerate work by paying wages?}

Some types of labour relations do not involve remuneration at all (corvée labour), some do, but only implicitly (reciprocal labour), others do, but only in the form of maintenance (unfree labour), and still others do in the form of wages in kind or in cash. ${ }^{4}$

Corvée types of labour in their most extreme form are one-sided: the polity requires labour just as it may require taxes in kind or cash. Apart from the cost of maintenance, which is needed when the corvée has to be performed far away from home, remuneration is out of the question. In a more benign form, such labour is remunerated in public goods (material or immaterial) or at least by the suggestion that the polity cares for its subjects. ${ }^{5}$

Implicit remuneration is provided in reciprocal labour relations, such as within self-subsisting households or groups of households working intensively together; for example, among hunter-gatherers. All members contribute through their labour, and the results are divided more or less equally. Unpaid work is also and foremost found inside the household, in which the head of the household works for the market, while notably women and children share the income by performing all the household chores for free. The Indian jajmani system has to be mentioned as well. In this highly formalized system, craftsmen in the village community provide free services to the local farmers in exchange for a share in the total harvest.

Unfree labour - if established on a permanent basis such as in the case of slavery and serfdom or on a (in principle) temporary basis in the case of convicts - requires maintenance, either provided in the form of minimal food and shelter, or in the form of small plots on plantations where labourers can grow their own food. Serfs are also allowed to work their own family plot.

4 Here, I refer to labour relations as defined in the Global Collaboratory on Labour Relations, based at the IISH.

5 For an excellent overview of taxation systems worldwide, including corvée, see Monson and Scheidel, Fiscal Regimes. 
Figure 11.1 The relationships between types of commodified labour relations (vertical from free to unfree) and of remuneration (horizontal from none to monetized) ${ }^{1}$

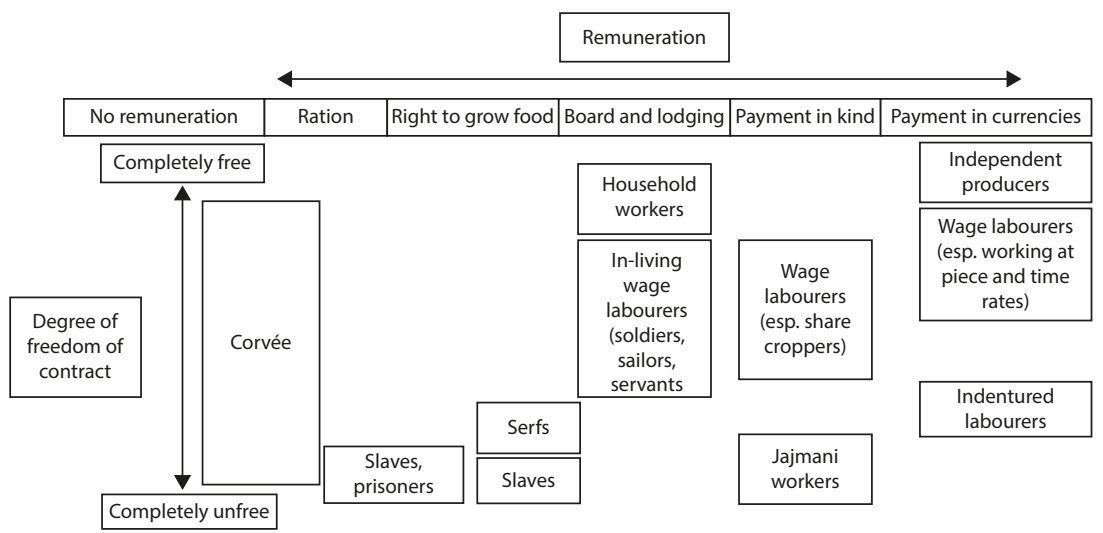

1 Cf. Simmel, Philosophie des Geldes, pp. 284-291.

Formal remuneration of labour only occurs in market societies where either small producers receive it for their products or services, or where labourers receive a wage. These formal remunerations may be in kind, in cash, or mixed. For example, payment in kind occurs in the case of sharecroppers, who work in exchange for half the harvest while the other half goes to the owner of the soil, who often also procures the seed and makes other investments. Like small, independent producers, sharecroppers have to sell the products of their labour on the market. Partial wage payments in kind occur when workers benefit from board and lodging (apart from remuneration in money), such as soldiers, sailors, and living-in servants do. Where this is not the case, and wage labourers or small independent producers form their own households, wages may be paid in kind or - much more commonly - in currency. For an overview of all possibilities mentioned in commodified societies, see Figure 11.1.

The link between work, remuneration, and currencies is not straightforward. It is, however, important in Eurasia, a part of the world that had seen markets develop long before $1000 \mathrm{CE} .{ }^{6}$ To formulate it differently, apart from the relations mentioned - which pertain more to unfree than to free labour,

6 For practical reasons, tributary societies such as the Egyptian and pre-Columbian civilizations, let alone older societies, fall outside the scope of this chapter. See Lucassen, "Outlines", and the site of the Global Collaboratory on the History of Labour Relations (GCHLR) of the IISH, 
and more to women and youngsters than to adult men - work in Eurasia was performed to a substantial extent in exchange for currencies, directly in the case of independent producers (farmers and peasants, craftsmen, traders and peddlers, transporters, shopkeepers, and performers of services) or indirectly in the case of wage earners.

By implication, the history of currencies and their circulation - covering the academic fields of numismatics and monetary history - might become important for labour historians, particularly in cases where not enough other indicators for labour relations are available. This is very often the case in more distant periods in time or in societies for which no or insufficient written sources for labour history exist. To put it extremely simply: if in such cases currencies particularly appropriate for paying wages suddenly disappear, this might be an indicator of the emergence of unfree labour and vice versa.

\section{Deep monetization ${ }^{7}$}

Circulating currencies can actually have several functions. If primarily intended for large-scale or costly trade, or when substantial amounts of savings are concerned, they originally consisted of large coins - mostly gold or heavy silver pieces - and later on paper money, bills of exchange, and the like. If intended for payments of rent, taxation, or wages, smaller denominations are often needed. Whereas the remuneration for work is one side of the circulation of currencies, the spending of income is the other. Sums used in spending are normally smaller than the sums received as remuneration for work. Even farmers selling their seasonal harvests, who receive relatively large sums, will divide their spending between the payment of rents and the purchase of necessities for the continuation of their business, as well as food, clothing, and other goods that they do not produce themselves. All others - craftsmen and wage labourers - will spend most of their income on shelter, on food in shops and at markets, and if anything is left, on small luxuries.

The difference in size between the sums received as remuneration and the sums spent takes us from medium-sizes coins most suitable for the payment of moderate sums at intervals of one, two, or a few weeks (the

which provides a taxonomy of labour relations that are used in this chapter: see https://collab. iisg.nl/web/labourrelations.

7 More extensively in Lucassen, "Deep Monetization in Eurasia". 
predominant frequency for the payment of wages, but also for advances that many craftsmen could not do without), to the coins used for weekly or daily purchases. For these transactions, much smaller denominations are needed, both because of the amounts involved and because it is impossible for people to always pay with the exact money, thus creating a need for small change. The intensity of participation by individuals and households in a market economy is therefore reflected in the degree to which medium and small denominations are available for circulation. Because small denominations best reflect the frequency of exchanges in a society, they may be considered the ideal yardstick of commercialized human relations.

In order to measure this across space and time, I have recently proposed a formal definition of "deep monetization". I take this to be "a substantial stock of currencies per capita in circulation, consisting of denominations equalling the value of one hour or less of wage work", in which "substantial" is defined as "a per capita stock equal to between five and ten times the prevailing hourly wage". ${ }^{8}$ The application of this definition to different societies may provide an indication not only of the levels of "deep monetization", but also (and more importantly here) of shifts in labour relations at their root: shifts between remunerated and unremunerated work, between remuneration in kind and in currencies, and between frequencies of payment.

Clearly, for societies with abundant records concerning these shifts - such as Western Europe in recent history - a detour via deep monetization is less interesting, however, for most parts of the world before 190o, it could provide a useful approach. For many places and periods, written evidence of shifts in labour relations is not readily found or, even worse, virtually nonexistent. Archaeological evidence concerning coin circulation, by contrast, is much more universally available, because of the metals used for most types of currency. ${ }^{9}$ The academic discipline of numismatics is centuries old and has brought us not only catalogues of coins from all over the world, but also estimates or even precise numbers of the quantities produced and the circulation patterns, as mirrored in coin hoards and stray finds. Sometimes, deep monetization is almost the only possible approach to detecting shifts in labour relations. Most valuable, however, is its importance for enabling comparisons by providing a clear and objective measuring instrument through time and space.

8 Lucassen, “Deep Monetization: The Case of the Netherlands”; Lucassen, “Deep Monetization in Eurasia".

9 A global introduction is provided in Cribb, Cook, and Carradice, The Coin Atlas. Cf. Lucassen and Zuijderduijn, "Coins". 


\section{Implications for wage payments and the development of wage labour: Europe c. 1885}

The first large-scale statistical overview of coin circulation in different countries that enables comparative research into deep monetization was made by the Austrian monetary statistician Ottomar Haupt (1839-1898). ${ }^{10}$ He produced a comparative table of coin circulation, including smaller denominations. With this detailed data, it is possible to reconstruct deep monetization levels (DML) for a number of countries (see Table 11.1).

Table 11.1 Deep monetization levels for several countries c. 1885

\begin{tabular}{lcc}
\hline & Country & DML \\
\hline Deeply monetized & Belgium & 10 \\
& Denmark & 9 \\
& France & 8 \\
& Germany & 10 \\
& Netherlands & 8 \\
& Switzerland & 8 \\
United Kingdom & 4.9 \\
Possibly deeply monetized & Austria-Hungary & 12 \\
& Greece & 6 \\
& Italy & 14 \\
& Portugal & $<17$ \\
Medium monetized & Spain & $<15$ \\
& Egypt & 2 \\
& Norway & 3.7 \\
& Russia & 1.5 \\
& Sweden & 2.2 \\
\hline
\end{tabular}

Source: Lucassen, "Deep Monetization in Eurasia"11

The majority of the Western European countries show deep monetization levels (a per capita stock equal to between five and ten times the prevailing hourly wage), which vary between eight and ten. For several technical reasons, it is very likely that the figures for Portugal, Spain (substantive exports

10 Haupt, L'histoire; Haupt, Arbitrages. See also Report of the Committee, Appendix II, pp. 213, 273-275.

11 Based on Lucassen, "Deep Monetization in Eurasia", where it is also explained why actual figures for some countries are far too high. 
of domestic small change to the colonies), Italy, and Austria-Hungary (a massive amount of small change minted, but not yet put into circulation) are too high, but nevertheless might belong to this group as well. The other countries deviate from this Western European pattern. I will discuss them in four groups: first, Norway and Sweden; second, the Balkans (including Serbia and Greece, with far too high numbers for the same reasons as Italy and Austria-Hungary) and parts of the Middle East; third, the United Kingdom; and fourth, Russia and the USA.

First, Norway and Sweden contrast interestingly with the third Scandinavian country in this group, Denmark. Not only was Denmark much more prosperous than its northern neighbours, it showed much higher urbanization figures and concomitant occupational differentiation and agricultural specialization. ${ }^{12}$ This situation apparently required a much greater number of transactions in Denmark than in Norway and Sweden. This is eloquently illustrated in the following description of the Norwegian countrymen $(85$ per cent of the total population) by the British Consul-General Crow, dated 9 November 1870, Christiania (Oslo). ${ }^{13} \mathrm{He}$ distinguishes three "classes" among them: the seafaring peasantry along the coast, the "Bonde", and the "Field Bonde" or mountain peasant. The second group is the most important:

The Bonde or real peasant is generally the owner of the land he farms. This class may be considered as the kernel of the nation. The property of the Bonde is not sufficiently large to exempt him from work, but large enough to afford him and his household establishment ample support. He farms in the majority of cases, not so much to raise produce for sale as to grow provisions and everything necessary for spinning wearing-apparel. ${ }^{14}$

Second, the equally low figures for the Balkans (the DML of Serbia and Greece was temporarily so high because of over-supply), Turkey, and Egypt point to similarly low demand for small means of exchange as in Norway and Sweden, even if certain indicators of economic development (such as the high literacy rates in the north) differed substantially. It is, however, possible that this cross section shows a more primitive situation than in the preceding decades. According to Michael Palairet, political freedom in the Balkans went hand in hand with economic decline in the period from 1878 to $1914 .{ }^{15}$ 
Third, of course, the low DML of Britain - although with some imagination still within the minimum margins of my definition of deep - demands an explanation. This situation was an echo of previous ages characterized by the scarcity of small change. Muldrew and Selgin have indicated that it took the government "well into the Victorian era" to supply the public with enough small change. Therefore, counterfeits and tokens found ready acceptance. ${ }^{16}$

Fourth, the low DMLs for the USA and especially for Russia also seem to be echoes from previous periods, in this case of the widespread use of unfree labour, maintained without paying wages. However, this point needs more research into the consequences of what Kolchin sketched as the commonalities of the post-emancipation USA and Russia: "there was a common legacy of forced labour that Russia shared with the United States and with all other former slave societies as well. New forms of dependency that provided the ex-bondsman with at best semi-freedom became the rule.,"17

\section{Deep monetization and wage labour in Europe in the long term, 1000 to $195^{\circ}$}

For a few of the countries contained in the above list with deep monetization levels in the late nineteenth century, it is possible to go back in time, sometimes only a few centuries, as in France, sometimes back to the Late Middle Ages, as in the Low Countries, and sometimes even to the High Middle Ages, as in England. These three cases will help us to understand long-term trends in Western Europe. To start with, the country with the longest trend available: England.

\section{England}

After China, England has the longest series of coinage statistics and estimates in the world, starting from the late eleventh century. ${ }^{18}$ The stage of deep monetization certainly had not yet been reached at the time of the Domesday Book (1086), let alone before. ${ }^{19}$ Precisely when it started may not

16 Selgin, Good Money, pp. 266, 295, 297; Muldrew, “Wages”, p. 409.

17 Kolchin, Unfree Labor, p. 375. For the circulation of tokens in the American South after the Civil War, see Lurvink, "Strapped for Cash".

18 For an extensive discussion of English DMLs between 1300 and 1900, see Lucassen, "Deep Monetization in Eurasia".

19 Naismith, Money and Power, especially pp. 284-29o, where he discusses the problems of small change in Anglo-Saxon England. 
be known exactly, but there is no doubt that in the first half of the thirteenth century, pennies per capita increased fivefold, that in the second half of that century it doubled again, and that the same might have happened in the first half of the fourteenth century, just before the Black Death, after which levels fell back to those of fifty years before. If compared with the prevailing wage levels, the English DML already stood at 5 in 1282 - the first date for which enough quantitative evidence is available - to grow to 10 or more in the decades before 1351. These early and spectacular jumps run parallel to the equally early and rapid expansion of wage labour. ${ }^{20}$

More surprisingly, these levels could not be maintained from the second half of the fourteenth century onwards, and recovered only very slowly, never to reach those of the early fourteenth century. Calculations based on the output of the royal mint in London show DMLs of 3 in 1720, 4.7 in 1857, and the already mentioned 4.9 in 1885 . The actual situation was slightly less worrying, as private tokens and counterfeits (officially condoned) filled the gap left by the authorities that were not willing or not able to provide their subjects with enough copper coins and small silver denominations. By including small change of all forms, DMLs in the seventeenth and eighteenth centuries may actually have oscillated around a meagre 5 .

How did such an economically highly developed society, where half of the population depended on wages, cope with this continuous shortage of small change? ${ }^{21}$ Payments in kind of course were one alternative, but not greatly preferred by employers. ${ }^{22}$ Group pay was another solution, although a very imperfect one. In 1794, a manufacturer explained:

If the work of two men comes to near a guinea, or three men to near two guineas, we give them the gold and they must go together till they can get change by purchasing whatever they want. If they go to a grocer he will not give change unless the quantity of sugar, tea, etc. amounts to a certain sum, and then he stipulates for their taking a certain quantity of [bad] halfpence. [...] It often happens that groceries are not wanted by poor men who come from villages around, who seldom care to take tea and sugar home; but they generally have a public house in the market town at which they call to refresh; And to it these two or three fellows (though not all countrymen) go, with a good excuse to get their gold changed: if

21 For estimates of the waged population, see Brown and Hopkins, A Perspective, p. 70; Mayhew, "Wages Currency", p. 213; Muldrew, "Wages and the Problem", p. 395.

22 Ibid., p. 401. 
they find, after drinking a pint or two, that they cannot succeed, what can they do but go to another house. [...] But whether they get change at the first or second attempt, they are not served without taking several shillings in copper, and this of the worst quality that can be forced into circulation. ${ }^{23}$

More importantly, Craig Muldrew has pointed in particular to the extension of small-scale local credit reducing the frequency of cash payments in the seventeenth and eighteenth centuries. Payments to industrial workers could not easily be solved by using wages in kind. Here, wages were often in arrears, which implies that shopkeepers had to extend credit to wage labourers. Muldrew provides the following telling example from Birmingham:

A shopkeeper who sued a brick maker in the Birmingham court of requests in the mid-eighteenth century claimed that the latter's master had told him that during the winter season the defendant "can get only clay, consequently his wages are small; trust him what he wants, and I will see you paid in the summer". Here, the brick maker's wages would have simply been turned into a debt owed by the master to the shopkeeper, eliminating the need for small change. ${ }^{24}$

At the same time, this implies that the brick maker was compelled to buy all his necessities from one and the same shopkeeper, with all the attached risks of abuse.

\section{The Low Countries}

After the demise of the highly monetized Roman Empire, a new round of monetization began with the emergence of towns in the Southern Low Countries around 1100, followed by the North one century later. Similar to England, for several centuries only one single denomination was coined; the silver denarius or penny. Around 1300, a multi-fractional system came into being with the introduction of various silver denominations of twoand-a-half and eight penningen, greatly facilitating payments. ${ }^{25}$ 
For the Low Countries, data is not as abundant as for England, partially because of long periods of political decentralization. ${ }^{26}$ The manorial system, in which people are bound to the land where they are forced to provide labour, had never been important in the northern maritime provinces, and in most others declined in the eleventh to the fourteenth century. ${ }^{27}$ Instead, small-scale and independent labour on peasant holdings and in artisanal shops became dominant. Wage labour emerged afterwards in the form of mercenary armies, and in the building, public works, and transport sectors. Think of the construction of churches, town gates, and walls in this most urbanized part of the world. According to Van Bavel, in particular in the fifteenth and sixteenth centuries in coastal Flanders and later in the Guelders river area, Salland, and coastal Frisia, wealthy tenant farmers with thirty-five to seventy hectares emerged, needing much additional labour during harvest time and all year round. This happened at the expense of small tenancies, where families now had to supply their labour. The proliferation of numerous mini-tenants was also ideal for proto-industrialization.

Not by coincidence, from the mid-fourteenth century onwards - but not earlier - there appears to be a certain correlation between the denomination coined most frequently over a longer period, and the level of the daily wage. This correlation suggests that the demand side preferred a currency equivalent to four times a wage earner's full daily wage (c. 1350-1450). From the fifteenth century onwards, this reduced to one times for the worse-paid and two times for the better-paid wage earners. ${ }^{28}$

Does it also represent a situation of deep monetization? By 1550, the Low Countries as a whole were certainly deeply monetized, and this process must have already started earlier on in certain provinces, first in Flanders and later in Brabant, most likely in the fifteenth century. ${ }^{29}$ The uncertainty about the exact timing is due to the lack of good population statistics combined with the validity of all Burgundian currencies in all provinces, irrespective of the province in which they had been struck.

Thus, the situation in the Low Countries in the mid-sixteenth century seems to have been in balance: a massive demand for small change and an equally abundant supply of it by the mint houses of Charles $\mathrm{V}$ and his son Philip II. The limited success of the central authorities to limit

26 What follows about the Low Countries and in particular its northern parts is a summary of Lucassen, "Deep Monetization: The Case of Netherlands”; most recent publications are Martiny, Het Munthuis, and Vanhoudt, De munten. See also Welten, Met klinkende munt betaald.

27 Van Bavel, "Rural Wage Labour; Van Bavel, Manors and Markets, pp. 200-204, 244-246.

28 Lucassen "Wage Payments", pp. 260-261.

29 Van Bavel, Manors and Markets, pp. 198-199. 
maximum wages in 1560 points in the same direction. The Utrecht city government, for example, stated that "wage setting is entirely God's work", which may be interpreted as a plea for the functioning of the forces of supply and demand. ${ }^{30}$ However, the balance was not stable; not as unstable as in England, but in the Dutch Republic, in particular, the circulation of small coins decreased in the second half of the seventeenth century. The country was prosperous, and overall coin production was impressive. The key merchants who commanded coins from the mint houses, however, were much more interested in the (comparatively cheap and thus more profitable) minting of large denominations than in the production of small silver and copper coins for the local market. Instead, the provincial governments in the seventeenth century tacitly condoned the circulation of (partially low-weight) copper coins, produced by small principalities and noblemen in border regions.

This example shows that supply and demand for specific denominations are not automatically in equilibrium. The more unified Burgundian Netherlands and the Kingdom of the Netherlands were apparently more willing to act than the decentralized Dutch Republic, in spite of its very high overall level of monetization. An intermediate solution was the responsibility taken directly by the county of Holland in 1702, followed by other provinces (asking for orders from their towns), for minting small change: solid copper duiten, and in 1738, silver pijlstuivers (equal to eight duiten). How badly these pijlstuivers were needed became apparent in Amsterdam in August of that same year. Workers, aware of the new coin, no longer accepted the old inferior wapenstuivers and their protests culminated in the occupation of the town hall. They only could be persuaded to leave after a number of them had been offered sums of ten to twenty new stuivers. Occasionally the stuivers were not sufficient, such as when the Republic's richest banker, Henry Hope, ordered new scheepjesschellingen (six-stuiver pieces) in order to make weekly payments to the men who were building his mansion "Welgelegen" near Haarlem..$^{31}$

The Low Countries were already deeply monetized in the sixteenth century, and problems concerning the supply and demand of small change had been mastered well. ${ }^{32}$ The occasional problems that arose in the Dutch Republic stemmed from its political structure and economic concepts, which determined who was responsible and which instruments were available. As a 
result, solutions were always inadequate, to the extent that in the second half of the seventeenth century, unofficial coins had to be allowed into circulation - just like in mid-seventeenth and again in late-eighteenth-century England..$^{33}$

\section{France}

Before we can speak of a (Northern or Northwestern) European pattern, it should be supplemented by other case studies. This is not easy, because research on what might be termed the social history of coin circulation has only just begun. ${ }^{34}$ Here, I can only briefly discuss the implications of some estimates for France, the largest country of Western Europe and as deeply monetized as the Netherlands around 1885 , when the DMLs stood at 8 (see Table 11.1).

Between 1789 and 1810, a number of coin reforms took place, mainly for ideological reasons. They combined a desire for science-based politics with a demand for in-depth reports on the current circulation of the coins. These reports show DMLs of 11 up to 17 for the revolutionary years. ${ }^{35}$

In contrast to the situation in contemporary England, the French state took responsibility for the circulation of small change, but it should be noted that this was not a direct consequence of the French Revolution; it had much deeper roots. France's DML was already 12 in 1789 . Although I do not know of earlier precise coin production figures, the introduction of the copper one and two denier tournois under Henri III (1551-1589) was a particularly great success, apparently satisfying a huge demand, not only from townspeople, but especially from small peasants and day labourers. ${ }^{36}$ These denominations, coined in enormous quantities, were very small indeed, as hourly wage levels then stood at one sou or twelve deniers. ${ }^{37} \mathrm{In}$ addition - comparable with the Dutch Republic somewhat later - adjacent small principalities started massive production of similar coins, which were circulated widely.

33 Muldrew, "Wages and the Problem"; Selgin, Good Money.

34 Lucassen and Zuijderduijn, "Coins”, pp. 1-13.

35 More extensively in Lucassen, "Deep Monetization in Eurasia”, mainly after Desrousseaux, La monnaie.

36 Cf. Béaur et al., "Northern France".

37 In the late sixteenth and seventeenth century, hourly wages were one rather than two sous, see, e.g., Goubert, Cent mille, pp. 333-340, and Le Roy Ladurie, Les paysans, p. 123. This coincides well with the end of the denier tournois after $165^{\circ}$ and of the double tournois after 1700 . 


\section{Conclusions for Western Europe}

First, deep monetization as a response to the commodification of labour - initially predominantly in the guise of independent producers, then gradually shifting to paramount wage labour - started in England around 1300, ${ }^{3^{8}}$ spread to the Southern Netherlands in the late Middle Ages, to the rest of the Low Countries and possibly France in the sixteenth century, and to other parts of Western Europe at the same time or later on. Further to the east, variations in unfree labour had an effect on the circulation of small change, as recently demonstrated for eighteenth-century Russia. Serfdom was the norm, and only noblemen could own and employ serfs. Thus, non-noble industrialists there needed labour, but were not allowed to own serfs. Alternating legislation increased or diminished the possibilities for bourgeois entrepreneurs to hire serfs as paid labourers, and these fluctuations were large enough to directly influence the demand for copper coins. In addition, non-noble entrepreneurs are documented to have requested that the state authorities provided more copper coins in order to pay wages. ${ }^{39}$

Second, once achieved, deep monetization is not necessarily sustainable. Apart from shifts in labour relations leading to variations in demand for small change, the supply may vary along with the quality of state institutions responsible for the output of small change. When governments fail in this respect, like England between 1350 and 1800 and the Dutch Republic between 1625 and 1725, other suppliers may offer themselves from inside or outside the polity. Alternatively, credit relations may expand or contract accordingly. ${ }^{40}$

\section{Deep monetization and wage labour in Asia, 1000 to 1900}

For two large areas in Asia, it is also possible to reconstruct the relationship between deep monetization and shifting labour relations over several centuries: India and China. For India, most evidence is available for the nineteenth century, but to a certain extent it is possible to go back to the Middle Ages. For China, circulation figures go back much longer in time, but information about labour relations still is very meagre for most periods.

38 Possibly also in Northern Italy (although not discussed here).

39 Bacherikov, "Monety i zarplaty". Information kindly provided by Bacherikov's supervisor, Gijs Kessler. Cf. Florén, "Social Organization".

40 For an example from late medieval Normandy, see Cardon, "Les petites". 
However, both cases enable us to put the results reached for Europe to the test in order to see whether we may speak of Eurasian instead of (West) European patterns.

\section{India, 1200 to $185^{\circ}$}

Coinage - and what is more, coinage of small denominations - in Northern India, goes back 2,500 years and its use is therefore as old as in the Eastern Mediterranean or China. Quantification is difficult and is, accepting many uncertainties, only possible from around 1200 onwards. ${ }^{41}$ What is clear, is that there was a first acceleration of small-value coinage (copper, billon, and silver coins weighing less than 5 grams) in the period from 1275 to the mid-fourteenth century. Because these denominations hardly equal hourly, but instead daily wage levels, we have to speak of medium, rather than of deep monetization in Northern India as a whole by 1300.

Firoz Shah, the Delhi Sultan from 1351 to 1388 , made a serious attempt to strike more copper denominations, which is also confirmed by his court historian, Shams Siraj Afif:

The thought crossed Firoz Shah's august mind that if poor people bought something from the market and a balance of half or a quarter jital was left of the amount paid, the shopkeeper would not have the quarter change. If the buyer let it go he would lose money. If he demanded it from the shopkeeper how could he be paid when no such coin existed? In the end, the balance due to the buyer would be left with the shopkeeper. For these reasons, the transaction between the buyer and the seller would drag unnecessarily. Sultan Firoz Shah gave orders for the striking of a half jital coin called $a d h$ [literally "half"] and a quarter jital coin called paika. ${ }^{42}$

A great leap forward towards deep monetization was seen in the short-lived Suri dynasty in Delhi (1538-1554) and under Akbar, the first Mughal Emperor from 1556 to 1605 . Billon (low-base silver) coins were replaced by copper "dams" (initially called paisas), as well as fractions of a half down to a tenth of a paisa. Whole and half dams were struck in immense quantities in a great number of mints over many years consecutively. Especially the half dams and lower fractions may be considered as small change (smaller fractions

41 Lucassen, "Deep Monetization, Commercialization and Proletarization".

42 Haider, "Fractional Pieces". For the actual coins meant, see Goron and Goenka, The Coins, p. 66. For frequency estimates, see Lucassen, "Deep Monetization”. 
were also made, but far less frequently). As craftsmen earned two dams per day or more, this suggests that a paisa equalled two to four hours work for craftsmen, and half a dam, one to two hours. ${ }^{43}$ The number of copper coins in Akbar's probate inventory even suggest a DML of 12 for the Mughal Empire around $1600 .{ }^{44}$ One of the reasons for this unexpectedly high figure may be the lack of small silver coins, which caused copper ones to be used instead. ${ }^{45}$ Deep monetization must anyhow have made an impressive jump in the second half of the sixteenth century.

The picture in the seventeenth and eighteenth centuries becomes less clear. The production of copper coins in the seventeenth century definitely decreased, but the usage of cowries and to a certain extent bitter almonds became more widespread. ${ }^{6}$ On the other hand, nominal wages rose, as a consequence of which, prevailing copper coins equalled hourly wages more than ever before. According to the VOC merchant Francisco Pelsaert, artisans in Surat and Agra in the years 1620-1627 earned five to six takkas (or paisa to the value of a thirtieth of a rupee) per day. ${ }^{47}$ As other wage data for the seventeenth century suggests, this entailed a substantial increase after Akbar, but it is very likely that prices rose as quickly, because Pelsaert comments: "They know little of the taste of meat. For their monotonous daily food they have nothing but a little kitchery, made of green pulse mixed with rice, which is cooked with water over a little fire until the moisture has evaporated, and eaten hot with butter in the evening; in the daytime they munch a little parched pulse or other grain, which they say suffices for their lean stomach." ${ }^{m 8}$

43 Lucassen, "Deep Monetization, Commercialization and Proletarianization"; Deyell, "The Development"; Habib, "A System" (see appendix by Deyell); Martin, "The Reforms"; Wages in Habib, “A System", p. 154; Prakash, "Long Distance Trade”; Haider, "Structure and Movement", pp. 293-321; Haider, "Fractional Pieces"

44 See Lucassen, "Deep Monetization in Eurasia".

45 See also hereafter the discussion of high deep monetization levels for China. For the low production of silver rupee fractions, see Prakash, "Long Distance Trade", p. 337, and cf. Habib, “A System", p. 145 ("It would therefore seem that everything that an ordinary person might buy in an ordinary North Indian city during Abar's reign would have its price fixed in copper money. Only luxury and export items would need payment in rupees."). See Haider, "Fractional Pieces", pp. 93-94, for a different view.

46 Habib, "A System", pp. 158-164; Haider, "Fractional Pieces", pp. 98-103.

47 Kolff, and Van Santen, De Geschriften, p. 309 (wage; cf. 311 for servants 3-4 rupees per month, which at 30 paisa per rupee would mean 3-4 paisa per day) and p. 117 (exchange rate); cf. much less favourable exchange rates of $57-58 \mathrm{dam} /$ paisa per rupee in these years: Prakash, "Long Distance Trade", p. 343 .

48 Kolff and Van Santen, De Geschriften, p. 309; Haider, "Fractional Pieces", p. 91 (quoting the English translation by Moreland and Geyl). See also De Zwart and Lucassen, "Poverty or Prosperity". 
When the copper content of the dam was reduced by a third in 1663 we hear of the reaction of the workers in Ahmedabad:

The administrator of buildings, gardens and other workshops of Ahmedabad City represented to the Celestial Court that $[. .$.$] workers have declined to$ accept the new coins in place of the old, saying that the difference between them is in the order of 10:15. When the intelligence of this matter reached the August Presence [Emperor Aurangzeb], an order was issued to the finance minister of the province [of Gujarat] that, in the ratio 10:15, the daily wages should be paid at the rate of one and a half tanka instead of one tanka. ${ }^{49}$

Such reactions, demonstrating that labour was paid in cash as well as illustrating the agency of the receivers, may be shown with a few more examples. The first dates from 1797, when the spouses of Bengal artillery soldiers fighting overseas in the Mysore War against the Tipu Sultan vehemently but successfully protested against the mode of payment of their husbands' salaries. Left behind with their children in the barracks of Dum-Dum, just south of Calcutta, they depended completely on these monthly allowances. One day, the officer in charge was unable to find enough silver coins and tried to pay them in gold. As soon as the wives of the gunners and their assistants (lascars) found out that they would consequently receive less copper money from the money changers (shroffs), they turned to the poor officer who reported:

I could not even with some degree of force, prevail on the women (those of the Lascars in particular) to receive their allowances, as I received them from the Pay Office, as their tickets were made out of Sicca Rupees, and they insisted on receiving the pice according to the bazar currency [...] Every argument I used, could not prevail on the people to believe that I had not taken a Dustoor for my own trouble, in the case, my quarters were daily surrounded by the amounts of hundreds [...] who became clamorous and were so grose $[s i c]$ in their abuse, that I was often obliged to appease them by ordering the Sircar, and Shroff, to pay them the difference..$^{0^{\circ}}$

The position of the shroffs was very strong indeed, and the British were unable to circumvent them. In 1810, for example, the Madras government felt compelled to form an official "Establishment of Shroffs" at the presidency. "If

49 Haider, "Structure and Movement", p. 311.

$5^{0}$ Lucassen, "The Logistics". For the payment logistics of Indian Maratha troops, see Lingen and Lucassen, "Warfare". 
you can't beat them, join them", must have been the consideration. However, this concession had its price. At an annual expense of the enormous sum of 240 pagodas, this institution voluntarily agreed to reduce exchange rates and standardize them. ${ }^{11}$ This may have helped for a while in Madras, but not always and not everywhere. Twenty years later, an engineer in charge of the building and maintenance of irrigation canals north of Delhi, having been sent there from Calcutta with boxes full of silver rupees, was confronted by workers who wanted to be paid only in exactly specified local copper coinage. Thus compelled to exchange his silver into copper, he complained about the shroffs that "the price of pice is always raised when my works commence". He even planned to go directly to the mint masters who he found out made the coins, but his masters in Calcutta frustrated this plan by ordering him to use instead the newly minted official colonial coins. The creative engineer lost his case, notwithstanding his reply that:

The supply of pice ordered up will be utterly useless to me on the works without a special regulation of Government making the pice of the Calcutta mint the only legal copper coin throughout the Companies' territories. The pice in question cannot be introduced by an individual and will only subject me to infinite trouble and annoyance as no one will willingly take pay from me in a coin not in general currency. ${ }^{52}$

Another example of workers' protests against malpractices in wage payments dates from the navvies, maintaining and repairing the Sonipat division of the Western Jumna Canal north of Delhi in 1849. When they found out that their British overseer had systematically embezzled part of their earnings, they became so "clamorous for their pay" that they lodged an official complaint with the executive superintendent, Lieutenant A.D. Turnbull. The lieutenant took action against his compatriot, stating: "It is impossible for work to be carried on while such irregularities exist. It is not to be expected that labourers will come to our works if they are not paid up regularly, but kept for long periods in arrears." Thus the British felt compelled to investigate the case by an official Court of Enquiry at the barracks of the $42^{\text {nd }}$ Regiment, Native Light Infantry, in Delhi, from 20 June until 12 July 1849 .

Several foremen and workmen had to testify, which went reasonably well considering that they were illiterate. From the court case, for which $23^{2}$ questions and answers were recorded, we not only learn precisely how the 
embezzlement had been organized, and that the accused were found guilty and therefore "wholly untrustworthy and totally unfit to be retained", but also importantly that the wages were paid out exclusively in one particular coin, copper takkas, most probably imported from Alwar, 200 kilometres south of the canal..$^{53}$

Copper coin production in India was heavily dependent on Japanese and European imports. Production figures for Indian and Nepalese copper mines are very scarce, but overseas trade statistics show on average constant figures for Japanese copper imported by the VOC in Coromandel and Bengal, and rising figures for European copper imported by the EIC in Madras and Calcutta. ${ }^{54}$ Combining all the data on nineteenth-century circulation levels, eighteenth-century copper imports, and fluctuations in intensity from the thirteenth century onwards, I am tempted to suggest that India underwent a first phase of deep monetization in the sixteenth century, which could barely be maintained in the seventeenth, returned to lower levels in the eighteenth, and surged to a second phase of deep monetization around 1800. This was then maintained throughout the nineteenth century.

\section{Indian deep monetization levels in the nineteenth century}

For the beginning of the nineteenth century more quantitative data at last becomes available, as the English had more grip on their dearly won new colony. We know that in the nineteenth century, proletarianization levels remained stable in the Deccan (about which there is more information below). If we assume that this trend is valid for India as a whole, we might expect that, all other things being equal, demand for small currency at the beginning of the century was the same as at the end of it. However, what about the supply side: the output of Indian mints around 1800 ? Most copper coins at the time were probably produced in mints under Indian control. The English wanted to replace these with their own coins, first completely in Indian (Persian) script, later with Latin script added on. In 1847, the collector of the Delhi district wrote that he needed 50,00o rupees "for the use of his district to replace the native pyce", partly in order to pay the sepoys. ${ }^{55}$ The efforts at replacement only became successful in the third quarter of the nineteenth century, and even then a number of "native" mint

53 In addition, coin transport over large distances involved great risks of loss and robbery; see Lucassen, “The Logistics", pp. 368-382.

54 Shimada, The Intra-Asian Trade. For details, see Lucassen, "Deep Monetization in Eurasia”.

Lucassen, "Wage Payments", p. 383. 
houses remained active, some of them until India's independence in 1947. This story demonstrates that the British institutions in India were less strong than the superpower of the time had wished for.

The colonial copper coin output for India in the first half of the nineteenth century already amounted to more than thirty-one million rupees, while a number of native mints were also still very active. ${ }^{56}$ Given the lower population figures than half a century later (see below), this points to deep monetization already existing at the beginning of the nineteenth century. These impressions find some corroboration in the more precise figures for the district of Benares. ${ }^{57}$ In 1808, the number of (copper) pice required for circulation in that district was estimated at 700,00o rupees, or roughly fifteen pice per capita. As the daily wage of a labourer was four pice, this would imply that the district as a whole was on the brink of deep monetization, especially if we include the number of cowries still circulating at the time in Bengal..$^{8}$

There was certainly a demand for these copper coins, as demonstrated by a reconstruction of labour relations in the Deccan in the 1820 - the earliest data so far for India available in the Global Collaboratory on the History of Labour Relations - which are not substantially different from the 1901 outcomes for about the same geographical area. ${ }^{59}$

\section{Table 11.2 Primary labour relations (\%) in three collectorates in the Deccan in the 1820 S}

\begin{tabular}{|c|c|c|c|c|c|c|c|c|c|}
\hline \multirow{2}{*}{$\begin{array}{l}\text { Labour Relations } \\
\text { Category }\end{array}$} & \multicolumn{3}{|c|}{ Khandesh } & \multicolumn{3}{|c|}{ Poonah } & \multicolumn{3}{|c|}{ Dharwar } \\
\hline & male & female & total & male & female & total & male & female & total \\
\hline 1 not working & 15 & 15 & 30 & 15 & 15 & 30 & 15 & 15 & 30 \\
\hline 2 affluent & 0 & 3 & 3 & 0 & 3 & 3 & 0 & 2 & 2 \\
\hline $\begin{array}{l}5 \text { working in the } \\
\text { household }\end{array}$ & 0 & 16 & 16 & 0 & 23 & 23 & 0 & 18 & 18 \\
\hline 7 slaves & 7 & 0 & 7 & 8 & 0 & 8 & 6 & 0 & 6 \\
\hline
\end{tabular}

56 More extensively in Lucassen, "Deep Monetization in Eurasia".

57 Stevens, The Coins, pp. 264-265, 319-323, 336-342, 355-367, 378-379, 488. For information on the Benares Division, District, and City, see Imperial Gazetteer of India.

58 Stevens, The Coins, passim; Lucassen, "Introduction", pp. 31-32; Hogendorn and Johnson, The Shell Money.

59 Lucassen and Stapel, "Shifts". Following this, data for neighbouring Goa since the late $1830 \mathrm{~s}$ (ongoing work in the framework of the Collaboratory with Paulo Mattos, Lisbon) has confirmed this impression. 


\begin{tabular}{lrrrrrrrrrr}
\hline $\begin{array}{l}\text { Labour Relations } \\
\text { Category }\end{array}$ & \multicolumn{3}{c}{ Khandesh } & \multicolumn{3}{c}{ Poonah } & \multicolumn{3}{c}{ Dharwar } \\
\hline & male & female & total & male & female & total & male & female & total \\
\hline $\begin{array}{l}12 \text { a+b small } \\
\text { producers } \\
\begin{array}{l}14 \text { wage } \\
\text { labourers }\end{array}\end{array}$ & 18 & 4 & 22 & 24 & 5 & 29 & 22 & 5 & 27 \\
$\begin{array}{l}18 \text { in state } \\
\text { employ }\end{array}$ & 10 & 8 & 18 & 1 & 1 & 2 & 8 & 7 & 15 \\
\begin{tabular}{l} 
Total \\
\hline
\end{tabular} & 4 & 0 & 4 & 5 & 0 & 5 & 2 & 0 & 2 \\
\end{tabular}

Source: Lucassen and Stapel, "Shifts in Labour Relations", Tables 1-3

After all these estimates, we may end with the earliest reliable reconstruction of the total money supply of India, which dates from around $1880 .^{60} \mathrm{At}$ that time, gold coins were used only for hoarding, for export, or in order to be melted down for ornaments. Silver coins were used for paying rents and taxes, and for petty trade transactions. The ordinary person, however, saw only the lowest possible denominations in copper. ${ }^{61}$ Most surprisingly, these copper coins, with an estimated value of 48.1 million rupees - or a fifth of a rupee (three annas) per capita - expressed in hourly wages of a quarter of an anna, resulted in a DML of no less than 12.

This comparatively high level may need some qualification. Wages outside agriculture may have been slightly higher than a quarter of an anna, and working days may have been longer than eight hours, but even so the result would be a per capita copper circulation of more than five times the hourly wage. Further, the actual circulation of copper coinage is likely to have been higher, because the estimates may very well exclude both copper coins produced before 1862 - the first coinage under the British Crown - and the numerous humble "native coins" that continued to circulate. Nevertheless, there are other reasons to suppose the conclusion that India was already deeply monetized by 1880 may be not too far off the mark. A recent reconstruction of labour relations for the subcontinent in 1900 shows levels of commodification (31.2 per cent self-employed and 12.1 per cent wage labourers) that are not very different from contemporaneous outcomes for European countries. ${ }^{62}$

60 More extensively in Lucassen, "Deep Monetization in Eurasia".

61 Report of the Committee, Appendix I, pp. 148-149.

62 Lucassen and Stapel, "Shifts", Table 23. For Europe, see cross-sections 1900 for Italy, Spain, and the Netherlands on https://collab.iisg.nl/web/labourrelations. 


\section{Conclusion: India from 1200 to 1900}

After a first attempt in the fourteenth century, Northern India is very likely to have been deeply monetized in the sixteenth century. After possible dips in the seventeenth and eighteenth centuries, it was certainly back to similar levels in the early nineteenth century, which goes for the entire subcontinent in the later decades of the century. These are certainly unexpected results for a subcontinent that is hardly ever considered a candidate for serious economic growth. Although research in this field still is lacking, the ubiquity of paid labour (both independent and waged) and the insistence of wage workers for payment in specific types of small change may be termed remarkable. This not only points to much greater agency of Indian wage labourers than expected, ${ }^{6_{3}}$ but also to small circulation circuits per type of coin before the middle of the nineteenth century. Political disunity may offer one explanation, but that is not very convincing if compared with Europe at the same time. Coin production might have been prolific, but state institutions in India hardly ever seem to have taken the responsibility for exchange ratios between silver and copper, leading to an enormous amount of power held by the intermediate layer of money changers. Consequently, workers tried to avoid exchange costs by insisting on the method of their wage payments. At the same time, this must have slowed down the velocity of money, which might point to an actual decline of deep monetization levels, especially during the period of decentralized coin production between around $175^{\circ}$ and $185^{\circ}$.

\section{China}

Like India, China has a tradition of small copper coin circulation going back well into the fourth century BCE. What is more, and unlike India, China's well-developed central polities, characterized by much more continuity, were able to produce these small copper "cash" coins centrally and -important for us - have kept production records since the Han (206 BCE to 220 $\mathrm{CE}){ }^{64}$ These show that average annual production of five to ten cash coins per capita was quite feasible, but also that in some periods many more were brought into circulation, leading to impressive stocks. Two periods stand out at once: the Northern Song (96o to 1126), with an annual production

63 For workers' agency in India in general from the late eighteenth to the nineteenth century, see Lucassen, "The Brickmakers' Strikes", and Lucassen, “Working”, pp. 19-56.

64 Lucassen, "Deep Monetization in Eurasia”. 
in the late eleventh century reaching over fifty cash coins per capita, and the Qing (1644 to 1912), with ten to twenty. The latter may seem much less impressive than the former, but the difference is smaller than one might think. On the one hand, the Song coins also circulated in Japan, which for centuries depended fully on imports of small change from China, and on the other, in the eighteenth and nineteenth centuries the stock of officially cast coins was supplemented substantially by illegally made specimens from all sorts of sources (including Vietnam), which demonstrates how great the demand was.

In the following paragraphs, I tackle two aspects: the methods of payments to workers, showing as far as possible the importance of cash coins for the functioning of the labour market, and the relationship between shifts in stock and shifts in labour relations. By way of conclusion, I discuss the comparability of the Chinese figures with those from other parts of the world.

The practice of daily payments in cash coins is abundantly testified to in official and unofficial written sources. Whether cash coins originated from castings in official mints did not matter, as long as they were accepted at the market and in shops. The government only intervened in grave cases of forgery, such as in 1794, when it closed down the Old Crow's Nest, a complete village of forgers in the mountainous border region of Sichuan and Guizhou. It had been active for eight years and in its heyday looked like a small town. ${ }^{65}$

Apart from the abundant availability of cash coins during most of the Qing period, what enhanced their use was also the accessibility of the courts for litigation cases regarding payments. Christine Moll-Murata found litigations in Baxian (Sichuan), over sums as low as 350 or 420 cash coins, at the time good for purchasing respectively 10 kilograms of rice or 2.5 kilograms of pork. Equally important was the likelihood for wage earners to win a case. It demonstrates, according to Moll-Murata, "that to a certain extent, the 'small people', who in their plaints and testimonies were required to refer to themselves vis-à-vis the authorities as 'ants', harboured the hope that they would get their cash and acceptable working conditions by virtue of adjudication from the representatives of the state". ${ }^{66}$

Hope could also spring from collective action, especially by craft guilds. In extreme cases, strikes would break out. The most famous one in this period is possibly the strike in one of the two large (more than 3,000 workers in

65 Cao and Vogel, "Smoke on the Mountain".

66 Moll-Murata, "Legal Conflicts", quotation on p. 276. 
total) metropolitan mint houses in Peking in 1741. Because of illegal wage deductions and bribery by their foremen, focusing on incorrect exchange rates between copper and silver money, a number of industrial actions took place. On one occasion, the workers in one of the factories climbed onto a mound within the mint, clamouring and shouting, and throwing bricks and tiles, even after troops had arrived. After several rounds of blanks were fired, the throwing stopped, but not the shouting. The prefect had the ringleaders punished, but at the same time requested that the emperor punished the foremen as well. It is also very probable that the workers received compensation for the illegal deductions and frauds committed by their foremen. ${ }^{67}$ Methods of payment really mattered, and this was widely recognized.

The impressively deep monetization levels for the Song period are perhaps less surprising than those under the Ching. Kent Deng quotes the famous dictum by Eric Jones that Song China was just a "hair's breadth" away from a genuine industrial revolution and adds: "Counterfactually, if the stand-off between the nomads and the Songs had continued for another 200 to 300 years, China might indeed have become a capitalist economy. ${ }^{p 68}$ Another indicator for the growing importance of labour markets is the number of major cities, including the port Quanzhou, with a population of 100,000 households in 989, and Hangzhou - the capital of the Southern Song - with $55^{0}, 000$ inhabitants in 1165 and $1,240,000$ in $1173 .{ }^{69}$

It also may be significant that around 1050, compulsory work for the Chinese state was converted into a tax, which had to be paid in cash. This suggests that self-employed peasants and craftsmen as well as wage earners became the new taxpayers. From the twelfth century onwards, far fewer cash coins were produced, and Von Glahn emphatically states that bronze coin circulation virtually stopped for two centuries..$^{70}$ The partial replacement by paper money would not have been useful for regular wage payments or advances to craftsmen, and certainly not for their shopping. In the fifteenth century, the increase of private coinage brought some relief. The rise of "bond servitude" in late Ming China implies a shift from free to unfree labour in those cash-ridden centuries. ${ }^{71}$

As they did during the Song population growth, the extension of labour markets and deep monetization went hand in hand under the Qing. This

67 Vogel, "Unrest". For mutinies caused by contentious modes of payment, see Kaske, "Silver", p. 378 .

68 Deng, "Imperial China", p. 326.

69 Ibid., pp. 325-326.

70 Von Glahn, Fountain of Fortune, pp. 39-56.

71 Chevaleyre, "Acting”; Moll-Murata, "Legal Conflicts". 
distinctive pattern of monetization intensity becomes understandable if we link it to shifting labour relations, in particular those described in detail by Christine Moll-Murata in the framework of the Global Collaboratory on the History of Labour Relations..$^{72}$ Wage labour became increasingly important, especially from 1780 onwards, in various industrial sectors such as printing, porcelain making, and shipbuilding..$^{73}$

China stands out for maintaining the circulation of one specific coin denomination, the "cash" for more than 2200 years. It is apparent that a large increase in monetization levels took place in the eleventh century, followed by a decrease between the twelfth and the sixteenth century, and again an increase in the eighteenth century. Although this periodization is important for the study of labour relations, it is not so easy to answer the question of what per capita stock would represent "deep monetization" as defined in the introduction to this chapter. At first sight, the requirements of "a per capita stock equal to between five and ten times the prevailing hourly wage" are more than fulfilled. However, we should not forget that a substantial proportion of the cash coins did not circulate as individual pieces, but as "small" strings of (ideally) 100 pieces or "big" strings of 1,00o pieces, which compares with medium and large silver coins in the southern and western parts of Eurasia. ${ }^{74}$ With a few minor exceptions, multiple cash coins were cast and circulated by the state in large numbers only at the times of highest production in the Song and Qing periods. At these times it is apparent that there was a substantial demand for these larger denominations of five, and especially ten and higher cash coins. ${ }^{75}$ In order to enhance comparability with other polities, it might be advisable to divide the Chinese DMLs by ten.

\section{Conclusion}

This chapter shows that for several parts of Eurasia, as a rule the degree to which people participate in a market economy is reflected by the intensity of which medium and small denomination coins are available for circulation. Small denominations best reflect the frequency of exchanges in society and so may be considered the best yardstick of commercialized human relations.

72 Moll-Murata, "China, Taiwan, Japan". For the Middle Ages, see Von Glahn, Fountain of Fortune, p. 5 o.

73 Moll-Murata, State and Crafts; idem, Moll-Murata, "Legal Conflicts", pp. 275-276.

74 As all Chinese cash coins were holed, they could be strung together.

75 For the 1854 issues, in use at least until 1879, see Kaske, "Silver", pp. 371, 392. 
Figure 11.2 Deep Monetization in Europe and Asia, 1000 to 1885

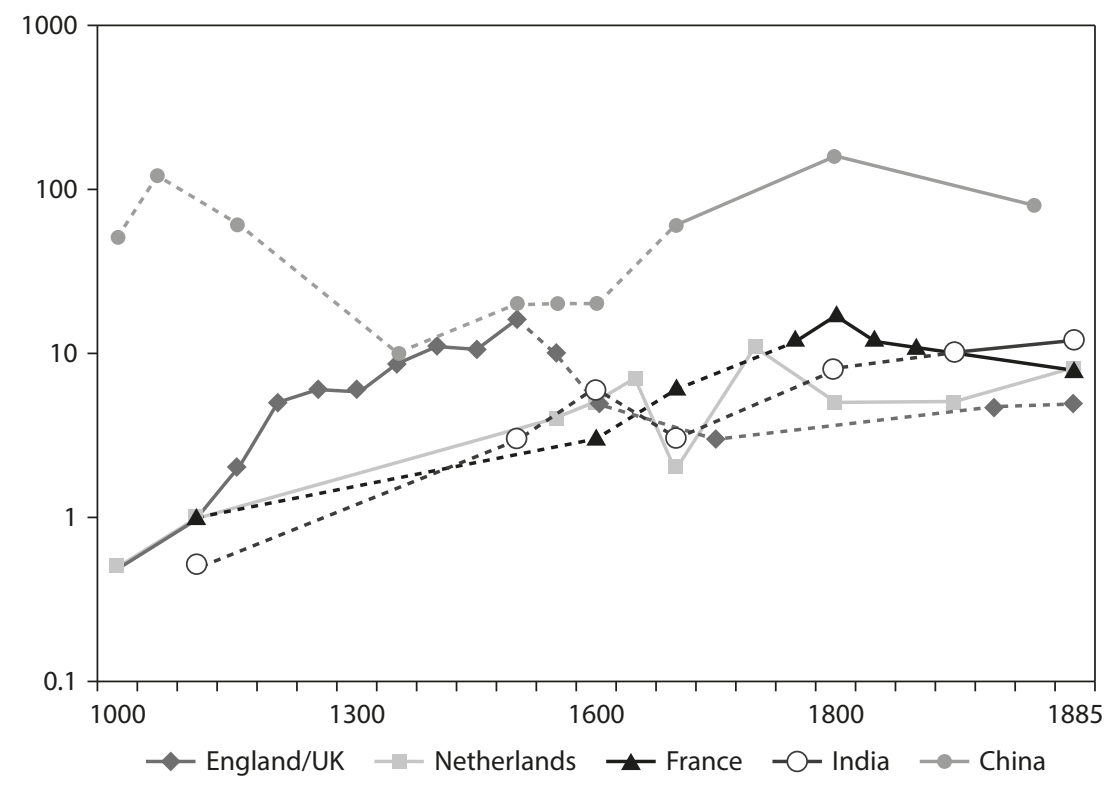

The concept of DMLs is used here as a yardstick for tracing shifts in labour relations. The chapter uses archaeological and other numismatic evidence as a supplement to and an alternative for written evidence of the history of work. It has proven useful for the multi-metal and multi-denominational currency systems that prevailed in the west and the south, but less so in the mono-fractional Chinese system (unless adjustments are made for the usage of cash coins strung together in units of 100 or 1,000 in order to pay larger sums because of the lack of intermediate denominations). Nevertheless, in all cases, shifts in the levels of monetization may indicate possible shifts in labour relations.

Available data for different parts of Eurasia (England, the Low Countries, France, India, and China) show unexpected results (see Figure 11.2): (1) similar levels of deep monetization in Western Europe and South Asia from around 1100 to 1900; (2) similar periods of increasing and decreasing levels overall, but diverging in the seventeenth and eighteenth centuries (an increase in Europe versus a decrease in India); (3) diverging developments between China and the rest; (4) the importance of institutions regulating coin circulation; and (5) the agency of workers if the circulation of the denominations they depend on is endangered. 
To a certain extent, these results question accepted wisdom in debates on labour history, but also on the Great Divergence, urbanization, migration, and economic development. Although deep monetization did not automatically and directly follow the introduction of coins as currency, it took place every where much earlier than the advent of "modernity" or the "industrial revolution", and it is certainly not a prerogative of the West.

On the other hand, this institution is not a simple function of the demand for small change, as the supply side in particular is determined by a number of political factors, and therefore this institution can vary and appear somewhat unstable. One alternative for the demand for small change that is not met by sufficient supply is the extension of small credit (not shown in Figure 11.2). Variations in demand and supply explain why the lines in Figure 11.2 sometimes run parallel and sometimes do not.

In this chapter, two explanations have been proposed for the varying levels in deep monetization: first, actual shifts in labour relations, and second, shifts in the modes of payment, independent of such relations. As we have seen in the introduction, each form of labour relations (as defined in the "collaboratory") involves its own type of remuneration, which is linked to specific methods of payment. Actual shifts of many people engaged in free work to unfree work are likely to diminish the demand for small denominations, whereas shifts from reciprocal work to commodified work will have the opposite effect. Shifts in modes of payment may also occur when the supply of small change varies independently of developments in labour relations. In such cases, intervals of payment, and consequently credit relations, will have to change. Examples of both have been discussed: shifts in labour relations in all the countries analysed here, as well as changing credit relations in England between the fourteenth and the nineteenth century. Other shifts in DMLs still are not well understood (for example, India in the seventeenth and eighteenth centuries).

Explanations for changing levels of deep monetization may be found on the demand side in shifting labour relations (free versus unfree; (de) commodification; independent versus wage labour), as well as in changing practices in frequencies of payment, and thus in the credit relations of workers that determine their power relations. 


\section{Bibliography}

Bacherikov, Pavel, "Monety i zarplaty: vypusk monetykh denominatsii kak indikator rasprostranenii naemnogo truda v Rossii v XVII veke”, paper, Higher School of Economics and New Economic School, 2013.

Béaur, Gérard, et al., "Northern France, 1000-1750", in Bas van Bavel and Richard Hoyle (eds), Rural Economy and Society in North-western Europe, 500-200o: Social Relations: Property and Power (Turnhout, 2010), pp. 111-166.

Biernacki, Richard, The Fabrication of Labor: Germany and Britain, 1640-1914 (Berkeley, 1995).

Bolton, J.L., Money in the Medieval English Economy, 973-1489 (Manchester, 2012).

Brown, Henry Phelps, and Sheila V. Hopkins, A Perspective of Wages and Prices (London, 1981).

Cao, Jin, and Hans Ulrich Vogel, "Smoke on the Mountain: The Infamous Counterfeiting Case of Tongzi District, Guizhou Province, 1794", in Jane Kate Leonard and Ulrich Theobald (eds), Money in Asia (1200-190o): Small Currencies in Social and Political Contexts (Leiden, 2015), pp. 188-219.

Cardon, Thibault, "Les petites monnaies étrangères en Normandie au XIVe-Xve siècles: provenances, modalités d'introduction et circulation", in Jérémie Chameroy and Pierre-Marie Guihard (eds), Circulation monétaires et réseaux d'échanges en Normandie et dans le Nord-Ouest européen (Antiquité-Moyen Âge) (Caen, 2012), pp. 207-228.

Chevaleyre, Claude, "Acting as Master and Bondservant: Considerations on Status, Identities and the Nature of 'Bond-Servitude' in late Ming China”, in Alessandro Stanziani (ed.), Labour, Coercion, and Economic Growth in Eurasia, $17^{\text {th }}-20^{\text {th }}$ Centuries (Leiden, 2013), pp. 237-272.

Cribb, Joe, and Barrie Cook, and Ian Carradice, The Coin Atlas: The World of Coinage from Its Origin to the Present Day (London, 1990).

Deng, Kent Gang, "Imperial China under the Song and late Qing", in Andrew Monson and Walter Scheidel (eds), Fiscal Regimes and the Political Economy of Premodern States (Cambridge, 2015), pp. 308-342.

Desrousseaux, Stéphane, La monnaie en circulation en France sous Napoléon (Paris, 2012).

Deyell, John S., “The Development of Akbar's Currency System and Monetary Integration of the Conquered Kingdoms", in John F. Richards (ed.), The Imperial Monetary System of Mughal India (Oxford, 1987), pp. 13-67.

De Zwart, Pim, and Jan Lucassen, "Poverty or Prosperity in Bengal c. 1700-1875? New Evidence, Methods and Perspectives", presented at $26^{\text {th }}$ World Economic History Conference, Kyoto, 2015. 
Florén, Anders, "Social Organization of Work and Labour Conflicts in ProtoIndustrial Iron production in Sweden, Belgium and Russia", International Review of Social History, 39 (1994), pp. 83-113.

Further Reports from Her Majesty's Diplomatic and Consular Agents Abroad Respecting the Condition of the Industrial Classes and of the Purchasing Power of Money in Foreign Countries (London, 1871).

Global Collaboratory on the History of Labour Relations (GCHLR), International Institute of Social History, Amsterdam. Available at: https://collab.iisg.nl/web/ labourrelations.

Goron, Stan, and J.P. Goenka, The Coins of the Indian Sultanates, Covering the Area of Present-day India, Pakistan and Bangladesh (New Delhi, 2001).

Goubert, Pierre, Cent mille provinciaux au XVIIe siècle. Beauvais et le Beauvaisis de $1600-1730$ (Paris, 1968).

Habib, Irfan, "A System of Trimetallism in the Age of the 'Price Revolution': Effects of the Silver Influx on the Mughal Monetary System”, in John F. Richards (ed.), The Imperial Monetary System of Mughal India (Oxford, 1987), pp. 137-170.

Haider, Najaf, "Fractional Pieces and Non-Metallic Monies in Medieval India (12001750)", in Jane Kate Leonard and Ulrich Theobald (eds), Money in Asia (1200-19oo): Small Currencies in Social and Political Contexts (Leiden, 2015), pp. 86-107.

Haider, Najaf, "Structure and Movement of Wages in the Mughal Empire, 1500-1700", in Jan Lucassen (ed.), Wages and Currency: Global Comparisons from Antiquity to the Twentieth Century (Bern, 2007), pp. 293-321.

Haupt, Ottomar, Arbitrages et parités: traité des opérations de banque: contenant les usages commerciaux, la théorie des changes et monnaies, les dettes publiques et la statistique monétaire de tous les pays du globe, $8^{\text {th }}$ ed. (Paris, 1894).

Haupt, Ottomar, L'histoire monetaire de notre temps (Paris, 1886).

Hogendorn, Jan, and Marion Johnson, The Shell Money of the Slave Trade (Cambridge, 1986).

Honnindal Grytten, Ola, "Economic Growth and Purchasing Power Parities in the Nordic Countries, 1830-1910", in Sakari Heikkinen and Jan Luiten van Zanden (eds), Exploring Economic Growth: Essays in Measurement and Analysis: A Festschrift for Riita Hjerppe on Her $60^{\text {th }}$ Birthday (Amsterdam, 2004), pp. 89-104. Imperial Gazetteer of India, Vol. 7: Bareilly to Berasiā (Oxford, 1908).

Kaske, Christine, "Silver, Copper, Rice, and Debt: Monetary Policy and Office Selling in China during the Taiping Rebellion", in Jane Kate Leonard and Ulrich Theobald (eds), Money in Asia (1200-19oo): Small Currencies in Social and Political Contexts (Leiden, 2015), pp. 345-397.

Kolchin, Peter, Unfree Labor: American Slavery and Russian Serfdom (Cambridge, 1987). 
Kolff, D.H.A., and H.W. van Santen (eds), De Geschriften van Francisco Pelsaert over Mughal Indië, 1627 Kroniek en Remonstrantie ('s-Gravenhage, 1979).

Le Roy Ladurie, Emmanuel, Les paysans de Languedoc (Paris, 1969).

Lingen, Jan, and Jan Lucassen, "Copper Circulation in Northern India in 1830", Numismatic Digest, 34-35 (2010-2011), pp. 148-183.

Lingen, Jan, and Jan Lucassen, "Warfare and Coin Circulation: Two Lacs of Bharatpur and Bindrabund Rupees and 15 Bags of Copper Pyce, Captured at Dig on Christmas' Eve 1804", Numismatic Digest, 36-37 (2012-2013), pp. 157-181.

Lucassen, Jan, “The Brickmakers' Strikes on the Ganges Canal in 1848-1849", International Review of Social History, 51 (2006), pp. 47-83.

Lucassen, Jan, "Deep Monetization, Commercialization and Proletarianization: Possible Links, India 1200-190o", in Sabyasachi Bhattacharya (ed.), Towards a New History of Work (New Delhi, 2014), pp. 17-55.

Lucassen, Jan, “Deep Monetization in Eurasia in the Long Run”, in Bas van Leeuwen and Bert van der Spek (eds), In Search of Trust: Currencies and Crises in the Past 2000 Years (London, forthcoming).

Lucassen, Jan, "Deep Monetization: The Case of the Netherlands 1200-1940", Tijdschrift voor Sociale en Economische Geschiedenis, 11 (2014), pp. 73-121.

Lucassen, Jan, "Introduction: Wages and Currency, 500 BCE-20oo CE", in Jan Lucassen (ed.), Wages and Currency: Global Comparisons from Antiquity to the Twentieth Century (Bern, 2007), pp. 9-58.

Lucassen, Jan, "The Logistics of Wage Payments: Changing Patterns in Northern India in the 1840 o", in Jan Lucassen (ed.), Wages and Currency: Global Comparisons from Antiquity to the Twentieth Century (Bern, 2007), pp. 349-390.

Lucassen, Jan, "Outlines of a History of Labour", International Institute of Social History, IISH-Research Paper 51 (2013), available at: https://collab.iisg.nl/c/document_library/get_file?p_l_id=273223\&folderId=338337\&name=DLFE-174901.pdf.

Lucassen, Jan, "Wage Payments and Currency Circulation in the Netherlands from 1200 to 200o", in Jan Lucassen (ed.), Wages and Currency: Global Comparisons from Antiquity to the Twentieth Century (Bern, 2007), pp. 212-263.

Lucassen, Jan, "Working at the Ichapur Gunpowder Factory in the 189os", Indian Historical Review, 39 (2012), pp. 19-56.

Lucassen, Jan (ed.), Global Labour History: A State of the Art (Bern, 2006).

Lucassen, Jan, and Jaco Zuijderduijn, "Coins, Currencies and Credit Instruments: Media of Exchange in Economic and Social History", Tijdschrift voor Sociale en Economische Geschiedenis, 11 (2014), pp. 1-13.

Lucassen, Jan, and Rombert Stapel, "Shifts in Labour Relations in India, 1800-2000", presented at the $10^{\text {th }}$ International Conference on Labour History, Noida (India), 22-24 March 2014. 
Lurvink, Karin, "Strapped for Cash: Non-cash Payments on Louisiana Cotton Plantations, 1865-1908", Tijdschrift voor Sociale en Economische Geschiedenis, 11 (2014), pp. 123-151.

Martin, Marie H., "The Reforms of the Sixteenth Century and Akbar's Administration: Metrological and Monetary Considerations", in John F. Richards (ed.), The Imperial Monetary System of Mughal India (Oxford, 1987), pp. 68-99.

Martiny, Jean-Claude, Het Munthuis in Gentvan de Karolingers tot de Calvinistische Republiek 1768-1584, 3 vols (Gent, 2014).

Mayhew, Nicholas, "Wages Currency. The Case in Britain up to c. 160o", in Jan Lucassen (ed.), Wages and Currency: Global Comparisons from Antiquity to the Twentieth Century (Bern, 2007), pp. 211-220.

Moll-Murata, Christine, "China, Taiwan, Japan, 1500-200o", presented at the International Institute of Social History conference on Collaboratory Global Labour Relations, 1500-2000, Amsterdam, May 2012.

Moll-Murata, Christine, "Legal Conflicts Concerning Wage payments in Eighteenth- and Nineteenth-Century China: The Baxian Cases”, in Jane Kate Leonard and Ulrich Theobald (eds), Money in Asia (1200-190o): Small Currencies in Social and Political Contexts (Leiden, 2015), pp. 265-308.

Moll-Murata, Christine, State and Crafts in the Qing Dynasty (1644-1911) (Tübingen, 2008).

Monson, Andrew, and Walter Scheidel (eds), Fiscal Regimes and the Political Economy of the Premodern States (Cambridge, 2016).

Muldrew, Craig, "Wages and the Problem of Monetary Scarcity in Early Modern England", in Jan Lucassen (ed.), Wages and Currency: Global Comparisons from Antiquity to the Twentieth Century (Bern, 2007), pp. 391-410.

Naismith, Rory, Money and Power in Anglo-Saxon England: The Southern English Kingdoms, 757-865 (Cambridge, 2012).

Palairet, Michael, The Balkan Economies c. 180o-1914:Evolution without Development (Cambridge, 1997).

Prakash, Om, "Long Distance Trade, Coinage and Wages in India, 1600-196o", in Jan Lucassen (ed.), Wages and Currency: Global Comparisons from Antiquity to the Twentieth Century (Bern, 2007), pp. 323-348.

Reddy, William M., Money and Liberty in Modern Europe: A Critique of Historical Understanding (Cambridge, 1987).

Report of the Committee Appointed to Inquire into the Indian Currency (with Minutes of Evidence, Correspondence, Index, Further Papers) (London, 1893), republished in Marina Kovalchuk and Georges Depeyrot (eds), Documents and Studies on $19^{\text {th }}$ C. Monetary History: India (Wetteren, 2011).

Sargent, Thomas J., and François R. Velde, The Big Problem of Small Change (Princeton, 2002). 
Selgin, George, Good Money: Birmingham Button Makers, the Royal Mint, and the Beginnings of Modern Coinage, 1775-1821: Private Enterprise and Popular Coinage (Ann Arbor, 2008).

Shimada, Ryuto, The Intra-Asian Trade in Japanese Copper by the Dutch East India Company during the Eighteenth Century (Leiden, 2006).

Simmel, Georg, Philosophie des Geldes (Munich, 1922).

Spufford, Peter, How Rarely Did Medieval Merchants Use Coin? (Utrecht, 2008).

Spufford, Peter, Money and Its Use in Medieval Europe (Cambridge, 1988).

Steinfeld, Robert J., The Invention of Free Labor: The Employment Relation in English and American Law and Culture, 1350-1870 (Chapel Hill, 1991).

Stevens, Paul, The Coins of the Bengal Presidency (London, 2012).

Thue, Lars, "Norway: A Resource-Based and Democratic Capitalism", in Susanne Fellman et al. (eds), Creating Nordic Capitalism: The Business History of a Competitive Periphery (New York, 2008), pp. 403-415.

Van Bavel, Bas, Manors and Markets: Economy and Society in the Low Countries, 500-16oo (Oxford, 2010).

Van Bavel, Bas, "Rural Wage Labour in the Sixteenth-Century Low Countries: An Assessment of the Importance and Nature of Wage Labour in the Countryside of Holland, Guelders and Flanders", Continuity and Change, 21 (2006), pp. 37-72.

Van der Linden, Marcel, Workers of the World: Essays toward a Global Labor History (Leiden, 2008).

Vanhoudt, Hugo, De munten van de Bourgondische, Spaanse en Oostenrijkse Nederlanden en van de Franse en Hollandse periode 1434-1830 (Heverlee, 2015).

Van Zanden, Jan Luiten, "The Road to the Industrial Revolution: Hypotheses and Conjectures about the Medieval Origins of the 'European Miracle', Journal of Global History, 3 (2008), pp. 337-359.

Vogel, Hans Ulrich, "Unrest and Strikes at the Metropolitan Mints in 1741 and 1816 and Their Economic and Social Background", in Christine Moll-Murata, Song Jianze, and Hans Ulrich Vogel (eds), Chinese Handicraft Regulations of the Qing Dynasty: Theory and Application (Munich, 2005), pp. 395-422.

Volckart, Oliver, “The Big Problem of the Petty Coins', and How It Could Be Solved in the Late Middle Ages". Working Papers No. 107/08, London School of Economics, February 2008, available at: http://www.lse.ac.uk/economicHistory/pdf/ WP107.pdf.

Von Glahn, Richard, Fountain of Fortune: Money and Monetary Policy in China, 1000-170o (Berkeley, 2010).

Welten, Joost, Met klinkende munt betaald. Muntcirculatie in de beide Limburgen 1770-1839 (Utrecht, 2010). 


\section{About the Author}

Jan Lucassen is an Honorary Fellow of the International Institute of Social History, where he founded the research department in 1988 . He is also Emeritus Professor of the Free University (Amsterdam) and a member of the Royal Netherlands Academy of Arts and Sciences (The Netherlands). His publications include Global Labour History: A State of the Art (ed.) (Bern, 2006) and Wages and Currency: Global Comparisons from Antiquity to the Twentieth Century (Bern, 2007).

E-mail: lucasjan@xs4all.nl 


\section{Notes on Contributors}

Rossana Barragán is Senior Researcher at the International Institute of Social History in Amsterdam (The Netherlands). Among her most recent articles are "Dynamics of Continuity and Change: Shifts in Labour Relations in the Potosí Mines (1680-1812)", International Review of Social History, 61 (December 2016); "Working Silver for the World: Mining Labor and Popular Economy in Colonial Potosí”, Hispanic American Historical Review, 97:9 (May 2017). Focused on the dynamics of labour in the colonial period in Latin America, she is writing a new book on the colonial mining industry in Potosí. rba@iisg.nl

Ulbe Bosma is Senior Researcher at the International Institute of Social History in Amsterdam and Professor of International Comparative Social History at the Vrije Universiteit Amsterdam (The Netherlands). His publications include The Sugar Plantation in India and Indonesia: Industrial Production, 1770-2010. (Cambridge, 2013), Commodities, Ports and Asian Maritime Trade, 1750-1850 (Bastingstoke, 2015) (co-edited with Anthony Webster), and Being "Dutch" in the Indies: A History of Creolisation and Empire, 1500-1920 (2008) (with Remco Raben).

ubo@iisg.nl

William Gervase Clarence-Smith is Professor of the Economic History of Asia and Africa, at SOAS, University of London (United Kingdom). He is editor of the Journal of Global History. He has researched the history of cotton textiles and various export-processing industries in the Global South. More widely, he has written on the history of commodities, animals, labour, diasporas, and Islam. His latest book is Islam and the Abolition of Slavery (London, 2006). wc2@soas.ac.uk

Johan Fourie is Associate Professor of Economics at Stellenbosch University (South Africa). His publications include studies using colonial probate inventories (Economic History Review, 2013), population estimates (Journal of African History, 2015, with Erik Green), and credit records (Journal of Southern African Studies, 2017, with Christie Swanepoel). His contribution to this volume is the first chapter of a new project - The Cape of Good Hope Panel - in which a panel dataset of Cape settler households spanning more than a century will be created.

johanf@sun.ac.za 
Erik Green is an Associate Professor of Economic History at Lund University (Sweden) and a Research Fellow at the Department of Economics, Stellenbosch University (South Africa). His main research interest is agricultural history and labour history. His recent publications include studies of wage shares in Malawi (Journal of African History, 2015, with Jutta Bolt), involutionary growth in Ghana (Journal of Agrarian Change, 2016), labour and land tenure changes in Zambia (Journal of Southern African Studies, 2017, with Milja Norberg), and slavery and the Nieboer-Domar hypothesis in South Africa (International Review of Social history, 2014).

Erik.Green@ekh.lu.se

Karin Hofmeester is Senior Researcher and Deputy Director of Research at the International Institute of Social History in Amsterdam (The Netherlands) and Professor of Jewish Culture at the University of Antwerp (Belgium). Her publications include The Joy and Pain of Work: Global Attitudes and Valuations, 1500-1650 (Cambridge, 2012) (co-edited with Christine Moll-Murata), Luxury in Global Perspective: Objects and Practices, 1600-200o (Cambridge, 2016) (co-edited with Bernd-Stefan Grewe), Conquerors, Employers, and Arbiters: States and Shifts in Labour Relations, 1500-2000 (Cambridge, 2016) (co-edited with Gijs Kessler and Christine Moll-Murata).

kho@iisg.nl

Jan Lucassen is an Honorary Fellow of the International Institute of Social History, where he founded the research department in 1988 . He is also Emeritus Professor of the Free University (Amsterdam) and a member of the Royal Netherlands Academy of Arts and Sciences (The Netherlands). His publications include Global Labour History: A State of the Art (ed.) (Bern, 2006) and Wages and Currency: Global Comparisons from Antiquity to the Twentieth Century (Bern, 2007).

lucasjan@xs4all.nl

Elias Mandala teaches African history at the University of Rochester, New York (United States). His major publications include Work and Control in a Peasant Economy: A History of the Lower Tchiri Valley in Malawi, 1859-196o (Madison, WI, 1990) and The End of Chidyerano: A History of Food and Everyday Life in Malawi, 1860-2004 (Portsmouth, NH, 2005). He is now working on a political and environmental history of the Magololo Chiefs of southern Malawi and former servants of Dr. David Livingstone. elias.mandala@rochester.edu 
Elise van Nederveen Meerkerk is Associate Professor at the Department of History and Art History at Utrecht University and Professor of the Comparative History of Households, Gender and Work at Radboud University Nijmegen (The Netherlands). Her work is mostly in the field of comparative labour relations, gender, and households from the early modern period to the present. Publications include: "Challenging the De-industrialization Thesis: Gender and Indigenous Textile Production in Java under Dutch Colonial Rule, ca. 1830-1940", Economic History Review (2017); Towards a Global History of Domestic and Care Workers (Leiden, 2015) (co-edited with Dirk Hoerder and Silke Neunsinger).

e.j.v.vannederveenmeerkerk@uu.nl

Karin Pallaver is Associate Professor at the Department of History and Cultures, University of Bologna (Italy), where she teaches African History and Indian Ocean History. Among her recent publications: "From Venice to East Africa: History, Uses and Meanings of Glass Beads", in Karin Hofmeester and Bernd-Stefan Grewe (eds), Luxury in Global Perspective: Commodities and Practices, c. 1600-200o (Cambridge, 2016), "The African Native Has No Pocket': Monetary Practices and Currency Transitions in Early Colonial Uganda", International Journal of African Historical Studies, 48:3 (2015); "Population Developments and Labor Relations in Tanzania: Sources, Shifts and Continuities from 1800 to 2000", History in Africa, 41 (2014). karin.pallaver@unibo.it

Matthias van Rossum is Senior Researcher at the International Institute of Social History in Amsterdam (The Netherlands). He works on global labour history with a special interest in maritime labour history, coercion in labour relations, and the dynamics of labour conflicts and social relations. He was awarded a NWO Veni Grant for research on the history of slavery and slave trade in early modern Dutch Asia (2016-2019). His publications include Desertion in the Early Modern World (co-edited with Jeannette Kamp) (London, 2016).

mvr@iisg.nl

Pim de Zwart is Assistant Professor at the department of Rural and Environmental History, Wageningen University (The Netherlands). He received his $\mathrm{PhD}$ (cum laude) from Utrecht University in 2015 and his work has mainly dealt with the Dutch East India Company (VOC) and the integration of global commodity markets and the development of living standards in the VOC's empire in the East Indies in the period between 1600 and 1800. 
Articles on these subjects have appeared in, among others, the Journal of Economic History and the European Review of Economic History and he has recently published a book entitled Globalization and the Colonial Origins of the Great Divergence (Leiden, 2016).

pim.dezwart@wur.nl 


\section{Index}

abolition 21, 116, 118, 120, 128, 141, 288

Accra riots 44

Acemoglu, Daron 14, 23, 109, 111, 129, 209-210, 230-231

advance see credit

Africa 12, 14, 36-37, 40, 44, 51-52, 56, 82, 85, 88, $102,116,137,174-177,182,185,199,201,268$, $300,302,322,328$

agency 11, 17, 19-20, 23, 120, 137-138, 149, 167, 211, $232,344,349,353$

Agra 343

agriculture 18, 58, 85, 130-131, 143, 147, 153, 159-16o, 165, 173, 175-177, 180-189, 192-201, $226,269,283,306,348$

Akbar 342

Aldsie 247-249

Ali, Muhammad 43

America see United States of America (USA)

American Civil War 148

Amsterdam 252-253, 300, 339

Anatolia 50

Angola 32, 50, 52, 56, 85

Arab Agricultural Revolution 112

Arabian Seas 243

Arabs 45

Areaal 121, 126

Argentine 49

army see soldier

Arnhem 52,165

artisans $33-36,38,40,42,140,165,243,251,300$, 343

Arts and Crafts Movement 37, 159

Asia 14, 16, 19, 22, 37, 39, 44, 51, 54, 110-112, 114$115,118,128-129,137,139,239-240,244-245$, $247,249,254-256,259-260,341,353$

Aslam, Ishrat 72

Assadourian, Carlos Sempat 218-219, 226

Atlantic, the 113, 116, 128, 240, 254-255

Austin, Gareth 15, 211

Australia 49

Austria-Hungary 333-334

Backar, Aboe 248-249

Bahia 78, 84-85

Bakewell, Peter 215, 222

Balandao 174

Baltic 250, 254

Banco de Rescates (also San Carlos Bank) 224-225

Banians 69

Banto West coast 82

Barba, Alonso 216

Basutoland 98, 100, 103

Batavia 115, 119, 148, 242, 247, 268
Bates, Robert 174

Batig Slot 163

batik $36,39,41,139,149,157-159,164-167$

bazaar 19, 119, 301

Bechuanaland 98, 103

Belgian Congo 15, 20, 51-52

Belgium 150, 333

Bengal 34, 112, 118, 244, 247, 344, 346, 347

Bentinck, William 34

Berry, Sarah 175

Bethlehem 37

Billiton Company 52

black Africans 93

Black Flag Revolt 94

Blantyre 184, 193

board and lodging 330; see also wage payment in kind

boers $89,96,272,277$

Bolshevik 45

Bombay Deccan 127

Bombay Presidency 118

Bosch, Johannes van den 120, 127

Bosma, Ulbe 17, 19, 117, 245

Brazil 55, 67-68, 75, 78, 82, 85-88, 95, 101-102, $113,116,255$

labour 68, 89, 102, 104, 113

labour relations $67-68,78,89$

slave $20,55,67-68,75,78,80-83,86,102,104$, 113,255

slavery 55,88

Breman, Jan 245

bridewealth 22, 91, 309, 311-313, 317-318, 321

Britain 34, 43, 47, 51-52, 118-119, 128, 159, 174, 177, 200-201, 257, 272, 328, 335

British Colonial Office 90

British Cotton Growers Association (BCGA) 194, 196

British Empire 103, 177, 211, 266, 287-288

British India $38,40,42,44-45,47-48,52,56$, 158, 257

British Malaya 50-51

British South Africa Company 193

British West Indies 125

Brown, Ian 30

Bruijn, J.R. 253

bujangs 115

Bulmer-Thomas, Victor 40, 49

Bultfontein 89-90, 92-93, 97

by-employment 122

Calcutta 345

Calico 137

Calico Acts 141-142, 156

California 47, 53 
Cañete, Pedro Vicente 229

Cape Colony 21, 89, 96, 266, 269, 272, 274, 282, 288

Cape Town 96, 266-267, 272-273 parliament 96, 266

Cape Town Archives Repository 266

Cape Verdean Islands 113

Capoche 219, 228

Caribbean 47, 109, 111, 113-114, 116-118, 121, 255

Caribbean islands 110, 115, 119, 122

Carolino Code 229

Carter, Jimmy 198

caste $38,40-41,56,74$

cattle $22,85,186,196,198-199,266-268,271-272$, $274,301,304,310-312,315-319,321$

Ceded Districts 74-76

census 159-160, 162

Central India 69, 76

Centrals 117, 125

cents 22, 297-299, 310, 316-321

Ceylon 42; see also Sri Lanka

Charles V 207, 338

Charlesworth, N. 118

Chikwawa District 180, 184, 186-187, 190, 199

Chikwawa Cotton Development Project (CCDP) 186

Child Labour Law 152

China 22-23, 34-35, 37-39, 41-43, 46-47, 49-50, $5^{2}, 54-55,112,114,139,327,329,335,341-342$, 349-353

Han Dynasty 349

Ming Dynasty $35^{1}$

(Northern) Song Dynasty 349-352

Qing Dynasty 43, 350-352; see also Qing Empire

Chinese Empire 114

Choisa, Joan de 248-249

claim holders 94-95

claims $17,88,90,93-95,210,248,258,277,288$

Clarence-Smith, William 18-20

closed compounds 99-100, 102-103

cloth $35-36$, 39, 42, 135, 137-141, 144, 146-148, 150, $154-155,157-158,164-166,174,297,311-312$

Coatsworth, John 212

coffee 19, 50, 54, 85, 143, 164, 177-178, 194, 267, 302-303, 305-306, 318-319

coins 22-23, 296-299, 316-317, 319-322, 327, 331-332, 326, 339-354; see also currency coin circulation $327-328,332-333,340,349$, 351,353

Cole, Jefffrey 222

colonial 11, 14-23, 32-33, 40, 43-45, 51-52, 57, 78,

84, 95, 102-104, 110-111, 113-116, 118-119, 121, $123,127-129,135,137-139,141-142,144,147-148$, $150,15^{2}, 155^{-156}$, 163-164, 166, 173-174, 176-178, $180-182,185,194,199-201,210-211,213,218$, 227, 231-232, 240, 245, 256-261, 295-302, 305-307, 309, 311, 313, 316-318, 320-322, 345,347 economy $18,120,137,143,153,159,165,181$, 183-184, 199, 201, 232, 288-289, 296, 298, 300, 302-303, 316, 321-322

government 17-18, 23, 89, 118, 120-121, 123, $142,173,181,185,199,232,302,305,314$, 316

institutions 11, 14-15, 17, 19-20, 23, 45, 67-68, $78,88,101,103,135^{-139}, 141,146,165$ policy $18,23,135^{-137}, 165^{-167}, 245,321$ colonialism 112, 120, 135, 139, 141, 181, 183, 201, 210, 230-231, 239, 257-261, 295

commodification see market economy commodity $26,50-51,67-69,78,84,101,110,116$, $118,128,192,211,297-298,316$

production $17,20,110$

Compagnie Française 98

competition $35,115,121,137,140,147-149,151-153$, $156,165,194,226,240,259,261$

compulsory labour 97, 232, 303-306, 351

consumption $20,31,36,112,115,125,128,140$, 148-149, 155, 164-167, 198, 309

convict 75,329

labour 77, 97, 99-101, 103

station 97

coolie hire 75

labour 242

system 33

cooperative 109-111, 125-128

copper $217,344,346,349$

coins 22, 297-298, 336-337, 339-349, $35^{1}$

stamps 39

Coromandel 244, 346

corvée 222-223, 329

cotton 17-19, 34, 36, 38, 41-43, 46-47, 56, 85, 119, 124, 136-141, 144, 146-151, 153-155, 157, 161, 163-166, 173-174, 176-178, 180-201, 241

craft $32-35,38,40-42,45,139-140,350$

craftsman $158,329,331-33^{2}, 343,35^{1}$

credit 23, 41, 111, 119, 267-268, 327, 337, 341, 354

Crete 113,116

Cuba 17, 109, 111, 116-118, 121-123, 127-128

Cuddapah 69, 74-75

Cultivation System 19-20, 120-122, 127, 137, $142-144,146-147,153,155,163,165$

culture 118, 159, 175-176, 178, 200, 210, 239

currency 22, 46, 112, 139, 295-299, 316, 320-322, 327-328, 330, 332, 334, 338, 344-346, 353-354; see also coins

denomination/fraction 22, 295-299, 316, 319-322, 327-328, 331-333, 336-340, 342, $348,35^{2-}-354$

small change $328,332,334-342,349-35^{\circ}, 354$ Cyprus 113,116

dambo 182-184, 186

De Beers Mining Company/De Beers consolidated Mines 96-100

Deccan 69, 71, 74, 101, 127, 346-347

De Coutre, Jacques 72 
De Lange, Pieter 73

debt 46, 73, 109-110, 123, 127, 163, 251-253, 337

deep monetization level (DML) 320-321, 327-328, 332-336, 338, 340-343, 346-349, 351-354

deindustrialization $18,20,29-30,33,111,136-137$, 146,167

Dejung, Christof 119

Delhi $38,342,345-346$

Denmark 254, 334

Dependency Theory 30

Dependentistas 30, 33-34

dependents 176, 201

desertion 93, 249, 251

Dewey, Clive 43,48

Diamantina $78,84-86,88$

diamond 68-69, 71-72, 78, 81, 83-85, 88-90, 93 , 95-97, 99-103

Diamond District 81-85, 87-88, 102

diamond global commodity chain $67-68,78$

diamond mines 16-17, 20-21, 67-68, 74-75, 86-91, 96, 100-101, 103

Diamond Trade Act 96, 101

division of labour $38,113,143,145-146,151$, $166-167,177-178,217$

Dom Pedro I 88

Dorstfontein 89-9o

Drakenstein 277

Dutch 19, 39, 41, 84, 113-114, 118-120, 128, 135, $137-138,140-142,145,148,150-153,158,161-164$, 166-167, 239-240, 254, 256, 258-259

Dutch East India Company (VOC) 26, 71, 73, 114-115, 139-142, 165, 244-245, 248-251, 253 $255^{-25} 6,267-269,343,346$

Dutch East Indies 137-139, 144, 152, 163-164, 245

Dutch Empire 137, 139

Dutch Navy 253

Dutch Republic see the Netherlands

Dutch West India Company 268

dye $34-36,38,140,149,157-158,166$

dynamism 11

East Africa 45, 298-299, 301-303

East Africa Protectorate (EAP) 22, 297, 299-300, 303-304, 306-307, 311, 319-320

East African Campaign 303-304, 313

East Asia 32, 38

East India Company (EIC) 34, 72-76, 101, 119, 142,346

East Indies 26, 139, 141-142, 150, 152-153, 161, 164 , 251,268

East Java 120, 123-124, 159

education 43, 53, 57, 111, 270

Egypt 37, 43, 47, 112, 334

elders 181,183

Eliot, Sir Charles 302

employer 17, 56, 93, 95, 222-223, 240, 246-247, $257-261,273,283,304,307,312,318,336$

enframing $31,47,57$
Eng, Pierre van der 146-147, 155

Engerman, Stanley 18, 210

England see United Kingdom (UK)

English Navigation Acts 254

enslavement 86, 210

Eurasia 256, 327-331, 342, 352-353

Europe 16, 22, 32, 37, 67, 113, 118-120, 126, 128, $137-138,140-141,149,157,163,166,185$, 239-240, 243-244, 247, 250, 254-256, 259-26o, $329,333,335,342,349,353$

Western Europe 16, 162, 192, 327-328, $332-335,340-341,353$

export (textile) $135,145,152,161$

export processing 19, 29, 32, 37, 43, 46-50, 52-53, $5^{6-57}, 65$

export-substituting industries 49

extraction $39,78,84,111,137,163,166,207$, 211-212, 214, 218-219, 230

factor endowments 111, 121, 123, 210

farmer 19, 21, 69, 73, 89, 95, 98, 103, 121, 126, 173-174, 176, 180-181, 184-185, 187-189, 191, 195, 197-201, 265-273, 277-278, 283-284, 288, 303-304, 311, 314, 317-319, 329, 331, 338

Faroqhi, Suraiya 35

Feinstein, Charles 103

Ferguson, Kathy 30

Fernandes de Oliveira, João $82-83$

fertilizer 43,48

Feuerwerker, Albert 34

First World War 37, 43-44, 52, 123, 139, 161, 163, $167,180,299,303,306,308$

Formosa see Taiwan

Fourth Dutch-Anglo War 249

France 32, 254, 327, 329, 335, 340-341, 353

free trade $18,29-30,32,34,42-43,48$

freedom 13, 81, 87, 181, 195, 210, 219, 242, 244, 270 , $288,328,334-335$

freedom of contract 330

frequency 197, 327, 332, 337, $35^{2}$

Furtado, Celso 49

Gandhi, Mahatma 44

Geertz, Clifford 117, 127

gemstone $5^{0}$

gender 139, 149, 153, 274, 282

men $56,72,74,77,83,89,97-100,124,138-140$, $143,145,151,158-160,162,166,219,221$, 244, 253, 255, 274, 282, 304, 306, 311-313, $316,318-319,321,331,336,339$

women $17,20,56,71-72,74,76-77,100,135$, $138-141,143,145,147,149,151,153,157-163$, 165-167, 274, 282, 306, 318-319, 329, 331, 344

geography $15,35,42,155$

Geological Survey of India 75

Georgia 198

Germany 53

Ghana 44 
Gildemeester, Daniël 84

Giusti-Cordero, Juan 117

Glave, Louis Miguel 227

Global Collaboratory 212

Global Collaboratory on the History of Labour Relations 11, 110, 287, 300, 321-322, 347, $35^{2}$

globalization 152,239

Global South 14, 18-19, 30, 57, 111, 126

Golconda (mines) 69

Gold Coast 44, 82, $15^{2}$

gold mines 100

Graaff-Reinet 265-266, 271-275, 277-278, 283, 288

Grafe, Regina 211

Great Depression 51-52, 194-195, 318

Great Divergence 136, 354

Greece 334

Griqua 89-90, 95

Griqualand-West, Crown Colony 89-9o, 94- $96,98,103$

groundnut $47,51,187,194$

guild $35,140,167,224,35^{\circ}$

Gujarat 69, 344

Gunder Frank, Andre 17

\section{hacenderos 124}

Haiti 122

Hall, K.L. 174

handicraft 29, 31, 33-36, 38-40, 44, 55, 57, 157-158

Harries, Patrick 100

Haupt, Ottomar 333

Haynes, Douglas 40-41, 146

Hemisphere

Eastern 110

Western 110, 112, 114, 116, 128

Heyne, Benjamin 74

historiography 212, 232, 245

hoard 317,332

Hoernel, Robert 117

Hong Kong 54

Hope, Henry 339, $35^{\circ}$

household $13,17,20,33,40-41,68,110,122,128$, $141,143-144,147,151,155,160,164,166,180$, 183, 187-189, 197-198, 201, 226, 268-269, 273-274, 284, 286, 291, 316, 329-330, 332, $334,35^{1}$

Howard, Henry 73

huayras 214

Huff, Gregg 31, 43, 46

Hyderabad 37

\section{Igler, David 47}

illegal miners (garimpeiros) 83-84

illicit mining and trading 69, 82, 84, 87-88, 102 Illife, John 175

imperialism 29, 32, 43, 113, 177, 179, 184

new imperialism 173,177

imports (textile) 34, 135, 138, 145-146, 150, 153-154 import substitution 18, 29, 31, 33, 42-44, 48,

$$
5^{2}, 57
$$

Inca 208, 212, 219, 226

independent producers 330-331, 341

India $19,22,34,37-38,40,42,46-48,53-56$, 67-69, 77-78, 81, 95, 101, 109-112, 118, 125-129, 136-137, 139-140, 144, 146, 244, 301, 329,

341-343, 346-349, 353-354

British rule 74

convicts 75,77

debt bondage 73

family labour 77

labour 67-68, 70-71, 73, 77, 101-102, 349

labour migration 74

labour relations $67-68,75,77,101,103$, 109-111, 341, 344, 347-348, 353-354

mining methods 71

reciprocal labour 101, 329

self-employed miners 75

slavery 118

wage labour $75,77,101,244,247,348-349$

wages $72,101,343-344,346,348$

women and children's work 72, 74, 77

Indian National Congress 126

Indian Ocean 42, 67, 114, 255, 297

Indian Sugar Committee 126

Indochina $5^{2}$

Indonesia 45, 52, 55, 111, 118, 126-129, 137, 167

labour 128-129, 167

labour relations 111, 137

slavery 118

industrial 29, 31-34, 36, 39-40, 42-43, 45-51, 53$57,112-113,116,125-127,138,141,15^{0}, 15^{2-153}$, 160-162, 214-215, 306, 337, 351-352, 354

Industrial Revolution 47, 354

industrialization 30-33, 39, 42, 44-49, 51, 53, 57, $110,125^{-126}, 135^{-138}, 144,150,15^{2-153}, 163$,

$166-167,338$

labour-intensive industrialization 136

inequality 21, 210, 232, 239

infrastructure $33,121,123,268,300$

institutions 11, 13-19, 21, 23, 30, 32, 35, 42, 57,

67-69, 89, 96-97, 101-104, 111, 120, 129, 136-137,

$141,152,165-167,183,191,207,210-211,213$,

226, 230-231, 233, 240, 258, 261, 328, 341, 347,

349, 353

colonial 11, 14-15, 17-20, $23,45,67-68,78,88$, $101,103,135-139,141,146,165$

economic 12, 15-16, 18-19, 21, 67-68, 89, 137, $240,243,258,261,328$

extractive 14-16, 23, 67, 104, 109-111, 121, 138, 210

inclusive 14, 16, 23, 103, 240, 243, 258, 261

political 114, 209

institutional change $13,23,38,68,93,259,296$, 321

institutional perspective 57, 207, 209, 211, 230

insularity $117-118$

integration 256-258, 26o-261 
intermediaries 69, 123, 242, 246-247, 249,

251-252, 257, 260, 272

intermediate goods $32-33,54$

intervention 120-121, 181, 185, 218, 296

intra-Asiatic shipping 260

Iran 33,37

Irian Jaya 112, 128

Irigoin, María Alejandra 211

Issawi, Charles 35

Italy 334

itinerant miners (faiscadores) 81

\section{jajmani 329}

Jamaica 116, 119, 122

Japan 32, 35, 38-39, 46, 49, 56, $35^{\circ}$

Java $17,36,39,41,48,52,56$, 109-111, 114-123, $126-128,135,137-140,143,145,147-148,150-151$, $153-155,162-163,165,244,247$

Java Sugar Syndicate 123

Jesuit Reductions of Paraguay 32

Johnson, Simon 14, 109, 111, 129, 210

Johnston, Sir Harry 193

Joint Stock Companies 95, 97, 103

Jones, Eric 175, 351

juniors 183,201

Kamba 301, 307, 315

Kenya 295-296, 299-300, 302-303, 307, 315, 321-322

khandsaris 119, 125

Khoesan 21, 265-267, 269-274, 277-278, 282-284, 288-289

Khoikhoi 89, 269

Kikuyu 304, 306-307, 309, 312-315, 318

Kimberley Central 98-99

King

Dom Pedro I 88

Willem I 142, $15^{\circ}$

Knight, G. Roger 56, 117

Kollur 69-70, 72, 77

kongsis 114

Kurnool 69, 75

labour

coerced 113, 121, 127, 241

coolie $33,75,242$

convict 75, 77, 97, 99-101, 103, 329

corvée 222-223, 329

forced 16, 21, 43, 97, 101, 103, 122, 153, 179, 242, $257,305,335,338$

free $23,56,207,209,211,213,217,220-221$, 231-232, 241, 254, 330

involuntary 242

slave 19, 21, 55-56, 67-68, 102, 104, 113, 122, $128,243,265-266,271,278,282,286-287$. 289,300

slaves for hire $85,88,102$

squatter $300,304,306,308$ unfree 13, 18, 21, 101, 207, 209, 211, 213, 217, 220-221, 231-232, 329-331, 335, 341, 351

voluntary 99,242

labour history (historian) 328, 331, 354

labour protest 328

labour migration 74, 186, 199

labour relations

coerced 21, 113, 121, 241, 270

commodified $57,110,143,165,321,354$

indentured 109-110, 114, 123, 241, 267, 270, 283

reciprocal $13,23,31,64,68,101,112,165,300$ $306,329,354$

serf 329,341

slavery $33,40,55-56,88,109,111,115-116,118$, 122-123, 211, 231, 241, 265-266, 270, 273, $275,284,287-288,329$

tributary 13, 31, 73, 77, 102, 110, 212

wage labour $13,20,22,41,45,56,72,76,78$, 86-87, 91, 93-95, 98-101, 103, 115, 117, 135, 137, 143, 153, 161, 163-164, 166-167, 177-178, 181, 189, 196, 198-201, 212, 214, 219-221, 223-224, 231-232, 241-243, 245, 249-251, 256-257, 26o, 295-297, 300-311, 313-318, 320-321, 328-333, 335-346, 347-352

labour(er) see labour

labour unions 247, 258-26o

lace 37

Lal, Deepak 33

Lancashire 36

land grabbing 97

landlords 124

lands, colonial 57

Lanyons, Owen 94-95

Larkin, John 111, 125, 129

latex 51

Latin America 14, 36, 40, 42, 49, 54, 109-110, 118, $127,212,230-231,233$

Laws of the Indies 229

Lebanon $5^{\circ}$

legislation $96,167,176,178,185,194-195,198,228$, $270,288,328,341$

Leiden 140

Leur, J.C. van 244

Linden, Marcel van der 9, 113, 207, 232

Lisbon $52,78,82-85,88,102,104$

Livingstone, David 193

London 9o, 100, 193, 256, 298, 336

Loney, Nicholas 124

loom 34, 38-39, 41, 143, 156

handloom $34,38,42,146,15^{0-151}$

Low Countries, the 150,333

Lower Shire District 180

Ma, Debin 50

maandbrief 251-252

Macpherson, William 49

Madagascar 40

Madras 51, 54, 344-346 
Madura 123

Mafale, Headman 190

Majalaya 38-39

Malabar 244

Malacca 244, 247-249

Malawi Congress Party 190

Malay Peninsula 48, $5^{2}$

Malaya 31, 43, 46, 50-51, 54

Malaysia 248

male breadwinner 164, 166-167

Mallavilly 73,77

Manchester 181, 241

mandurs 123

market economy $327,332,35^{2}$

markets $13,16,20-22,26,31,33-34,36,42,45-46$, $48-49,52,54-55,112,114-115,119-120,126,135$, $143^{-146}, 150,152,155,166,175^{-176}, 194,211$, 218, 227, 239-248, 254-261, 297, 315, 319, 321, $33^{0}-33^{1}, 35^{1}, 363$

Marquis de Pombal 84

married women 140, 151, 161, 163, 166

Marseilles $5^{1}$

Marseille, Jacques 32

Marx, Karl, Das Kapital 34, 241

massacre 115

Master Farmers Scheme (MFS) 199

Mauritius 114-115

Mawe, John 87

Mazrui, Ali 175

Mazumdar, Sucheta 112

McCoy, Alfred 124

means of exchange see currency

meat 5o, 55, 319, 343

mechanization 48, 127-128, 136, 151-153, 161

Medansche Machine Fabriek 54

Mediterranean 112-113, 116, 119, 254, 342

Meiji Restoration 49

Mesoamerica 36

Methwold, William 72

Mexico 42, 271

Middle East 35, 37, 41, 50, 334

middlemen 19, 119

military labour 243, 258, 303

mill 112, 120, 125, 212, 214-215, 217, 225, 229

Minas Gerais 78, 81-85, 87-88, 102, 104

miner 70,80

mine 69-77, 85, 89-91, 94-96, 98-101, 207, 212-213, 217-218, 228-230

diamond 16, 20-21, 67-68, 74-75, 86-91, 96, 100,103

gold 100

silver $16,207,209,228,230$

mineral/minerals $17,47,49,51,55-56,89-90$,

$94-96,101,103,177,210,213-214,218,224,228$

mining methods 71

deep mining 68, 98-99, 103

Mintz, Sidney 117

Mokyr, Joel 39

monetary history 299, 328, 331 monetization 21-23, 143-144, 223, 232, 296, 321, $328,337,339,35^{2-353}$

deep monetization 320-21, 327-328, 331-333,

$335,338,341-343,346-347,349,351-354$

money see coins or currency

money changer 344,349

moneylenders 119

money supply 348

Moradabad 38, 40

Morris, William 37

Mphala 182-184, 186

Mughal Empire see India

Mysore 54, 344

Nagano, Yoshiko 47

Napoleonic Wars 34

National Exhibition of Colonial Industry 165

Native Labour Commission (NLC) 307, 309-312, 317

Nederlandsche Handel-Maatschappij (NHM) $120,142,150-153,166$

Negros 111, 118, 123-124, 128

Nepal 346

Netherlands, the $19,52,118,128,135,137-138$, 140-142, 146, 150, 152-153, 163-167, 242, 249-251, 254, 256-258, 339-341; see also the Low Countries

Netherlands Indies 19-20, 123

Netherlands Trading Society 120

New Guinea see Irian Jaya

New Institutional Economics 13

New World 116

New Zealand 49

Newbury, Colin 96

Ngabu 199

Ng'ong'ola, Clement 194

niche markets 34,135

Nigeria $15,36,51$

Nizam Asaf Jah II 74

North America 120, 211, 231, 255

North, Douglass 13, 32, 230

Northern Africa 328

Northey, Governor Edward 305

Norway 334

Nsanje District 184, 186

numismatics 22, 328, 331-332

Oliveira Salazar, António de 44

Ommelanden 115, 119

Orange Free State 89-9o, 98

Orange River 89

ore $47,49-52,55,207,211,213-214,217-218$, 224-225, 229-230, 232

Orientalist 37

Ottoman Empire 42-43, 47

Pakistan 37

Palestine 37

palm oil $37,5^{0-51,54}$ 
Panna 69, 76-77

pass law 93, 95-96, 101, 103

Pauer, Erich 39

peasant $18,29,38,41,46,72,111-112,115,117-118$, $121,125-129,143,146,149,173-174,176$, 180-186, 188-189, 191, 193-196, 198-201, 226, 232, 302-303, 316, 331, 334, 338, 340, $35^{1}$ peasantry $21,110-111,118,120,129,173,180-181$, 334

(per capita) income 155

Pereira, Juan de Solórzano 219

Persia see Iran

Peru 218

Philip II 338

Philippines 37, 47, 109-111, 114, 118, 125, 127-128 plantations $17,19-20,54,109-129,181,198,267$, $271,295,300,304,306-308,312-314,317-319$ 322,329

planters 54, 111-113, 118-119, 123-125, 128, 201, 241

Pollard, Sidney 31

Pomeranz, Kenneth 35

porters 298, 300-304, 308, 318

Portugal 44, 87, 333

Portuguese Crown 68, 82-83, 87, 101-102

Portuguese Empire 52, 104

post-colonial 11, 17-18, 111, 126-128, 153, 173, 186, $194,201,212$

Potosí 16, 21, 207-209, 211-214, 217-220, 223-224, 226, 228-230, 232-233

mountain of $207,214-215,228$

Ribera of Potosí 215

power relations $15,17,23,67,103-104,261,327$, 354

pre-colonial 11, 15, 17, 21, 23, 67, 101, 139, 165, 214

pre-industrial 116, 153

Priangan 147,156

prices $18,30,49,81-82,86,90,94,99,100,121$, $136,140,142,146,148,163-164,173-174,176$, 189-197, 200, 265, 268, 275, 282, 288, 308-309, 343

primary goods $17-18,30,33,48$

probate inventory 275,343

productivity $21,29-30,38,41,49,57,136-137,152$, $265-266,278,282-284,287-288$

proletarianization $30,40,44,56,122-123,228$, 231,346

proletarians 213, 228

property rights $13,15-16,19,21,68,90,103,111$, $118,120,125-126,129,212-213,227,230,233$, 243

protection $17-19,29,33,36,42-44,46,51,54-55$,

$57,74,89,15^{2}, 193,241,25^{8}, 261,270$

protoindustry 40

Prussia 254

Public Debt Administration 43
Qing Empire 43

Quataert, Donald 35

Raad van Justitie (High Court) 248

Raffles, Sir Thomas 141

Raije, Bicker 250

railway 42, 53-55, 178, 193-194, 200, 298, 300-301, $303,306,308,318$

Ray, Rajat Kanta 119

ratooning 122

real wages $153,155,161,166$

reciprocal village economy 112

reciprocity 13,40

recruitment $21,115,178,181,239-241,244$, 246-249, 251-258, 260-261, 303, 305-306

Regimento Diamantino 88

remuneration (of labour) see wage

Republican Revolution 56

revisionist 35

Rhodes, John Cecil 96, 98, 193

rice $35,47,49,53,75,143,154,194,343,35^{\circ}$

Riebeeck, Jan van 267-268

Rio de Janeiro 78, 84

Robinson, J.B. 96

Robinson, James 14, 109, 111, 129, 209-210, 230-231

Rosenthal, Jean-Laurent 16

Roy, Tirthankar 40-41

Royal Decree 226

Royal Extraction (Real Extraçao do Diamante) $84-88,102,104$

rubber $46,48,5^{\circ}, 54$

runaway slave communities (quilombos) 83

rupee 22, 46, 75-76, 248, 297-299, 301-302, 304, 307-309, 312-320, 343-348

Russia 334-335, 341

Sahara 36

sailor 239-240, 243-245, 247-251, 253-261, 330

Sambalpur 69

São Paulo 54

Sayer, Andrew 200

Scandinavia 31,250

Schrijver, Gidion 247-248

Second World War 44, 173-174, 185, 187-188, 192, 259

segmentation 239-240, 256-257, 259, 261 second colonial occupation $173,185,199$

Senegal $5^{1}$

Serbia see the Balkans

serf see labour relations

Serro do Frio 78, 81, 102

settler mortality 14

settler $44,88,124,176-178,180-181,183,200$, 266-270, 272, 274, 277, 282-284, 295, 300, 302-305, 307, 310-311, 316-318, 322

share working/workers 94-95 
sheet metal 38

Siam 52,114

Sicily 116

silk 38, 43, 47, 49-50, 139, 209

silver 16, 38, 207-214, 217-218, 223-225, 230, 233,

299, 345, 349

mines 16, 207, 209, 228, 230

silver coins 22, 217, 298-299, 331, 336-337, 339,

$342-345,348,35^{1-} 35^{2}$

Singapore 54

Sixth Comintern Congress 31

slave see labour

slavery see labour relations

smallholder 95, 109-110, 117, 123-124, 126-128, 173, 176, 200-201, 211

Smith, George 177-178

Smith, Thomas 39

soap $43,48,54$

social engineering 56

Sokolofff, Kenneth 18, 210

soldier $84-85,248,251,253,300,303-304,330$, 344

Somalia 36,41

South Africa 15-17, 21, 67-68, 89, 101-104, 179, 265 British Crown 94-95, 348

self-employment 93, 102

share working 94

subsistence farming 21, 91, 100

wage labour 18, 21, 67-68, 91, 95, 98, 100-101, $103,266,273$

wages 91, 95, 98-99, 103

South African Republic 89-9o

South America 50, 55

South Asia 39, 327, 353

South India 51,75

Southeast Asia 30, 35, 41, 49, 114-115, 139, 247, 260

Southern Pacific Railroad 53

Southern Rhodesia 193

Southey, Richard 94

Spain 72, 122, 254, 333

Spanish Atlantic trade route (the Carrera de Indias) 254

Spanish Crown 219, 226-227, 231

Spanish Empire 207, 209, 211-213, 230

specialization $17,57,136,176,266,283-284,334$

spinning 34-36, 42-43, 140-141, 143-144, 146-147, $151,155^{-157}, 160-161,165-166,334$

spray technology 186-187, 189-191, 196-197, 199

Sri Lanka 42

standard of living 49,190

state $12,42-46,49,54,71,77,83,89,96,101,125$, $128-129,135,166,178-179,181,185,194-196$, 200, 211-212, 219-220, 226, 241, 270, 277, 302-306, 310, 322, 340-341, 349-352

colonial 17, 22, 95, 111, 115, 123, 129, 176, 178, 200, 296-297, 305, 321

semi-colonial $17,110,123,129$

Stellenbosch 267-277
Straits Trading Company 51

strike 41, 45, 99, $35^{\circ}$

subcontractors 98-99, 123

Sub-Saharan Africa 36, 40, 287

Sudan 82

Sugar Syndicates 111, 114

Sugarlandia 111, 124-125, 129

Suharto 126-127

Sukarno 126-127

Sumatra 54, 140

Surat 244, 247, 343

Suriname 120

Sweden 334

Swol, Jan van 253

sugar $17-19,43,45,47-5^{0}, 5^{2}, 54,5^{6}, 109-128,160$, $164,209,267,312,336$

Table Bay 267,288

Taiwan 115, 244

Tan, Kah-Kee 48

Tanimoto, Masayuki 39

tariff $19,34,42-44,46,55,57,140,142,150,15^{2}$, 166

Tavernier, Jean-Baptiste 72

$\operatorname{tax} 15,22,41,80,140-141,163,165-166,173,176$, 178-18o, 182-183, 185, 198-200, 217, 220, 228, 266, 269, 273, 295, 297, 308-309, 311, 313-316, $319,321,351$

hut tax 22, 95-97, 101, 103, 179-18o, 182-183, 312-315

tax censuses $265^{-2} 66,273^{-2}-44,287$

taxation 21-22, 94, 174, 179, 296, 315-316, 331

taxonomy of labour relations 12

tea $49-50,143,164,176-178,194,198,201,312,336$

Tebu Rakyat Intensifikasi (TRI) 127

Textiel Inrichting Bandoeng (TIB) 38

textile production 135-141, 144-146, 149-151, 153, $155,160,162,165^{-167}$

thangata $178,198,201$

Third World 30, 32, 35, 136

Tijuco 78,88

Tilly, Charles 12, 243

Tilly, Chris 12

tin $5^{1-52,54,55}$

Tipu Sultan 74, 344

tjap 39, 149-150, 158-16o, 166

tobacco $18,43,46,85,177-178,194-196,198,200$

Toledo, Francisco de 218, 222, 228-229

Tomich, Dale 113

trade 14-15, 17-18, 21, 29-30, 32, 34, 36, 41-43, 48, $69,73,78,82-85,87-88,95,99,112-113,115$, 119-120, 124, 128, 136-137, 139-140, 142-143, $145,147,152,154,158,165,173,176,180,208$, 212, 233, 239-240, 244-245, 254, 272, 297, 302, $313,318,331,346,348$

trade liberalism 139

transportation $178,181,193-194$

transportbrief 251-253

trekboers 269 
tribute $13,15,193$

Turkey 45, 334

Twente $150-152,165$

tyres 51

Uganda 193, 297-298, 300-303

United Kingdom (UK) 140, 150, 227, 254, 271, $327,334-335,337-341,353-354$

United Plantations 51

United States of America (USA) 47, 52-53, 127, 210, 241, 334-335

urbanization $44,56,334,354$

Vaal River 89

vassals 219, 228-229

Vietnam $32,114,350$

violence $173,176,179,183,198,245$

VOC see Dutch East India Company

Volkart, Swiss house of 119

waganyo 197, 199

wage labour(er) see labour relations

Wallerstein, Immanuel 17 wanchito $197-198$

warp $35,15^{2}$

Watson Commission of Enquiry 44

weavers 34-35, 38, 40-41, 140-141, 146, 150-151, 161

West Africa $36,51,181,268$

West India 117-118, 127

West Indies 119, 125

West Java 38-39, 120, 147

Williamson, Jeffrey 18, 30-33, 42, 48, 57, 136, 167

Wolf, Lucien 117

women's work $135,138,159,163$

Wong, Roy Bin 16

World Bank 173, 186

work(er) see labour

workforce $56,78,88,99,102,122-123,197,199$, $257,259,260$

World War I see First World War

World War II see Second World War

yarn $34-36,38-39,42,46,135,140-141,146-148$, $150,154,157,165$

Zimbabwe 193 
